


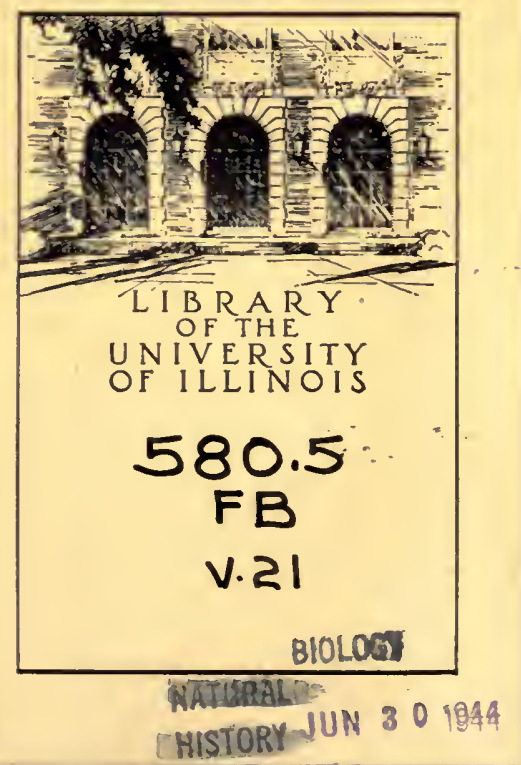


Return this book on or before the Latest Date stamped below. A charge is made on all overdue books.

University of Illinois Library

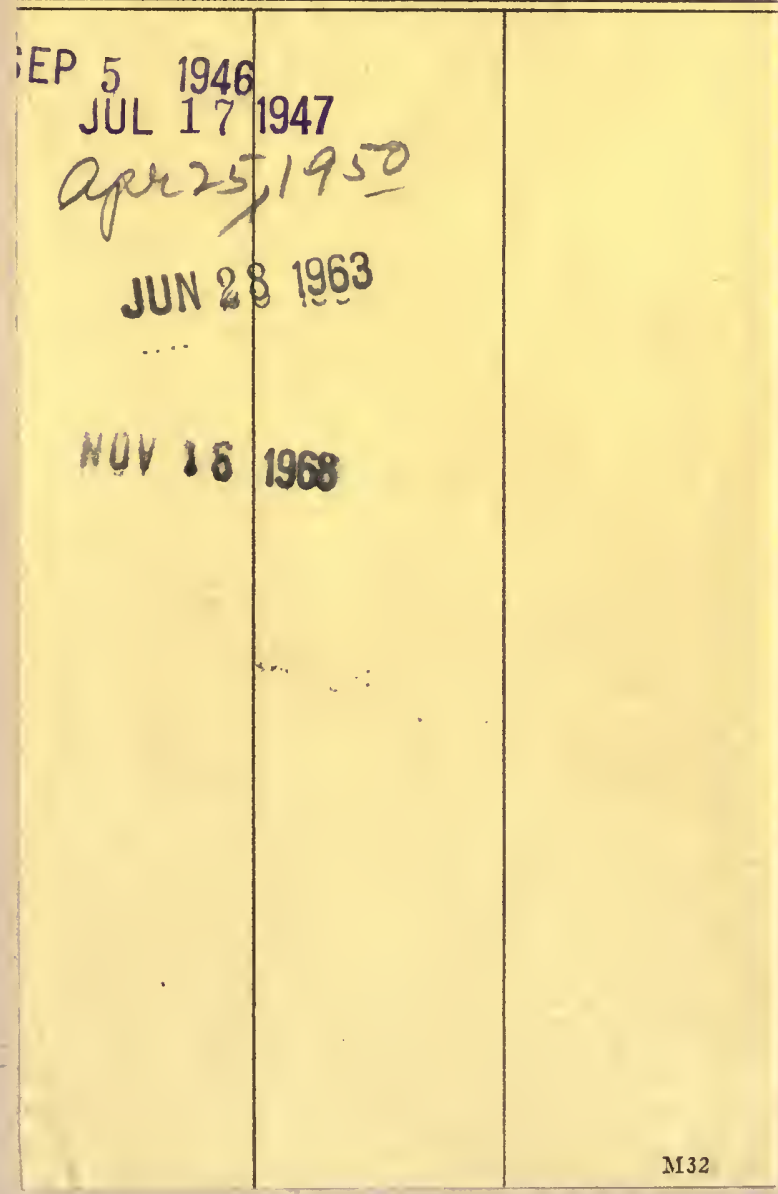




\title{
TRAVELS OF RUIZ, PAVÓN, AND DOMBEY IN PERU AND CHILE \\ (1777-1788)
}

\author{
BY \\ HiPóLITO RUIZ
}

With AN Epilogue AND OfFicial Documents ADDED BY AGUSTÍN JESÚS BARREIRO

THE LIBRARY OF THE APR 131940 UNIVERSITY OF ILLINOIS

TRANSLATION

BY

B. E. DAHLGREN

CHIEF CURATOR, DEPARTMENT OF BOTANY

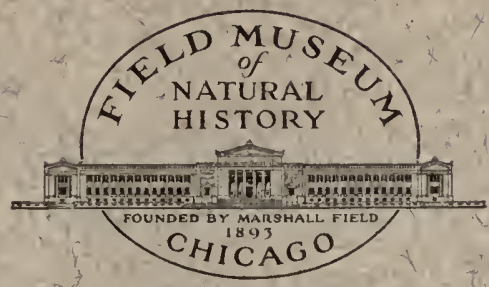

BOTANICAL SERIES

FIELD MUSEUM OF NATURAL HISTORY VOLUME 21

MARCH 28, 1940

PUBLICATION 467 


\title{
TRAVELS OF RUIZ, PAVÓN, AND DOMBEY IN PERU AND CHILE \\ (1777-1788)
}

\author{
BY \\ Hirólito RuIz
}

with an Epilogue and Official Documents

ADDED BY

AGUSTÍN JESÚS BARREIRO

THE LIBRARY OF THE

APR 131940

TRANSLATION

UNIVERSITY OF ILLINOIS

BY

B. E. DAHLGREN

CHIEF CURATOR, DEPARTMENT OF BOTANY

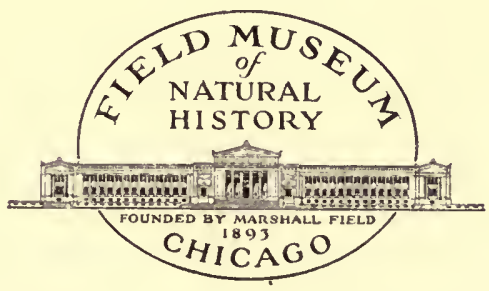

BOTANICAL SERIES

FIELD MUSEUM OF NATURAL HISTORY

VOLUME 21

MARCH 28, 1940

PUBLICATION 467 
BY FIELD MUSEUM PRESS 


\section{CONTENTS}

Preface

Foreword of Spanish edition . . . . . . . . . . . . . . . . 6

Title page of Spanish edition . . . . . . . . . . . . . . . . 7

Hipólito Ruiz, Travels in Peru and Chile . . . . . . . . . . 9

Epilogue by Augustín Jesús Barreiro . . . . . . . . . . . . 243

Appendices: Documents from Spanish Archives . . . . . . . 277

Index of chapters in Ruiz, Travels in Peru and Chile . . . . 333

Index of chapters in Epilogue . . . . . . . . . . . . . . 338

Index of Appendices . . . . . . . . . . . . . . . . . . . 340

Index of Botanical Names . . . . . . . . . . . . 341

Index of Vernacular Names of Plants. . . . . . . . . . . 360

Index of Geographical Names . . . . . . . . . . . . 366

MAPS

Provinces of Peru visited by Ruiz, Pavón and Dombey with itinerary of Ruiz and companions . . . . . . . . . 8

Provinces of Chile visited by Ruiz, Pavón and Dombey . . 112 



\section{ERRATA}

p. 27 last line L., read R. \& P.

p. 28 line 18 Cujute, read Cujete.

p. 30 last line Parkinsonia, and glandulosa, read Parkinsonia glandulosa.

p. 43 line 7 caerulea, read coerulea.

p. 46 line 13 coccinia, read coccinea.

p. 48 line 13 Sepium, read Sapium.

p. 67 line 32 huaura, read huanucara.

p. 78 line 17 allata, read alata.

p. 118 line 11 continu-, read continued.

p. 136 line 30 amentos, read aments.

p. 182 tisaceiro, read tisackeiro.

p. 211 line 30 picna, read picma.

p. 232 line 36 Mais, read Mays.

p. 367 Index \& pp. 116, 126 Concura, Corcura, read Colcura.

p. 368 Index \& pp. 136, 138, 140, 149 Huilguelemu, read Huilquilemu.

p. 367 Index \& p. 152 Collumo, read Coliumo.

Questions of orthography of place names on the maps generally may be settled by reference to the Index of Geographical names at the end of the volume.

Note on the Ms. of Ruiz (cf. Chapter X of Epilogue). British Museum (Natural History) Library Catalogue, p. 1765 lists a Ruiz Ms. as follows: Ruiz Lopez (H.) [original manuscript] Relación historica del viaje que hizo a los Reynos del Perú y Chile el botanico H. Ruiz en el año de 1777 hasta el de 1788, en cuya epoca regresó á Madrid. fol. [ ].

[Revised transcript of about the first half. fol.] There is the beginning of an English translation bound in at the end. 



\section{PREFACE}

The various botanical expeditions dispatched to the Western hemisphere in the last quarter of the 18th Century unquestionably deserve high rank among Spanish contributions to science. Undertaken at a time when botanical work had received a powerful stimulus through the publications of Linnaeus, these expeditions mark an important epoch in the botanical history of this continent. To students of the flora of the former Spanish possessions the names of Peter Loefling, Sessé \& Mociño, Ruiz and Pavón, and Mutis and his collaborators will always remain enduring landmarks.

Unfortunately the preparation of the reports of these expeditions and the publication of their results did not always fulfill the magnificent intentions of their promoters and patrons, nor correspond with the diligent and often elaborate performance of the botanists in the field. An outstanding exception is furnished in the published works of Ruiz and Pavón. Their Quinologia, Systema, Prodromus, and three splendid folio volumes-all that were actually completed-of the Flora form a monument to the zeal, industry and persistence of the botanical explorers of Peru.

A brief outline of their travels is given in the Quinologia (1792) and again in the Prodromus (1794). The existence of a more detailed account of their excursions among the mountains and valleys of Peru and Chile was generally unknown and even unsuspected until the discovery of the manuscript of a Relacion del Viaje which Ruiz had prepared from his diaries and completed for publication in 1793. The circumstances of its discovery after the lapse of almost a century and a half are set forth by Father A. J. Barreiro in the Epilogue provided by that eminent member of the Academy of Sciences of Madrid, who edited and annotated the original and appended pertinent official documents from Spanish archives.

The fact that this work of Ruiz awaited publication for a hundred and forty years detracts but little from its present value or interest. His original account of the historic botanical expedition, on which he and his famous companions spent more than ten years, must be considered a major addition to the still relatively meager literature of Peruvian botany.

In view of the fact that Field Museum has undertaken to publish a new Flora of Peru, it is considered appropriate to call attention to this recently discovered account of the botanical explorations of the early Spanish students and to provide an English translation. For permission to do so, the Museum is under obligation to the Royal Academy of Sciences of Madrid, particularly to Dr. José Cuatrecasas, through whose offices authorization was obtained during the troublesome period of the recent Spanish civil war.

The text of the work is mostly of botanical interest, and the translation is intended primarily for botanical readers. It follows the original as faithfully as the English language permits and at times perhaps even more closely. No literary graces have been added in the translation; no attempt has been made to alter the style or to improve the author's more rambling sentences. In the matter of scientific names, only obvious typographical errors of the Spanish edition have been corrected, generally with reference to the other published works of Ruiz and Pavón; however, many of the names that appear in the text seem not to have been published elsewhere. No attempt has been made to modern- 
ize terminology; thus, for example, Jatropha Manihot, Pinus chilensis and Platanus otahetianus are transcribed without footnotes. The spelling of vernacular and geographical names also follows closely that of the Spanish edition, sometimes to the point of inconsistency. Doubtless some typographical errors remain, and in spite of all care, others have crept into the translation.

Ruiz was not a zoologist and one looks in vain for a single scientific name for any of the relatively few animals mentioned. A zoological index to the volume would consist of a list of vernacular names; but the author must be credited with some zoological knowledge such as of the life history of the liver fluke of the sheep, and with one of the earliest of existing accounts of the habits of leaf-cutting ants. Curiously enough, he evinces no suspicion of the true nature of the almost unbearable irritation of the skin that robbed him and his companions of sleep after excursions into the forest.

For assistance in the task of preparing the present publication, acknowledgments are made to Mrs. Pura Ferrer for making a first draft of translation, to Miss Sophia Prior for checking the botanical names and preparing the index of plant names which substitutes that of the Spanish edition, to Miss Lilith Butler for typing, proofreading, and work on the geographical index, to Mr. Albert Frey for the production of the maps, and especially to Mr. David Gustafson for his careful and scholarly editorial work and close attention to diction.

B. E. DAHLGREN

\section{FOREWORD OF THE SPANISH EDITION}

Thanks to the diligence and interest of R. P. Agustín JESÚS BARREIRo, it has been possible to recover the manuscript of the Report of the Journey of RUIZ and PAVón in Peru and Chile which, unpublished, remained in the hands of an individual of the family of the former; and the Commission has decided to begin with it the publication of documents concerning the naturalists of past centuries who contributed so much to clarify our knowledge of the American flora, in consideration of the interest it has because of the many facts that it contains relative to the state of the countries that were surveyed by these naturalists at the time their journey was made. The manuscript has been edited by said member of this Commission, supplied by him with explanatory notes, and divided into chapters preceded by short titles indicating the contents of each one of them, for the convenience of the reader.

Madrid, June, 1930.

The Commission 


\section{RELACIÓN DEL VIAJE}

HECHO A LOS REYNOS DEL PERÚ Y CHILE POR LOS BOTÁNICOS Y DIBUXANTES ENVIADOS PARA AQUELLA EXPEDICIÓN, EXTRACTADO DE LOS DIARIOS POR EL ORDEN QUE LLEVÓ EN ESTOS SU AUTOR

\section{DON HIPÓLITO RUIZ}

Publicada por primera vez por la Comisión de Estudios retrospectivos de Historia Natural de la Real Academia de Ciencias Exactas, Fisicas y Naturales de Madrid y revisada y anotada por el vocal de la misma

R. P. A. J. BARREIRO, O. S. A.

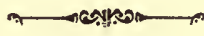

M A D R I D

EST. TIPOGRAPICO HUELVES Y COMPANIIA

Calle df Hilarión Eslava, 5

1931 



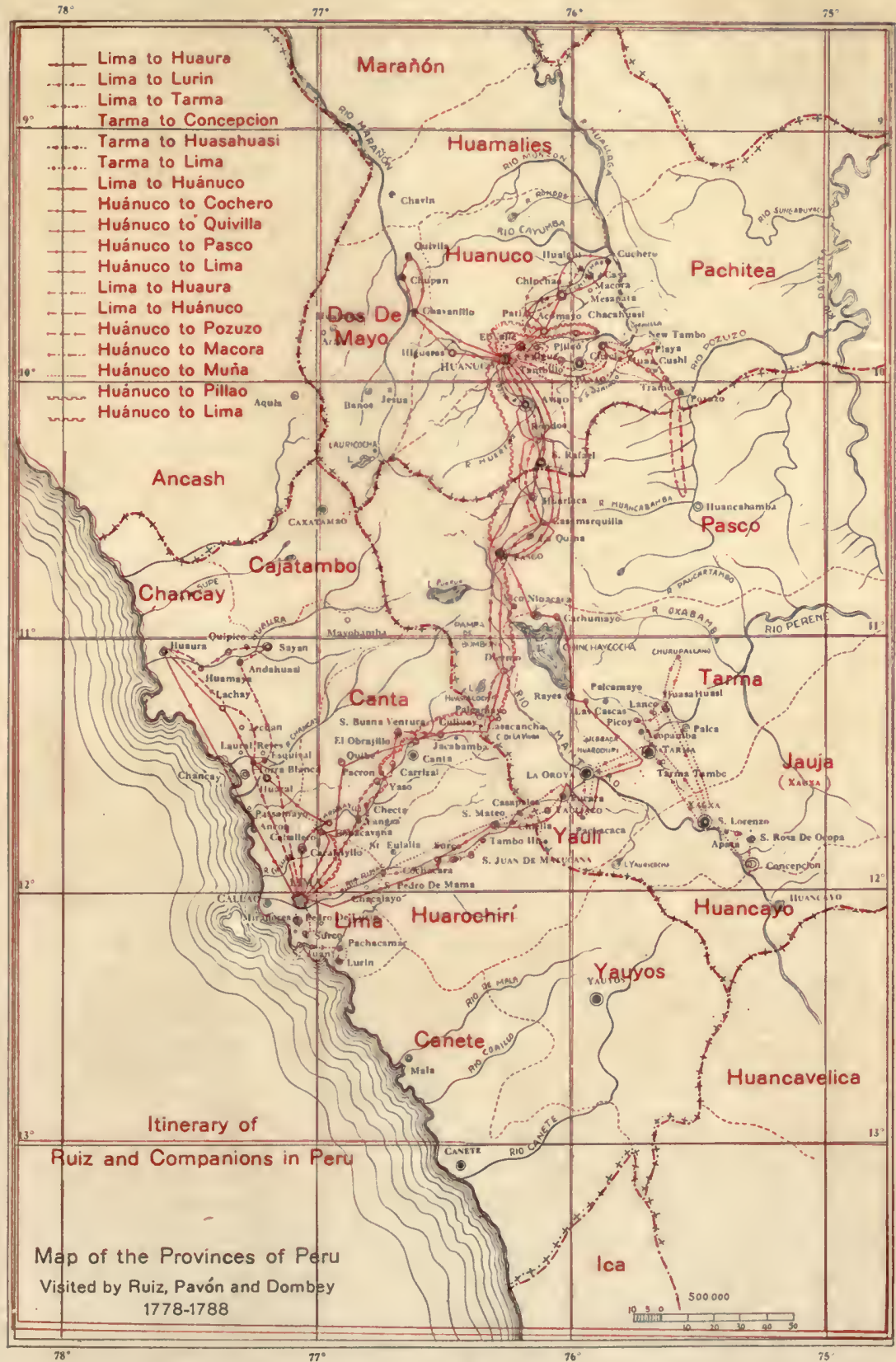




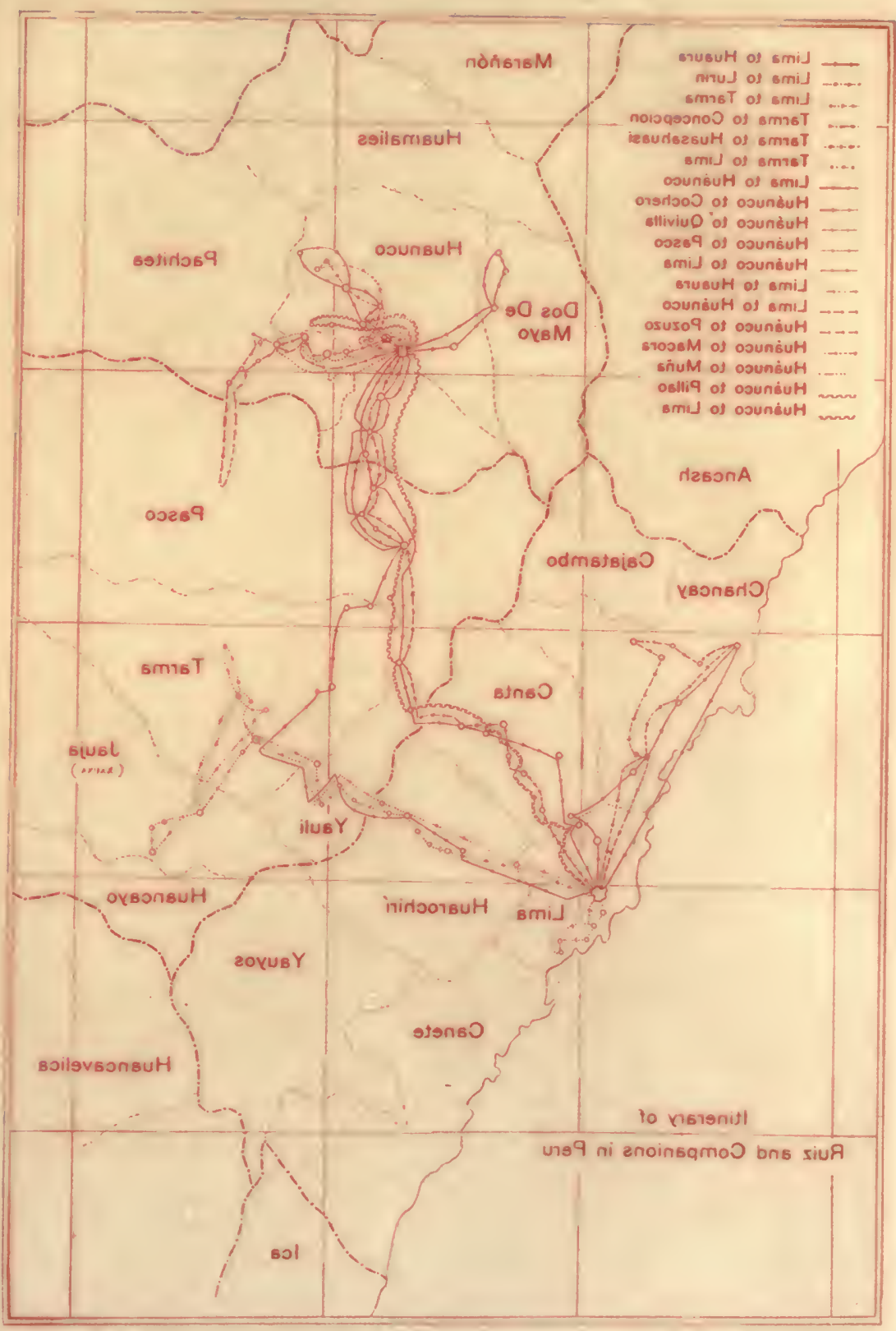




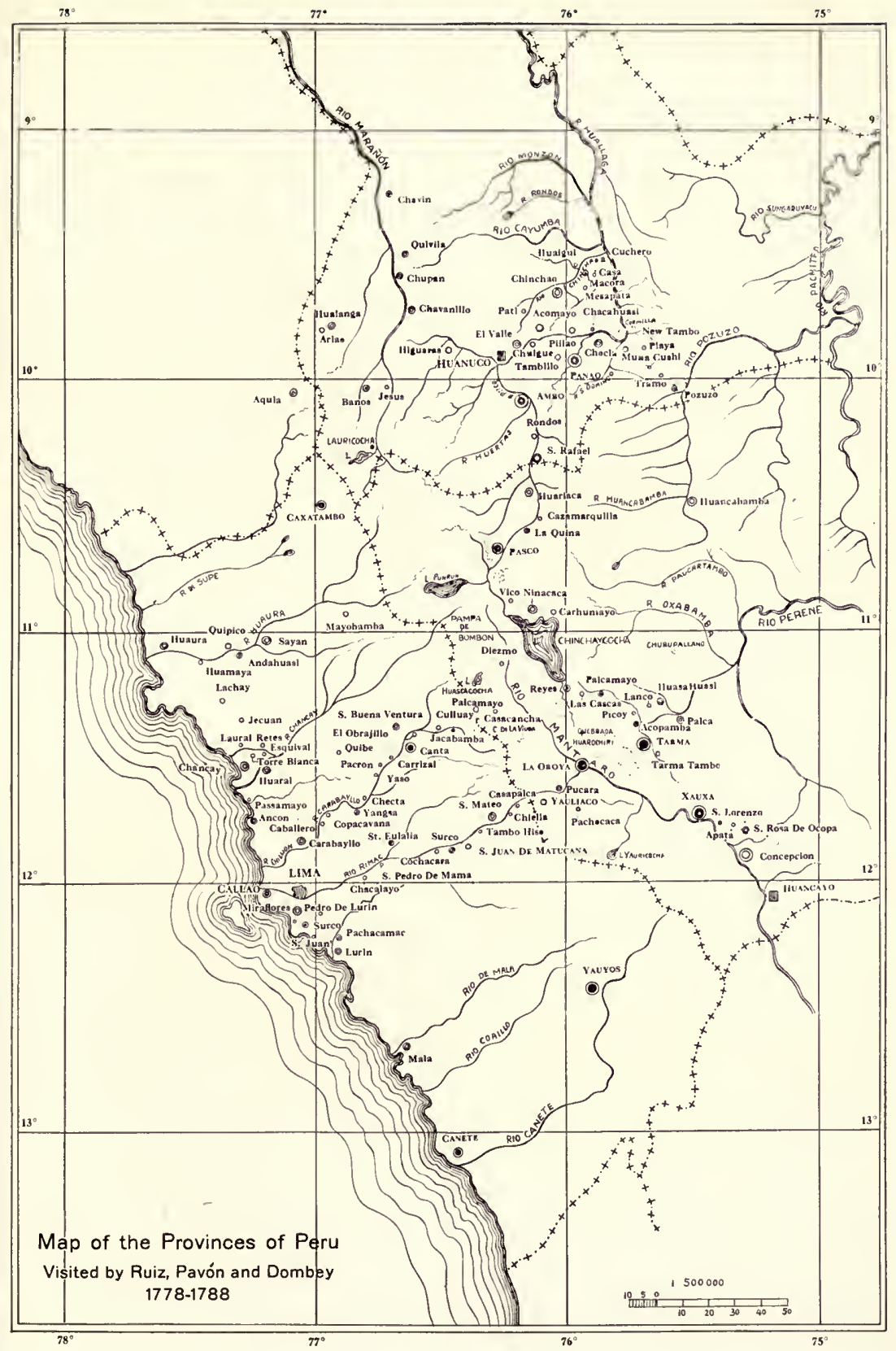


THE LIBRAKY

OF THE

UNIVERSITY OF ILLINOIS 


\section{CHAPTER I}

Organization of the expedition-Gómez Ortega consulted-Botanists and draftsmen-Addition of Dombey-From Madrid to Cádiz-Preparations for the voyage-Departure-Good voyage-Arrival at Callao.

\section{REPORT OF THE JOURNEY}

Our Majesty, the Catholic Monarch Dn. Carlos, eager for his subjects to receive the benefits and profits that could be obtained from the vegetable kingdom by methodical investigation, and also for the promotion of botany throughout all his domains in America, and thus to make it possible to discover and increase the number of medicinal plants and others of commercial, industrial, artistic, and economic interest, issued, on April 8, 1777, royal orders that two botanists, disciples of his Royal Garden of Madrid, should go to the said kingdoms with two draftsmen to observe, describe, and draw, and to form herbaria of the plants that they might discover in those parts of South America.

The King was informed by the first professor of botany, Dn. Casimiro Gómez Ortega, about the most studious and advanced pupils in this science. He named me as first botanist and chief of the expedition, and as second Dn. José Pavón, and as first draftsman Dn. José Brunete, and Dn. Isidro Gálvez as second. Likewise, he gave permission to the French botanist Dn. José Dombey to go in our company to said kingdoms of Peru as commissioned by his King for the purpose, and with the definite condition that on his return from Peru, before going to France, he should leave in Spain a copy of his observations so that the Spanish botanists could incorporate them in their works; this he apparently never did, or only in part, submitting some specimens of dried plants with very few notes and a few descriptions. ${ }^{1}$

\section{FROM MADRID TO CÁDIZ}

On September 19, 1777, the five individuals mentioned above departed from Madrid for Cádiz, where we arrived the 2nd of October without having experienced any setbacks of importance; on the contrary, I, who left Madrid sick, had recovered when we reached Cádiz, to my surprise and that of the doctors who had

${ }^{1}$ Dombey, J., French naturalist, born in Macon in 1742, died in 1794; was commissioned by Minister Turgot for the exploration of Peru, in the company of the learned Spaniards, and sent to France a precious herbarium that is preserved in the Jardin des Plantes of Paris. 
predicted for me in accordance with the dangerous character of the disease that I had been suffering from for more than four months.

In the 18 days that we lived in Cádiz we equipped ourselves with the things most necessary for the voyage and were ordered to make it by way of Cape Horn in H. M. S. "Peruano," which was commanded by Dn. José de Cordova. On October 18, 1777, we, the two Spanish botanists and the second draftsman, passed in taking on board the boxes of paper, books, presses, and so forth, but returning a little late to Cádiz we found that the port was closed for the night, so that, after the sailors had carried us out of the boat on their shoulders for a long distance, and a little wet, we had to spend the night, dressed, in the poor house of the keepers. The French botanist and draftsman Brunete, who missed us in the lodgings, were convinced, by what was said that night in Cádiz, that the boat had set sail, and they spent a very anxious night; before dawn they brought all the equipment to the Puerta de Bahia, having forgotten in the lodgings some of our things that we could not find later, and with an order of the president that as soon as it was daylight they should be permitted to board a boat to overtake our vessel if this had already set sail.

\section{EMBARKING IN THE BAY OF CÁDIZ}

The 19th found us all aboard, and at nine in the morning, with a moderate E. N. E. wind, we departed with all sails set. At 11:30, the wind having died down, we anchored in 8 fathoms of water. On the 20th we set sail, at 3 in the morning with a fair E. wind as before, steering to the W. At noonday the wind came a little cooler from the S.W., and the horizon became dark and windy; for this reason the captain, with the approval of officers and pilots, decided to return to Cádiz.

At 2 o'clock we raised flag and pennants; a little later we fired a gun calling the harbor pilot, repeating this four times. At 3 o'clock the weather cleared after several showers, and we could see the tower of San Sebastian to the N.E. At 4:30, coming through the shoals of San Sebastian, the pilot boat arrived and took charge of our entrance into the bay. At 5:45 all sails were furled and we cast anchor in 8 fathoms of water, mud bottom, the Punta de San Felipe being to the W. $1 / 4 \mathrm{~S}$.W. and the Castillo of Santa Catalina to the N.N.E., all by the compass. At 6:30 we launched the boat and the jolly boat. Dusk came with the horizon dark and showery.

A fresh wind came from the S.W. and thus we remained all night, with the anchor to the larboard. 
The 21st came with showers, and the pilots, having come aboard at 10:30, decided that the weather was unfavorable for starting; for this reason we stayed in port until November 4th, and at this time the weather cleared and we set sail at seven in the morning with the three maintopsails. At 8 o'clock we unfurled all sails; at $8: 30$ we lowered the boat and the jolly boat, and the pilots left when we had rounded the points. At noontime we sighted the tower of San Sebastian at an angle of $82^{\circ} 1^{\prime} 4^{\prime \prime}$ E.; according to this observation in the latitude $36^{\circ} 34^{\prime \prime}$ and longitude $10^{\circ} 8^{\prime}$ we were $41 / 2$ leagues from the tower by the French chart.

We continued our voyage, and on it we saw swordfish, many ballenatos, tiburones, bonitos, bufeos, albacoras, lobillos, and other fishes and a variety of birds that were seen also on the return from Peru. On the 12th of November we saw the island of Salvajes and Ascension, and on the 7th of February Tierra del Fuego, and Staten Island on February 8, 1778, without having seen during the whole voyage more than one vessel until we came to the vicinity of Pisco where, about 25 leagues from the port of Callao, we met two small packets that were carrying slaves of both sexes to Pisco. On April 20,1778 at 8 o'clock in the morning, we discovered land at a distance of 10 leagues. The 6th of February we saw the island of San Lorenzo, and we thought that we had run aground on one of the banks in front of the pueblo of Lurin. We dropped anchor in the port of Callao April 8th, 1778. 


\section{CHAPTER II}

Presentation to the Viceroy-Visited by the literati-Survey of the environs of Lima-Surprise of the Indians-Botanical work-Extent and limits of the province of Cercado-Climate-Parishes-The stay in Carabaillo-The robber Uracán-Hacienda of Torreblanca-Work accomplished.

\section{ENTRANCE TO THE CITY OF LIMA}

We landed on the 9th and went to Lima with the officers of the ship to present ourselves to the Viceroy of Peru, His Excellency Sr. Dn. Manuel de Guírior, who received us with great affability and offered us his protection in anything that was in his power.

We were later visited by the literati and by the most distinguished people of Lima, visits which we all together returned at once.

\section{FIRST HERBORIZATION}

After having secured the license and passport from the Viceroy, we started our botanical excursions the 4th of May of the same year, about the ravines of Lima and the truck farms and villages of the province of Cercado, walking on foot and with our portfolios under our arms in order to collect in them any plants that we could find. This work caused great curiosity among the natives, who were not accustomed to go on foot in the country nor to see such activities as ours; for this reason they stopped everywhere to observe us with surprise and astonishment, pointing their fingers at us and calling us herb doctors.

Nevertheless, we three botanists continued to look for herbs and plants on foot through the fields of Lima and the towns near the capital until the 22nd of July; during this time we dried, described, and sketched various new plants and some already known to botanists, but observed and described in a hurry and with less care and exactness than by the method used by Linnaeus, which was the one we had adopted as the most approved in all Europe for determining and describing plants, new as well as those already known, being satisfied to indicate the generic, specific, and trivial names of the best described, and to record their local names and their virtues.

\section{DESCRIPTION OF THE PROVINCE OF CERCADO}

The province of Cercado is 13 leagues in length N.S. and 8 in width. It is bordered on the north by the province of Chancay; on the northeast by the province of Canta; on the east by the 
province of Huarocherí; on the south by the province of Cañete and on the west by the South Sea. Its climate exposes one to fevers, colds, influenza, tetanus, diseases of the lungs, rheumatism, smallpox, mal del valle, and much venereal disease.

The winter cold is not felt by people from other colder countries, but it is penetrating for the natives, and in this season the atmosphere is laden with a mist that lasts all morning until noonday and sometimes all day and night; they call it garúa, which means drizzle. There are no storms, but in the spring, which comes in October and November, there are great earthquakes.

As it does not rain in this district nor along the coast, the houses and ranchos are roofed with wood, reeds, chacla, and so forth, and a cement of a very sticky clay. All the fields give an abundance of corn, beans, some barley, squashes, and various types of pumpkins, vegetables, sweet potatoes, fruits, and flowers in the gardens and orchards. The most important products are alfalfa and maizillo, which are taken to market in Lima to sell for fodder for all kinds of animals. Without these plants it would be impossible to maintain so many animals, notwithstanding that in the winter many people take their cattle 5 or 6 leagues from Lima, to the pasture grounds of the farms, which some people own for that purpose.

There are a few haciendas where they make some sugar, but what is manufactured mostly is atuarapo (sugar-cane juice), miel (syrup), chancaca (bread prepared with molasses), and alfeñique (a paste of sugar and oil of almonds).

The rivers that water these fields are the Rimac, the Carabaillo, and Lurin, that come from the cordilleras of Canta and Huarocherí. When the snow melts, these rivers have abundant water, sufficient to water the whole valley, but in the dry season the water is very scanty.

In the towns of this province illness is treated with medicines that come from Lima, but those who cannot afford to pay use herbs administered by themselves.

The city of Lima, capital of Peru, belongs to this province, and of it we shall give a separate description. ${ }^{1}$ Aside from the parishes of Lima, there are seven more in the province, which are that of Carabaillo with an annex called Lacosi; of Late with an annex named Rinconada; of Lurigancho with its annex called Huachipa; of Bellavista, founded after the event of October 28, 1746, when a flood covered the town and garrison of Callao, a fourth of a league from this port in direct line toward Lima.

${ }^{1}$ Such description could not be found in the copy. 
On the site of the town there is now the fort or garrison of San Fernando, also called Callao. In this bay, which is protected at the southeast by an island called San Lorenzo, there anchor all the vessels that come from the southern parts of America and those that arrive from Spain.

The fifth parish is that of the town of Magdalena with an annex called Miraflores. The sixth is that of Surco with an annex named Chorrillos inhabited by fishermen who sell their catch every day in Lima. The seventh parish is that of Lurin with an annex at Pachacamac; the Indians of Lurin also are fishermen who sell their catches in the capital.

\section{FIRST TRIP TO THE PROVINCE OF CHANCAY}

On July 22, 1778 we left Lima bound for the province of Chancay. We stopped over night in the hacienda of Caravaillo three leagues from the city, the Marques de la Rl. Confianza, owner of the hacienda, and the lawyer Dn. Manuel Graso with two more gentlemen having accompanied us from there. We spent the night of the 23rd in the tambo or inn of Copacabana, where we were attacked, a little after evening prayers, by robbers whose chief, named Uracán, came in disguise to the tambo to ask for alfalfa for his horses. He was accompanied by two negresses who remained on horseback while Uracán entered into a dispute with the innkeepers for the purpose of surprising us and taking our arms and everything that could be found where we were lodging; but having seen through his trick, we surprised him by pointing two pistols at his chest, and the five of us surrounded him, making him give up a long sword with which he scared the poor muleteers and passengers that he met, robbing them of whatever gold and silver they had. This the mayordomo of the Count of Villar told us when he arrived with two negroes shouting to the innkeeper to tie that hardened bandit, the captain of four others that had gone a little ahead, where he knew they were waiting for him or his results. The negresses, seeing Uracán tied, left on a run to inform their companions, but the mayordomo with his negroes ran after them, and, when they did not want to halt at his command, the mayordomo fired twice and shot the mare on which one of the negresses was riding, and the other, not daring to continue, stopped and was taken prisoner by the negroes and the mayordomo. Tied with Uracán, they were conducted to the hacienda of the Count of Villar and, the three of them having been separated, they confessed that their intention had been to come at 10 o'clock at night to rob us when we were asleep.

At this news we decided to stay awake and stand sentry in the gate under a huarango tree near-by, changing sentries every half hour. At 9 o'clock in the evening we heard the hoofs of the horses that 
the four companions of Uracán were riding, and three times they were asked in a loud voice "Who goes there?" The sentinel discharged his gun in that direction with such good aim that the bullet, having passed through the ear of one horse, struck Uracán's bodyguard, who fell to the ground badly wounded, and his companions escaped leaving him helpless; all of this was discovered the next morning when the mayordomo went to inspect the field in the direction in which the shot was fired the night before, and found the man with a broken thigh and weakened by much loss of blood.

That very morning the mayordomo took the two bandits and the two negresses to Lima. The wounded man died on the third day. Uracán was exiled to Valdivia, and the two negresses were given back to their owners as no other offense could be proven against them than that of having been carried off by the bandits to travel in their company. The two bandits that were in jail were denounced by public crier as fugitives from several prisons.

The 24th we arrived at Torreblanca, hacienda of Dn. Toribio Brabo de Castilla and half a league from the town of Chancay. This gentleman treated us with great generosity and ordered his servants and mayordomo to give us food and anything that we might need during our stay in his house, which lasted until the end of August, and at this time we went to the town of Huaura where we lodged in the beautiful hospital founded by the Illmo. Sr. Castañeda, a short time before.

We stayed in Huaura until the 22nd of October, when we returned to Lima with a quantity of dried plants, descriptions, and sketches of plants gathered on the coast, hills, valleys, and ravines of the province of Chancay, with not a little fatigue and difficulty because of the excursions we made on foot through those mountains and hills where the horses could not take us, and because of the intense heat of the sun. 


\section{CHAPTER III}

The town of Arnedo-Jurisdiction of the province-Limits and extension-Ports, coves, and small bays-Rivers-Animal and vegetable products-Climate-Fertility of the valleys - The huano-Silver mines-Grave mounds-Ancient monuments -Salt mines-Parishes of this province.

\section{DESCRIPTION OF THE PROVINCE OF CHANCAY}

At a distance of 12 leagues to the north of Lima, and half a league from the sea, is the town of Arnedo, capital of the province and the first settlement that one meets on the road from Lima. This town is commonly called Chancay. It has been the residence of many magistrates, but today they reside in Huaura.

The jurisdiction of this province starts six leagues from Lima. It is divided into two territories: one to the east, with cold climate, at the head of the cordillera is called Chacras, and the other warm one, toward the sea to the south, is named Costa or Valles.

There are 30 leagues of road along the coast from south to north, and 27 from west to east. It is bordered toward Lima by the province of Cercado, to the north by that of Santa, to the north and northeast by Caxatambo, and to the east by that of Canta. There are several ports on its coast. The first one in the south is the most spacious and calm, called Ancon, on the coast of which live a few fishermen that take their fish to Lima. Traveling to the north, one finds that of Arnedo or Chancay, where all the huano [guano] or fertilizer used in the province to fertilize the soil is landed, and some wood brought from Guayaquil. A little farther on is that of Chancaillo; at this small port very few vessels land huano. The port of Huacho follows. It is also small, but nevertheless some vessels usually anchor in it when they go or return from Guayaquil to Lima.

Besides these ports there are a few coves and small bays but they offer little safety.

This province is irrigated by two rivers. In the southern part is the Pasamayo river that comes from the cordilleras of the province of Canta and fertilizes the valley of Arnedo and Pasamayo, and in the northern part the Huaura river that descends from the mountainous country of Caxatambo and waters the beautiful sugar-cane valley of Huaura. This river has more water throughout the year. Near Huaura it passes under an arched bridge built between the rocky banks that confine it for more than four hundred feet. To one side of the town there is a small fort that was used in earlier 
times to guard the town from the enemy. At the entrance to the gate of the bridge, there are two columns under which are two stones in the ground. On one, there are carved the royal arms of Spain, and on the other is found this inscription, "Reynando Philipo 3o. This bridge was begun and completed in the year 1611, the commissioner being Dn. José de Rivera y Avalos." On two other stones placed in the columns, one reads the following inscription: "His Excellency Sr. Dn. Juan de Mendoza y Lima, Marques de Montesclaros, built me, being Viceroy in 1611." And on the fourth stone one reads the name "Juan del Corral," the artisan that directed the construction.

In the mountainous country of this province and its cool ravines the following products are gathered: arracachas, yacones, massuas, potatoes, and ockas. In the ravines that are temperate in climate there are produced beans, corn, and wheat. In the punas or high cold grounds where there are only herbs, there is an abundance of ichu and other grasses that feed many herds of sheep and cattle that are consumed by the hacienda owners and their negroes.

From the Castilian sheep they get some wool with which they manufacture xerga in the workshops, and from the milk of the cows they make butter and cheese.

On the punas one finds vicuñas, llamas, huanacos, and viscachas. In the ravines and mountain ravines are found some deer, bears, foxes, small pumas, and sheep.

In the coast and valleys the climate is milder and more pleasant than that of Lima because the air does not allow the formation of so many dense clouds, and thus the sun is not covered all day as happens in Lima almost every day in the winter. In spite of its general pleasantness there are a few places exposed to intermittent fevers and other sickness due to the great humidity and stagnant irrigation water, together with the excessive heat throughout the year; these are also the reasons for the abundance of fleas, piques, or jigger-fleas, and mosquitos, and all of these insects are insufferable.

These valleys are extremely fertile in wheat, barley, corn, and sugar cane. There is an abundance of yucas [cassava], camotes [sweet potatoes], several varieties of zarapayo [squash] or calabazas, and all kinds of vegetables, like cabbages, cauliflower, broccoli, lettuce, endives, onions, ynyus, and cashuas.

The following fruits are very common: sandías [watermelons], pepinos [cucumbers] that are different from those in Europe, 
chirimoyas, anonas, huanabanas, huayabas, palillos, paltas, lucumas, pacaés, granadillas, tumbos, ciruelas de Fraile, agrias, and peras, manzanas, membrillos, melocotones, and duraznos, which are produced only in the foothills of the mountainous ranges.

There is a great abundance of oranges, limes, lemons, sweet and sour citron, and grapefruits. In the gardens as in the orchards, one finds a great variety of flowers such as arirumas, narcisus, pilillas, amoncaes, coronillas del rey, fior de cuenta, feligranas, pelegrinas, junquillos, tulipanes, azuzenas, margaritas white and blue, lirios, alelies, flores de muerto or chinchi, taconcillos, paxarillos, ambarinas, marimoñas, piochas, narbos, claveles, roses, jasmin, espuela de caballero, chochitos, albaca, orégano, mejorana, manzanilla, aromas, suches, flowers of chirimoya and azar, and so forth.

In the time of the garuas or rains, the hills and slopes of this coast are covered with many different plants that in flower present a beautiful carpet to the visitors as well as to the people that go there for diversion and a few days in the country; the lomas of Lachay, that are situated between Arnedo and Huaura, have great name and fame in Lima for variety of plants and flowers. As to the opinion of the people who think that it is a paradise covered with a multitude of different plants, there are at most some 40 species that cause this beautiful and varied ground cover of Lachay, and only 12 species more conspicuous and more abundant than in the other lomas of Lima, Lurin, etc., where the same plants exist but without producing the beautiful sight of those at Lachay. With these plants and their roots they feed great quantities of pigs, horses, and cattle at the time they call the season of lomas, which is in the winter. As these lomas are on the road along the coast, the plants serve as pasture for the animals of the muleteers when, tired from the heat and dust of the sandy grounds, they come eager to refresh themselves on these juicy pastures.

Maize is the most abundant grain gathered in the valley of Arnedo, because it serves for the maintenance of the negroes and workers of these haciendas; in addition, the owners of these fatten about 30,000 pigs. The greater part of them come from the valley of Huaura and are fattened in the valley of Arnedo, whence they are taken to supply Lima.

Each hacienda owner slaughters his cattle mostly on Saturdays and sells the lard and fat together at $2 \mathrm{rs} ., 2 \frac{1}{4}, 2 \frac{1}{2}$, so that the money 
that is collected each year in the province of Chancay from lard alone comes to more than 340,000 pesos.

Formerly, the main harvest in these valleys was of wheat and wine; at the present time there is none of the latter.

The valley of Huaura is more than 10 leagues in length and more than 2 leagues in width at the site of the town but continues beyond, becoming narrower near Sayan. It is occupied by sugarcane plantations. There is an hacienda in this valley that sends to Lima 50,000 pesos worth of sugar of superior quality, each arroba selling for $3 \frac{1}{2}$ and 4 pesos.

In this province it has become so necessary to use huano or manure to fertilize the maize plants that without it they produce very little. The natives use two handfuls for each plant as they plant it, and two more when it grows and they clear away the weeds. In the whole province more than 60,000 fanegas of huano are consumed per year, and each weighs 8 arrobas and is worth 4 rs. Each one of the vessels carries from 600 to 1,000 fanegas. The pilots maintain, and apparently with good reason, that huano is the true manure of birds called huanoes, and of others that sleep at night on those small islands situated at 5 leagues from Pisco and near Cañete and Arica, towards the nor thern part of the coast. They assert that so great is the multitude of birds that come and inhabit those islands that there cannot be the slightest doubt that they produce yearly as many fanegas of huano as are used in the provinces of Chancay, Pisco, etc. Moreover, they affirm that some islands that are buried in the manure have been bare of this soil for some years, as some have thought, or of this huano, as is evidenced by the petrified eggs that are found buried in the manure and the ground of bare rock of which those islands of the southern sea generally are made, and that after a certain time the carriers have returned to gather and load innumerable fanegas of it.

The use of this huano has recently been discovered, and the birds have been living on these islands since time immemorial, so it is not surprising that it is only manure of birds reduced to the consistency of yellowish soil of the color of ochre of Siena, by the action of marine acid, wind, sun, and water. It gives off such a heavy odor that it gives headaches to those unaccustomed to it.

In the hill of Jeguan near the town of Arnedo, there is a silver mine that a few years ago was worked and produced from 50 to 80 marks [ 8 ounces] of silver per box. 
Between Jeguan and Torreblanca there are a multitude of huacas or Indian graves from which we took several instruments and vessels of clay and a thousand other trifles that accompanied the bodies that had gone to waste there since paganism.

At a distance of one league from Huaura to the north, there are some strong walls three yards in width at the base and gradually narrower at the top; they extend about three leagues; apparently they served as a boundary between the lands of some caciques. Beyond the port of Chancaillo, there are found two lone stones that, because they bear some remote resemblance to the "sea wolf" [sea lion], the Indians call "the wolf" and "the she-wolf," and they are convinced that they came out of the sea and were turned into stone. The truth is, that they are two very peculiar stones and the only ones found in those hills and sandy beaches on which there are many sea lions and great quantities of carrion vultures that come to eat the ones that perish. Four leagues to the south from Huaura, at the edge of the sea, there are abundant deposits of salt which is taken in rectangular blocks of 75 and 100 pounds. This salt, as has been said in the survey of Lima, is a natural muriate of lime that, in the damp climate, dissolves in great quantities in a short time; for this reason, in the mountains, montañas, and other damp places, they keep it near the fire so that it will not stick together. From these salt deposits there are supplied the provinces of Cercado, Caxatambo, Caritas, Huarocherí, Tarma, Xauxa, Huánuco, Huamalíes, Concuchos, and Huaylas, for cooking as well as for the extraction of silver. They use large quantities for the sheep of Castille to preserve them from an insect called alicuya in Peru and pixguin in Chile that, damaging the liver, causes their death.

This province is divided into nine parishes that in all comprise 14,000 souls of all classes. The first parish is that of the town of Arnedo or Chancay, capital of the province; it was founded in 1563, the Viceroy then being the Conde de Nieva, who destined it for the university which never was established. It is the best city of the province, the one with most inhabitants of all classes, but with few families that are fairly well-to-do. It has the best buildings and a very spacious square in the middle of the town at one side of the parish house; the camino real [royal highway] that goes to the coast and mountainous regions, passes through it; it is called the Calle Mayor, being very straight from one end of the town to the other. Besides this there are other streets that cross without order.

There is a royal hospital and a convent of Franciscan monks. The pueblo of San Juan de Huaral is the only one annexed to this parish, but there also belong to this parish district the many haciendas in the valley which are owned by native gentlemen who have their families living in Lima, though some of them stay the greater part of the year on their chacras, that are cultivated by negro slaves. 
The town of Arnedo is located a quarter league from the sea at the entrance to the valley. It is surrounded by orchards and farms that beautify it with a variety of vegetables and fruit trees.

The buildings are of one story only, like those in Lima; some have a second one for grain. They are constructed of the same materials and in the same style as those of Lima, as are also all the buildings along the coast. Near the salt deposits there is a port where they land the huano.

The 2nd parish is that of Huacho, the first town that is found from Arnedo to Huaura beyond the sands and hills of Lachay. It is located a mile from the sea, at the beginning of the valley of Huaura. Although in the part of the town where there is a church there is a large square, there are but few small buildings. Its extent is about a league square and it is divided into chacarillas or orchards, each with a rancho where the farmer and his family live; for this reason it is the most beautiful and best cultivated town that can be found in the vicinity of Lima, and I am of the opinion that of its kind it is the only one in Peru, as each Indian has around his house or rancho his fields with grain, vegetables, and fruit trees in sufficient abundance not only for his support and that of his family but for sale to travelers and for transport to Huaura, Arnedo, and Lima.

There is no land without cultivation, so that the cattle must be fed in their stables.

You find in this town the most exquisite anonas that are known in Peru, and you find also the cañafistola and tamarinds. In fact, Huacho is a small garden where nothing in the vegetable kingdom is lacking for the amusement, pleasure, and support of its inhabitants, all of whom are Indians, very industrious and of good disposition, with an occasional half-breed.

The natives of Huacho supply the town of Huaura with all kinds of provisions; in the morning they are brought for sale by the women who from maize make a chicha among the best that are known in Peru.

The 3rd parish is that of the town of Huaura founded in 1608. It has two annexes, Mazo and Vegueta, with few Indians near the sea; one convent of Franciscan monks, rebuilt in the year 1781 and a royal hospital, finished in 1764 by the Illmo. Sr. Dn. Juan de Castañeda Velázquez de Salazar, bishop of Panamá and later of Cuzco. He died the in same year that the hospital was finished, and for that reason he could not endow it in accordance with his charitable intentions.

The construction of this hospital was paid for by the King, and for its maintenance there was assigned the tomin [head tax] of the towns of Vegueta, Supe, and Barranca, which meant that each Indian had to pay 5 reales a year. In those times the Indians were numerous so that there was enough for the subsistence and treatment of the sick. Today the tomin amounts to only 34 pesos and some lands and annual pensions that make a total of 250 pesos. The main church is a cross-vault in whose arms and head there are placed the beds of the sick, and the rest serves as a chapel so that the sick can hear the Mass from their beds, as the altar is placed in the center of the vault.

The town of Huaura has only one street, straight and wide and about a quarter of a league in length. Its buildings are low and in the style of those of Lima. The population is composed of Indians, criollos, mestizos, and other classes. The main road passes through the same street. 
The 4th parish is that at Barranca, seven leagues from Huaura. Its annex is Supe, five leagues distant from the village. The 5th is that of Aucallama, founded in 1551. In this parish, they worship a miraculous image of Nra. Señora del Rosario, that was donated with appropriate ornaments by Sr. Carlos V. The 6 th is that of Sayan, with two annexes, Tapaya and Quintay. This last town belongs to the province of Caxatambo. The 7th is that of Chanchas, Marayo Checras, with ten annexes, Juraciaco, Picoy, Parquín, Yacul, Canin, Moyobamba, Puñun, Turpay, Tongos, and Chiuchin, where there are some baths of thermal waters, where many people come crippled from rheumatism and venereal diseases, and become well after bathing in and drinking those waters; our colleague Dn. José Dombey analyzed them when he went there with a Sra. Oydora of Lima, who was crippled and returned in the same condition to this capital. Here Dombey found several plants of which we had gathered many in Tarma and other places at the time when Dombey was in Chiuchin. The 8th parish is that of the pueblo of Paccho with eight annexes: Ayaranga, Huacar, Musga, Llacsanga, Apache, Santa Cruz, Huanangui, and Auquimarca. The 9th and last parish is that of the pueblo of Yguari with six annexes: Llancao, Obeguet, Huachinga, Yunhuy, Acotama, and Huaycho. 


\section{CHAPTER IV}

Miraflores and Surco-Picturesque landscapes-The ruins of Pachacamac-The Lurin river-Location of Lurin-Form of the houses-Administration-Entertainments and patrons-Products-Militia-Manner of fishing-Most common fishes-Fevers and their remedies-Birds-Plants.

\section{JOURNEY FROM HUAURA TO LIMA AND FROM THERE TO LURIN}

On October 22, 1778 we returned from Huaura to Lima, where we finished the drying of the plants we had discovered in the province of Chancay and put in order and boxed up for safe transportation all the other natural products, and we provided ourselves with everything necessary to go on to Lurin, because we had heard of the fertility of its lomas and coasts.

On the 5th of December we started together from Lima to Lurin, passing to one side of the pueblos Miraflores and Surco, both situated on level ground and with pleasant breezes; for this reason and because of the luxuriance of the trees of the farms, orchards, and gardens abounding in all kinds of fruits, vegetables, and flowers, many families from Lima come for fifteen, twenty, or more days of rest. At a quarter of a league from Surco we found the hacienda called San Juan, where they manufacture a quantity of sugar, alfeñiques, chancaca, miel, and huarapo from the sugar cane. Farther on there is a beautiful olive grove; passing this, one enters on a sandy stretch that extends to the Lurin river and in which not a trace of plant life is found even in times of rain. To the left there are the lomas of Lurin, which in winter are covered with small plants; then many people from Lima come for recreation in the country.

On the right hand side near the river, there can be seen over a bluff the ruins of the Castillo de Pachacamac, in which the Gentiles [Incas] kept five thousand men in arms. At the foot of this castle are also the ruins of a town very populous in the times of the Incas. At a short distance from this, there flows through the reeds the river called Lurin, which at times when it rains in the mountains increases in volume so much that the fords are lost; and for this reason they send chimbadores [guides] who look for the shallow parts in a river to carry the travelers from one side of the river to the other, but notwithstanding this help, many persons and cattle are usually drowned every year. At times of drought, this river is almost without water, but its banks are pleasant and beautiful with the shrubbery and plants by which they are covered. 
A short distance from this river is situated the hacienda of the fathers of San Pedro, which is a small sugar estate, as is that of San Juan. It produces more than 10,000 pesos worth of sugar, alfeñique, etc.

\section{LURIN}

Beyond this hacienda there is found the pueblo of San Pedro de Lurin, distant a short six leagues from Lima and a quarter of a league from the sea in a luxuriant and beautiful valley with a mild and much healthier climate than Lima and the other towns of the vicinity; for this reason some viceroys and other gentlemen of Lima and their families spend some holidays and amuse themselves there. This pueblo is inhabited by 120 well-to-do Indians with as many houses or ranchos, mostly constructed of quincha or wild cane and straight logs that generally are of willows and Erythrinas called hauyros, green and frondose; many of them are plastered in and out with mortar, and sometimes they are whitewashed, especially on the inside, with lime made of shells. They are of one story only, square, with a flat roof. Each house has an orchard with various kinds of flowers, and in each are found suches or Plumarias of as many as five different and beautiful colors. There are four principal streets named Calle de Malambo, Calle del Mentidero, Calle Nueva, and Calle de la Costilla. The others have no name, except one called de la Palma.

All the streets are straight and in the center of the town is situated the main plaza, square and spacious, with the church at one side and the assembly house on the other.

Every year they name three alcaldes [mayors]: two for the pueblo and one for the country, with one alguacil [constable] each. Furthermore, there is a cacique, governor and defender of the Indians.

This pueblo presents such a beautiful sight with its luxuriance and variety of flowers that can be seen among the adobes in the orchards, that it could be called "the Town of Recreation" because all of it is a delightful place. Nevertheless, it has a walk called the Uña del Diablo [the devil's claw] because the shape of a hand is stamped on a stone to be seen there.

On the day of San Pedro, the patron of the place, there are bullock fights and fireworks. On the day of San Miguel there are the same entertainments, and some years there are bullfights; for this reason many people come from Lima and occupy themselves with diversions and games for fifteen to twenty days. 
They celebrate also the day of Ntra. Sra. de Guadalupe; and on the day of San Nicasio, festivity of "precepto" for the Indians, in the afternoon there are cock or duck races for which the birds are hung by the legs, head downwards, so that the most dexterous rider on horseback who pulls the head off the animal, is the winner. When the races are over, they set off a few fireworks hung from the same cord, while the Saint's procession enters the church. When the procession is finished, all the Indians go to the houses of the mayordomos, where they celebrate with several jugs of chicha.

Although the land of Lurin is very fertile and productive, the natives are satisfied with sowing only what is necessary for their support. Their most important commerce is in fish, which they take to Lima to sell; nevertheless, with the fish, some of them also take yucas, sweet potatoes, beans, and squash, the only foods with which they maintain themselves, using instead of bread, boiled maize, of which they raise a big crop for the chicha which is never lacking in the town, and they make it in the following manner. They take as much corn as they want and put it to soak for one night, then lay it out on banana leaves, and cover it with other leaves until it germinates. In this condition they spread it out to dry in the sun so that they can reduce it between two flat stones into meal, which they boil twice, each time with a suitable quantity of fresh water. When it is almost cold, they strain it, squeezing it out well, and put the liquor in earthen jugs to ferment for two or three days, in which time a pleasant-tasting beer or intoxicating liquor is produced which they call chicha.

Of all the neighbors, there are formed two companies of militia of fifty men each, whose duty it is to go to the port of Callao twice a year for work on vessels and to take care of the sick in the hospital of Bellavista. While they are on this duty they are paid two reales a day.

The method of fishing used by these Indians is to sit on big floats of totora [a rush], well tied and capable of floating two or three days in the water, and to go out to sea for a distance, where they cast the net, and then they separate in opposite directions as far as the rope allows. Afterward they return to shore, and when they are near land the two fishermen approach each other to close the net so that the fish within it may not escape. Then they land, and by the strength of their arms pull the fish ashore. The most common ones that are taken here are corbinas, lenguados, robalos, chitas, cabrillas, cazones, chalacos, pintadillas, lornas, xureles, 
bonitos, anchovetas, pexe reyes, pexe sapo, pexe gallo. The anchovetas are greatly esteemed in Lima for their delicious taste when fried.

Although Lurin enjoys a very mild climate the greater part of the year, fever is common in winter; they cure this with a concoction of yerba hedionda, apples, and the juice of lemons, and cream of tartar, taken before breakfast for three days, half a quart a day. Some years there is much smallpox. There is always caracha or itch and gonorrhoea, and it also happens that some women suffer from cancer and spasms. The medicines commonly used are herbs administered according to the ability and experience which they have acquired one from another.

In a little brools in the hills there is a spring between two rocks, with very pure and clear fresh water.

Between the town and the sea, there are some small lakes from which some of the fish already named are obtained and, in addition, ducks, zambullidores, aradores, herons, flamingoes, and other aquatic birds. In one of these lakes, called that of Sn. Pedro de Quilcai, is the site of the ancient town of that name; but its inhabitants had to abandon that place on account of the frequent overflow of the sea caused by earthquakes, and those that were not drowned by the sea moved to the present site of Lurin.

Opposite the shore at Lurin, and about three leagues out at sea, there are a number of rocks or banks extending from N.W. to S.E. in a straight line, the first about two leagues distant from the last. The first rock is called Viuda [Widow] because it is alone and farther distant from the rest; then follows the one named Pachacamac, which is the largest of all. There are several caves in this barren island inhabited by a variety of birds, among which are a mass of nestlings. When a person approaches the entrance of one of these caves, they set up such a clamorous squeaking that it sounds like a multitude of braying asses that deafen you with their noise.

On this island they gather quantities of huano for the benefit of the corn fields. Farther on there is another rock called Arenisco. It is very small and has the shape of a pyramid. After that comes one named San Francisco, a little smaller than Pachacamac and of the shape of a tall pyramid, and finally, one finds the one named "The Hunchback," for its shape, and the only one among the smaller ones that has a name.

Besides the many fruit trees, seeds, vegetables, and ornamental flowers that we mentioned from Chancay, there are found in Lurin 
almost the same plants that have been noted at Lima, but there is an abundance in the former place of species that are rare in these fields, and there are also found some that are different, of which I gathered and described the following. Dianthera repens. Heteranthera reniformis. Lithospermum dichotomum, tiqui-tiquil. Nolana acutangu$l a$, chaves. The chickens feed on the last-mentioned plant. Convolvulus secundus, campanillas de lomas. This is a plant which can serve as an ornament in gardens because of its light blue flowers and the size of its corollas; its root is purgative. Convolvulus sepium L. The infusion of this milky plant also is used as a laxative. Convolvulus stipulatus. Cordia rotundifolia, tina and membrillejo, for the shape of their leaves, which are much used in infusions for jaundice. Lycium falsum, cachicasa, that is, salty espino, because of the taste of its leaves. Potamogeton compressifolium. Atropa umbellata. Asclepias sp., arbol de la seda, flor de la reina, and chuchumeca, because you find it everywhere in abundance and always in bloom. Asclepias hastata, amarra judíos, because its shoot is very long and branchy and is used to tie various things. Solanum variegatum, pepino; they propagate this plant by the stems as the seeds do not give fruit until the second year after it is transplanted from the nurseries which they make for that purpose. This plant is laden with fruits the size of eggplants, varying in color from yellowish, whitish, and spotted with different colors: purple, violet, and sometimes reddish. Its excessive use causes tertian fevers and stools with blood and is very harmful for the mal del vicho or dysentery. Its taste resembles that of melons, but is not so sweet and pleasing. Hydrocotyle vulgaris and umbellata L., orejas de abad and patacones, for the shape of their leaves. The juices of these two species are used to cure mouth sores and, if applied to pimples, they clean, heal, and cure them. Plumeria rubra, suche, purple and rose. $P$. tricolor, suche blanco-rosado, and carinata, suche turumbaco. They are milky-juiced trees of beautiful luxuriance and loaded in January, February, and March with thousands of beautiful flowers. They grow to a height of 6,7 , and 8 yards. They can hardly be distinguished from each other except by the color and size of their flowers. They last two or three years without drying out after they are cut, and they take root easily, if planted after one or two years. They bear leaves only at the tips of the branches and flowers in the center, as if in flower pots. They are beautiful trees for gardens and their shade is not harmful. Alstroemeria peregrina L., pelegrina, for the beauty of its variegated 
flowers; it abounds in the ravines of the hills of Lurin and Chancay. It is a plant that is cultivated in gardens for ornament. Amaryllis aurea, amancae antiguo, a beautiful flower for gardening; its bulb is surrounded by many smaller ones. Polyanthes tuberosa L., margaritas blancas. Its odorous flowers are used for ornament in gardens and in mixtures, and its bulbs are applied as an emollient in poultices. Pancratium flavum. A beautiful flower of an orange color. Cassia mimosioides L., huarandillo, and Cassia Tora L., cañafistola cimarrona. With an infusion of one or the other of these species, the natives purge themselves. Bauhinia aculeata, uñas de gato, for the thorns on its branches. Sapindus Saponaria, jabonera. It is a tree of about 8 or 12 yards in height, of ordinary wood and leafy. Its fruits, called cholocos and bolillos, with which the children play, are covered with a rind that is used to wash baize cloth, as it forms suds like soap. Sesuvium Portulacastrum L., litho. With this plant, that resembles purslane, they make glass in Ica and it is used in some places for soap in place of the bars. Malva rotundifolia and sylvestris. Crescentia Cujute, tutumo, is a tree of 6 to 8 yards in height, with masses of branches erect like rods and of a beautiful green. See the account of the plants of Chancay for the use of its fruit called tutumas. Lantana salvifolia, maestrante. Its decoction and infusion are used against jaundice. Dolichos uncinatus L., trifolitos and taconcitos. Dolichos Lablab L., frijol de Antibo, and in the mountains sencapuspu. Although the seeds are somewhat bitter, the slaves on the plantations consume quantities of these beans, and remove the bitterness by leaving them in hot water over night. Phaseolus vexillatus, frijol cimarrón [wild bean]. Crotalaria incana L., cascabelillos, for the noise that the seeds make within the pods. Hedysarum asperum, pega-pega, because with the stickiness and roughness of their leaves and pods, they adhere to the clothes of those that pass near them. Erythrina corallodendron L., huayro and huayruru. This tree grows to be 8 or 10 yards tall; it is covered with thorns and it bears so many flowers that when these trees bloom, they form together the most beautiful sight from a certain distance, because they appear like trees loaded with coral the color of scarlet. The pods are eaten when green, but are somewhat bitter. They are propagated by cuttings and root very quickly, and in a short time they grow thick trunks; therefore they use them for straight posts in the corners of the ranches. Hypericum angulare. Senecio scandens. Eupatorium scandens, yedra. Bidens cuneifolia. Lobelia decurrens, contoya. The Indians use the 
infusion and decoction of this plant as a drastic purgative, and when they want to stop its action, they drink cold water. Pistia Stratiotes, lechuga cimarrona. Passiflora minima, borbo cimarrón. Passiflora foetida L. Mimosa pernambucina L., cierrateputa, for the action of closing its leaves when the plant is touched. It is abundant in the grain fields. Mimosa punctata? L., tapateputilla. It is the most sensitive species that I have seen, for as soon as you touch a leaf with a finger or any other object, all the other leaves of the plant suddenly appear retracted and closed, so that in a whole afternoon I could not gather an open leaf between sheets of paper in spite of all the efforts I made. It is found spread on the ground where it is dry and sandy between the huarancales. The powder of its leaves is esteemed in Lurin as the best healing remedy for ulcers. Mimosa Inga L., pacae, is a very frondose tree of about 15 or 20 yards in height. From its thick trunk is obtained wood valued for various purposes, and the pulp of its fruits or pods is like white cotton, juicy and sweet, of pleasant flavor, and it is much esteemed by the fair sex because real of pacaes serves for entertainment at the holidays. Laurus Persea L., palto, is a very stout and frondose tree of about 12 to 28 yards in height. Its wood is valued for several uses, and the flesh of its fruits, called paltas, which is of a light green-yellowish color, is very tender, and buttery, and partakes of a flavor very similar to that of fresh nuts, especially if eaten with bread; but the more usual way to eat this fruit is to add some salt to it; nevertheless, it is very good with honey and not to be despised in salads. These fruits do not ripen so that they can be eaten until a few days after they have been cut from the tree; then they are seasoned. The largest and best paltas that are known in Peru are the ones from Sta. Olalla and Chavin. The seeds from the palta are used as astringent in dysentery and give a red ink that is indelible and is used by many to mark white clothes. The meat of this fruit relieves the burning sensation of piles when applied by itself to the parts and without the need for the addition of oil, saffron, and egg yolk that some people add to it. Sagittaria sagittifolia L. Gentiana Conchalaguala, conchaguala. It grows only six inches high and is found in the hills in the time of lomas or in winter. 


\section{CHAPTER V}

Stay in Surco-Plants collected and their uses-First shipment of plants and drawings sent to Spain (1779)-Shipment by Dombey.

\section{JOURNEY FROM LURIN TO SURCO AND TO LIMA}

On February 3, 1779 we went from Lurin to Surco without any misfortunes on the way. We stayed there until March 6th. During our excursions in the fields of Surco, a pueblo of few Indians and with some houses and orchards belonging to gentlemen from Lima, we gathered several plants, and among them I observed and described the following. Utricularia aphylla. Sagittaria dulcis, escobilla. Heliotropium pilosum. Cynoglossum pilosum. Ipomoea acuminata and subrotundifolia. Cedrela odorata L., cedro. A few trees of this kind are found transplanted from the forest. In some orchards they are up to 20 yards in height, leafy and beautiful for the short time that they have been planted. Illecebrum Achyrantha L. This plant is preferred to others for leaves in which to wrap fruits that mature or become soft, so that they can be eaten, such as the chirimoyas, anonas, huanabanas, paltas, lucumas, ciruelas de Fraile, plátanos, and so forth. Cynanchum racemosum?, piochas. Plant well suited to cover summerhouses and lanes in gardens as it spreads and tangles very much. Its milky juice is reputed to be a strong cathartic, and with the flowers women embellish their hair. Anethum parvum, heneldo cimarrón. This plant is used in place of the heneldo. Pancratium maritimum L., coronas de Rey and caribaeum?, pilillas. Women adorn their hair with both flowers; they are also used as ornaments in gardens. Achras mammosa, lucumo. Tree of about 15 to 20 yards in height, thick, leafy, and of beautiful green color; gives abundant fruit called lucumas, globose with a small point and weighing 4 to 10 ounces, green on the outside and with dark yellow flesh; the fruit cannot be eaten until a few days after they are gathered and covered with cloth, bran or chaff, plants, or other materials, to keep them warm and to start vinous fermentation. The wood is of excellent grain, flexibility, color, and resistance for various kinds of construction. Tropaeolum majus L., mastuercillo. This plant is used against scurvy, and the buds of the flowers are often pickled like capers. Innkeepers and people of refined tastes also add the flowers to salads, which attain a not unpleasant taste. Larrea glauca, Parkinsonia, and glandulosa. Poinciana bijuga, tara. Shrub, about 
4 to 6 yards high, of beautiful appearance when in bloom. Its pods are used instead of galls for making ink, and with them, as well as with the wood, they $\tan$ and dye leather. Triglochin palustre. Euphorbia hirta, hypericifolia, and Chamaesyce, yerbas de la golondrina. They make use of the milky juice of these three plants in Peru to destroy cataracts of the eyes, and with infusions they purge the bowels. Spondias Mombin L., ciruelo agrio. This tree grows to almost 6 yards, is a handsome tree with bunches of fruits called ciruelas agrias, which are bittersweet and not at all unpleasant to the taste. Cleome triphylla L. Cassia tenuissima, Malva coromandelina? Escoba cimarrona. Corchorus siliquosus L. Melochia corchorifolia L. Dolichos suberectus, Geoffraea spinosa L., azofaifo. Ageratum conyzoides, huarmi-huarmi, i.e. woman-woman, because of the property that this plant has of correcting menstruation. Bidens tripartita L. Sisyrinchium palmifolium. Acalypha indica L. Ambrosia maritima L., artemisa, which is used instead of Artemisia officinalis. Zizania octandra. Juglans nigra L., nogal de la tierra, native walnut; this is a tall tree, frondose, and with very good wood for many purposes. From its fruits, when they are tender, they make candies like those of limoncillos and from its small nuts, with honey, peanuts and other seeds, they make an alfajor of very good taste. Castiglionia lobata, piñoncillo: this shrub grows almost to 5 yards; it has leaves four months of the year; the rest of the time it is bare, but not of fruits, for these stay a long time afterwards, and each one of the fruits encloses three seeds called piñoncillos, a little larger than pine-nut kernels; they contain a small almond, white and sweet but very laxative, and for this reason people use them to play mean tricks, preparing them as candies or extracting the milk and mixing it with cow's milk so that the deceit cannot be detected. The way to check the bowels is by drinking a lot of cold water. Some have the habit of purging themselves with three or four of those seeds or almonds, especially those that suffer from venereal troubles. Even the boys know its properties, and it is perhaps to their curiosity and pranks that we owe our knowledge of this and many other plants. Erigeron philadelphicum, Samolus Valerandi, Psoralea capitata, yerba de San Agustín, de la Trinidad, del carnero, and huallicaya. In Peru they frequently use the fresh leaves of these plants to cleanse dirty ulcers and produce new flesh, and afterwards they heal them with the powder made of dry leaves.

We went to Lima to put in order the collections made up to this time, and we sent them to Spain in the vessel "El Buen 
Consejo" that left the port of Callao for Cádiz, in the month of April (1779). This first shipment of dried plants and other productions of the vegetable kingdom was composed of seventeen boxes of live plants, 242 drawings, and 11 boxes of dried plants in which there were included 300 different species.

On March 11, 1779 Dn. José Dombey left us to accompany Sra. Oydora from Lima, who was going to the baths at the thermal waters of Chiuchin. For this reason he asked me to ship together with our boxes, seven that he had packed with dried plants, hunqueros, and other curiosities from the mineral kingdom.

After we had made the shipment of 18 boxes and 17 containers of live plants, we asked permission and passport from the Viceroy to go to the forests of Tarma and Xauxa, for we had been informed of their fertility and abundance of rare and valuable plants. After securing everything that we asked and being equipped with all we might need for the trip, we decided to start on the 12th of May. 


\section{CHAPTER VI}

Journey to Tarma-Incidents of the journey-Yauliaco-Pucará-Dangerous ridges-The encañada of San Mateo-The province of Huarocheri-Fauna of the punas and lagoons-Flora-The parishes.

\section{FROM LIMA TO TARMA}

On May 12th, 1779 we left Lima for Tarma. We traveled 6 leagues and passed the night in a dilapidated ranch house, without undressing, for fear that we might be surprised by a band of negro bandits that were committing atrocities and robberies in that territory. The mosquitoes and fleas tormented us to their satisfaction.

On the13th we reached Surco,a town of the province of Huarocheri with a population of about 100 , without any other incident than the excessive heat and the plague of mosquitoes, over the troublesome and dangerous road that starts from San Pedro de Mama. On the 14th we passed through San Juan de Matucana, a town of about 160 people, and reached San Mateo, where the corregidores [magistrates] of Huarocherí of ten reside; we had walked long stretches on foot, along those dangerous inclines, ravines, and walks of steps made of small stones from the river put one on top of the other, without the use of lime, plaster of Paris, mud, or any other equivalent material to hold them together, so that in parts the road is a wall of stones brought together on the mountain side and the top is covered with soil tramped down by foot. If one stone gives way on those roads, it is certain that the rest will follow, likewise any beast or person traveling there at the moment.

On the 15th we waited in San Mateo for the mayors and other persons that were at their little farms, so that on the following day they might give us beasts of burden; we finally obtained them by force of insistence with the mayors, and at eleven we left San Mateo and passed the night at San Juan de Chicla.

On the 17th we were informed that the muleteers and peons that the mayors had given us had gone back to San Mateo taking with them three transport mules, and we were left with only one muleteer unable to load-and conduct so many loads of baggage over those roads. Although we were in a district of 60 people, we found only with great difficulty three pack mules instead of those that had been taken by the muleteers to San Mateo. After having searched in all the ranchos of Chicla, we found only one man that was going to the mill at Yauliaco; we asked and begged him kindly to help 
the muleteer to load the beasts, which he would not do until we used force and threats; then we all helped those two men to load. We again begged the Indian to accompany us to the next town with the loads, paying him in advance what the muleteer told us to pay him, but we were unable to make him take even double pay. We had walked barely 50 yards when the Indian that we had begged and forced to aid us disappeared; for this reason we all had to act as muleteers until we reached Yauliaco, where the Indian had preceded us and told the mayordomo all he pleased about us. This man came with several Indians to the road, and he had the first load that came along brought to his room and unloaded to pay for what he thought was our insolence in forcing his worker to help our muleteer. My three companions that reached Yauliaco first, received the volley of threats from the mayordomo and, being unable to contradict him, they decided to abandon the load and to continue on their way.

They were already about one-eighth of a league distant when I arrived at Yauliaco with the last loads and, finding the mayordomo with the two chests by his side and surrounded by all his workers, I greeted him with courtesy and asked him what those chests were doing there; he answered me with such imperiousness and such words that the whole world seemed too small for him at that moment. Thinking that he was Andalusian, I answered him even more strongly, and I told him all that had happened to us, and he not only yielded but begged me to call my friends and pass the night in the rancho, and he promised to give us for a guide the Indian that had caused all the trouble, and all the aid that we might need to continue our trip. The good Vizcayno, ashamed of that Andalusian temper, served us an excellent supper and breakfast, and next day he provided us with the three mules required, taken from the field, and the same Indian to help the muleteer. So ashamed was this mayordomo that he did not dare dine or breakfast with us, as we found out later from his employer, Dn. Pablo Carreras, owner of that mill.

On the 18th we left Yauliaco with only two muleteers. We crossed the snow-covered ridge of the cordillera without mishap, although with some difficulty, because of the small number of muleteers for so many loads. We had just reached the punas when night descended, and for that reason one of our mules was stuck in the mud and drowned with two loads in a channel of Lake Huacracocha, where the ford is. At that time, notwithstanding 
the excessive cold, my servant went in to cut the straps from the loads, and with a rope we succeeded in getting them to solid ground where we left them, and we walked alone through those punas and where the mules wanted to take us, until, stumbling here and falling there, we came to Pucará at 10 in the evening very cold and very hungry. At 11 at night the miners of Pucará sent two men and two he-mules to bring the chests that had been left on the banks of the laguna, and they returned at 12:30. The 19th we stayed in Pucará so that I could dry in the sun my clothes, books, papers, and so forth, all of which I found tinted with several colors that the artists had put in loose in papers in the chests at the time the clothes were packed.

In all these silver mines that are found from San Juan de Chicla to Pucará and that are in very cold mountains and punas, they use the llamas or sheep of the region to carry the metals from the mines. Instead of wood they use champas or turf that they get from the swamps in which many plants grow, very small although with many-branched, strong roots which, with the soil that they hold, form a kind of material suitable for fuel; but it gives off much smoke of a very unpleasant odor, and harmful especially to persons not used to its odor and continuous smoke, because it produces a a choking sensation with bad headaches and irritation of the eyes, and causes nosebleed and inflammation of the throat when one goes out into the fresh air to get rid of the headache.

In the midst of all these difficulties these men live engaged in extracting the treasures hidden under the snow in these mountainous regions.

The most common plants that exist in these damp places from which they get champas, are gentians, geraniums, valerians, and some grasses, all very small plants that spread or adhere to the spongy ground; the beasts become stuck there very easily, and then one sees the water that is covered with the champas.

We four travelers left Pucará on the 20th, with headaches, watery eyes, rash on the face, and open or cracked lips, and more or less dizzy from the smoke that is continually present in all the rooms of the houses.

At a distance of about half league from this smelter, we passed a short natural bridge formed by the waters of a brook that passed under it. Another half league from the hacienda Pachachaca we crossed a plain called Chaplanga or Chaplamha that extends more 
than 600 feet in length and as many in width. It is so level that a a brook of very clear, petrifying water extends and runs over all of it, and it is no doubt this quality that has made it form that gentle and beautiful cascade, which looks like a single piece of porcelain made and placed there on purpose. At a few feet from Chaplamha there is another natural bridge under which the water of this cascade runs rapidly, and the water from the brook of the former bridge and from many other small brooks that descend from the cordillera and punas. A little ahead, this brook unites with the famous river Pari, the first bridge over which is of rope or cables, so that with pulleys they pass the people in a wicker basket or in a sack of leather from one side to the other. At 8 P.M. we reached the Puente de la Oroya, built with cables made of hide and thin vines. Beasts cannot be transported over this bridge, so that it is necessary to carry all the loads on the shoulders and leave the burdened animals to cross the river swimming; we started this work at such a late hour that bunches of ichu grass, with which the two roofs at the entrance of the bridge were covered, served us for lights. Before we passed the loads, one of the party tried to get a mule across the bridge, and as the hole where the cables are fixed had only two boards, the mule fell in, and to get her out of it required more than an hour; for this reason the others were taken across at the ford and, as the river runs so rapidly, one of them was drowned. It took us three hours to take the loads and saddles across the bridge, so that it was 12 when we arrived at the pueblo of Oroya.

The above-mentioned bridge is about 40 yards in length and less than two in width. When one crosses, it shakes and swings from one side to the other so that with the noise of the river below, it causes terror even to think of crossing it at night.

On the 21st, because the alcalde of San Mateo had sent us some more muleteers who joined us before we reached the bridge of Oroya, we four travelers were able to set out from this pueblo at daybreak and entered the pueblo of Tarma, capital of the province of that name, leaving the loads to the care of the muleteers that arrived next day without any trouble.

On this trip we suffered many hardships and repeated tragedies, as may be inferred from what has been said already and, to complete our tribulation, after two mules had been lost by drowning, another was stolen the day the muleteers arrived at Tarma.

All the way and specially around the quebrada of Huarocherí we collected many of the new and rare plants which cover the margins 
of the canõn river and the frequent little brooks and falls that drain into that river, with which we shall deal later.

From Lima to San Pedro de Mama, the grounds of which are level on both sides of the river, you find in succession farms or plantations of sugar cane, alfalfa, sweet potatoes, potatoes, cassava, yacones, squashes, porotos or beans, maize, figs, plantains, and many other seeds and fruit trees belonging to the country, which make all of that large, luxurious meadow handsome and delightful.

From Chaclacayo to Cocachacra one can see, on the sides of the hills, the ruins of several towns of the gentiles, most of them showing that they had had but few houses. Near Surco, there is a little brook that passes through the road and comes from a small cut in the hills, and the natives assured us that the water of this brook causes the sickness there called verrugas [papules] and is contracted especially by those who, sweating, drink of it.

From Lima to Cocachacra the hills on both sides are arid and bare, so that in most of them one cannot find a green thing at any time of the year.

In the cañon from San Pedro de Mama to the cordillera, night comes one hour earlier and dawn an hour later than in the heights and open places, because of the elevation of the mountains and the narrowness of the gorge; into its depths the sun does not reach until 9 or 10 in the morning and is concealed by the lofty crests at 2 or 3 in the afternoon. While the rays of the sun pierce the depths, one feels such an excessive heat that it would be intolerable to walk in the gorge if it were not for a fresh breeze that comes down from the mountains at the same time almost daily, tempering and at times refreshing the whole gorge.

From Cocachacra on, the mountains and hills are covered with various herbs and shrubs all year round, and in its valleys potatoes, beans, corn, and arracachas are planted and harvested. The climate of this gorge is generally mild and healthy; nevertheless, there are some places where the people suffer from tertians at the beginning or at the end of the rains, the seasons for which should be called autumn and spring. The Indians cure themselves of this and other maladies with herbs administered by themselves because there are no doctors or surgeons.

From Surco to San Juan de Chicla, as the valley is very narrow, there are very few farms and properties, except small fields of alfalfa, 
maize, potatoes, abas, and okas. From Chicla on, one finds only a few rows of green barley that the miners plant to feed to their animals.

The road in this gorge is, throughout almost all of its length, very narrow and dangerous, since it is near the river bank, and as this river comes from the mountains to San Pedro de Mama by such a narrow cut and with such velocity that it forms an almost continuous waterfall, in parts it is made frightful by the noise and concussion of the water against the great rocks that are found in the middle of the river, so that it is impossible for travelers to hear each others' questions even if shouted, and with the fog or mist and small drops of water that are scattered in the atmosphere and around the circumference of the big rocks, necessarily, travelers cannot avoid getting wet in many places along the way. In some places the falls of the river are so serene and beautiful that they charm and distract the imagination with the foamy, smooth water, which at a distance appears like pure snow that is always in movement or in total repose, forming extraordinary and beautiful designs.

Among the various declivities and narrow passes of the road there is one called Punta de Diamante, situated between San Juan de Matucana and the tambo called Viso. This declivity is so steep and narrow that one shudders at crossing it, and the animals have to climb it at a run and stop from time to time at the small offsets to rest and recover their breath in order to continue to the summit. If any person or animal should fall from this declivity, it would be useless to look for him, for the force of the fall and the pounding of the waters against the rocks would mangle him completely.

Many pieces of the road are formed from small rocks put one over the other from the border of the river to the top of the road, which, if any stone from its foundation should become dislodged, would be entirely ruined. The resistance of these roads is particularly worthy of admiration, as the rocks are not cemented together with any lime, gypsum, mud, earth, or any other material used for that purpose, and they resist-those tall pilcas or walls-the pounding of the water and have endured since the time of the Incas unto the present with no other care than some repairs when needed.

In this gorge of San Mateo there is an abundance of a species of little parrots and other birds that with their singing and variety of colors help to amuse the curious traveler and offer him distraction from the sadness caused by that long, narrow, deep, and murky gorge. 


\section{DESCRIPTION OF THE PROVINCE OF HUAROCHERI}

This province borders to the west on the jurisdiction of Cercado, which begins five leagues from Lima. On the north it is bordered by the provinces of Canta and Tarma and on the east by that of Xauxa. It is 30 leagues in length and 6 in width. It has two distinct climates: one more or less temperate in the valleys, gorges, and cañons, and the other more or less cold in the mountains, punas, and cordilleras.

In the encañadas and temperate lower elevations as on some slopes of the hills, they cultivate various roots, fruits, and seeds such as potatoes, sweet potatoes, arracachas [apio], yucas [cassava], yacones, okas, ullucas, massuas, plantains, pacaes, paltas, palillos, guavas, lucumas, chirimoyas, soursops, membrillos, and frutillas, corn, abas, and porotos or beans. Alfalfa is never lacking in this district, and in those places that, even if they are valleys, are near the punas and cordilleras where frigid temperature does not allow the production of alfalfa, it is replaced by alcazer, which can be planted in some punas, but must be in enclosures made for this purpose within the towns.

The mountain ridges are barren and during the greater part of the year are covered with snow; for this reason there are very few plants that can be seen in the crevices of the holes and rocks. In the punas the grass and the ichu are abundant, and support great flocks of sheep and many herds of cattle and horses, and the great number of llamas or native sheep which, as has been said before, the miners use to transport metals from the mines to the smelters which are always situated in the creeks and cañons.

In the punas there is an abundance of vicuñas and huanacos and a species of rabbit called viscacha [chinchilla].

There are many lakes in these punas; one of the largest is that of Huacracocha, which is three quarters of a league in length and about one league in width. In some of these lakes there are fish called vagres and cachuelos, both delicious in taste. There is an abundance of several species and kinds of birds, such as the huachas (the maw of which applied to cotos or goitre, the Indians affirm has the virtue of dissolving it), ducks, swans, freguilles, sarapicos dominicanos (a kind of eagle), condors or vultures, neverillas llorones or burladores, because they moan and later make a sound as if they were laughing heartily. These and the ducks always inhabit the lakes; the birds of prey are found in the rocks and punas; the swans, 
sarapicos, neverillas, freguillas, and huachas are always near the border of the lakes and swampy places.

Near the towns some other birds are found, such as cascabelillos, papamoscas, zorzales, and gorriones or pichuisas, and one species of aloica or calandria.

Some small lakes that are met before one reaches Tuctu, give rise to the Lima river, and others empty by way of the provinces of Yauyos and Cañete, and swell the Mala river, which like the Lima has its outlet in the southern sea; the little brook of Sta. Olalla joins the Lima river near San Pedro de Mama. The remaining lakes of this province empty their waters to the north and form the voluminous Parí river.

In the quebradas and heights are found various medicinal plants, some of which are taken to Lima to be sold, such as the authentic and true calaguala, the quinchamali, salvia, excorzonera, puma, and santra, and several others of which they make frequent use.

In the gorge of San Mateo de Matucana, 3 species of loasas abound, 2 calceolarias, 2 celsias, 2 saxifragas, 2 chilcas or molinas, 2 mespilus, 1 ferraria, 1 tropaeolum (which is cultivated and the root is eaten), 1 duranta, 1 talictrum, 1 fuchsia, 2 euphorbias, 1 buddleia, 1 sapium, several species of cactus, and various other plants of the Diadelphiae, Syngenesia, and Cryptogams, of which individual mention will be made in the Flora Peruana.

Among the different silver ores of exquisite purity, the most abundant are found in Pucará and in the Cerro del Nuevo Potosí that is situated in Saulí, where there are thermal baths.

Between Cocachacra and Surco, there is, as has been stated before, a brook that drains into the Lima river and the waters of which produce the trouble called verrugas. On the way between Pucara and the Parí river, there are two small bridges of one arch each, cut by nature in the rock, and a plain called Chaplamha, as is told in the account of the journey from Pucará to Oroya.

This province is divided into eleven parishes that are: The 1st, that of Huarocheri with two annexes named Calahuaya and Allocá. The pueblo of Huarocheri is the head of the district. The 2nd parish is that of the pueblo of San Lorenzo de Quintí with the four annexes of Huancayre, Quintí, Tantaranchi, and Carhuapampa. The 3rd is that of the pueblo of Olleros with the annexes of Mactara and Chatacancha. The 4 th is that of the pueblo of Chorrillos with 6 annexes, viz.: Chontay, Cochahuayco, Huamansica, Sisicaya, Langa, and Lahuaytambo. The 5th parish is that of San Cosme and San Damian, with the annexes of Sunicancha, Tupicocha, and Santiago de Tuna. The 6th is that of Sta. Olalla [Eulalia] (where they grow beautiful and large paltas [avocados], chirimoyas, and other fruits proper to 
that country) with four annexes: San Gerónimo de Punan, Chaclla, Xicamarca, and Collata. The 7th that of Carampoma with the annexes of Laraos and Huanza. The 8th is that of Sain Pedro de Casta with four annexes; San Juan de Iris, Huachupampa, Chanca, and Otáo. The 9th, San Juan de Matucana (pueblo of 160 inhabitants) with these annexes: Surco (town of 100 inhabitants), Nangos de Cocachacra or Cochacra, San Pedro de Mama, San Bartolomé, and Sta. Inés. The 10th parish is of San Mateo de Huanchor. This pueblo, which is usually the residence of the mayor, is divided into two suburbs called San Antonio and San Mateo and has 100 inhabitants. This parish has 3 annexes, that are those of San Miguel de Viso, San Antonio de Yauliaco, and Pumacancha. Between this pueblo and San Mateo is found a district named San Juan de Chicla with 60 inhabitants. Some say it is a pueblo, but others say it is only the residence of Indian peons that come from other towns to work in the mines.

The 11th parish is that of San Antonio de Yaulía with 13 annexes, namely: Pumacocha, the Asiento de Carahuacra, Pucará, Pachachaca (past Pumacancha are the haciendas de Ingenio, called Bellavista, after which come Ciricamcha, Yauliaco, Yanacolpa, Tingo, Casapalca; on the right-hand side one leaves Piedra Parada, and beyond the ridge of mountains and in front of Pucará is the Ingenio de Tuctu), Santa Rosa de Yaco or Saco, Concepción de Pacha, San Cristobal de Hucumarca, San Francisco Solano de Trapiche, San Gerónimo de Callapampa, Santiago de Huayhuay, San Antonio de Huarí, and San Lucas de Chacapalpa.

The Indians of this province occupy themselves with mules and work in the mines. The women generally work the fields, though at the time of planting and harvesting the husbands help them.

These women, on church holy days, take care of decorating the altars and saints with flowers from the country and others that they grow in the little gardens around their houses.

In each town there is usually no more than one church or chapel with 3,4 , or 5 altars. 


\section{CHAPTER VII}

Stay in Tarma-Plants found in this province and their medicinal valueLandscapes-The convent of Ocopa.

\section{ESTABLISHMENT OF THE BOTANISTS IN TARMA}

On the 21st, as soon as we arrived in Tarma and since the governor of the province was absent from the town, we went to the house of the comandante, Dn. Francisco Gómez de Toledo, to ask for quarters, which he arranged for immediately and with great activity, entertaining us that night and the next day at the table in his house.

On the 23rd of the same month of May, 1779, we wrote to the governor, Dn. Juan José de Abellafuertes, who was at Pasco, giving him notice of our arrival and the object of our commission, so that with his consent we could go in search of plants in every place in that province and be helped with food and beasts and all other necessities for the excursions and journeys that we began on the $26 \mathrm{th}$, and continued to the 24th of April, 1780, through the cuts, cañons, and hills of Tarma and through the montañas of Huasahuasi and Palca. During this time we discovered a considerable number of trees, shrubs, grasses, and herbs, many of them of known uses and virtues, all of which will be described extensively in the Flora of Peru, and I restrict myself here to indicating their generic and trivial names and the Indian ones, if they have any, together with their medicinal and economic uses.

\section{PLANTS DISCOVERED AND DESCRIBED IN THE PROVINCE OF}

TARMA AND IN THE FRONTIERS OF ITS MONTAÑAS

Cassia undecimpiga, setacea, procumbens, and hirsuta, the first two known by the names of hatumpacte and pachapacte. These have been used for a long time as purgatives, and their leaves are preferred to those senna leaves brought from Lima for the same purpose by the doctors. Celsia (affinis) lanceolata, huayansacha. Solanum calygnaphalum, nuñumya. Solanum lyciodes, foetidum, ama de casa, aserplanatum, sericeum, quercifolium, menhas, havanense, and tomentosum, hormis. Saxifraga tridactylites L., puchuppus and siempreviva. Bignonia stans L., ciarhirachero. Limosella subulata. Eupatorium aromaticum, chilca. They use this plant to dye green and yellow, and the pounded leaves are used to clean and heal ulcers and, above all, to soothe bruises and sprains. Buddleia incana, quisoar, quishuara, and colle, the trunk of which is used for buildings 
and plows, for its strength and durability and for the peculiarity of being resistant to insects. The Indians boil the shoots and drink the water as a cleanser for viscous humours and for colds, and from the pounded shoots, with urine, cooked over the fire, they form a poultice to banish toothache, applying it inside and outside. Some people color their food with the little heads of the flowers.

G. n. Polygala aff. caerulea, chisp-huinac and pahuata-huinac, that is, grows at night. The women wash their hair with an infusion of this plant, rubbing it in water because its soapy substance cleans the hair and makes it grow if the infusion is used frequently. Gardoquia canescens, sacconche, suyunmpai, and chinchi. They make use of the infusion or decoction of this fragrant plant, not only in Tarma but also in Lima and other places, against melancholy, pain in the sides, and lassitude, for which it is boiled in wine or rum with water. Psoralea punctata (Dalea? L.), with which some of the hills are covered, forming a beautiful carpet with the green of its small leaves and flower spikes, exhaling a certain pleasant odor when the sun shines upon them in the morning. Sisymbrium Sophia L. This plant is very common in this province and in Huamalíes. It is greatly esteemed by some for the virtue they claim it has against the retention of the urine. They give it the name of ucuspatallan. Hedyotis conferta, thymifolia, juniperifolia, and setosa. Krameria triandra, pumacuchu and mapato. Briza media L. Sedum ceallu, ceallu, for the likeness of its leaves to the human tongue. They use the juice of this plant to destroy cataracts of the eyes. Salvia grandiflora, plumosa, and fragtostissima, chenchelcoma and salvia menor. Salvia sagittata, huarnica and salvia real. Some Indians eat the leaves to prevent worms. They attribute remedial virtues to this plant in asthma and as a pectoral, and they think that it makes sterile women fecund. They use it as an aperitive plant, diuretic, vulnerary, consolidant, and as a restorative of the appetite.

Periphragmos uniflorus. This shrub is found only at the edges of orchards and plantations near the towns and in the ruins of the towns of the pagans, who because of their superstitition regard it as a magic-plant; but today the Indian women decorate the church altars and saints with bunches of these flowers. Panicum purpureum. Lupinus argenteus, quitatauri. Passiflora ciliata, urra-purupuru. Passiflora mammosa and biflora. Pteronia spinosa. Rhinanthus sagittata and glutinosa. Polylepis emarginata, quinhuar or quinuar. The trunks of these trees are used by miners for 
the beams of their factory buildings. It is a very strong wood and is not spoiled by borers. Its bark peels off in many layers thin as sheets of paper. Tillandsia recurvata, revoluta, coarctata, Huehle, huehle, and usneoides L., salvagina and sadcopra, millmahina and cotalaura. The Indians make great use of this plant in hot baths to invigorate the nerves, to recover lost strength, and to induce sleep. They make mattresses with the leaves, because they claim that it is shunned by fleas and other insects and that moreover it benefits those who suffer from backaches and kidney trouble. They apply this plant, pounded and with lard, to cure piles. Astragalus capitatus, garbancillo. Animals die that eat too much of this plant. Cleome glandulosa, tacma. Lycium obovatum, espino. Senecio nitidus, revolutus, abrotanifolius, frutescens, and quercifolius. Acaena ovalifolia and lappacea. Cacalia serrata. Polypodium serratum, lineare, Calaguala, fine callahuala which is the true and authentic calaguala of the shops and the Polypodium incopcam, cuca-cuca and incopcam that is, coca of the Inca, because the Incas used it instead of coca. Reduced to powder it is used to induce sneezing and to relieve the head. Polypodium crassifolium L., puntu-puntu and lengua de ciervo. They make use of the infusion and decoction of these roots against pains in the sides, and they are gathered in Peru to send to Europe under the name of calaguala gruesa. See my discourse about the calagualas included in the 1st book of the Memoirs of the Royal Academy of Medicine of Madrid printed in 1796. Acrostichum palmatum, Marantae L., and Cuacsaro, cuacsaro. See the same discourse about this plant. Pteris ternata, culantrillo, lineata, triangulata, tomentosa, and trifoliata. Polypodium coronarium, exaltatum, erecto-lineare, fibrosum, glabrum, nutans. Phylitidis L., repandum, revolutum, rhombeum, obovatum, scolopendroides L., and virginianum L. Acrostichum revolutum, lineare, and calomelanos L. Asplenium caudatum, falcato-lineare, multifidum, and lineatum. Adiantum capillus veneris L. Trichomanes crispum, lineare, and obovatum. Lycopodium corymbosum and lanceolatum: Polytrichum subulatum. Bryum nitidum. Lichen ruber, subulatus, cinereo-viridis, multifidus, oculatus, palidoviridis, and pyxicatus L. Sessea dependens. Munnozia trinervis. Justicia incana. Margyricarpus subfructicosus, yerba de las perlillas, for the resemblance of its sweet and tasty fruits to pearls. On the coast of Chile they are abundant, also Plantago hirsuta and tomentosa. Acrostichum squamato-tomentosum, nitidum, sulphureum, obovatum, squamatum. Asplenium cultrifolium, obovatum, praemorsum, fissum, acutifolium. Hemionitis rigida. Lycopodium subulatum. 
Cervantesia tomentosa, whose fruits, that resemble the hazelnut in taste and size, I ate several times without any harm, although they are not used for that purpose in that country. Datura sanguinea, floripondio encarnado and puca-campanilla. This tree is very beautiful because of the abundance of its large red flowers. Its leaves have emollient and anodyne properties, and its seeds stupefy and cause insanity, and the natives say that some people have become crazy by merely going to sleep under its shade. Galium mucronatum, croceum, corymbosum, and ciliatum. Calceolaria scabra, uniflora, tomentosa. Peperomia pubescens. Valeriana lanceolata, huarituru. Its roots are used to heal fractures. Valeriana thyrsiflora, coronata, pilosa, interrupta, globiflora, and oblongifolia. Pinguicula stellata. Ipomoea subtriloba, papiru. Its tuberous root is used as a very strong purgative. Jarava Ichu, ocssa and ichu. In Huancavelica they use it in place of firewood to melt cinnabar. When tender it furnishes excellent pasture for cattle, llamas, vicuñas, alpacas, venados, and huanacos-all ruminant animals. They use this grass as roofing for buildings and they fill mattresses with it; it is also used as fuel for cooking and for warmth for, even if it is green, it burns very well and gives good heat. Finally they make it into rugs, mats, and many other similar things. Anchusa alba. Gomphrena purpurea. Atropa biflora. Saracha biflora, the small fruit of which is eaten by children. Gardenia spinosa, milluscassa. Oenanthe? pedunculata. Celastrus triflorus, rurama and picma. From its wood they make carpenter tools because of its strength. Anemone digitata, arracacha cimarrona. Dichondra repens, fragosa, crenata, multifida, reniformis, frutilla de monte, for the similarity of the leaves with those of the strawberry. Anemone pubescens, polizones. Gentiana maculata. Caucalis grandiflora. Viburnum verticillatum. Rhamnus acuminatus. Lithospermum aggregatum and incanum. Cynanchum minimum and glandulosum. Asclepias cordata. Illecebrum lanatum. Achyranthes mucronata. Sambucus glandulosa. This small tree can be found only in the mountain towns, and they use it as they do Sambucus nigra. Stereoxylon resinosum, tiri encarnado and chachacoma. Its shoots are used to dye red and purple. Gentiana biflora, subulata, umbellata, and quinquepartita. Desfontainia spinosa. Alchemilla pinnata. Nicotiana Tabacum, true tobacco. Varronia rugosa and obliqua. Tournefortia polystachya and virgata. Nerteria repens? It is very abundant in Chile near Concepción. Pancratium coccineum, margaritas encarnadas. Crinum? sagittatum, margarita. Pancratium viride. Its flowers are all green, like half of those 
of the white lily. Berberis mucronata and tortuosa. Hydrocotyle asiatica L. Ribes luteum and dependens. Swertia corniculata. Loranthus luteus and pentandrus. Piper scabrum and Churumayu, churumayu. Cynoglossum revolutum. Triglochin ciliatum. Chenopodium tuberosum, ulluco. Its roots are used as food, and its decoction serves as an expectorant and is claimed to make childbirth easier. Astronemia linearis. Ornithogalum pyrenaicum L. Cyperus striatus. Tropaeolum tuberosum, massuas, the tuberous roots of which are cultivated and eaten in Peru and are of an inverted conic shape and of a golden or yellow color. Dodonaea viscosa L., chamisa and chamassa. Its crushed leaves are applied effectively in poultices for sprains, and its trunk and branches are used for fuel in Tarma and many other towns. Alstroemeria trifida, pini-pini, coccinia, spiralis, capitata, and crocea, chocllocopa. Coccoloba nitida and volubilis, muyaca. The infusion is used as a superior diuretic in urinary troubles. Gualtheria cordifolia, alba, hirsuta, rhinnin cussau. Columellia ovalis, ullus and usluss. A very bitter shrub, wonderfully effective against tertian fevers. Used as an infusion. Fuchsia apetala and verticillata, mollocanto; its ripe fruits are eaten by children, and they often make of them an excellent preserve with sugar. Embothrium emarginatum, catas and mastimpanrani, i.e. priapus simiae, for the shape of the pistil and follicle, very similar to the genital parts of monkeys. Its pounded leaves are used for bruises; from its flowers the Indian women form sprays to decorate the altars and arches that they erect for processions. Vaccinium biflorum. Rhexia repens, ola-ola and olla-olla. It serves as a yellow dye if mixed with other plants. Rhexia hispida. Weinmania oppositifolia. Arbutus multiflora. Andromeda affin. purpurea, macha-macha. Its fruits eaten in excess are intoxicating; for this reason they gave it the name. Vaccinium affin. trinerve, punctatum, grandiflorum, uchu-uchu, i.e., aji-aji or pimiento-pimiento, for the shape of its corollas, nitidum, lanuginosum, and alatum, pucssato. Its fruit is eaten and is often sold in the market by the Indian women. Polygonum subulatum. Portulaca pilosa. Cuphea cordata. Acunna oblonga, rosa-rosa. Psychotria coerulea. Cacti species variae. Potentilla prostrata. Rubus biserratus, salvifolius, and fructicosus L., siracas. Geum urbanum L. Loasa spiralis. Vallea cordata, cunhur. Rubus roseus, chilifruta. Psidium nitidum, aseca. Duranta plumosa, and tomentosa, sanacassa and tantarprieto. Gardoquia conferta. Rhinanthus rugosa. Thalictrum polygamum L. Bartsia hirsuta, purpurea, and prostrata. Mespilus uniflora, ferruginea, prostrata, 
and subspinosa, millucassa. Its fruits are eaten. Geranium filiforme. Sium biternatum. Hedysarum pubescens. Ruellia prostata. Cytisus purpureus. Hypericum subulatum, chinchanho. This plant is generally used as a yellow dye. Eupatorium angulatum and trinerve. Tagetes odoratissima, chinchi. Bidens nasturcifolia. Artemisia hirsuta. Lantana involucrata. Aster pinnatus, tomentosus, auricularis, foliaceus, vira-vira del monte. Hieracium triflorum. Gnaphalium trinerve, and Vira-Vira, vira-vira, i.e. gordura-gordura, since the plant is crushed and used for contusions and sprains. Melastoma tomentosa, tiri blanco. This plant is used to make a yellow dye, the color changing with the addition of other plants. Molina scabra, taya. They make great use of this plant to fumigate the rooms, and the Indians employ it also as a superior stomachic. Helianthus glutinosus and lanceolatus. Molina uniflora, ferruginea, caespitosa, and obovata, taya hembra, and emarginata, taya macho. The same use is made of these species as of the preceding. Eupatorium subsessile and Huaramachia, huaramachia. Pteronia? gemina. Polymnia resinifera, puhe and taraca. This plant is plentiful in Xauxa, Chaclla, and Tarma, where many gather the resin that exudes in transparent white drops which, when reunited, form a compact mass that loses its transparency but not its odor, similar to that of the goma de limón. They apply it as a plaster for fractures and headache. Bacasia spinosa. Atragene villosa. Perdicium lanatum. Cosmos laciniata. Bidens pinnato-multifida. Ranunculus cordatus. Virgularia revoluta, mancapagui. Talinum ciliatum. Viola obliqua, parviflora, and subulata. Lobelia purpurea, tomentosa, purpureoviridis, and bicolor. Maxillaria alata, bicolor, tricolor, grandiflora, and cuneiformis. Humboldtia aspera, spiralis. Masdevallia uniflora, rima-rima. Epidendrum maculatum, croceum, volubile, emarginatum, biflorum, triflorum, acuminatum, lineare. Gongora quinquenervis, angulata, uniflora. Sobralia dichotoma. Cypripedium grandiflorum. Satyrium album, luteum, bicolor. This family of orchids is so plentiful in the quebradas of Huasahuasi and Palca, that it would be difficult to find any other place in which there are so many plants of this kind, for it appears that nature has destined this land for that purpose since the beginning of creation.

Notwithstanding the variety and abundance of these plants in these parts, there is no lack of many other species at the other entrance to the montaña of Panatahuas, and even in the actual mountains they grow upon the trees, rocks, and sunburnt ground. 
This family deserves a monograph upon these localities, and the number of species would probably be more than 500. Among the maxillarias there is bicolor which is called cacca, that means pavement, because the land is so covered with its bulbs that it looks like a pavement placed there on purpose. These bulbs are so juicy and tender that they can be chewed very easily, and they give so much tasteless juice that six of them are sufficient to quench the thirst; the Indians do this very frequently when they pass through those places in order not to go out of their way to drink in the depths of the quebradas. Plazia conferta. Cissus obliqua. Croton pulverulentum and striatum. Siegesbeckia occidentalis L. Clusia? thurifera, arbol del incienso, for its exuding resin that is used in Peru for incense. Sepium nitidum, chichis. Coriaria pinnata. With the racemes of this plant the Indians dye their cotton and wool. Aralia aff. digitata. Myrica sternutatoria, tuppassaire and ssaire. They use this shrub to dye cordwain black, and its pulverized bark makes one sneeze immediately on snuffing a little powder instead of tobacco. Although this powder excites speedily to ten or twelve sneezes without pause, it does not irritate or harm the nose as do other excitants, for when the nose is blown and wiped with a handkerchief, the sneezing stops and the stimulus also. It has been found that this powder clears the head and relieves headaches, etc. Sisyrinchium luteum and purgans, ossca purga and paja purgante, for the value of its roots used by the Indians as one of the best and most active purgatives. Its action is restrained by simply drinking cold water. Urtica spiralis. From the incisions and cut branches of this little tree there flows a clear gum like gum arabic. Urtica orbicularifolia and fumans. When the rays of the sun strike this plant in the morning, it expands such a multitude of flowers that the fine dust from the anthers fills the air as if it were a dense pall of smoke, remaining for more than two hours, and during this time it continues to open flowers and anthers with marked elasticity greater than that of the other species of the genus. Ephedra distachya L. Atriplex monoica. Betula alba L. Salix pyramidalis. Viscum luteum and sessile. Lycopodium dichotomum. Mutisia acuminata, chimchiculma, chincumpa, and huincus. It is a beautiful flower for gardens because of its size and color.

On the 13th of June the peons and train of pack animals in the company of Dn. Juan José de Avellafuertes left the pueblo of Tarma, governor of the province, to join the peons that P. San José, Apostolic missionary of Ocopa, had taken with him on the 10th, and also the P. Guardian of this convent, who had started from Tarma on the 
11th with the idea of opening the road to Chanchamayo that was impassable for many years, because the inhabitants of that town had moved to Tarma after the last invasion by the Indians, and also with the idea of establishing a fort with a corresponding settlement such as there had been formerly.

On the 27th of July I went with draftsman Dn. Isidro Gálvez to the province of Xauxa, two leagues from Tarma. We found in ruins the conspicuous castle of Tarmatambo, from which can be seen the ruins of a pueblo of the pagans that is situated at the very top of a hill. By this castle passes the royal highway of the Incas that runs from Cuzco to Quito. We continued by this road a long way and, leaving it after about two leagues, we turned to a wide, barren plain or pampa of more than half a league and, crossing a hill, we came to another pampa of more than one and a half leagues, at the end of which there is a spring of abundant clear, cool, soft, and very fine water, that probably comes under ground from a lake that can be seen on the right-hand side of the road and about a quarter league distant. With this water they irrigate two small quebradas where they raise wheat and barley. From this spring we passed to a wide plain very fertile in grass with which they feed great numbers of sheep, cattle, horses, and pigs. Afterwards we entered another plain also abounding with pasture. Having passed a small ridge, we crossed the little brook that comes from the spring already mentioned and came to a pampa in which there is a lake about one league in length and a quarter of a league in width. At the left-hand side of the lake are seen two towns, and various haciendas extend all over the pampa, which on account of the climate produces nothing but pasture that, although it is scanty, is good for the cattle. There are, in this lake, an abundance of totoras or eneas and various aquatic birds. At the end of this pampa one goes down to another lake almost as large as the last, but with less water and more marshy and muddy, and at a short distance there is seen the pueblo of Xauxa, the capital of the province of this name, where we stayed for the night.

On the 28th we went to the convent of Sta. Rosa de Ocopa, six leagues distant from Xauxa, passing through the pueblos of Mojon de San Lorenzo and Apata, in the vicinity of which a small lake is seen to the west. We arrived in the convent after midday, and we used the afternoon to inspect that magnificent construction and to examine the neighborhood with the purpose of discovering a few new plants, distinct from those produced in the province of Tarma, 
but we scarcely found any that were different; among them abound the true calaguala, Calceolaria linearis, and Polymnia resinifera or taraca.

\section{DESCRIPTION OF THE CONVENT OF OCOPA}

The convent of Sta. Rosa de Ocopa is situated at the foot of some hills, not very high, that border on the montañas of the pagan Indians, in a beautiful plain guarded by the hills that form a cove in the form of a half-moon.

The architecture of this convent is of the best that is found in Peru. It is whitewashed inside and out. It is surrounded by tall and luxurious alders at the facade, which is of excellent modern architecture. It has a spacious court with various rooms for the travelers that come for religious exercises, and at the rear it is adorned by a beautiful garden with an abundance of excellent vegetables. In the interior there are two cloisters, each one with its little garden of different flowers and aromatic plants of Europe and of the region.

In one of these cloisters there is painted the life of Saint Francis of Assisi, done by a good painter in pictures that fill the recesses of the four walls. In the other cloister are the paintings of the martyr missionaries that suffered martyrdom on various missions and excursions into the montañas of the heathens. Among the martyr missionaries, there are found several seculars that accompanied the missionaries in their preaching and martyrdom. An extensive plan of converted pueblos is also to be seen. On the second floor there is another cloister with a Calvary, and in each one of the three angles a big cross with a crown of thorns and a clock with an appropriate case.

The silence and retirement, and the care taken with the mystic ornaments that are found in this convent edify and inspire to the deepest devotion and meditation.

The church has only one single, spacious nave, very light and beautifully decorated, as are its altars, dedicated to different Saints.

The vestry is a square room, decorated as much as the church, with some beautiful cabinetwork for the ornaments and chalices occupying the four walls. For each priest there is a vestment and a chalice. The walls are adorned with beautiful paintings brought from Europe. Among these there is a Passion of Our Lord, in pictures covered with glass. This entire collection is of Roman paintings. In another higher row, there is found the life of Sta. Rosa in 
small squares of stone. This convent possesses an abundant library of books on various subjects and arranged in alphabetical order.

Many windows in the vestry as well as in the cloisters are of white and transparent stones resembling glass, for which they are substituted.

On the days of the Porciuncula of Saint Francis, in Lent, and on other religious days, many people come from the province of Xauxa, from the province of Tarma, and elsewhere in the vicinity to confess and to receive Holy Communion, and many come to engage in spiritual exercises.

From this convent they send missionaries to all the towns bordering on the heathen Indians, in order to give them spiritual nourishment and instruct them in Christian morality, providing the missionaries with all that they need for support and for the fulfillment of their ministry; to the expenses for this, His Catholic Majesty contributes a certain number of pesos.

In the orchard of Ocopa there is a birch (Betula alba L.), from the root of which there rise nine new trunks, thick, very tall, straight, and very luxuriant. The rest of the birches that surround the convent are wont to produce two to four equal and very frondose trunks from one root.

The brook that waters the orchard and the trees, even though small, has sufficient water to irrigate much more ground.

After having examined this convent of Ocopa, we went on to pass the night at the pueblo of Concepción, distant a league from Ocopa, crossing a brook that in time of rain carries much water and is dangerous to ford.

On the bank of this brook I found the Calceolaria linearis, which was sketched by Gálvez in Concepción, and I described it and put it to dry.

In the pueblo of Concepción a company of soldiers is stationed as a garrison. The pueblo has many inhabitants, with an abundance of food, with a large square plaza, and its jail is the most secure one in the province, and for this reason prisoners of importance are sent there.

On the 29th we returned to the pueblo of Xauxa, that is situated at the foot of small hills, in a spacious and somewhat sloping plain. The streets are straight and are paved only at the principal crossings. When it rains, a mud forms that makes them impassable. The buildings are of the usual kind, and some houses are very good and 
have two stories, but most of them have only one story. They are built of mud, lime, and stone and roofed with tile. The largest plaza is a large square and always supplied with provisions. In this plaza is the principal church, served by two priests, and on the other facade there is a beautiful, roomy chapel where masses are celebrated daily.

The temperature of this pueblo is cool throughout the year, and one feels the cold more here than in the rest of the valley.

The water that is used in this place comes from a chalky spring to which everybody comes to fetch it, and to give the animals drink; drink, for this reason the water is always muddy or turbid at the first movement that the people make to get it and with the hooves of the animals that come there to drink. The truth is that this defect, of having water always turbid, could be remedied at a very small cost by the numerous inhabitants of Xauxa by building a reservoir and an aqueduct from that to the town. 


\section{CHAPTER VIII}

Climate-Seasonal differences in the vegetation-Abundance of cattle-The Xauxa river-Revolt of the Indians (1742)-Plants-Towns and annexesExcursions of the naturalists-Hardships and misfortunes-Journey to Huánuco-Details of the landscape-Dyeing processes-The town of Reyes-Its products-Origin of the Ucayali, Huallaga, and Marañon-The town of Pasco -Its mines-Caxamarquilla.

\section{DESCRIPTION OF THE PROVINCE OF XAUXA}

The province of Xauxa is situated 45 leagues from Lima in a level valley, or pampa, which extends for eighteen leagues from east to west and twelve from north to south. To the north and northwest it borders on the province of Tarma, to the east on the montañas of the heathen Indians, to the southeast on the province of Huanta, to the south on that of Angaraes, to the southwest on that of Yauyos, and to the west on that of Huarocherí.

The climate of this beautiful valley is generally temperate, but in the highest parts one feels the cold, especially at night, on account of the winds that come from the nearby cordilleras. In winter there are continual frosts, and for this reason vegetables become scanty, and they cannot get the alfalfa that is raised in the vicinity of some pueblos near Xauxa.

Six leagues away the climate is milder and on higher ground is good for sugar cane, which in fact is produced; from it they get some sugar. They gather plentiful harvests of wheat and barley. There is no lack of maize, potatoes, ockas, yucas, arracachas, yacones, and some fruits, vegetables, and flowers in the gardens and orchards. On the ridges and at the entrances to the montañas, coca, pineapples, plantains, papayas, and other fruits are gathered.

In time of drought one cannot find in the greater part of this spacious valley any plant that measures any more than half a foot in height, except in those few lower spots where sugar cane is produced, but in spring all the fields are beautiful.

Many pigs are raised; from them good hams and sausages are made. In the heights where it is cold the natives raise innumerable heads of sheep, and with the wool they make xerga (a cloth by that name), and the women weave wool and cotton, especially into ponchos.

In the higher and colder punas, there is an abundance of vicuñas and huanacos, the wool of which is gathered to make delicate weaves 
such as for neck scarfs, kerchiefs, girdles, belts, garters, stockings, caps, socks, etc.

To be able to catch these animals to advantage, the natives arrange chacos or hunts, as is explained in the account of the province of Tarma.

Through the middle of the province of Xauxa runs the Oroya river, called by others the Parí; it comes from the province of Tarma and has its origin in the famous Laguna de Reyes, or Lake Chinchaycocha, of which we have already told[?] in the description of the latter province.

This river that in Xauxa is called the Xauxa river and takes on a different name wherever it passes, until it enters the Ucayali that joins with the Marañón river, is of very little use for watering the valley of Xauxa because of its depth; nevertheless, its waters could be conducted through canals if there were more need of it.

In the time of the Marques de Cañete, Viceroy of Peru, at about 5 leagues from the pueblo of Xauxa, they built a stone bridge with a single arch over the Parí river, but its waters destroyed it because of the laziness of the natives, who took no care to repair it, unlike that over the Huancayo river which, though built at the same time, exists up to the present and is very advantageous for communications and traffic in those pueblos. Thus the Huancayo river, like all the small brooks of the province of Xauxa, joins the Parí river after having irrigated many fields of the province.

In past times they thought of founding the capital of Peru in this valley of Xauxa, but several obstacles prevented its establishment there.

In the year 1742 the Indians of many towns already converted to the Catholic faith, revolted and threatened hostilities in this province, such as took place in that of Tarma and Huánuco, where all the new pueblos were destroyed, some of them with many inhabitants, such as Huancabamba, Cerro de la Sal, Metraro, Eneno, Tulumayo, Urubamba, and others.

In the territory of this province there are several old pueblos in ruins and some small forts of the pagan Indians.

Although there are several silver mines in this province, at present only one, that was discovered in the year 1779 , is worked as the rest do not pay the cost of the labor.

There are various medicinal plants in this province, but all are very small and adapted to that cold climate. Among them, there 
is an abundance of the true legitimate calaguala, Polypodium Calaguala Ruiz. Diss. de la Calag. Act. Acad.

The plants that are produced in this valley are very few, and the fruit trees and other trees very rare.

All of this is described in the Flora of Peru, in which is cited the place and province with the uses and properties that they have.

This province includes fourteen parishes: The first is that of Xauxa, head district of the whole province, with two annexes named Ricrán and Mojon. The second parish is that of Apata with the annexes Uchubamba and Huamali. The third is that of Concepción with a convent of Observancia de San Francisco. The fourth is that of Comas with one annex called Andamarca, and is situated on the frontier of the montaña. The fifth is that of San Gerónimo with the annexes Hualhuas and Quichuay, and the sixth that of Huancayo, with two priests and the annexes Pucará, Huayucachi, Caxas, Punta, Zapallanga, Miraflores, Hualayo, and Mejorada. The seventh is that of Cochanhara with the annexes Pariahuanca and Acobamba. The eighth is that of Chongos with the annexes Carhuacallanca and Colca. The ninth parish is that of the town of Chupaca. The tenth is the pueblo of Sicaya. The eleventh is that of Orcotuna, the twelf th that of Mito. The thirteenth is that of Matahuasi and Cincos, with the annex of San Antonio de Huancani. The fourteenth is that of Huaribamba with the annex named Muquiyauyo.

There are scarcely 53,000 inhabitants in this province, most of them half-breeds and Indians, because there are barely 2,000 Spaniards and sixty slaves, negroes and mulattos.

On the 30th of July I returned with the draftsman to Tarma, because I saw that in this province of Xauxa there were no products with which I could occupy my time to advantage, and, without anything special having happened to us on the way, we entered Tarma before vespers. The distance from the pueblo of Tarma to that of Xauxa is nine leagues.

Until the 2nd of October, 1779 I continued making my excursions among the quebradas and hills of Tarma, in which time I discovered a great number of plants that I dried, gave to be sketched, and described.

In September, Mr. Dombey came from Chiuchin to Tarma, because of the return of Señora Oydora, whom he had accompanied during the time she stayed at the thermal waters.

Our companion Pavón went with draftsman Brunete to the fort of Palca.

October 2,1779 , at 9 o'clock in the morning, I left in the company of Mr. Dombey for the fort of Huasahuasi 5 leagues distant

${ }^{1}$ Flora Peruviana et Chilensis sive descriptiones et icones plantarum peruvianarum et chilensium secundum systema Linneanum digesta. A. A. Ruiz et J. Pavón. Madrid 1798-1802. 3 vols. 
from Tarma; we lost our way and after we had reached the pueblo of Picoy, the natives directed us to the path that should have taken us to the road to Huasahuasi, on which we found one of our muleteers with whom we continued until we reached the top of the Portachuelo, where there is a wooden cross; in that place there almost always blows a strong cold wind, and a thick, humid fog commonly covers the place, so that at 12 to 14 feet travelers cannot distinguish each other. Here we were caught in a heavy rain for over an hour.

We arrived at three-thirty in Huasahuasi, a pueblo of those parts, the last of the province of Tarma, with its lands bordering on those of the heathen Indians. It is situated in a deep ravine on the bank of a river that is small, but quite noisy because of the rush with which the waters descend and break on the rocks and stones.

In this small pueblo that has only 40 inhabitants, there is a fort with a garrison of eight men with two small cannon, one of iron and the other of bronze and forty new muskets that just had been sent to replace as many old ones of no further use. Two leagues from this town there begins the montaña real, ${ }^{1}$ to which the savages often come on their hunts.

On the 7 th we made the first excursion with the ensign of militia and three peons, penetrating down the river until we reached the hut of the advance sentinel, where we left all the horses and started on foot to inspect those beautiful fields, delightful for the variety of the plants and the fragrance they exhale.

There are so many and different species of gynandrous plants that the rocks appear to be paved with their bulbs and the ground tinted with their flowers. We returned to the fort with more than forty plants, all new, and different from those that we had found near Tarma and its ravines. We continued working in Huasahuasi until the 12th, and on that day we went to the Royal Coffers of Xauxa to get a third of our salary, Mr. Dombey having stayed in Huasahuasi.

On the 15th I returned with draftsman Gálvez to this fort, our companion Pavón having stayed in Tarma with draftsman Brunete, resolved to come to Fort Huasahuasi after Pavón's return from Lima, where he arrived on the 25th with two chests of dried plants that had been gathered in Palca, where they found, as we did, great numbers of precious plants, Gynandrias or orchids. They went on to Huayabal, the road to which was already open at that time, and

I Forest of tall trees without undergrowth. 
the missionary fathers continued to Chanchamayo for the purpose already stated.

On the 31st of October, 1779 I went with Mr. Dombey and draftsman Gálvez to the montaña called Churupallana, a distance of 5 leagues from Huasahuasi, on account of the height of its ridge and the many turns that the road makes to climb to the summit. Accompanying us were the ensign of militia, our servants, and four Indians that went as peons. We had hardly climbed halfway up the mountain when it started to rain; it continued without interruption until dawn next day. A short time before dawn we heard mournful screams in the woods that sounded as if they were made by people in conflict and that put us into a state of apprehension, especially all those of us who did not know the cause that produced such an extraordinary lamentation in that solitude, but the ensign of militiaacquainted in those parts, and having some cattle feeding there the whole year on account of the abundant, tall, and good grass-assured us that the noise was not from the Indian savages as might be presumed, since the place was only six leagues from Chanchamayo, where at present there were thousands of those Indians for the purpose of preventing the construction of the fort and town that we Spaniards were going to repeople in that plain and on the banks of the river. The ensign added that the extraordinary noise and those mournful screams that we heard in the montañas, were caused by certain birds, called almas perdidas [lost souls], that commonly inhabit the most isolated parts of these montañas and are heard regularly at night and at dawn. At this time we lighted a big fire to dry our clothes that had become wet during the night. After having warmed ourselves, although the woods were full of water and it was threatening to rain again, I went into them with the peons and servants, the draftsman staying in the hut in company with Mr. Dombey who, having slipped the afternoon before, could scarcely walk because of the pain in the injured leg. I came out of the woods very soon afterwards with an abundance of flowering branches from beautiful trees and shrubs; we made a big bundle of them and took it to Huasahuasi and, after having aired them, we put them to dry, but left some branches in water, to describe and sketch as we did on the following days.

On the 1st of November, 1779, seeing that the rain continued without a let-up and that there was no prospect that the weather would improve that day, we decided to return to Huasahuasi. 
We had hardly come down a league when we found ourselves out of the dense cloud which continued to discharge rain all day on Churupallana, but from there on we experienced a very strong, stinging sun, which compelled us to find shade under the luxuriant trees on the banks of the Siusa river, where we collected several plants, some of which we dried and preserved, keeping others to describe and sketch. We arrived at the pueblo at sundown.

On the 3rd we sent a servant to Tarma for the drawings that our partner and Brunete the draftsman had made at Palca and Huayabal, in order not to have to do them again but to progress with our work by doing others. The servant came from Tarma on the $4 \mathrm{th}$, bringing the drawings.

On November 24th I went with Mr. Dombey to a place called Lanco, a league and a half distant from Huasahuasi; in this place there are so many species of orchids, and in such abundance, that it is astonishing even to look at the patterns they form on the ground with the peculiar structure of their flowers, leaves, and bulbs which the Almighty gave to this rare family of plants, of which there are some bulbs of which we chewed and drank the juice to relieve our thirst, as did the Indians who came with us, without need of going down to the river to drink, because their taste was pleasant and we noted no suspicious flavor.

On November 26th, Dn. José Pavón having returned from Lima, I went with Brunete to Huasahuasi to complete several drawings of the orchids, of which he had found an abundance in Palca, and of other Dioicas and Polygamias, plants that had been taken incomplete on the expedition from Palca and Huayabal.

On the 5th of December, 1779 I returned to Tarma with $\mathrm{Mr}$. Dombey and draftsman Gálvez, and Pavón and Brunete stayed in Huasahuasi until the 12th, perfecting the sketches from Palca.

The five of us continued our excursions and work until the 19th of January, 1780; on this day I left for Lima with draftsman Gálvez, taking along the dried specimens of plants and other products gathered in Tarma and Xauxa. Mr. Dombey, Dn. José Pavón, and Dn. José Brunete came to Lima on the 13th without incident on the way, save a few showers.

I left Tarma with Gálvez on the 19th at 2 o'clock in the afternoon, traveling without mishap to the top of Oroya, where we encountered a good hailstorm and afterward a heavy, continuous shower that not only soaked us and silenced us neatly but also hid some 
parts of the road from view. Gálvez, trusting in his mule and thinking that he could reach the town of Oroya before sundown, went ahead leaving me behind, but had the misfortune to wander off the right road about a quarter of a league, which I noticed when I saw him almost at dark, at the summit of a hill, where at my loud cries and whistling he stopped, but as the distance that separated us made it impossible to understand each other, I went toward my partner after marking my way by throwing pieces of paper on the ground, shouting at intervals, until he understood me and followed me in search of the road. After having found it, as it was dark already, we were forced to allow the mules, very tired by this time, to take us at their own will, and at a slow and tired pace they brought us to the pueblo of Oroya at 8:30 at night, very wet and very cold. We had the good fortune to have the mestizo, at whose house we arrived, give up his bed with good, clean wool bedding, in which both of us found room; and the mestizo and his wife put all our clothes to dry around a fine fire.

Our servants, who had come ahead of the muleteers, each one leading a horse by the bridle, were lost, although one of them was familiar with the road, and they went on so as to sleep at the pueblo of Reyes, having strayed from us at least eight leagues. The muleteers, being unable to climb to the summit of Oroya on account of the rain, took shelter in a cave, where they spent the night; at 10 o'clock on the next day they arrived at this pueblo, whence we had sent an Indian to look for the servants, who arrived at 11 on the same day, and we started all together at 1 o'clock from Oroya, after having crossed the famous Parí river and lost a mule by drowning.

At a distance of a mile from the bridge we were caught by several squalls of hail and rain, until we reached Pachachaca, where we stayed a good while until the afternoon would clear. At 5:30 we continued our journey and arrived at Pucará at vespers. On the 21st we left this smelter, accompanied to the cordillera by the miner of this property. We crossed the cordillera under an intolerable sun, although it was well covered with snow.

Coming down to Casapalca, I had the misfortune to fall into a narrow cut or gorge formed by the rains, but was fortunate enough to stay astride the mule and to have the horse, which was tied to the girth of the mule, although he fell after me, strike the mule on one side while I was bending to the other, thanks to the warnings of my partner to guard myself against the fall of the horse; it was hurt very little, but the mule was hurt in the haunches and head, 
and the saddle was torn to pieces. I broke one of the silver spurs and completely smashed the head of my whip, and I received a light scratch on the right cheek from a hoof of the horse, which, on getting up, delivered some kicks at the mule and myself, who found myself down with one leg under the mule, being unable to move from the place, not even an inch. No sooner had I cut the halter by which the horse was tied to the girth of the mule than he started to walk down the gorge, scratching his belly at some very narrow places, but because he was free and had long legs, he could pass the narrow places while the mule could not, with or without saddle, because she was short and pot-bellied, so that I was forced to remove the saddle, and with a rope my partner hoisted it and with a rock tried to open more space to get the injured mule out from that ravine. This was finally accomplished. The animals were caught by a mestizo who was passing at the time, and we tied the saddle the best we could and continued our retreat to San Mateo.

A short time after we left the gorge into which I had fallen, we found that another traveler had had the same misfortune, but his horse had broken a leg.

On the 22nd we left San Mateo and went without mishap to pass the night at San Pedro de Mama, where we arrived at 8 o'clock at night and slept in a field so that the horses might graze during the night.

We arrived in Lima at noon on the 23rd, without any other inconvenience than the excessive heat of the quebrada. On the 24 th the muleteers arrived at Lima.

We stayed in Lima until the 23rd of April, 1780, rearranging and moving the dried plants, completing the drying and description of several we had gathered on the way and of some collected in the fields at Lima. I made a fair copy of the descriptions from Tarma, arranged my herbarium by classes, putting the generic and trivial names on the plants, boxed them for shipment and cleaned several packages of plants that I had left in Lima and that had become infested with the insects that Linnaeus calls Termes fatidicum Syst. Nat. Tom. 1, par. 2, fol. 1016, which he claims to have been the first to examine in dried plants that were sent him by Loefling.

I also found in some plants another species of insect, smaller but of a different genus and not at all harmful to herbaria, in which they are never found if the plants are well dried. Nevertheless I fumigated the boxes with sulphur before placing the herbaria in them. 
After having finished this and other work that we did in Lima, we all decided to leave the boxes of dried plants in the Royal Armory, for which we presented a petition to the Viceroy, who ordered that a suitable place be assigned us for them. At the same time, we asked to be advanced some months' salary in order to proceed to the montañas of Huánuco, and notwithstanding some objections made by the officials of those coffers, the Viceroy ordered it to be given to us, on account of our having to go to places distant from the Royal Coffers, and we were obliged to become bondsmen for one another for the return to the treasury of the salaries that in case of death would not become due.

We rented a room for storing the trunks, boxes of paper, and other equipment that was not needed on the journey which we were about to undertake.

\section{JOURNEY TO HUÁNUCO}

On April 23, 1780, we despatched the muleteers with the draftsman Gálvez' and my loads, and on the 24th we left by the gate of the Maravillas at 6 o'clock in the morning. We passed the night in Cocachacra, using our capes as bedding. We met with no other inconvenince than the excessive heat of the sun. On the 25th we left Cocachacra at daybreak and went on, expecting to sleep at the hacienda or ingenio of Pumacocha. Having traveled that day along the sides of mountains and very dangerous slopes, we arrived at San Mateo at 4 in the afternoon and, thinking that we could climb and descend the hill of Cacray, we resolved to leave San Mateo and go to San Juan de Chicla, but night came when we were in the upper part of the ridge, and we were forced to let the mules conduct us until we came to a dangerous pass, where we alighted on the advice of the miner of Pumacocha whom we had met before we came to this place. He invited us to his house to pass the night there; for this reason we did not go on to San Juan de Chicla. On the same day, Dn. José Pavón and Dn. José Brunete left Tarma by the same road, and Mr. Dombey took the road through the quebrada of Canta.

At 8 o'clock in the morning on the 26th we left Pumacocha with a rather cold wind that lasted until we climbed the mountain where, although it was covered with snow, we were well warmed by the sun. Having passed the mountain and Lake Huacracocha, we arrived without incident at Pucará, where we passed the night. We had already alighted when there came a terrific hailstorm accompanied and followed by a long and heavy rain. 
On the 27th we left Pucará and came at nightfall to Tarma without mishap. On the 30th the muleteers arrived in Tarma. We stayed in this town until the 11th of May, 1780, finishing several descriptions that had been left incomplete during the preceding excursions. At the same time I inquired from some women that were occupied with dyeing wool and cotton, about the colors they used for their dyes.

Red color. To dye red they prepared the following mixture: Of pircay, or pilcay as some pronounce it, which is a mass made with true cochineal, eight ounces of red tiri, two pounds and one ounce of alum put to boil with four azumbres [gals.] of water, and into this the cotton or wool that is to be dyed. After it has taken the color well, it is washed and dried. The mass called pircay is formed with liver and cochineal well mashed and then dried.

The cochineal is gathered, although but little of it, in the quebrada from Tarma to Acobamba, but it is not as good as that which is cultivated and brought from other places; this is not done in Tarma because of the laziness and abandon of the natives. The tiri is a species of Melastoma.

Violet color. They take two quarts of lye of quinoar or quinhuar [Polylepis], two ounces of Greek pitch (resin), and all of this mixed with the red tint makes a very good violet.

Yellow color. They take equal parts of fine or yellow tiri and of chinchanho, a species of Hypericum, a little piece of alum and some urine, boil all together in water with the wool until this takes the color that they desire. If they do not want a bright yellow, they omit the alkali.

Aromo color. They take four ounces of pahuau, a species of Bidens (foliis Nasturtii), boil it with 16 pounds of the above-mentioned yellow, and the wool comes out a beautiful aromo color.

Orange color. They take four ounces of pahuau, boiled in 6 quarts of water until the color is well extracted, and afterwards they put the wool that has been wet, in alum water first, and boil it until it takes the orange color.

Green color. They take sticks of the male chilca, a species of Eupatorium, and they boil them in plain water with indigo and urine and, after the color has become green, they boil the wool until it takes the color.

Violet color. They take sticks of the wood of tara, Poincianabijuga, and they cut them in pieces, put them in the sun, taking care to sprinkle them from time to time with urine and, after they are aired, they are boiled in plain water with red tiri, and the wools or cottons take on a beautiful violet color when boiled in that water.

Rust color. They take dry pods of tara, and with a little soot they boil them in plain water, and then they put the wool in the mixture; after this wool has been treated with green vitriol and washed well until the acid cannot be detected, the wool comes out a good rust color.

Cinnamon color. They take pahuau and tara sprinkled with urine as has been said about the violet color, a little alum, lemon juice, and soot, and boil the wool until it is dyed the color of cinnamon.

Raisin color. They take the bark of the walnut-tree, Juglans nigra L., soot, and Greek pitch, which are boiled together in ordinary water, and then they add wool treated with alum, and boil it until it takes the color of raisins. 
On the 9th of May, 1780 we sent the muleteers from Tarma to Huánuco; and because it had rained on the 10th when Dn. José Pavón and Brunete left in the early morning, I delayed my trip with Dn. Isidro until the 11 th, when at 8 o'clock in the morning we left Tarma and started for the pueblo of Reyes, where we spent the night, passing a hacienda called Las Casas, three leagues distant from Tarma, where they harvest a great quantity of potatoes and barley, short-eared but very well filled. A half league from this hacienda one enters a beautiful and very extensive pampa or plain, with very little grass, that reaches to Reyes, 10 leagues distant from the pueblo of Tarma.

The pueblo of Reyes is situated in the middle of the pampa of the same name, and has a cold climate the year around; for this reason trees, shrubs, and grass are not found in its vicinity, and they must plant barley in order to have alcazar [green barley] in the months of April and May to maintain their animals and to sell to travelers, because the rest of the year it cannot be produced on account of the cold.

This little green barley is planted in fields enclosed with stone fences that they have around the town and even within it, because far from the town they cannot plant on account of the cold.

On the whole of these pampas of Reyes and Bombón they plant no other crop than roots called maccas, and even these not beyond the pueblos of Ordones, Carhuamayo, Ninacaca, and the annexes of these three parishes.

The natives are convinced that by eating the root of the maccas, which are as big as hazelnuts and taste very good when they are boiled, women can make themselves fruitful; for this reason many who are childless request them. The truth is that the maccas are stimulating, at least when eaten in quantities.

On the 12th we left Reyes at 7 o'clock in the morning. It was very cold due to the frost of the night and the dense fog that generally comes almost every day at 4 or 5 in the morning and lasts until 8 or 9 , when the sun disperses it.

Half a league from this pueblo is the beginning of the famous Lake Chinchaycocha, which extends to the vicinity of the pueblo of Vico (as has been said in the description of the province of Tarma); we crossed the already mentioned highway of Reyes with great difficulty, as that great work of the pagans was already almost entirely destroyed, and we passed Carhuamayo and Ninacaca and, leaving Vico to one side, we came to Pasco before vespers. 
In these large pampas of Bumbun, or Bombón, asitis called today, the three famous rivers Ucayali, Huallaga, and Marañon have their origin. The first comes from Lake Chinchaycocha and follows its course through the province of Xauxa and the montañas with the Apurimac river, which joins the voluminous Pano or Bení river that crosses the pampa of the Sacramento, where it takes the name Ucayali and joins with the Marañon river in the lands of the Omagua Indians; the second comes from Lake Yauricocha two leagues from Pasco and waters the province of Huánuco to the montañas of Cuchero and joins a little below this town with the Monzón river that comes from the province of Huamalíes, and together they traverse the lomas to form the Huallaga river that empties into the Marañón river near the pueblo of Laguna.

The 3rd river, called Marañón, has its origin in Lake Lauricocha that lies between the pueblos of Jesús and Lauricocha and, crossing through the provinces Huamalíes, Chota, Caxamarca, and Pataz and by the kingdom of Santa Fé, it joins farther on with the two previously mentioned rivers. Lake Chinchaycocha is hardly 4 leagues from Lake Yauricocha and 10 from Lake Lauricocha and, although their waters take opposite directions, after they have gone their separate ways many leagues, they join in the country of the Omaguas, under the name of Marañon, the most voluminous river that is known in the world. Its mouth at the ocean of the North is 85 leagues wide. Some are of the opinion that this river was given the name of Marañón on account of the many turns that it makes through extremely tangled territory from its origin to its outlet into the sea.

TOWN OF PASCo. On the 13th of May we left the town of Pasco, where the Royal Coffers are situated so that the miners of all those mines can come to pay their fifth and to smelt the cones of silver that are extracted in their works. This town is situated at the foot of a lake the waters of which are retained by a dam that lets out only enough for the use of the smelter.

The streets, improperly called so, as they are without order, are not paved except for some pieces of sidewalk, and are perennially filled with mud.

The buildings are the best of all of the towns situated in the pampas and punas of Bombón, because several miners, merchants, and silver refiners live there; the construction is of mud and stones, and they are roofed with wood or ichu; they are one story high and their shape is rectangular, square, or conical; few are whitewashed 
on the outside but many of them on the inside, although most of them are completely smoked; they are not clean inside. Their rooms are generally dark because of the few and small windows they use on account of the continuous cold that prevails the year round, and the inhabitants are forced to keep a brazier or fireplace always burning with champas and taquia, which is sod and manure from sheep; for this reason smoke is always present and an intolerable stench that gets into the clothing and even into the body, and lasts many months, even though the natives may go to other warmer climates and stay there a long time.

Only the interest in the silver could induce people to live in those places and force them to live closed in, smoked, and frozen with the cold, and unable to walk any long distance on foot without resting and taking fresh breaths, so as to be able to breathe and not suffocate with the nitrogen and carbonic acid gas that are expelled from the calcined minerals and the champas, and that fill and infect the atmosphere with a mephitic and fatal air that they call beta.

Passing several smelters of minerals and lakes we came down to the quebrada of Quinua, a name given to it for the tree called the quinar or, as others pronounce it, quinhuar, which is abundant there and is very useful to the miners of the hill of Yauricocha for the construction of houses and smelters and for fuel, as the wood is very strong and resistant. From this tree we established the genus Polylepis, a name taken because of the peculiarity of its bark to peel in many thin layers in the manner of vellum or of paper the color of molasses.

PUEBLO OF CAXAMARquilla. We went on to Caxamarquilla, a pueblo of a few inhabitants, situated on the summit of a high hill, though it has also a few houses with several families on the bank of the river; throughout the year they enjoy the best climate in the valley, and they have very good pieces of ground planted with maize, massuas, potatoes, alfalfa, cabbages, lettuce, garlic, onions, and carnations and other ornamental flowers.

We had hardly dismounted in Caxamarquilla when a furious storm came up with thunder and lightning accompanied by a hailstorm that lasted continuously for more than an hour.

The road from Quinua to Caxamarquilla is a succession of puddles and mud-filled pits which are produced by the animals when it rains and, when the downpour stops, they become open graves affording very bad footing and very likely to cause horses to stumble and fall, and break their hind or front legs, as happens many times. 
On the 14th we left Caxamarquilla at 10 and, because of the hail of the day before, we found the holes all filled with water and the ground very slippery; for this reason we traveled with not a little discomfort and much effort to the pueblo of Huariaca, situated on the brow of a hill with good soil and covered with various plants which are continually green, and some of them in flower. From Huariaca on, there is a road about half a league long with very few holes, but dangerous because of the declivities and ravines sloping toward the river; beyond this space the road is more level and without hazard until half a league past San Rafael, a small pueblo situated in a small valley with a good climate and at the bank of the river; from there one climbs by a steep hill and about a league of bad road to Rondos, a small Indian pueblo situated on a plateau that is formed at about the middle of the high hill. Its temperature is cool, and cold at night; for this reason there are in its neighborhood only potatoes, quinoas, and abas, and some vegetables for consumption, and in the deep quebradas plenty of maize. This hill of Rondos is covered with a variety of minor plants, bushes, shrubbery, trees, and with excellent grass for all kinds of cattle, and for this reason numerous deer frequently appear at the road.

We passed the night in Rondos. From Quinua to San Rafael there are found at all times alfalfa, vegetables, meats, and other kinds of provisions, but bread is not to be had from Pasco to Huánuco. This entire quebrada is covered with various and diverse herbs large and small, green, and some of them flowering throughout the year.

In some of the lakes that we passed on the way from Pasco to Caxamarquilla, we saw only two species of ducks and a bird called huehne of the size of a heron with long, thin legs and long, sharp bill. On its head it has two white, long linear feathers. Its body is gray, with some white feathers on the breast.

DISTRICT OF AMBO. On the 15th at daybreak, we left Rondos and climbed more than a league of road, very bad because of the many holes that are found in it until one reaches the summit of the hill over which the road continues to the district of Ambo, a distance of five leagues from that pueblo. At this place the river that comes down the valley of Huariaca joins the river that descends from Huacar, and they form the Pillco river that with that name passes Huánuco. From Ambo to the city of Huánuco there is a level road five leagues in length and very attractive because of the many 
houses and orchards that are found along its course. One notes on this road a penetrating and agreeable scent, produced by the perfume that is exhaled continuously by the chirimoyas, guavas, and other fruit trees native to this country and the orange and lemon trees that are plentiful in those orchards. We entered the city of Leon de Huánuco de los Caballeros at three in the afternoon burned by the sun, although its rays were tempered by the north wind blowing in the whole valley from 11 in the morning to 4 or 5 in the afternoon.

The day before, all my other companions had arrived at Huánuco, and all together we spent the following days until the 21st in making the necessary preparations to begin our work, looking for rooms, and returning the visits that we received from all the most distinguished persons.

On the 21st we made the first of our excursions, and we continued them until the 2nd of July, when we set out for the montañas of Cuchero.

\section{DESCRIPTION OF THE CITY OF HUÁNUCO AND ITS PROVINCE}

The city of Leon de Huánuco is the capital of the province of this name, which borders to the south on that of Tarma, to the east on that of Huamalies, and to the north and west on the province of Panatahuas and the montañas of

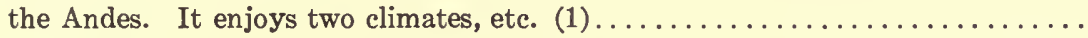

During the 42 days that we remained working in Huánuco, we gathered various plants of which I could describe only the following: Buddleia sarmentosa. Solanum incanum and spicatum. Sessea stipulata. Calyxhymenia viscosa. Loranthus puniceus, liga. Prunus virginiana, cherry, for the color, size, and taste of its fruit. It is cultivated in some orchards of Huánuco. Cuphea ciliata, yerba de culebra, the decoction of which is used frequently to relieve weakness and lassitude. Gardoquia striata, socconcha and pichuisa. Gen. nov. Celsia aff. linearis. Heliotropium incanum, parvicalycum, and lanceolatum. Lepidium foetidum, pichiccara, huaura, and mastuerzo silvestre. It is used frequently in enemas to cure the mal del valle, the plant being extracted and rubbed in water and applied hot to the affected parts to clean and heal them. Pounded with lard it is applied to the abdomen for the swelling preceding the stopping of the menses. Lantana purpurea. Malva aspera. Urena trilobata, and biserrata. Bignonia coerulea, yaravisco. The natives use the bark of this tree for anti-venereal decoctions; from the wood they make

${ }^{1}$ In the original the rest of this description is missing. 
vases in which they put water and drink of it freely against rheumatic pains, and finally they use the powder of the leaves to heal sores after having cleaned them. Coreopsis trifida. Viola purpurea. Passiflora quadrangularis L., tambo. Its fruit, which is the size of a grapefruit, has a bittersweet taste that is not pleasant, but nevertheless the natives eat it. Mimosa expansa. Tessaria integrifolia, paxaro bobo. Verbena hispida. Salvia nodosa, sacconche, and racemosa. Cestrum undulatum, miu. 


\section{CHAPTER IX}

From Huánuco to Acomayo-Fatiguing march-Appearance of the soilAccident to a mule-Description of plants-Departure from Acomayo-The landscape-Rosapata-Difficulties on the march.

\section{JOURNEY TO CUCHERO AND TO ITS VERY FERTILE MONTAÑAS}

On the fourth day after I had left my bed, I made arrangements for the journey to Cuchero and, feeling that I had strength enough to undertake it, I left with the two draftsmen on the 2nd day of July, 1780, following the two botanist companions who had started the day before from Huánuco for the same pueblo. We traveled three leagues this day with no little difficulty caused by my lack of strength. On the 3rd at dawn we continued our second day's journey through a very high declivity, dangerous because the road was in part very difficult and the hill so steep that there is no way to save one's life if one falls from that narrow declivity to the river. After passing the latter, one arrives at a regular and pleasant road with many kinds of shrubbery and plants that are found up to the town of Acomayo, that is situated at the entrance to the quebrada, where the montaña begins. At a distance from this small Indian pueblo, we spent the night under a big rock where we could scarcely find room, and we passed the hours awake because of the disturbing noises that came from a near-by rock and of the singing of the thousands of little toads that inhabit that place. It had scarcely begun to be daylight on the 4 th when the muleteers went to get their animals, and they found a mule dead that had not been tied for grazing like the rest but had come to harm. One of the muleteers went to Acomayo in search of another mule, and we continued our journey accompanied by two men from the pueblo of Huánuco who were passing to the montaña, traveling always among shrubs and thorns and other twining plants that cross the narrow road from one side to the other so that it is necessary to walk with the utmost care in order not to hurt one's face and hands on the thorns and branches. At a distance of about a league and a half we found in some fields a number of deer that were grazing without fear of those of us who passed among them. Half a league ahead we came to a very dense montaña and a road full of holes, where it is necessary to let oneself be guided by the mules without attention on part of the rider except to free himself of the branches of the trees that cross the road, in order not to fall, as happens many times to those who travel absent-mindedly. 
Most of those who travel here walk on foot, because the roads are free of branches to the height of a loaded mule, and they walk barefoot on account of the ever prevailing mud that is found all year round in those places, and on account of the wretchedness in which the natives live. We climbed the steep, hard ridge with great toil, because of the very narrow and deep road and the high steps of which it consists and its deep holes and mires.

Frequently, these roads are blocked with fallen old trees, and for this reason the transport men carry hatchets to cut them, and the Indians never travel through these montañas without carrying machetes for the same purpose. At two in the afternoon we arrived at the place called Tambo, which is a small plain with a roof made of branches and ferns, under which travelers take cover at night and when it rains. In this place I described the purple-leaved cascarilla or quina, that is, Cinchona purpurea, which is abundant there. At 4 we arrived at the pueblo of Chinchao where we rested from the fatigue of the road and the bad past nights. On the 5th we left this town at 8 o'clock in the morning, although the roads were impassable with the rain that fell all night. We passed many farms or plantations of coca, the only product that is cultivated and sold in this quebrada, because all the other things that are planted are only for consumption at home together with other provisions that necessarily are brought from Huánuco.

We found the road to Rosapata - in which chacra we passed the night-so bad that the mules could scarcely walk without slipping at every step, and many times they slipped with great dexterity by placing the four feet together when the road was steep; other difficulties of this road were the crossing of branches that impeded the traffic, the narrowness of the slopes, and the continuous climbs and descents.

On the 6 th we arrived at 2 o'clock in the afternoon at Cuchero after having suffered numerous falls and great discomfort on the way, because this road was even worse than those of preceding days. Dombey and Pavón told us that they had had the same difficulties on their trip. We slept that night all together in a small ranch that our companions had found.

On the 7th the three of us lodged in another one-room hut of the same kind, damp and badly protected from wind and water, as are the very few that can be found in that poor pueblo. 


\section{CHAPTER X}

Extent of Cuchero-Pueblo Nuevo-The Huánuco river and its tributaries - Pampahermosa-Commerce of the Indians of Langostan-The Inca-Blowguns-Manner of hunting with them-Products of the mountains of CucheroClimate-Its effects and the apparel of the peons-Fauna of the district of Cuchero -Flora-Sufferings and want-Before the Chuncho Indians-Departure from Cuchero-Plants described.

\section{DESCRIPTION OF THE PUEBLO OF CUCHERO}

At a distance of 26 leagues toward the north from the town of Huánuco, the pueblo of Cuchero is situated in a small plain on a hill surrounded on all sides by other higher and rough hills clothed with big trees, shrubs, reeds, and innumerable plants that cover the entire ground, without leaving the smallest place to plant anything, and without pasture. The pueblo of Cuchero hardly occupies 300 yards in length and 50 in width; in this space there are 11 ranches, a small church with a room for the missionary under whose direction and spiritual guidance there are also recently converted Indian inhabitants, who, being unable to support themselves except with maize and yucas that they planted in small clearings near the pueblo to the east, and with the fish and game that they obtain from the river and mountains, were conducted two years ago by P. Fr. Juan Sugrañez to a better place, where they founded the pueblo of San Antonio de Chicoplaya or Pueblo Nuevo. The cascarilleros, or collectors of quina, took possession of the ranches as soon as the Indians were moved to Pueblo Nuevo. There are only two entrances to Cuchero, one to the south from Huánuco and the other through the north on the road to the landing place two short leagues downhill to the Huánuco river; it passes there with a considerable volume of water, which comes from the Chumayo, Cascay, Acomayo, Yarumayo, Panao, Sto. Domingo, and Chacahuasí rivers, and many other small brooks that descend from all those montañas. At half a league from the wharf it is joined by the Chinchao river, a league farther down by the Cayumba river, and five leagues down the large Monzón river empties into it, going on through Pampahermosa to Lamas until it joins the famous Marañón river near the pueblo of Laguna.

The Indians of Pampahermosa go up this river in canoes to the wharf at Cuchero, going upstream in eight to twelve days a hundred miles, which they make in four days coming down. The Indians of Lamas spend two or three months in going up to Cuchero and 
return in about twenty days. The trade of these Indians consists only of certain cotton materials, tobacco, cacoa, loros, monkeys, parrots, and some resins and poisons for hunting with a weapon called the zerbatana [blowpipe], in the use of which they are very skilful. They mix this poison from several milky plants called vejucos, boiling and preparing them in the form of a solid extract, so that to use it and to anoint the points of the little sticks, called darts, they dilute it first with the milk of the roots of yuca, or Jatropha Manihot, that is cultivated in abundance in the hot valleys and montañas of Peru, as an edible root when roasted or boiled; from it they get an excellent starch and in some places also make the bread called cazabe. They use the leaves boiled in water to reduce oedematous inflammations, bathing them with the decoction. They make the zerbatanas from the chonta palm, the wood of which is black and very hard, making two half-tubes beautifully worked and polished on the inside with very fine sand as smooth as the barrel of a gun; afterwards they unite them and dress them with agave thread and they smear them with some resins, producing a perfect tube about two and a half yards long, placing in the opening two tusks of wild boar or other animals, adjusted perfectly so that no air escapes at the time of discharging the dart. This is a small stick of the size of a darning needle, made of wild cane with a very sharp point in front and covered at the other end with wool or cotton of inich, a kind of Bombax, forming a little ball so that it may enter snugly into the zerbatana and without much pressure, so that the breath may discharge the dart with violence and it will take its direction without deviation. The poison is so active that the blood of the bird or other animal hit with the dart begins to clot immediately. In shooting at monkeys, the Indians take the precaution of cutting off the point of the dart and then replacing it again, because the speed with which those cunning animals pull out the darts does not allow the poison to act, and if this is not left in, they do not die no matter how deep it may have gone in unless it be in a vital spot, but when the point has been cut it remains within and takes effect actively. The game that they hunt with this poison is eaten by the Indians without any fear of the slightest bad effect.

On the 9th day of this month three individuals from the Renta de Tabacos, accompanied by the priest of Cuchero, embarked to go down to Lamas with the order to establish navigation and the transport of tobacco by the river to Cuchero and to send it afterwards 
in loads to Huánuco and Lima. Inasmuch as a few days later there arrived at Cuchero a countermand to the effect that in case the individuals had not embarked they were not to do so, but to return to Lima, it is to be suspected that this excellent project will not be carried out which in my judgment would be the principal means of expanding the province of Huánuco and of founding new settlements from the pueblo of Lamas along the whole course of the river and of establishing a good commerce in cacao, resins, quina, balsams, seeds, and various other products that grow wild in those fertile montañas, such as the arbol del sebo, the almendrón, the pinoli or pucheri, vanilla, and so forth.

The climate of Cuchero is continuously mild; in the daytime the thermometer registers 19,20, and 21 degrees Réaumur and in the nighttime it falls to 6,7 , and 8 degrees. Among the natives it is reputed with good reason to be unhealthy, as are all the places in the mountains where humidity and heat are frequent; to this is added the poor ventilation of those places and the abundance of carbonic acid gas that is expelled by the trees and plants during the night, all of which contributes to excessive transpiration, so that one perspires and drinks water to excess and the body swells and loses its coloring, or auriflamen, as they call it. No less unfavorable to the health of those people and to the peons that come from Huánuco and other places for the gathering of coca and cascarilla, is the food with which they maintain themselves, for they are reduced to salted meats, yucas, maize, peas, and beans, and to going barefoot, covered only with a shirt and short pants of tucuyo or of thin baize.

There are two scanty springs of water in the neighborhood of Cuchero. To conduct the water from one of them to the town, the missionary father has taken trunks of the tree called tucuna, a species of Cecropia, splitting them in two lengthwise and leaving them like channels by removing only the septa at the joints.

In the whole district of Cuchero there is no pasture since it is all covered with very tall trees, shrubbery, and minor plants; for this reason they do not keep any other stock than some chickens and pigs, but in the mountains there is an abundance of parrots, magpies, turkey hens, mountain chickens, pajaros arrieros and bacas, two kinds of mountain pigeons, and some night birds with a sad song, like the so-called alma perida, owls, and bats with such a love for the blood of the horses that the animals that spend the night in that place show many bites on their necks in the morning. There are many little birds of sweet song, such as the oropendola [weaver 
birds], picaflores [hummingbirds], papamoscas [flycatchers of fam. Tyrannidae], a kind of ruiseñor [nightingale], zorzales [thrushes], and birds of seven colors, and above all the so-called "organist" that with its melodious warbles and trills, enraptures, enchants, and amazes; if its song were lengthy instead of short, there probably would be no other bird in the world to compare with it. This little bird, as big as a canary, feeds on the berries of the innumerable species of Melastomas that abound in that whole montaña. In the mountains of Cuchero there are also found monkeys, peccaries, michus, bears, armadillos, casonas or forest dogs, cavies, macamucas, leoncillos, and huayhuas, a kind of small weasel a little larger than a house rat, but longer, and swifter in all its movements, moss-colored on the back and yellowish on the belly, and with a bushy tail like the fox; it is tamed very easily and hunts rats. I had one for more than four months, and during the last days she used to jump to eat at my table and got on my chest without hurting me. A variety of small butterflies, ants, horseflies, mosquitoes, and many other insects are abundant in those forests. There are three species of bees, two that manufacture very good honey and wax, especially the larger one, which in size is a half smaller than the common European bee, with the difference that it does not sting and almost always makes its hives in the ground or sometimes in the trunks of trees; the other two are very small, the size of an ant. One of them makes small honeycombs of good honey and wax and does not sting; the other, which is all black and looks like an ant, produces an intolerable smarting when it stings and causes a large swelling that lasts many hours. Although the natives say that there is a snake more than six yards long, I saw only four or five small species and a viper called flamón, that, although very slow in its movements, is so dreaded by the natives that they flee from it as from a great enemy, on account of the force of its bite and the speed with which the poison coagulates the blood. The antidote that those people have discovered to save themselves from death when they have been bitten by the flamón, is human excrement dissolved in urine or water, taken by mouth, and applied to the bite. I dissected one of those vipers which was two yards long, and I have seen them as long as three and one-half yards. This one was about as thick as a wrist, and it was of a dark gray color on the back and a darker gray on the belly with lines whitish and brilliant. It had a wide head and a flattened mouth like that of a toad with only one row of curved teeth in each jaw, with only the difference that the fangs are longer 
and more curved; its eyes were dull, and the tail was 6 or 8 inches long and round like the rest of the body. When the Indians saw me skinning the first one, they left me and told me not to touch it because the poison might kill me.

Among the many species of trees, shrubs, and plants with which these rocky montañas are covered, one finds the beautiful cascarillo from which cascarilla bark or official quina is obtained, especially in the hills of Casape, Casapillo, Cayumba, and San Cristóbal de Cuchero. In these places the trees grow to excessive size, some of them being more than 40 yards tall, and thick and luxuriant in proportion.

In order to live in this pueblo, one must bring food from Huánuco because there is no surplus to be found among the poor, unhappy people who inhabit this place and the coca haciendas that are found in that quebrada.

At the end of the month that we stayed in Cuchero, we suffered continual difficulties and need because, as we were inexperienced in this place, the food that we brought on the advice of the natives was insufficient and not of the best, so that some days we had to eat salted meat half putrid, and boiled maize and roasted yucas instead of bread.

Hardly a month had passed since we came to Cuchero when, on August 1st, 1780, a few minutes after vespers, a peon of the cascarilleros (gatherers of Peruvian bark), named Salinas, spread the alarm and assured Mr. D. and Pavón that we were surrounded by more than three thousand Chuncho, or savage, Indians. To the questions asked him he added that he had seen in Alcalde Minaya's clearing about half an hour before sunset, more than two hundred Indians who had climbed the trees to examine the ground. This sudden incident at such an hour not only surprised and alarmed everyone in that pueblo, but it also frightened Dn. Pavón and Mr. Dombey, to whom the information had been given by the peon Salinas, to such a degree that they decided that the five of us should leave by the road to Huánuco notwithstanding the darkness of the night, which was dangerous with the dense fog that had come after vespers in that whole montaña, and the wretchedness of the road all filled with holes, mud, and great precipices. The reasons that we gave one another for remaining in the pueblo had no weight with any of us, so, taking our arms and some bread in our pockets, and loaded with our books of botanical descriptions, we left Cuchero with a boy as guide, followed at a few paces by Dombey, Pavón, 
Gálvez, and Brunete. I alone stayed behind on account of my weak state after the sickness that I had just passed through, but I resolved to defend myself or die. At that time of the night we sent a man named Rafael Figueroa to an hacienda about half a league from Cuchero to call the cascarilleros, and about fifteen more men from Cuchero, and they joined us before nine in the evening. As Brunete and Gálvez were not accustomed to the road like Dombey and Pavón, at the beginning they called to the others and followed the echo, but since those that were ahead did not answer, those in the rear called me so that we could return to the town, where after much talk we decided to pass the night with sentinels at the end of the road so that the peons should not escape and leave us alone. Among the 45 people that we were, we hardly had one and a half firearms, because the mayor had provided himself with a rusty blunderbuss, without a lock, that he found in a corner of the house of the missionary-who on this occasion was in Lamas with the tobacco officials - and to be able to discharge the blunderbuss, he had provided himself with a half-burned stick from the fire. The second piece of firearms was that of draftsman Gálvez, whose flint had broken, and the largest piece was as big as a silver real; to fire it, it was necessary to strike seven or eight times. To this misfortune was added another one. When he went to load it for the second shot, he was unable to get the ramrod out of the gun and it was necessary to discharge the second bullet and lose it, so that we had only my carbine, and its ramrod was used by Gálvez and me. With these three firearms we discharged about twelve or fifteen bullets into the air in the course of the night to frighten the Chuncho Indians because they are much afraid of firearms. The peons, our servants, and we ourselves prepared the other arms that were reduced to half a dozen sabers and three or four swords, cutlasses, and knives, and all armed pointblank, we passed the night, some playing and others sleeping. The three companions served as sentinels at the end of the road and, observing how hastily the fog gathered in the quebradas, went down to the river to get water, climbing slowly and spreading over the hills; they repeated this operation three or four times during the hours between midnight and five in the morning. At this time it began to dawn, and we could relax our vigilance, sending two men to the place where Salinas had said that he saw the savage Indians. Our companions Dombey and Pavón spent more than four and a half hours in getting to Casapillo, which is about half a league distant from Cuchero, suffering indescribable hardships on the way where 
thickets and the inky darkness of the night compelled them to travel almost on all fours in order not to fall into the ravines or to break a leg or the head in the deep holes where they had to walk in mud up to their knees. The boy who served as guide did not know the way, and for this reason they would have fallen into a precipice if their fear had not kept them back. They arrived at Casapillo covered with mud; there they secured clothes and dried those that they had on. They passed the rest of the night at watch over their arms with no less care and fear than we had of the Indians; but the peons were happy with a jug of rum that our companions paid for.

The 2nd day of August it was barely daylight when our companions sent Juan de Mata and two men with him to Cuchero to find out if the savages had killed us; they thought this had happened, because that and how they could save their lives, had been the subject of their conversation all night long.

Informed by the foreman Juan de Mata that our companions were not thinking of returning to Cuchero, we seized two mules, that had just arrived with food for the cascarilleros, to carry our loads and to take loads of cascarilla on their way back.

We left Cuchero at three in the afternoon, and with no little trouble, because we were traveling on foot, we went to pass the night a little beyond Casapillo, and there in the morning after the third we met our companions, and together we continued our trip on foot until we came to the hacienda of Machainio or Rosapata where we spent the night. On the 4 th, after having been provided with horses, Dombey and Pavón went off on the road to Huánuco, leaving the loads in Cuchero in the care of their servants until they sent muleteers from Huánuco to get them. We three went to Chinchao to continue our botanizing for another month.

With the arrival of our companions at Huánuco the city's militia was set in motion, and the news spread even to Lima that we had been killed by the savages and that these Indians had invaded our lands; for this reason the Commandante of the montañas, Dn. Simon Govea, sent to them Lieutenant Dn. Francisco Señas so that, after being informed of what had happened, he might take the necessary measures to resist the heathens. When the said Señas reached Chinchao, he was informed by us that all had been an invention of Salinas, and he returned to Huánuco after going through Casapillo, where he also was one of the principal overseers.

During our stay in Cuchero we discovered many plants, of which we described the following. Cinchona nitida, cascarilla or quina tree. 
Cinchona magnifolia, flor de Azahar. Vainilla officinalis, vainilla, the fruits of which are gathered by the Indians and sold in Huánuco. Sauvagesia ciliata, yerba de San Martín. Polypodium simile L., Lonchitis cultrifolium, amomum, racemosum, and tyrsoideum, the seeds of which are quite aromatic and oily, for they spot all paper in which they are kept. Psychotria lutea, repanda, and rubra. Heliocarpus glandulosa, balsa wood, as the trunk of this tree is used for balsas or rafts, very light and buoyant. Prunus nitida. Hippotis triflora. Tafalla glauca, aitacupi and almaciga, for the resin that this tree produces in drops, very similar in odor and color to the grains of the almáciga. Condalia sessilis. Laurus aurantiana. Acalypha pubescens and purpurea. Melastoma grossularioides. Lisianthus quadrangularis. Begonia lobata and obliqua. Melastoma grandiflora, hispida, flexuosa, and latifolia. Solanum anceps, ternatum, and laciniatum, rocotico de monte. The Indians eat their fruits. Commelina nervosa. Lobelia scabra. Besleria radicans and biflora. Ruellia allata and paniculata. Rhexia purpurea. Polygala affinis albopurpurea. Lantana aculeata. Browallia demissa. Vandellia diffusa. Hopea tinctoria, gives a beautiful canary-yellow color. Godoya oblonga and spathulata; both species are known by the name of laupe, and their wood is valued for durability and resistance. Sanchezia oblonga. Miconia pulverulenta, triplinervis, and lanuginosa. Cypripedium grandiflorum. Paulina striata. Maranta capitata. Cuellaria obovata. Ageratum secundum. Guatteria glauca. Clusia rosea, matapalo, the resin of which is used in hernia. Senecio pyramidatus. Cissampelos cordata and peltata. Convolvulus quinquefolius. Citrosma pyriformis. Cestrum pulverulatum. Molina quinquenervis. Laugeria hirsuta. Verbena adpressa. Eupatorium hirtum. Cytisus purpureus, chucholle. Sobralia dichotoma. Cecropia aquifera, tacuma. Coussapoa latifolia and obovata. Ficus striata. Coffea occidentalis. Theobroma Cacao. Erythrina incarnata, haynura, abundant in Puzuzo. Palma pullipuntu. Palaua hirsuta. Peperomia obliqua, striata, scandens, and concava. Echites acuminata and subsagittata. Piper acutifolium, scabrum, polystachion, obliquum, filiforme, acuminatum, ovatum, and mite. Calceolaria perfoliata. Justicia tenuifolia and punctata. O'Higginsia aggregata. Riqueuria avenia. Negretia plana. Vismia tomentosa. Macrocnemum pubescens. Bixa Orellana, achote, achiote, and huantura. The seeds are reputed to be an excellent diuretic, and they give color to food and serve also as dyes. This tree is cultivated in the whole of Peru. Pothos volubilis. 


\section{CHAPTER XI}

Location of Chinchao-Inhabitants-The clergy-Climate and temperature -Lack of pastures and cattle-Agricultural products-Fauna-Plants gathered.

\section{DESCRIPTION OF THE PUEBLO OF CHINCHAO}

Eighteen leagues by the road from the city of Huánuco to the north, there is situated the pueblo of Chinchao, on the east side of the river, in a small plain between this and the top of the hill which on that side forms the quebrada. It consists of 9 ranches, with as many families, and another eleven who live on chacaritas or small coca plantations, situated near the pueblo. There is also a church where mass is said and the other church festivities of the year are celebrated only in the three or four days when the priest from Valle, the parish to which it belongs, comes to this place accompanied by two other priests to help him with the confessions and to celebrate the observance of Lent, Corpus, and the burials that have been made during the year by the inhabitants; however, the priest does not neglect to collect in full all the fees usually charged, besides the tax prescribed by the laws of the Indies.

The materials of the huts and of the church are stakes and mud or adobe, and the roof is of straw. The sky in summer is very bright and, although in the other seasons of the year it rains frequently, there is not a day when the sun does not shine. The prevailing winds are north and south, and for this reason the climate is mild. The thermometer goes down to six or eight degrees Réaumur during the night, and rises at most to twenty-four degrees.

In the vicinity of Chinchao there passes a little brook of good, cold, and transparent water that descends by a small gorge situated at the entrance to the town. No cattle are raised because there is no pasture, and the little that is found where they have cut down the trees is a very rough and hard grass that is eaten only as a matter of necessity by the mules that come and go in the valley to take the loads of coca and cascarilla or quina.

To be able to get that poor and scanty pasture, the natives are obliged to burn those places in the months of July and August to prevent any trees and big plants from growing, and in that way to get more tender grass.

Some food is usually to be found in this pueblo since it is on the route from Huánuco to the 74 coca plantations that exist 
in the valley up to Cuchero, but the natives are reduced to four or five common, ordinary articles. Aside from the coca, Erythroxylon Coca, which is the only commercial product of that valley, they plant some roots and fruits for their support, such as yucas, achyras, arracachas, potatoes, mallicas, a species of Dioscorea, ssagui (a species of Calla), montaña cabbage (a species of Carica), sugar cane, maize, beans, anonas, avocados, plantains, papayas, and some pineapples. The chicha is seldom missing in this pueblo and on those haciendas the houses of which are on the road to Cuchero.

There are the same kinds of animals, birds, and insects that have been mentioned in the account of Cuchero. Like that of this pueblo, the terrain of Chinchao abounds in various kinds of trees and plants.

During the month that I stayed in this place, I gathered a beautiful collection of plant skeletons (dried plants) and sketches, of which I described the following. Erythroxylon Coca, coca. This shrub is cultivated in the whole quebrada of Chinchao, in Puzuzo, Chacahuasí, and in all the entrances to the montaña of Peru. Acosta aculeata, monte-lucuma, that is, lucuma of the mountain; this fruit when ripe tastes good. Schinus Mayco, mayco. A beautiful little tree, but its shade causes a great number of poisonous boils, with burning and itching, that appear on the hands and the exposed parts of the body of those who seek shade under it. Not all constitutions are receptive to this poison, which is cured with the Valeriana chaerophylla, known by the name of albergilla, roasted and applied as hot as it can be borne. Sisyrinchium Bermudiana? Peperomia purpurea, filiformis, quadrangularis, trinervis, uniflora, foliiflora. Psychotria truncata. Solanum diformifolium, obliquum, pubescens, variegatum, and acuminatum. Fuchsiamitifolia. Melastoma subsessilis and cordata. Amaryllis miniata, lacre de montaña, because the gluten of its bulbs which, when cut and exposed to the air turns the color of sealing wax, is used to close letters that then cannot be opened without tearing the envelope. Crotalaria retusa? Gonzalagunia dependens. Cornidia umbellata. Passiflora maliformis, granadilla de mono. Urtica sparsa, geniculata, striata, nuda, and fumigera, which has been discussed in another place in this book. Dracocephalum? odoratum. Aster crosum. Condalia lanceolata and obovata. Eupatorium obovatum, carinatum, and coriaceum. Ageratum secundum and trinerve. Melastoma crenata and carinata. Macrocnemum venosum and corymbosum, ccarato, i.e. cow's hide, from the size and consistency of its leaves. Achyranthes geniculata. Molina venosa. Calla acuminata and polystachia, ssagui and gaqui. They 
cultivate this plant in order to eat its fleshy roots, which are bitter and poisonous when they are not cultivated. Pothos sagittatocordata and hastata. Arum rosaceum, a plant that climbs the trees and kills them. Roetia glandulosa. Arum lanceolatum. Clinopodium procumbens and biserratum. Althaea cornuta, an Urena? Eupatorium balsamicum, the flowers of which are in great corymbs and exhale a sweet aroma very similar to that of black or Peruvian balsam, and which may be noticed all over the quebrada from sunrise to midday. Serapias ciliata. Echites spiralis. Besleria diversicolor and auriculata. Senecio odoratus. Palaua biserrata. Polygala aff. incarnata. Ficus retusa? Lobelia hirsuta. Escobedia scabra, saffron and spice of the montaña, the roots of which they make the use already mentioned. Dioscorea triloba, mallica or papa de montaña, which they cultivate between the coca trees to gather the fleshy roots, that are quite large and are divided into several branches like the roots of Peonia; inside their color is purple, and the flavor is very good and pleasant to the taste when they are boiled or roasted. Mecardonia ovata. Cacalia? pubescens. Bombax trilobum, huampo and balsa wood; its moss cotton, although a little short, can be used for mattresses and pillows owing to its softness and light weight and because, when compressed, it returns to its spongy state by exposure to the sun. Its wood is esteemed for rafts because of its light and buoyant quality. Sobralia dichotoma and amplexicaulis. Actinophyllum pentandrum. Gesneria acinaciformis. Heliconia latifolia and angustifolia. Malpighia glandulosa. Costus ruber. Satyrium pubescens. Lisianthus corymbosus and ovalis. 


\section{CHAPTER XII}

Departure of Gálvez, Brunete, and Ruiz-Finding of cinchona trees-Tiresome march-Plants gathered-Stramonium and its uses-Case of intoxication - The maguey and its many uses.

\section{JOURNEY FROM CHINCHAO TO HUÁNUCO}

On September, 1st 1780, draftsman Gálvez left Chinchao for Huánuco, and on the 3rd Brunete set out in my company, and without trouble we reached the inn at Pati, where we spent the night with much inconvenience as the cold wind came through that shelter everywhere. Here is found not only Cinchona purpurea, but also officinalis, of which a few arrobas of bark have been gathered.

On the 4 th at 8 o'clock in the morning we left Pati, and at 5 o'clock in the afternoon we arrived in the pueblo of Acomayo after having suffered greatly on the steep ridge of Carpis from the climb and descent of those steps and the holes and bad condition of the road. On the 5th we arrived in the city of Huánuco at 4:30 in the afternoon, leaving the muleteers behind with the loads.

During the months of September and October I gathered, dried, and described the following plants in the vicinity of Huánuco. Coccoloba carinata, mullaca, the infusion from which is used against bladder trouble. Ruellia ciliata. Pectis trifida, afcapichana, a bitter plant used against fevers in infusions and decoctions. Lycium spathulatum. Croton nudus. Varronia erecta[?]. Agenium pimpinelaefolia. Tribulus maximus L. Indigofera argentea. Melochia plicata. Allionia incarnata L. Lathyrus incanus. Cineraria perfoliata. Triumfetta subtriloba and Lappula. Rauwolfia flexuosa, turucaffa. Its flowers expel a beautiful fragrance in the morning, and from its branches small crosses are made in some places, the thorns serving as arms. Bignonia pentagona. Zinnia pauciflora L. Datura Stramonium L., conco tronco and franuco, the name by which it is known in all of Peru for its abundance and the bad use that the Indians make of its seeds reduced to powder, to stupefy one another when they feel offended, by putting a certain quantity into food or drink; hence the common saying in Peru: Está chamicado or chamicada, a person who is pensive, taciturn, or too happy or drunk.

At the time we were in Huánuco it happened that a boy ten years of age gave another boy of his own age chamico powder in bread, and in a few hours its malignant properties produced their effect, making him drunk as if he had taken wine. Our companion 
Dombey was called to treat him and, although he administered repeated emetics, the boy became stupefied and did not at that time regain his natural happiness and skill in boyish games and pranks. This plant is so abundant in Huánuco that there is not a street where it is not found and, on account of what had happened, the corregidor ordered that all the plants in the town be burned; this order was carried out exactly as given but, when we later returned to Huánuco we found the same abundance in the streets. The crushed leaves and seeds are applied as a poultice to skin bruises with very good results. Some drink the infusion of a few leaves for irritation of the urine and sores caused by drastic purgatives. The crushed leaves applied with vinegar to spine and kidneys are often used to mitigate the fevers and pains of gout and to reduce the inflammation of hernias.

Agave americana, maguey of Mexico, pita and ancas champatra, a plant very abundant in the province of Huánuco; its boiled roots are employed by the Indians as an excellent sudorific for rheumatic and venereal pains. The stems, that regularly grow to 8 or 10 yards, are straight and as thick as a thigh at the base and, getting thinner toward the tip, are used instead of beams to roof houses and, although they are spongy so that their heart serves as excellent tinder, they resist the weight that is put on them and never become insect-eaten. From the leaves the natives get thread for various purposes, and from their juices they make an admirable extract, or "honey," as it is called, to clean and heal ulcers. The method of obtaining this honey is to half-roast the leaves and express the juice while still hot and then to evaporate to the consistency of honey, which they apply to cure the scabies that animals get in the head and feet. They use maguey to enclose orchards, and it forms an impregnable enclosure for all kinds of animals.

Padre Acosta, speaking of the maguey, calls it "the tree of wonders" because of the many useful things that are made of it, such as wine, vinegar, oil, syrup, honey, needles, thread, and ropes.

Yucca laevis and escabra, cabullas or native magueyes; from these thread is obtained for various purposes, and their stems are used to cover roofs in the whole province; removing the woody exterior, they use it as tinder, burning it first at one end so that it will catch fire more readily at the stroke of the flint against the stone. It is an excellent substitute for cork, for stoppers in jugs and bottles.

After I had arranged the dried plants of my collections into classes and had put the generic and trivial names on each species, I decided to go with draftsman Gálvez to the province of Huamalíes. 


\section{CHAPTER XIII}

Departure from Huánuco-The picturesque ravine of Huánuco-Loss of Gálvez' mule-Arrival at Chavinillo-The corregidor Dn. Ignacio de UlloaCahuac, Ovas, and Chupán-Vegetation-Woolen works.

\section{JOURNEY TO THE PROVINCE OF HUAMALIES}

On October 25th, 1780 I left Huánuco with draftsman Gálvez at 8 o'clock in the morning; there was some cloudiness that ended in a copious rainfall just as we had passed the quebrada of Las Higueras, pleasant and interesting on account of the luxuriance and fertility of its fields and the plantations of vegetables and corn with which the two banks of the river are covered, cultivated by the Indians of those ranches. Sixleagues from Huánuco theguide stayed behind because his mule was tired, and Gálvez, a servant, and I continued our trip half a league ahead, where we lost our way until a traveler put us right. As Gálvez was turning his mule to return to our road, the animal lost its footing and fell over a high, sloping bank, Gálvez being saved by holding on to a small plant. At this misfortune we left the servant with the injured animal and, Gálvez mounting the servant's mule, we continued our way to the town of Chavinillo, a distance of 14 leagues from Huánuco, where we arrived all wet at 5 o'clock in the afternoon without having been notified that the corregidor Dn. Ignacio de Ulloa had just left the town after he had finished the trial of several rebellious Indians later sent to the house of correction in Quivilla; for this reason we found only women and four men in the town. We passed the night in great discomfort, reclining on some stone benches on which there was a little ichu that served us as mattresses.

On the 26th we passed through the pueblos of Cahuac and Ovas, where the corregidor, with 200 mestizos that he had with him, had finished meting out justice to the rebellious people of that town and had sent them to Chupán where he punished those who had taken part in the revolt.

The town of Chupán is situated like the others in high hills with a cold climate; one finds there only grass on which great numbers of cattle and sheep are raised, and one sees no large plants, unless it be Sambucus nigra within the settlements, but in the depths they plant potatoes, the only product in those towns.

On the 27th we went on to Quivilla, taking ahead of us the rebellious people to make them pay for their guilt in the house of correction that is operated in this seat of the corregidores. 
On the 28th it was raining, and we could not go out to find plants in that quebrada, and we were satisfied to examine the work of the house of correction and the warehouses for woven goods which are brought by the Indians of that province in great quantities, as this is the largest branch of trade that they have.

The following days until the 2nd of November I made several outings through the quebrada, notwithstanding the continued showers, but I found scarcely any larger plants, and the few that are found there I had already examined in Huánuco and other places. For this reason we decided to return to Huánuco by way of the old town of Huánuco, but this we could not do on account of the rains, and we passed on the 2nd to Chavinillo, wet to the bone, and had several scares as we traveled for more than an hour in the dark over bad roads with narrow and dangerous precipices. On the $3 \mathrm{rd}$ we arrived in Huánuco. 


\section{CHAPTER XIV}

Boundaries and extent of this province-The river that crosses it is the Marañon, according to La Condamine and other geographers-The Patay Rondos, Tazo, and Huánuco rivers-Fertility of the soil-Abundance of cattle-The trade in wool-Discovery of silver in the desert of Huayanca-Discovery of mercury and silver in the hill of Chonta and district of Ayras-Placer gold in Chavín -Thermal springs and ancient monuments-Aetites-Parishes-Quivilla and the bridge-Inhabitants of this province and their dress-Drunkenness and its consequences-Love of dancing.

\section{DESCRIPTION OF THE PROVINCE OF HUAMALIES}

This province borders to the north on that of Pataz, to the southeast on that of Huánuco, to the south on that of Tarma, to the southwest on that of Caxatambo, and to the west and northwest on that of Conchucos. It also borders to the north on that montañas of the pagan Indians.

Its length from north to south is 82 leagues, and its width from east to west is 30 , although in some parts it is only 12 .

It is divided into mountains and valleys, the latter having a mild climate and the high ground a rigorous one, especially in its southern part. In the principal quebrada or narrow valley of this province, there is a river that Padre Fritz in his geographical letter holds to be the Marañón, an opinion also held also by M. de la Condamine; Padre Fr. Manuel Sobreviela confirms their opinions, in a map made in 1791.' It has its beginning in Lake Lauricocha at the end of the province of Tarma, 6 leagues distant from that of Huamalíes. The Patay or Rondos river and the Tazo river go to join the Monzón that joins with the Huánuco seven leagues farther below the wharf of Cuchero. In the parish of Huacaybamba there are found some farms with so much heat the year round that to this is attributed the fact that the inhabitants are darker than those of the rest of the province; that is the reason they call them zambos.

In the depths and warm quebradas they gather abundant and excellent fruits, vegetables, and seeds, such as some wheat, barley, much maize, potatoes, ockas, alfalfa for the animals, sugar cane from which they make chancaca, alfeñique, honey and guarapo, guavas, excellent and large paltas and chirimoyas, plantains, tunas, figs, peaches; and, in the montaña, very good pineapples.

1 This last statement is written in the margin of the original, and no doubt it was added by Dn. Hipólito Ruiz when in Spain he finally wrote the history of his journey. P.B. 
In gardens they cultivate a variety of flowers with which, during the year, the women decorate the altars and images in the churches. The montañas produce a multitude of trees and plants with medicinal and various other uses. They also produce the cascarilla or quina oficinal and other species, samples of which I have in my possession. At the entrances or edges of the montañas there are some coca trees the leaves of which they sell to the miners of Huayanca and Pasco. There are also found precious woods.

As for the elevations where no fruit is raised because of the cold, thousands of heads of cattle and horses graze there, and for this reason there are many farms in the punas. The pasture on which all these cattle are maintained is the grass called ichu, and some other smaller grasses and small nutritious plants.

They gather considerable amounts of wool from which they make native cloth; the principal commerce of this province is taking this cloth to be sold at Bombón, Lima, and other places.

Besides the wool that they obtain from the sheep of the whole province, they buy many arrobas from other places, so as not to stop the work in the mills, and usually these purchases are paid with the cloth made from the same wool.

In the years 1778 and 1779 many silver mines of good yield were discovered in the desert of Huayanca. Some ores had given 400 marcos [3,200 ounces] per box. For this reason there is a town of about 500 inhabitants today, while in the year 1776 there were only vicuñas and other animals of the punas inhabiting that site.

In the hill called Chonta they have discovered a mercury mine, from which they have taken some small quantities of that metal. Some twenty years ago they discovered silver mines in the district of Ayras, where there are only two miners working and there is only one country house, at a short distance from Huayanca.

There are some gold mines that are not worked because of the great cost of operations. In the town of Chavín there are gold washers, and some persons have taken out good quantities of the metal.

Between Aguamiro and Baños, there are fountains of thermal water. Near this last town are the royal highway of the Incas which I mentioned under the province of Tarma, the ruins of one of their palaces with a bath of stone perfectly joined, and the ruins of a temple and fort in the summit of a mountain looking towards the Quivilla or Marañón river. Finally, in a pampa or plain with a cold climate, called Huánuco el Viejo, 14 leagues distant from where the 
city of Huánuco is situated today, there are found thousands of aetites, or del aguila stones.

The province of Huamalies is divided into 8 parishes distributed on the two banks of the river, and most of the towns are located on high ground.

The first parish is that of the town of Baños with 7 annexes named Rondos, Cosma, Chupán, Quipas, Chuqui, Marías, and Margos that belong to the jurisdiction of the province of Tarma. The second is that of the town of Jesús with the annexes Xivia, Huaccrin, Choras, and Llacos that also belong to Tarma. The third is that of Pachas with the annexes Sillapata, Llanas, Aguamiro, Ovas, Cahuac, and Chavinillo. The fourth that of Llata with the annexes Puños and Miraflores. The fifth that of Zinha with the annexes Punchac and Huacachi. The sixth that of Chavin de Pariarca with the annexes Tantamayo, Hacas, Xican, Chipaco, and Monzon. The seventh is that of Huacaybamba, in which they grow sugar cane, with the annexes Rondobamba and Huarihancha. The eighth is that of Huacrachuco, where sugar cane is raised also, with the annexes Llamos and Quirin.

The valley of Arancai, situated to the east[?] of the Monzón river, has five farms that belong ecclesiastically to the parish of Uco pertaining to the province of Conchucos.

In the large house of correction at Quivilla, that is in the center of the province on the banks of the Marañon, the corregidores had their residence until the year 1780 when Dn. Ignacio de Santiago de Ulloa established his in Huayanca, on account of the discovery of the mines. Quivilla belongs to the parish of Pachas.

In Quivilla, to facilitate the communication of the pueblos of one bank with those of the other, there is an excellent cable bridge constructed by Corregidor Dn. Domingo de Cagiga, who was killed by the Indians who later went to Quivilla and burned his house in the dead of the night. This bridge is more than 30 yards long and is well constructed on top of some rocks.

The majority of the inhabitants of this province are Indians, and some are mestizos but very few are whites. They dress in clothes from their own looms, of a navy-blue color. They walk barefoot even on the coldest of days and, if at any time they protect their feet, it is with a piece of cowhide to cover the sole of the foot, tied with two strips of the same hide, This footwear is called sucuyes.

Many women dress in petticoats, although many dress in arracos in the towns as on the farms where many spend their lives taking care of the cattle and spinning wool in the fields, for the making of xergas, tucuyo, ponchos, neckpieces, handkerchiefs, and rugs of different forms and sizes, decorating them with various animals, birds, and other figures. 
The Indians are given to drunkenness, especially on holidays, and under the influence of this, they continually start disturbances among themselves or with the mestizos and sometimes with the priests, justices, and corregidores.

In the towns where there is a cacique, dissensions are known to have lasted more than a year, the cacique inciting the Indians not only of his town but of other towns as well, and neither the authority of the justices nor the respect for the priests has been sufficient to control the natives.

The women are more peaceful and not at all inclined to drunkenness, and they try to keep the Indians from many fights. They are more industrious in any type of work and prove it by their continuous attention to the ranches, family, and cattle, and they do not take part in the drinking bouts of their husbands; if they do so at any time, it is when they seed or plant the little farms and at this work the husband helps with all of his relations. If it were not for the chicha that their wives make for these days, the Indians would not help with this work.

In the harvest the women work alone and likewise at the urias, or weedings.

The Indians are very fond of dancing festivities and, when they have them on the days of the Feast of the Three Kings, Corpus, and the days of the patron saints of their pueblos, and so forth, the fun and drunkenness last eight or more days, and if the corregidores and justices did not make them work to pay their tribute to the King, and other taxes that are imposed, the whole year would be a holiday; so it is said that one day of drinking is worth more than hundred lashes.

The Indians are not religious, in contrast with their wives, who on feast days as well as on workdays decorate the altars and images with various flowers which they cultivate in their gardens for that purpose.

They are also more friendly and charitable in the midst of their poverty produced by the laziness and abandon of their husbands, who spend in drink what their wives make with their continuous work of spinning wool, weaving, and planting.

On November 2nd we returned to Huánuco through Chavinillo. 


\section{CHAPTER XV}

Misfortune of a muleteer-Incidents of the trip-Work of the botanists during the year 1780-81-Plants gathered and their uses.

\section{TRIP TO PASCO}

On November 20th, 1780 I went from Huánuco to the Royal Coffers of Pasco to receive all my companions' salaries with authority given to me by them for that purpose. I spent the night in San Rafael. On the 21st, when we had traveled more than a league and a half beyond Huariaca, the leading muleteer's animal became tired, and the rider dismounted in the middle of a very dangerous and narrow incline, so that he had to walk behind his mule. On arriving near the summit of the hill, the mules that were going ahead stopped and, to make them start again, he threw a stone, but at the same time his mule gave him a kick in the face that broke the cheek bone, and he fell to the ground unconscious, where with his twistings he would have been in imminent danger of falling into the river from those heights, if I had not dismounted so quickly and pulled him by the legs to the middle of the road. At my cries his brother and my servant that were ahead came immediately, and between the three of us we were able to hold him until he came to his senses. For the time being I placed two handkerchiefs drenched in brandy on his cheek to stop five spouts of blood that came out of that poor muleteer in profusion, as if from as many incisions. We took him to the first brook and washed him, and I applied some balsamic plants pounded between two stones, and with these I succeeded in stopping the bleeding completely, because he was almost fainting and could scarcely speak. We took him afterwards to the first house, where I treated him again and left him with instructions, telling them what to do with him until my return from Pasco; the rest of us continued our journey thither, reaching that town at eleven at night with great difficulty on account of the darkness of the night and the lightning and thunder that followed us for more than two leagues on the heights of Bombón where we lost our way. I stayed one day in Pasco, and on the 23rd we returned to Caxamarquilla, being unable to continue farther because of the heavy showers, and because my servant and the muleteer had gone astray more than two leagues.

On the 24th we stopped to sleep at Rondos, and we found the man who was hurt at Huariaca more spirited and determined to go to Huánuco by way of the quebrada, which he did as soon as he had 
been treated. We arrived at Huánuco on the 25 th without any other trouble than losing a mule and its load of silver in one of the precipices. The wounded man recovered within two months, after having had four pieces of bone extracted from his cheek.

From the 4th of November, 1780 until the 22nd of March, 1781 we continued our work in the hills, quebradas, and valleys of Huánuco, and during this time I finished several descriptions of the plants I brought from the montañas. I dried and described the following plants gathered on the road and in the territory surrounding Huánuco. Viola bicolor. Eupatorium scabrum. Spermacoce pilosa, and tenuior, uspica. Cardiospermum biternatum. Vermifuga corymbosa, matagusanos, contrayerba and chinapaya, which is employed crushed and is applied in the form of a poultice to cure maggots in beasts; for this purpose it is very useful. Calceolaria pinnata L., mancapagui. Callisia repens $\mathrm{L}$. Ricinus communis, higuerilla de la tierra. Ricinus ruber, higuerilla mexicana. From the seeds of these two plants the natives obtain, by expression, an oil that is used for lighting their houses, and especially for the lamps in the churches. They also use this oil as a caustic and suppurative for external tumors. Achyranthes obovata and rigida, Moorish grass, female and male, the decoction of which is used to stop hemorrhages, and when ground with salt is applied to clean ulcers and heal them, poultices being changed every 24 hours. Finally, with them they cure injuries to the feet caused by the pricks of their calyces to those that go barefooted, for the grass is so common in Huánuco that its plazas and streets are paved with them. Celosia conferta, yerba de la sangre, on account of the property of the juice and decoction of its bulbs, of stopping the flow of blood. Sicyos cirrhosa, calabaza cimarrona, or wild pumpkin. Bauhinia rosea and aculeata. Gentiana serrata, minutissima, and luteopurpurea. Lobelia subpetiolata, hirsuta, biserrata, and purpurea. Acaena amentifolia. Molina ferruginea, palmito. Malva incana. Tagetes integrifolia, chinchi. Passiflora subtripartita. Eryngium coeruleum. Salvia alba. Calceolaria dentata, bicolor, verticillata, and viscosa. Periphragmos uniflorus and flexuosus. Pineda incana, llogui. Strong wood suitable for making ramrods and walking canes. Horminum? triangulare. Aster lyratus and lanuginosus. Dioscorea acuminata. Urtica rugosa. Sida incana. Mimulus subumbellatus. Piper angustifolium, moho-moho, and lineatum. Psychotria hirsuta. Solanum angustifolium, dichotomum, and diffusum. Caballeria ferruginea. Sanicula canadensis L. Cuellaria ferruginea. Banisteria fulgens. 
Pothos volubilis. Silphium dichotomum. Acrostichum acutum. Asplenium salicilifolium. Adiantum trapeziforme and brachiatum. Hemionitis falcata. Polypodium acanthifolium, volubile, racemosum, furcatum, trilobum, dichotomum, and acutifolium. Pteris bipartita, curvata, auriculata, and crenata. Marchantia polymorpha L. Trichomanes fimbriatum and interruptum. Lycopodium peregrinum, nutans, and prostratum. Scorzonera ciliata and peruviana. Bryonia cordifolia. Phyllanthus Niruri L. Narcissus odorus, abundant in Lima and Chancay. Eupatorium sagittatum. 


\section{CHAPTER XVI}

Dangers of the road-The advice of a traveler-Arrival at Huariaca-Plants of this region-Sickness of Ruiz and Pavón.

\section{JOURNEY FROM HUÁNUCO TO LIMA}

On the 22nd of March, 1781 I left Huánuco for Lima and, without any mishap on the way, I slept that night at the site of Ambo; on the 23rd I went on from there to the pueblo of Rondos ahead of the muleteers, with the purpose of gathering the plants that were in bloom at that season.

For this reason the muleteers stopped one league from the pueblo, claiming that the road was too heavy from the rain that overtook them during the trip.

The draftsmen Brunete and Gálvez left Huánuco on the 23rd, and Dombey and Pavón on the 24th. This same day my muleteers arrived at Rondos at 10:30, and at this hour I made them unload the paper and presses to accommodate and change the plants that I had gathered. At 12 I left Rondos, travelling with the muleteers until 5 in the afternoon when, to avoid a furious and sudden storm, I went ahead with my servant and my bed, leaving the muleteers with the rest of the loads because it was impossible to hurry the mules, frightened as they were by the noise of the thunder and lightning, and the heavy showers that followed. The men had to stay in that place in order not to expose the mules to a fall down one of the precipices and ravines of the slippery road that remained to Huáriaca, where, in spite of the dark night and the terrible storm, I arrived happily, following the sound of the steps of a person that I heard walking ahead of me with his donkey after my servant had fallen behind and failed to answer my calls.

I asked the Indian or mestizo where he was going, and what the distance was to Huariaca, and how many bad passes there were. To all my questions he answered in Spanish, and he promised to tell me when we reached the bad passes; this he did properly, otherwise I would have fallen into the river on one of the three occasions when my mule slipped, but the Indian told me to let the animal get up and walk at his will without my touching the bridle. After having passed all the bad places, I begged the Indian, offering him money, to go back and look for my servant, but he answered that the latter would appear sooner or later. Nevertheless I continued to repeat the whistling, calling for my servant, and he did not answer 
long after the Indian, or whatever he was, had gone ahead by another path, leaving me after he had told me that I was near the town. For more than half a league my servant did not answer me; for this reason I thought that he had fallen down the precipice to the noisy river that prevented us from hearing one another.

A little before reaching Huariaca I repeated the whistle and had the satisfaction of hearing my servant answer, saying that the mule with the bed and the other saddle mule that came unencumbered had been lost.

We arrived in Huariaca at 8 o'clock at night, wet from head to foot, and the priest, having been informed of our whole story, gave orders to the alcalde to send two Indians in the morning in search for the bed; they found it, a league and a half from Huariaca, on top of the mule which was resting in the road. For the saddle mount he asked to have a horse tied in the plaza, and after it whinnied, the mule appeared in a quarter of an hour.

Never before had I found myself in such imminent danger of losing my life as on this nocturnal trip over a narrow path made slippery by the water that poured without ceasing from the bursting of the frequent clouds that succeeded each other without intermission for more than an hour.

The muleteers arrived at Huariaca on the 25th, with the loads soaked, and for this reason we had to stay and dry them that day.

At 2 o'clock in the afternoon, the draftsmen arrived at this town, and they went the next day, leaving the loads behind. I followed my muleteers about 2 leagues, going ahead then to the mine at the cerro of Yauricocha, being detained there by another storm like the previous one.

I arrived at the cerro without having experienced on the road any misfortune except the cold of those heights, the inconvenience of several mudholes, and a brief shower that caught me a little before arriving in the town. The muleteers did not come until the 27th. On the following day, the 28th, we left the mine of the cerro; I slept in Diezmo on the skin used under the riding-saddle, because my muleteers had taken a different route. The 29th I spent the night in the estancia of Palcamayo without any other trouble than the cold of those punas, situated at the foot of the cordillera where, notwithstanding the cold of the nights, they keep numerous cattle and Castilian sheep; these graze on the ichu and the short but abundant grass that is found there throughout the year with other plants, 
among which there are several gentians and some Diadelphias, Syngenesias, and Cryptogamias.

On the 30th we were overtaken a league from Palcamayo by.a thunderstorm and by lightning, and a copious fall of hail followed that lasted for two hours until we crossed the lofty Cerro de la Viuda, that is permanently covered with snow because it is the highest in all those cordilleras.

At 8 o'clock at night we arrived at the pueblo of Culluay so wet and shivering with cold that the overseer of the muleteers came down with an attack of tertian fever such as he had just had in Huánuco.

On the 31st we travelled only four leagues, because some of the mules had bruised their feet, owing to the dampness and the hardness of the roads.

On April 1st, 1781, we spent the night in a small hut, a quarter of a mile from Obrajillo; the extreme heat caused by the rays of the sun is felt there in the daytime. On the 2 nd we slept in another little hut half a league from Quibe, and because I could not find there any plants different from those found in Lima, I went ahead of the muleteers by the road to Ríoseco, a very hot, dry, and sterile place, as it is boxed in between two high hills of rock and sand. I passed the hacienda of Caballero where they maintain a number of cattle and horses in the alfalfa and grass fields. I arrived at Lima at 3 o'clock in the afternoon.

My loads arrived on the 4 th. On the 8 th the draftsmen arrived in Lima without any special incidents on the trip they had made through the town of Tarma and the quebrada of Huarocherí. Finally on the 15th Dombey and Pavón arrived by way of the quebrada of Canta without other misfortune than many showers and cold weather such as I had experienced, and that of being held up by robbers who tried to steal their mules one night.

As the result of our daily excursions, our legs were covered, as in Puzuzo, with a kind of eruption that ended in very annoying and itching pimples, so that especially at night we passed whole hours scratching until our skin was raw. The remedy for our trouble was either to leave the montañas or not to walk on foot in the bush. Our companion Pavón was stricken, besides this itch, with a skin disease called mayco, resembling the itch but consisting of papules filled with matter which cover the hands and the buttocks and sometimes the neck, accompanied by some fever. This malady originates, 
according to the Indians, from two species of Schinus, known there by the name mayco. This affliction is cured with albergilla, a species of Valeriana, which is applied roasted in bunches as hot as it can be borne over the boils, and in that way they disappear in 8 or 10 days. While this malady lasts the patient is almost unable to work. 


\section{CHAPTER XVII}

Limits of the province of Canta-Products-Rivers-Lakes-SicknessesPlants of this region-Population.

\section{DESCRIPTION OF THE PROVINCE OF CANTA}

The province of Canta borders to the northeast and east on the province of Tarma, to the west on that of Chancay and part of the province of Chacras, to the south on that of Huarocherí, and for the rest on the province of Cercado. It extends 24 leagues from north to south and 35 from east to west, forming a rectangle.

The climate in the mountains and in the punas is quite cold, and at night it freezes and there is ice, but in the daytime this is melted by the heat of the sun. In the folds and low places of the mountains it is temperate, but in the luxuriant quebradas hot all year round. The land is broken, although on the sides of the mountains and in the quebradas there are some small plains where they plant and gather various roots and seeds, such as potatoes, massuas, arracachas, maize, abas, beans, barley, alfalfa, vegetables, and several fruits of the country, such as guavas, granadillas, pacaes, chirimoyas, avocados, soursops, etc.

In the heights and mountainous regions where there is an abundance of ichu and short grass, many cattle are kept and many sheep and horses. In the punas there is an abundance of llamas, vicuñas, huanacos, and viscachas.

In the houses and farms of the punas and the mountains, they burn champas or tufts, prepared as I have already told in the account of the mine of Pucará.

On the way down the range of mountains toward Culluay there are a few mines that formerly were worked and gave as much as 200 marcos [3,200 ounces] of silver per box, but none are worked now in this province. There are gravel pits, and hematite, alum, and vitriol ores and two hills of magnetite.

There are various small brooks that descend from the range of mountains and quebradas, but there are only two rivers with an abundance of water; one is the Carabaillo that has its origin in the lakes Hacaybamba and Sorococha; it empties into the sea to the south between Lima and Chancay. The other river is the Huombra that comes from Lake Punrum, which is 3 leagues in length and 2 in width, and enters the Parí or Oroya river, as do also the waters 
that pour from lakes Huaychao, Pamacocha, Cullue, and from Lake Huayllasrun, that is 5 leagues in length and 2 in width.

In the pueblo of Santa Catalina there is a spring of thermal waters that join the Carabaillo river.

From the mountain of Hacaybamba all the snow is obtained that is needed in the icehouses of Lima.

In some quebradas, the malady called verrugas is common and, if it does not break out immediately, there follows a long, troublesome, and dangerous sickness. To cure the verrugas the natives make much use of Mespilus uniflora.

Also very common is a malady with corrosive ulcers, particularly of the face; it is healed only after a long time and with difficulty, and for this reason many people die of it. The natives blame this affliction on the sting of the uta, a very small insect almost imperceptible to the naked eye.

Finally there are in this province some cases of tertians, pains in the sides, and spotted fevers; all of these maladies are treated by the Indians with herbs, as there are no doctors there, nor could any be maintained with the scanty means of the inhabitants, so that they make use of medicinal herbs which are very abundant in those quebradas, serranías, and punas. Among these plants there are the true calaguala, the ramaysantra, quinchamali or chimchamali, chancano or huachancano, that is, poor man's purge, Euphorbia tuberosa, of the roots of which the Indians make frequent use, taking about a drachm in an infusion for a laxative and, when they want to stop the action, they take a glass of cold water. In Huánuco they make a conserve with equal parts of sugar and fresh roots, and they give two drachms for each dose; in this way the purge is more gentle.

There are many different species of cactus found in the hot quebradas and on the sides of the hills, and in the depths there is an abundance of calceolarias, several Syngenesias and Malvaceas; there are many other precious plants, such as the molinas, sarachas, ambrosias, ferrarias, periphragmos, loasas, Fraxinus, Scorzonera peruviana, etc., Loasa rosea.

This province includes 54 pueblos and some ranches and farms, 12,150 inhabitants, most of them Indians, and not more than 60 Spaniards and 1,730 mestizos.

It is divided into 9 parishes, which are: The first that of the pueblo of Canta with the annexes Chaqui, Carhua, Obrajillo, and Pariamarca. The second that of Pamacocha with the annexes Ccarhuacayan and Llanta. The third that of Parí with 12 annexes: Uchayucarpa, Huayllay, Huaychao, Pacaraos, Vichaycocha, 
Santa Cruz, Sta. Catalina, Chapcá, Ravira, Chuspas, Culli, and Viscas. The fourth that of the high Atabalillos with the annexes Pasachisque, Huaroquin, Ccormo, Pirca, Baños, and Ataxpamarca. The fifth that of Lampian with the annexes Cotoc and Cárac. The sixth is that of the low Atabalillos with the annexes Pállac, Chaupis, San Agustín, Huascoy, San Juan, and Pampas. The seventh that of Huamantanha, where they worship a sacred crucifix which is visited very often; with the annexes Puruchuco-where there is excellent earth for the making of pottery-Quipan, Marco, Sumbirca, Aina Huandaro, and Rauma. The eighth is that of San Buenaventura with the annexes San José, San Miguel, Huacos, Huaros, and Culluay. The ninth is that of Arahuay with the annexes Bucas, San Lorenzo, Pampacocha, Anaica, Yaso, Mayo, Quion, Tansa, and Quibe. Here is found a poor chapel that was the house in which the glorious Sta. Rosa de Lima lived several years.

The natives of this province work mostly as drivers of mules, especially in the mines of the hills, carrying the ore from the mines to the smelters. Others work at digging mines and for that reason have many mules. The women work the fields and take care of the family while the husbands labor at the mines. They also spin, and one sees some wool and cotton cloth for their use. They dress in anacos and many petticoats.

From the 16th of April, 1781 until the 4th of July of the same year, we stayed in Lima drying the plants that we had gathered on the trip. I finished with the descriptions of the same, and I arranged them by classes in packages and then collected several plants in the hills and valleys of Lima to replace those sent in the boat "El Buen Consejo," which, we were told, had been captured by the English, but we did not know then that it had left all the freight in the Islas Terceras.

After packing in boxes the products gathered in Tarma and Huánuco, and their montañas and trails, we decided to go to the province of Chancay again, to replace the loss of the dried plants and sketches from that province that were sent to Spain in the vessel "El Buen Consejo."

After permission had been obtained from the Viceroy, and all preparations had been made for the journey, we sent the muleteers with our baggage to Chancay on the 4 th. 


\section{CHAPTER XVIII}

The hacienda of Torreblanca and Dn. Toribio Bravo-Botanizing and plants gathered-Trip to Huaura and plants studied-Tutumos, huanábanos-Uses and common names.

\section{SECOND JOURNEY TO THE PROVINCE OF CHANCAY}

On the 5th of July, 1781, we, the Spanish botanists and draftsmen, left together for the hacienda of Torreblanca, a distance of half a league from the pueblo of Chancay. Mr. Dombey stayed in Lima by order of the Viceroy, to go in the company of an official of the navy and a pilot to the port of Callao where they were to make some observations on the tides. We arrived at Torreblanca at 7:30 at night without mishap.

From the 6th of July, 1781 until the 10th of August of the same year, we stayed in the hacienda of Torreblanca, accompanied many days by the owner, Dn. Toribio Bravo of Castilla, a gentleman of the most distinguished nobility of Lima and one of those who took pains to help us in that country, for he not only asked us to stay in his house but also provided us with food at his table both times we stayed there, and sometimes he accompanied us on our trips.

During this time we explored the hills, slopes, and valleys of Chancay, Pasamayo, Jeguan, Retes, and Laral, where we discovered several new plants of which I described the following. Chenopodium album, yerba del gallinazo, the decoction of which is used with good results against jaundice. Amaranthus retroflexus and spinosus L.?, yuyu. We ate its leaves several times in boiled salads, and they have the property of softening the stools. Allium triquetrum L., and angulosum, feligranas. Serapias flava. Satyrium viride. Bantisa rivularis. Solanum repens and peruvianum, wild tomato. Jussiaea peruviana, flor del clavo. Euphorbia striata. Galinsoga quinqueradiata, and quadriradiata, pacoyuyu. The natives make use of the juice of these two species for treating sores of the mouth. Eclipta alba L. Sida frutescens, pichana. The roots are sold in little bunches by the negroes and are used in Peru to clean the tartar off the teeth; they also serve the fair sex for diversion, especially on holy days at home, in the carriage or when visiting, and are not removed from the mouth, except for spitting. Sida capillaris, matayerno. Crotolaria incana. Bidens cuneiformis. Calceolaria pinnata L. Heliotropium synzystachyum. Spilanthes urens, salivatoria. Valeriana pinnatifida. Malva peruviana L. Buddleia occidentalis. Boerhaavia 
viscosa, pegajosa. Hedysarum prostratum. Passiflora suberosa. Spermacoce tenuior L. Potamogeton compressus. Xuarezia biflora, thee del Perú. Oenothera prostrata. Encelia obliqua. Sidalutea. Elaterium pedatum, caihua. It is cultivated in Peru, and its fruits are used instead of young pumpkin, filled with ground meat or meat balls. When eaten young and tender, they taste like Spanish cucumbers. Elaterium bifidum, caihua de lomas. Atriplex crystallina. Bowlesia palmata. Sobreyra repens. Matricaria tripartita. Campanula biflora.

On the 11th day of August, 1781 we went from Torreblanca to the pueblo of Huaura, where we arrived at 10 o'clock in the night, without other inconvenience than the excessive heat, after we had crossed the hills of Lachay where there were dense fogs.

We stayed in Huaura until the 3rd of September of the same year. During this time we sketched and dried some plants, and I described the following. Crescentia Cujete, tutumo. From its fruits, called tutumas, the exterior of which is very heavy and strong, the natives make cups to drink chocolate or mate. They are made by merely sawing the fruits transversely and cleaning out the pulp and seeds with which they are filled. Afterwards they trim them around the edges and bottom with a thin plate of silver or gold to embellish them. They also use these calabashes or tutumas to keep balsams and resins, making a small hole in one of their extremities and emptying the pulp through that. From this pulp they make a preserve, excellent for the cure of internal abscesses, by adding equal parts of sugar and sweet oil of almonds and cooking them in the same fruit over a low fire to the consistency of honey. The dose is a half to one ounce. Cassia Tora, wild cañafistola. With the pulp found in the pods the natives purge themselves, as also with the infusion of the fresh leaves from a half to one ounce. Molina scandens, chilca. From the crushed leaves and shoots of this they make a poultice to soothe pain from sprains and bruises. Sida jamaicensis and cristata L. Salvia rhombifolia. Anona muricata, huanábano. Tall, thick, luxurious tree of beautiful green, cultivated in Peru.

The fruit called huanábano is of the shape of a heart, and some of them are from one to six pounds in weight, Its meat is white and has a bittersweet taste, inferior to the chirimoya and the anonas in all its qualities, and for this reason one cannot eat so much of this fruit as of other delicate fruits that are species of the same genus. From the trunk of the huanábano are obtained good boards, beams, and planks for buildings and other works. Dolichos Soja? L., frijolillos, the seeds of which are eaten boiled and have a very good 
taste. Anona squamosa, anono, a big, tall, and luxurious tree, cultivated in Peru. Its fruit called anona is between round and conic in shape and resembles the pineapple, with a hard and scaly skin and a white, tender pulp, sweet and soft like butter and of a more delicate taste than the fruit of the chirimoya, particularly those that are grown in the town of Huacho, from where they sent them to Lima as a great delicacy. Its wood has the same uses as that of the huanábano. Dianthera mucronata. Lycium aggregatum, macapagui or quiebra ollas, because its wood bursts when it burns and usually burns and breaks the pots that happen to be at that time on the fire. The ground leaves mixed with lard are applied as an emollient and suppurative. Alstroemeria peregrina L., peregrina, a plant with flowers of varied tints, that serves for decoration in the garden. Boerhaavia scandens L., yerba de la purgación, on account of the property that its decoction has to resolve and cleanse gonorrhoeal discharge. Centaurea napifolia L. The infusion and decoction is used for treating intermittent fevers. Cissus compressicaulis, yedra. Malpighia nitida L., ciruela de Fraile. Its fruit has a very sweet and cloying taste, and its seeds taste like almonds but are very nauseating. In order to mature, this fruit must be kept in straw, bran, or other matter for a few days after it is ripe, and then it becomes as soft as butter. Its flesh is red. Cordia rotundifolia, tina and membrillejo, because it resembles the quince. Its decoction is used with good results for the cure of jaundice. Poinciana..., pai-pai. Luxuriant tree the trunk of which has several uses in carpenter shops because of its strength, and its pods are used for black dye and to make a very good ink on account of the gallic acid in which they are rich. Malva coromandelina? Calyxhymenia ovata and expansa. Mimosa sensitiva, tapate and cirrateputa, for the peculiarity that this plant has of contracting its leaves when touched. Passiflora foetida, puchepuche. The children eat the ripe fruit, and the ants eat it before it is ripe. Salvia excisa. Physalis angulata L. Basella rubra. Tillaea connata, almizclilla, because of the odor it exhales, similar to musk. Atropaumbellata. Crotalaria laburnifolia L. Mimosa latisiliqua, yerba de la lancha. The natives say that the animal that eats of this plant loses the hair of the mane and tail, and that the hair does not come back in a long time. They also say that any person who washes his hair several times with the water in which the leaves of this plant had been rubbed will become bald-headed. Sida americana and repens, pila-pila. Water in which this plant has been rubbed is used by the women of Peru in combing their hair to make it grow. 


\section{CHAPTER XIX}

The hacienda El Ingenio-Its sugar production-Quipico-Plants described - The farm of Andahuasi-Its good management.

\section{JOURNEY TO SAYAN}

On September 3rd, 1781 we went from Huaura to the pueblo of Sayan, a distance of ten leagues inland, crossing the hacienda called "El Ingenio," of Dn. Francisco de la Puente, a gentleman from Lima, at which they make every day from 20 to 30 loaves of fine sugar, each one weighing two arrobas. Each one is sold at 30 or 40 reales of that coinage. At this hacienda, which was formerly the property of the Jesuits and is about one league in length and one in width, and on level ground, two sugar mills operate every day.

When we had crossed this hacienda, we traveled through the one named Pativilca, owned by Dn. Pedro de la Presa, a gentleman from Lima, larger in extent than the previous one, but actually they have only some cattle, and they do not make the excellent sugar that in ancient times used to be made there, because the owner has taken all the negroes away to another hacienda. From Pativilca we went to the hacienda Humaya, much larger than the previous one and the property of the sons of Dn. Juan Antonio Blanco. This hacienda had also been property of the padres of the Compañía. Sugar cane is ground day and night with four, and sometimes six, changes of oxen, and every day they get 30 to 40 loaves of sugar of quality superior to that of any of the neighboring haciendas. This hacienda needs about 150 negroes more than it has, so that the work in the mills may not stop, as happens frequently for lack of men, and because the negroes are liable to be sick there. Because of the great humidity and excessive heat many die and others are crippled for life and unable to do even the simplest manual labor. The place is about 5 leagues from the pueblo of Huaura. From there we went to the hacienda Quipico, owned by Dn. Antonio Boza and administered by one of his sons. In that also they harvest about 24 to 30 loaves of sugar, and it is more than two leagues in length. The workshops, living quarters, and church of this hacienda are better arranged than any of those previously mentioned and than the others in the valley.

The buildings of the haciendas Paila, Punga, Seca, and Almacen do not detract any from those at Quipico, and yet the best are in the hacienda de Puente. The millroom of the hacienda Humaya is 
larger than those in other haciendas, and the rest of the shops where the sugar is worked are not inferior at Humaya.

We slept in Quipico, where we stayed a day.because we found there Sr. Dn. Joaquin Galdeano, the attorney general, who was exiled with half his salary by order of Sr. Visitador Areche. He stayed at this hacienda thirty months, until by order of the Ministry of the Indies communicated to him by the same visitador, his exile was ended, and he was named Oydor de México, an appointment that came the day before our arrival at Quipico.

On the 4th we inspected the whole hacienda, at which I described the Momordica operculata of Linnaeus, so abundant there that the dried fruits, called jaboncillos, serve the negroes as excellent dishcloths to wash the gourds or calabashes from which they eat.

On the 5th we left a little after noon, accompanied by Sr. Galdeano, and went to the pueblo of Sayan where, arriving at 3 in the afternoon, we noticed that those near-by hills and quebradas did not have materials for our work; informed by the natives that until we reached the sierra we would not find plants, we decided to return to Torreblanca to finish several plant descriptions. We made the muleteers load the mules, and we went to spend the night at Andahuasi, hacienda of the Augustine fathers of Lima, where they make 18 to 20 loaves of sugar daily. They had just finished a big rectangular addition with many rooms or little separate ranches well distributed in uniform rows, so that the negroes that were married could sleep separated from the single men under one key, and each couple in its own ranch. The priest or monk that made this hacienda from the arid field, began work with only 14 pesos, but through industry he had improved it so that it produced a profit of 60 pesos a day with the prospect of soon yielding more. In this hacienda there is an abundance of Parkinsonia aculeata that we sketched and dried the next day.

This valley is very pleasant, gay, and interesting because of the many sugar-cane properties, the variety of fruits and seeds that are gathered there, and the variety of trees and plants that grow spontaneously.

It is surprising that almost all the hacendados of this valley are always short of money and without a sufficient number of people for their work, especially since they have discontinued the yearly shipments of negroes that used to arrive in Lima, the owners making from 40,000 to 60,000 dollars annually in sugar, sirup, chancaca, and alfeñique. 


\section{CHAPTER XX}

Location of Sayan-Its houses and ranches-Inhabitants-Barrenness of the soil.

\section{THE TOWN OF SAYAN}

The pueblo of Sayan is located at the foot of a hill of purple soil or red clay and at the entrance to one of the quebradas at which the valley begins and from which the river that waters it descends. When it rains, the river is voluminous and without a ford, and therefore at that time can be crossed only by the bridge of Huaura or that at Sayan, which is made of timbers lashed together. On the way to Sayan there is a big rock broken from the mountain in the form of an arch under which the road passes. Around the town there are several small plantations of alfalfa with some fruit trees. The houses and ranches are quite distant one from the other, excepting the houses around the plaza where the well-to-do mestizos live. These are built of quincha or canes and afterwards covered with mud. The inhabitants are mestizos or tributary Indians, and the rest live on their small plantations where each one has his rancho.

The hills that surround the quebradas of Sayan and five leagues ahead, are arid all the year round, without any plants to be seen on them, large or small. A league distant from the pueblo of Sayan by the same quebrada, begins the jurisdiction of the province of Caxatambo, where there are some silver mines. Through the other quebrada descends a small brook whose waters suffice to irrigate the small plantations situated on both sides.

All through this valley and these quebradas the heat is excessive all the year round, and the sky is generally clear night and day and without rain or drizzle except on the coast and for about two leagues inland from the sea, which has its drizzles and mist as on all the coast of Lima, etc.

On the 6th the draftsmen went to Huaura, and from there they went on to Lima. With my companion Pavón I returned from Andahuasi to Torreblanca by the narrow passes of Jeguan in which I experienced great heat because of the bare and sandy hills and ravines until a league before entering the hacienda of $R$..., by which we crossed to that of Esquivel. Later we reached Torreblanca where we again found Dn. Toribio Bravo of Castilla, our benefactor and lover of botany and other sciences, as he showed by accompanying us to the country, not only at his hacienda but also in Lima in the hills of the Amancaes where he gathered various plants. 
On the 7th I went to survey the hills of the hacienda of Jeguan, the property of Dn. Mauricio Zuazo, a gentleman from Lima. There I gathered several plants, among them the Salsola fragilis that is plentiful in those open fields of sulphate of soda that are there called salitrales, because this salt in fact contains much niter or nitrate of potash; of this I picked some crystals on the grass.

In all of these haciendas in the vicinity of Chancay, they keep and feed a great number of hogs in order to supply lard to the city of Lima and the pueblos of that province. 


\section{CHAPTER XXI}

Plants gathered-Uprising of Tupac-Amaro.

\section{JOURNEY TO LIMA FROM TORREBLANCA}

On the 9 th of September, 1781 we two Spanish botanists went on to Lima without experiencing other discomfort on the way than the heat of the sandy places between Torreblanca and the heights of Ancón or plain of Copacabana.

We remained in Lima until the 13th of December of the next year, completing the drying and description of various plants gathered on the way from Huaura and Sayan and from this town to Torreblanca and Lima, among which there were the following.

Dodartia fragilis. The famous Platanus otahetianus, called the arbol de las mantas, because in the islands of Otaheti, they get from its bark, blankets of four and five yards in length and two and a half in width, without any other labor than pounding the bark on a flat stone and freeing the fibrous parts of sap and woody crust: afterwards they often paint them with circular spots in several colors. In Lima I saw two small trees about four or five yards tall, brought there from the islands of Otaheti, with several bread trees that had been destroyed by some mules in the same orchard, so that I could see only the trunks divested of bark. Rudbeckia multifida or Cosmos pinnatus of Cavanilles, which is used as an ornament in gardens. Llagunoa triphylla, rosary tree, because the round and black seeds resemble the beads of a rosary. Hibiscus rosa sinensis, and esculentus L., napu, with the fruit of which the negroes prepare a dish, disagreeable and offensive to us for its mucilaginous quality. Helianthus pubescens, anisillo de lomas, for its fragrance that is more pleasing than that of anise seed. Weinmannia pinnata, transplanted to Lima from the mountains. Parkinsonia aculeata L. The leafstalks of this plant could be used for their flexibility, length, and strength, to make little baskets, mats, and several other things, especially if they would prepare them as is done with esparto grass and flax. Atropa aspera. Ipomoea hirsuta. Tessaria dentata, paxaro bobo; the wood of these two shrubs is that most frequently used in Lima and in the towns of the coast, although as firewood it does not last long because it is light; they use their branches to cover the roofs of the ranches.

I changed all the herbaria or dried plants to new paper to free them from the humidity that might remain and, after distributing 
them in packages according to classes, I packed them in boxes for safe shipment.

After we had arranged all the work and collections made in the province of Chancay and the vicinity of Lima, and had deposited the boxes of dried specimens, sketches, seeds, and other natural products in the hall of the Royal Armory in Lima, we resolved to embark for the kingdom of Chile, not only because of the information we had of the fertility and abundance of the plants and other natural products of that earthly paradise, but also because we could not penetrate into the montañas of Peru, as several of its provinces were in revolt because the brothers Gabriel and Diego Tupac-Amaro were determined that one of the two should be crowned in that kingdom. They might have succeeded if it had not been for the activity, speed, and zeal with which Sr. Visitador Areche beheaded these rioters, going for this purpose to Cuzco.

Granted permission from the Viceroy of Peru and from the Visitador to go to the kingdom of Chile to continue our undertaking, we arranged for our passage with the captain of the vessel named "Nuestra Señora de Belen." 


\section{CHAPTER XXII}

Departure from Callao-Navigation-Phosphorescence of the sea-Strong wind and heavy sea-Misfortune on board.

\section{VOYAGE FROM LIMA TO THE KINGDOM OF CHILE}

On December 19th, 1781, we left Lima with our baggage to board the vessel "Belen" in the harbor of Callao. It was going to the kingdom of Chile to load wines and grain in the port of Concepción. On the 20th the ship was inspected by the chief guard of the port of Callao, and the 21 st we set sail at 10 o'clock in the morning with little wind; at 6 o'clock in the afternoon we could still see the point of the island of San Lorenzo near the port of Callao, but a short time later it was concealed from us by a heavy fog. We traveled two miles per hour during the day. The south wind calmed during the night.

On the 22nd at nine in the morning the wind began to blow from the south, and we traveled at two to three miles an hour, the sky remaining cloudy all day until it cleared at night. We saw a great number of bonitos, dolphins, and seals. The 23rd dawned cloudy and with the same wind blowing from the south, and we traveled up to three miles an hour; we had some heavy seas, the sun came out, and the seasick came to dinner, as they had not done on the previous days. Up to the 27 th we sailed with the same wind, traveling from two to four and a half miles per hour without having changed the sails since we left Callao. At night, on the 25th, a handsome calf fell into the sea, but we could not rescue it, and later we missed it. From the 28th the wind freshened more from the south, and we had some showers. We traveled from three to six miles until the 15th of January, when it was observed that we were at $32^{\circ} 2^{\prime}$ without having had any mishap of importance, nor having noticed in the sea anything of more importance than some goldfish and, during the last seven days, some streaks of fire.

The 15th of January we noticed such fire or sparks of light in the sea that it looked as if the rudder, stern, and prow of the boat were on fire with wine or sulphur spirits, also the wake left by the boat. The cause that produces this light or phosphorus is attributed by some to the bituminous or oily substances that are expelled by various fishes, which, mixed with the marine salt and churned by the rudder or prow of the vessel or with the waves motivated by the wind, form the beautiful phenomenon. To observe if there were any 
insects, as others had suspected, or to see if it was some oily substance, we bailed some pails of water and agitated it with sticks and other instruments of several kinds of metals, but we discerned only a few small lights, but no insect or oily substance although we used good lenses.

From the 17th to the 26th the wind continued to cool, and it was so strong that it was necessary to gather the sails, and in those days we sailed with only the mainsail and the foresail. There were many showers, continued and violent rolling, and pitching from stern to prow, and heavy cracking of the knees and other timbers of the ship; endless numbers of heavy waves came in by the hatchways, and we suffered continuous and troublesome heavy seas, all of which kept us in constant fear. When we went to eat, we had to do so holding ourselves with ropes, each one with his plates in the hand, and confined to the cabins.

On the 24th at 6 o'clock in the morning, a passenger from Vizcaya, named Baltaya, fell into the sea and, although everything possible was done to rescue him, we never saw him again on account of the heavy seas and the vessel's having seven miles of headway. This unfortunate person was going to the city of Concepción with sugar and other commercial products. Not daring to go to the privy, he tried to move his bowels at one of the chainwales, from which he fell when the boat rolled.

On the 26th we sighted the island of Sta. María by the prow, and a little later the Tetas de Biobio; for this reason, and because the wind had increased its velocity, we gathered the sails until it calmed down at nightfall and they were lowered anew. With the moonlight the pilot decided to enter the port of Talcahuano, and this we accomplished without mishap until midnight when the wind died down and did not blow again until 7 in the morning; at this time, the sails being hoisted, one of them knocked a sailor, who was working, into the sea from the main-topsail. As the wind was blowing gently and the sea was calm, the vessel was turned with ease, and they threw two pieces of wood overboard, to one of which the sailor laid hold; it served to support him until they lowered a boat, for which he was asking insistently. This was done with the utmost speed, and four sailors went in it; they picked him up a mile away from the vessel and, when he was in the boat, he took an oar to warm up and to drive away the cold, so that he arrived at the vessel without further mishap, and he suffered no ill effects. 
At 9 o'clock on the 27 th there came from Talcahuano with an officer of the royal squadron a boat, commanded by Sr. Bacaro, that was anchored in that port. He was given the mail and returned to the port.

At 2 in the afternoon near the anchorage, the vessel missed the turn, and for this reason it was on the point of being dashed to pieces on a rocky bank, from which we were saved by the activity of the boatswain, who cut the anchor's cable, and the boat was stopped a few yards from the banks. The captain went ashore and went to Concepción for a license to permit him to unload.

It became calm on the 28th, and the vessel was towed to sea after the hoisting of the anchor, and we set sail. The vessel succeeded in making the first and second turns, but on the third we lost some ground, and we could not steer close to the wind on the fourth, so we dropped anchor again in nine fathoms of water. Suddenly we found ourselves in four, but in a little while the wind carried the vessel to ten fathoms, where we stayed anchored until the next day because the wind had increased. 


\section{CHAPTER XXIII}

Arrival at Talcahuano-Hospitality of the maestre de campo-Arrival at Concepción.

\section{ARRIVAL AT THE PORT OF TALCAHUANO}

On the 29th we anchored in the port, the vessel being towed in. On the 30th the ship was inspected and we went ashore with our luggage. We introduced ourselves to the Mre. de Campo of Concepción, Dn. Ambrosio O'Higgins, who had come to Talcahuano on account of the arrival of the vessel and because the fleet was there. This official received us very affably and offered us all the help that he could give. He fulfilled his promise very generously, giving us our meals for as many days as we wanted to go to eat at his house. After 12 o'clock we went to Concepción without any incident.

When we reached Concepción de Chile, rooms could not be had in one place until the 7th of February, 1782 and in others until the 12th, because the houses were not big enough, as the city was only 31 years old. The buildings had been finished only 17 years on the site where the people who moved from Penco el Viejo have been living since the 24th of November, 1764, on account of the flood and destruction caused there the 24th of May, 1759 by the great earthquake and tidal wave, when nothing was left in Penco but some remains of the ruins and a fort with some farm buildings.

On the 13th of February, after having returned the visits received by us from the most distinguished people of the city, we began our botanical excursions through those fertile fields, and we continued them with many discoveries until the $24 \mathrm{th}$, when we went to the fort of Arauco in company with the mre. de campo. 


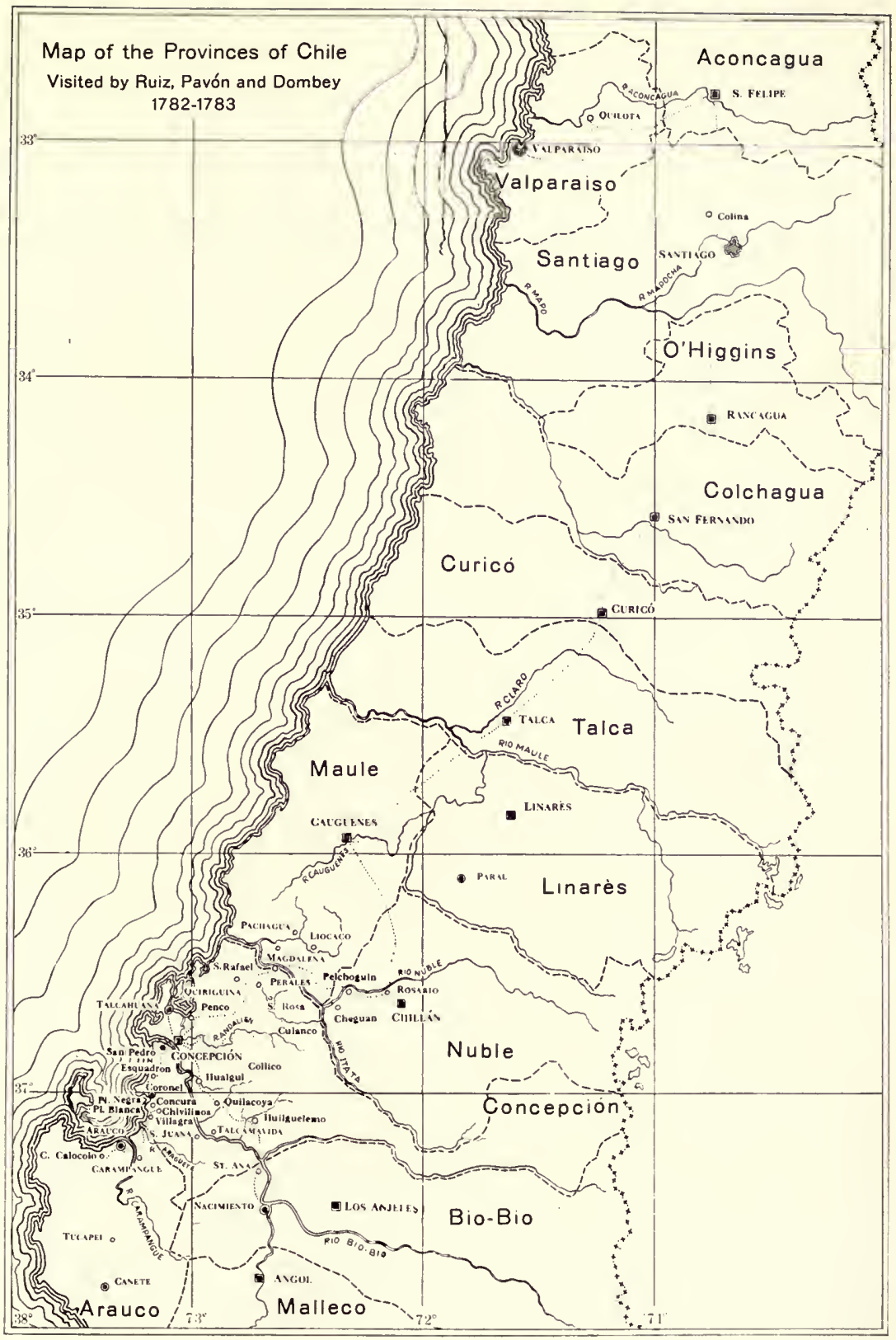




\section{THE LIBRAKY \\ OF THE
UNIVERITY OF ILLINOIS}




\section{CHAPTER XXIV}

Crossing of the Biobio-The rafts-The territory-Abundance of horse farms - The guazos-Plants and their applications-The cinnamon tree-Superstitions of the Indians-Reception of Mre. de Campo Villagra-Murders committed by the Indians-Defeat of the mre. de campo-The Araguete river-The plainArboreal vegetation-The Carampangue-Piedras de cruz-Salutations-Speeches -Instructions-Enthusiasm of an old man-Plants of the field near AraucoFarewell to the Indians-Preparations for the parliaments-Revolt of 1766Quarrelsome character of the Indians-Cremation of dead from the plaguePehuenches and Huiliches.

\section{TRIP TO FORT ARAUCO}

On the 24th of February, 1782 at 2:30 in the afternoon, the two draftsmen and botanists Dombey and Ruiz left in company of Dn. Ambrosio O'Higgins Vallenar, Lieutenant Colonel of the Royal Armies and Mre. de Campo of the plaza of Concepción, for the plaza of Arauco where he was going to talk with the Indians of that vutalmapu. As we arrived at the shore of the Biobio river where the rafts were ready, it began to rain very hard, so that some were of the opinion that we should go back to the city and make the trip another day; but the rest of us insisted on going on, and this was the opinion also of the mre. de campo. He ordered the rafts to be brought, so that in half an hour we safely crossed the river, which at this season is about. half a league wide but in the wintertime widens to about a league. This river has a sandy bottom without rocks to interfere with the passage of the rafts. They are constructed of five or seven logs a quarter of a yard wide and three or four yards long, nailed to others that cross underneath and, the middle beam being longer and the laterals gradually shorter, there is formed a long raft over which they make a lengthwise seat or barbacoa of sticks joined together with strips of hide, as a place for the baggage and a seat for the passengers. At the ends of the raft there is a short space left free for the use of the ferrymen, and from this they guide it with poles four or five yards in length. They may also tie the raft to the tail of a horse, which, sometimes walking and at other times swimming, pulls it and passes from one side of the river to the other; but this method is more dangerous because the horses are apt to stick in the sand and, with the violent movements which they make to free their feet, they may upset or bury the raft in the sands, a thing that did not happen this time to those that were hauled by horses. Farther down the animals cross 
this river swimming, directed by one or two naked men on horseback who go with them.

After passing the river, we went up to the fort of San Pedro, and from there we were escorted by a company of militiamen, to sleep at Esquadrón, a country house 5 leagues distant from San Pedro by a smooth and pleasant road covered with spreading trees and plants that are green throughout the year and form a beautiful sight. We crossed some plains called lagunillas because in time of rains they fill with water and must be crossed in rafts. This place is one league from San Pedro and the same distance from the sea. On this whole unappropriated coast, there are several pasture grounds for the king's horses, which are cared for by many families of guazos that live in ranches scattered over that extensive and pleasant plain, and on this they plant and gather various fruits and seeds for their support, with the definite obligation of militia service and an understanding to be ready in case of necessity to go out and fight against the Indians. The weapon that is used by these guazos ${ }^{1}$ is a long spear, of about three or four yards, in the use of which they are very skilful, running on horseback with surprising speed and freedom through those hills and plains. The more hilly region and the mountains are inhabited by pagan and renegade Indians.

On the 25th, because of a heavy rain that lasted from the night before until 10 o'clock in the morning, we stayed in Esquadrón, inspecting those fertile fields, and in them we gathered many plants that we dried; we sketched and described the following. Sarmienta repens. Schizanthus pinnatus. Laurus Peumo. Drimys acris, canelo, because of the odor and taste of the wood, leaves, and bark, which are extremely pungent. These trees exude a few tears of aromatic gum. The smoke of their wood is annoying to the eyes. The bark and leaves preserve clothes from moths and, boiled, they furnish baths against convulsions, nervous debility, spasms, paralysis, empyema, itch, and ringworm, and against the frush and louse of horses, for which many use it, adding urine and salt. Its smoke purifies the air, and for this reason they use it for fumigations against contagious diseases and against insects. The infusion of its shoots brightens the color of indigo; for this reason they mix it with the dye of that substance. Some use it against venereal eruptions, in baths and fumigation. The natives make use of the leaves of these beautiful and showy trees for fishing, pounding and

1 Americanism equivalent to llanero, a man of the plains. 
placing them in the brooks and rivers. They get very good planks and boards for buildings from the canelos, and under their shade the Indians used to hold their councils and conjurations in order to discover hidden offenders and punish their crimes. For this superstitious ceremony they call the most famous and oldest machi or soothsayer who, when the whole multitude of Indians are kneeling around a tall and spreading canelo tree, with the greatest respect, silence, and attention and with their eyes fixed on the ground, climbs the trees from which she makes her invocations, calling to Pillan, or God, in the direction of the four principal winds, throwing, after various ceremonies, a little stick in each direction. These ceremonies are followed by a long speech and, when finished, she answers all questions put by the caciques. The machi, as if she were an oracle, answers what she pleases, and in that way she blames those she has in mind to destroy, for her sentence is executed as if it were a true order from Pillan. Finally, in a short speech, she exhorts all to give thanks to Pillan and then recommends that her sentence be carried out. Then she descends from the tree and, while all are standing, she is given a small drum, so that at its sound all of them will follow her around the canelo tree until the machi thinks it is time to start drinking the chicha that they have prepared for feast. With this they get drunk, and killings and warfare between the opposite parties result from her diabolical sentences. The canelos are abundant in the damp and muddy places and in dry and smooth fields in summer and are covered with water in winter. Their bark and leaves have a very bitter, biting, sharp, and nauseous taste, although somewhat similar to that of cinnamon. Wild doves are very fond of eating canelo berries or fruits, and for this reason great flocks of them come during the time that the tree is in fruit, but their meat then gets tough and is very disagreeable to the taste.

On the 26th we left Esquadrón, and without any mishap we arrived at the stopping place called Coronel, a distance of two leagues from that horse farm; here the militia company was exchanged for another, also armed with lances which they carried resting them in the saddle or stirrup, with the metal point upwards. To change the militia the captain of the company sent an officer with sword in hand to come and meet the mtre. de campo long before he arrived at the place where they were stationed. After he had given the message, which consisted of greeting the chief and saying that his captain was awaiting him in a certain place, and had received the answer, he returned at a gallop to his company. This, divided in two lines, then 
passed in front of the whole retinue after both performed the customary courtesies and ceremonies and after two or three men from the heights were examined to see if there was any trouble on the part of the Indians.

At a distance of a league from Coronel we arrived at Playa Negra, a place so called on account of the dark color of the sand, and also to distinguish it from another farther on with white sand and called Playa Blanca. Following this is the hill of Concura, and at the top of this is situated the plaza of the same name, five leagues from Coronel. In this plaza they changed the militia again with the same ceremonies as in the other places. When we came down the hill of Concura, we came to a beach a quarter of a league in length, by which the Indians from the plains or from Santa Juana had an easy outlet, that is from Fort San Pedro to this beach, because from San Pedro up river the Indians have several outlets. They use these from time to time, as happened in 1772 , when they cut off the head of a valiant officer who had beheaded three Indians a few days before, while defending himself bravely from a band that had encircled him in the woods; from this danger he saved himself then, but he could not free himself after he was surprised together with two soldiers, whom they burned alive in a ranch after having tied them together.

After passing the beach we crossed the hill of Villagra, with three leagues of climb and descent. This name was given to it after the battle that the Indians fought there against Mre. de Campo Villagra, who was buried there, and his men destroyed.

At the foot of this hill there is another beach about a mile long where we ate in the shade of several apple trees and other trees by which it is surrounded. Afterwards we climbed the hill of Chivilingo where a guard is placed by the mre. de campo to prevent the passage of arms, wines, liquors, merchandise, and contraband, which the Spaniards and guazos often exchange with the Indians for ponchos, a trade that is not allowed without permission from the mre. de campo.

After descending this hill, we crossed the river Araguete, a name that is also given to the beach and plain that extend to the Carampangue river, five leagues distant from the other. On this plain there are seven spacious and straight lanes of different wild trees, formed, according to the natives, by nature; but it seems impossible that nature would place the seven lanes at the same distance, giving them forty to fifty yards of equal width throughout their length of five leagues, so that there is not a plant or a shrub in 
those lanes except the trees that make up the rows, namely arayanes, pataguas, bolbus, maytenes, peumos, litres, voguis, and other climbing and twining plants, the variety of the foliage of which, the intertwining of the branches themselves, the diverse and continuous green of their leaves, and the size, color, and fragrance of their flowers and fruits and other parts present the most beautiful tones and the most wonderful rustic sight. The ground, which at this time was covered with small fruits or strawberries of exquisite taste and other small plants with various flowers, contributed not a little to heighten the effect. The streets or lanes are the distance of a rifleshot from the sea and are situated on a sandy ground, which proves that these lanes have been made by art and not by nature.

Beyond the plain is the river Carampangue, a name that means cara de leon [lion face], derived perhaps from the great flood and ebb of more than a league when the tide rises or falls; but when the river swells, it is crossed in rafts. The Carampangue is perhaps 100 yards in width at this place. Three leagues up river from this ford, there is a creek in the vicinity of a mill, where one finds cylindrical stones, somewhat oblong, with both extremities flat, showing a cross resembling that of the Order of Malta, which is present also in every transverse fragment into which it may be divided. The stones are of several sizes and of different colors; most of them are white with a black cross, and black with a white cross; some are bluish and others purplish.

When we had crossed the river, the governor of the Indians, named Neculgud, which means perdiz corredora [running partridge], presented himself to the mre. de campo with two companies of Indians on horseback formed in two lines without any other arms than the sabres that were carried by those in charge of their small banners. The music they had was produced merely by some small flutes or little wind instruments, called pivilcas, the sad and mournful sound of which can scarcely be heard at a distance of fifty feet.

Governor Neculgud, after he had greeted the mre. de campo, ordered his companies to start at a good gallop, as is the custom on such occasions, and they were followed by two other companies of our militia armed with lances; after them followed the suite of the mre. de campo, closing the two lines. Near the plaza there was a crowd of Indian men and women in shelters of branches they had made on both sides of the road for cover during the five days they had to be there until the end of the meeting. When the mre. de campo passed with his suite, these people saluted, repeating many 
many times the words: "maximari señor, maximari capitan." At the entrance to the plaza the companies of Indians were stationed in two lines through which all our people entered Arauco, in front of of the barracks, in which we found the troop of that garrison formed in a row and playing a march to the sound of the drum and fife while the chief and his suite passed.

The mre. de campo dismounted and gave orders by means of the interpreters for the caciques to come in and greet him and to appoint the day and hour for the parliament. The greetings lasted the rest of the afternoon, or about one hour and a half. This ceremony, that was begun by High Cacique Neculgud and was continin order by the oldest and most honored caciques, consists merely of their presenting themselves one by one at two paces from the mre. de campo. The cacique greets the latter with a bow and then, raising his head, he goes to the chief, saying "maximari señor" and puts his right hand over the left shoulder, and with the left hand, in which he carries his hat, he gives a pat on the back. Then he retires with another bow; to all of this the mre. de campo responds, as do all the others that have had to suffer this long, tedious welcome.

Finishing the greetings, the mre. de campo gave thanks, in the name of the King and the President, to the caciques that had sheltered and had given help to the troops that passed freely, without the least extortion, through their lands to the plaza of Valdivia; then he reprimanded several caciques who had encouraged others to start a riot against their neighbors. All of this he made clear by means of the interpreters. Many of the principal and better-inclined Indians offered to inform the mre. de campo in case of any new feud or any suspicion of riots and uprisings. At the sound of retreat the caciques and the Indians that were in the plaza went out, and the doors were closed until the next day, the day marked for the parliament.

On the 27th at nine in the morning, when the caciques had congregated and had seated themselves in the patio of the house of the mre. de campo, with a multitude of Indian men and women standing behind them, and when the same greetings had been exchanged as on the previous day, the parliament was opened by a short speech in which, in short, the mre. de campo said that His Catholic Majesty would be very sorry that there could be no peace and harmony among the Indians and no co-operation with the Spaniards, because he had to use force to punish the mischievous and put an end to their plots, disorders, bad conduct, etc. Afterwards they were notified, and the 
order was repeated, that at no time were they to leave the coast without sentinels, so that they could inform the plaza of any vessels that might be seen in numbers above two. That they should not permit any deserter from the plaza of Valdivia to pass through their lands. That they should not admit or hide any fugitive offenders there. That any person who for any reason promoted a revolt, or discords and misunderstandings, or who incited some caciques against others, should be taken prisoner and safely conducted to the plaza to be punished as he deserved. That every robber, Indian or Spaniard, should be captured and brought to the plaza, or at least held, and notice be given to the commander immediately. That they should help one another in case that the Pehuenche or Huiliche Indians, their bitter enemies, should make war on any of their number. That they should take care to plant their land with seeds and fruits for their sustenance. That they should live without disorder and drunkenness and should observe all that makes for a peaceful and well regulated government.

The junta was finished at one o'clock in the afternoon, and the caciques were given a glass of wine with which they hailed Our Monarch and his Family. Among the caciques there was one 86 years old who, when hailing the King, threw the wine into the air with joy and happiness, and in the performance of his act he burst into tears. This good old man had walked 85 leagues on foot to come to the parley and showed so much pleasure when he heard that more towns were wanted, that he offered to build the church of his district at his own cost, and asked earnestly that priests be sent for the divine service and spiritual nourishment which they had been without for some years.

On this day we walked over the entire hill of Colocolo, and the coast and vicinity of Arauco, where we gathered several curious plants that I described and gave to be sketched. Among these plants there was the nipa, Stereoxylon rubrum. Its decoction applied in baths relieves nervous pains, and its wood is strong for handles of instruments. Mutisia spinosa, Cymbanthes punctata, etc.

During the days of the parliament the young Indians passed the time riding their horses in a small plaza outside the other in the manner of picaderos, making the horses bend their knees, stand on two feet and on three, and jump in various ways until the animals were tired.

We inspected the ranches in company of the mre. de campo, and the wives of the caciques treated us to their chicha; in return we 
gave them some money which they accepted as a singular form of politeness.

At 8 o'clock in the morning of the 28th, the caciques gathered to say good-bye with the same ceremonies as on the previous days; the articles of the previous day were repeated to them, and several caciques were reprimanded who had been accused by the others of various crimes. Then they gave thanks to the mre. de campo, or "Martín Campó" as they called him, for the good and sane advice he had given them, and anew they offered to warn him of any disorders that might occur and to maintain peace and quiet among themselves. This same day the Indians left for their lands, and no one remained in or out of the plaza, except Neculgud.

For the celebration of these parleys, by order of the King, a certain quantity of wine and meat was sent to the caciques to be distributed among the Indians; because these provisions are not sufficient food for the five, six, or seven days that the juntas often last, they also provide their own chichas, and ulpo, roasted corn flour. With all of this they make merry, and most of the Indians get drunk; they also use these days to run on horseback around the shelters, a form of amusement they are sorry to end so soon.

These Indians, called coast and plains Indians, are generally short in height and commonly have ugly faces, in contrast to the Peguenches or those of the cordilleras, who are tall, or to the Huiliches or Indians of the southern part, who are of taller stature the nearer they are to the Strait of Magellan and the lands of Patagónia. The men dress with jacket, breeches, and waist, and short, rough woolen stockings without soles; some use plain homespun cotton shirts, and the caciques use linen ones. They cover themselves with a poncho, instead of a cape; they use slouch hats but they do not wear shoes or any equivalent. The women wrap their bodies with a cotton blanket tied at the waist with a belt, ribbon, or band, also of cotton, fastening the ends on each shoulder with a wooden pin, so that the whole body is covered except the arms and from the ankles down. Over this blanket they cover their backs with two or three other smaller blankets of about a yard or a yard and a half square, whose upper ends, carried over the shoulders, are fastened over the chest with other stick pins introduced or pinned horizontally with the point to the left side, leaving its head, small face, or plate on the right side. From the two sides of the tupos [stickpins] they hang several llancatas or chaquiras, that is, beads and ribbons of several 
colors. They put two, three, or more strings of beads of various colors about their necks. They decorate their ears with uples or arracadas [earrings], that are little plates of silver very thin, square, or half-moon-shaped, about two or three inches long and each weighing about half an ounce, with a little handle that is curved from one upper corner to the other and that pierces the ear. The hair, which is generally thick, long, and abundant, they divide into two braids, each one falling between ear and cheek to the chest, and on the forehead there is a large lock of hair of the length of the face, which, divided into two parts along its sides, makes them look very well. They walk barefooted, and do not use shirts or petticoats. When they do housework, they pin the ends of the exterior blankets to the back to be out of the way of the work they are doing; in this way they leave the arms bare. They wait on their husbands even to saddling their horses. The younger girls obey the older one that is married and, even if this one is uglier than all the rest of them, she is the most beloved and the most respected in the house. Among the Indian women there are graceful and grave faces, although in general the women are not beautiful.

The Indians are very fond of all kinds of alcoholic liquors, and they drink until intoxicated, chicha of corn, apples, huighan (Schinus), and quinoa. They marry as many women as they can support, without other ceremony than giving a present to the fathers or relations of the brides. When any of the wives die, the parents or relatives return to the husband another gift equivalent to the one that he gave them when he married. They have no religion or cult, although they believe in a supreme being, whom they call Pillan, and they believe in the immortality of the soul. On this subject see chapter $\mathrm{V}$ of the Sistema de religion $y$ funerales, of the Compendio de la historia civil del Reyno de Chile, by the Abbé Dn. Juan Ignacio Molina, translated in Madrid in 1795 by Dn. Nicolás de la Cruz, page 84 . They are very superstitious, accepting all that the male or female machis or soothsayers say, as revealed to them by Pillan, and of it they say that it was communicated when they asked. Among these Indians there live many Christians who renounced their religion after the general uprising that happened in the year 1766. It was started in Angol on December 25th, at three o'clock in the morning, by the Indian Cuniñancai; he stole mules and horses belonging to the Spaniards, wounding three soldiers and the capataz of the troop Alberto Fernández, and killing one of the servants. On the 31st at five o'clock in the morning, General Mre. de Campo 
Dn. Salvador Cabrizo ordered the signal given which calls the troops to arms to go to the plaza of Nacimiento, where he arrived safely at nightfall, because he was not secure in Angol. Commonly, the renegades are the most crafty and principal agents of disorders and uprisings.

The Indians are generally sullen and belligerent; they fight and make frequent excursions on horseback, and they use the lance and lague, arms that they manage with dexterity. For war they dress in untanned leather jackets of cow- or horsehide, with a hat of the same material decorated with feathers of various colors on the crown. Their war music consists of some small drums and pivilcas, small instruments on the order of a horn. If any one contracts a contagious disease or has died from one, they burn him alive or dead, with his poncho and other belongings and even with those who have taken care of him during the sickness; sometimes they take him to the woods where they throw him tied into a fire, so as not to contaminate other people.

The Indians of Chile are divided into four principalities called uthanmapus and vutalmapus, aillos or partidos. At this time they are somehow subject to the President of South Chile. Those from the three vutalmapus of the coast, plains, and slopes of the cordilleras, grow several kinds of grain for their support, keep herds of all kinds of animals, and catch the excellent fish and mussels that are found abundantly in the rivers and on the coast. Most of the Indians of the fourth vutalmapu, called Pehuenches, that inhabit part of the mountain range, are given to laziness, lewdness, and stealing; so they live miserably, eating horseflesh, tallow, and pine nuts and what they can steal at the nearby haciendas from Indians and Spaniards, or from travelers. In their frequent forays, like the Huiliche Indians in the pampas of Buenos Ayres, they generally kill the men and capture the women to serve them as their own; as a result of this union there are among them many white Indians of fine figure. Some of these women prisoners become so accustomed to that type of life that later they have no desire of returning to the Christians; such is the lure of that liberty and mode of living, without subjection to anything or fear of God.

The Pehuenches have frequent fights with the Indians of the plains and coast, with the Spaniards and, above all, with the Huiliches who also inhabit the cordilleras, the montañas, and the frontiers of the pampas of Buenos Ayres, spreading towards the south. 
The first vutalmapu is on the coast and extends from the Arauco through Tucapel, Imperial baja, to Toltero bajo. The second is in the plains that start in Santa Bárbara and continues through Angol, Mopecura, Imperial alta, Maguehue, and Tolten alto. The third is through the slopes of the cordillera from Nacimiento past Chacayco and Menayco to Querchereguas. The fourth is in the cordillera and comprises only the Pehuenche Indians. These four vutalmapus are distributed among the president, mre. de campo, commander of infantry, and the sergeant-major. Beyond the Pehuenches, towards the south, the Huiliche Indians live; they are not subject to any of these chiefs and are much more savage than the most harmful and violent in the pampas of Buenos Ayres.

There is clear proof that the Huiliches also believe in the immortality of the soul, since they live in the belief that when they die they make a voyage to another shore; for this reason they are buried with food and saddle horses to travel in greater comfort, and the mourners pray to Pillan and the Ballena to help them in their voyage.

There are many old people among the Indians, from 100 to 120 years of age, without gray hair, and with all the teeth white and strong, either as an the result of their way of living or by reason of the mild climate.

All the Indians are declared enemies of the Spaniards and other Europeans, or rather of our ideas and customs, and it is very difficult to induce them by mild and reasonable methods to live in settlements. If the Chileans were permitted to dominate them by force, they would compel them to live in settlements, or in a few years they would put an end to them, to be free from their forays and frequent robberies at the haciendas that they destroy at times, killing some of the people that live in them.

When these Indians start a general revolt, besides the signals that they place in the mountains with lights and fires, they try to capture a Spaniard. Then, forming a cahuin or council of war, they put the man in a hole and, with superstitious ceremonies, they kill him with a blow of a macarra, take his heart, dip the points of their lances in his blood and then suck it. Afterward they cut all his fingers and toes and distribute them to the factions in what they call the running of the dart, and the caciques that receive any of those parts of the Spaniard, are thereby sworn to join in the uprising, for which, with the utmost secrecy, they also call the Yanacorras, Indians who serve the Spaniards, who buy them for that purpose, but without considering them as slaves or mistreating them. 
During their travels, forays, and revolts, each one of the Indians carries with him the necessary rations for a few days; these consist only of a little bag of ulpo or flour of roasted corn, or of beans, wheat, or barley. They also carry a vessel of horn that they call huampar, in which to mix the flour with water; that usually is their only nourishment and on it they live for many days. When it is gone, if they do not find any better food, they nourish themselves with the blood of their own horses; and if these animals die from the repeated bleedings they suffer, they also serve for food.

The men ride well and on horseback are skilful in handling lance, lague, macarra, spade, cutlass, knife, and dagger. They fight and attack in platoons. They make their assaults and quick forays from ambush, and these they call malocas. When any of them die in battle, good care is taken to hide them from the Spaniards, to whom they never give any mercy as they kill them immediately.

They are excellent swimmers, especially the Indians of the coast. When they assemble to gather mussels, they put out in rafts or canoes with their wives, who are the ones that dive into the sea to pry loose and get the shellfish, and the men stay in the rafts to receive the catch and to help them come up from the bottom of the sea when they signal.

When the women give birth, they have the habit of washing themselves, as well as their babies, in cold water.

To establish tranquil relations and commerce with these Indians, we Spaniards have sought to use all means that policy has dictated, but none has been enough to conquer their persistence in their wild and savage life. The last method was to force them to live in settlements, and this idea was accepted by some; but in the year of 1766 they revolted, as has been told, and they burned all the churches and buildings of Angol and other pueblos.

In several parleys that have been held repeatedly, they have promised peace and good harmony; but this has lasted a very short time. In the last general parley celebrated the 21st of December, 1774 by Governor Dn. Agustín de Jáuregui in the Campo de Tapique, they agreed, among 18 other stipulations, to send several caciques to Santiago with the title of ambassadors, and to date they maintain this kind of embassy and, to hold them more firmly, twenty-two young men, sons of the caciques and principal Indians, are educated in the college of San Pablo. 
The general parliaments that are celebrated with these Indians to talk about peace or its continuation, consist of some juntas of the caciques and principal Indians, attended by the president of the royal audiencia as captain general of the kingdom, the mre. de campo of Concepción, and other officers of the army. For this occasion they make shelters of branches and camping tents in the level and spacious plains. When the parleys are finished, the president distributes among the Indians hats, knives, scissors, razors, colored beads, ribbons, and many other baubles that, though of little value, are greatly prized by the Indians. 


\section{CHAPTER XXV}

Orders regarding the plaza of Corcura-Fishing on horseback in the sea-Botanizing in the vicinity of Concepción-Plants sketched and described.

\section{RETURN TO CONCEPCIÓN FROM ARAUCO}

On the first of March, 1782 at six in the morning, we left the plaza of Arauco in company with the commandant of the place, and Neculgud, and two companies of our militia until we reached the Carampangue river; from there the commandant and Neculgud turned back with one company of militia, the other accompanying us to the Araguete river. At ten o'clock we arrived at the plaza of Corcura, where the mre. de campo gave the necessary instructions to do some repair work on it. We went to eat at the district of Capitán, after remaining a while on the beach that is situated at the foot of the hill of Corcura. There we watched the act of fishing on horseback; this performance the fishermen execute with great dexterity and without danger because the horses are so well trained that, when they see a wave coming, they turn their backs to receive the blow in the back, and the horseman at the same time bends his body so that the water passes over him. Turning immediately towards the sea, they continue gaining ground until the horses start swimming, and then the two fishermen get together and, closing the net, they take it to shore with the fish that is in it. At two o'clock we left Capitán, and we reached Fort San Pedro at four. We crossed the Biobio river in rafts pulled by the horses, and we entered Concepción before vespers, without having had any trouble on this hurried trip that was made at a trot and gallop from Arauco.

From the 2nd of March until the 24th of April, we continued working in the vicinity of Concepción, making daily trips on horseback through those fertile fields and woods in which we gathered, dried, and sketched great number of valuable trees and plants of which I described the following. Calceolaria scrophulariaefolia, rugosa, sessilis, and dentata, arquenitas and arguenillas. Cotyledon lyratum. Nicotiana angustifolia, wild tobacco. Cestrum virgatum, pargui and palgui; its decoction is used by the natives as a remedy against intermittent fevers; of the infusion of the inside bark they take some large cupfuls hot for stomachache. The lye from the trunks and roots of the palgui is very good for cleaning clothes, and the juice of the berries gives a beautiful bluish color tending somewhat toward purple. Aster lanuginosus. Santolina tinctoria, poguil, used 
for dyeing a beautiful, permanent yellow color. Solidago secunda, bullel; this plant they also use for a yellow dye. Coriaria nervosa, deu. Myrtus revoluta, patagua; this tree is abundant in several provinces of Chile, and the places where it grows are called by the natives pataguales; from the trunks they get excellent timbers, boards, and beams. Loranthus verticillatus, ictnigo. Oenothera lineatiflora. Schinus, huighan or huignan; from its ripe fruits or pods the Indians and creoles make an excellent chicha, valuable against bladder trouble and dropsy. From this sickness they had recently cured three persons by frequent use of the chicha. The Indians, in spite of its repugnant taste, resembling pepper, characteristic of the whole tree, drink this chicha all the time; they make it by rubbing the fruits in water until they give up the sweet part, and in this state they leave it to ferment for three or four days until it gives off a vinous odor. A resin produced from these trees is excellent for toothaches and headaches, applied in a plaster on the temples and behind the ears, and it is frequently preferred to other resins by musicians for use on the bow of the violin. Tricuspidaria nutans, patagua, the trunk of which makes very good boards, while its bark serves for tanning. In some places one finds on these trees a kind of silkworm. They grow in damp places. Mutisia subulata, wild carnation. Mollugo radiata. Myrtus nuda, white arrayan. Loranthus semicalyculatus, michtria, ictnigo, and quintral, names also applied to the other species of Loranthus; it is used for a black dye. Aristotelea glandulosa, maqui; from its fruits they make a bittersweet and tasty chicha, excellent for refreshment; applied on the back and kidneys, the mashed shoots of the maqui mitigate and temper the excessive heat of these parts in a person with fever and, masticated, they clean and cure sores in the mouth. The pounded bark is good for making rope, and the wood, because of its light weight and flexibility, is suitable for rafters of roofs, for hoops, and for musical instruments. Molina concava and linearis, romerillo; its leaves mashed and applied to bruises and sprains, hardens and strengthen the parts. Myrtus communis, cheguen and arrayan. Coreopsis Bidens. Chenopodium amarum and dulce, quinoa amarga and quinoa dulce. Chenopodium multifidum, paico; its infusion in hot water is used in Chile as a digestive in place of tea. This plant is quite fragrant. Myrtus acuminata, arrayan colorado, for the color of its strong lumber, useful for many kinds of carpentry work. Gomortega nitida, queule. After the Chilean pine, this tree is the most leafy, tall, and handsome to be 
found in Chile and, at a distance, it is distinguished from all others by the verdure and brilliance of its leaves. From its trunk exquisite wood is obtained of a dark red color and beautiful luster. Its leaves, that have an acid, astringent taste, stick to the teeth when chewed, because of the great amount of resin that they contain; squeezed between the fingers they expel an odor similar to rosemary and to spirits of turpentine; for this reason it is much used in medicine to stimulate and comfort. Its beautiful fruits are as big as a small hen's egg and have a brilliant yellow color that invites tasting, but if one eats many, they cause a headache. The pulp is quite sweet but has little juice; and its pit or stone, as hard as a rock, contains two or three small almonds. This tree is always green and in flower or fruit all the year round, and it is usual for it to flower again when the fruits are ripe. Another species of cuzle, the natives say, is grown in the mountains from Arauco to Valdivia, but I have not seen any but the stones of the fruits. Acaena trifida, pinnatifida, pimpinela cimarrona, and amaerinifolia, broguin. The pinnatifida is used as an excellent diuretic and refrigerant, and the decoction or infusion of the broquin is used to resolve gonorrhoea. Triptilium spinosum, siempreviva, because the odor of its flowers continues after they have been dried for many years. It is a beautiful plant for decoration and has excellent diuretic properties; for this reason it is frequently employed in urinary troubles. Fuchsia violacea, thilco; its wood is good for making black dye, and its infusion and decoction is applied as a refrigerant in taberdillo (a hectic burning fever) and chavolonjo. Santolina scabra. Eupatorium urens. Euphorbia portulacoides L., pichoa; the natives take the decoction of this plant as a purgative. It is very drastic, and to stop its action they drink cold water. Volkameria verticillata, haumun, and its fruit chaguis; when this shrub blooms, it is all covered with flowers, and it gradually fills with fruits, forming a beautiful sight. Euphorbia tricuspidata. Bromelia bicolor, and sphacelata, chupón. Sophora cassia L., mayo. Cassia reflexa, mayo and mayu. With the bark of this plant they dye the color of golden yellow. Quadria pinnata, avellano de Chile and negú; its wood is excellent for making oars, and its fruits are sold in the market of Lima by the name of avellanas. 


\section{CHAPTER XXVI}

Woods and fields of Culenco-Cattle and fruit trees-Vineyards-A special kind of olives-Origin of the name Culenco.

\section{TRIP TO THE HACIENDA OF CULENCO}

The 24th of April, 1782 draftsman Gálvez and I went to the hacienda of Culenco, twelve leagues from Concepción, fording the Andalien river eight times through Palomares and crossing the Nongen.

During our stay in Culenco we explored the woods and fields, as well as those at the haciendas of San Salvador, Yeguaragui, Collico, Cheguen, Pelchoguin, Loicacas, Santa Rosa, Santa Ana, Parral, Rosario, Cangrejillos, and Chaymavida; the fields are suited to all kinds of fruits and seeds, and with the abundant grass and excellent water of the quebradas, for the breeding of cattle and horses. There are few hacendados that plant wheat and barley, because the pasture is so good that they are satisfied to breed cattle, of which they slaughter great numbers for changuis or hung beef, grease, and tallow; and to have one or two vineyards of 40,000 or 50,000 vines from which they obtain great harvests of exquisite wine as good as that of Valdepenas. In the orchards of these haciendas they cultivate several fruit trees from Spain, such as the apple, pear, cherry, clingstone and freestone peach, fig, walnut trees, and some pines, chestnuts, olive trees, and quince trees that they call lucumas, with a delicate taste and odor. There are several kinds of grapes, among which the muscatel and Italian are delicious, as are also the Joaquin pears and other European fruits, which are of better quality in this climate than in Spain. They prepare olives there so small that they look like peas, and they are eaten with a spoon because their pits are so small and tender that they can be chewed with ease; there is no need of ejecting them if one does not wish to. In the woods there are wild trees of beautiful wood for buildings and other uses, as in Concepción and other provinces. In one word it is a beautiful country in every way.

The name Culenco is derived from the abundance of culen or Psoralea glandulosa that grows there in all the valleys and gullies. Very few plants were found on these excursions that differed from those found at Concepción; among them we sketched the Sophora cassia and the Mimosa carbonaria, espino, of which I shall speak elsewhere as well as of the other plants gathered on this trip. 


\section{CHAPTER XXVII}

Plants gathered-Medicinal and industrial uses.

\section{RETURN FROM CULENCO TO CONCEPCIÓN}

On May 3rd, 1782 we returned to Concepción, where we continued our excursions and botanical work until the month of December; during this time we dried and sketched many plants and trees, of which I described the following. Campanula filiformis, hunopergi. Embothrium obliquum, dentatum, raral. The bark and leaves give a good black tint or dye, and the wood is used in the construction of arches. Emb. lanceolatum, nothro. When our troops were surrounded by the Indians in the hill of Villagra, they found themselves obliged to make small cakes with the seeds of this shrub, although they are so small and give so little flour, but the need of food forced the men to use what they could find. Lardizabala biternata, coguillogi or traunuvoqui. The pulp of its fruit has a very good taste and is eaten by the natives. With this reed they tie walls of clay and cane, and the roofs and crosses of the houses because of its flexibility, durability, and strength. Aextoxicon punctatum, aceitunillo, for the resemblance of its leaves and fruits to that of the olive tree. The fruits of this tree are poisonous to goats; from its trunk the natives get very good wood, beams, and boards for construction and other carpentry work. Decostea scandens, yelmo; this climbing shrub stays green the year around. Ruizia fragrans, boldu; this small tree stays green the whole year, grows from ten to twelve yards, blooms in August, and sprouts in October. It gives beautiful and pleasing shade by the density of its branches and leaves; their wonderful fragrance that it continually exhales, somewhat resembling cinnamon, spreads all over those fields for long distances. The mashed leaves are used by the natives to strengthen the stomach and to cure its pains, and with their juice extracted with water, they stop earaches. They apply them halfroasted, crushed, and sprinkled with wine, for colds in the head. Hot baths made with the leaves are reputed to be antirheumatic and antihydropic. They are boiled for general baths and are used like bay leaves for condiments and for pickling fish. The ripe fruits, although small, are very appetizing because of their fine, sweet taste. With the stones of these fruits some persons make rosaries since, besides being hard, they are naturally carved. Barrels made of the wood improve the quality of the wines that are contained in them. 
Periphragmos foetidus, huevill-huevill; they use the infusion of this plant in enemas to move the bowels. Dioscorea filiformis. Azara obovata, lanceolata, and elliptica, corcolen; all these small trees are a beautiful sight when in bloom, and their yellow flowers are as deliciously fragrant as the flowers of the aromos. Erysimum tuberosum. Sophora alata, pilo or pelu. Tree with an excellent, white, solid, and heavy wood for making keels of boats on account of its hardness and resistance; the pods are used for black dyes. Viola lutea and chilensis, violets, are used in place of Viola martia. Anemone digitata, anemona. Croton trinerve. Ribes punctatum. Coccoloba hastata, quilo. Horminum? salviflorum, alhuelaguen. Cynoglossum decurrens and pauciflorum. Fagus Pellin. They call this tree pellin when it is old, roble when it is in its greatest vigor, and gualle when it is small. From its trunks they get beautiful timbers, beams, boards, and planks, and its wood is of the best known for the making of keels and keelsons of boats and for many other kinds of building, also for carts and parapets. The crushed bark prepared with lime and bran tans and dyes sole leather red. This tree breeds two species of excrescences: one is called digueñes and is a kind of puffball of an obovate shape and the size of a chestnut of white color, but when the balls get ripe they become reddish and full of holes like a honeycomb in which one finds some insects; for this reason I thought that they must be insect nests. The natives eat them raw, notwithstanding their insipid taste, similar to that of some tender mushrooms. The other excrescence is a small gallnut, reddish and adorned with small blunt points that the natives take to be the fruits of the tree, without noticing that they enclose only small worms while the true fruit has three seeds. Macignata, guillipatahua, a tall tree with a thick trunk that makes good timber. Its bark is used to pickle hides; it is also a powerful emetic, and in greater doses purges the bowels, as do also the fresh leaves infused in water, which is the way they use them. Gnaphalium uniflorum. Talinum monandrum, nitidum, and umbellatum, yerba de la mistela, because with its flowers, that are the color of lac, they color mistelas (drink made of wine, water, sugar, and cinnamon), and the guaza women use them to redden their cheeks with the juice. Valeriana hyalinorrhiza, crispa, and Cornucopiae L. Gunnera thyrsiflora, panke. The root of the panke or pangue is as big as a thigh, it penetrates almost a yard into the ground and divides into two or three branches of the same thickness; the people use them for tanning hides. The stems of its leaves, called nalcas, are eaten raw when cleaned of the 
fibrous parts; they have an acid, astringent taste, and the gum that is found in abundance in the shoots and tender stems is applied with considerable benefit to the kidneys to mitigate the heat of the blood in high fevers. Gualtheria acuminata. Pourretia coarctata, cardón and puya; the wood of the stem is used in place of corks for the cover of earthen jars, and a bunch of its flowers, which are fragrant and pleasing, applied to the ear mitigates pain and restores hearing. Polygala vulgaris L., quinclin; it is used as a diuretic in infusions. Geum urbanum L., quelgon and canelilla, for the odor of its roots, used in decoctions as an aperitive and resolvent. Sisyrinchium cavum. Cymbanthes punctata, arquenilla, the infusion of which is given as a diuretic. Myriophyllum verticillatum L. Solanum cristatum, natre; it is used in infusions with good results against the chavalongo, a kind of tabardillo [burning fever]. Ornithogalum coeruleum. Loasa tricolor, ortiga. Serapias plicata, gavilu and margaritas. Soliva sessilis. Rhamnus pretiatus, retamilla, and prostatus, llague; these two thorny plants are used by the Chileans as a hedge around their properties, and with the barks of the roots, which make suds like soap, they wash cotton clothes, tocuyo, and even linens. Aster repens. Amaryllis formossisima L. Galvezia punctata, pitau, a tree small but leafy, of handsome appearance, green all the year round and of better fragrance the more its glossy leaves dry. Torresia utriculata, ratonera, because its tuberous roots, tender and transparent and of the size of small misshapen pearls, serve as food to the many rats that come to the places where these plants grow. Silene anglica L. Alstroemeria Salsilla L. Sapium fragrans, collihuay; its roots when burned expel a delicious fragrance, but produce headaches in those that get too close to the fire of this plant. Its juice or milk is very caustic, and so active is this quality that persons have lost their sight when some of the milk got into their eyes while they were cutting firewood. Myoschilos oblongum, godocoypo, that is, food of the coypo. This small shrub is one of the very few in Chile that lose their leaves, and it blooms before budding. Sisyrinchium echinatum. This plant, after it is dried and kept between papers, leaves a beautiful pink color stamped on them; from this it is presumed that it might be very valuable as a dye. Cineraria fasciculata. Sonchus purpureus. Statice Armeria L. Phlox aterifolia. Lithospermum muricatum. Serapias lutea. Mimulus luteus L. Sisyrinchium caducum, setaceum, and quadriflorum, guilmo; its roots are used frequently in decoctions to purge the bowels and for venereal humours. Ornithogalum plumosum; its 
white flowers are covered with long hairs. Pavonia sempervirens, laurel of Chile, is a tall, luxuriant, and beautiful tree which stays green throughout the year; its wood is white and workable, and has wavy stripes in the center. It is fragrant like sassafras; from the trunk they get good beams, girders, and boards for buildings and other works of carpentry. In Chile they use its leaves instead of bay leaves in the preparation of pickled fish and other dishes; it might find excellent employment in medicine, on account of its fragrance and the corroborant properties of its leaves and wood, hot baths of which fortify the nerves and are useful in paralysis, spasms, and convulsions; an infusion of the leaves taken at all meals relieves rheumatic pains. Ferraria Lagues. The bulbs or onions of this plant, called lagues, grow in abundance in Chile, and are eaten baked, boiled, and even raw; but the baked taste best, and after that the boiled, the taste being like that of hazelnuts. The pigs that graze in the places where these plants grow become admirably fat, and their meat is delicious. Loasa laciniata, wild ortiga. Buddleia globosa, pagnhin. It is a beautiful shrub when in bloom and in fruit; in this case the fruits are of the size of a small hen's egg and are found hanging. Sisyrinchium alatum, and multiflorum, tecal and quilmo blanco. The Chileans use this species as an active purgative, infused or boiled in water. Rhamnus verticillatus, chacay; the infusion of its bark is employed against boils. The wood is incorruptible; for this reason they build huts with it. Plantago hispidula. Hedysarum plumosum. Ornithogalum sympagantherum, illmo. Its bulbs or onions that have the shape of a Cucurbita Lagenaria, or calabash, taste very good when boiled, and even raw they are delicious. Verbena corymbosa, and multifida, sandía laguen. They use the decoctions to produce menstruation, to hasten childbirth, and to lessen bladder pain. Herreria stellata, quila and salsaparrilla, because their creeping roots are used instead of the Smilax Sarsaparilla. This plant is an excellent food for cattle, and the shoots, resembling canes, have the same uses as reed grass. Dioscorea hastata. Lotus utricularis. Salpiglossis sinuata. Senecio capus. Oenothera mitis and oblonga. Hypochaeris laciniata. Lathyrus albus. Scabiosa sympaganthera. Lupinus rhombeus. Myosotis corymbosa and gracilis. Cissus striata, vogui, a name also used by the Chileans for turbulent and troublesome people. Malva hispida. Aldea pinnata. Weinmannia corymbosa, tiaca, a small tree whose wood is used for buildings, raft poles, and other works of carpentry. Lathyrus lutescens. Alstroemeria Ligtu, liutu. From 
the roots of this plant the Chileans get a very white starch with which they make very delicious mazamorra [a sort of pap, made of flour, honey, and sugar], or puches, soft and transparent as jelly, that not only is rich nourishment for children and old people, but also is preferred to any other nourishment for the sick, because it can be digested with ease and because it has no odor or taste that could make it disagreeable; on the contrary, with the sugar and powdered cinnamon they add, the taste is delicious. They get this starch, or "flour of liutu" as they call it in Chile, by grinding the roots between two stones and placing the product in water, collecting the liquor in trays or troughs and straining it; after sedimentation, they decant it, and the flour stays in the bottom, is dried in the sun, and is kept to be sold. Each zelemin [about an English peck] usually is worth $2 \mathrm{rs}$. in their currency. In Fort San Pedro they make much of this flour, that is greatly esteemed in Lima and in the whole kingdom of Chile by people of good taste. From all the species of Alstroemeria they can get a similar flour because all of them have tuberous roots of the same consistency, odor, taste, color, and transparency. Oenothera incurvata. Astragalus dependens. Serapias alba. Kageneckia oblonga, red guayo. This is a beautiful tree, and its trunk is used for many purposes because its wood is strong and red and becomes brighter by pouring urine over it, so that they make walking canes of it and various articles turned on the lathe. The bark is used to dye hides, and with the seeds they sometimes purge themselves. Laurus rubra, peumo. A tall and very leafy tree, and therefore, of beautiful appearance and lovely shade, especially when it is full of its red fruits, the size of small olives. Although these contain little pulp and are disagreeable in taste to those who are not used to eating them, they are very tasty to the natives who, after boiling them in water without any condiment, suck with avidity the little pulp covering the seeds or pits, which are bitter, viscous, and so disagreeable in odor and taste, resembling that of celery, that they cause nausea. The wood, bark, and leaves have the same taste and odor as the pits. From the trunk of this tree they get very good beams, planks, and boards for various uses, the wood having good working qualities and resistance. The bark possesses astringent properties and gives an orange color in tanning. To the fruits they attribute antihydropic properties. The country people, who are very generous in inviting to their table any traveler that happens to arrive at their house at midday, encourage him to eat with this expression: "Join us, my dear, in the pot; it has 
peumo." Celastrus dependens, maythen and magthun, a handsome tree because of the abundance of its pendant branches, the perennial green of its leaves, and the many flowers and fruits with which it becomes loaded. It generally grows among shrubs and small plants; this circumstance makes it stand out and be more conspicuous and well-known to all. This little tree is the antidote to the malignity of the lithre or lithi, a species of Schinus, that regularly is found on the same grounds; its shade and smoke, when it is burned, produce a multitude of poisonous pimples on the exposed parts of the body of persons who take shelter under it or inhale the smoke or the vapors expelled by it when it is cut. Divine wisdom seems to have placed these two trees near each other on purpose so that one could curb the bad and rapid effects of the other, simply by applying the the crushed leaves in the form of a poultice over the pimples and by purging the bowels with an infusion of leaves. In Chile some people use the leaves of maythen, instead of senna leaves. Many persons, although they sleep under the lithre and inhale its vapors and smoke, do not get sick or suffer any harm; but there are some who are so susceptible to this poisoning that after a short time they become ill and are attacked by fever. The wood of the maythen is white, and pink and glossy in the center; it is of good quality, and suitable for odd pieces. The cattle eat its tender branches with relish. 


\section{CHAPTER XXVIII}

Boundaries of the province of Puchacay-Botanizing at Huilguelemu-The Chilean pine-Plants of Rere-Medicinal and industrial uses-The pizguin-More plants.

\section{VISIT TO THE PROVINCE OF RERE AND FORT NACIMIENTO}

In December, 1782 the three botanists and the draftsmen left together, for Fort Nacimiento, that is situated at the foot of the cordillera, where by royal order they were cutting Chilean pines for masts and the interiors of boats. We passed through Hualgui, capital of the province of Puchacay, which borders to the west on the province of Concepción, to the south on the Biobio river, to the east on the province of Rere, and to the north on that of Itata. It has two parishes; they are those of Florida and of Conuto, besides that of the town of San Juan Baptista de Hualgui.

On arriving at Huilguelemu or Estancia del Rey, capital of the province of Rere, all of us spent the night there in the house of Dn. Miguel Montero, corregidor of the province, who informed us of the fact that there were very few plants in Nacimiento to occupy us according to the purpose of our commission; for this reason, impressed by this information, I determined to stay in Huilguelemu with draftsman Gálvez to gather and sketch the plants that were present in those fields and woods. My companion Dn. José Pavón, with draftsman Brunete and Mr. Dombey, went next day to Nacimiento; they returned on the fifth day to Concepción, having satisfied themselves about the information given us by Corregidor Montero. Dn. José Pavón went in company of Dn. Isidro del Postigo, naval official in charge there of the commission for the cutting of the pines, from Nacimiento to the cordillera to get branches of these pines that we might inspect them. This I did myself when my companion left for me in Huilguelemu, while on the way back to Concepción, branches with strobiles or small cones and amentos or male shoots, after the three botanists had agreed that it was a species of the genus Pinus of Linnaeus, although a dioecious tree.

I remained with my draftsman one month in Rere. During that time I gathered and gave to be sketched several plants of which I described the following. Stereoxylon virgatum, revolutum, liun and siete camisas, and pulverulentum, mandoño. Alstroemeria revoluta, discolor, tricolor, and sanguinea. All these plants are valuable for gardens on account of the color of their showy flowers, and useful for their tuberous, white, and juicy roots from which one can get 
the same kind of starch that is taken from the liuto or Alstroemeria Ligtu. Smegmadermos emarginata, quillay, a big, tall, and luxuriant tree; from its crushed bark the natives make balls, that they sell for half a real, for washing cloth instead of soap, and with the decoctions they give enemas against hysterical attacks. These trees are also found in abundance in the provinces of Puchacay, Concepción, Itata, Cauquenes, and Maule, and in almost the whole kingdom of Chile, where they make use of their trunks for beams, planks, and excellent boards for buildings, framework of windmills, and mines, and other work, because it is more resistant in damp places than in dry. Stachys lanuginosa. Eryngium ciliatum, achupalla; trifidum, anisillo and Eryngium tripodum, calcha; its stalks, or part of them that grow buried underground, are eaten raw as a salad and taste like endives. Fabiana imbricata, pichi, a shrub that is abundant on the beaches and sands of the rivers and lakes near the sea of the provinces of Rere and Itata; it is recognized there as an admirable specific to cure the pizguin of the goats and sheep, a sickness produced by an insect that breeds in the livers of those animals and that causes the death of whole flocks. However, the hacendados, experienced in the knowledge of this sickness, immediately take their flocks to graze where there is pichi, and with this nourishment they get well and fat in a short time; when they kill a goat or a sheep later, no pizguin is found in the liver. This same sickness strikes the sheep of Peru when they have grazed on weeds, particularly in the montañas where there are no grasses or small plants, as we ourselves had found in case of the sheep that we had taken there at various times. Calceolaria alba, arguenilla blanca. Fragosa spinosa. Sisyrinchium campanulatum. Aster multifidus. Carthamus ciliatus. Tropaeolum hexaphyllum. Chaetanthera ciliata and serrata. Navarretia involucrata. Gardoquia multiflora. Oldenlandia uniflora. 


\section{CHAPTER XXIX}

Boundaries of the province of Rere-Its climate-Salting industry-Gold washers-Round stones-Birds of the province.

\section{DESCRIPTION OF THE PROVINCE OF RERE}

The province of Rere is bounded to the west and northwest by the province of Puchacay, and to the east and south by the fortresses that we have there to prevent raids by the Indians living in the cordillera. The capital of this province is the town of Huilguelemu or Buena Esperanza and today called San Luis Gonzaga or Estancia del Rey, with a parish in the same town, where all the people from the nearby farms and haciendas gather for Mass and all the other Christian observances, except from those places where they also have Masses on holy days.

The climate of this province is almost the same as that of Concepción, so that good harvests of wheat are gathered. Little wine is produced, and it is very inferior to the wine of Nipas and other haciendas of Itata and Puchacay. Plenty of cattle are slaughtered for charqui, fat, and tallow. Some flocks of sheep and goats are also raised in those fine pastures.

There are deposits and washers for nuggets of fine gold, of which they gather considerable quantities in the course of the year by only washing the sand of those deposits that are from two to five yards deep. They sometimes get nuggets, or papas, as they call them, of a half or one pound, and even of two pounds in weight; those of half an ounce are common.

At a distance of two or two and one half leagues from San Luis, there are some hills near the Biobio river where one finds round stones like bullets and others larger than'walnuts; of these I gathered two bags, digging with a knife on the surface of that copious deposit.

In Rere there is an abundance of small parrots, treguiles, aloicas, sparrows, and other small birds called huros, that destroy the plantations of maize, beans, wheat, and other small grains, not only in this province, but also in others in the kingdom.

At a short distance from San Luis Gonzaga, there is a brook abounding in shrimp and crabs that have a delicious taste. 


\section{CHAPTER XXX}

Excursions in the neighborhood of Concepcion-Plants gathered-The shade of the lithre-The maythen-Uses of the merulanguen and other vegetablesCollection of woods-The Chilean pine and its great utility.

\section{RETURN FROM RERE TO CONCEPCIÓN}

In January, 1783 I went with my draftsman to the city of Concepción, without having experienced any particular trouble on the way.

We continued all of our botanical excursions through the mountains and fields of Concepción and Cauquenes until the 29th of March of the same year; during this time we dried and made drawings of a great number of plants of which I described the following. Lardizabala triternata, coguillvogui; its fruits are edible and, although they are smaller than those of biternata, are equally sweet and tasty. Schinus frondosus, lithre and lithi. A large tree, about twenty yards in height and handsome on account of its globose crown of foliage and green color the year round, though it is greener in spring and more exuberant then than in winter. It gives such fine shade that, more than any others, it invites the traveler to shelter in summer and on days of hot sun. The lithre shade is so malignant that it immediately produces in many persons that have sought its shade, a certain kind of purulent pimples accompanied by fever on all those parts of the body that have been uncovered during the siesta.

The same effect is caused by the smoke from its wood and the vapors it expels when the wood gatherers cut it, as has been explained in the description of maythen, which is its antidote, as are also, according to the repeated observations made by the natives, grains of corn chewed and applied to the eruption caused by lithre.

Notwithstanding the malignant property of this tree, its thick trunk yields valuable timbers for the keels of boats on account of its peculiarity of increasing in strength the longer it stays in water; they also make from these trunks excellent beams, planks, and boards for buildings, wheels, and axles of carriages, points of ploughs, and other uses. Loasa multifida. Stemodia maritima. Laurus revoluta, ligney-lingue. - This tree is very common in the bishopric of Concepcion and in many places in that of Santiago. Its trunk is valued for small articles because its wood is solid and spotted like jasper, and it is made into wash basins, trays, and bowls. With the bark they tan sole leather and red gauntlets. The fruit gives a bitter taste to the flesh of doves that eat it, and it is poison to ruminant animals. 
Linum confertum, merulanguen; the infusion and decoction of this plant is much used in affections of the chest and also against coughs and colds; mashed and mixed with wine and applied as a poultice, it reduces swellings and stiffness. Apium graveolens, panul and wild celery; the natives eat its raw leaves to curb hemorrhages from the chest, as they say, and to cure this sickness. Oenothera grandiflora, guadalaguen. The natives assure us that the juice and the hot infusions of this plant willmake internal abscesses discharge. Hyssopus? punctata. Molina reticulata, racemosa, viscosa, and oblonga. Erigeron scabrum and canadense L. Hydrocotyle alchimilaefolia, exhales a fragrance like the torongil. Campanula denticulata. Arbutus racemosa. Fagus oblongifolia, pellin; luxuriant tree with excellent wood for buildings, parapets, keels, keelsons, props, and other works of carpentry, for its durability in water; it is one of the few trees that loses its leaves in winter in Chile; with the bark wools are dyed dark purple. Oxalis prostrata, yerba de la perdiz. It is so abundant in spring that the fields of the coast of Concepción form a beautiful carpet with the green leaves and the more or less brilliant gold color of their flowers. Its leaves are very agreeable to the taste and, because of their slight acidity, some people use them in salads.

While we remained in the bishopric of Concepción, we made an excellent collection of woods in small cut boards which, by their colors, grain, and consistency, makes one admire the greatness of the Creator. These were lost with all the collections from the kingdom of Chile - there were many representing all the three kingdoms of nature - in the wreck of the ship "San Pedro de Alcántara." We also sent to Madrid, every month, packages of all the seeds that we found in those beautiful fields, mountains, and fertile coasts.

I finished the description of the Pinus chilensis started in Huilguelemu, by going with Dn. José Brunete, so that he might sketch the habits of this magnificent tree, to the road of Talcahuano, where there were three female trees, one of them stretched on the ground, but held to it by the roots. This very tall tree, although dioecious, corresponds in all its parts of fructification with the generic character of Pinus of Linnaeus, according to the examination made by us three companions; we agreed unanimously that it was a new species of this genus and probably the most valuable of all those discovered up to that time for its exquisite white wood of excellent grain for working and for use for masts of boats and many other purposes, for its pine nuts contained in great cones and serving as nourishment 
to the Pehuenche and Huiliche Indians, and finally for its resin, very useful in medicine. There are cones that contain as much as a celemin or almuz of pine nuts, bigger than acorns, in the shape of a wedge, and of the the color of chestnuts in and out, and with a similar taste raw, boiled, or baked, for they are eaten in all these ways. The resin possesses especial balsamic virtues and to large wounds it is applied by the very men that cut the trees, when by neglect or accident the axe slips and they get cut themselves. They also apply it as a soothing remedy for all fractures in any part of the body. (See the description of this singular tree in the Flora Peruviana et Chilensis, where the curious will find all the account that they could desire of its structure and its economic and medicinal uses and virtues.) I will say here only that the Chilean pine rises to forty, fifty, and sixty yards in height and that, according to the account of the natives, forests of it extend more than 200 leagues from $36^{\circ}$ south unto near the straits of Magellan; its territory is inhabited by the Pehuenche and Huiliche Indians. Padre Ignacio Molina in his Natural History of Chile, describes this pine. Lamarck has separated it from the genus of Pinus and called it Dombeya and Antonio Lorenzo Jussieu, Araucaria. This last was adopted by my companion Dn. José Pavón in the description of this tree that he presented to the Real Academia Médica of Madrid, but on no other grounds than his own choice or that of a third person, as I have proved in my Respuesta para desengaño del público a la impugnación que ha divulgado prematuramente el presbitero José Antonio Cavanilles contra el Prodromo de la Flora del Perú, impresa en Madrid en 1794 . 


\section{CHAPTER XXXI}

Shape, limits, and parishes of the province of Concepcion-The bay of Quiriquina-Talcahuano and its castle-Valdivia and its origin-Earthquakes and inundations in 1730 and 1751-Description of Concepción-Its inhabitantsConvents-Birds-Mammals-"The amphibious horse"-Fish-CrustaceaMollusks-Echinoderms-Amphibia-Reptiles-Arachnids-Insects-Plants.

DESCRIPTION OF THE PROVINCE AND THE CITY OF CONCEPCIÓN OF CHILE AND ACCOUNT OF THE NATURAL PRODUCTS OF THE WHOLE BISHOPRIC OF CONCEPCIÓN AND THAT OF SANTIAGO

The province or corregimiento of Concepción of Chile consists only of the small territory that lies between the sea on the west and the boundary of the provinces of Cauquenes and of Puchacay that lie to the east and northeast of Concepción about two leagues distant. From north to south it extends from the Andalien river to the Biobio river, including the places called Mochita, quebrada of Carcamon, and Hualpen, and the ports Penco el Viejo and San Vicente, not frequented by boats and situated behind the Tetas de Biobio next to the port of Talcahuano and in which the vessel "San Miguel" was launched in our presence, and, finally, the port of Talcahuano with a great bay that has at its entrance a desert island called Quiriquina, where they quarantine people that come from Peru and other places with smallpox and other contagious diseases, which the officials try to discover when any ship gets into port. This bay has two entrances: a big one in the north where the big ships come in, and a small one on the south for smaller vessels.

In Talcahuano, that may have thirty people, there are bodegas or warehouses for products and goods that are taken to Peru; from there four to six ships come annually. In the hills of Talcahuano there is a castle to defend the port and guard the entrance; in this there is small garrison of troops, regulated by a commandant who governs as a political and military official.

This province has three parishes: Concepción incorporated in the Cathedral, and those of Hualgui and Talcahuano.

In the year 1550 Valdivia founded the city of Concepción at the port of Penco, in $36^{\circ} 43^{\prime}$ southern latitude and $303^{\circ} 18^{\prime}$ longitude from the meridian of Tenerife. In 1567 the Royal Council was established there; this was ended in 1573, and in 1609 it was reestablished in the city of Santiago. Concepción of Chile was destroyed several times by Indians, and by earthquakes, especially 
on the eighth of July, 1730 , an earthquake being followed by a tidal wave that flooded most of the city. On the 24 th of May, 1751 with another earthquake, the sea again overflowed twice. The first time the people were warned to flee to the hills, which they did, most of them in undershirts, as it was night; the second time the sea flooded and ruined the whole city. For this reason it was moved to the valley of Mocha on the 24th of November, a distance of three leagues from Penco, near the Biobio river, and at the foot of the hill of the Puntilla where the gunpowder warehouse is situated.

The streets of Concepción are laid out in straight lines from northeast to southwest and from northwest to southeast; its ground is sandy and remains uneven, because of the few inhabitants and the short time it has been built, The houses are of a single story, constructed of timber, lime from shells, and stones, with adobe baked in the sun, and are roofed with tiles; most of them have partitions of boards, which is the quickest and cheapest material because of its abundance in woods and fields. The population is composed of ten thousand souls, more than half of whom live in their haciendas, or campañas as they call them, most of the year. The men are generally of good stature, of good appearance, healthy, and serious and formal in their behavior and dealings. They dress in Spanish style, but on horseback they use ponchos. The women are of medium stature, pretty, healthy, clean, affable, and obliging; they dress in the fashion of Lima.

As to politics, this city is governed by a council composed of one corregidor [magistrate], two ordinary alcaldes [mayors], four regidores [aldermen], a royal alferez, and the other corresponding officials. The ecclesiastic chapter consists only of the bishop, dean, archdeacon, a magisterial canonry, and another of mercy; although according to the regulations the number should be much larger, the small decimal taxes have not permitted it to date. There is a small cathedral situated in one of the facades of the big town plaza or square which is in the center of the city, to the right of the Bishop's palace, where they worship Our Lady of the Snows, a miraculous image by whose intervention there have been many miracles. The religious convents are five, namely those of the Agustinos, Mercedarios, Franciscos, Dominicos, and San Juan de Dios. There is a monastery of barefoot Trinitarians, a colegio, and a meeting house.

Although this city is not walled, it is the principal garrison place of the whole frontier, and the commandant or mre. de campo and the sergeant-major of the kingdom reside there. Formerly, the 
captain general and the president of the royal council of Santiago lived in this city six months each year, but now they live in this capital of the kingdom of Chile the entire year. There are also royal coffers with their accountant and treasurer, customhouses, and some traders in European and native products.

The bishop resides in this city, and his jurisdiction comprises the six provinces or corregimientos of Concepción, Cauquenes, Chillán, Itata, Puchacay, and Rere, none of which has appropriations; nor do the corregidors [Spanish magistrates] have other salary than the very small judicial revenues. For this reason these posts are not desirable and no one wishes to claim or solicit them at court, so that this and the bishopric of Santiago are provided for almost always by the captain general of the kingdom.

Besides these corregimientos there are three governments belonging to the kingdom of Chile which are provided for by the king; these are Chiloé, Valdivia, Valparaiso, with the comandancia [district] of the island of Juan Fernández, the commandant of which governs in political and military matters.

The climate of this province during the four seasons of the year, as in the other provinces of this bishopric, is generally milder than the climate of Spain, with which country the kingdom of Chile has a notable resemblance in this as well as in many of its natural productions. The winters are not so cold, nor the summers so excessively hot; for this reason, most of the trees are green and leafy throughout the year, especially on the coast and at the seashore where the waves beat against the trees. The sky is beautiful, and in clear weather the nights are bright, even when there is no moon. The most usual and healthful winds are from the south and southwest; with the winds from the north it rains abundantly. The wind, called puelche, that comes from the cordillera is cold and dry to extremes and very harmful to the health, causing paralysis, convulsions, colds, that turn into burning fevers that are called chavalongos, though others more dangerous come from sunstroke; the Indians and the people of the country cure these with cold baths on the head and with infusions of several plants. When the puelche blows for a long time, it is a sign of earthquakes.

This bishopric, like the whole kingdom of Chile, is a country very fertile in pastures; for this reason there are many mountain animals of all species, such as zorzales, gallinas, aloicas, gilgueros, pirenes. Those used for food are the torcaces, perdices, papagayos, tortolitas, cotorras, the small chickens of which, called tricahues, 
have a delicious taste. The papagayos breed in the steepest ravines of the rivers, where the guazos, or people from the country, get them with rash fearlessness, coming down the ravine tied with a rope that at the other end is tied to some tree, if there is any, or if not, to the horse they are riding; as they gather tricahues, they haul them up by the same rope without thinking that their lives depend on the strength of the rope and of the girth and on the loyalty and tameness of the horse, because if that fails they fall into the river, or if the horse gets restless or frightened or cannot hold the weight, they are liable both of them to fall into the river or be dragged along and cut to pieces. Besides the birds used for food, wild or domesticated (that are the hens, turkeys, doves, ducks, and geese), there are in Chile calandrias, or tencas, that imitate the song of the birds they hear; tordos, papamoscas, and small birds that sing softly; picaflores, diucas, announcers of the new day with their singing, inhabiting towns and villages; woodpeckers that bore trees with their beaks, making quite a noise with their blows; tichles or chilis from which this kingdom took its name; pillos, a kind of heron, from which they get beautiful feathers for writing; treguilles, watchmen dependable day and night, because when they hear the least of noises of persons or animals they fly away, repeating incessantly the word treguill, so warning others of their species, (they commonly live in damp places and near the lakes); gualas, urus, that eat the seeds that are sown, and because they are small birds, neither the beans, vetches, nor peas, nor even the abas are free from them; gallinazos with black and with red heads; small eagles, of brown color; condors, big eagles; gavilanes and lechuzas; herons or garzotas; Martín pescador, golondrinas, piuques, cucus, and chonchones, a nocturnal bird of such sad singing that when the Indians hear it, they take it as a bad omen.

At the seacoast and lagoons, there is an abundance of potojuncos and rabijuncos, nestling birds, gulls, alcatraces of beautiful feathers, jardelas, cuervos marinos and of game birds, ducks; zambullidores, a species of duck; flamingoes, geese, swans, bandurrias, piuquenes, gallinules, gualas, and coscorrobas, a specie of goose the cackle of which is called coscorroba, whence the name.

The domestic animals are cattle, Castilian sheep, goats, pigs, good horses, mules, and asses. The wild animals are small pumas, small wolves, foxes, and chingues [skunks]. In the cordilleras, there are vicuñas, huanacos, deer, chilihuegues, topos, mice, and pericotes or ratones. In the lakes, rivers, and coastal marshes you find the 
coipo, a species of large rat, otters, wolves, pumas, cats, and bears. They assure me that in Lake Avendaño there is a kind of amphibious horse that sometimes has been seen playing on land. In the year 1723 a guazo roped one such, but it jumped into the lake where it developed such strength that, if the man had not cut his rope, he might have been drowned with his mount, as it dragged him to the shore very violently. In Lake Papal, a distance of twelve leagues from Avendaño, they found one of those horses dead and floating in the lake; it was taken ashore in the presence of the corregidor and many people, and we noticed that it was double the size of the land horse, of a sorrel color, with thin neck, small ears, and plenty of long and thick hair on the neck and tail; the limbs were slim and without joints, and to all appearances with gristle instead of bones, and terminating in soft and flat paws in the shape of wings. ${ }^{1}$ For lack of interest they were satisfied with this short examination.

Fish and shellfish are found in quantities, and there are some of very delicious taste. In the rivers are found truchas, corbinas, eels, puyegues, anogagatos, and mirereyes. In the sea the following are very common: bobalos, one of the most excellent, corbinas, cabrillas, lenguados, pexe reyes, pexe sapo, pexe gallo, pexe perro, puyeguenes, aoumes, lisas, pintadillas, dorados, caugues, anchovetas, sardinas, tollos, congrio, vieja, pampanito, chichi, boconos, terguillas, pintarrojas, vagres, chalacos, tembladerilla, bollizos; ballenatos of large size that come to the island of Quiriquina and even to the Bay of Talcahuano; tiburones [sharks], or taurones as they are called by the sea people and in America (when they are small they call them cazones, and at this time they taste very good and are much esteemed), and octopuses, a kind of "mamas." The bestliked shellfish are choros, cholhicas, and female dollimes [mussels] the flesh of which differs notably in its color being like the yolk of an egg in taste and consistency, from the flesh of the males of the three species which is gray or viscous white, loathsome, and almost chalky; most times they are full of very tiny pearls, among which are found some of the size of peas and even the size of small chick peas, but because the supply is small and because in general the pearls are so tiny, the natives do not care to gather them. Dollimes are also found in rivers and lakes. There are four species of apancoras or crabs of the sea called talicunas, reynas, remadoras, and peludas; two species of crawfish or crabs, one with a delicious taste being found in the rivers, salt marshes, and lakes, and the other on land, where it bores

1 The reference is probably to the manatee [sea cow]. 
into the earth like the mole. For this reason Linnaeus called it Cancer talpa; ordinarily this is not eaten, because it has little meat and its shell is very hard. In the rivers and salt marshes there is a kind of small apancora that, because it has little flesh and because its shell is very hard, is not gathered either. There is an abundance of sea urchins and shellfish: picos, tracas, navajuelas, chapes, petacones, palanganas or aseytaderas; locos, the flesh of which needs to be pounded with a heavy stick to make it tender; pipes, a kind of barnacle that adheres to fish and other shellfish; oysters in banks; peninpenin, so called for its shape; potos, that are rosas, olonturies, and sea anemones. Pinnes, starfish, and several other small snails and shellfish are found in rivers, salt marshes, and lakes. Frogs are found of more than two pounds in weight. Large toads are seen in the fields when it rains in the summer; there is another smaller species of toad that is scarcely larger than a cricket but much more troublesome than this, and with a similar noise. There are two or three species of small snakes. Scorpions are found in the quebradas under the stones; among the several species of house and country spiders, three are rather conspicuous. One is big and hairy, another smaller, about one-sixth the size of the former; both are harmless and carry their young on their back, but the bite of the third, which is much smaller than the second and of a dark color with a pink posterior, is very poisonous and sometimes fatal, causing a strange convulsion that contracts the limbs with very intense pain. As night approaches, the pains increase until next day when, as soon as the sun comes up, they diminish, and the limbs begin to relax, so that at noonday they feel normal again as if completely recovered. This species is found frequently in the summertime in the grass, and it is at this season that they bite.

Insects are numerous in the kingdom of Chile, and the best known are a kind of silkworm that breeds in the quebradas of Petorca and Cordillera; cucuyos [fireflies] breed commonly on the laurels, and in the night they give a beautiful phosphorescent light; concorras, a kind of caterpillar of several sizes and colors, and one that lives on the huignhanes is very abundant and among the largest that are found there; from this comes various species of butterflies. Of pinathas or pinathras, that is moscones, there are several species. There is an abundance of zancudos [mosquitoes] and a very small species that breeds in the manure of cows. When they fly, they fill the air and expel a fragrance similar to ambar; some people catch the mosquitoes to put them in their clothes so that these may become 
impregnated with that fragrance. Perhaps this odor can be attributed to Geranium moschatum, which is found in those pastures. Fleas are abundant in the whole kingdom. Bedbugs are not missing in Santiago, where you also can find some chiggers or piques.

Thus in the bishopric of Concepción as in that of Santiago, the vegetable kingdom is no less favorable than the animal, because, besides the wheat, barley, legumes, grapes, and other fruits and seeds that are cultivated and gathered, the ground is generally covered with shrubs and trees of excellent timber for factories and construction, plants and herbs of known economic uses and medicinal virtues, as has been said already. With these the natives cure their sicknesses and pains, many being guided by a natural instinct for the application of these medicines and specifics, and by accident and observations gained by experience. The trees and shrubs suited for construction are the Chilean pine, for the masts of boats; and pellines, ranlies, and listres, for the keels; nebu or avellano, for oars; queule, laurel, peumo, lumas, coihue, belloto, aceitunillo, quillay, guayo colorado, wild lucumo, algarrobo, and espino, a species of Mimosa, molle de Chile, canelo, voldo, several arrayanes, patagua, guillipatagua, pitau, pilo, manihue; pines, olives, cypresses, and walnut of Spain, lingue or linge, huayacanes, coquito palms. The uses and properties of these trees, as of the other plants of Chile, have already been stated or will be stated in their respective places, as I have been describing them; for this reason I shall not repeat them here. Among the fruits found there is the famous Fragaria chiloensis; those called frutillas are found up to an ounce in weight; avellanos and piñones different from those in Europe; nuts, almonds, peladillas, peaches, pears, the excellent Joaquin pear that is sent to Lima as a present; quinces, apples, plums, and grapes of several kinds, and beautiful decorative flowers, and vegetables. 


\section{CHAPTER XXXII}

Gold - Metals - Lime - Gypsum - Coal - Clays-Minerals - Thermal waters Lakes-Rivers-Ports-Products-Textile and other industries-Ulpu.

\section{GOLD MINES: STONES AND SOILS}

In the bishopric of Concepción, at the boundary called Quilacoya belonging to the province of Rere, there are several placer mines of gold dust and nuggets of 21 carat gold up to one gram; of these considerable quantities have been gathered, not in Quilacoya alone, but also in Huilguelemu, the capital of the province. But as the country gives its inhabitants an abundance of provisions and much hospitality, there are very few who undertake to recover this treasure that nature so generously offers on the face of the earth. The natives say that, in the sand and salt marshes, there are various other mines of gold, silver, iron, and copper in this bishopric, but because of lack of workers they are abandoned.

Lead, tin, and iron are found in some places of the kingdom and especially in Coquimbo.

Amianthus is found in the salt marsh of the quebrada of MillanAntun, a distance of six hundred feet from Nacimiento; it is of the strength and color of chalcedony, and the natives use it for fuel. The natives are sure that it consists of roots of petrified willows because of the form that it presents, and because those trees are found there. It appears to be the species of Amiantus immaturus L. Syst. N. 158, Num. 2, T. 3, page 55 .

Stone bullets are round stones the size of a gun bullet, found in the hill of Tanahuillin, situated near the Biobio river about two leagues from Huilguelemu, where I gathered a good quantity, digging on the surface of the place.

The natives assert that there are other deposits of these bullets, as well as others of several sizes, in different places of this bishopric; I acquired several of them.

Cross stones are found in a salt marsh four leagues distant from Arauco, as I have already said in the description of the trip to that place.

Lime is found in several quarries excellent for making good lime. Nevertheless, they use only the lime from shells of picos, locos, choros, cholinnas, and tracas, calcined; it is not very strong. There are deposits of these shells in many places in the kingdom.

Gypsum, a very special mineral easy to calcine, is taken from several places near Santiago in the cordillera; after being calcined, it is taken from there for sale to several provinces of the kingdom for use in wine-making over the pressed grapes to facilitate the extraction of the must and its fermentation. In Santiago, it is sold for two or three reales per arroba, and in Concepcion for eight reales. 
Hard coal. There are some mines in Chile. One of them is found near Talcahuano on the road to Concepción, another near the road to Penco el Viejo, and another in Nacimiento.

Black sand, or salvadera, is found in a mine on the hacienda of Culenco, 12 leagues from Concepción; another is in the island of Quiriquina, and there are several others in other places in the kingdom.

Robo is a black soil found in marshy places; it is used to dye cloth black, the first dip being given with this soil.

Colos is a kind of clay more or less pure and of several colors, such as yellow, red, violet, buff, etc.; this the Indians and other natives use to color jugs, jars, pots, gourds, and pitchers and other pieces of pottery, and also to paint the churches, portals, halls, and friezes and baseboards of houses. It is found in the vicinity of Penco el Viejo and other places in Chile.

Rap or gredas. A kind of clay marl which they use to make gourds, cups, small jars, plates, pots, and barritas of several figures that they call barritas de Indias. They put it into water and clean out all the sand and other extraneous substances, passing it through a thin cloth and changing the water several times after the heavier portions have settled to the bottom; afterwards they leave it standing for some time, and when the water has been decanted, there remains at the bottom of the vessel the fine and soft clay, which is left to take the consistency required to work it and form pieces of pottery as desired.

They dry these in the shade, as the heat of the sun would shrink or crack them too much. In case that any of the pieces crack, they attempt to cover the crack with a little of the same clay. When they are thoroughly dried, they are polished and shined as much as possible with small touchstones and other very soft stones until they shine like mirrors; later they bake them or not, depending on the use they are going to have, and they give them the colors they desire for making them beautiful. The black color that they give to the pitchers and gourds is obtained with the burnt straw of any grass; at the same time they bake them with the same straw put in little piles without the use of an oven. . Thus in the use of this method, as in the manufacture of ponchos, blankets, bands, and other textiles, the Indians have advanced very little from ancient times, because in the graves or huacas there are found pieces similar to those made today. The Chilean ponchos are different from the ponchos of Peru in being of one piece, those of this kingdom being of two or four parts.

Jasper is found in several parts of the kingdom.

Marble is also found in Chile. In the hill of San Cristóbal of Chile there are red, strong marbles, and in the hill of Santo Domingo of Chile white, soft ones.

Ordinary topaz and some of average fineness is found in Maule province. 
Amethyst, or cristalmontano morado, is found in the province of Maule, in that of Petorca a distance of two leagues from the town on the hill called Polcura, and in that of Quillota between Pupio and Flana, where they are better.

Cristal montano is found in Algue in the province of Rancagua and in that of Maule.

Pumice stone is found in abundance on account of the many volcanoes that this kingdom has, the principal ones being that of Aconcagua, that of Rancagua towards San Pedro Nolasco, the volcano of Villa Roca near Valdivia, and another in a plain between Chilos and Valdivia.

Mine salt, or rock salt, is found in some places towards Copiapó.

Lake salt is found on the other side of the cordillera towards the side of the provinces of Maule and San Fernando or Colchagua.

At springs, salt is found in the shape of small tubes like candles, on the other side of the cordillera.

White and red polcura, a kind of alum, which is used by the natives to grease and dye; it is found in different parts of Chile.

Yellow sulphur, good and pure, is found in Copiapó.

Mineral tar is found in the province of Maule and in the cordillera, but the natives do not know how to give it the required preparation.

Brea vegetal. They get it by boiling a shrub called paxaro bobo, in Copiapó, and they use it to seal jugs.

Resins are taken from pines, huinghan, litre, and a species of Helianthus that is very abundant in Coquimbo and in Chile; they call this resin "incense of Coquimbo."

Hot and thermal waters, very effective for all kinds of venereal troubles and for cripples, are found in Chillán and in Caugue, province of Colchagua. In Colina, twelve leagues from Santiago, there are also temperate baths.

Loadstones are found in Copiapó, and twelve leagues from Santiago towards the coast.

There are several rivers that irrigate the kingdom of Chile from Huasco to the Plaza of Arauco and toward Mendoza: the largest are the rivers Colorado, Tachal, San Juan, Mendoza, Tunuyan, Choapa, Huasco, Limón, Ligua, Longotoma, Aconcagua, Mapocho, Maypo, Claro, Tinguirinica, Cachapual, Lontue, Teno, Maule, Itata, Andarien or Andalien, Lapa, Biobio, Araguete, and Carampangue. These last six are tidal rivers; that is, they flow and ebb and can be navigated with rafts and boats, but not as Molina says (page 44), in ships of the line, from the river Maule and Biobio. Besides these rivers there are many salt marshes or shore lakes aio. other rivers from Arauco to Chiloé: Cautín, Tolten, Valdivia, Chaivin, Rio Bueno, and Rio Sinfondo. There are several lakes in Chile; the best known are the Choapa, Avendaño, Papal, Huanacache, Quinel, Nahuelguapio, Villarica or Lauquen, Tahua-tahua, Aculeu, Bidahuel, Bojeruca, Cahuil, Bocalemu. 
At a distance of seven leagues from San Fernando there is a lake at whose surface there is an extensive floating sod formed by the interlaced roots of the maytenes, arrayanes, voldos, and other minor plants, with an abundance of grass which tempts cattle to to go on this small and buoyant island when it approaches the shore; they may stay on it for many days until the wind returns it to shore so that they can leave it.

The principal ports of the kingdom are those of Coquimbo, Valparaiso, and Talcahuano. There are several others, as those of San Vicente, Penco el Viejo, and Collomu, that is a very good port.

The commercial products that are produced and shipped to Peru and elsewhere are big harvests of wheat, 2,302 fanegas being shipped to Callao in 1780; barley, charqui or hung-beef, fat, which the people of Chile use for cooking instead of the lard of hogs or oil; tallow, of which they export to Peru 302 quintals; hides, tanned goatskins, sole leather, dressed sheepskins, chamois, cheese, of which the best liked is from Chanco; butter, the best being from San Pedro on the other side of the Biobio river; brandies and wines, the best being from the provinces of Puchacay and Itata, the finest and most famous being the wine from Nipas; walnuts, cherries, hazelnuts, almonds, lentils, wild marjoram, saffron, bastard saffron. ${ }^{1}$ Other products circulate only in the kingdom, as olive oil, of which they get a very small harvest, greenish, thick, and with not too good a taste; the best is from Coquimbo. Soap is made in quantities in Santiago, with tallow and lyes of espino, and aromo; from this tree they get an excellent wood and make very good soft coal that lasts in the fire pan up to 24 hours, and even two days if sheltered. Linen and hemp are produced in the province of Quillota, where they manufacure riggings, ropes, twine, and tow, all of which is supplied to vessels that come to Valparaiso. Other articles manufactured are baize, country bedspreads, and a coarse frieze.

In Chillán and other places they also make superior ponchos, woolen blankets, spreads, cotton blankets, rugs, and pellones [robes] make of skins for saddles, mats of wool to place as runners over rugs in the wintertime; they manufacture hundreds of them in Petorca. From the sugar cane that is cultivated in Quillota they make some honey, as also from the shoots of the coquito palms; it is very tasty and is called miel de cocos. There is a kind of reed that they use instead of cotton for wicks for candles; they give beautiful light, make little smoke, and can be snuffed with little

${ }^{1}$ Species of saffron; its seeds are used to fatten birds. Spanish ed. 
trouble. They last a little longer than those that have cotton wicks and do not give headaches; their light is bluish and, when they fall on the floor, they break into several pieces. The people say that the sosa or barrilla grows towards the coast, but I have been unable to find it. From the root of the liutu they manufacture an excellent flour, as I have already mentioned, which they call liutu flour; it is in demand in Lima and other places. They manufacture great quantities at Fort San Pedro and in all of that level country. In Chile they use a great deal of a drink called ulpu, that is made of one tablespoon of roasted corn flour, sugar, cinnamon, and of a huampar, or glass, of water. Many, when they do not have corn flour, use wheat, barley, or beans, and the Indians drink this without any dressing; bean flour taken with water is much appreciated in Chile as a sure remedy against distress.

The principal commerce from Peru to Chile is in sugar and some Castilian products, that is, from Europe.

The kingdom of Chile is unquestionably, as might be inferred from its benign climate, its products, and the character of the inhabitants, one of the most pleasant and enviable countries in the world. 


\section{CHAPTER XXXIII}

From Concepción into Chile-Reception in Talca-Arrival in Santiago-Plants observed during the trip-Kindness of the authorities and nobles-Ruiz becomes ill-Survey of the mercury mine of Coquimbo by Dombey-Earthquakes and floods.

\section{JOURNEY TO SANTIAGO DE CHILE}

After I had put in order and boxed the collection of dried plants, seeds, minerals, stones, and other natural products gathered in the bishopric of Concepción and I had made the preparations for a journey of 160 leagues, I left Concepción on the 19th of March, 1783 with the two draftsmen and a soldier who was given to us by Sr. Mre. de Campo Dn. Ambrosio O'Higgins to accompany us to Santiago. We passed the night in Penco el Viejo. Mr. Dombey and my companion, Dn. José Pavón, accompanied by another soldier, could not follow until the 31st because they had no horses.

On the 30th we spent the night in Potreros del Rey, territory belonging to the province of Cauquenes where, as we went, I gathered several plants. The following day we entered the province of Chillán, and we spent the night in a country house.

In April, 1783 we continued our trip in company of the muleteers, crossing the provinces of Chillan and Itata; their river we crossed in a raft, with the animals swimming, and we reached Talca, the capital of the province of Maule, where we stayed two days to rest the horses. In this beautiful town we were entertained very kindly by the corregidor and visited by the persons of the greatest distinction. From the province of Maule we passed to that of Colchagua; we spent the night in the town of San Fernando in the house of the corregidor, who was very obliging to us and showed us a vineyard near his house where he had put as fertilizer four thousand fanegas of wheat that had spoiled. From this province we entered that of Rancagua; in its capital we spent the night.

On the 15th, Holy Tuesday, we arrived in the city of Santiago without having had any mishaps on the whole trip, not even a shower. Without trouble we crossed the big rivers on the way from Concepción to Santiago; the roads are generally level, although there are a few hills, but so low that they cannot be called by that name.

On that whole road we could scarcely find any plants different from those already gathered in the provinces of Concepción, Cauquenes, Rere, and Puchacay, and the hill of Arauco. We could find only an abundance of small trees about six or seven yards in height, 
called espinos, that are a species of Mimosa (when in bloom it expels a wonderful perfume throughout all the fields), and the higarrobo or Mimosa in the province of Rancagua, which are not found in the above provinces. There are very few towns along this road, but there are large haciendas of grain and cattle of all kinds, with good and large country houses, where the owners receive travelers with the greatest readiness and good will, generously offering them even food, as happened to us in some places.

Having reached Santiago, the five of us went together to see Sr. Presidente Dn. Ambrosio Benavides, who received us very graciously and offered his assistance and his table any time that we wished to dine with his Lordship. The same offer was made to us by the Ilmo. Sr. Obispo Aldaz and the Sr. Regente of that Audiencia, Dn. Thomas Alvarez de Acevedo. All of these three officials gave us a day of entertainment, each one taking pains to place on the table the most delicious food of the country and the best liquors of the whole kingdom, and many from European countries.

Following the example of these three officials, all the nobility of Santiago paid us a visit and persisted in taking pains to feast us in their houses during the time that we stayed in that capital of the kingdom of Chile.

A few days after we reached Santiago, as a result of the trip and of my being overheated during botanizing, I contracted a kind of illness that they call chavalongo, which kept me in bed with fever twenty-five days and another twenty-five with a strong pain that settled in my right side and extended to my shoulder; it did not permit such bodily activity as coughing, sneezing, yawning, laughing, or any kind of work.

When I was at the worst stage of my sickness, the Sr. Regente resolved to send my companion Mr. Dombey to inspect the quicksilver mine of Coquimbo, which he did on the 21st of May. On this trip he wished to take with him one of the draftsmen, who did not go because I had asked but failed to receive some guarantee against the separation of the two individuals. Mr. Dombey left alone and returned in a few days with samples of the mineral from several mines, to make the desired tests of all of them. They revealed, as it was said then, that they yielded one ounce of quicksilver for every three pounds of metal; for this reason they sent the general superintendent of Lima two bags of ore, that M. Dombey left deposited in the royal customhouse, without hearing later the result of this transaction. The miners of Coquimbo assert that the 
mine did not pay in proportion to its expense; for this reason many of them suspended extraction as many times as they started it.

On the 25th of May, 1783, an earthquake of short duration although quite strong, was felt in Santiago.

On June 15th, 1783 at 10:30 in the morning, it began to rain heavily and continued to do so without cessation until 2 in the afternoon of the 17th; for this reason and because the snow of the cordillera started to melt, the rivers of the bishopric of Santiago overflowed so extensively that experts calculated that the losses suffered by the hacendados of this bishopric were more than two million silver pesos. The Mapocho river, that passes through Santiago, overflowed in such a manner that, after carrying away many ranches and several houses that were located on its banks, it entered the city of Santiago in two places, destroying the parapet above the hill of Santa Lucia and flooding many houses and convents of the district of the Cañada and the calle of Santo Domingo. A little farther down the bridge, it broke the parapets also and carried away an avenue of trees planted in the time of Sr. Guil and more than three hundred ranches and huts of the poor people; these unfortunate unhabitants were left without clothes, as we could see in the morning of the 17th when they were found, sheltered by the walls, many of them in shirts and covered with the mud that the river had left in the streets and houses where the confusion and crying continued the whole day.

The river carried away a great part of the stone bridge that served as communication between the city and the district of Chimla, when it destroyed, on that side also, the parapets and the convent of the Carmen Bajo, where the nuns climbed to the tower and rang the bells and signaled with their handkerchiefs. From the city three men on horseback crossed the rapid stream by swimming their horses and, entering over the walls of the orchard, took the nuns one by one on the croups of their horses to the convent of the Dominicans which was being finished in that same district. In the church of this convent, the waters reached more than a yard in height, and brought in a quantity of mud. The gardens, cells, and other rooms of the nuns were completely flooded and full of sand and clay for more than a yard and a half. The furniture and images that the nuns had in their rooms were entirely swept away by the river. The destruction of this convent was such that it could not be rebuilt for less than 100,000 silver pesos. In this district the beautiful house and orchard of one Dn. Luis Zañartu 
was also flooded; it had been made in front of the convent of Carmen, when that sumptuous convent was built by Tajamanes del Rio, at a cost of many thousand pesos for all these magnificent works that the Mapocho river destroyed in one day.

Many were the farms, orchards, and pastures that were flooded, and such was the terror caused by this flood that the people of the towns situated on the shore of these rivers went one and all in great confusion to seek shelter in the hills, as happened to the inhabitants and cattle of Carrizal, where the river carried away forty-five houses. Many odd things happened in several places in this flood; many persons were caught unawares and found themselves isolated and protected by the roofs of their ranches or houses, waiting for death from one moment to another; others climbed trees and held their own against the fury of the waters, and others took to swimming and found refuge in the near-by hills. We had information in Santiago that, in a ranch already surrounded by water, there was a man sick in bed, and when four men that went swimming to help him were very near to the ranch, the water carried the ranch and the man downstream. There was a cradle on the river with a nursing baby in it, and a man who was on the shore of the river, thinking that it was a bundle of clothes, had the good fortune to catch the baby by the clothes and to pull him out alive, after he had floated in the water for more than a quarter of a league. The parents that had followed the cradle a long distance had turned back heartbroken, without their child until the following day when they were informed of the deed.

The Mapocho river carried away the carriages of Srs. Guil and Guirior that were stored near the convent of Carmen. On the second and third days of the rain, there was much confusion in Santiago with the prayers, cries, and lamentations that were heard everywhere in the city.

After the rain had stopped a few hours later and the river had receded, by its shores and margins there were found several pieces of furniture and between them a small box with 260 pesos, a pair of silver spurs, rugs, pictures, and a San Juan de Bulto standing up unharmed with a glass chalice in his hands, and, hanging on a tree, a cart that lacked more than a yard and a half of touching the ground.

During our stay in Santiago we gathered and sketched several plants and completed and revised several descriptions. 


\section{CHAPTER XXXIV}

Location-Buildings - Monasteries - Inhabitants - Garrison - Provinces - Mines -Strange event.

\section{DESCRIPTION OF THE CITY OF SANTIAGO DE CHILE}

The city of Santiago is situated at $33^{\circ} 35^{\prime}$ latitude and $71^{\circ}$ longitude, at the foot of the hill of Santa Lucia and at a distance of about five leagues from the cordillera. It lies to the south of the Mapocho river, in a big and beautiful plain a little sloping and airy, with two large districts called the Cañadilla and the Chimba on the opposite side of the river, and at the south, at a distance of four blocks from the main square, with a street of about 50 yards in width and 1,800 yards in length called the Cañada. From east to west the city has thirteen similar squares and from north to south nine, with as many straight streets, in the center of which is located the plaza mayor, a square in size; the facade that faces the south is occupied by the palace of the president and the royal council; on the opposite side there are houses and shops with porticos; on that which faces the east are the cathedral and episcopal palace, and opposite these there are several individual residences.

The buildings, although generally only one story high, are spacious and beautiful with their flower gardens, most of which can be seen from the streets, and a big court at the entrance; they are constructed of lime and sun-baked bricks, stones, and tiles, and the bases, halls, and courts are painted with earths of different colors, which embellish them wonderfully. Some of the buildings have a second floor. The streets are paved. The houses all have drains of running water which are covered by the pavements of the streets and, although the atmosphere is clear most of the year and the sky beautiful, nevertheless in wintertime there rise from the river and drains dense fogs that cannot fail to be injurious to health.

In Santiago, there is a royal council, established in 1609 , composed of the president who is governor and captain general of the kingdom, of a regent and five judges, two attorney generals, a head constable and chancellor, a head auditor of the royal treasury, also royal coffers with an auditor and treasurer. The secular chapter is composed of the corregidor, two ordinary mayors, twelve aldermen, and other corresponding officers. The ecclesiastic chapter is composed of one bishop, five prebends, dean, archdeacon, precentor, teacher, and treasurer, four canons of Mercy, and three prebends of rations. A Roman architect was finishing a magnificent and sumptuous cathedral at the expense of the Illmo. Sr. Dn. Manuel de Alday, its very reverend bishop. 
There is a mint in which they coin from 700,000 to 800,000 pesas in gold and from 200,000 to 300,000 in silver. There is a university with the title San Phelipe, with 10 professorships, a seminary college for the creoles, and another of studies for the Indians in the college of San Pablo, that was a Jesuit institution. There are five regular orders; that of Mercy, which was the first to come to the kingdom to preach the gospel; and those of the Dominicans, Augustinians, Franciscans, and Joannites. Besides the principal convents, that of the Dominicans has a new convent in the Chimba and, at a short distance, the chapel of Our Lady of the Rosary, called de la Vida, very miraculous. The convent of Mercy has a school below the dale; that of the Augustinians has another one in the same place; and the convent of the Franciscans has a school in the division of San Diego, and a small convent called Monte Alverne outside the walls of the town, and a convent in the Chimba.

There are seven monasteries; two of Santa Clara, an old one founded for the nuns that found refuge from the cities destroyed during the general uprising of the Indians, and a new one, that of Concepcion, of the Augustinian order; two of Carmen, one in the city and another in the Cañadilla that are of the reformed discipline of Santa Teresa; one of the Capuchins and one of Nuestra Señora de Pastorina de Santa Rosa, Dominican.

There are a shelter house, houses of meditation, a foundling home, a chapel of Charity and another of San Lazaro. The Jesuits had three houses. The parishes, besides that of the cathedral with two priests, are those of Santa Ana, San Isidro, and San Borja.

In the district of the jurisdiction of the corregimiento of this city, the parish of Tango is situated. The parish of Nuñoa, with four sub-parishes, that of Colina with four, that of Renca with four. In the church of Renca, they worship the miraculous image of Santo Cristo del Espino.

The number of inhabitants of all races amounts today to about 34,000 ; among them there are many illustrious families and some descendants of the first conquerors. The number of Indians is very small. The majority are Spaniards and creoles. They are of good height, of fine appearance, well educated, serious in their dealings and business, and gentlemen in their bearing and manners. The feminine sex is beautiful, clean, affable, and obliging, and generally very devoted to music, so that one can scarcely find a young lady who cannot play some kind of instrument, and there are many able to play three or four instruments rather well; and at the same time they sing music taught by teachers, as they are fond of this honest and pleasing diversion.

All the natives of Chile are usually generous towards strangers and the helpless. They gather in groups for popular diversions and picnics, going to these in covered carts with cushions and carrying various musical instruments.

There is a company of dragoons and the splendid regiment of mounted militia that I saw arrayed on the plaza mayor where they made their evolutions with great skill during the three days of Easter. 
The bishopric of Santiago comprises the eleven following provinces: Copiapó, Coquimbo, Aconcagua, Quillota, Valparaiso, Melipilla, Santiago, Rancagua, Colchagua, Maule, and Cuyo, in all of which all kinds of grains are produced and many kinds of natural products and, especially, the following minerals are found.

In the corregimiento of Maule in the hill called the Chivato, there are three gold mines in the same run, two of which yield twenty-five to thirty pesos per box of ore and the third from fifty to eighty pesos. This gold is twenty carats and two grains pure. From a mine owned by Dn. Ignacio Zapata they had taken 100,000 pesos, but because a spring had been struck in the depths of the mine, that was about a hundred estados deep, the mine filled to the top with water, and Zapata lost nearly 200,000 pesos worth of metal that had already been prepared but could not be gotten out on account of the condition of the ground. In this same corregimiento, in the hill called Loma Blanca, there are other gold mines that give seventy to eighty pesos per box of ore; it is fourteen, fifteen, and sixteen carats pure. In this same mine they discovered a rich vein that was called the Mulamuerta that gave 16,000 pesos in only two boxes of ore, each box of ore comprising twenty loads of fourteen arrobas each.

In the corregimiento of Colchagua or San Fernando, there are several mines, the best known being in the town of Nancagua; between these are the ones called Cocinilla and Millague, which give 100 pesos per box, and their gold is of eighteen to twenty carats in purity. In the same hill there is another mine called Descubrimiento de las Catas; the purity of its ore is of about seventeen carats. There are several other mines in this corregimiento, but they are of little value.

In the corregimiento of Rancagua or Santa Cruz de Triana, a mine is being worked that is called Alhue (meaning the Devil) where there are many nuggets of gold of from thirteen to twenty-one carats and two grains. There is another mine called the Alto de las Salinas, from which, when it was discovered, they took many thousands in gold of eighteen to nineteen carats. It yielded from twenty to three hundred and even six hundred pesos per box of ore; it is worked by Manuel Benegas. In this corregimiento there are also the silver mines called San Pedro Nolasco and San Simon; they were worked by Dn. Agustín Castillo, Dn. Manuel Mena, Dn. Miguel Fernández Quintano, Dn. José Palma, and Dn. Agustín Tapia. These ores yield from twenty to forty marks 11 mark equals 8 ounces] of about eleven dineros [ 1 dinero equals 24 grains] and two grains per box of ore. In the same corregimiento, in the hills called the Potreros, that had belonged to the Church, Dn. Xavier Palacios works some mines of copper mixed with silver of which it is not known, or they have not figured out, how much it yields per box, but it is known that he has sold ore in Santiago at 150 pesos per quintal [a hundredweight].

In the corregimiento of Santiago de Chile there are the gold mines called Tiltil and the Guindo, Chicauma, Lampa, Caren, the Manzano, Membrillejo, and Durazno. The gold is twenty to twenty-one carats and two grains pure. These mines produce sufficient to pay their cost. The gold of the Durazno is of thirteen carats in purity, or in small lots of trabajo acido without fixed purity: at intervals they find gold but, as there is much [sic], it is worked with difficulty. In the district of Tiltil there are copper mines that do not go deeper than sixteen to 
twenty fathoms; they yield about sixteen or eighteen quintals per box; it is superior copper for working, but not so good for smelting.

In the corregimiento of Quillota are situated the mines called La Dormida, from which they extracted more than 100,000 pesos; although these riches are gone, some is still being extracted. This gold was found to have a purity of twenty-three carats and three grains. In the same place you find the mine washers of Culiguay, where they extract much gold of twenty-one to twenty-three carats in purity. In this same corregimiento is situated the mine called La Ligua that has been very rich but is on the decline today. Its gold is of twenty-two carats. In the same ore there is an old mine called Mazon that yielded from four to six thousand dollars per box of ore; today that mine is tumbled down, and it yields its owners only enough to pay its cost. In the hill of Petorca there is a copper mine called La Corrida; it yields from five hundred to one thousand pesos per box of mineral and, when it is low-grade, it yields two hundred dollars; year in and year out it yields 100,000 pesos; its purity is of seventeen to nineteen carats; it is worked by Dn. Antonio Muxa, Dn. José Sepulveda, and Dn. Francisco Larrañaga.

In this same district there is a mine that is called the Arcaya, owned by Dn. Martín Brito. The workings of this mine are very deep; an Indian laborer, having found a rich vein in the mine's depths in 1780 , covered it up with the idea of stealing its metal, and for this purpose he called eight of his companions and at night they went to get metal. The first to go down to get a sample was the Indian who discovered it and, when he went to load the quipe, there came to him a terrible apparition without hair; however, the Indian came up with the metal, but he was so frightened that he could scarcely speak. He told his companions what had happened, but they did not believe his tale, and six of them decided to go down into the mine with the Indian; the two that had been left behind, noting that the other seven had been in the mine a long time, decided also to go down themselves to see why they did not come up, and a few steps inside they found one man lying on the ground. Thinking that he was asleep, they passed on and shortly found another man stretched out and when they found that he was dead, they returned to inspect the first one and found him also dead. This made them go to the town to notify the authorities, who came with more people; going down into the mine, they found all the men dead, long before they had reached the place where the vein was. The people attributed this natural accident, doubtless caused by gas in the mine, to a punishment from above for the theft the men were about to commit. One of the two peons that had been saved from the tragedy was an apostate from the religion of the Santo Domingo de Santiago de Chile and, frightened by what had happened, he resolved to return to his convent, but in the neighborhood of Renca he died suddenly. The owners of this mine asserted that it is very difficult 
for them to find people to work in the mine on account of the depth and the continuous, terrifying noises always heard there. By the way, we will say here that offenders, and other like them, go as mine workers and as crafty people, even though occasionally there are some good ones among them, and they prefer to work for half wages in a rich mine rather than for whole or double wages in a poor one. This is because they are possessed with the idea that they can take the metal of the guia for their own without any scruple, as they say that the proprietor is the owner of the vein only because of the custom of naming only him in the petition and title that must be obtained to work it. For this reason, most of the peons steal the best metal from their owners, and therefore the father-confessors have to go to the mine owners to find out if they forgive them their thefts, so as to be able to absolve these dissolute people; they have little or no respect for their employer and less for the judges, because when pursued by them, they get together and with stones keep them out of the mine, which they use as a parapet and shelter for their wickedness and insolence.

There is another gold mine in Petorea, called Old Yerro, which yields little gold but of a quality superior to that of any of those that have already been mentioned in this corregimiento. There is another mine is the province of Quillota, called Illapel, in which there are many workings close together and others quite a distance apart. This mine and the one at Petorca are the richest in the kingdom, or they yield more gold, that at Illapel exceeding in purity that of Petorca, as the gold is twenty twenty-two and a half carats pure. There is another gold mine between Petorca and Illapel, called the Pupio; its gold is of twenty-two carats, but the ore is not plentiful. Finally, in Quillota there is a mine called Las Bacas, near Illapel; it is filled with water which they remove with a windlass and with much work. It yields a pound of gold per box, of a purity of twenty-one grains and of an excellent color.

In the corregimiento of Aconcagua they have discovered some silver mines that ancient people worked for copper, and this metal was brought in quantities to Spain. As the copper became exhausted and it began yielding silver, the miners abandoned it because they did not know how to extract the ore until the mining was resumed with modern methods. It yields from twenty-five to thirty marks per box of picked or double guia; it is silver of high purity. In this valley the copper mines have declined very much because most people have devoted themselves to the mining of silver. The corregidor of this district cannot live from the proceeds of visiting the mines, like the one of Quillota; he draws 1,600 to 2,000 pesos a year from those visits, each mine paying six pesos, and in that 
way he can meet his expenses with the taxes he takes in wheat at harvest time, conveying it later to be sold at the port of Valparaiso.

In the corregimiento of Coquimbo, there is the Talca mine, that yielded a pound of gold per box and up to six hundred pesos from the picked mineral or guia. Today, this mine is on the decline, and is worked only by pirqueñeros, or peons without masters, because the later can get no profit from it. Two rows of houses and ranches have been abandoned at this mine by their owners who, on account of the decline in ore, have gone to another place with their business. This gold is twenty carats and two grains pure. At a distance of twelve leagues from Talca there is another mine called the Amolanas, which is in the same state of decline as the mine of Talca; about the year 1750 this mine was very rich, and the gold was of twenty-one carats. There is another mine in Chillamahuida that is being worked, and there they get gold of twenty-two carats and two grains. This gold can never be worked because it is so friable that it turns into small flakes. In the valley of Limari there is situated the copper mine that was worked by Dn. José Guerrero with the aid of Indians and other neighbors of Coquimbo. In the years 1778 and 1780 there were discovered in this neighborhood some silver mines that promised riches on the surface, but nothing was realized through digging, so that work was suspended. Near this valley there is a hill called Andacollo; on its slope or brow is situated the chapel of Our Lady of Andacollo, whose image is greatly venerated and miraculous. On the hill there are gold mines that are worked although they are of low grade. There are also quicksilver mines in the same hill, which, for lack of encouragement, are not worked. On May 21st of this year, 1783, my companion Mr. Dombey went on a commission to survey and inspect this mine and to assay the metal. Finally, between Coquimbo and Copiapó there is another gold mine called Quebrada Onda which has had its ups and downs; today it yields a pound of gold per box of ore, of a purity of twentyone carats and a half.

The corregimiento of Copiapó, the last town of the kingdom of Chile and where begins what is called the despoblado [uninhabited region], reaching to Peru, has an open mine where they work ores of gold, silver, and copper. The gold, which is of the kind they call capote, is of twenty-two carats and two grains. In 1772 and successive years they discovered the silver mines, and because careful administrators had come from Peru, they got much pina silver, but this work has declined. With the instructions that the natives have 
had from the miners from Peru, they are discovering several mines towards the cordillera one of which, worked by Dn. Francisco Vercasacin, is on top of the earth; its metals are very rich, and it was expected that it would soon produce silver in bars. Between the Quebrada Onda and Copiapó, there is a valley called the Huasco, where they work many copper mines, and all of this metal regularly goes to Spain; the best mines are the Cortes and the Corbalan. These mines also extend towards the cordillera, where they find the ore called tarilla, of the same metal, worked by Dn. Jacinto Perez. Besides the minerals already referred to, there are others of little value throughout the kingdom, and it can be said that all of it is ore of gold, silver, copper, etc. From one year to another from 14,000 to 16,000 quintals of copper are exported from the kingdom of Chile a quantity much less than that stated by Padre Molina on page 100 of his Compendium of the History of the Kingdom of Chile.

Since my daily accounts for the period of three years, among which were those from Chile, were burned in the fire at Macora, it has been impossible for me to insert in this place the descriptions of each one of the provinces of this kingdom, which I wrote out at length during my stay there; consequently it has been very difficult to describe in detail the natural products that I saw and about which I had information that they could be found in such or such a district. But anyone interested will find many of them in the descriptions of Padre Molina. ${ }^{1}$

${ }^{1}$ Historia geográfica natural y civil del reino de Chile. Madrid, 1788, 95. 


\section{CHAPTER XXXV}

Itinerary-Plants gathered-Arrival at Callao-Stay in Lima-Material shipped in the "San Pedro de Alcantara."

\section{FROM SANTIAGO TO VALPARAISO}

On October 5th, 1783 the five of us left Santiago and, without incident, we went to spend the night at a distance of three leagues, on the shore of the Mapocho river; we passed through the provinces of Aconcagua and Quillota and reached Valparaiso on the 9th; we stayed there until the 14th, waiting for the departure of the native vessel called "Nuestra Señora de las Mercedes," which set sail at 2:30 P.M. on the fifteenth with a favorable wind.

On the way from Santiago to Valparaiso and in the vicinity of the port, I gathered several plants and described the following. Suriana apetala. Aristolochia vaginans; its leaves expel a fetid odor similar to that of the zorrino, and its flowers emit a still more nauseous one. Lobelia purpurea, tupa. Helianthus resinosus, maravillas; in Coquimbo, arbol del incienso, because there they gather its resin that is used in churches instead of incense. Stachys hastata, male salvia; they make the same use of these salvias as do the Spaniards. Fuchsia rosea. Polygala tricolor. Eupatorium salvifolium, barbas de viejo [old man's beard]. Schinus procera, molle de Chile.

We arrived at the port of Callao on the 3rd of November, 1783 at night, and in the morning of the 4 th we dropped anchor at the anchoring-ground, without having experienced any other inconvenience during our trip than the poor and scanty food served to us by the captain of the vessel, but seasoned with jokes and witty stories. We could not put our baggage ashore until the 6th because of holidays. That same day we went to Lima, and we deposited the boxes in the customhouse; from there they were brought to the vessel "San Pedro de Alcántara," in which we were ordered to return to Spain.

We stayed in Lima, waiting for the departure of the "San Pedro de Alcantara" until the month of April, 1784, and during this time $I$ put in order various plants that I had brought from Chile in leather hampers and had packed with many other products for safe transportation. I finished some descriptions and copied them all in two folio volumes that were sent by mail to the Minister of the Indies, Sr. Visitador Don Jorge Escobedo. I put names on the drawings and made a list of all of them. And finally I surveyed 
anew the hills and fields of Lima to gather and describe the new plants that the season exhibited to view. I described the Psoralea americana and Theobroma Cacao.

After all of our baggage and the necessities for the voyage and return to Spain had been prepared, there came a royal order for us to continue our work through the montañas of Tarma, Huánuco, and Cuchero; for this reason we had to provide ourselves anew with necessary equipment like that which we had sold at a bargain a few days before.

Complying with the royal order, we shipped in the vessel "San Pedro Alcántara," 55 boxes of dried plants, ores of gold and silver, animals, birds, dried fishes, shells, stones, soils, and other curious natural products and instruments and Indian clothing; also 800 sketches of plants painted in their natural colors, and 6 heated cases with 33 pots of plants of valuable trees of Peru and Chile which had been cared for by an intelligent young man for 50 pesos that were given to him in Lima for his work. 


\section{CHAPTER XXXVI}

Departure from Lima-Plants gathered in Yaso-Tiresome march-Illness of Ruiz.

\section{FROM LIMA TO THE MONTAÑAS OF HUÁNUCO}

Because of the voyage we had made to Chile, the disadvantageous sale that we had made of the outfit we had for traveling by land, and the expenses caused by the preparations for our voyage back to Spain, we were left without the means required for new excursions; for this reason we informed the Sr. Superintendente of the impossibility of our undertaking it. This minister, after having taken our statement under consideration, offered to make it known to His Majesty so that our pay might be increased; in the mean time he ordered that a year's salary be given us in advance. By this we benefited during our travels and were able to provide ourselves with the most important equipment, I, for my part, spending 1,004 silver pesos.

Provided with the most necessary items, I left Lima with my companion Dn. José Pavon on the 12th of May, 1784 at 12:30 P.M., and we spent the night in a field two leagues distant from the capital, without any other incident than experiencing two earthquakes, one at eight o'clock at night and the other at daybreak of the 13th. On this day we went to Yangas, where I described four new plants. On the 14th we traveled a league and spent the night in a country house, where I described three plants. During the afternoon I felt a disturbance of the pulse. On the 15th we went to spend the night near the pueblo of Yaso, where I described five species of Cactus: squamatus, lanatus, erinaceus, echinatus, and cancelatus. Oxalis, okas. Mimosa spicata. Hedysarum mimosioideum. Hydrolea urens. Clematis Vitalba? The fever continued to increase, as did the headache. On the 16th we went to Carrizal, where we spent the night in the open and I felt worse than on previous days. On the 17th we arrived at San Buenaventura, the capital of the province of Canta, where we stayed one day to rest the animals and to see if, with some rest, I could feel better, but I was stricken with a strong pain in the right side that did not permit me to carry on some of the-natural bodily activities, such as coughing, yawning, sneezing, laughing, and changing to certain positions.

On the 19th, in spite of the insistence of the corregidor that I move to his house and stay there until I recovered from my illness, we left at noon and went to pass the night in the pueblo of Culluay, where I felt quite weak. On the 20th, although overcome by sickness, 
we climbed the cordillera; in the middle of this climb we had to spend the night on the snow because the mules had become tired out when we climbed the Cerro de la Viuda, and darkness overtook us there. I thought I was going to die in that uninhabited place for lack of some warm nourishment and on account of the cold I suffered during the night. I was attacked by a terrible griping and thirst, and we had to break the ice to drink water. They had to put me on horseback on the 21st because I had not the strength to do it by myself, and we went to spend the night at the rancho of Palcamayo, where we had a sleet storm of more than two inches. On the 22nd we went to Diezmo, where I felt a little relieved of the pain in my side. On the 23rd we came to the town of Pasco, where we stayed until the 27 th in order that I might keep to my bed for a few days and be able to continue our journey, as we did on that day, going to Caxamarquilla where, with the benefit of a good lettuce salad and the apples that I had eaten in Pasco, I felt much better. We reached Huariaca on the 28th, and there I repeated the salad and felt much relieved. On the 29 th we left this town, and at a distance of half a league a load with two of my companion's cases fell into the river, but we fished them out and put all that they contained in the sun and succeeded in drying everything that day. On the 30th we went to the pueblo of Rondos, where I felt quite feverish on account of my exposure to the sun the day before. On the 31st we went down to the asiento of Ambo, where I arrived sore and almost without strength to keep myself on my feet. The following day, the 1st of July, 1784, my companion found himself without his muleteer, who had fled with the mules, afraid that several debts he had in Huánuco would land him in jail; finally they furnished us with mules, and we reached Huánuco, where I spent a few days in bed and succeeded in recovering my health.

The draftsmen Brunete and Gálvez came to Huánuco on the fourth day after our arrival without having had any special mishap on the way.

We all rested from our trip and, since I had recovered from my illness, we acquired the provisions necessary for the three months that we decided to spend in the montañas of Puzuzo, forty-five leagues distant from Huanuco, after we had been informed of the fertility of that place bordering the territory of the Carapacho Indians. On the 5th of July we sent two men with fifty sheep for our maintenance. 


\section{CHAPTER XXXVII}

Departure from Huánuco-Itinerary, and plants found-Hardships-Arrival in Puzuzo-Work done by the botanists.

\section{JOURNEY TO THE MONTAÑAS OF PUZUZO}

At noon on the 8th of July of 1784 I was able to leave Huánuco with twenty-one loads of food, presses, papers, books, and other necessary equipment for my use and that of the expedition. I camped about two leagues from Huánuco, near the town of Valle. On the 9 th I spent the night at Tambillo, eight leagues distant from Huánuco, where I described Ambrosia Marco, which some Indians apply under the saddle pad of the horses to prevent their fatigue, Cestrum rigidum, and a species of Rhexia, cachigusi, a plant used for a yellow dye. In this place, among many other plants, Psoralea glandulosa is found in abundance. On the 10th I passed the pueblo of Panao, where I stayed one day, the 11th, to change mules and then continued my trip. This same day my companion Dn. José Pavón left Huánuco. In Panao I gathered several plants and corrected some descriptions. I described Ornithogalum compressifolium, Perdicium lanatum, and Psoralea datesa?

I left Panao on the 12th with fifteen Indians to conduct the loaded mules through the declivities and dangerous places. I spent the night in the pueblo of Chaclla, situated in a beautiful elevated plain with a cold climate and abundant pastures, three leagues from the river. On the 13th I left this first pueblo, accompanied by an Apostolic Missionary father from Ocopa, and went to pass the night in a place called Llamapañahui, where I examined Smilax China which I had found a league back, and I described the beautiful Dalechampia rosea. This day I gathered many and special plants, notwithstanding the difficulty of the way, especially at the Cuerno Retorcido and Torre sin Agua. Before reaching the Cuerno Retorcido, we found a silver mine which a miner had abandoned because he had no money to work it. On the 14 th we went to the pueblo of Muña, accompanied also by the missionaries of Ocopa, after having crossed the quebrada and river of Santo Domingo and the steep hill of this same name. On this side the climb is painful and dangerous, including some forty long and excessively steep turns; on the opposite side, however, it is more gradual and not really dangerous. We crossed another brook and began the ascent to the pueblo of Muña by another hill no less difficult and dangerous than the last one, 
particularly the Ladera de la Colmilla, where the narrowness and elevation above the river make one shudder when crossing.

On the 15th we left Muña, and we passed the night three leagues from there in a small clearing called Tambo Nuevo which, although cold and filled with water by the frequent showers that fall there almost daily, so abounds with ichu that the muleteers stopped, in spite of the dense and damp fog, to let the animals graze on that grass and rest, so as to be able to continue the ascent of this elevated hill, for at the summit there are no trees nor any other larger plants except a species of Stereoxylon corymbosum, known there by the name of suiba. These small trees grow to be eight or ten yards tall; their trunk and branches are so covered with black mosses and lichens that they appear like trees singed and clad in mourning. They have the property of burning so badly and emitting so much smoke that no one can get warm by their fire or endure the nuisance of the dense smoke. Among the smaller plants, there is an abundance of two species of Ranunculus with a beautiful pink flower and another with green flowers, the Swertia corniculata, two Gentiana, one Hedyotis, and two Syngenesias. I felt indisposed and had such distress that I could hardly continue the trip next day, the 16th, but it was necessary to go on a league and a half where, on account of the grass and the continuous showers, we had to stop at the side of a field somewhat sheltered from the cold that was felt in those heights. Although we made six big fires, we spent a very cold night with great inconvenience on account of the dense smoke formed by the wood of the suiba, after having crossed the Portachuelo in the snow and sleet that are very frequent the greater part of the year though they do not turn into ice. From this summit one can see a multitude of peaks of the cordillera of the Andes all covered with snow, and a great expanse of hills and mountains covered with trees and plants that extend to the pampas of the Sacramento. On the 17th we left this sheltered place, harassed by the cold, wind, and smoke, and by an immense number of white mosquitoes called huahuaches, which can hardly be seen on account of their small size; their bite, however, can be felt a great deal, as is the insupportable irritation which lasts for more than an hour, without leaving a wheal or any other mark. We slept in a place called the playa [shore], where we were wet most of the night from a shower that did not stop until after midnight. Here the muleteers had to go to the woods to look for carrizo to feed the animals. On the 18 th we went to the place they call the Tramo, where I felt much better from the stomach pains 
and the distress that had hindered me from picking many more plants than the ones I gathered in these delightful woods. Next day I arrived in Puzuzo at the time the bells were being rung by order of the missionary, who was in that remote place to administer spiritual nourishment to the fourteen families of which the pueblo is composed. Three leagues from Puzuzo there are salt-water springs that are sufficient to salt the waters of the river and make it unpleasant to the taste. On the 20th I put my luggage in order and prepared everything necessary to begin work.

My companion Pavón arrived on the 21st, and the two draftsmen Gálvez and Brunete on the 22nd, without having experienced any other inconveniences than such as I had suffered.

We started work on the 23rd that continued until the 20th of September, when the draftsmen left Puzuzo to go to Huánuco, which neither my companion nor I could do until the 27th, when the muleteers arrived with mules for both of us.

During our stay in Puzuzo, I described 403 plants and corrected descriptions of some 250 of those gathered in Cuchero, Chinchao, and other places. About 300 plants were sketched, and I dried 314. We gathered many seeds and several species of woods and other odd native things. The fear of the jaguars, bears, wild hogs, tapirs, and other animals that are found in the luxuriance and denseness of those forests, and the difficulty of traveling through those fertile montañas made it impossible for us to examine a great number of very tall trees, reeds, palms, and beautiful plants with which those low and high hills, ravines, springs, and margins of the river are entirely covered. Although we had to walk on foot and scrape ourselves to pass, we went as far as the Huancabamba river that joins the Puzuzo river two leagues below this town, the two forming quite a large river.

There were days when we walked on foot through those forests four, five, six, seven, and eight leagues and returned at night to the town all in tatters caused by branches and thorns, and thirsty, out of breath, and exhausted, but loaded with beautiful plants. Many times we were saved from death from the sudden fall of some old trees and from landslides of rocks and of soil that followed the fall, especially if it had rained, and at other times from the resulting havoc caused by the fall of the trees that our peons felled for us to examine. We botanists worked so hard here that we left Puzuzo practically naked and with our legs and thighs flayed on account of eruptions and itch that followed after any walk in those woods. 


\section{CHAPTER XXXVIII}

Location of Puzuzo-Lack of pastures-The river-Particles of gold-Harshness of the water and its effects-Inhabitants-Vegetable products-CommerceClimate-Fauna-Bridges-Harmful insects-Plants.

\section{DESCRIPTION OF THE PUEBLO OF PUZUZO}

This last Spanish pueblo is situated in a deep ravine which is at most four to eight blocks in width in some places. It is surrounded by high and continuous hills entirely covered by large and spreading trees, reeds, or twining plants, shrubs, bushes, and herbs. There is no grass for the animals to graze, and for this reason the fifty sheep that we brought for our food, became so thin in a few days that, after they were skinned, they were as transparent as parchment; several died from the pizguin, a little animal or fluke, of the shape of a watermelon seed, that consumes the liver. This ravine is bathed by a river which is formed by the water that descends from the Portachuelo of Muña and the following hills, cascades, and several salt-water springs that are found at its margins. The bed of this river is of big rocks and sand with clay. In its water there are lisas, cachuelos, and boconcitos of from two to three pounds. All these fish have a delicious flavor.

In the sand and soil there are also found small particles of gold; we gathered some of them one day when we took some soil from the bank to wash.

Three leagues from Puzuzo the quebrada begins to widen and, a little more than a league below, it narrows again in such a way that there is no more space than is occupied by the river. Because of its depth this river cannot be used for the irrigation of the small plantations that the inhabitants have, and they use the water of some springs which, wherever it passes, leaves stalactites or lumps of white lime of various shapes.

They drink daily of this water, and for this reason they are so sickly and swollen and have such bad color. The natural laziness of these Indians keeps them from using the water of a rivulet called Chinizo, which is a quarter of a league from the town; from this place we had it brought to us for our own consumption, because it was sweet, clear, and without a sign of containing the least trace of gypsum, alum, or other earths or salts. The advice we gave them, not to drink that limewater on account of its harmfulness, was of very little use to the Indians, and only the missionary father 
sent with a little more frequency than before for the water of Chinizo for his use.

The pueblo of Puzuzo is reduced to fifteen small huts, one church, the house of the missionary father which they call the convent, and a hut for the traders that are in the habit of coming to this miserable town.

There are only fourteen men in this pueblo today, miserable because of their poverty and bad nourishment. They are small and ugly-faced. They use trousers and jacket with a shirt made of tucuyo, and they go barefoot. The women, whose appearance is even worse, wear aprons and skirt and also go barefoot. They love chicha and Venus.

There is not a valley or a meadow in that whole vicinity; for this reason the Indians have a few clearings on the mountain slopes and river banks for cassava, sweet potatoes, ssagui, corn, and mountain beans, the daily food of these poor people. The rice that sometimes is planted by the missionary is very welcome, as are also the peanuts and sugar cane which they eat as sweets. In their clearings they also plant a Diadelphia that they call berbasco, and it is used in fishing. Without cultivation they have anonas, caimitos, guavas, sweet and bitter oranges, and limes, and lemons; these trees and the place where they are found indicate that there was a large town in ancient times and that its founders or inhabitants were more industrious than the present people. There are other wild fruits that they eat with appetite, such as a species of Spondias which they call manzanas de monte [mountain apples], and the species of Celtis that they call atpuallin. Pineapples, bananas, and papaws are found at the side of the plantations and are the fruits that they use most. The only article of commerce they have is coca, which they exchange with the traders that come there, for corn, cakes, woolens, cotton goods, tucuyo, belts, beads, and other trifles, with which they dress and adorn themselves on festival days and when they get drunk from chicha made from corn. The men as well as the women are much given to the use of coca, which they keep in their mouths continuously; for this reason their mouths are always green and filthy. They also eat the shoots of the chonta and other palms and as many animals and birds as they can hunt with arrows or gun.

These Indians are so lazy and slack that if the missionary father did not make them plant and cultivate the soil for the few products that have already been referred to, they would live very happily 
like savages and would go naked like the other barbaric Indians of the Carapacha tribe.

The climate is very hot and damp all year round so that one perspires to excess. The heat is tempered by the north wind that blows from eleven in the morning until nightfall; without this relief one could not go out of doors at this time in places bare of trees. Storms and showers are very frequent, but we noticed no thunder. It rains to excess during the months of December to April and sometimes also in November and May; for this reason the place is not very healthy.

These Indians can give no account of the diseases that are common there; but it can be seen that they suffer continuous pains in the whole body, that they are covered with purulent pimples, that they lose their color, that they have little strength and are short-lived. They treat themselves with herbs.

In the woods there are found tigers [jaguars], leoncillos [pumas?], osos [bears], javalies [peccaries], gran bestias [tapirs], saginos, osos ormigueros [anteaters], guamataros, michus, mucamucas, [opossums), and huaihuas [coatis]. The most common birds found there are pichicapapanes, no vengas aqui, yasefue, woodpeckers, hummingbirds, pajaros hediendos, pajaros de siete colores, quianquianes, fandangueros, and some very small ones with beautiful song, such as the organists, papamoscas, and oropendolas. There also can be seen one or other aquatic bird and some herons. Mosquitoes are very rare and cause little trouble. There are no reptiles or insects other than a variety of small ants, but the bite of one that is found in the palo santo is insufferable, and its smart lasts for several hours. There are a number of butterflies of beautiful colors. There is also a species of bee, the honey and wax of which are very good; it makes its honeycomb in the trunks of trees or on the ground.

The Puzuzo river has two bridges made of reeds, one at one side of the pueblo and the other two leagues farther down, where it joins the Huancabamba river. The way to the Mayro is by this bridge, but it is usually out of order as it is used only when the missionary fathers pass over it for the conversion of the pagans. At one side of this bridge grows a multitude of palms of several species, such as the chonta? wild chonta, camona, cuyol, sia-sia, and palmitos, on the fruits of which many wild animals feed. This is one of the most beautiful places in this quebrada.

About three leagues from Puzuzo, there are several coca plantings of poor people who are persecuted for debts by justices, priests, and 
the worthies of the pueblo where they leave their families abandoned for many years.

Among the plants that I described while we remained in Puzuzo are the following: Spigelia Anthelmia. Sanchezia ovata. Pitrex unguiculatum. Bixa muricata, maxpachin and wild achote; the natives use its seeds to dye various things and to color food, as they do also with Bixa Orellana. Paullinia pinnata, rubicaulis, gracilis, obliqua, lacticinosa, hirsuta and rubra, all of these species being climbers. Ficus gemina, hirsuta, retusa? L. Gesneria violacea, hirta, viscosa, and verticillata. Ruellia bicolor, coccinea, maculata, punicea, and violacea. Hamelia secunda. Gardenia longiflora, iscumnim; the corolla is eight to nine inches in length, and white; the Indians eat the sweet pulp of their ripe fruits that are three inches in length, cylindric in shape, and yellow. Banisteria papilionia, auriculata, and flabelliformis, climbing plants. Aralia aff. trinervis. Foveolaria cordata. Clitoria? pubescens. Cerdana alliodora, garlic tree, on account of the odor of its leaves and bark, which are used by the Indians as a condiment. On this tree small ants gather, the bite of which produces a wheal that lasts from sixteen to twenty hours, with considerable sting at first but subsiding later. These insects totally destroy the leaves of the Cerdana and, cutting them into triangular pieces like deitas, they carry them to their anthills, where they store them in a peculiar, symmetrical way one on top of the others, without wasting space. To convey these uniform fragments of the leaves to their nests, they hold them by the shortest side and pushing the longest upward and the other forward, they carry them as if they were small boats with lateen sails swaying with the wind, with the greatest speed although the small piece of leaf is six times bigger than the ant. There are so many ants busy in this exercise all day that they have made a path about eight inches in width. They call them tragineras [porters], on account of their ceaseless activity. Having inspected some anthills, I have at times found more than two arrobas of the fragments of the leaves beautifully arranged. Cinchona grandiflora, azucena. Cinchona rosea, asmonich. With the leaves of these trees the ants make the same havoc, and for this reason-one occasionally finds on these two trees only one or two branches with whole leaves. The bark of both species is a little bitter. The Indian women decorate images with bunches of flowers of asmonich. Tabernaemontana corymbosa, a tall tree that abounds in resin that is white when it first exudes and later turns red; the milk that springs from these trees when they are cut is so 
abundant that it stains the ground. Bletia catenulata and ensiformis. Peperomia alata, septemnervis, pilosa, dependens, and emarginata. Cecropia canescens, tacuna, a tall, beautiful tree, the jointed and hollow trunk of which sometimes contains, from joint to joint, a clear, drinkable water without any taste, and the Indians, when in the mountains and unable to find water, quench their thirst with it. Coussapoa radicans, chichillica, a tall tree; from its trunk roots are produced that descend and push into the ground or twist themselves about other tree trunks in the vicinity. From its flexible bark the Indians make fishing nets, and pouches in which they gather coca or other products to carry home, and several other implements; they also make rope, and finally they tie and hold together the timbers of their houses with them. Passiflora Vespertilio, vesicularis, serrata, and rubra. Pothos apetala, sagitatto-cordata, geniculata, laciniata, and umbellata. Arum auritum L., lanceolatum, lineatum, parviflorum, tripartitum, and volubile. Calla nuda, remedy against snakes, because of the virtue attributed to the roots against snake bites. Calla bracteata, pinnata, radicans, and undulata. Clarisia racemosa, tulpay. Clarisia biflora, yasmich. A thickstemmed and very tall tree, with beautiful wood, from which there is obtained by incision an abundance of white resin that exposed to the air becomes gray and has some elasticity. This resin is excellent for waterproofing, and the Indians cover their blowpipes with it. An incision made in any part of these trees brings forth so great a quantity of milk that it covers the ground and curdles into resin. The bark of the tulpay is of a bloody color and brighter; the bark of the roots that extend horizontally shows through in many places so red that it looks as if blood had been spilled there. Capsicum frutescens L., arnaucho, and pubescens, rocobo; both species very abundant in Peru. Solanum grandiflorum, mite. Betula acuminata. Myristica longifolia, arbol del sebo. From the seeds a fat like tallow is pressed out; for this reason they have given it that name. This precious tallow with no bad odor or perceptible taste, but only oily and smooth, is used by the Indians for light. To obtain this oil, they pound the seed very well and press it hot between two stones. Myroxylon peruiferum, quino-quino, a very tall, leafy tree, with a large trunk, straight, smooth, and ash-colored outside as are all its branches. The bark is of a straw color, white on the inside; according to the greater or smaller quantity of resin with which it is permeated, it is more or less grainy and heavy and sometimes has a greenish color, at other times a yellow, and at others a dark brown. It has 
an odor and a taste quite similar to the balsamo rubio peruviano, that, under the name of white balsam, is sold in stores and pharmacies. Many persons in Peru call this resin estoraque [storax], and they use it to perfume their rooms, as they also do with the fruits which, powdered together with the bark, they mix with tallow or resins and apply in plasters to relieve headaches. The freshly crushed leaves heal new wounds as do the balsam and bark, known as admirable balsams and vulneraries. From the fruit of the quinoquino, called quina-quina, they make the oil of the same name. They take four ounces of well mashed fruits and soak them in a pint of wine for twenty-four hours, after which they boil them over a low fire with a pound and a half of common oil until it dries; then they add a pound of turpentine and finally an ounce and a half of incense and as much of myrrh. This balsam is said to have a miraculous effect on ulcers of the breasts, and to close up and cure ulcers and sores.

From the trunk they get beams for stanchions, and they prefer these trees to others for their strength and durability. At the end of the branches of these trees, as they are farther removed from the trunk, the birds poccochycuys, kcuychis, or hediendos, make their nests in preference to other trees. See the description that I have given of this tree in the appendix of my Quinologia, printed in Madrid in 1792, where the reader will find all other information regarding this matter. Olmedia aspera and laevis. Trees that on incision give an abundance of a very white milk, which, exposed to the air, turns into a very elastic resin of a reddish-chestnut color; it can be shaped into any form desired. Aechmea paniculata. Pourretia lanuginosa. Bromelia incarnata. A very showy plant because of the color of its leaves, bracts, and flowers. Crinum? luteum. Plant with beautiful flowers of goblet shape, of a yellow color, and green at the borders. Achras tetrandra, caimito. A very luxuriant tree about twelve to sixteen yards in height and very green; its fruits are the size of duck eggs and are yellow like peaches; they have a delicious taste when fully ripe. Alstroemeria fimbriata. Guarea abrupta, ferruginea, and purpurea, yechenor; the last one is used by Indian women to dye their wools and cottons a violet color. Laurus pubescens, purpurea, fragrans, muca-muca. The seeds of this last species are aromatic and good for the stomach, and the Indians gather them to sell to the traders that come there. Swietenia macrocarpa, an Mahomi? A tall tree with a large trunk and valuable wood. Heisteria coccinea L., a tree twelve yards high and very leafy. Cassia procera, cañafistola. 
Tree more than forty yards in height, thick-stemmed and leafy; its pods, that are from four to six inches long, contain a bitter pulp with which the natives purge themselves. Cactus parasiticus. Calyptranthes paniculata. Shrub with flowers that exhale a wonderful fragrance. Prunus amara. Calyplectus acuminatus, cabeza de monge. A corpulent, very tall, and leafy tree. Verticillaria balsamifera, aceyte de María. A conspicuous tree on account of the disposition of its branches in whorls and the bright green color of its leaves and branches. It distils a greenish resin that the Indians call balsamo and aceyte de María, which they gather in quantities in the rainy season. Trillis auriculata. Guatteria lutea. Erinus prostratus. Verbena virgata. Bombax aculeatum, inich?; its cotton they call sun cotton and blowpipe cotton. It is a thick-stemmed, tall, and leafy tree. Bombax microcarpon. A very tall, corpulent, and leafy tree, of which the cotton has a tobacco color or the color of the wool of the vicuña. One of these trees that was cut by the peons for us to examine might have killed my companion and me if we had not fled in a hurry at the warning cries of the peons. Erythrina glandulosa, villcatauri, articulata, Villcatauri, and volubilis? Securidaea scandens and punctata. Polygala rhombiflora. Galega hirsuta. Dolichos umbellatus, mountain bean. The natives eat its fruit, which has a good taste but produces flatulence. Lobelia coccinea and laciniata. Satyrium bicolor and plantagineum. Epidendrum coronatum, cristatum, viride, and equitans. Vanilla volubilis, vainilla. Gongora quinquenervis. Sobralia biflora and dichotoma. Phyllanthus foetida. Urtica baccifera and aculeata. Begonia cucullata, purpurea, and repens. Jatropha urens. Anguria trilobata and trifoliata. Smilax China, purampui and santo palo. The infusion of its roots is an excellent sudorific and anti-rheumatic. See the use made of them in Peru, in my memoir on the Raíz de China, published in the first volume of the Memoirs of the Royal Academy of Medicine of Madrid, printed in 1797. Carica septemlobata, papayo. Its fruit, called papaya, is as large as a small melon and tastes much like one, but to improve its taste a few longitudinal incisions need to be made the day before, so as to rid it of a certain milky substance that imparts a somewhat bitter taste. Clusia radicans, pullapuil, quelpuan. A small, leafy tree, beautiful when bearing fruit that somewhat resembles the apple or, more closely, the mangosteen. The fruit is of a pinkish white color and impregnated, like the whole tree, with a resin which the people gather and use as incense. Heliocarpus serratus. Celtis biflora and spinosa. The Indians eat the fruits of 
both species called atpuallin; they are of the size of a cherry, yellow in color, and sweet. Celtis scabra, chichillica. Its bark has the same uses as the bark of the Coussapoa radicans. Guarea tomentosa. Mimosa quadrijuga, and nodosa, pacae de monte. Carludovica acuminata and palmata. From the unexpanded leaves of this last plant, thin, straight, and flexible splints are formed. Martinezia ensiformis, linearis, interrupta, cuyol, and ciliata, chonta. This palm has the trunk covered with long, black, sharp spines. Its wood is black on the exterior, solid, and very hard; nevertheless it is easy to work lengthwise, so that the Indians make bows of it and the points of their arrows, ramrods, walking sticks, and blowpipes, beautifully polished. The shoots, called palmitos, are tender and tasty, raw or cooked, but reputed to be coarse. I have eaten them in salads, raw and cooked, and they have not caused me any harm. Nunnezharia fragrans, chutasllium. The flowers of this small palm exhale a wonderful fragrance, superior to that of the lilies of Florence, which spreads a long distance through this montaña. Morenia fragrans, sia-sia. A beautiful palm. Iriartea deltoidea, camona. A very tall and luxuriant palm. Calamus hamatus, cacharpurin. Climbing palm that extends many yards, holding on with the barbs that it has at the end of its leaves, as if they were long fishhooks; for that reason they have given it the name cacharpurin, which means walking courier. Its fruits are found in large racemes and contain a yellow pulp or meat, sweet, and with a very good flavor when they are well ripened. From the small stem the natives make fish poles or walking sticks, straight, black, glossy; they can be bent into a loop with ease without breaking, when well seasoned and cured with smoke. Dianthera ciliata and appendiculata. Fagara coriandriodora, culandro, from the smell of its leaves, reminding of coriander. The trunk of this small tree, although it is hardly as thick as a thigh, has wood that is almost as hard as iron. Rivina secunda. Convolvulus cymosus. Ipomoea angulata and villosa. Cestrum lanuginosum. Strychnos brachiata, comida de venado, because deer like its fruit. Strychnos auriculata, abilla. The seeds of this plant yield a great deal of oil by expression, and the Indians make various uses of it. Achyranthes papposa. Cynanchum macrocarpum and pentagonum. Aralia globosa. A luxuriant tree about ten to fifteen yards in height. Tournefortia volubilis and longifolia. Bromelia Ananas, piñas, because of the shape of its magnificent and beautiful fruits, some of which are from four to eight pounds in weight and have an excellent flavor when they 
are cut already yellow; they can then be eaten without adding sugar or without having to be kept in a sheltered place for a few days, as is commonly done, so that they may improve in taste after they have been cut from the plants when green. The plant forms a clump, similar to the aloe, that gives off many shoots, and each one in time carries a piña at the tip of its low stem. If the fruits are cut before they are ripe, they lose so much in quality that many times they cannot be eaten because of their bitter, viscous taste, and they cause intolerable pain in the teeth, and indigestion and pains in the stomach. From the piñas a tasty and excellent chicha is made, and they give a pleasant flavor and odor to lemonade and chicha or beer. Piñas cut in circular slices with sugar are put on the table as an appetizer. Everybody knows the superiority of this fruit, when perfectly ripe, over almost all others known in North and South America for its bittersweet taste, its special fragrance, and the cooling property it possesses. The beatas [religious women] of Huánuco have singular skill in making piña candy. They first peel the fruits and then boil them in water with or without salt, to remove the acidity and viscosity. When the fruit is in this state, they remove the pulp from the heart that constitutes about half of its bulk, and they pound it with almonds, raisins, sugar, and cinnamon, forming a soft dough with which they fill the empty fruit already cooked with sugar. Later they give these piñas two or three baths in sugar, and the result is a very delicious candy from two to six pounds in weight; it is sold very dear on account of its tedious and lengthy preparation. Finally from the cooked and peeled piñas the natives make crushed sweets and jellies of exquisite taste and wonderful fragrance when the operator is skilled. Justicia spicata. G. aff. Piper hexandrum. Neea verticillata. The fruits of both species give a dye of a bright violet color. Erythroxylon stipulatum. Oxalis frutescens. Euphorbia erosa. Psidium rugosum, huayabo de monte. It is a small tree of about twelve to fifteen yards in height, and its fruit has scarcely any pulp. Myrtus limbosa. Shrub of about four yards; its flowers exhale an admirable fragrance. Bignonia lanuginosa, muricata, clavata, brachiata, planisiliqua, and alba. On the 17th of September, early in the morning, we noticed that many of the trees that covered the sides of a hill were in bloom and looked as if it had snowed over them, but on the 19th we could see only a single flower here and there, although the trees were naked of leaves but full of sprouts or tender fruit. This tree is one of the few that, in these montañas, 
becomes bare of leaves. Gomara racemosa. Besleria radicans. Elephantopus spicatus. Cleome aculeata and longisiliqua. Cavanillesia umbellata, arbol del tambor, because its bark is used for drum hoops; it is a tree of thirty to forty yards in height with a trunk very thick and out of proportion and with such soft wood that it has the consistency of cork or mushroom. The axe cuts into it as if it were a pumpkin, and for this reason, although two men could not embrace or clasp the tree that we asked to be cut, one of them felled it easily with a few strokes. Its crown of branches, that also looks swollen, has almost a spherical shape. This is another tree in these montañas that loses its leaves, and it blooms before the new leaves come. The flowers are so short-lived that on the fourth day the ovary has attained its greatest growth, and as their fruits are formed of four or five big wings, they appear, in the top of the tree, like a multitude of small lanterns placed on purpose on the branches. The wood, as it is so porous, is extremely light; for this reason it might be very useful for buoys and rafts. Erythrina glandulosa. Tall and thick tree, with a very straight trunk, and very luxuriant. Its wood is soft, white, and of good figure. This species, like the other of this genus, loses its leaves, and the flowers sprout before new leaves come in; in this state the trees present a most beautiful sight on account of the red color they have as if they were of red coral; a few days after the flowers have faded, the leaves expand, and the trees acquire a beautiful verdure. Negretia spinosa, llamapañaui, that is, eye of the llama or of the carnero de la tierra. The seeds reduced to powder are applied to the bite of reptiles and insects, and the Indians assert that drinking about a drachm of the powder in water is an excellent antidote. The little thorns or small hairs that in some places are called picapica on account of the ease with which they enter the skin, causing acute pain and indisposition, several persons assured us are an excellent anthelmintic, half a scruple being taken in a cup of chocolate, milk, or honey and water. Aristolochia caudata. Cynomorium ramosum, puyutchrin. The Indians use the heads or aments of this plant, that look like a bunch of mushrooms in the shape of clubs or maces attached to a long and branching root, infused in water, to recover the strength lost on long journeys, and therefore they have recourse to puyutchrin when they are tired and fatigued. Acalypha betuloides and polygama. Croton hirsutum, umbellatum, and gummiferum, sangre de drago [dragon's blood], on account of the bloody, gummy-resinous juice that drips in abundance from 
an incision. Some people gather this resinous gum in calabashes and sell it later as true dragon's blood, and in truth its taste and astringent flavor make it worth using. This small tree grows to twelve or more yards in height, its trunk is straight and somewhat ashen gray, and its semispherical leafy crown gives good shade. Tragia peltata. Juanulloa parasitica. Gimbernatia oblonga. A tall tree with a strong wood suitable for various purposes. Triplaris octandra, palo santo, chupillo, and tisaceiro. This tree grows from twelve to fifteen yards high, very straight with its top in the shape of a pyramid; for this reason and because its leaves are very large, it makes a beautiful sight when in bloom, especially the female tree with its flowers. They are large compared with those of the male, and of a showy reddish color and, as they are found in large racemes, make a very agreeable sight from a distance. The upper trunk and branches of this tree have joints and are hollowed; hence it serves in Puzuzo as habitation for a certain species of ant; thus we found in the trees that we had cut, myriads of these insects, whose bite produces the most intolerable smarting, stinging pain, and a wheal sometimes lasting for more than eight hours. Contrayerba; from its habits and fruits I assume it to be a species of Cissampelos or vejuco de la estrella. I was not able to see the flower of this twining plant, the alternate and heart-shaped leaves of which are covered by a tomentum, as are the shoots and bunches of the oneseeded, drupaceous oval fruits, with little pulp, four lines long and three wide. The root of this plant that is quite long and as thick even as a wrist, consists of a thick bark, brittle when dry, and of a singular fragrance; the woody part if cut transversely, presents like many others the obscure figure of a star; therefore, they give it the name of vejuco de la estrella. The Cholone Indians use this root to cure rheumatic and venereal troubles, drinking the decoction of it at night, and not only the Indians, but also the missionary fathers, assert that a few hours after drinking the decoction the patient's temperature rises; this is followed by a very copious sweating that lasts until the third day and, entirely well, he is out of bed on the fourth day with a disposition to work and without the least ill effects. The only thing for which I have applied this root in Peru on the recommendation of the missionary padre Francisco González Laguna, has been to relieve the pain of a toothache. It is to be expected that in time this root will have great value in medicine because its taste and odor indicate excellent properties and various applications. Cedrela odorata, cedro. On the side of 
the hills that face to the east of Puzuzo, there are very tall and leafy cedars that shade a great area, and their trunks are more than eight yards in circumference. Two trees that we ordered to be cut to make boxes, carried with them, when they fell to the ground, many other smaller trees that grew beneath them and dislodged so many big stones and so much soil from the hill that all together they made such a frightful noise that we thought at the moment it was an earthquake, or a cave-in of the hill, as we were on the spot and had forgotten that in the morning we had sent the peons to cut these trees. They were able to bring them down after six hours of work for four men. Besides this beautiful wood, there are many more trees in Puzuzo, valuable for their color, grain, and other qualities. The variety of plants in these montañas is so great that all of them could scarcely be examined in one hundred years by a whole succession of botanists. 


\section{CHAPTER XXXIX}

Itinerary-Report and seeds sent to the Ministry of the Indies-Addition of Tafalla and Pulgar to the expedition-Illness of Ruiz.

\section{JOURNEY FROM PUZUZO TO HUÁNUCO}

On the 20th of September the draftsmen left Puzuzo to go to Huánuco, while we stayed until the 27th, when our muleteers arrived and we left about midday without other misfortune than the lack of good nourishment, because instead of bread we were eating baked yucas and boiled corn, and the little meat we had was salty and not very good. We spent the night in the Tramo and the 28th in Cushi, having been caught by a heavy shower that lasted from two o'clock in the afternoon until about nightfall. My companion Pavón's three mules tired, but the muleteer had the good luck to find a change of animals on the way, otherwise it would have been necessary to leave the loads in'the desert until after we had reached the pueblo of Muña. On the 29th we went to spend the night on the height of Playa, where we were caught in a dense or thick fog until early morning of the 30 th; my muleteers then went to the pueblo of Muña to rest and feed the animals, which could not be done by my companion's muleteer, because the fourth mule became exhausted and two of the three that became fatigued the day before died. In spite of the inconvenience of the bad road, we gathered for drying several plants that we found in fruit between Puzuzo and Muña.

On the 1st my muleteers stopped in Muña, and in the afternoon my companion's muleteer arrived with mules that were lamed on account of the brambles on the roads and the lack of food. On the 2nd my muleteers persisted in traveling to the hill of Santo Domingo but could not be followed by my companion's muleteer until the 3rd; I spend that night in the town of Chaclla. On the 4th I compelled my muleteers to wait for my companion's driver, and on the 5th we started together from Chaclla with the idea of passing the night in the Portachuelo of Panao, where my companion's muleteer's animals could not climb, so he was obliged to sleep on the bank of the river. This day we had a brief shower. On the 6 th I arrived in Huánuco and my companion, not willing to abandon his loads, slept in Yanamayo and arrived without incident in Huánuco on the 7th, although his muleteer had lost another mule. Notwithstanding the troubles of the trip and the lack of food until our 
arrival in Muña, we worked along the way and gathered a good number of plants, which we finished drying in Huánuco.

On the 12th I notified the Ministry of the Indies of the discoveries made in Puzuzo and its montañas, at the same time sending a good package of seeds for the Royal Botanical Garden. I sent additional packages by the three mail boats of the following months, and during this time I arranged my dried plants, perfected my descriptions, and packed them in boxes for safe transportation with a quantity of packages of seeds and other curiosities.

The Indians of Panao brought to Huánuco the loads of raiz de China for which I had contracted with them, and after having had them cleaned and dried, I placed them in five well arranged boxes with two other boxes of roots of the contrayerba or vejuco de la estrella.

\section{ADDITION OF TAFALLA AND PULGAR}

On the 14th of November, 1784 , two young men were added to our group by order of the general superintendent of Peru, one to learn botany and the other to perfect himself in drawing, with the idea that after our return to Spain, they could continue working and clearing up doubts and answering questions that might come from Madrid during the publication of the Flora Peruana. On the 20th of this month, Dn. Juan Tafalla started to take lessons in botany under our guidance, and Pulgar in drawing under that of the draftsmen.

The whole month of January, 1785, I spent in bed with a kind of sunstroke like the previous ones; I became free from it at the beginning of February, although I had severe pain in one side and in the back and kidneys for more than fifteen days. When restored, I continued until June making clean copy of the descriptions worked out in Puzuzo, and on the way, and of others that I made and corrected anew in the vicinity of Huanuco with the idea that at the same time they might serve as lessons for the new assistant.

On the 12th of May, 1785 I notified the Ministry of the Indies of the expeditions we were going to make to the montañas by way of the quebrada of Chinchao. 


\section{CHAPTER XL}

Tafalla's misfortune-Arrival at Macora-Excursions-Very abundant collections-Hardships-Comforts of the draftsmen-Excursion of the peons -Cholon-Revolt of the draftsmen-The catastrophy at Macora-Flight of the mayordomo-Great losses-Praiseworthy conduct of some hacenderosDeparture from Macora with great hardships-Return to Huánuco-Intendente Gálvez-Meeting with him, and proposal of the botanists-The draftsmen reprimanded by Gálvez-Illness of Ruiz-Ruiz asks permission to return to Spain-Order of the Ministry of the Indies for the discharge of the new assistants, and objections of Ruiz-Shipment of living plants.

\section{TRIP TO MACORA}

In June, 1785 we made the necessary preparations to go to Marimarchahua, a coca hacienda in the quebrada of Chinchao. On the 10 th we sent two men with 55 sheep for our food. On the 12 th I left with Pavón and Tafalla and went to Chulgué to sleep; from there we started on the 13th. When we were three leagues from Huánuco, assistant Tafalla's mule ran away. He followed it and reached Huánuco at night, tired and exhausted not only by the walking but because of having to carry the weight of the pellon that the mule had thrown on the ground; he lost his traveling case with his clothes and 20 duros that were later recovered almost intact by the alcalde of the town of Cascay. We spent the night on the pampa of Mayobamba because one of the muleteers could not go on to the pueblo of Acomayo where the rest had gone. On the 14th we overtook the first muleteers, and very late we camped for the night a little beyond the tambo of Pati, where we arrived with some trouble caused by the bad road that was full of holes. We gathered several plants that we put in the press. On the 15th we camped for the night beyond Chinchao in a small clearing at the side of the road. Next day we arrived at the hacienda Macora, where my companion Pavón had gone ahead in the company of Dn. Mathias Trabuco, the administrator of that hacienda, persuaded by him that the place was more advantageous for our work than Marimarchahua and that he could provide us with food and give us information about those mountains.

On the 17th and 18th we occupied ourselves with the arrangement and disposition of everything necessary to begin our excursions and botanical work, and we continued this until the 6th of August, the day of the lamentable fire. Assistant Tafalla arrived on the 19th from Macora, after having gone to Marimarchahua. The three draftsmen arrived in Macora on the 22nd. 
On the 24th they began to sketch, and they continued until the 5 th of August, when their muleteers arrived for the draftsmen's return to Huánuco without our consent.

During our stay in Macora we made several excursions in the woods, where we discovered a great number of fine trees and plants that we dried. We collected an infinite amount of seeds, many tree barks, roots, and some gums and resins; several birds were shot down with gun and with the blowpipe wielded by an Indian from Pampahermosa who very seldom lost a shot no matter how small the bird. I described not only the plants that had been sketched, but also many others that were left unsketched, and finally I corrected various descriptions and finished others that had been made when we first came to these montañas.

One day, when we had gone farther than usual into the woods, the guides that accompanied me lost their way, and we walked for more than two hours at night without knowing where we were and without hope of finding a way out. I ordered the guides to discard the plants they were carrying and to follow me, because they had already decided to stay there for the night.

Although we had to descend through some ravines, in half an hour we found ourselves in the cocal of Mesapaba, barefooted, halfnaked, and bruised by the branches and continuous falls we had had. Finally we reached Macora at 10 o'clock at night, fatigued and exhausted by the long struggle and walk through the mountains. My companion with the assistant had already planned to search for us in the morning with firearms, so that by the sound of the guns we might find them if we had not been killed as they had suspected.

Our draftsmen, as always, worked with every possible comfort without having to go out to the fields or woods, and without taking the long walks that the botanists took almost every day on foot. Thus they escaped the two most troublesome illnesses as well as the constant hardships, knocks, falls, heat, hunger, thirst, showers, storms, and torn clothes that the botanists had to suffer because of the roughness and steepness of those montañas and ridges.

On the 12th we sent three peons to the new pueblo of Chicoplaya to bring us back information of the condition of the road and also of the plants of that place, with the idea of going there to further the discoveries of our mission. After ten days our peons returned loaded with a great number of rare seeds and other curiosities that they had gathered by themselves in the mountains, and with others acquired from the Indians, one of whom accompanied them on 
their return. This they made by boat by the Cuchero river so as not to suffer again the hardships that they had experienced by land. This Cholón Indian stayed with us several days, getting birds for us with his blowgun which, as already has been said, he handled with unique mastery; he hunted even the smallest hummingbirds without damage to their smallest parts. This Cholón was equally skilful in handling the bow and arrow, and with it he hunted all kinds of animals. We therefore asked him to accompany us in our travels; with apparent willingness he promised to do this, not only in America but also to Spain. When we thought he was most content and obliging, he made an excuse of having to go on a very important errand to the pueblo of Cuchero, but from there he returned to his country, leaving us deceived.

Before starting from Huánuco to the montañas of Chinchao, we had decided among ourselves to continue at least three months on this excursion; nevertheless the draftsmen, disgruntled, it seemed, with living in an uninhabited country, agreed among themselves to leave Macora at the beginning of August and to leave us alone in the montaña. To justify their premature departure they used two pretexts, that there were no more plants to sketch, and that they were sick.

The first excuse was to satisfy the mayordomo of the hacienda and other "montañeses" that had gathered there and knew before we did of this untimely march; the second, although one could detect no sign of sickness on their faces and none was ever verified, was for our benefit, so that we should not wonder at the arrival of the muleteers with whom they had arranged for the beginning of August for their return to Huánuco. This departure took place on the 6 th, in spite of the reproaches and representations that for our part we made regarding the need we had of them in order to advance the work in their care, which was far behind, on account of the loss of the 800 drawings in the vessel "San.Pedro de Alcántara," and because of the numerous plants daily coming into flower that we had already described without drawings, besides many other new plants that we were discovering.

Before this occasion we had not discerned here, any more than in other parts of Macora, the aim and desire of the draftsmen and we gave each one of them 2, 3, and even 4 plants a day to sketch as they were wont to do, even though incompletely, and without the care and accuracy with which they worked many times in the cities. For this and other similar reasons, few sketches were finished to 
our satisfaction and, although we complained of the inaccuracy of their work, they answered that they did not know how to do any better. Nor did we succeed in getting them to draw the fructification first, as being the most important part and most likely to wilt and spoil before the branch or plant. Hence, in Macora as in other places, many sketches were left without the parts of the fructification.

On the 6th of August, after we had sent a peon to Huánuco with the mail and with a package of coffee that we had discovered in that montaña, so that Sr. Visitador Dn. Jorge Escobedo might send it as a sample to the minister with ten special small trees, the draftsmen's muleteers arrived in Macora. To avoid the unpleasantness produced by their departure, with a repetition of reproaches, I left for the woods with three peons to look for wood to make boards for boxes and to gather new plants that I might discover on the way.

At five o'clock in the afternoon on our return towards Macora, one of the peons announced from the top of a hill that the hacienda had been reduced to ashes. The fright, pain, and grief that this bad news caused us cannot be told, particularly what it did to me who was affected more than any one else, and on account of the drawings that by accident had been spared because they had been left abandoned on the threshing floor when the fire surrounded it on all sides and the men fled from the place reached by the sparks and flames. Without stopping we ran in haste down the hill; I fell several times, and almost without breath I reached Macora and went through the fire, where the flames had almost finished consuming the houses and all the furniture, baggage, skeletons of plants, books, manuscripts, provisions, and all the products we had gathered in our big house. The first question I asked was about my manuscripts. I barely heard my companion and the assistant say that every thing had been burned except the few pieces of furniture that they had near them, when, without thinking of the danger to which I exposed myself and without paying attention to the warning cries of the people present, I dived into the midst of the flames in search of my manuscripts and in vain sought to save them; but two peons came after me and dragged me away from the danger I had exposed myself to. It was already one o'clock in the night, when at the request of an old man who was there, called Dn. Agustín Ruiz, and when I was already exhausted from walking from one side to the other and threatening, like a man out of his mind, the mayordomo, the draftsmen, and even those present, I sat down tired, hoarse, weak, sad and pensive, in the middle of the threshing floor, where 
all had thrown themselves down and were sleeping quite cold, although surrounded by fire, resting from the bodily fatigue resulting from the work they had done during the day in the effort to save the movables and the houses.

On the 7th, in the morning, feeling calmer and ready to hear an account of the unexpected and deplorable misfortune, I asked how it had happened, and they told me that, as soon as I had gone out, the mayordomo of the hacienda, taking advantage of the favorable day to burn the clearing and the stumps of the trees that had been cut north of the buildings, set fire at the foot of the hill at the summit of which the houses were, and that, the north wind having increased about 10:30 in the morning, at the time the draftsmen departed, the fire extended throughout the entire clearing with the rapidity of fireworks. Almost immediately the fire was on the roof of our big house, and because of the violence of the flames many leaves on fire passed over the chapel, from which the draftsmen had just left; noticing this from the house of the mayordomo, the above-mentioned Dn. Agustín Ruiz called out to the companions of the assistant and to the servants and peons that were inside. While two peons went on the roof to extinguish the fire, the chapel caught fire, and from this the flames passed with incredible force to the big house; having lost all hope of extinguishing the flames, they started in the confusion to pull out furniture without order and got in the way of one another and, when they tried to go in for the second and some for the third time, the roof caved in completely, burying under it all the things we had stored there and all the plants we had hanging on the walls and racks we had built to preserve things from dampness. My companion was the only one to suffer a slight burn in his leg when they were coming out of the house and the roof caved in. At this calamity some came with water to try to extinguish the fire, but there were very few people and the water served only to nurse the flames more and to leave the men too exhausted to be able to rescue the furniture from the main house where the mayordomo lived, which was the last to get on fire with two outbuildings that served as kitchens. When they saw the terrible spectacle, several persons came from the neighboring farms, but they arrived too late. Only the draftsmen continued unsympathetically on their way, although the owner of the hacienda where they were spectators of the misfortune, had insisted, as he later told us, that they return to help their companions. 
The mayordomo of the hacienda ran away, as soon as he found I had arrived at Macora from the fields; I did not see him again until I was in Huánuco, where the unfortunate man was made a prisoner and remained almost half a year in jail following the trial for something he probably had not done with any evil intent but for lack of reflection and thought. Nor did we, knowing his innocence and integrity, ask for his imprisonment, but we were satisfied to get a certificate attesting the true facts of the event as we requested and the intendente Dn. Juan María de Gálvez asked to be made, but his assessor Dn. Bartolomé Bedoya unjustly made the event a criminal one as he had an interest in the houses of the hacienda.

In this fire I lost all the clothes and baggage that I had carried from Huánuco for my use, all the natural products gathered in those montañas during two months, diaries for three and a half years, the botanical descriptions for four years (among which there were 600 observed in the preceding years, and finally corrected and perfected in Puzuzo and the quebradas of Chinchao from the same living plants); the works of Linnaeus, Murray, Plumier, Jacquin, and several other books on botanical as well as other subjects; the presses, and drying, preserving, and writing paper; six saddles with bridles, saddle skins, and other accessories; two rifles, pistols, and swords; the greater part of my companion's luggage and the clothes belonging to the assistant, servants, and peons, and finally the two months' supply of food we had, with the pewter plates and some silver pieces that were melted and mixed by the fire.

At a moderate estimate, the botanists, servants, and peons lost that day from 4,000 to 5,000 pesos, silver, aside from the botanical works mentioned, the loss of which was more painful to me than the 2,404 pesos that I had to spend later to provide myself anew with the most essential implements, as I stayed in the montaña like another Simonides, although more disconsolate than he because of the lack of my manuscripts.

On the morning following the 7th, many of the hacendados of that country side came at daybreak with as much food as each one could afford to bring for our immediate need; we thanked them hastily, and against their will they were paid immediately in cash. Then all together we went to extinguish the fire in our big house, and in the ruins we picked up pieces of silver and iron from the presses and bridles that were found there. When we had finished this work, we arranged as best we could, in two hampers which had been saved by my companion and in another one of mine that they 
saved, the seeds and other things that were spread out on the threshing floors, and several packages of dried plants that had been saved from the fire were packed in pieces of canvas which were found half-burned in the ruins; carrying on our shoulders as much as we could, we went to the small, dismantled rancho of the hacienda called Hualqui, where we arrived worn out although it was less than half a league distant. We spent the night there with much discomfort and trouble, because at 10 o'clock there came up a furious storm with thunder and lightning, followed by a heavy rain which wet almost all of our poor and ragged luggage although we tried to save it by making small ditches and canals with the pieces of iron we had and with stones about the small rancho.

On the 8th it rained continuously until noon; but in spite of the tragedy that had befallen us, we tried to collect and dry several plants that were found around the rancho in some papers that had been saved from the fire; and at the same time I started to describe them with pencil on brown paper.

The weather clearing, we decided to go to the road to commandeer the mules of the traders that came to that montaña to get coca; and in fact, we succeeded in assembling the necessary mules to load the little goods we had saved from the fire. Making bundles with the pieces of canvas and chichillica bark, we left Hualqui on the 9th at eight o'clock in the morning, all walking on foot until we could find saddle mules that of necessity had to be the trader's pack animals that we seized on the way. Some hacendados provided us with saddles, and the servants and peons that could, climbed on the mules with packsaddles, changing from time to time, as they got tired. We reached the pueblo of Chinchao in the afternoon, where we spent the night and I described some plants, and the companion and the assistant changed the ones that gathered on the road and placed them in the press that we still had.

On the 10th we left Chinchao and slept in the inn at Pati. On the way we gathered several plants to dry, and I described six of them. On the 11th we left Pati and passed, fortunately, without encountering any showers, the steep, high hill of Carpis, reaching the hacienda Chulgué at eight o'clock at night, after we had gathered many plants to dry and describe. On the 12 th we entered Huánuco at noon, and people came to their doors to see the trophies of the fire evidenced by the pieces of canvas in which were wrapped the loads of plants that had been saved from the fire, because some of them were at the threshing floor at Macora and others at the 
entrance of the big house where those that were near the door could be saved.

Until the 17th we continued drying plants and seeds gathered on the way, and describing the ones we brought dried. On that day two companies of the regiments of Estremadura and Soria arrived in Huánuco, commanded by their captains Dn. Diego Herrera and Dn. Juan Vibes to enter the Mayro and establish towns there and to clear the way for navigation and communication with the Portuguese.

On the 19th, at 4 o'clock in the afternoon, there arrived in Huánuco the intendant of Tarma, Dn. Juan María de Gálvez, accompanied by several persons from Pasco and the subdelegado of the secular chapter and by some priests, officials of militia, and several other important persons that had set out from Huánuco to meet them at the district of Ambo, 5 leagues distant from the city, where they were received with the ringing of bells and with fireworks, the troops of the militia being extended from the entrance of the city to the house that had been assigned to them. As soon as the chief of the province and of the expedition to the Mayro dismounted, we botanists, together with the secular and ecclesiastical chapters, the prelates, and all the principal people of Huánuco went together to congratulate him.

In spite of this event, so unusual in that country, I described three plants and continued the other work of my commission.

On the 20th the botanists and the draftsmen with the principal people of Huánuco were called by the intendant to a general meeting to decide about the expedition to the Mayro. The journey was postponed for that year because the season was too far advanced to undertake it. At the conclusion of the meeting, the intendente mentioned his desire to see the city and its vicinity, and several people from the meeting went along to accompany him. When we had reached the place called Carrera del Campo, it was pointed out to him how useful it would be for beautifying the city, to plant an avenue with different kinds of trees to make a public walk and to furnish recreation and desirable shade. The proposal was accepted, and he commissioned the subdelegate and some regidores to accomplish this with the aid of the botanists in the shortest time possible, and this was done, four streets being planted with trees, and two small squares at the ends.

In the remaining days of that month I described various plants of which the descriptions had been burned in Macora, and we continued drying many others of the vicinity and hills of Huánuco. 
In September, 1785 I replaced, with the drawings and dried specimens, many of the descriptions consumed in the fire at Macora, and later I perfected them with living plants as opportunity offered in the montañas.

On the 11th of this month I wrote the news of what had happened in Macora to the Ministry of the Indies, to the acting director, Dn. Casimiro Ortega, to the superintendent of Peru, Dn. Jorge Escobedo, and to the R. P. Francisco González Laguna, in charge of botanical matters in Lima. On the 16th I, with my companion, presented a brief to the intendant of Tarma, soliciting a certificate of the happening in Macora so that at any time it could serve us as authentic testimony. So this was decreed, and his assessor was asked to make it, after taking testimony from all the persons that were present at the fire. The assessor, perhaps on purpose, delayed attending to the matter until the 29th, when, at our request, the intendente asked again to have it done, but because the administrator Dn. Mathias Trabuco had not appeared, afraid of being compelled by judicial order, the investigations that remained in order to give us the certificate were suspended for the reason that the intendant and his suite had gone to the province of Huamalíes.

On October 7th, 1785 I received orders from the ministry of the Indies, for myself and companion to replace the small trees lost on the vessel "San Pedro de Alcántara" at 45' south.

The same day I received a letter from the general superintendent in which he informed me that he had sent an official order to the intendant of Tarma to make a judicial investigation of the fire of Macora, accompanied by another letter to the effect that in the future the draftsmen and others of the expedition would be under the orders of the first botanist. This he did on the grounds that he had had information that the trip was going to last at least three months, and that the draftsmen had left the montañas before this time was up without the consent of the botanists, adding that, if they had stayed in Macora, as they should have done, until the departure of the botanists, they might at least have helped to save from the fire the things that were burned after they left Macora. From all of this he inferred that there existed in the expedition a monster with many heads and no subordination. When the draftsmen read this letter, they got very angry and burst out saying that they did not recognize any other chief than the king and the minister, and that since the last order was for the botanists to replace the small trees that had been lost in the "San Pedro de Alcántara," and did not 
make any mention in it of the draftsmen, they considered themselves already free from the expedition, and for this reason they were going to Lima to return to Spain.

On the following days up to the 14th, I continued describing several plants, and I answered the letter of the superintendent, sending him a package of seeds of those saved from the fire so that he might forward them to the Ministry of the Indies, to which I wrote giving information about all that had happened on the expedition.

On the 15th I became ill and kept to my bed until the 4 th of November, when I got up, though with some difficulty on account of extreme weakness and the pain that, as on other occasions, had settled in my right side; on the 14th I started anew to describe plants and to transcribe the descriptions made after the fire. I continued this work until the 17th of December, when I went to bed again with the same sickness until the 1st of January, 1786, when I got up with the same pain in the back and without any appetite until the 23rd. Then with the help of lemonades and four bleedings I was able to recuperate and to drive off the fever and the dry cough that kept me exhausted until the 22nd of February; then I began to eat fruits, vegetables, and fresh fish, and through this means I was completely restored to health.

On the following days of February and in March, I replaced a good number of descriptions and I corrected not a few of those made on the coast, of plants that were found also in Huánuco, particularly of the Malvaceae.

Already harassed by repeated sickness and realizing that the work of the expedition that was in my charge was very hard on me and that I felt the burden more every day because I had not the necessary strength to continue, I wrote on the 11th of March, 1786 to the Minister of the Indies, asking to be returned to Spain.

On the 13th of March Gálvez, the draftsman, and Tafalla, the assistant, went to Pasco to collect pay for all of us from the Royal Coffers. The assistant returned on the 25th with his salary and that of his companion, Gálvez staying there a few days longer to await the arrival of money to the coffers so as to receive the salaries of the others. On the 9th of April I received a letter from Gálvez, in which he told me that a mule had fallen down a precipice at the Huariaca river with four thousand pesos and that I should go without delay and see if I could give some advice on how to recover the bags, because the river was getting very high. On the 10th, early in the morning, I left Huánuco in company of Pulgar and my 
servant; I arrived that day at the Ollerias [pottery place] where Pulgar and I spent the night dressed because the servant had not been able to arrive with the beds. The multitude of guinea pigs and the fleas that those small animals bred kept us awake all night. On the 11th, on entering Huariaca, we were informed that Gálvez with all the Indians of a near-by town had succeeded in getting the money from the river and that he had gone to Rondos the afternoon before by a road different from the one we had traveled. Without dismounting in Huariaca, we returned to Huánuco, where we arrived at 11:30 at night, very sore and tired after the 20 leagues that we had traveled that day and the 10 of the day before through rough country; nevertheless, I brought back to Huánuco six plants that I described the next day, after I had sent off the correo de España [mailman] with a package of seeds.

On the 10th of May we sent to Lima, with Dn. Juan Tafalla, 28 pots of live plants, and on the 27th Pulgar took to Lima as many more plants of different and beautiful trees, with which we not only replaced the loss of the plants on the ill-fated vessel "San Pedro Alcántara," but also increased the shipment a great deal with the specimens of quinos, laupes, Weinmannias, laurels, arboles del sebo, yasmich, arboles de incienso, Triplaris or santo palo, coca, Porlieria, quino-quinos, Bombax, and other very special ones from those montañas of Panatahuas.

On May 12th I showed the superintendent the urgent need of added funds to continue the explorations in the montañas, sending him an exact account of the extraordinary expenses incurred with the peons on the journeys and the conveyance of the effects of the expedition.

On the 7th of June I received orders from the Minister of the Indies that the work of the assistants should stop as soon as we returned to Spain. By virtue of this I answered on the 11th of the same month that the royal order would be obeyed; but that at the same time I could do no less than explain to H. M. the application and progress that the assistants had shown, and how important it would be to have them continue the mission after our return to Spain, to clear up doubts that would arise, to answer questions that might be made from Madrid, and to add to the work with new discoveries that they could be making. I made the same representations to the superintendent of Peru and to the director of the faculty, Dn. Casimiro Ortega. 
I described and dried various new plants. I corrected and made fair copy of several descriptions.

On the 9th of July the assistants returned from Lima, after leaving in the care of Padre González the 56 pots of living plants, bringing the necessary funds to make the expedition into the montañas. They had the good luck to get to Lima almost all the live plants that they took from Huánuco without having lost but one or two because of the shaking with the ups and downs of the road. 


\section{CHAPTER XLI}

Shipwreck of the vessel "San Pedro de Alcántara"-Plants gathered after the fire at Macora-Their use-Curious observations.

\section{ShIPWRECK OF THE "SAN Pedro DE AlcÁNTARA"}

On the 19th of this month we received news that the vessel "San Pedro de Alcántara" had stranded on the coast of Portugal and that only some three hundred persons had been saved. On the 30 th it was learned that the fortune the vessel carried in gold and silver had been saved and also some boxes. We had the hope then that among them might be some of our 53 cases of plants, drawings, and metals, etc.

After the fire of Macora until the end of July of 1786, I described the following plants, most of them described before the fire at Macora, and in Huánuco.

Nepeta, muña and coca. The natives apply the concoction of this plant with salt in hot baths for oedematous and gouty swellings and for pains in the side; and to relieve the head they take hot infusions of this plant as an aperitive and diuretic remedy to banish gloomy and melancholy choler, to clear the spleen, and to diminish obstructions. Cynomorium fungiforme, hatum, puyutchrin. This plant has the form of a spongy and reddish cake, and over it are found sessile many big catkins in the shape of clubs of the size of a hen's egg, also reddish. The Indians eat them to regain the strength lost after long travels and after too heavy work. Heliconia discolor. Begonia ciliata. Cecropia coriacea. Elephantopus capitatae. Clusia aff. triflora. Palaua lanceolata. Amomum racemosum, achyra de monte. Its seeds are still more aromatic than the seeds of cardamon and, preserved between papers, they give off so much oil that the papers become entirely spotted. Escobedia tinctorea, saffron and mountain spice, because its root is used, instead of saffron, to give color to stews and for dye. Bocconia frutescens, palo amarillo, on account of the color of its juice and because the whole of the shrub is used to dye cotton, wool, and other cloth. Hippocratea viridis. Anthodon decussatum. Olmedia aspera. When incisions are made in this tree, a white resinous milk flows, that is very elastic when condensed. Miconia pulverulenta. Costus argenteus and scaber. Purum piña. Sobralia amplexicaulis. Its flowers are very fragrant and beautiful on account of their size and color. Chaetocrater pubescens and serrata. Ceanothus granulosus. Lettsomia tomentosa 
and lanata. Tovaria pendula. Marcgravia calyptrata, purumhigos and higos de monte [mountain figs]. The Indians eat the fruits when they have opened. Loranthus triflorus. Lobelia volubilis. Citrosma echinata. Lisianthus.... This is a beautiful plant for gardens on account of the large size of its pink flowers. Prunus virginiana, cerezo or cherry tree. It is cultivated in some orchards of Huánuco, where they call the tasty fruits cherries. Cestrum undulatum, hierba hedionda or fetid herb; although this small shrub is fetid, its flowers exhale an agreeable fragrance at night and in the morning; the natives use the infusion and concoction of the miu to temper the heat of the blood and for many other uses, and for this reason they call it yerba santa. Schinus Molle, molle. It is said that the Incas called it the "tree of life," because of its properties and uses. In cases of dropsy, gout, and oedema, baths are prepared with the leaves and bark with salt. From the ripe fruits, rubbing them in water so that they give up their saccharine matter, and later fermenting this liquor, the Indians make a chicha, sweet and agreeable to them and excellent against dropsy. In Peru, even the most intelligent people are persuaded that the fruit of this tree is the true pepper of the East and that it is because they do not know how to prepare it that it is not as much esteemed. Because of the slight taste and resemblance in size and odor that the seeds of the molle have to the grains of the true pepper, some after roasting mix them with the latter, with great harm to their health; for this they should be severely punished if, after being warned, they should continue with these harmful mixtures, for from them originate the vicho or mal del valle and terrible hemorrhoids. The white, fragrant resin of the molle, applied in plasters, is excellent for mending fractures and sprains and for cleaning and healing ulcers. From its ashes results an excellent fixed alkali for the purification of sugar and for dyes. The wood is quite strong and lasting in the fire, but its smoke causes headaches. From its trunk they cut excellent boards, beams, and timber for various purposes. Vermifuga corymbosa, matagusanos, contrayerba, and chinapaya, in the region of Cuzco; when ground together with salt and lard, it kills the maggots of the beasts more rapidly than when applied alone. Mimosa farnesiana L., aromo; on account of the special fragrance of its flowers, the ladies adorn their heads with them, and they are used in the making of the puchero mixtura, as a mixture of various fragrant flowers is called in Peru. Its seeds when chewed and ejected with saliva in any room, give off an insufferable odor, 
resembling that of human excrement. Galinsoga quinqueradiata and quadriradiata, pacoyuyu. The leaves and juice of this plant are. used to cure sores of the mouth, as an excellent detergent, and to promote healing. Boerhaavia viscosa, pegajosa. Boerhaavia scandens, yerba de la purgación, on account of the virtues of the infusion and concoction against venereal infections. Calyxhymenia viscosa and Mirabilis Jalapa, trompetillas and flor de Panamá, the root of which is used as a mild laxative. Achillea urens, botoncillo; a plant with burning taste, that stimulates salivation as does the pelitre, and they use it against toothache in place of the roots of the latter. It is a deadly poison to guinea pigs. Achillea lutea. It has the same vernacular name as the other and produces similar effects; it appears to be merely a variety of the other. Talinum dichotomum. Tafalla laciniata. Krameria triandra, rataña, pumacuchu, and mapato. This plant grows in the provinces of Tarma, Huánuco, Canta, and Huarocherí. Its root has such powerful astringent properties that it stops any bleeding; and when the infusion or decoction of half an ounce of dried root per dose is taken, or a drachm of its watery extract is diluted in two or three ounces of water, this root serves to clean and strengthen the teeth. This use it had already in Peru when I discovered its great astringent virtue, superior to that of any other plant known to date for stopping hemorrhages, without the bad effects of other astringents, as has been demonstrated by the experience of more than 800 persons who have taken its extract under the direction of physicians of the best reputation. See my memoir upon the rataña inserted in the first volume of Memoirs of the Medical Academy of Madrid, printed in 1797, where all that I have observed about this particular will be found. Zannichellia palustris. Pectis trifida, ascacpichana, escoba amarga [bitter broom], and canchalagua cimarrona; it is a low plant, extremely bitter and an excellent febrifuge and a stomachic tonic. Porlieria hygrometrica, tarucasa and huayacan in the kingdom of Chile. In this country, balls, ladles, bodies, and shafts for various instruments are made of its wood in preference to other substances on account of its density and resistance. In Huánuco these shrubs are used for fences, and handles of axes, hoes, and hammers are also made from their wood. Its leaves watch by day and sleep at night, closing or folding in such a way that the tree appears to be without leaves or to be dead. The leaves begin to open or unfold half an hour and a few minutes before sunrise and are completely open an hour and a few minutes after the sun has risen; they start folding up 30 to 40 
minutes before the sun sets, and they are all closed an hour and a few minutes after sunset. If it is going to rain the next day, they always announce it the evening before, delaying the folding of the leaves by half an hour and a few minutes more or less, probably according to the saturation of the atmosphere; to this cause I attribute this movement of the leaflets. I do not doubt that the same phenomenon could also be observed in plants with winged or compound leaves, such as mimosas, cassias, poincianas, and other legumes. It remains, however, to make exact observations to discover this movement of the leaves that varies according to changes in the weather, as I have done with two plants of Porlieria in the voyage from the port of Callao to the Bay of Cádiz, keeping an exact account in writing, every day from the 16th of June, 1788 until the 12th of September. On that day I landed the 24 crates of different small trees that I was lucky enough to bring from Lima to the port of Santa María, where they arrived after 5 months and 12 days of sailing by way of Cape Horn, 77 live plants out of 87 that I brought from Peru. On the 16th of November I delivered to the Royal Botanical Garden of Madrid 68 living plants, notwithstanding the cold season that overtook me on the way between Sierra Morena and Madrid.

Croton ciliatum, huanarpo macho and higos del duende. The natives assert that the infusion of the root of this plant excites powerfully to sensual pleasures, and they say that its opposite is the infusion of the huanarpo hembra, or female, another species of the same genus, whose flowers are white, while the flowers of the male are red. Cacalia punctata, a plant of more pleasant fragrance than that of the Tagetes, which it resembles considerably. Solanum sicioides. Spondias Mombin, ciruela agria [bitter plum]. Its fruit is red and has a bittersweet taste, quite agreeable. Psidium pyriferum, sahuintu and huayabo. It is so abundant in the whole valley of Huánuco that for that reason the natives are called huyaberos, a term they apply to impostors; to say, "What a big lie!" they use in Peru the expression, "Que huayaba tan gorda" or "What a big guava!"' The fruits of the huayabo [guava] tree vary so much in color, shape, and size that there are found more than ten varieties, to which they give as many names, like verde sahuintu, ducasahuintu, coarhuasahuintu, yorasahuintu, etc., meaning green guava, red guava, yellow guava, white guava, etc. From these fruits, that are desirable to many, they make a very good candy resembling pear jelly, stop bloody urine, excessive flow of menstruation and of the 
bowels; this is usually done with fruits not quite ripe, and with ripe fruit the action is the same but less effective. The trunk of these trees looks as if it had no bark because it is smooth and has a dull, tawny color. The leaves, as well as the fruits have a fragrance resembling somewhat that of arrayán and are astringent like the leaves of the latter; for this reason they are sometimes chewed to relieve and strengthen the teeth. Campomanesia palillos, palillo. This tree, like the preceding, is cultivated in Peru, where they eat its fragrant fruit called palillos, and it is placed in the "mixture of flowers" to add to the attractive fragrance of the latter. The wood is very good for various purposes, and its leaves have a very agreeable odor. Galium lappaceum. Buddleia diffusa, quisoar. Oenothera lyrata. Dianthera hirsuta. Asclepias curassavica?, arbol de la seda, and chuchumeca. Urena villosa and hamata, lausahacha; the women wash their hair with the gum of these two plants, extracted in cold water, for the purpose of removing dandruff and grease from the hair and of making it grow. Spermacoce gracilis.

Anona reticulata, chirimoya. In Peru they cultivate this beautiful and luxuriant tree, the trunk of which is very good for various purposes; its flowers exhale a very sweet fragrance, and for this reason they are added to the compound of flowers called "mixtura." In Huánuco its fruits reach a weight of 10 to 12 pounds and, although there are few of this size, there is an abundance of those weighing 3 to 6 pounds, which I have not seen in the rest of Peru, their regular weight in other places being half a pound to a pound and a half. The skins of these fruits vary, being more or less smooth or rough, and so they call the chirimoyas that have points, chirimoyas de cabeza de negrito, and the ones that have the surface smooth, chirimoyas reales. The flesh or pulp is white, juicy, sweet, and very soft. Solanum incanum, yurahuacta, that is, white back, on account of the white color of the back of the leaves; the natives use the leaves to clean ulcers, applying to them the upper surface, and then to cure the sores they apply the under side of the leaves. Malpighia nitida, ciruelo de Fraile. They cultivate this tree in Peru; its fruits, after they have reached a certain ripeness, are picked and put in chaff or bran, straw or grass, so that, with the heat and the slight fermentation that takes place there, they will ripen completely and their pulp become soft and sweet, red and cloying. The seeds that are sweet also and somewhat similar in taste to fresh almonds serve as a purgative and produce nausea. Rubus fructicosus?, siraca; its fruit is bittersweet. Nicotiana Tabacum, tabaco verdadero or 
true tobacco. Although this plant is cultivated in several provinces of the kingdom, where they have large crops and make them into bundles that they call tabaco de andullo and long cigars, it is found wild in abundance in all torrid climates. Physalis pubescens L., capuli; the children eat its bittersweet fruits, and the women that sometimes also eat one or two add them to the mixtura of flowers, anointing them with a little amber to give them greater fragrance than they naturally have. Finally they serve as ornaments for the hair, placed among the other flowers with which those cleanly people adorn themselves.

I described anew 180 plants of those of Puzuzo, the descriptions of which were burned in the fire of Macora; their generic and specific, as well as vernacular names and uses, are already recorded in the chapter on that journey.

Those that I succeeded in describing in Huánuco, of those that were worked on in Macora and that were burned in that fire, are the following.

Canna paniculata, achyra: the natives eat the roots like the roots of the Canna indica L., also called achyra. Acosta aculeata, caimito de monte, on account of the similarity of its fruit to that of Achras Caimito. Peperomia foliiflora and concava. Hirtella racemosa. Dorstenia ovalis. Its root is as fragrant as that of D. contrayerva. Coffea occidentalis, café; name introduced by us among those natives that knew the plant. Cynanchum lanuginosum. Stapelia volubilis. Rhus atrium. The juice of its bark and stalks give a black and glossy ink like the best printing ink; when one writes it is clear, but as it dries it becomes darker with a varnishlike luster. Ornithogalum rubrum. Laurus crassifolia and coerulea. Murraya racemosa. Cassia viminea L. Melastoma acuminata and coerulea. Vaccinium ? bicolor. Trichilia acuminata and trifoliata. Valdesia repens and ovalis. Triumfetta fructicosa and Lappula L. Myrtus pseudopimentas. The berries have an odor quite similar to the tabasco or malagueta pepper. Prunus nigra. Anona lutea, anona. The fruits of this species ripen on the trees until the skin turns completely yellow; this does not happen with the chirimoyas, huanabanas, and anonas of the coast that have to be covered with grass, bran, or clothes so that through a short period of fermentation they may become tender and fit to eat. The pulp of the anonas of the montañas seems to me more delicious than that of those from the coast. Mollinedia lanceolata, repanda, and serrata. Justicia mucronata. Peperomia filiformis, purpurea, tetragona, and trinervis. Piper 
Carpunya, carpunya. Its leaves are aromatic, and they acquire greater fragrance when well dried; natives with delicate taste often drink one or two cups of the infusion of these leaves made with boiling water to help the digestion, in preference to the tea of the East. Piper dichotomum. Its leaves can be substituted for those of carpunya as they have almost the same fragrance and taste. Callicarpa globiflora. O'Higginsia aggregata. Convolvulus quinquefolius. Gimbernatia obovata, chuncho; a tall, leafy tree with a thick trunk and with very strong wood. Lisianthus acutangulus, oblongus, and ovalis. Echites acuminata. Cestrum longiflorum and racemosum. Clavija lanceolata. Macrocnemum pubescens and venosum. Psychotria umbellata, tinctoria, coronata, viridis, glandulosa, angustifolia, and acuminata. Coffea tetrandra. Porcelia dependens, platanos de monte [mountain bananas], on account of the similarity in the shape of the fruits to that of the banana. This tall, leafy tree has a straight, thick trunk with good wood. Its fruits, that grow in clusters of as many as nine from each flower, are about 5 inches long, cylindrical and with prominences; between the seeds they contain a sweet and pleasant pulp which can be eaten if the fruits after picking be allowed to ripen in a sheltered or warm place. Chiococca ovata. Cedrela inodora. Tree with an excellent wood; for this reason, on the day of the fire at Macora, I had had a trunk of that tree cut into boards to make boxes. Achyranthes secunda. Alzatea verticillata. The trunk of this tall, leafy tree, that I examined on the top of Mesapata, was divided into six thick props that formed an arbor underneath, and at the height of four yards they united in a single trunk, divided a little farther up into five arms, thick and leafy, the central one being erect and the lateral ones extended outwards, and all of them subdivided into airy, straight branches. Cynanchum lanceolatum. Staphylaea serrata. Aralia aff. ferruginea. Pourretia paniculata and lanuginosa. Loranthus retroflexus. Guarea acuminata. Rhexia grandiflora, a beautiful plant for gardens because of its flowers. Rhexia flexuosa. Semarillaria obovata, acutangula, and subrotunda, monte lucuma. The Indians eat the fleshy, white, sweet arils that half cover the seeds. Laurus alba, foetida, obovata, and subpubescens. Melastoma carinata, nitida, sericea, and serrulata. Banisteria rugosa. Guatteria dependens and hirsuta. Anona microcarpa; a small leafy tree with small fruits. Mendozia racemosa and aspera. Gesneria frutescens. Cleome coccinea. Bombax polyandrum or Carolinea? Tall tree with thick trunk and soft wood, the fruits or capsules of which contain a very soft white cotton very excellent 
for mattresses, pillows, sofa pillows, settees, and for stuffing chairs and other articles of rest and comfort. This wool can also be spun by mixing it with wool of the vicuña of Huánuco, because by itself it is very difficult to spin. This wool has the property that, when it is compressed, it puffs up in the sun, and for this reason it is called sun cotton. When with the heat of the sun the capsules open and the wool covering the seeds expands, each fruit forms a mass of very white and quite bulky fleece. Erythrina articulata, huilcatauri. These thick, tall, and leafy trees flower before the leaves come out, and then they present a beautiful sight. Hedysarum pilosum and virgatum. Indigofera Anil, añil. From this plant is extracted the indigo blue that is used in dyeing. Crotalaria trigona. Negretia mitis. Trifolium hirsutum. Eupatorium canescens and sambucinum. Elephantopus tuberosus. Tagetes chinchu and anisidora, anis-anis. This species is the smallest that I have seen of its genus, but the most fragrant. Orchis punctata. Epidendrum ferrugineum and cordatum. Maxillaria ramosa. Rodriguezia lanceolata and ensiformis. Humboldtia polystachya and acutiflora. Limodorum coriaceum and lineare. Calla canaliculata. Pothos perforata. Arum aliaceum, on account of the very penetrating odor of garlic that this caustic plant exhales when it is trampled or ill-treated. Satyrium virescens. Phyllanthus gemina. Urtica diaphana. Cucumis purpureus. Cucurbita fragrans, upe. The natives eat the fruits or calabashes of this plant stewed, and with them the women decorate altars and rooms on account of the delightful fragrance that the fruits exhale for many months and even without noticeable loss in a whole year; after this they replace them with new ones. Begonia ciliata. Synzyganthera purpurea; a small, low, slender, tree. Cucumis quinquelobatus. Cecropia digitata and aspera. These trees, called tacunas, grow from 30 to 40 yards; the trunk is very straight and jointed and hollowed in the upper joints, in which quite often there is found a quantity of clear, potable water without any disagreeable taste whatever. In some of them the cavity reaches almost to the roots. The trees are of a beautiful luxuriance, and the leaves follow the course of the sun, remaining during the night with the face downward and in the daytime inclined toward the sun. Ipomoea glandulifera. Auroras, because their flowers open in the morning and remain open until eleven or twelve of the same forenoon and wilt at two or three o'clock in the afternoon when they have been beaten by the sun so that the pollen or fructifying powder has scattered; they are ephemeral as are almost 
all the flowers of Ipomoea and Convolvulus; they emit an abundance of white milk when their branches are cut. Smilax lanceolata. Its fibrous roots have the same use as that of the zarzaparilla. Populus glandulosa. A very tall, leafy tree, with a thick trunk. Schinus aculeatus, huillca. It is a tall, leafy tree with a very thick trunk and covered completely with thorns swollen at the base, in the shape of little nipples or teats with a sharp point in the center. Coussapoa obovata and triloba. These tall trees have a thick trunk and admirable foliage. Isquierdia aggregata. Carica monoica, col de montaña [forest cabbage]; although the fruits of this species are not eaten because they are tasteless, its leaves are put in the pot in place of cabbage. The Indians of Pampahermosa carried the seeds of this plant to the quebrada of Chinchao, where it has multiplied abundantly. Myristica longifolia and oblongifolia, tallow trees, because a heavy oil, similar to cocoa butter is expressed from the seeds and is used by the Indians for illumination. The seeds of the first species are the size of a nutmeg, and the second are the size of hen's eggs. Tafalla triflora, aitacupi, and its resin, almaciga, which they gather in some places for soothing plasters: the whole tree exhales a pleasing fragrance; its resin is white and flows in drops spontaneously. Mimosa planisiliqua. Ficus acuminata, cordata, and lineata. Carludovica latifolia and angustifolia. Martinezia lanceolata. Pullipuntu macrocarpon and microcarpon, pullipuntu. Luxuriant palms that bear their fruits at the base of the trunk. The fruits are numerous and united in big prickly heads like clubs. At the beginning the fruits are filled with a liquid as clear as water, in place of which it is sometimes used by those that walk through the woods; when some days have passed, it turns milky and acid, and later it changes into a sweet and pleasant emulsion and successively acquires greater consistency, solidity, and weight, until it becomes as hard as ivory. For this reason we gave it the name vegetable ivory because it seems to have almost the same qualities as that animal matter, with the superiority of remaining white even after being carved and exposed to the air for many years. Small objects may be turned in a lathe from these fruits with more ease than in the case of ivory, because the substance of the former is neither splintery nor fibrous like the bones and teeth of marine or land animals. Ephedra distachya L., suelda consuelda, on account of its property of uniting fractures, when applied in the form of poultices. Urtica globifolia, piñi-piñi. It is the only plant that I know with globular 
leaves. Portulaca pentandra and cristallina. Euphorbia Peplis? In Peru almost all Euphorbias are known by the name yerba de la golondrina, because their milk cures cataracts of the eyes. Coreopsis trifida. Lycopodium ciliatum. Elaterium glandulosum. Pineda incana, llogui. From the woody shoots they make staffs, walking canes, and ramrods of great resistance. Cleome concava. Solanum pubescens. Coffea subsessilis. Nepeta ciliata and calyciclausa, hupaimuna, both species. Valdesia repens and ovalis. Acunna oblonga. Cissus lobata. 


\section{CHAPTER XLII}

Stops on the way-Arrival at Muña-Excursions-Description of Muña-Occupation of the natives-Products of the country-Population-Peaceful character of the Indians-Clothing-Flora.

\section{TRIP TO THE MONTAÑAS OF MUÑ̃}

On the 2nd of August, 1786, we botanists left for the montañas of Muña, and we spent the night on the farm of Taullan, near the town of Valle. On the 3rd we went on to Tambillo without other incident than the excessive heat of that ravine. On the 4 th, passing through the pueblo Panao, we went to spend the night at Huamanmayo. On the 5th, passing through the pueblo Chaclla, we went to spend the night at Piñapata, where we felt quite cold with the frost that is a daily occurrence there. In this place we collected some new plants. On the 6 th we slept at the summit of the hill of Santo Domingo; its steep and dangerous ascent has 39 steps in the shape of winding stairs, besides the climb from the river to the beginning of the winding stairs. On the 7th we arrived happily in Muña, having gathered on the way a great number of plants that we put in press to dry.

From the 8 th to the 12 th we were busy arranging the things needed for work and in making a spacious rancho of timber and branches to accomodate our beds and effects, because the room assigned to us by the missionary father and justice of Muña was too small. Besides, we arranged our traveling tents so as to be able to work with more ease and with better light and to make place at night for the presses and dried plants with which we worked under shelter. Finally I corrected several descriptions made on the trip from Puzuzo and that were burned at Macora.

On the 13th we started our excursions through those thick montañas; in them we found a great number of new plants that we discovered by means of long walks and continuous work through those woods.

On the 15th the draftsmen arrived in Muña and, after being housed in the house or convent of the missionary father, they began their work on the 16 th.

In the mail that the draftsmen brought me from Huánuco, I received definite information of the loss of the vessel "San Pedro de Alcántara," dashed to pieces on the coast of Portugal against the rock of Papona; but I was not informed whether our 53 boxes of 
products of nature had been rescued as were the boxes with gold and silver.

We remained in Muña until the 24th of September, 1786, when we returned to Huánuco because the rains were becoming continuous, and we could no longer work with freedom or to advantage.

\section{DESCRIPTION OF THE PUEBLO OF MUNA}

The pueblo of Muña is located at $10^{\circ}$ latitude almost opposite Huánuco, to the east 24 leagues by the road from that city, on a plateau that is formed there by that very tall mountain which rises from the river on with five leagues of continuous incline to its summit, a league and a half from the river. Muña is located in a place sheltered from the south, west, and east winds and is reached by the north winds only; therefore the heat is excessive during the day, but is usually tempered by the north wind, which begins to blow at eleven o'clock in the morning.

The ground at Muña, called the rinconada, which is where the natives plant grain and roots for their maintenance, is fertile and suitable for all kinds of grain and fruits, but the natives are satisfied with maize, beans, potatoes, sweet potatoes, gourds, zapayos, arracachas, achyras, and some poorly cultivated vegetables.

Although there are good pastures between Muña and the river, the natives do not have any cattle grazing except a few mules or horses for their transportation to Puzuzo and Huánuco. Most of the Indians occupy themselves by day with gathering the cascarilla or quina that is abundant in those montañas, as much of the fine, or officinal sort, as of the yellow and purple-leaved kind. They also pick small lots of incense and carry them to Huánuco to sell for use in the churches.

In Muña there are two small brooks with very good water that comes by two gorges from those hills.

There are some wild animals and fowls, as elsewhere in the montaña, and there is no lack of redheaded buzzards.

Near Muña on the slope of a hill of the rinconada at a corner, there is abundance of a kind of black slate which is found in long, quadrangular pieces in the shape of bars more or less perfect. I picked up one that I have in my possession, three fourths of a yard in length with four level faces, the two opposite ones polished perfectly and the other two, although one not as much as the other, sufficiently so to sharpen an edged instrument if you put oil on 
them; it does not have the same effect if you use water. At its extremities this slate is cut diagonally, one slant in the opposite direction from the other. Some of these slates are found to be of a very dark gray color on some faces. So many were found in that place that from some distance I thought they were pieces of burned tree trunks.

The number of inhabitants in Muña barely reaches 40 Indians and a few mestizos, governed by a missionary father from Ocopa, who provides their spiritual nourishment, living continually with them. For this reason there are no serious disorders, as happens in other towns where there is no one to restrain them from their drunkenness. These Indians are very obedient in all that the missionary father asks them to do; so they meet in church every night and morning after they return from their work and before going out to it, to pray and sing their petitions and praises to God and the Virgin Mother, with the greatest devotion, and no one is absent except for good reason. Although these Indians do not possess riches, nothing is lacking for their sustenance or for ordinary simple clothing, which consists merely of a cloak, jacket, vest, shirt, and pants, and for the women, skirt, blouse, and shirt. Each inhabitant has his own rancho or house, with corresponding fields for plantation, with no sign of superiority of riches among them. On working days only the alcalde [mayor], uses the cloak; but on feast days all the married men use it to church while the bachelors come in their jackets. During the week the padre says Mass early, and most of the people go to hear it, but no one is required to do so on those days except for the praises and prayers in the early morning and at night.

While we remained in Muña, I corrected many of the descriptions already made and described the following, most of which were sketched.

Salvia incurvata and galeata. Justicia racemosa. Calceolaria heterophylla. Peperomia acuminata. Valeriana decussata and paniculata, macae. The root of this species can be used in medicine instead of Valeriana officinalis as it has almost the same fragrance. Embothrium pinnatum, emarginatum, and monospermum. Paco-paco, the first species, is a small tree, but leafy and has rather fetid bark; the second species is called catas, picahuai, and machinparrani. The Indian women decorate the altars and images with the racemes of these flowers, and they form arches with their branches in bloom, which are a beautiful sight when there are church parades; the third 
species they call paco-paco de la sierra. Spermacoce corymbosa. Callicarpa cordifolia. O'Higginsia obovata and verticillata. Buddleia spicata. Periphragmos flexuosus. Lygodisodea foetida, yurahuanium and vejuco blanco [white vine]. This twining plant, whose stems are used as rope to tie the beams in buildings on account of their flexibility and resistance, have a fetid odor like rotting cabbage. Cinchona angustifolia, cascarillo bobo amarillo, on account of the color of the inner side of its very bitter bark. Asclepias reticulata. Staphylea serrata. Synzyganthera purpurea. Solanum acutifolium, lineatum, sessile, incurvum, pendulum, and scabrum. Nicotiana tomentosa. Psychotria alba. Gumillea auriculata. Fragosa corymbosa. Eccremocarpus viridis. Stereoxylon pendulum, pumachillca. This small tree, when in bloom, makes a beautiful sight with its racemes of pendant flowers. Its wood is resistant and is used for handles of instruments and various other purposes. Its leaves, especially the buds, are covered with a soothing resin; for this reason they are crushed and applied in the form of a poultice to soothe sprains and bruises. Huertea glandulosa, cedro macho. A tall tree with good wood. Laugeria stipulata. Cestrum rigidum. Gentiana violacea. Portlandia corymbosa. The bark of this small shrub is somewhat bitter, and from a certain distance its white flowers resemble those of jasmine. Hydrocotyle tenuis and globosa. Heliotropium oppositifolium. Clavija spathulata and macrocarpa, monte lucuma, from the shape of its fruits. Echites glandulosa. Lisianthus revolutus and viscosus. The calyces of this small shrub as well as the flower stalks are covered with a white, crystalline gum that dissolves completely in water and crackles in the fire like gum arabic. Gardenia viscosa. Marcgravia pentandra. Its flowers, that are found in long bunches, exhale a very agreeable fragrance. Celastrus corymbosus, picna, and in Huasahuasi, rurama. When the seeds of this shrub are preserved between papers, these in a few days become soaked in oil; from this one may infer that on expression they might yield a considerable quantity. The wood is strong and very suitable for handles of axes and other implements; its foliage is found in corymbs; for this reason it is a garden shrub suitable for forming into various shapes. Celastrus lutescens. This is a tree with very good timber for varied uses. Aralia aff. digitata and lanceolata. From these shrubs there flows a white and clear gum that completely dissolves in water. Sambucus glandulosa. They make the same use of this shrub as they do of Sambucus nigra. Berberis lutea, ccarhuascassa and palo amarillo, 
gives a canary-yellow dye and is a strong wood for various purposes. Varronia globosa. Solanum stellatum, huiscacassa and campucassa; the spines of this plant introduced into the flesh produce blisters, filled with a watery fluid, that burst and are cured by applying to them the half-baked leaves. Solanum granulosum, chuculate. Tillandsia recurvata, paniculata, juncea, and parviflora. Loranthus dependens, liga. Loranthus grandiflorus, moma. Alstroemeria punicea, tomentosa, and secunda. Tradescantia deflexa. Actinophyllum angulatum, acuminatum, and pedicellatum. Gilibertia umbellata. Rhexia alba, quinquenervis, and trinervis. Fuchsia grandiflora, involucrata, parviflora, pubescens, and punicea. Tropaeolum discolor. Melastoma repens, olla-olla. They use this plant for a yellow dye, mixing it with several others. Axinaea lanceolata and purpurea. Andromeda aff. cordifolia and punctata. Brunellia aculeata and inermis. Eugenia procera. A tall, branching tree with strong wood that has a pleasing smell like that of its leaves. Negretia inflexa and elliptica, llamapañaui, that is, eye of llama or sheep of Peru, on account of the shape of its seeds, to which is attributed the virtue of being an antidote. Divided into two parts, it is taken in powder and applied to the bites of poisonous animals. [N.] planata; a plant with beautiful flowers for gardens. Munnozia lanceolata. Molina latifolia. Soliva pedicellata. Palaua glabra. Bacasia corymbosa. Mutisia. Cypripedium grandiflorum, rimarima. Anguloa uniflora, flor de Espíritu Santo. Sobralia dichotoma, tahue-tahue; its flowers are beautiful for their color, size, and fragrance. Maxillaria ciliata, grandiflora, longipetala, and undulata. Epidendrum corymbosum, flor de todo el año [yeararound flower]. Epid. nutans, paniculatum, and parviflorum. Fernandezia contorta, ensiformis, laxa, and punctata. Humboldtia cordata, contorta, oblonga, parviflora, and revoluta. Pothos acaulis. Arum tuberosum. Llagunoa nitida, arbol de cuentas de rosario, or tree of rosary beads. Acalypha glandulosa and granulata. Begonia monadelpha, coccinea, hirsuta, incarnata, parviflora, rosea, and utriculata. All these plants have beautiful flowers. Jatropha aphrodisiaca, simayuca. The Indians attribute aphrodisiac properties to the root of this plant. Urtica citriodora, on account of the odor exhaled by its leaves. U. cymosa, hirsuta, dauciodora, longifolia, punctata, and rugosa. Morus nigra and spinosa. Citrosma muricata, pyriformis, ovalis, and tomentosa. On all of these small shrubs there is found a fluid that looks like saliva purposely thrown over them. Schinus oblongifolia, mayco. A shrub the shade of which produces a 
bitter, stinging rash, that later ends in papules with matter, accompanied by fever. Schinus aurantiodora, mayco, produces the same effects as the former species, but the Indians say that the shade of this shrub is more harmful than that of the former. Its effects have been already been explained in another place. Tafalla scabra, aitacupi. It is a branching, leafy shrub with the same fragrance as the species already mentioned elsewhere. Cecropia alba and tubulosa, tacuna. Both species are trees beautiful for their luxuriance and the size of their leaves; these follow the course of the sun, and they always turn their face to it until at night they turn the back up and the face to the ground, although not completely, because they face a little obliquely. Clussia aff. macrocarpa, arbol del incienso [incense tree], rotundicapsula, arbol del incienso. From both species in Peru they get a beautiful, crystalline resin that is used in the churches as incense; it is found in drops of more than a pound. These trees are tall, frondose, and showy, especially the first species, which grows to more than 40 yards in height. Carica glandulosa, monte papaya. Caballeria dentata, dependens, ferruginea, latifolia, and pellucida, manglillos and lucumas. Mimosa punicea, huaita rebozo, on account of the color of its red flowers, similar to the rebozos or mantillas that are commonly used by the Indian women, and monte pacae for the resemblance to Mimosa Inga or pacae. Celtis aspera, chichillica. With the bark of this tree the Indians make fishing nets, bags, and other rough and ordinary weaves, as they do not do anything to refine them; they use them frequently for ropes and for cables. Adiantum reniforme. Morenia fragrans, sia-sia. Saracha punctata. Carludovica trigona. 


\section{CHAPTER XLIII}

Pavón's misfortune-Itinerary-Plants, barks, and seeds-A large shipment prepared for Spain-Ruiz studies the Malvaceae of Huánuco and refutes Cavanilles -Illness of Ruiz.

\section{JOURNEY FROM MUÑA TO HUÁNUCO}

On the 20th of September, 1786 the three draftsmen returned to Huánuco, and on the 24th we three botanists left Muña and, without any other inconveniences than a brief shower and the great heat of those places, we spent the night in Llamapañahui. On the 25th we left Llamapañahui, and a few steps ahead in climbing a winding hill, one of the mules pushed another loaded one, and the latter came tumbling down several yards to the place where Dn. José Pavón was traveling and collided with his saddle mule, which might have gone the same way but was stopped without misfortune because Pavón had dismounted before the pack mule stumbled against his. We continued with good luck, climbing the hills called Torre sin Agua and Cuerno Retorcido, or Twisted Horn, which we climbed on foot because of the excessive steepness of the very narrow and sandy road that had been completely stripped by the burning that still continued that day all over the hill. We ate in the town of Chaclla and for the night went a league ahead, after we had been caught by a shower that lasted, although with short intermissions, until 9 o'clock the next morning. Then we started to load, but it began raining again and continued for more than an hour from eleven o'clock on. We arrived in the pueblo of Panao to supply ourselves with provisions, and we found there the priest and his assistants, who were celebrating all the feasts of the whole year, a feat which they accomplished in eight consecutive days; we slept in front of Panao on a hill; there we also collected several plants. We spent the night of the 27th in Yanamayo, and there we were caught by a brief shower after we had already put up our tents. On the 28th we arrived happily in Huánuco.

On the way we gathered a great number of plants that were placed to dry, and I described and finished describing them during the following days. Among these plants was Cinchona ovata, cascarilla de pata de gallareta, on account of the external color of its bark, spongy and light.

In the months of October, November, and December of 1786, we finished the drying of the plants gathered in Muña and on the 
way; we arranged the dried specimens according to classes, and made them into bundles, packed them well in boxes to send them on their way, with many seeds, barks, roots, and other products and curiosities that we had accumulated.

Every month I sent to the Ministry of the Indies several packages of fresh seeds for the Royal Botanical Garden of Madrid, at the same time giving information of the progress of our discoveries and work.

On the 23rd of November draftsman Brunete went to Lima, declaring that personal affairs obliged him to make the trip.

YEAR OF 1787.- On the 12th of January, 1787, my companion Pavón left Huánuco with Pulgar, the assistant, taking to Lima 73 boxes of dried plants and other natural products, and 586 drawings and 18 crates of living plants in which were included about 40 quinos or plants of Cinchona officinalis with other precious shrubs of those montañas. All of this was shipped to Spain in the vessels "Brillante" and "Pilar," addressed to H. M. in care of the Exmo. Sr. Minister of the Indies.

Having perfected the descriptions that I had prepared at Macora, on the way, and in Huánuco, and having made a fair copy of them, I started anew to gather the plants of the vicinity of this city that I thought had been lost in the shipwreck of the vessel "San Pedro de Alcántara," although I did not have definite information of this loss. I corrected the descriptions of many, and I devoted myself especially to examining anew the Malvaceae that abound in Huánuco. I did this because of the information that Abbé Dn. Antonio Cavanilles gave us about having found nine new genera of this family among the herbaria of different botanists; by the four printed leaves that he sent us about the character of said genera, I did not find a solid basis for separating those plants from other genera already established by Linnaeus and other botanists. I devoted myself with eagerness to the examination of this family, and I verified, in part, the mistakes made by Abbe Cavanilles in the dried specimens he had examined.

As we did not have any definite information concerning the loss of the 800 drawings sent in the vessel "San Pedro Alcantara," the draftsmen were determined not to reproduce them until they had proof of their loss.

At the end of April I had an attack of croup that passed with the help of two bleedings and a copious sweat that I had the 2nd 
of May, and on this day I received a messenger from Pavón sent from Pasco asking that we send him authorization to collect our salaries from the royal coffers.

On the 12th of May, Pavón and Pulgar arrived in Huánuco with twelve loads of paper and our salaries and other equipment needed for our journey into the montañas of Pillao. 


\section{CHAPTER XLIV}

Illness and death of Brunete--Details--Intervention of Ruiz.

\section{DEATH OF DRAFTSMAN BRUNETE}

On the 16 th of May at 9 in the morning I received a messenger with a letter from the accountant of the Royal Coffers of Pasco, in which he informed me that draftsman Dn. José Brunete had been given the last rites of the Church in his own house and requested me to come without delay to that town because the sick man was asking for me. At 3 in the afternoon I left Huánuco with Gálvez, the draftsman, and we spent the night on the farm of Ambo. On the 17th near the pueblo of Huariaca I received a second letter from the accountant and another from the subdelegate of the province, in which they announced the death of Brunete and asked me to come without further delay and get the belongings left by the dead man, as he had named me his first executor. We spent that night in Huariaca and on the 18th arrived in Pasco, where the servants of the deceased, the subdelegate, and the accountant gave me the following account of the happenings that preceded the death of Brunete.

On Brunete's return from Lima to Huánuco with his two servants, he had the misfortune to have the mule that was carrying the two traveling cases with the bed, clothing, and several other things for his use, fall down a precipice of the high and dangerous ladera of Pacron. On account of this happening he stayed there that night, after sending the servants to the pueblo of Canta to look for people to help gather the traveling cases and their contents that had been scattered along the steep hill and to the other side of the river, where the mule had been catapulted and mangled. With the aid of the Indians, he gathered almost all the effects, although some of them were damaged. Regret for this misfortune and the bad night that he was forced to spend, affected him very greatly, so that the servants noticed from that day that his expression was troubled, that his breathing was labored, and that he was very sad; all of these symptoms increased more and more as the travelers were nearing the cordillera, punas, and mines. When they reached Pasco, Brunete decided to wait for the mail; at that time the accountant observed what the servants had noticed in Brunete, especially on the fourth day when they went together to the coffers, and he noticed that Brunete could not follow him 
without resting every ten or twelve steps; Brunete, however, attributed his fatigue to the gases or vapors that are constantly expelled by the minerals of those hills and that sometimes fatigue and choke mules that arrive tired.

On the night of the 11th the accountant, observing that Brunete fell asleep during the conversation, asked him if he felt anything the matter with his health and, although he repeatedly denied this, the accountant made him go to bed and, as soon as he had fallen asleep, they heard such a loud and extraordinarily harsh sound that the companions felt compelled to wake him and ask him again if he felt any indisposition; he answered that there was a slight pain in the chest and some difficulty in breathing. They gave him some cups of hot water with sugar, and this mitigated the harsh sound, and he went to sleep and was more calm. On the 12th he went to church and, when he returned to the house of the accountant, the latter and the rest of those present noticed a great change in Brunete's face; therefore they advised him to go to bed and called a doctor to give him some medicine, to ease the respiration, and to soften the sound in his chest. The ointment, enemas, and hot water that were ordered by the doctor did not produce the desired effect, and during the night he became lethargic; for this reason they advised him on, the 13th, to make his confession, which he did immediately, and a little later he asked for extreme unction. The illness grew worse each moment until the 14th, when they asked him to make his will in the presence of the subdelegate judge, and between 8 and 9 o'clock at night he died in the place that during his life he had hated the most because of its severe climate and because every time he passed through there he had felt sick. On the 16th they buried him in the church of Pasco with a magnificent attendance ordered by the accountant.

An inventory was made on the 19th of May before the subdelegate judge and the proper witnesses, of the belongings of Brunete found there, and this, together with the receipts for the expenses incurred in the burial, was given to me as first executor.

On the 21st, after all details had been attended to, we left Pasco and spent the night at Huariaca, where we waited for the muleteer until the 22nd; he arrived then with the belongings of the deceased and, after changing the mules, we went to spend the night at the Ollerias. We arrived at Huánuco on the $23 \mathrm{rd}$, and on the three following days all of Brunete's belongings were sold at auction. 
The rest of the month I spent in rewriting various descriptions of plants that I had in rough draft.

In June I gave notice of the death of our companion Brunete to the general superintendent of the Royal Exchequer of Peru and to the Ministry of the Indies and to the facultative director of the botanical expeditions.

I continued the rest of the month describing plants and drying new specimens of many lost on the "San Pedro." I made a clean copy of the descriptions and gave some to be drawn.

In July of the same year I repeated the notice of the death of the first draftsman and continued replacing the specimens of plants lost on the "San Pedro" and renewing their descriptions.

After having prepared supplies for a trip to the montañas of Pillao, we decided to begin this journey in August. 


\section{CHAPTER XLV}

Chulguillo-Vegetation of hills and ravines-Preparations for the work.

\section{JOURNEY TO PILLAO AND ITS MONTAÑA}

On the 3rd of August, 1787 I left Huánuco with my companion Pavón and Tafalla, the assistant, at 9 o'clock and went to pass the night at Chulguillo, a hacienda 3 leagues distant from Huánuco, where there are four date palms that do not yield ripe fruit because they are all females and lack the male palm, a circumstance that was not known to the owner of that property. On the 4 th we arrived in Pillao, without anything worth mentioning except the great heat of the sun. On this road nothing special is to be found except the various plants covering the hills and ravines; among them there is an abundance of cactus, tillandsias, manglillos or caballerias, bignonias, pipers, Macrocnemum, Poinciana, Rubus, calceolarias, and orchids, and many other larger and smaller plants in those good pastures.

On the 5th we arranged everything necessary to start our work, placing the camp tents in front of the small rancho that had been been assigned to us by the mayor, in order to be able to dry the plants with convenience and good light. On the 6th we began our excursions through the woods and hills of Pillao. On the 10th in the afternoon, the draftsmen Gálvez and Pulgar arrived, and the next day we began to give them plants to draw. We continued working in Pillao until the 25th of September, and during this time we gathered many dried specimens of new plants. 


\section{CHAPTER XLVI}

Location, climate, pastures, fields-Population-Building construction-FishingMinerals-Birds-Waters-Healthfulness of the place.

\section{DESCRIPTION OF THE PUEBLO OF PILLAO}

The pueblo of Pillao is situated to the north-northeast of Huánuco and at a distance of 12 leagues from this city, near the summit of an extensive and high hill where the temperature is pleasant in the daytime but quite cool at night, as they often have frosts. Fogs are also very frequent during the time of the rains, and in the summer there are clouds and showers of short duration. From the town to the Huánuco river, that passes at the foot of the hill, there is a very steep climb of a league and a half, but all of these grounds are covered with good pastures, bushes, shrubs, and trees, as is the entire ground from the town upwards to the highest of the hills where the quinos or slender cascarillos grow among an infinite numbers of other trees, shrubs, bushes, and grass. The pastures found on the highest ground of Pillao are very abundant and extend, in part, four leagues until they enter the dense montaña where no more grass can be seen. In these pleasant places with good pasture, the Indians graze some cattle and some mules with which they travel to the montañas to get quina and coca, the only articles of commerce that those Indians have.

The fields are excellent for all kinds of plantations, but because of the small number of inhabitants the fields are idle, and the natives are satisfied to plant only the few seeds and roots that they need for their nourishment, these being reduced to corn, beans, potatoes (which are very good, for this reason they sometimes take loads to sell in Huánuco), yucas, and some poorly cultivated vegetables.

The population hardly exceeds 55 inhabitants, all of them Indians and poor, in the midst of the riches of those vast grounds they possess, because this is the last town that we Spaniards have in that region, the rest of it being the royal montañas adjacent to the heathen Indians. Pillao belongs to the government of the montañas and to the parish of Valle. Thoughout most of the year it lacks the spiritual nourishment that it had a few years ago, when it was assigned to the missionary fathers of Ocopa, as the last settlement of that place. 
The other buildings and the church of Pillao are built of soil, adobe, lime, and stone, and are roofed with wooden framework and straw. The ranchos are separated one from the other to prevent fire from spreading; behind each rancho the owner has a garden with some vegetables and various flowers with which images and altars are decorated.

In the river they catch bagres and cachuelos with a very delicious taste. A fine black sand is found at the margin of the river, below Pillao. In different places there are signs of minerals, of silver and gold, and even in the town itself we started to dig a vein that gave signs of being a branch of a gold mine because of the varied colors of the soil excavated in the two days that we had six men at work there. In the hills of Pillao there are several species of clay of different colors.

In the town, thrushes and sparrows abound; but in the country, there are turkey hens and gallinas del monte, parrots, treguilles, condors, dominicanos, picazas or woodpeckers, that also are found in the town, and several other small montaña and water birds. There are many deer and a few leoncillos and michus.

The waters of the brooks of Pillao are very good, but on the heights there are some waters containing lime because they pass through or are detained in cretaceous or calcareous ground.

The ground of Pillao is healthful because of its altitude, but conducive to colds and pains in the side. The Indians cure themselves with herbs applied by the women, because physicians are not known there. The enemas are administered by means of a cow's bladder with a little tube made of carrizo or caña braba [wild cane]. 


\section{CHAPTER XLVII}

Tiresome march-Misfortunes-Narrowness of Chacahuasí-Torrential rains -Earthquakes-Landslides-Location of Chacahuasí-Dangerous environsThe Pilco river and fishing in it-Birds-Butterflies-The heat-Fogs-Unhealthfulness-Parrots and monkeys-The bridge over the Río Grande-Hardships of the cascarilleros-Procedure in crossing the rivers-Skin affections caused by the humidity and heat.

\section{JOURNEY TO CHACAHUASI OR CASA DEL PUENTE}

On the 26th of September, 1787, we left Pillao for Chacahuasí, passing the night on the hill of Sillcay. On the 27 th we had traveled barely a quarter of a league from Sillcay, when we entered a very narrow road, which for more than two leagues is made almost impassable by the deep miry places and holes, with the frequent showers that are experienced at that elevation all year round; indeed it is a very rare day that does not bring rain or fog, though most of the days succeed in getting some interval of sunshine. We spent more than six hours in traveling those two leagues, because it was a rare pack mule that did not fall or get stuck in the mud at least ten times; and there were occasions when they all were mired or lying down at the same time in those swamps and narrow places. The muleteers, being tired of contending not only with the mules but also with the ground in which they sank to above their knees, and not being able to attend to everything at once, sat down tired and disgusted until we encouraged them by dismounting and helping them to unload, load, and get the mules out of the mud; otherwise we would not have been out of that small hell until the next day. When we were almost out of those mudholes, to complete the show, two of our pack mules fell down a slope between trees and bushes which we had to cut to be able to pull them out with ropes and help them climb the slope to the road.

The muleteers, mules, and loads were covered with mud everywhere; and it was pitiful to see those unfortunate men, who are naturally patient and silent, almost crazed and desperate. Finally we reached solid ground, but the road was very narrow and had high stone steps and was covered with coarse gravel for more than a league. On this stretch the mules suffered greatly from pounding those steps, from the swaying of the loads, and with the pain in their feet caused by the stones; for this reason they arrived bruised and most of them very tired at Iscutunam, a place distant a league and a half from Chacahuasí, with very little and poor grass. Here 
we were obliged to spend the night that had overtaken us an hour before arriving at this place, which was very inconvenient, situated on steep ground, damp and surrounded by different trees, among which abound Cinchona purpurea, the purple-leaved quina tree.

On the 28th, after having descended from Iscutunam to the river, we had to climb another hill; the winding of its steep road makes its descent no less dangerous, especially for the pack and saddle mules and even for men who walk on foot wearing boots, because the soil is of coarse sand and therefore slippery. We arrived in Chacahuasí, that is, the "House of the Bridge," because there is one there made of reeds, for communication with the other side of the river, where the natives were drying fine cascarilla and making extract of its fresh bark.

When we found ourselves in that very narrow, deep dungeon where the sun penetrates only at midday and, surprised, surveyed with our eyes that oppressive and gloomy. place, in which at night, if it ever were clear at that season, one could count the stars; nothing could make us stay one single day, except the desire to comply with our commission by examining those three towering and inaccessible hills, covered from the summit to the banks of the two turbulent rivers, with tall trees, shrubs, and bushes. Nothwithstanding our feeling of oppression, we discharged the muleteers, and we asked the Indians, who, by order of the mayor of Pillao and at our expense had begun to construct a rancho or shelter, to surround it with pieces of balsa trees, because we had hardly arrived in that deep, dark cavern when copious showers began to fall, the water coming in on all sides of the shelter, the low eaves of which were not sufficient to prevent its entrance.

On the 29th the enclosed rancho was finished and, since the Indians had gone with the muleteers, we were left alone with four gatherers of cascarilla who lived in as many small ranchos that two of them had made for this purpose; because the other two ranchos on the opposite side of the little river were already constructed in two small coca groves that belong to the Indians of Pillao. At nightfall the rain continued and throughout all the next day, the 30th, without let; because of this the river became so swollen that its precipitate, noisy current frightened us terribly. At 7 o'clock in the morning the ground shook, and this phenomenon caused great uneasiness on account of the depth and narrowness of the place in which we were. At noonday we heard a sudden, terrific displacement of several cliffs that came down accompanied by 
stones and a great quantity of soil and trees into the big river from the hill of the other side opposite our rancho. The landslide lasted more than half an hour with repeated intermissions. In the afternoon the slides were repeated until the rain stopped. These landslides of the hills and trees are very frequent in the montañas in the time of rains, and therefore it is very dangerous to travel at that time over its narrow, badly formed trails.

Chacahuasí, or the "House of the Bridge," is situated at the foot of one of the three very tall, rough hills that form that narrow, triangular depth, bathed by two confined rivers that descend from the quebradas of the south and east; uniting there with incessant noise, its waters run very precipitately through the quebrada of the north towards Cuchero.

In the vicinity of Chacahuasí there is not the smallest clear space to be found and, although there are three or four coca groves, these are located on the slopes of the hills and at the margins of the rivers on rocky ground and surrounded by bushes and precipices, so that no one could travel through those places at night without being in imminent danger of losing his life. The river that passes by the south quebrada is the same that flows past Huanuco with the name of Pillco, but carrying much more water, and its waters are quite salty, on account of the several saline springs that empty into it from Huánuco on. They fish in this river, getting bagres, boconcitos, cachuelos, and corbinas up to half a yard in length and six pounds in weight, but we lacked fishermen.

There are few species of birds in that deep dungeon; the most common are the kuiches or poccochicuis, the tunguis, quianquianes, and papamoscas; but half a league from the bridge on the way to Pillao one may hear the melody and sweet singing of several small birds of different sizes and colors, such as the oropendolas [weaverbirds], ruiseñores [nightingales], and organistas. There are few beautiful butterflies, but there is no lack of small moths or Phalenas, that at night come to fly around the candles until their wings are burned and they fall; there are also many mosquitoes and other insects of different sizes that help the crickets, frogs, and cicadas that kept us company in that gloomy depth, to annoy us day and night with their discordant singing and disagreeable and incessant creaking and buzzing. This disorderly orchestra, accompanied by that of the two noisy rivers, did not permit us to understand each other's conversation without shouting and repeating most of the words, and it made us stupefied and almost crazy, and 
tired of ourselves, and we had the disadvantage of not being able to have recourse to any place more quiet, nor to better company or conversation.

The heat there is excessive and the rains frequent, and from the rivers comes a dense and continuous fog especially from September until May, all of which makes that place unhealthy and dismal, and so damp that the food taken there spoils very readily. Even the little coca that is harvested in that spot is of bad quality on account of the excess of dampness and lack of sunshine, so that it scarcely is desired even by the Indians who cultivate it.

On the way to Chacahuasí very small fields are planted with sugar cane for chewing and for making huarapo [fermented cane juice], a drink enjoyed by the Indians. In the same coca groves and sugar fields there are some pineapples, plantains, papayas, red peppers, yucas or cassava, sweet potatoes, and ssaguis.

In the mornings and afternoons one sees, flying high, flocks of parrots and magpies in such numbers that they shade the ground as if they were clouds. Every day flocks of monkeys come down to the river, jumping from tree to tree with great clamor and racket. There are two kinds, black and purplish; the first are big and ugly, and the others small and well shaped.

The bridge over the large river by which the cascarilleros and peons who come for the quina have to pass, is about sixty yards in length and is made of three cables of vines very well joined; the two lateral ones serve as handrails, and the one in the middle for walking on. From the laterals to the other cable thin vines are laced and passed with a turn around the middle rope; they secure and hold together the three ropes or cables, forming all together a bridge with very light balustrades and one that because of this is very dangerous to cross. They renew it every year or before if necessary, and mend it frequently, changing the transverse vines that break or stretch too much, thereby preventing the passengers from reaching the guide ropes; this happened to my companion Pavón, and when he was at the middle of the bridge and not able to reach the balustrades, he would have been in the greatest danger of perishing in the river below if one of the peons had not helped him in that predicament. Likewise the following day, a peon crossing the bridge with a load of three arrobas of quina was saved from falling, as did his load, into the river but, although he complained of having hurt his neck, he saved his own life. 
Only the interest in the valuable and universal specific quina could move man to live as those laborers live so many days; they appeared at times, in the frequent showers, dense fogs, and very dark nights of those dark solitudes with the greatest of inconveniences and poverty, going little short of naked, and nourished with ccamcha and coca when their salted meat and green peas or beans gave out, soaked continually in the woods, and walking over precipices and inclines so dangerous that only to think of them makes one shudder. When there is no bridge, the Indians pass this and other rivers with rafts that they make of the wood of two species of Bombax or of the huampo, a species of Heliocarpus dioica. Also from the barks of the chuuima, a species of Bombax, they make cables with which they cross the river after having fastened them to trees, timber, or rocks, loaded with a quie or bundle of three arrobas of quina that they bring down from the mountains on their shoulders four, five, or six leagues; many times when they cross the river, this will carry the load away, and sometimes it has happened that the Indians have drowned.

In these deep places the heat is so great and damp that one perspires continually, and those who are not used to walking through the montañas reales ${ }^{1}$ are attacked by innumerable eruptions, particularly on the legs, with intolerable itching that starts in the afternoon and continues most of the night, compelling one to scratch with the back of a knife, because the nails are not sufficient, until one makes a bloody mess; this has happened many times to us botanists after we have arrived from the montañas at the ranchos or camp tents.

${ }^{1}$ See footnote on page 56. 


\section{CHAPTER XLVIII}

Miserable condition of the cascarilleros-Abuses and outrages-Improper felling of trees-Imperfect methods of packing--Order for our return to SpainPlants gathered in Pillao and Chacahuasí-Their uses.

The Indians of the pueblos of Comayo and Panao and especially those of Pillao, have brought thousands of arrobas of cascarilla; nevertheless they are always naked, and they owe almost continually a hundred or two hundred arrobas, the intrinsic value of which greatly exceeds that of all their dwellings, fields, and cattle. This obvious truth will surprise those that do not know that the buyers recover the money that they always pay them in advance for the quina, by odd and not the most direct methods; but this is not the worst, for most of them die without spiritual help, as we have witnessed several times. Their burial, too, that by schedule is not worth any more than four and a half pesos, is not paid with 50 and sometimes 100 pesos and will never be completely paid, because the priests, interests, and magistrates keep the accounts as they see fit, and they never cancel debts even if they have been paid three times over. The feasts of the Church, since they are observed by the Indians not because of true devotion, rather for getting drunk and so that the priests may make their harvest, are often transferred and postponed by orders of the priests, so that the parishioners may first gather the arrobas of cascarilla that they need to pay Dn. So and So, who has applied some pressure; that is, when they are not relations of the priests, in which case, like these, they will never be completely paid. The people who trade in this branch of commerce try to advance to the Indians not only money, but also baizes, light cotton goods, clothes, and other effects, for which they are always in debt, a practice which has made agricultural production in the frontier towns of the montañas notably backward, so that the Indians, because of lack of nourishment, are more subject to illness and their pueblos are on the decline.

In the year 1784, in only eight days 55 Indians from Pillao gathered 1000 arrobas of quina, but if one examines the wealth of the whole town, he will find it not worth 100 arrobas.

The Indians, who by nature are indolent and lazy in their work, are oppressed with orders from the priests and justices if they do not pay at the time specified and, to get out of debt, they attempt to gather in a few days all the quina that they owe, and so in 
their rivalry they destroy mountains of cascarilla, cutting all the tree they can in one or two days. Then when they want to remove the bark, the trees are already too dry, so that, not being able to cut it with ease, they abandon a great number of trees, or the bark is very poorly cut. Other and no less damage has been done to the mountains by cutting the old and new quino trees near the ground, and so it has come to pass that in less than 10 years the Indians of Pillao, who formerly gathered cascarillos at a distance of one or two leagues from the town, have to go more than 14 leagues into the montañas to be able to obtain cascarilla, and they have to transport it on their shoulders 5 and 7 leagues, as they were doing in the year 1787. This same mutilation of quino trees has been going on in Cuchero, Sayan, Cayumba, Muña, Panao, and in the provinces of Huamalíes, Tarma, and Xauxa, from the montañas of which they have taken, in eight years, according to ordinary calculations, more than 140,000 arrobas of quina, without counting the many arrobas that have been worked for extract made from fresh bark, superior to any made from dry, stale bark.

On the 11th of October they took out, from the Puente de Pillao to Huánuco, 120 arrobas of quina and 6 of extract. On this occasion I observed anew the poor method employed by the gatherers in sacking up and packing the quina in bags of coarse weave or homespun cotton, because while many barks are still wet and somewhat mouldy in their interior, they put them into the sacks, stepping on them vigorously and breaking them excessively so as to be able to get more into the sacks. Afterwards they travel to Huánuco without any covering or, if they use anything to protect the sacks from the rain and fog, it is thin blankets of the same weave, that has little or no value for the purpose.

On the 12th of October of the same year, I received a notice from the general superintendent, Dn. Jorge Escobedo, that, because of a royal order, I should return with my companions to Lima to go on from there to Spain. This order I communicated immediately to my companions as the most favorable, according to my feelings, that I could give them, considering it as redemption and rest from the repeated hardships, hard toils, and misery that we had suffered through those thickets and precipices, as we wandered over mountains and deserts, badly nourished and completely exhausted.

During our excursions through the montañas of Pillao and Chacahuasí, I gathered and put in press a great number of plants, of which some were sketched, and I described the following. 
Canna iridiflora, achyra; on account of its beautiful and varied flowers it serves as decoration in gardens. Buddleia incana, quisoar; its wood because of its strength and durability is valued for buildings. Basella diffusa, uspica. This plant is used in stews, called locros, a common food in Peru. Salvia acuminata. Myosotis humilis. Veronica rotundifolia, peregrina, and serpyllifolia L. Acaena globosa. Celsia affin. ovata and linearis. Phytolacca icosandra L. Gualtheria rubra and alba. Calceolaria umbellata. Abatia rugosa, tauhac-tauhac, Yoriturp, and Galvetana. Alchemilla rotundifolia and tripartita. Cinchona hirsuta, fine and thin cascarillo. Dillenia aff. rubra, incense tree. Pinguicula stellata. Stapelia hirta. Alstroemeria tomentosa. Rhynchotheca spinosa. Eriocaulon vaginans and parvum. Psychotria coerulea. Weinmannia ovalis, machi; from its trunk one gets beautiful boards and planks for buildings and boxes. Virgularia lanceolata, manccapagui. Stereoxylon patens, tassta. Cuellaria revoluta, ferruginea, cineraria, linearis. Columellia corymbosa. A very thick tree; its wood is suitable for various purposes, and its leaves have febrifugal properties and are very bitter. Anthericum aff. falcatum. Weinmannia pubescens, ovata, and alata. Hypericum subulatum and corymbosum, chinchanho, plants used by the Indians for dyeing wools and cotton yellow. Munnozia corymbosa and venosissima. Arbutus parvifolia, macha, on account of the intoxicating properties of its fruits. Betula nigra, ram-ram. With the bark of this tree infused in urine, the Indians tan and give color to sole leather, and give a cinnamon color to cotton and woolen goods. The leaves ground with lard in the shape of poultices clean and heal ulcers, and without the lard are used against inflammations; applied to recent wounds they stop the flow of blood. Maxillaria paniculata. Browallia demissa L. Antirrhinum avenium. Sisyrinchium anceps and ocsapurga, palma-palma and paja purgante, for the purgative value of its roots when administered as a concoction. From only tasting of the roots, the mouth retains for more than six hours a biting and bitter taste which is very disagreeable; for this reason I think that this laxative should be administered with care, although in Huánuco, where they call it paracso, and in Tarma, where it is known by the name of ocssa purga, they use it very frequently. Gentiana violacea. Vaccinium dependens; a beautiful shrub for gardening because it can be shaped like the box; it is known by the name of sachsauro. Mespilus ferruginea, llinlli. Senecio foetidus. Piper granulosum and ovale. Cuphea cordata. Acrostichum Cuac- 
saro, cuacsaro, that is, masked back; in the market they sell its roots for the true calaguala, although it does not have the same virtues as this specie of Polypodium, as anyone who likes may inform himself in my Memoir on the Calagualas in the first volume of the Memoirs of the Royal Medical Academy of Madrid, printed in 1797. Andromeda aff. glauca, congama. And. aff. mellifera, sumacmisqui, that is, sweet honey, for the nectar contained in its flowers. And. aff. bracteata, pucsato; its fruits are very tasty, and the Indian women take them to the market place of Huánuco to sell. Ternstroemia globosa and quinquepartita, beautiful shrubs for gardening on account of the shapes that may be formed from them. Xyris lutea. Perdicium lanatum. Cineraria lanceolata. Foveolaria ferruginea, ovata, and oblonga. Molina corymbosa, nitida, prostrata, incana, and salicifolia; resinous, balsamic, and corroborant plants. Prunus ovalis; tree with an ordinary wood. Melaleuca coriacea; shrub ten yards in height. Juniperus aff. Tree of Dioecia monadelphia. Passiflora rosea, puru-puru. The children eat its fruits. Loranthus luteus, enlaora. Shrub of 10 to 12 yards in height and not parasitic, as are the other species of this genus; when it is in bloom, it is very beautiful because of the abundance of its yellow flowers. Polygala aff. discolor, mascea. With the bark of its roots, which are very bitter and form a foam as of soap, the Indian women wash their hair to clean it and make it grow. Cytisus canescens, chucchoclle. Its shoots or saplings are used to make ramrods, and the leaves are eaten with relish by the cuyes or ccoyes [guinea pigs]. Solanum nitidum, oblongum, nutans, and stellatum, campucassa, and in Panao called huiscacassa. Their leaves when toasted have the virtue of expelling thorns in the hands or any other part of the body and draining putrid sores. Caballeria venosissima. Solanum granulosum, chuculate. Anthemis striata, virgenhacha and manzanilla cimarrona or wild chamomile. Anthemis pallescens; the roots of this plant are more burning and excite salivation with more activity than pelitre; the sharpness lasts on the tongue for six hours. Cuscuta odorata, cabellos de angeles. Acunna lanceolata, tall tree. Fernandezia denticulata, graminifolia, and haematodes. Bowlesia lobata. Epidendrum scabrum.

In Chacahuasí, I described the following plants. Heliconia tricolor. Cissampelos villosa. Clusia rosea, matapalo; see the chapter on Cuchero for the application of its resin. Maxillaria longipetala, ligulata, and hastata. Glycyrrhiza undulata. Eupatorium stridens. Varronia dichotoma. Olyra latifolia, bombilla. Its 
culms or hollow canes are used to make bombillas or cañoncitos for drinking mate or any other hot liquors, according to the custom in Peru. This grass is excellent nourishment for the animals, and deserves to be extended for that reason all over the world, as it is a magnificent grass and well bunched. Scirpus fragrans; the precious fragrance of the roots is similar to that of spikenard in the green state; it serves also as feed for the cattle that come from Pillao to Chacahuasí. Heliconia angustiflora. Actinophyllum conicum. In this shrub as in the other species of its genus, there are found drops of white and clear gum that dissolves in water. Tafalla laevis, aitacupi. Sauvagesia subtriflora, yerba de San Martín. Its concoction is employed by the natives against sickness of the chest. Tovaria pendula. Spermacoce capitata. Guarea nitida. Piper nitidum, asperum, punctatum, crocatum and longifolium, secundum, betulioum. Marcgravia monopetala and pentapetala, purumhigos, that is, false figs, on account of the similarity of the shape and taste of its fruits to figs; when ripe, they are eaten by the Indians. Erythroxylon patens. Costus laevis. Celtis spinosa. Peperomia rhombea and secunda. Nycterisition ferrugineum, chicchimicuna, that is bat's food; a tall tree, leafy, and with a straight thick trunk with strong wood of good grain. Villaresia emarginata. Clusia decussata and trioecia. Turraea guinata. Croton acutifolium. Peperomia variegata. Pourretia sympaganthera. Fagara coriandriodora, culantro, on account of the odor similar to coriander. Its wood is of extreme hardness and, although it is not a very tall tree, it has a medium trunk and good foliage. In Chacahuasí I observed that this tree was dioecio-polygamous, but it had been considered before as hermaphrodite of the class Tetrandria where it was placed by Linnaeus. Cissus compressicaulis. Cynanchum acuminatum. Milium crinense, maiz de Guinea [Guinea corn]. They plant small patches of this plant in the pueblos of Pampamarca, Pueblo Nuevo, Cuchero, and other places in the montañas in order to harvest its grain which they eat afterwards as camcha, or roasted. After being made into flour, it is used to make mazamorras or puches [a sort of pap], and ullpus; its flour is very white and has a better taste than the flour of Zea Mais. Justicia longistaminea. Psychotria violacea. Melochia cordifolia. Elephantopus capitatae. Ruellia curvata. Acladodea pinnata. This small tree has only a trunk without any branches; the leaves are found at the top and, although they proceed from separate points, they present the shape of a parasol in the manner of the tree ferns and 
palms: from the extremity of the trunk arises a single cluster of flowers, large and beautiful. This is the only tree I have seen with the peculiarity of lacking branches and not bearing more than one cluster of flowers, which, after the new tip of the tree has grown out, stays inserted at one side of it. Neea oppositifolia. Humboldtia lanceolata. Chondodendron tomentosum. Tafalla racemosa and angustifolia, aitacupi. Synzyganthera purpurea. Stereoxylon paniculatum. Miconia emarginata. Hedyotis filiformis. Echites laxa. 


\section{CHAPTER XLIX}

Fatigue of the mules-Fury of a mule-Illness of Tafalla-Painful marchDeadly gases-Arrival and work at Huánuco-The year 1788.

\section{FROM CHACAHUASÍ TO HỨNUCO}

On the 22nd of October, 1787, we left Chacahuasí at ten o'clock and spent the night at Iscutunam, and in the vicinity we collected several plants, which we put in press. It rained a little on the way. On the 23rd we left Iscutunam at nine in the morning; after half a league of travel, two of the pack mules became tired. One of them had to stay on the spot because she could not walk any farther, and the other continued with the load a quarter of a league farther, where we left her, changing the load to my servant's saddle mule. The fatigued beast was so furious that if any one approached her after she had been unloaded, she attacked, biting, and in one of her attacks she seized a mouthful from the side of Tafalla, the assistant, and pulled a strip off his coat from top to bottom, and in half a turn that the mule gave she tore from an Indian a piece of his trousers and afterwards followed him around like a wild beast for about ten paces until he saved himself by hiding behind a tree. In both cases the spectators were surprised, and a little later we laughed excessively at the mere thought of the antics and of the cries of "bull" and "bullfighters" of those who were as frightened as if they had been in the claws of a lion. That lawless animal was left there, and we continued on our way; about two hundred yards farther on, Tafalla's saddle mule felt so tired that it was necessary to take the saddle off and place it on my servant's saddle mule, leaving the tired mule. From this place the assistant and the servants went on foot. A little farther ahead, another fatigued pack mule fell into a patch of reeds by the side of the road, from which it had to be pulled out by the combined efforts of all; we left only a half load on her, and the other half was carried by a muleteer until we climbed the tiresome hill of Saria, where this last mule became so completely exhausted that we had to transfer the half load she was carrying to Pavón's servant's saddle mule, the muleteer continuing with the other half load from Achapatumam until Torrehuasí, a long half league of mudholes and bad road. When the last of us reached the Pascana, the muleteers had gone ahead and had already fixed the camp tents over a place filled with short grass but full of water. There Tafalla, the assistant, who 
had gone ahead since he found himself on foot, and was in bed shivering with cold and with such a high fever, owing probably to fatigue on the way and to the cold that is felt at that altitude the year round, that we though he was going to die that same night; but with the help of some hot water with sugar and of shelter, he perspired and recovered sufficiently to be able to travel by mule the following day. This night a very heavy shower fell that lasted three hours and soaked almost all of our baggage.

The 24th arrived with a dense fog, so that it was difficult to get the mules; for this reason we loaded a little late and were caught on those heights by a long, heavy shower, with the result that the pack mules were stuck at each step. Because the muleteers were not able to get them up, we constituted ourselves their helpers, as before, until the shower stopped, and they could manage their charges alone. Those of us who rode mules were obliged, by the frequent muddy places, to walk on foot most of the way through those marshes, mires, moors, and mudholes, and we fell into them many times, not one of us escaping these tiresome mishaps during the two leagues of this bad road. All of us came out of this well soaked and covered with mud from head to foot.

From the bridge to Achapatumam there are five leagues of dangerous and very trying climb, because the road is a continuous and narrow declivity of a rocky, rough ground, with high, narrow steps, and on account of there being there what they call beta, that is a silver mine, with antimony, from which gases are expelled that fatigue even the most resistant animals and take the life of many beasts, as is evident from the multitude of bones that are found there. From Achapatumam to Sillcay there are three leagues of road, perennially marshy, especially the two leagues near to Torrehuasí. Any animal that is tired when it reaches the mires, generally dies in them, and for this reason the Indian muleteers try to pass this place in one single day. Only interest or honor could make a man travel by such a miserable road as the one from Pillao to Chacahuasí.

We arrived before dark at the pueblo of Pillao, and we remained there the 25th to dry the baggage that had arrived wet and covered with mud.

On the 26th at midday, we were able to leave Pillao, and we traveled three leagues until we reached the Tingo, or union of the Acomayo river with that of the Huánuco, having had a brief shower 
on the way. On the 27 th we arrived in Huánuco without any other unpleasantness than the excessive heat of that quebrada.

From the 28th of October until the end of December of the same year we continued drying the plants that we brought in presses from the montañas and the ones we gathered on the way, and the roots, seeds, and other parts of various plants. I finished several descriptions, and worked anew with other plants of the vicinity of Huánuco. I answered all official letters, and sent to the Ministry of the Indies all the seeds collected in the montañas and at Huánuco. We made packages of all the dried plants after classifying them. Our entire collection of natural products we boxed to take to Lima. I corrected the descriptions of many Malvaceae and made clean copy of various descriptions.

THE YEAR 1788

We asked for beasts of burden to go down to Lima and return to Spain in the first vessels to leave for Cádiz.

In the month of January, I described Berberis lutea, ccarhuascassa, that is, "espino amarillo," common sea buckthorn, with wood of which the Indian women dye baizes and cottons a beautiful and permanent yellow color; the Indians make axe handles, hoes, etc., from its wood because it is very strong. I continued making fair copy of several descriptions.

On the 17th of January, we received from the province of Huamalíes and from the pueblo Chaucha, 32 mules, with which we equipped the assistants, who left that same day with 25 loads of boxes and other effects.

On the 24th there arrived from the pueblo of Chaulan the additional mules needed for the rest of us for our departure for Huánuco. This very day we sent the remaining loads with the muleteers a distance of a league from the city. Because it rained all day the 25 th, we could not leave until the following day. 


\section{CHAPTER L}

Itinerary-Plants gathered and described-The Limonia trifoliata and Verbena citriodora-The Cerbera salicifolia-Uses of its seeds-Packing the collections - Good offices of Father González Laguna-Settlement of accounts-Preparations for embarking-Living plants for Madrid-Reversal of the edict-Embarking in the "Dragon."-Arrival in Spain.

\section{RETURN FROM HUÁNUCO TO LIMA}

On the 26th of January, 1788, I left Huánuco with my companion Pavón and our servants; on the advice of a mestizo that joined us on the way near the district of Ambo, we spent the night in the pueblo of Chaucha, without having been able to overtake the muleteers.

On the 27th, we overtook the last muleteers in the descent of the pueblo of Rondos, and we spent the night in the pueblo of Huariaca, where the assistants were detained with the other loads.

On the 28th we all left Huariaca, passed by Yacan, a small pueblo surrounded by elders that beautify it and make that height conspicuous from a distance. We slept at one of the several baguenas, or grazing farms, that are found in those cold and high places with bad trails, with many mudholes, mires, and rocks. Here I picked and described the Nicotiana parviflora. On the 29 th we arrived at the town of Pasco, crossing through the mine at the hill of Yauricocha, without any other mishaps than frequent hailstorms and showers upon those muddy trails. On the 30th we waited in Pasco for a change of mules, and on the 31st we went on to sleep at the estancia Diezmo.

On the 1st of February, 1788 we went on to the pampa of Palcamayo, and we had showers several times. We spent the night of the 2nd on the pampa of Hacaybamba with hail, snow, and showers the 3rd we came to Obrajillo [coarse wool and cotton cloth factory], after having successfully passed the cordillera and its difficult descent by the rocky, stony road to the pueblo of Culluay.

For lack of mules we were detained in the pueblo of Obrajillo until the 7th. This gave me opportunity to put in press several plants, and I described anew Cestrum auriculatum, hierba hedionda; its properties and uses are already referred to in another place. Lycium umbellatum, quiebra ollas. Molina scandens, chilca, a resiniferous, balsamic, and corroborant plant. Physalis subtriflora. Verbena cuneata. It is found in Mayobamba. Salvia ovata and linearis. Carica canescens, mito, the ripe fruits of which are the size 
of an ordinary lemon with a good odor and a not unpleasant flavor. Pancratium uncinatum, chihucanhuaita. Calceolaria inflexa, angustiflora, crenata, maculata, nutans, trifida, cuneiformis, virgata, pulverulenta. Valeriana virgata. Galium hirsutum. Saracha contorta, dentata, and procumbens. Rhinanthus lutea. Scutellaria coccinea. Euphorbia tuberosa, huachamccana; with the roots of this plant the people purge themselves frequently in several parts of Peru, and the Indians of Canta bring them down to Lima with other roots to sell them on the corners of the plaza mayor. Although the purgative is strong, the Indians moderate its action with only a glass of cold water. Staehelina sarmentosa, rincri-rincri, that is, orejaoreja [ear-ear]. Achyranthes purpureo-violacea. Periphragmos uniflorus, ceantu, a beautiful shrub with which they decorate the fences of the orchards and properties, and that in the time of the pagans was used by the Indians in their auguries and superstitious rites. Baitaria acaulis. Kageneckia lanceolata. Its bark and leaves, which are bitter, are used in infusions against tertian fever.

On the 7th the mayor, using his power, compelled the Indians by force, putting some of them in jail, to transport our baggage because our commands or money paid in advance could not make them do it; in this way we left Obrajillo near noon. We spent the night at the foot of the hill of Pacron, where Brunete's mule had fallen down the precipice and had had other mishaps that bad night, costing it its life. On the 8th we climbed and luckily passed the ascent to Pacron, although, in a most dangerous place, the girth of one of the pack mules broke. We slept at Checta. We spent the night of the 9th at the hacienda of Caballero, and from there we went to Lima on the 10th without other unpleasantness than the excessive heat on the way.

After we had delivered the boxes of products in the customhouse, we went to look for a place to live and to put our baggage; it arrived in Lima the next day with part of the boxes, and these were also taken to the royal customhouse.

On the 14th we went to present ourselves to the Viceroy and general superintendent, Dn. Jorge Escobedo, who repeated to us the order for our return to Spain in one of the vessels that were about to sail.

During the following days of this month I continued drying the plants gathered on the way. I described Limonia trifoliata, the limoncillo of China, from the fruits of which they make the sweets called limoncillos de China. This plant is not a native of Peru but was 
carried from some Asiatic country to Panamá and from there brought to Lima. I examined it and also the Verbena citriodora, cedron, that was sent from Chile to Lima, and there I repeated the description that I made in Santiago de Chile, where this plant was brought from Buenos Aires. I described the Cerbera salicifolia, which, with the previous ones, the R. P. Francisco González Laguna was cultivating in his Jardín de la Buena Muerte. With the shells of the fruits of this plant the Indians make a string called cascabeles, which they use frequently in their dances, placing them about the neck, arms, and legs for the rattle they make when they are shaken against each other. To be able to form these strings, they burn the nuts or bony fruits of the Cerbera on one side, not only to open them there to take out the almond, but to make them more solid.

I went to the office of the secretary of the Viceroy and there they handed me a copy of a letter of the minister, Dn. Antonio Porlier, in which he gave us the pleasing news of how satisfied the King was with our work and important acquisitions. On this occasion, the Viceroy, Dn. Theodoro Croix, talked with me, asking that one of the two botanists remain there for the establishment of the catedra and botanical gardens ordered established in Lima by S. M.; His Excellency thought that Tafalla, the assistant, might be a little too young to perform these duties. I answered His Excellency and his secretary, Dn. Esteban Varea, that the assistant, Dn. Juan Tafalla, was already sufficiently well trained in botany to be able to discharge his commission, and that we others were both called to the court for the publication of our "Flora Peruana" and, that for my part, I could no less than obey the orders of the King. With this answer His Excellency desisted from his proposal; and he showed himself well pleased with my way of thinking.

After having dried the plants we had gathered on the way and made them into bundles by classes and with their generic and specific names, I boxed them up for a safe journey together with various seeds, stones, ores, and many other products gathered after the packing done in Huánuco. I made fair copy of some descriptions, and I had boxes made and fixed others for transporting to Madrid the living plants deposited in the Jardín de la Buena Muerte in the care of the R. P. Francisco González Laguna, who had preserved them with the best of care since we sent them from the montañas of Huánuco.

I appeared in the name of all of us to ask permission of the Viceroy for our return to Spain with our collections of natural products. 
On the 26th we went to say our farewell to Sr. Dn. Jorge Escobedo, who sailed for Spain on the 27th in the vessel "La Concordia."

Because the Viceroy had decreed that our boxes should be divided between the vessels "Dragon" and "Jason," I went to make arrangements with the masters of both vessels about the places where the boxes could be stowed and, when we had decided that they should be placed between decks, I went to tell the Viceroy, and it was thus ordered.

In the probate court I presented the accounts of the executorship of draftsman Brunete, exerting myself with Sr. Moreno so that my companion's property might be sent to his sister Doña Agustina Brunete by the very vessels that were getting ready to set sail after our frigate; this the judge promised to do without delay and assured me that the property would not be delayed in the coffers as usually happens.

In March, 1788, we three companions called on the Viceroy and asked for our pay as far as due and an advance of some months so that we might adjust our accounts with the merchants and supply ourselves with the necessities for the voyage. There were difficulties about everything, concerning the request by the royal officials from Lima to stop our pay from the officials of the Royal Coffers of Pasco, although we had not received anything from them except by an order from the general superintendency, where they found all of the documents. After we had presented the accounts of what we had asked in Pasco, they gave us our pay for the months due and some advance wages with which we paid our creditors and provided ourselves with the necessary things for our voyage.

On the 18th my two companions went to the port of Callao with the boxes to be distributed as arranged with the masters of the "Dragon" and the "Jason."

I wrote to the Viceroy, asking him for a cabin in which to put the pots of plants; this request was conceded, and I was assigned another adjoining cabin so that I could take care of the plants and could continue writing my botanical observations, as I did during our voyage at the same time as I was bringing to Madrid 23 crates of living plants with 68 species out of the 87 with which I left Lima.

I asked for a report of the proceedings about the fire at Macora, and it was ordered that I be given a decree annulling the sentence passed by the assessor of Tarma, Dn. Bartolomé Bedoya, that charged us, the plaintiffs, with the expenses and charges of the lawsuit against Dn. Mathias Trabuco, administrator of the hacienda of Macora. 
On the 30 th the permit for our voyage to Spain was given us, and the same night we went to bid farewell to the Viceroy; he asked me to return next day in the morning for the document concerning the fire at Macora.

On the 31st we left Lima for the port of Callao, and we shipped our baggage in the vessel "Dragon" with the 24 pots of plants brought from Lima in six heated cases, placing them in the cabin in such a way that they would not suffer with the rocking of the vessel and so that they could be taken to the quarter-deck when the weather permitted.

At 12 o'clock at night after the permits had been signed by the governor of Callao, we set sail and we traveled about a league, anchoring with a kedge anchor because the master was still to come with some things he had to bring from the port.

On the 1st of April at three in the afternoon we set sail. At dawn on the 2nd we saw the vessel "Jason" that also was making the voyage to Cádiz, but we did not see it again until after seven days.

There was no mishap on the whole trip that lasted until the 12 th of October of the same year, 1788; on this day we landed in Cádiz, and there I was in bed with fever for ten days. Dn. José Pavón and Dn. Isidro Gálvez set out on their way to Madrid on the 18th of the same month. I left Cádiz the 27 th, accompanying the plants. On the 29th they were placed in carts at the port of Santa María, and we left for Madrid, where I arrived on the 16th of December. There I was met by Dn. Mario Loredo, my uncle, and Dn. Casimiro Ortega in his carriage. I deposited the crates with plants in the Botanical Garden. 



\section{EPILOGUE \\ BY P. AUGUSTÍN JESÚS BARREIRO}

I

Words of Lagasca-Indifference of the government to the encouragement of the natural sciences-The travels of Ruiz and Pavón in Chile and Peru-The Quinología of Dn. Hipólito Ruiz and the problem of the quinas-Description of this work and its success-Appointment of Dn. Juan Tafalla and Dn. Juan Agustín Manzanilla for the continuation of the campaign of Ruiz and his companions in Chile and Peru-Tafalla discovers new species of quina trees-Attack of Zea on the doctrines of Ruiz and the latter's answer-The Suplemento a la Quinología of Ruiz.

More than a century has elapsed since the botanist Lagasca, after proclaiming theadvantages of the Spanish and American soil for all classes of natural products and the great sacrifices made by our countrymen to study them, expressed himself in the following words in his Amenidades Naturales de las Españas: "The learned men who wrote about the natural products of Spain and its colonies, could only in this way obtain from nature the knowledge that they left of our soil, climate, and products. Knowledge as precious as unjustly forgotten, scorned, or at least, held, strangely enough, by the government to be of little value, because it seldom promoted it sufficiently so that it could give the abundant fruit that it promised; rather, smothered it many times in the very cradle that had been prepared. Such are the effects of the neglect and lack of enlightenment of a government: to spoil the fruit of many expeditions, after having spent on them more money, perhaps, than all other nations put together!"

What a sad confession to make! But the conduct of the public authorities in respect to the natural sciences has changed little, at least since Lagasca's time. Without the least injustice they may well be accused, if not of lack of intelligence, at least of apathy and indifference in this respect. The only important scientific expedition organized by the Spanish government in the entire XIX century was the one in 1862 to the coasts of the Pacific, and the fruits of that expedition, so poorly prepared and so neglected, were also smothered in their own cradle, the indispensable means being refused for printing the works in which the collections of said expedition were studied. 1

In regard to other scientific expeditions of less importance as, for example, the ones made to Marruecos, there has prevailed, almost always, a financial niggardliness so extreme that at times the travelers were placed in the position of having to resort to their own pockets to defray some of the expenses for the journeys. It is not, therefore, surprising that our governments should forget the very rich collections of the past centuries, when those of the present time are of so little interest to them. This explains why the Flora Guatemalensis of Mociño and the Flora Novae Hispaniae of Mociño and Sesse were locked up in the archives; the latter was finally published by Mexicans, although without the corresponding plates, because those had been lost here in Spain. ${ }^{2}$

${ }^{1}$ See our Historia de la Comisión científica del Pacífico. Madrid, 1926.

${ }_{2}^{2}$ The history of these plates is very eventful. They were brought from Mexico by Dn. Martín Sessé in the year 1808; they later passed into the hands of Mociño, 
Dn. Hipólito Ruiz and Dn. José Pavón were not so unfortunate with their work, but even so their luck and the government were far from favoring them completely. They left Spain in 1777 and arrived at Callao in April, 1778. They stayed ten years exploring Peru and Chile, returning to Spain in the year 1788. Their first work was the Quinología o Tratado del árbol de la Quina o Cascarilla con su descripción y la de otras especies de Quinos nuevamente descubiertos. Del modo de beneficiarla, de su elección, comercio, virtudes y extracto elaborado con cortezas recientes y de la eficacia de éste comprobada con observaciones; a que se añaden algunos experimentos químicos y noticias acerca del análisis de todas ellas.-Madrid, 1792.

The problem of the quinas offered at that time a truly exceptional medical interest, on account of the proved efficacy of quina against fevers, and this explains why the Ministry of the Indies came to assign to these botanists the examination and study of the cascarillas, or quina trees, as one of the principal objects of their trip. It was for that reason, doubtless, that the treatise mentioned had the advantage of being printed before the rest of the works of Ruiz and Pavón. A glance at its pages is sufficient to reveal the care and patience with which it was prepared and the care with which it was edited. There is nothing missing from it that might be of interest for the perfect knowledge of the subject.

In the introduction to the work, Dn. Hipólito Ruiz tells of his first observations on the quina tree, in these words: "Even before the departure of $\mathrm{Mr}$. Dombey who, because of his poor health, was obliged to return to Europe in the year 1784, I had had the good fortune to recognize the true cascarillo in bloom, in the year 1779 , in the montañas of Cuchero in the province of Panatahuas, 85 leagues from Lima and some 140 from Loja, an observation which I confirmed by repeated examination of its fructification and communicated to all my companions. This happy circumstance... made me devote myself to this, during the four years that we lived in Peru after Mr. Dombey departed, namely, to investigate, to collect, describe and have sketches made of as many species of cascarillos as I could find, the number of which I succeeded in bringing up to seven. The observation and comparison of such a considerable number of species made it easier to correct and perfect more and more the description of the character of the genus Cinchona, sketched by the immortal Linnaeus and improved in the Suplementum plantarum by his son, with the help of the information furnished by our noted botanist and naturalist, Dn. José Celestino Mutis, from whose careful and extensive work in the kingdom of Santa Fe, for the term of nearly thirty years, we should promise ourselves excellent observations about the true quina tree, and the history of some species of quinos. These are said to have been discovered on his journeys, quite different, in general, from those here described, and among them, it is to be believed, there would also be some common to the very territories which I have covered in my travels. And although Mr. de la Condamine, in his memoir upon the "Arbol de la Quina," that is found in the volume of the Royal Academy of Sciences of Paris of the year 1738, described and sketched a branch of the cascarillos that he had observed in the mountains of Caxaruma, one will notice, by the comparison of his drawing and description with ours, that he did not take

who carried them to France in 1814, handing them to DeCandolle who had copies made of them. In the year 1819 they were returned to Mociño, who lived in Barcelona, and later were handed to the doctor who attended him. In 1862 they were in the possession of Dr. Dn. Rafael Esteve, and they were requested in vain. Since then their whereabouts is unknown. There were in all 3,000 plates, botanical and zoological. 
time to distinguish botanically the species he indicates and that he had seen as a curious traveler. He reduces them to only one, which is number three, Cascarilla lampiña, and not number one, Cascarilla oficinal, that is Cascarillo fino, called quino par excellence, and almost all the writers have been influenced erroneously by this learned academician." Thereupon the author demonstrates the advantages that would accrue to commerce as well as to medicine by the proper differentiation of species of quinos, and he states how pleased he was to see his opinions confirmed, in a writing of Dn. José Celestino Mutis about the virtues of the quina, that reached his hands when the prologue of this work was being printed. "What enlightenment," Ruiz adds, "may we not expect from the publication of the Quinología of such a learned master!" Ruiz also tells that he presented a box of bark of all the different species of quinos to the King, so that he could see the differences at a glance and could convince himself of those of their properties. "If with this treatise," he adds, "one could succeed in removing such serious difficulties the refers to the confusion and mixture of the different quinas], I should consider justifiable my labors and the risks to my life which I have run more than once in order to gather the materials for this Quinologia with sufficient care, climbing through mountains almost inaccessible, and never marked by human footsteps, and climbing tall trees the branches of which gave way under my feet, to have the satisfaction of being able to present to the public my descriptions made in bad weather under those hardships and with the fatigue and danger that is familiar to any experienced botanist who knows how to appreciate and distinguish these works from those made in the shelter and comfort of a study, which are as different from the first ones as are the plants that are described and sketched in their native places from those that are cultivated for other purposes in gardens or are seen dried in herbaria and are published, although lacking a part as important as is the information about their uses and properties, in anticipation of the works of their discoverers."'1

The author divides his work into two parts, and in the first he deals with the following subjects. Discoveries of the quino tree and names given to it. About trade in cascarilla. About the damage to the mountains where it is found. Replanting of these and preparation for exploitation. False and true signs by which to distinguish the species of quina trees. The properties of quina in general and of extract made from fresh bark. ${ }^{2}$

${ }^{1}$ Quinología. Prologue, page 8.-In these last phrases the author seems to refer to Cavanilles. studied.

2 This first part comprises 8 articles, in which the following subjects are

\section{ARTiCle I}

Of the first discovery of the cascarilla in the province of Loja and other territories, and information concerning its uses to Europeans and other nations. Of the origin of the name quina and of the names by which it is known in the pharmacies, and of what is there called cascarilla.

\section{ARTICLE II}

Of the discovery in the last few years of the trees of cascarilla fina or quina fina of Loja, and other species of cascarilla, in the province of Huánuco and the vicinity of Lima.

\section{ARTICLE III}

Of the commerce and consumption of cascarilla in general, deterioration of the mountains where it is found, and proposal of means to restore them and increase the number of cascarillas and improve their quality. 
Dn. Hipólito Ruiz judges probable that the Indians of the province of Loja knew the virtues of quina as a remedy against fevers and made use of the same before the Spaniards arrived. When our botanists arrived in Peru in the year 1778, persons worthy of credit asserted that, according to a tradition current there, an Indian of the province of Loja, in the year 1636, had informed the then corregidor of that province, who was suffering from fever, about the virtues mentioned. This gentleman used the remedy recommended and, as he regained his health, the news began to spread in the Spanish colony, which promptly followed the example of this public official. Two years later this man heard that the wife of the Viceroy of Lima, Dn. Jerónimo Fernández de Cabrera, count of Chinchón, was suffering from tertian fever, and without delay he sent some quina bark with a letter to the corregidor recommending very earnestly the use of this remedy.

The Viceroy, being of the opinion that no one else could direct the experiment better than that man, called the official to Lima and entrusted him with making experiments together with the doctors in the hospitals. The order was immediately executed, and the results could not have been more satisfactory.

Then they decided to recommend it to the countess, and she also recovered her health, to the great satisfaction of all and especially the corregidor. The countess was eager to make known to the rest of the people the benefits of the bark and began to distribute quina bark free, and when she left Lima in 1640, she gave some to the Jesuit fathers, so that they might do the same.

These in turn sent some to Rome, which was used by Cardinal Lugo with satisfactory results. That is the reason for the names polvos de la condesa, polvos de los Jesuítas, polvos de Lugo, as well as others such as quina, quinquina or kinquina, kina-kina, corteza peruviana, loxa, china-chana or china-canna, china-chinae or corteza febril, genciana indica, antiquatanario peruviano, and palo de calenturas.

The author of this work tells us where the different species of quino were found and who the discoverers were, citing on this account Dn. Francisco Renquifo, who found the cascarilla fina or quina de Loja in the year 1776 in the mountains and hills of San Cristóbal de Cuchero, in the province of Panatahuas. Three years later, it was observed there in bloom by Dn. Hipólito Ruiz when he visited the same mountains, as has been said above. He says that the first years that the

\section{ARTICLE IV}

About the native place in which cascarillos finos and other species grow. About the maturity and cutting of the bark, and of its drying, transport, and other operations in its preparation.

\section{ARTICLE V}

Of the waste that occurs in the cutting and commerce of cascarillas, because too much attention is paid to the color of the back, and of the arbitrariness with which they are mixed and are given preference in commerce for one reason or another.

ARTICLE VI

Of the principal dependable criteria that distinguish good cascarilla of any species cut at maturity and well prepared and stored.

\section{ARTICLE VII}

About the properties that unanimously and generally have been recognized in cascarilla or quina.

\section{ARTICLE VIII}

About the method of producing the extract of fresh cascarilla in Peru. Of the reasonableness of its price. Of preference for it to that manufactured in Europe, and even above the extract of quina in certain cases. Of new observations of its efficacy and means to guard against its adulteration. 
doctors began using the cascarilla, a pound of it was worth 6 pesos gold in Peru and 12 in Spain, but later these prices decreased for a time, owing to the campaign against quina started by the same doctors, who condemned and disparaged its use, whether on account of the ordinary aversion to anything new or because of a maxim of Hippocrates that says: "Fever should be considered an excretion that nature evacuates from morbific matter."1

Regardless of this, quina regained its value, prevailing in the whole world to such an extent that between the years 1778 and 1788 more than 70,000 arrobas of quina were taken from the mountains of Peru. This gave rise to thousands of abuses in the exploitation of the quina trees, which were cut near the ground, the mountains by such methods being stripped with great injury to the industry. Fortunately, nature itself provided a remedy for such abuses, endowing those trees with the property of sprouting and recuperating ten or twelve years after being cut, as Dn. Hipólito Ruiz well observed. For his part he exposed in his work the deplorable consequences of these abuses, and the King, Dn. Carlos IV, having resolved to stop them, sent to Loja, in the year 1792, the botanist and chemist Dn. Vicente Olmedo, an advanced pupil of the Botanical Garden of Madrid, for the task of examining the quina trees, directing the cutting and shipments, and of coming to an agreement with the corregidor of Loja about what could be done for the betterment and prosperity of this industry.

In this same book are set down the most reliable signs by which cascarilla fina may be known and distinguished, the procedure employed at that time in Peru to prepare its extract, and finally the testimony of reliable doctors who testified to its virtue and efficacy in the cure of fevers.

The second part contains the botanical descriptions corresponding to the seven species then known by the author, followed by some observations on the same species. ${ }^{2}$

\section{Quinología, page 8.}

\section{${ }^{2}$ SECOND PART}

Botanical description of the seven species of cascarilla trees that are found in Peru, some of them recently discovered. About the characters by which quina colorada, calisaya, and hoja de olivo are distinguished, and description of the tree that gives the bark originally called quina-quina, with some chemical experiments and information about its analysis.

\section{ARTICLE I}

Generic character of the quinos or cascarillos.

\section{ARTICLE II}

Description of the tree of the cascarilla fina or quina oficinal.

ARTICLE III

Description of the second species of cascarilla from the heights of Pillao, considered in commerce one of the quinas finas.

ARTiCle IV

Description of the third species of quina trees, known in the montañas of Panatahuas, adjoining the one of Huánuco, by the name cascarillos bobos or cascarillos amarillos.

\section{ARTICLE V}

Description of the fourth species of quinos, known in the montañas of Panatahuas and Huánuco by the name cascarillos bobos or de hojas moradas. 
By way of supplement, next comes the description of Myroxylon peruiferum, of Linnaeus, a tree known in Peru by the name of quino-quino and its bark as quina-quina, later applied to the quina or cascarilla of the genus Cinchona, of the same Linnaeus. ${ }^{1}$

The publication of this Quinología constituted a scientific event of great note, not only in Europe but also in Hispano-America. The proof of this is in the versions made of the same in Italian in Rome (1792), recently printed in Spain; in the German language (1794) in Göttingen, and in English in London (1800).

Before our botanists left American soil, they had the foresight to teach and instruct, by order of Carlos IV, Dn. Juan Tafalla and Dn. Augustín Manzanilla, so that they might continue the investigations; the first-named, by study of the flora, and the second as a draftsman. And to those tasks they consecrated themselves with the greatest zeal and industry, as is demonstrated by the numerous collections sent to Spain, especially by Tafalla. Among the discoveries made by him, we should mention here four new species of quina that received, respectively, the names of cascarillo de flor fina (Cinchona micrantha), cascarillo ahorquillado (C. dichotoma), cascarilla de hoja aguda (C. acutifolia), Cinchona glandulosa (C. glandulifera).

At that time Dn. Sebastián José López Ruiz brought from Santa Fe the cascarillo or quina with narrow leaves, and this he called quina turnita, C. lancifolia of Mutis, and C. angustifolia of Ruiz.

In the year 1801, Ruiz and Pavón published the Suplemento a la Quinologia, with descriptions of the four species from Peru sent by Tafalla and also the quina unita of López Ruiz, who had sent a dried specimen of the same to Dn. Hipólito Ruiz.

In this volume the two naturalists included a work under the following title: Defensa que hacen de las Quinas finas peruvianas y las de Loxa, los botánicos de la Expedición del Perú, D. Hipólito Ruiz y D. José Pavón, respondiendo a la Memoria que Don Francisco Antonio Zea insertó en los "Anales de Historia Natural," cuaderno no. 5 (1800), sobre las quinas de Santa Fe y demonstración de que éstas son muy inferiores a aquéllas.

In fact, this Sr. Zea had lived for some time in Santa Fe, where he cultivated the science of botany for two years under the direction of Mutis. When the Quinología of R'uiz was published in the year 1792, he thought, no doubt, that they were taking the credit from his teacher, and he asserts that they had appropriated the

\section{ARTICLE VI}

Description of the fifth species of quinos, known by the natives of the provinces of Panatahuas and Huánuco by the name cascarillos de flor de azahar.

\section{ARTICLE VII}

Description of the sixth species of quinos, known in Panao, a town of the province of Panatahuas, ten leagues distant from Huánuco, by the name cascarillos con corteza de color de pata de gallareta.

\section{ARTICLE VIII}

Description of the seventh species of quinos, known by the natives of Puzuzo and Muña by the name asmonich.

I This famous botanist wanted to make the name of the counts of Chinchon immortal, and so created the genus Chinchona, dedicated to them, in which there are included the various species of quinas. [Linnaeus erroneously wrote Cinchona instead of Chinchona.] 
third part of his discoveries to the damage of his prestige. ${ }^{1}$ He then discussed the matter of the quinas, endeavoring to claim for Mutis and his expedition priority in the discovery of those from Santa Fe and denying that merit to Doctor López, whose botanical competence he places in doubt. He says that there were known only four classes of quina: the orange, red, yellow, and white; he enumerates their virtues and finishes by trying to reduce the Cinchona hirsuta, the purpurea, and the micrantha of Ruiz to mere varieties of the C. cordifolia of Mutis. Zea's attacks upon the Quinología of Ruiz caused him, as well as Dn. José Pavón, real surprise, and both were quick to refute them in the "Respuesta," which offers truly interesting information about the expedition of Mutis. According to them ${ }^{2}$ Mutis did not start his botanical work in Santa Fe until the year 1784, that is, seven years later than Ruiz and Pavón in Peru and Chile; consequently they could not well appropriate discoveries that had not yet been made. They add, besides, the following observations: First, that the expedition to Chile and Peru was carried on for eleven years by the same individuals, without any other casualties than the death of Brunete the draftsman, in 1787 , while there were very important changes of personnel in the expedition of Santa Fe. Second, that the botanists sent to Chile and Peru traveled on foot over a great part of the territories, making the observations in open country on living plants growing wild, while Mutis, for various reasons, was unable to travel and had to rely upon the information of persons more or less competent, which was very far from supplying personal observations. Third, that the expedition of Ruiz had constantly remitted, since it had made the first excursions, numerous specimens of living and dried plants, dried animals, antiques, etc., to the Ministry of the Indies, as it had been ordered to do, but this had not been done by Doctor Mutis, not even once during the seventeen years that he had then (1801) been the head of the expedition. And finally, that Mutis had neither sent to Spain any information about his discoveries or personal observations made in the 23 years prior to his appointment as director of that expedition, nor had he given to the press any other works than El Arcano de la Quina (without descriptions or sketches) and some others of little importance; this, in spite of the magnificence with which he was aided by the Viceroy, Archbishop Dn. Antonio Caballero and Góngora, as well as by the governor of the metropolis. ${ }^{3}$

\section{${ }_{1}$ Suplemento a la Quinología, page 23.}

${ }^{2}$ Suplemento a la Quinología, pages 110-114.

3 "In article No. 1 that appears at the beginning of the letter of appointment of Mutis, Ruiz and Pavón say (Suplemento a la Quinología," pages 24 and 25): "His Majesty ordered to be delivered to him at one time a gratuity of 2,000 doubloons, to pay his debts and to pay the cost of concluding and perfecting his manuscripts in order to send them to His Majesty before starting the expedition. Besides, he assigned them the salary of 2,000 pesos (money of the Indies), and for traveling 4,000, although from then on he always drew the latter amount and, according to information from Sr. Zea, he came to receive even 6,000 pesos." And we add that Dn. José Celestino Mutis doubtless knew how to use to advantage the abundant resources with which he was supplied, in influencing effectively the general culture and development of the sciences in that country, that will remember him always with gratitude and veneration; but we suspect that this magnitude of his program and enterprise was a great obstacle that prevented him from completing his botanical work, about which he always seemed to maintain reserve. If the text had been done like the iconographical part, his Flora of Santa Fe would not have a rival in the world today. 
In the matter of the quinas it is observed in this repiy: first, that the physicians always applied that of Peru and Loja, because they judged it superior to that of Santa Fe, and second, that the classification of the quinas by their respective colors was completely arbitrary and of no scientific value. Such is, in short, the answer of the botanist-explorers of Chile and Peru, to the memoir of Dn. Francisco Antonio Zea. This controversy caused great excitement among naturalists, and constitutes an eloquent testimony to the interest taken at that time in questions of natural history. 
The Prodromo de la Flora Peruviana y Chilense-Draftsmen and engraversContents-Genera dedicated to botanists and patrons of botany-Discussions between Cavanilles and the authors of the Prodromo-Criticism of Antonio Lorenzo Jussieu of this work and reply of Ruiz-The Systema Vegetabilium Florae Peruvianae et Chilensis of Ruiz and Pavón.

In 1794 there appeared the Prodromo de la Flora Peruviana y Chilense, o sea Descripciones y láminas de los nuevos géneros de plantas de la Flora de Chile y Perú, by Dn. Hipólito Ruiz and Dn. José Pavón. After the Quinología of Ruiz, the Prodromo was the first result of their work to come off the press. It formed a volume in great folio with thick linen paper, bilingual text (Castilian and Latin) in two columns, with good type and clean and careful printing.

The text has 175 pages, including the preface, and there follows the iconographical part, consisting of 37 engravings, with 219 drawings made by Dn. Isidro Gálvez, ${ }^{1}$ and engraved by the artists José Rubio, José Castro, Vicente Enguidanos, Tomás Enguidanos, Manuel Alegre, Vicente García, Félix Prieto, and Melchor Prado.

This work begins with a preface in which an outline is sketched of the history of botany in Spain from the time of the Romans to the end of the eighteenth century; it also has a brief account of the expedition of Ruiz and his companions during the years that they spent in Chile and Peru.

Then follow the descriptions of the genera, made with the greatest clarity and order in two languages, Latin and Castilian, and at the end of the text are the corresponding illustrations, executed with great exactness and detail.

In this work we have yet to recognize another merit, and not a small one: it is that of the dedication of the majority of the genera to Spanish personages eminent in the natural sciences. Across its pages march the names of those who either cultivated them, especially botany, or encouraged and promoted them by their support, material or moral. Confining ourselves to the eighteenth century, we can assert that the Spaniard will be very rare who does not have his place in the Prodromo, if he was a protector of the science of plants or had dedicated his abilities and zeal to it. Thanks to this foresight, we can recall here the names of P. Martín Sarmiento, Benedictine mathematician and botanist, to whom they dedicated the genus Sarmienta; of Dn. José Sánchez, professor of botany at the end of the eighteenth century at the Royal College of Cádiz, to whom they did the same with the genus Sanchezia; of Dn. Cosmo Bueno, cosmographer and author of the Historia topográfica y natural del Perú, genus Cosmibuena; of Dn. Antonio Condal, physician and botanist of the expedition of Iturriaga and Loefling (1751) to the Orinoco, genus Condalia; of P. Francisco González Laguna, pious divine, "a truly industrious person, learned, and patron of the studious, tireless promoter of learning and arts and the applied sciences, of whose help, guidance, favor, and generosity we took advantage during our residence in Peru and, since the King confided to his direction our pupils and successors Tafalla and Pulgar, we utilized his epistolary correspondence to the benefit of the Flora of Peru and

I His signature appears only on the first engraving, but we think, with reason, that he is the author of the rest. 
explanation of all our works; ${ }^{1}$ of Dn. Antonio de la Cuadra, tireless promotor of arboriculture, genus Quadria; of Dn. Luis Riquẻur, first apothecary of Philip V, cultivator of fruit trees in Soto de Migas Calientes and generous donor of this farm to the then Prince of the Asturias, later Fernando VI, for a botanical garden; of Dn. Francisco Aldea, director of the Royal College of Apothecaries of Madrid, professor of botany and companion of Quer on his explorations through Spain, genus Aldea; of Dn. Benito Paltor, Loefling's companion on the expedition to the Orinoco, genus Paltoria; of Dn. Francisco Fernández Navarrete, very learned collector and possessor of natural history manuscripts, especially of Nueva Granada, genus Navarretia; of Dn. Martín Sessé, director of the Botanical Garden of Mexico and chief of the expedition to Nueva España, genus Sessea; of Dn. Francisco Fabián Fuero, Archbishop of Valencia, who in his botanical garden at Puzol cultivates the rarest plants from both Indies, taking advantage of the benignity and fertility of that very fortunate climate, passing them on with the greatest generosity to the Royal Botanical Garden of Madrid, genus Fabiana; of Dn. Gaspar Xuárez, native of Tucuman, who, with Dn. Felipe Gil, devotes himself in Rome to the cultivation of exotic plants little known and used, with the idea of investigating their properties and of extending that information and use for public benefit, genus Xuarezia; of Dn. Jorge Juan and Dn. Antonio de Ulloa, companions of La Condamine, Jussieu, etc., who traveled in Peru for the purpose of measuring a degree of the equator to determine the shape of the earth, genus Juanulloa; of P. Isidro Saracha, Benedictine, "who has continuously engaged in the observation of plants, is happy in communicating his knowledge to several young men, and does not tire of enriching the Royal Botanical Garden of Madrid with extremely rare plants," genus Saracha; of P. Matías Villares, Bernardine monk, "who most of his life cultivated a botanical garden in the monastery of Santa Espina (Valladolid) and generously distributed his plants and seeds to the other botanists of Spain, genus Villaresia; of Dn. Francisco Cerdá y Rico, active protector of our botanists, genus Cerdana; of Dn. Vicente Cervantes, first professor of botany in Mexico and also in America, genus Cervantesia; of Dn. José Antonio Alzate, Mexican, a man of great knowledge in natural sciences, genus Alzatea; of Dn. José Cornide, "diligent and learned investigator of antiquities and of the works of nature, as is manifest in his Ensayo de la Historia de peces de Galicia and other publications printed in Madrid, genus Cornidia; of Dn. Antonio Porlier, marquis of Bajamar, who, when he was minister of the Indies added Ruiz and Pavón to the Botanical Garden of Madrid and ordered the Flora Peruviana et Chilensis to be prepared for printing, genus Porlieria; of Dn. Antonio Valdés, minister of the Navy and founder of the Botanical Garden of Cartagena, genus Valdesia; of Dn. Pedro de Acuña y Malvar, who promoted the edition of that work, genus Acunna; and finally of thousands more who for reasons already stated had made themselves worthy of such homage.

In this respect the Prodromo constitutes a curious register in which are inscribed the names and merits of the majority of those who cultivated the natural sciences, especially in Spain.

The Prodromo had scarcely been published when there arose about it the liveliest discussions, as happened with the Quinologia but, while in the case of the latter, the adversary had been Dn. Francisco Antonio Zea, this time it was Dn. Antonio José de Cavanilles. He was born in the year 1745 and carried on

1 Prodromo, page 12. 
various studies, without paying attention to botany. In 1777 he went to the capital of France and there, under the direction of the friar Chaligni, he began the study of that science when he was 36 years of age. He became acquainted with Lorenzo Antonio Jussieu, with Thouin and other men of learning, and made rapid progress in that science, as can be seen from his Disertaciones sobre la clase Monadelfia de Linneo, which he began to publish in the year 1785. Cavanilles was of an open nature, original and bold; he had near him the herbaria of Commerson, Jussieu, Sonnerat, and Thouin, made in various places in Asia and America, and taking advantage of this material, he formed new genera and species in great numbers. The first of his Disertaciones had hardly been published when there appeared a certain article signed by a vecino de Lima [neighbor from Lima] in which it was stated that Cavanilles had made himself a botanist impromptu, by establishing his genera and species from specimens dried and deformed by cultivation, and finally, by creating new groups without good reasons. The author of the aforementioned article was Dn. Hipólito Ruiz, who, true to his judgment, demolished the new genera Molina, Palaua, Pavonia, and Ruizia, established by Cavanilles.

In the year 1799, Pavón handed Ruiz an extensive note received from the French botanist Antonio Lorenzo Jussieu, by way of Cavanilles. In this were set forth some observations about the genera and species contained in the Flora Peruviana et Chilensis, inviting an opportune reply. Dn. Hipólito Ruiz did not delay answering with a very careful letter (January, 1800), in which he explained the motives that had impelled him not to admit the new genera Palaua, Pavonia, etc., created by Cavanilles, ${ }^{1}$ and he answered in detail the rest of the questions of Jussieu.

He also enumerated many species published by Cavanilles as new and that, according to him, were already known and some even cultivated in botanical gardens, and he finishes with these words: "Let us confess in good faith that the one who describes from dried specimens is in danger of making great mistakes when he even makes them so frequently about plants that he examines while living, as were most of those that I have just referred to." We must observe that such phrases reflected perfectly the antagonism already existing between Dn. Antonio José de Cavanilles and the botanists of the expedition to Peru.

Dn. Hipólito Ruiz had published his Respuesta a Cavanilles in 1796, including in it a multitude of objections and charges against the botanical works of the latter, and in the same year there appeared the answer of the pupil of Jussieu, replying to the reasonings of Ruiz. ${ }^{2}$ Who was right in this debate? With respect to the genera, we can affirm today that Cavanilles was right. The genera Molina, Palaua, Ruizia, and Pavonia have been accepted by science and they continue to exist, admitted by all botanists.

In regard to the species, they also figure as legitimate in the works of botany, not all, but a fair number of them.

${ }^{1}$ See Suplemento a la Quinología, pages 131-135, and volume III of the Flora Peruviana et Chilensis, IX-XXIII.

${ }^{2}$ Colección de papeles sobre controversias botánicas, by Dn. A. J. Cavanilles. Madrid, 1796. 
In the year 1798 Ruiz and Pavón published the Systema Vegetabilium Florae Peruvianae et Chilensis, ${ }^{1}$ describing in this work 620 species pertaining to the first four groups of the system of Linnaeus. At the same time they made known three new genera: the genus Alonsoa, the description and sketch of which was sent from Peru by Dn. Juan Tafalla; the genus Monnina, dedicated to Dn. José Moñino, count of Floridablanca, and the genus Phytelephas. Taking advantage of this opportunity, they corrected also some genera of the Prodromo, following indications and information given by Tafalla and other botanists.

${ }^{1}$ A volume of 455 pages in 8vo, without plates. Madrid. 


\section{III}

Publication of the first volume of the Flora Peruviana et Chilensis (1798)-Inexplicable delay-Diligence of Dn. Antonio Porcel-Support of ministers Llaguno and Jovellanos-The preface to the work-Classification adopted-Character of the descriptions-New genera-Species described-Draftsmen-EngraversAppearance of the second volume of this work (1799)-Contents.

In the year 1798, the first volume of the Flora Peruviana et Chilensis of Ruiz and Pavón was published. ${ }^{1}$ This work should have followed immediately on the Prodromo, which was printed in 1794 , but its authors say that it was delayed by unexpected difficulties. We do not think that these could have been from lack of money, because in 1789 the King, Dn. Carlos IV, sent a circular to all the official corporations of our colonies, stimulating their zeal to relieve the penury of the public treasury, with their contributions so that the Floras of America might be published; in fact, soon afterwards there arrived in Spain funds more than sufficient for the object mentioned.2 But whatever the nature of the obstacles, it is certain that they were not removed until the year mentioned, in which, thanks to the repeated efforts of Dn. Antonio Porcel before the Minister of the Indies, Dn. Eugenio Llaguno, a royal order was obtained for the immediate publication of the rest of the volumes of this Flora. Dn. Zenón Alonso was charged with supplying all the means required to carry out this royal order, and thanks to this and to the efficient help of Dn. Melchor Gaspar de Jovellanos, who succeeded Llanguo in the Ministry, the botanists of Peru and Chile saw the accomplishment of their desires, although in part only.

This volume has an appearance identical with the Prodromo and is headed by a preface with interesting details that deserve to be recalled here. According to Ruiz and Pavón, the only botanists who explored the flora of Chile and Peru were José Jussieu, Fevilles, and Father Ignacio Molina, but these explored only the littoral regions without reaching the very fertile and extensive montañas of the Andes. They also add that some of the species described in this work had already been mentioned or studied by Jacquin and Aublet, who traveled in Martinique, Santo Domingo, Guayana, etc., and others by Vandel, L. Heritier, Jussieu (A. L.), Smith, Cavanilles, Lamarck, Vahl, and Dn. Casimiro Gómez Ortega, respectively.

In the Prodromo they had estimated that the descriptions included in this work would reach 2,400 and the corresponding sketches 1,800 , but here ${ }^{3}$ they affirm that the former would reach 3,000 and the latter 2,000.

The classifications have been made according to the manner of Linnaeus, concise and clear language being employed to describe the species with the most

1 Flora Peruviana et Chilensis sive Descriptiones et Icones plantarum peruvianarum et chilensium secundum systema linneanum digestae, cum characteribus plurium generum, evulgatorum reformatis. Auctoribus Hippolyto Ruiz et Josepho Pavon. Reg. Acad. Medic. Matriti Sociis.

2 "Contribución de las colonias españolas para imprimir las floras de América en el siglo XVIII," by P. Barreiro. Trabajos del Congreso Hispano-Americano de Geografía e Historia de Sevilla, 1930.

${ }^{3}$ Flora $P$. et Ch. Preface, p. 1. 
appropriate terms. At the foot of each one there are cited the corresponding locality, or localities, and vernacular names. For reasons of economy, they have now omitted the descriptions in Castilian, contrary to what they did in the Prodromo.

In this volume they make known three new genera; the genus Anthodon, the genus Jovellana, dedicated to Dn. Gaspar Melchor de Jovellanos, and the genus O'Higginsia, that was dedicated to Dn. Ambrosio O'Higgins de Vallenar, marquis of Ozorno and viceroy of Peru.

The species described sum up to 277 belonging to the four first classes of Linnaeus. The book is illustrated with 106 plates, with 219 figures, drawn respectively by Brunete, Gálvez, and Francisco Pulgar. They were engraved by Francisco Suria, Isidro Gálvez, Vicente L. Enguidanos, Miguel Gamborino, José María Bonifaz, José Querol, Pedro Nolasco Gascó, Tomás López Enguidanos, Francisco Martí, Vicente Pascual Pérez, José Salas, Narciso Cobo, Manuel Navarro, Vicente Mariani, Mariano Brandi, José Rico, Guillermo Orejón, Felipe Prieto, J. Fonseca, Pedro Gascó, Vicente Albarracín, Vicente P. Pérez, Rafael Camarón, Julio Calvo, Francisco Ugena, Fernando Selma, Francisco Pérez, José Rodríguez, Cipriano Maré, Juan Rodríguez, José Bruneti, José Castro, E. M. Torre, Juan Bruneti, Francisco Ribera, José Vega, Francisco Mollera, Juan Becquer, Francisco Panfil, Mariano Latasa, Faustino M. Torres, Nicolás Besanzon, and José Rubio.

A year after the first volume, that is in 1799 , the second volume of this Flora was printed in a form identical with the first one. In it the authors included two new genera, namely, Calydermos and Leonia (the latter dedicated to Dn. Francisco León, who promoted the publication of the volume), and 251 species belonging to the class Pentandria Monogynia of $\mathrm{L}$. The illustrations in this volume consist of 116 plates and 203 figures, executed by the artists already mentioned. They state that some plates of the present book are colored to satisfy the curious, and in fact, these plates exist in the archives of the Botanical Garden of Madrid, but have not been incorporated with the text in many copies. The authors congratulate themselves on the many species described in this volume pertaining to the genera Heliotropium, Tournefortia, Nolana, Linanthus, Varronia, Rauwolfia, Plumeria, Cestrum, Solanum, Saracha, Sessea, Periphragmos, Psychotria, etc., etc. They also include here ten species of quinas: eight discovered by them and two by Dn. Juan Tafalla.

Finally they inform us of the following:

1st, that the corregidor of Loja called to Lima by the count of Chinchón to administer the quina to the countess, was named Dn. Juan López de Cañizares; 2nd, that Dn. Manuel Alcarraz was the first person to enter the mountains to obtain quinas, and took them to Lima to promote commerce in them in the provinces of Huánuco and Panatahuas, in advance of Dn. Francisco Renquifo, who found the Cinchona nitida in the hills of San Cristobal in the year 1776 when he was returning from the province of Lomas. 


\section{IV}

The third volume of this work comes off the press (1802)-Its contents and illustrations-New genera published by the authors-Personages to whom some genera included in the third volume were dedicated-Material sent from Peru by Dn. Juan Tafalla-Plans of Ruiz and Pavón for the Suplemento de la FloraThe preface to this volume and the letter from Ruiz to Jussieu.

The third volume of the Flora Peruviana et Chilensis came off the press in 1802 , edited, as were the others, by Gabriel de Sancha. It contained 223 descriptions, corresponding to as many species of classes V, VI, and VII of Linnaeus. The plates that illustrate this volume number 104 and the figures 176 . The authors state that the respective fruits are not represented separately in some of the plates, because they are already found in the drawings of the plants or branches.

By the time that this volume was published, Ruiz and Pavon had already described 142 genera, as follows: 134 in the Prodromo, 3 in the first volume of this Flora, 2 in the second volume, and 3 in the Systema Vegetabilium. In this are included 7 new genera: Bonapartea (dedicated to Napoleon Bonaparte), Lapageria (dedicated to Josefina Lapagerie, wife of Napoleon), Luzuriaga (to Dn. Ignacio María Ruiz de Luzuriaga, famous Spanish physician, chemist, and botanist), Isidrogalvia (to Isidro Gálvez, draftsman of the expedition), Guzmannia, (to Dn. Anastasio Guzmán, pharmacist and naturalist), Conanthera, and Cosmibuena.

These botanists state here that, having received enough material sent by Dn. Juan Tafalla after their return, they, are keeping, for the Suplemento de la Flora, the descriptions of all the species of this material pertaining to the first eight classes of Linnaeus, and of others belonging to the less known American genera, besides the study of the new species included in genera unknown in Europe.

In the same Suplemento they had expected to include many plants, specimens of which were lost in the shipwreck of the vessel "San Pedro Alcántara," and which they hoped to replace by new ones, substituting with examples from Dombey's herbarium of those that Tafalla could not supply from Peru.

The Suplemento was to be composed of four volumes dedicated to the study of all those plants that, after having been discovered in America by Dn. Hipólito Ruiz and his companion, had been described and represented defectively by other botanists.

In the preface to this volume ${ }^{1}$ they defend themselves against the charges of Zea, repeated by $\mathrm{C}$. Alibert; ${ }^{2}$ they inform Cavanilles of the inconsistency of his conduct in retaining the genus Gynopleura after having agreed that it was a species of Malesherbia; finally they cite the praise accorded by Jussieu to the Flora Peruviana et Chilensis.

In the front of the same volume is printed the letter of Dn. Hipólito Ruiz to Jussieu and the answer to the doubts expressed by him. There is also a note upon the material destined to form the Suplemento. ${ }^{3}$

${ }^{1}$ Pages II, III, IV.

${ }^{2}$ Dissertatio de febribus pernicioni intermitentibus, p. 228.

${ }^{3}$ Catalogue of the species of some genera that we have in our possession, together with drawings of them, pertaining to the first thirteen classes of Linnaeus, which were not inserted in the first four volumes, for the reasons explained in the preface, and for others that need not be mentioned here. All of this and other species sketched in America will be published in the supplement to this work. 
Preparation of volume IV-Approximate date of its conclusion-New genera described in it-New species-Illustrations-Genera and species published by the authors-Genera corrected in this volume-Suppressed genus-Sending of collections by Tafalla-Ruiz and Pavón criticize the reforms introduced by several botanists in the classification of Linnaeus.

After having finished the printing of the third volume of the Flora Peruviana et Chilensis in 1802, Ruiz and Pavón continued the work necessary for the preparation of the fourth one. They were moved to do so by the natural desire to bring their undertaking to a happy conclusion, thus keeping the promise made in the preface of the third volume; aside from this, they were also inspired by the warm praise bestowed by national and foreign botanists ${ }^{1}$ and even by the lively discussions to which it gave origin. The exact date on which the fourth volume was finished is not known, but we suppose it was from four to six years after the third one. In this volume Ruiz and Pavon made known three new genera, designated respectively with the names Alstroemeria, dedicated to Claus Alstroemer, Swedish botanist; Thibaudia, in honor of Thibaud, a professor of botany in Strasburg; and Villamilla, in remembrance of Dn. Juan Pérez Villamil, translator of Columella and former Spanish minister. Adding the three genera to the 138 already described as new by Dn. Hipólito Ruiz and Dn. José Pavón in their former publications, brought the number of such up to 141. The number of species described in this volume reaches 164 , remarkable, they say for their medicinal or industrial virtues. ${ }^{2}$ They belong to classes VII, VIII, and IX of Linnaeus. Of these, 124, with their corresponding sketches, are distributed among 100 plates executed by the artists Dn. José Rivera, Dn. Francisco Pulgar, and Dn. José Brunete. We have counted 37 colored by hand, that accompany the original manuscript.

The authors state that, up to this time, they had made known 922 species, of which 722 had been illustrated, and they add that they proposed to include in the Suplemento the plates for many of them, especially those that had not been described or had been described insufficiently by other botanists.

In the volume in question (fourth of the Flora), the characters of several genera are described, corrected, and revised, that are already in the Prodromo, and even some of the same Linnaeus and other botanists, as for example, Dodonaea, Weinmannia, Francoa, Sophora, and Myrospermum. They also corrected the descriptions and illustrated the forms of many plants already known and others that, discovered long before in America by the expedition to Peru, had been published by others with defective sketches and descriptions, such as the Dodonaea viscosa L., Weinmannia trichostoma Cav., $W$. dentata Flor. Peruv., Larrea glauca, Hoffmannseggia falcaria and trifoliata Cav., etc., etc.

As can be seen, our explorers did not turn from their desire to perfect the "Flora of Peru and Chile" and to find fault at the same time with the work of Cavanilles, with whom they had continued arguments.

${ }^{1}$ Comentario Literario, in number 29. "This famous work [Flora of Peru] will have a prominent place in botany. The edition is without doubt, splendid, the figures deserving particular praise. ..."

2 Prologue, p. 1. Ms. 
In this volume they abolished the genus Acunna, temporarily established in the Prodromo until they could consult the descriptions of related genera, to be found only in books that were not at hand at the time. In consequence of this, the species with which this genus had been formed were included in the genus Bejaria. Nevertheless they retained as legitimate the genus Stereoxylon, against the objections of Mutis and Zea.

They also thought it suitable to include in the genus Caesalpinia, the genera Poinciana and Parkinsonia.

While the first volumes of the Flora Peruviana et Chilensis were being published, Dn. Juan Tafalla was continuing his explorations through Quito, Guayaquil, and the montañas of Panatahuas, and sending to Madrid, as a result thereof beautiful sketches, of which four represented as many species of quina trees new to science, that is: Cinchona viridiflora, C. rugosa, C. globiflora, and C. rubicunda. With these and the ones collected by Ruiz and Pavón during their trips through those countries, they succeeded in bringing together in their herbarium all the species known at that time, giving information of them in the Gaceta de Madrid of September 8th, 1807.

In this volume several new species are included, belonging to genera also new or known. The genus Laurus is increased with 28 species; the genus Weinmannia with 11; the genus Talinum with 11; the genus Psidium with 6; with the same number, the genera Thibaudia, Semarillaria, and Axinaea; and finally with 5, the genera Foveolaria and Miconia.

In the last decades of the 18th century, and even later, modifications began to be introduced in the botanical classification of Linnaeus, classes being abolished according to the particular judgment of each author. Thus Linnaeus fil. and Willdenow reduced the first 24 to only 20; Cavanilles reduced them to 15 , and Brotero finished by admitting only 12. Ruiz and Pavón protested against these innovations, denouncing them as unjustifiable and confusing to knowledge. ${ }^{1}$ Also the carelessness with which some foreign botanists proceeded to cite the Cienfuegosia of Cavanilles, calling it Antonio L. Jussieu, Fugosia; Willdenow, Cienfuegia, and Lamarck, Cienfugosa, which destroyed the original, legitimate name, without any of them taking pains to add it to the genus Hibiscus, from which it should absolutely not be separated. ${ }^{2}$ As can be seen, Ruiz and Pavón followed with great interest the march and development of botanical studies, taking advantage of as many opportunities as were presented to them to perfect their work. Another proof of this is offered to us in the section that under the title of "Addenda et Corrigenda" immediately follows the preface. There are set down interesting observations and new details about the genera already published in the former volumes.

Finally, this volume is published with an alphabetical index of genera and species, which shows that it was ready then to be sent to the printers.

1 See their words. Preface to volume IV, p. 3. Ms. "One is astonished by the fact that, during the last twenty years, while noted botanists were perfecting the science, employing the natural method and the artificial system of Linnaeus, other botanists, have forcibly imposed defective classifications liable to errors and very difficult to use, urged thereto by an itching to make innovations and to capture the applause of the public by that procedure. But how much more benefit could accrue to botany if they, omitting the reductions in the classes, would have dedicated themselves to reforming and perfecting the generic characters and to establishing the names in a permanent and consistent way!..."

${ }^{2}$ Preface, p. 3. Ms. 
The authors of the Flora Peruviana et Chilensis continue their work-Contents of the manuscript and unpublished volumes of this work: V, VI, VII, VIII, IX, X, and XI-Idem of volumes I, II, III, IV, and V of the Suplemento-The platesThe botanical work of Ruiz and Pavón.

With the same zeal and steadfastness of which they had given magnificent proof since the first days of their enterprise in 1777, Ruiz and his companion continued working at the compilation of the Flora Peruviana et Chilensis, without allowing themselves to be hindered by the great confusion and excitement brought to Spain by the French invasion. This is made clear with great eloquence by the rest of the unpublished manuscripts and sketches with which we shall occupy ourselves immediately, reviewing their contents.

Volume V of the Species Plantarum. Several new genera are published in this, among them the genus Pineda, dedicated to Dn. Antonio Pineda, naturalist of the Malaspina expedition (1781-1795). The species described are more than 180, and the plates number 114 . It has a preface, without signature, but there is no doubt that the author is Dn. José Pavón, who directed the Flora Peruviana et Chilensis after the death of Dn. Hipólito Ruiz, which took place in 1816.1

Volume VI of the Species Plantarum consists of 99 pages (on each one of which, with the exception of very few pages, is described a new genus or species) and of 153 plates, all colored by hand, with the exception of eight, in black. Draftsmen: Gálvez, Brunete, Pulgar, Cortés, and Alcocer.

Volume VII. Ms. Consists of 131 pages in folio and as many descriptions of genera, some of them new, and of species also new, many of them belonging to

1 The interesting information that it contains moves us to insert it here as a document worthy of being known. It is as follows:

"This volume $\mathrm{V}$ comprises classes $10,11,12,13,14,15$, and part of 16 , so many new genera, corrected or reformed, new species with their descriptions and with pictures engraved with the best of care by outstanding professors.

"Most of these plants are shrubs and subshrubs, trees of great interest in medicine, dyeing, and civil, military, or naval construction, or as food for living beings. Some plants are natives of Peru, others of Chile, some are from Guayaquil, and others from the kingdom of Quito.

"Of the live plants whose condition has permitted it, we have represented the anatomy of the generative parts, some of them enlarged by means of the microscope because of their minuteness. Part of the branches are of natural size, as is the anatomical part of the fructification.

"This volume V was quite advanced, although not corrected, during the life of my never-enough-mourned and wise companion and botanist, the immortal Dn. Hipólito Ruiz, my loyal and generous companion, esteemed for his kind manners and virtues, whose conduct was irreproachable and tireless during eleven years of traveling on very laborious journeys through the rough and fertile mountains, forests, valleys, and cordilleras of the Andes, of Peru and Chile; he was in peril of death then, both at the hands of savage Indians to whom he exposed himself, and also by the very dangerous illness from which he suffered from the time he left Madrid on the expedition.

"Some of the observations are written in Latin and others in Spanish but, instead of translating them into Latin, I think it is more proper to send them out 
classes XVI, XVII, and XVIII of Linnaeus. It is illustrated by 101 plates, two in black and the rest colored by hand. Draftsmen: José Rivera, Brunete, Pulgar, and Gálvez. Without preface or index.

Volume VIII. Ms. Contains the descriptions of several new genera and about 100 species, belonging to class XX of Linnaeus. Plates in colors 105 , done by the artists mentioned above.

Volume IX. Ms. The descriptions amount to 55, class XXI of Linnaeus. Some lack the name of the genus and species, and others the name of the latter. The plates in color number 116. There is one in black. Draftsmen, those already mentioned.

Volume X. Ms. Descriptions 80. Classes XXII and XXIII of Linnaeus. Colored drawings, 115. Some of these without title. Draftsmen: Brunete, Pulgar, and those already mentioned.

Volume XI. Contains 97 pages with descriptions of several genera and some 90 species belonging to classes XXIII and XXIV of Linnaeus; 81 colored plates of the class Polygamia, 20 of the Cryptogamia, and 20 of palms. The draftsmen, those already mentioned.

During the time that the botanists were completing the volumes of the Flora Peruviana et Chilensis that we have just finished citing, new shipments of plants, descriptions, and plates were being received from America, sent by Tafalla and his companions.

In the study of this material new genera and species were found belonging to the classes already included in the volumes printed, or unpublished but already written. Ruiz and Pavón did not want so much effort and sacrifice employed in gathering such material to go to waste; in consequence, they determined to make it known in a supplement, that comprises the following volumes, a review of which we are offering here.

to foreign countries in our majestic, fluent language so that it may be seen by all the writers on the natural sciences.

"This volume $\mathrm{V}$ and the succeeding ones, as to the historic, descriptive part and drawings (some in black and white, others in colors), are equally entitled to share in the praise that the supreme tribunal of justice of the learned national and foreign naturalist-botanists might find it suitable to bestow on Dn. Hipólito Ruiz, my companion and first botanist of the Flora Peruviana et Chilensis, and Dn. Juan Tafalla, a very progressive, tireless, and industrious botanist, pupil of Ruiz and Pavón, who stayed in charge, instructed to continue the new discoveries, by order of the King, Sr. Dn. Carlos IV. In respect to the drawings, the draftsmen are worthy of all praise for their care and skill. Dn. José Brunete, who died from pneumonia in the mining town of the cordillera called Pasco, was the first draftsman, a very accomplished painter in oils and miniature, and pupil of Dn. Antonio Rafael Menor. His loss was greatly felt because he was so much needed; but he left some remains of illuminated drawings in which his mastery and expertness shine and for which he is worthy of high praise. Dn. Juan Manzanilla and Dn. Javier Cortés, both pupils of Tafalla in botany, who became also good professors and sent good, interesting collections of herbaria, colored drawings scientifically very accurate, and many good, although incorrect, descriptions; fruits, seeds, gums, resins, barks, and woods of the precious quinas of the kingdom of Quito, and several others, with small planed boards of outstanding valuable woods and some native products. Dn. Francisco Pulgar, progressive pupil of the very accomplished draftsman and colorist of the expedition, Dn. Isidro Gálvez, whose knowledge in his noble art of drawing and painting as also in line engraving, was 
Volume I (Supplement). In it descriptions (about 100 in all) are found of several genera and numerous species, corresponding to the Linnaean classes Monandria monogynia or Tetrandria trigynia, that is, I, II, III, and IV. Colored plates, 100. Draftsmen, those mentioned above.

Volume II (Supplement). Descriptions 206, belonging to the class Pentandria of Linnaeus. Plates 152, of which 148 are colored and 4 in black. Draftsmen, those already mentioned.

Volume III (Supplement). 100 descriptions. Classes, Triandria, etc. to the Decandria, in part. Illuminated plates 99 , corresponding, respectively, to classes VI, VII, VIII, and X. Draftsmen, those already mentioned.

Volume IV (Supplement). 103 descriptions, belonging to the plants of the classes Decandria (in part) to Didynamia, or XIV. 118 plates, colored entirely or in part, corresponding to species of classes $\mathrm{X}$ and $\mathrm{XI}$.

Volume V (Supplement). 3 descriptions. One new genus. Plates colored entirely or in part: 24 of class XII, 16 of XIII, and 50 of XIV.

The result is, therefore, that the botanical works of Dn. Hipólito Ruiz and Dn. José Pavón consist of the following volumes: 1 of the Systema Vegetabilium, 1 of the Prodromo, and 3 of the Species Plantarum, all of them already published, besides 12 unpublished, as follows: 7 of the Species and 5 of the Suplemento. Of these there is a volume, the fifth, that has only the three descriptions above mentioned. Its iconographic part is complete. The other four are almost finished, like the five of the Species. The two remaining of the latter are ready for printing.

superior to that of many artists in botany as well as in zoology, as is proved in the "Flora Peruana." All the above-mentioned men with the exception of Cortés have died.

"Two-thirds of the plates of this volume were engraved during the life of my partner, but the names and arabic and roman numbers were not engraved. It thus happens that the descriptions, original drawings, and plates have been corrected and increased by those needed for the perfection and conclusion of volume $\mathrm{V}$ and, as it is expected that some errors might be made and found in a diffuse work, mihi imputetur, place the blame for them on me; I hope that discreet readers may correct my involuntary mistakes with the moderation characteristic of the wise, and I beg them to enlighten me and not to use indulgence, because in matters of science everything should be done for enlightenment and for demonstration of truth, and nothing should be omitted. That is true friendship. Amicus Plato, sed magis amica veritas. I will give, if I live, many thanks to him who enlightens me, because my heart does not admit the maxim veritas odium parit, obsequium amicos, and I confess that this is the way I have done.it.

"How strange it is that in such a voluminous piece of work, containing so much meditation on the mysteries of Nature, in which the wisest naturalist, our God, has left us so much beauty, so many fascinating charms, so many objects worthy of the greatest admiration of man, deep study and meditation which lift the soul of the naturalist to the contemplation of the Creator of the universe, and, according to my manner of philosophizing, one comes closest to some knowledge of our benign Lord through his works which he has left us created in the organic beings and inorganic, this is to me an outstanding naturalist-theologian." 


\section{VII}

Time consumed in the preparation of this Flora-Those who worked on it until 1816-From 1816 until 1832-Workshops of Floras in Madrid at the time-Royal orders commanding that they be directed by the botanist-Those of the Floras of Nueva España and Nueva Granada also assigned to him-The Flora of Peru stays independent-Dn. Demetrio Rodríguez is assigned to this-Sums expended on the Floras of Nueva Granada and of Peru-Scientific value of the latterComparison of the same with former botanical works of Spanish authors-Influence of Linnaeus in Spain-Glorious generation of botanists here during the eighteenth century - Works and drawings-Excellence of the Flora Peruana above the others mentioned-Deplorable neglect with respect to this-The voice of a deputy-What has been published of the Flora Peruana-What remains of the genera and species published by Ruiz and Pavón.

Having finished the preceding account, we shall present some additional information that offers real interest for the proper understanding and appreciation of the importance of this enterprise.

How much time was spent on it? No less than fifty-four years(!), or that is, from 1778, when the work was begun, until 1832, when it was ended. The work of editing was in charge of Dn. Hipólito Ruiz and his companion, effectively helped by Dn. Juan Tafalla, who continued the explorations through Chile and Peru until the beginning of the nineteenth century. Dn. Francisco Pulgar was assigned to Tafalla as a draftsman.

In 1816 Ruiz died, and then Dn. José Pavón and Dn. Isidro Gálvez were left in charge of the workshop of the Flora of Chile and Peru. At that time three similar workshops were functioning in Madrid, the one we have just named and the ones respectively called that of the Flora of Nueva Granada, and that of the Flora of Nueva España. It seemed natural that, there being at the Court a scientific center called the Botanical Garden, provided with a good library and dedicated to the cultivation and extension in Spain of the knowledge of plants, the abovementioned offices should be added to it, under the direction of such competent professors as Dn. Casimiro Gómez Ortega, Palau, Cavanilles, Rojas, and Clemente, and Dn. Mariano Lagasca; this was ordered by royal command of June 17th, 1801, August 16th, 1814, and June 24th, 1815. ${ }^{1}$

In 1816 Lagasca insisted anew on the convenience of such an aggregation, but he succeeded only in having the materials existing in the workshops of the Floras of Nueva Granada and Nueva España sent to the botanist, and that because their directors had died. With respect to the other, it continued independent, owing, no doubt, to the stubborn opposition of its chief who, like Dn. Hipólito Ruiz, had remained apart from that establishment since the time of Cavanilles, disagreeing with its professors.

In 1828, the Dn. Demetrio Rodríguez, professor of botany, was added to the staff of the Flora of Peru, but there is no evidence of his collaboration in this work. This was exclusively the product of the travellers and artists already mentioned.

1 See Lagasca's information (No. 4 of 1816) with respect to the executors of the estate of the wife of Dn. Hipólito Ruiz. Archivo del Museo Nacional de Ciencias Naturales. Docket 2,525 taken from the Archive of Alcalá. Fascicle "Botanists and draftsmen of the expedition to Peru." 
What was the cost of the Flora Peruviana et Chilensis? Although its cost did not reach the amount of 7,500,000 pesetas invested, according to Lagasca, ${ }^{1}$ in the expedition of Mutis, we can estimate it approximately at $3,000,000$ pesetas. Now, was this expense justified by the importance and quality of the work? We think it was, although this has been very much questioned by Cavanilles and others. Aside from the praises that it drew from men of learning in foreign countries as well as in Spain, it is sufficient to recall for a moment the perfection with which the descriptions had been made, of genera as well as of species, the considerable number of both made known to science, and the care with which the localities are given as well the uses of those plants and at the same time the habitus or aspect, if not of every species, at least of the majority of them. All of this, together with the great number of beautiful and very exact illustrations that complete this work, justifies us in characterizing it as something exceptional in the history of botanical science, especially in America.

This character will be more evident if we compare it for a moment with the principal works about this material that other Spanish naturalists produced in those countries. We can affirm that, since the beginning of the sixteenth century, there has been no lack of Spaniards in our Spanish colonies from whom the vegetable products of those countries deserved especial attention. The annalist Gonzalo Fernández of Oviedo dedicated to the plants of America books VIII, IX, $\mathrm{X}$, and $\mathrm{XI}$ of his Historia general $y$ natural de las Indias, islas $y$ tierra firme. ${ }^{2}$ Dr. Francisco Hernández studied Mexican flora during the years 1570-77 that, by command of Philip II, he spent in that country in investigating its natural productions. His work De Historia Plantarum Novae Hispaniae ${ }^{3}$ is, without doubt, the most finished work that was produced at that time with reference to botany.

The Franciscan Bernardino de Sahagún also studied the plants of America, in his Historia de las cosas de Nueva España; $;^{4}$ and P. Bernabé Cobo, S. J. in his Historia del Nuevo Mundo; $;^{5}$. José de Acosta, in his Historia natural y moral del Nuevo Mundo, ${ }^{6}$ and some others that we shall not mention.

These productions of a character that we could call pre-scientific were, nevertheless, the plough that broke the ground of those virgin forests of botany and zoology in the New World, giving us information and facts so numerous and interesting that, thanks to them, the naturalists that came after then could recognize and classify many American vegetables, following the route that had been traced by the authors above mentioned. It is unquestionable that the works of some of these, such as Dr. Hernandez and P. Cobo, are among the most finished of their kind for the epoch in which they were written. It is true that they cannot be compared with the Flora Peruviana et Chilensis, with which we are concerned, because it is a question of works chronologically separated by two centuries and

1 Information already mentioned.

2 Edition of 1851 . Madrid.

${ }^{3}$ It was published in Madrid in the year 1798 by Dn. Casimiro Gómez Ortega and contains three volumes in large quarto.

${ }^{4}$ Book XI, chapters VI and VII. Mexican edition, 1870.

5 Books IV, V, and VI. Edited in Sevilla, 1890-95, by the Sociedad de Bibliófilos andaluces, under the direction of Jiménez de la Espada.

${ }^{6}$ Books III and IV. Madrid, 1608. 
governed, as is natural, by very different criteria and scientific norms; even so, it is true that they came to constitute a precedent of a value beyond question for future investigators, a very firm basis for their work, and a revelation to the scientific world. What can be claimed for the work of Ruiz and his companion, within the considerations above mentioned, as an exclusive quality by which it surpasses ancient works, is the greater number of plants that they made known.

The profound revolution introduced in botany by Linnaeus brought with it procedures of such consequence that they changed completely the course and face of this science. In Spain the influence of the doctrines of Linnaeus was felt, and they were embraced with enthusiasm by the botany professor Dn. Casimiro Gómez Ortega (1771-1801) and his contempory Dn. Melchor Palau to whom we owe the Spanish version of the Filosofia Botanica of the famous Swede. They must have been greatly influenced by Peter Loefling, pupil of the Swedish botanist, who came to Spain in 1751, residing here until 1754, when he embarked for Guiana, taking part in the expedition of Iturriaga.

This school gave to science a glorious generation of botanists, to whom belongs the honor of having studied the vegetation of both Americas. They bequeathed to us such eloquent testimony of their campaigns as the Flora Cumanensis, of Peter Loefling (1754-56); the study of the plants of Guayaquil and especially the quina tree by Dn. Eugenio Alvarado (1755); the works of Mutis and companions on the Flora of Nueva Granada (1782-1808), the Flora Guatemalensis, by Dn. José Mociño, and the Flora Novae Hispaniae, by Mociño and Dn. Martín Sessé (17881808); the researches of Dn. Luis Nee and Dn. Tadeus Haenke on American and Polynesian vegetation (1789-1797); and in conclusion the work of Ruiz and Pavón with which we are concerned here. These works are composed according to Linnaean norms, and they can be compared one with the other.

Now then, what position is occupied by the "Flora de Chile y Peru" in respect to the others already mentioned? In regard to the iconographic part, the "Flora of Nueva Granada" is found to be greatly superior as much for the number as for the excellence and magnificence of the plates, about 7,000 for that of Colombia, compared with 2,000 or a little more for that of Chile and Peru. ${ }^{1}$ In regard to the respective texts, we cannot compare them yet because up to the present time the whereabouts of that of Mutis and his pupils is not known. We shall only state here that the personnel of the expedition of the Flora of New Granada was not constant, as was that of Chile and Peru; this must, doubtless, have been prejudicial to the unity and orderly progress of the corresponding work. ${ }^{2}$ In regard to the illustrations of the Flora Guatemalensis and Flora Novae Hispaniae, they have also been lost, a circumstance the more deplorable since a large part of them had been done by Dn. Mariano Echevarría, whom Lagasca, in 1815, held to be the best naturalist-draftsman that could be found in Europe. The iconographic part that we know of in the works the other botanists above mentioned, although good, is inferior in number and execution of the drawings to the Flora Peruvania et Chilensis.

${ }^{1}$ According to Ruiz and Pavón (Suplemento a la Quinología, page 23), Mutis came to have up to $18($ !) painters working at the same time in the workshops of the Flora.

${ }^{2}$ In fact, the botanist Dn. Bruno Landete, the geographer Dn. José Camblor, and the draftsman Dn. Antonio García, added to the expedition in 1783, later ceased to belong to it. 
In regard to the descriptions of genera and species, in all of them there are evident the expert hands of great masters who, knowing their profession well, studied and labored long, although most of them could not finish their works on account of adverse circumstances; having made this concession, we will declare here, finally, that the Flora Peruviana et Chilensis is superior to all the others already mentioned on account of the extent and ampleness of the text and for the new scientific contributions that it contains; it constitutes at present, in spite of the lack of the text of vol. V of the Suplemento, a botanical work of highest order and proportions, dedicated to the fiora of our former colonies of America.

And now, the reader will ask, as we also do: Is it possible that, after this scientific monument had been almost finished that had cost Spain 20,000,000 pesetas, and to which our former colonies of America and the Philippines had contributed great sums ${ }^{1}$ to have it published, and, finally, when there never were lacking here, even after the death of the authors, very competent botanists capable of directing the publication and of correcting the deficiencies of the text ..., is it possible, we repeat, that it has been left unpublished until now, without the Spanish government even thinking of redeeming it from an obscurity and forgetfulness so unjust and unpatriotic? Although the nation experienced very deep political and economic crises during the nineteenth century, we do not think that it lacked the funds with which to publish at least one of the volumes, as for example the fourth of the Species Plantarum, which was completely finished with even the engravings for the plates prepared.

And the curious thing about the case is that, in the midst of such neglect, even at the beginning of the nineteenth century, the voice of some deputy could be heard in Congress, asking that young men be sent to our colonies to study their zoological and botanical products, etc. What ideas could that "padre de la patria" have of the great work carried out in the Americas from 1750 to 1808 by the scientific expeditions of Loefling, Ruiz and Pavón, Mutis, Malaspina, etc. in order to make known its gea, its flora, and its fauna? Doubtless, he did not know that their fruits had been neglected because, if he had known, it is obvious that he would have asked above everything for the speedy publication of the results. It would have been the most natural thing to do and most in accordance with common sense.

Unfortunately these ideas did not prevail; hence the naturalists who exhausted their energies in the American forests, some of them even losing their lives, and the 20,000,000 pesetas sacrificed by the Spanish government for those journeys-all availed nought, as if some mischievous shadow was pleased to make a failure of such a gigantic enterprise.

Of the fioras of America already mentioned, only the third volume of the Species Plantarum of Ruiz and Pavón was published within a century. ${ }^{2}$ After such deplorable neglect, are we surprised now at the reproaches of foreigners when they tell us that we have done no scientific work in our colonies? But, finally, let us pass to another matter. What is left today of the new genera and species made known by

1 When circumstances permit we shall publish, God willing, the list of donors and donations that is in the Archive of the National Museum of Natural Sciences of Madrid.

2 The Flora Novae Hispaniae was published by the Mexican government in the middle of the past century, but without plates. 
our explorers of Chile and Peru in the Prodromo, in the Systema Vegetabilium and three volumes of the Species et Icones Plantarum Florae Peruvianae et Chilensis?

We will state first of all, that the creation of these groups depends at times on a very personal judgment in the way of appraising characters, their importance varying, in many cases, according to the opinion of each author. That is why genera and species judged by some as new to science are not always regarded as such by others, and it happens even that a genus or a species eliminated by a naturalist from the catalogue of new ones has been replaced in it, later to figure again in its original category. There are very few authors all of whose creations have been respected, especially if they have been numerous.

The new genera established and published by Dn. Hipólito Ruiz and Dn. José Pavón amount to 141 according to what we have seen. And so, an investigation of the Index Kewensis has convinced us that 102 genera are still maintained, and in regard to species, these that have preserved the names of said authors exceed 500. If this work were published complete, we can affirm that it would triplicate, at least, the number of each.

Such is the fundamental work of Dn. Hipólito Ruiz, Dn. José Pavón, Dn. Juan Tafalla, Dn. Isidro Gálvez, Dn. José Brunete, Dn. Agustín Manzanilla, Dn. Francisco Pulgar, and the rest of the Spaniards that collaborated in it. In view of our own forgetfulness and that of foreigners, we congratulate ourselves on being able to record their names here and to offer this homage to their glorious memory. 


\section{VIII}

Other works of Dn. Hipólito Ruiz-Other works of Dn. José Pavón.

If the authors of the Flora Peruviana et Chilensis had not given us any more evidence of their industry and scientific knowledge than that work, it would be enough to immortalize them, placing them on the level of other great botanists and explorers named in history. But their tireless activity was not limited only to this: Dn. Hipólito Ruiz, especially, and Dn. José Pavón, in the midst of continuous work dedicated to the Flora, found sufficient time to produce other works that we shall enumerate.

Besides the Quinologra and the answer to Cavanilles, above mentioned, Ruiz wrote the following.

1. Memoria sobre la Ratanhia (Krameria triandra) R. \& P. Madrid, 1799. Dn. Hipólito discovered the extraordinary virtue of the root of this plant for controlling hemorrhages, having obtained unquestionable success with an extract of this in the treatment of the son of a silversmith from Lima, of a young slave girl of Huánuco, and of a daughter of the physician and first cosmographer of Peru, Dn. Cosme Bueno.

2. Memoria sobre las virtudes y usos de la raíz de la planta llamada Yallhoy [Monnina polystachya] R. \& P. Madrid, 1805. In Peru the author had observed the effectiveness of this medicine for curing dysentery, and, once in Spain, he compiled the work, which was presented in 1803 to the Royal Academy of Medicine. The Academy decided to include it in the second volume of its memoirs, but when the publication of this was delayed, the Academy gave permission to the author to have it printed himself. ${ }^{1}$

3. Memoria sobre la Calaguala [Polypodium Calaguala] R. \& P. Madrid, 1805. In this memoir are set forth its resolvent and anticoagulant properties as well as others equally beneficial.

4. Memoria sobre la Conchaguala [Gentiana Conchalaguala] R. \& P. Madrid, 1805 .

5. Memoria sobre el Smilax (China peruviana) R. \& P. Madrid.

6. Memoria sobre el Bejuco de la estrella (Aristolochia fragrantíssima) R. \& P. Madrid, 1805.

7. De vera fuci natantis fructicatione. Madrid, 1796. Study of the seaweed commonly called sargazo.

8. Breve discurso acerca de los progresos de la Botánica en España. Ms. Very short notes. ${ }^{2}$

1 The manuscript information about this exists in the Royal Academy of Sciences of Madrid and is very laudatory to Dn. Hipólito Ruiz. In it the good results obtained with some patients are cited, according to the testimony of doctors Dn. Ignacio Ruiz de Luzuriaga, Dn. Tomás García Suelto, and Dn. Eugenio de Arrieta. In the same file that contains this information, there is a manuscript of Dn. José Celestino Mutis (Santa Fe de Bogotá, December 19th, 1803), entitled Plan de curación de las disenterías. This is based on the use of Yallhoy root.

${ }^{2}$ Archive of the Royal Academy of Sciences. Bundle of documents, donated by Dn. Joaquín González Hidalgo. 
9. Observaciones sobre la raíz del Yallhoy. Ms. ${ }^{1}$ Several clinical cases are cited.

10. Reflexiones sobre la raiz de Serpentaria (Serpentaria virginiana) y la del Reyno de Estrella (Aristolochia fragrantissima) R. \& P. Ms. ${ }^{2}$

11. Annotaciones circa genus Thibaudiae. $\mathrm{Ms.}^{2}$

12. Relación y noticias que da el botánico D. Hipólito Ruiz al Dr. D. Hipólito Unanico? para que por ellas puedan enviar desde el Perú a aquel naturalista algunos zurrones de raíces de "China peruana," a fin de que dicho botánico continúe las observaciones sobre la virtud y usos de esta nueva droga sumamente interesante al comercio español y de las más preciosas para el alivio del hombre en sus dolencias. Ms. ${ }^{2}$

13. Memoria sobre la fructificación del género "Cynomorium" y de sus virtudes $y$ usos. $\mathrm{Ms.}^{2}$

14. Impugnación de la doctrina de Cavanilles sobre los estigmas del iris. Ms. ${ }^{2}$

15. Observaciones sobre el Fucus natans. $\mathrm{Ms.}^{2}$

16. Instrucciones a que deberán arreglarse los botánicos de Méjico. Ms. ${ }^{2}$

17. Géneros naturales.-Cuestión suscitada en la Real Academia Médica de Madrid sobre si hay o no.-Parecer que dió D. Hipólito Ruiz contra Cavanilles. Ms. ${ }^{2}$

18. Observaciones y reparos a las obras del Abate Cavanilles. Ms. ${ }^{2}$

19. Compendio histórico-médico-comercial de las quinas. $\mathrm{Ms.}^{3}$

20. Reparos y reflexiones críticas sobre la Memoria de las quinas. Ms.4

21. Experimentos sobre las quinas. 1811. Ms. ${ }^{\mathrm{s}}$

22. Causas por que las calenturas intermitentes no cortándose en los primeros accesos pasan a malignas y contagiosas. Ms. ${ }^{6}$

23. Estampas de quina. Ms. ${ }^{7}$

24. Tratado que puede servir de suplemento al diccionario y gramática de la lengua Quechua. $\mathrm{Ms}^{8}{ }^{8}$

25. Memoria sobre la quina francesa. Ms. $^{9}$

26. Formulario para hacer viajes cientificos. Ms. ${ }^{9}$

27. Suplemento de la "Filosofía Botánica de Linneo" en colaboración con D. Antonio Palau. Ms. ${ }^{9}$

28. Las guerras de Chile. Ms. ${ }^{9}$

${ }^{1}$ Leg. cit.

${ }^{2}$ Ibid.

${ }^{3}$ Exists in the British Museum (Natural History). See the Catalogue entitled Cinchona Tercentenary Celebration and Exhibition. London, 1930. P. 100, no. 974.

${ }^{4}$ Op. cit., p. 101, no. 976.

5 Ibid., p. 101, no. 977.

Ibid., p. 101, no. 978.

7 Ibid., p. 101, no. 979.

${ }^{8}$ Cited in the "Discurso leído ante el claustro de la Universidad Central por D. Tomás Pascual de Miguel, en el acto solemne de recibir la investidura de doctor en la Facultad de Farmacia." Madrid, 1867. P. 15.

${ }^{\circ}$ Speech and page mentioned. 
The productions of Dn. José Pavón were not as many as those of Ruiz, but nevertheless he left a legacy of several with merits beyond dispute, which we cite here.

1. Laurografía o estudio de las especies de Laurel. Manuscript existing in the Archive of the Botanical Garden, accompanied by 28 plates drawn by Gálvez and Pulgar and engravings by Suria, Gascó, Rodríguez, and Panfil.

2. Indice alfabético de todos los nombres indicos, provinciales y castellanos de todas las plantas publicadas e inéditas de la Flora Peruviana y Chilense, algunos de Nueva España y la Habana, con la correspondencia de los nombres botánicos, genéricos y específicos. Se citan las especies que producen gomas, resinas y bálsamos, como también las que sirven en tintorería y Medicina y las artes y las maderas para la construcción civil $y$ naval. Ms. Archive of the Botanical Garden of Madrid.

3. Disertación botánica sobre los géneros "Tovaria," "Actinophyllum," "Araucaria" y "Salmia," con la reunión de algunos que Linneo publicó como distintos. Madrid, 1797.

4. Nueva Quinologia. Ms. in the British Museum of Natural History. 1825. This work, in which 40 species of the genus Cinchona are described, was published in London in the year 1862 with great luxury and with the title: Illustrations of the Nueva Quinologia of Pavon, by John Eliot Howard. It has 28 plates in color and more than 100 figures. ${ }^{1}$

1 It cannot fail to attract attention that this manuscript and the others by Ruiz above cited have passed to the Museum of London. Perhaps Pavón, urged by pressing needs and without hope that they might be published here, transferred them, as he did a part of the herbarium of the quinas, to Mr. Aylmer Bourke Lambert. See the work Cinchona Tercentenary Celebration and Exhibition, 1930. P. 101, no. 982 . 
José Dombey-His scientific competence-Arrival in Spain-Information about means to combat the plague of ants-His appointment as a member of the expedition-Leaves for Peru-Commissions confided to him-His botanical campaignsHis return to Spain (1784)-His collections-Inaccuracy of Larousse.

The history of this journey cannot be written without mentioning Dn. José Dombey. He was a French physician and naturalist who joined the Spanish explorers of Chile and Peru at the request of his government.

He possessed knowledge not only of botany, but also of other branches of the natural sciences, and was entrusted with the task of studying the plants and other products of those Spanish colonies. The French government assigned him the salary of 6,000 pounds French currency per year and 600 silver pesos, at one time, for his equipment.

Dombey arrived in Spain in the first months of the year 1777, and a little later, answering an inquiry, no doubt, he presented to the Monarch some instructions about combating the plague of ants, that, after having destroyed the harvest of sugar cane in Martinque, they feared might extend to Cuba.1 His appointment was made by the Spanish monarch with the caution that he should not publish his discoveries before his traveling companions could do the same, and that he should leave in Spain at least one specimen of each one of the plants he might find. In October, 1777 the vessel that carried the explorers weighed anchor en route to Callao, and six months later anchored in that port after a good voyage. Apart from his botanical work, Dombey discharged several commissions that were confided to him by the Spanish authorities of those countries.

In 1779 he received from Dn. Manuel Guirior instructions to proceed, as a physician, to examine and analyze the mineral waters of Cauchin and vicinity, and he discharged this commission with true zeal. A little later he went to Callao, in the company of several Spanish sailors, to make studies of the tides.

In 1779 a royal order was sent from Spain for a careful investigation of the existence of saltpeter in Peru, and Dombey was also designated to carry out this commission, as indeed he did, although making a mistake. ${ }^{2}$

A little later he made an excursion to several mining districts of Peru, and he edited a report that contained the result of his observations. ${ }^{3}$

In 1783 , he was assigned anew, by command of the Regent of Chile, Dn. Tomás Alvarez Acevedo, to examine the veins of quicksilver of the hill of Jarilla in the

1 The manuscript is entitled Moyens pour détruire les fourmis dans l'Isle de la Martinique. These means had already been used against the insects in France and in Vals (Catalonia).

${ }^{2}$ On the coasts of Peru Dombey found a substance that he remitted to Madrid and Paris, calling it by the name of saltpeter, because he thought it to be niter, but Professor Gómez Ortega, who analyzed it, demonstrated that it was only a sulphate of magnesia, abundant in various regions in Spain.

${ }^{3}$ Reflexiones sur les mines du Perú quant à leur formation, par Mr. J. Dombey. Lima, September, 1780 - Two pages in folio written on both sides. Archive of Alcalá. Bundle 2,525, transferred to the National Museum of Natural Sciences of Madrid. 
district of Andacollo, not far from the city of "La Serena," and after minute study he presented the result of his work, and it brought the warmest praises from the Regent.1

On the 14th of April, 1784 Dombey retired from the expedition, returning to Spain in the vessel "Peruano," commanded by Brigadier Dn. Antonio de Córdova. The crossing lasted a year and was very trying indeed; they were several times on the point of shipwreck. In spite of this, Dombey recovered somewhat his lost health, arriving in Cadiz during the first days of May, 1785. He brought with him very valuable collections of minerals, plants, etc., and it was his duty to deliver half of everything to the Spanish government, according to the agreement obtained from him at the beginning. Consequently in August of the same year (1785), a representative of the authorities came to Cádiz to inspect the equitable distribution of these collections; when this was accomplished, Dombey was authorized to send on to Paris the part belonging to him. ${ }^{2}$ It was also required of him that he repeat in writing the promise not to publish the discoveries made on this trip until the return of his collaborators. Nevertheless, he obtained permission of the Spanish Monarch to communicate them to the King of France and to the Royal Academy of Sciences of Paris, which was not a small matter.

Such is the part that belongs to Mr. Dombey in this scientific expedition.

1 The letter of the Regent is reproduced here as an interesting document: "Sr. Dn. José Dombey: My dear Sir: From the context of the report or description of the quicksilver mines of Xarilla and Andacollo that you remitted to me in triplicate the 30th of August last, with respective plans, geometric and in perspective, of said mines and the metals that you brought to make tests in this capital, and other results expressed in said report, I understand that you have discharged with satisfaction the task entrusted to your care in the order I sent you, under the date of 20 th of May, for the inspection and examination of said mines. In view of this, I can do no less than inform you, by means of this letter, that I am satisfied and pleased with the care, zeal, and love for the royal service with which you have discharged said commission. ..." Despatch of Dombey.-Personal.-17781785.-Bundle 2,525. Transferred to the National Museum of Natural Sciences from the Archive of Alcalá.

2 There was thus no confiscation of half of the collections for the benefit of the King of Spain. The reproaches of Larousse (Grand Dictionnaire Universel, etc., [Vol. VI], p. 1,048) relative to the confiscation are therefore not justified. 
The journals and the Viaje of Ruiz-Date at which it was terminated-Information given in the Prodromo and in the Quinologia-The doctoral thesis of Dn. Tomás Pascual-The extract of the Viaje by Jiménez de la Espada-Our investigations-Persons who advised us-Praiseworthy conduct of Doña Isabel Pascual-Our additions-Acknowledgments to those who have helped us.

One of the first cares of Ruiz and Pavón was to keep an exact and detailed account of all the events that happened on their journey from the time of their departure from Madrid until the date of their return. With these journals they could trace a complete and finished picture of their scientific campaigns and the localities where they took place.

Approximately eleven years of continuous labor and tiresome travels through the hills and mountains of Chile and Peru gave them abundant and valuable material for writing a Viaje full of profitable information and interesting episodes. They began to do this as soon as they returned to Madrid, with the natural illusion of making public in Spain and to the scientific world, the fruits of a campaign so full of sacrifices and results for the sciences. By the year 1793 they had already prepared a fair copy of the Viaje in the expectation of receiving means to enable them to publish it. This copy contained, according to its author, 90 sheets in small writing, ${ }^{1}$ and it contained a very detailed account of the work of the expedition. Insuperable difficulties prevented it from being published, and when Dn. Hipólito Ruiz died in 1816, the manuscript must have been left to his family, if it did not pass into the hands of Dn. José Pavón.

There was some information about the journey by both botanists in the preface of the Prodromo and by Dn. Hipólito Ruiz in the Quinología, but it is so scanty that it was impossible on the basis of these statements to form even an approximate idea of the importance of the expedition. That is why the memory of it faded and was preserved only by some naturalists of the past century.

Matters stood that way when, in the year 1867, an individual by the name of Dn. Tomás Pascual de Miguel, possessor of a copy of the Viaje, conceived the idea of utilizing it in the composition of the doctor's thesis with which he completed his studies in pharmacy. ${ }^{2}$ This circumstance revived for a while the remembrance of the botanical expedition to Peru, but it was soon forgotten again. Interested in clearing up this matter, we had the good fortune to find an extract of the Viaje, thanks to Dn. Marcos Jiménez de la Espada, who had the happy idea of making a note, at the bottom of this extract, of the name and place of residence of the possessor of the Viaje, that is, Dn. Tomás Pascual de Miguel. To us it was an unsuspected clue that we decided to follow, although without hope, because Note.

${ }^{1}$ This is the statement of Ruiz in the Suplemento a la Quinología, p. 115.

${ }^{2}$ It was published in the year mentioned (1867), with the following title [in Spanish]: "Speech read before the Assembly of the Universidad Central by Dn. Tomás Pascual de Miguel in the solemn act of receiving the degree of Doctor in the Faculty of Pharmacy. Comparison between the botanical expeditions made to the New World by Dn. Hipólito Ruiz and Dn. José C. Mutis." We remember having heard from the late Dn. Blas Lázaro that there existed another doctor's thesis about the journey, but we have been unable to see it. 
thirty years had not passed in vain since the death of Sr. Pascual de Miguel. We shall not mention here the questionings and search, almost police-like in method, that were made by us to find the whereabouts of the Viaje; but it would be ungrateful of us to omit now the names of Dn. Fernando Gayoso, Dn. Luis Siboni, and Dn. José Reimundo, who helped us in our course. Thanks to the last-mentioned, who had been a clerk of Dn. Tomás Pascual, we found that the daughter of Dn. Tomás Pascual, named Doña Isabel was living in the town of Arvaca; after having made inquiries through the priest Dn. Félix Martín, we went to that town, being accompanied by him to the house of that lady. She received us with the greatest affability and, after hearing the object of our visit, she placed in our hands the desired manuscript, which we brought to Madrid, well worth all the hardships incident to such a tiresome task. Acknowledgment should be made here of our most profound gratitude, first to Doña Isabel Pascual, and also to the gentlemen mentioned above.

As soon as we arrived in Madrid, we presented the manuscript to our dear teacher Dn. Ignacio Bolívar, director of the Museum of Natural Sciences, who was greatly pleased with the recovery, promising us, furthermore, to have it published as soon as circumstances would permit. After some years of waiting, the opportunity appeared at last, and Sr. Bolivar, fulfilling his promise, ordered that it be done. Thus he is the promoter of this work which, thanks to his zeal and enthusiasm for our scientific glory, emerges from obscurity to be presented to the educated world. It is hoped that it will be well received.

The manuscript that has been used for this publication contains 67 double sheets of paper (papel de barba), covered with the handwriting of Dn. Hipólito Ruiz. On most of them the writing remains perfectly legible. There is an abundance of marginal additions, and on some pages, there are interlinear corrections. The orthography and punctuation are very careless. We have corrected the latter. The description of Lima and also that of the city of Huánuco are missing, but there is no doubt that they were included in the last copy prepared for publication. We tried, in fact, to find that copy, appealing to the person who we were told should have it, but our attempts failed, with great noise, and we received a very impolite and intemperate reply through a third person. We forgive it willingly.

To each chapter we have given a number; furthermore, at the head of each we have placed a summary from which one may see its contents. The book also includes some notes, and we should remark here, that those on pages 25-26 [omitted from the English translation], referring to the technical names of fish, are by our dear friend Doctor Dn. Luis Lozano, professor of this faculty of sciences.

That the work might be consulted with ease, it is provided with four indices, made by us, one by subject, and three alphabetical. In the arrangement of these, we have had the co-operation, with the greatest zeal and disinterestedness of our dear friend, the curator of the museum and assistant of the university, Dn. José Huidobro, to whom, as well as to the former, we are deeply grateful.

The text of the Viaje is followed by the unpublished documents referring to it, greatly enhancing its value with references and information not included in the Viaje. 
Contents of the Viaje-Geographical part-Botanical part-Mineralogical part-Zoological part-Curious entomological detail-Historical episodes-Appendices.

It is enough to glance through the pages of this Viaje to convince oneself that it constitutes a very valuable and exceptional document in our HispanoAmerican literature. Nearly eleven years of traveling through the lands of Chile and Peru, with the idea of observing, studying, and describing all their products, gave Ruiz and Pavón more than enough material to give a complete picture of life in those colonies in its various aspects. Consequently, it is not one of those diaries in which are registered chronologically happenings and episodes of a more or less personal character. The Viaje that is published today follows a more ample plan and a more objective orientation. To convince oneself of that, a brief examination of it in its principal aspects, will suffice. One of those of great importance is the geographical. Since the Relaciones geograficas de Indias, made in time of Philip II, ${ }^{1}$ nothing has been written so detailed and complete about the geography of Chile and Peru as in this Viaje.

Our botanists started their work in Lima proper, which they described minutely, and its vicinity, where they caused astonishment to the natives who called them witch doctors, brujos yerbateros. ${ }^{2}$ Then they went to the province of Cercado, included in the present department of Lima, and afterwards to the provinces of Chancay (in the same department), Tarma (department of Junin), Huarocheri (department of Lima), Huánuco (present department of the same name), Xauxa (department of Junin), and Huamalies (department of Huánuco). Province by province and region by region are minutely described in this Viaje, beginning with the respective limits and continuing to temperature and climate, nature and topography of the soil, natural products, inhabitants, commonest ailments in each locality, etc., etc. In regard to ecclesiastical organization, the author makes reference not only to the convents and shelters existing in each town, but also to all the parishes and the annexes belonging to them. But although the geographical part is very interesting, the botanical part is much more so. More than 500 genera and 1,600 species of plants are cited in it. And that is not all. There are described furthermore the type and aspect of many trees, shrubs, and herbs, the domestic uses of a large number of the same, their medicinal and industrial applications, their native names and the "why" of each one.

Nor did Dn. Hipólito Ruiz forget the mineralogical part, to which he dedicated principally articles XIV and XXXII, nor the zoological part, of which there is much important information of positive interest in the whole story. Among these there is one worthy of particular mention, and that is the one referring to the small ants, destroyers of the Cerdana, the leaves of which they cut into small triangular pieces, transporting them later, holding them by the sharpest angle and hoisting them in the manner of a lateen sail. And so they travel with them, by means of help from the wind, until they deposit them in the anthills in a very clever and ingenious way

1 Published in Madrid in the year 1881, written by Dn. Marcos Jiménez de la Espada, who managed the editing.

${ }^{2} \mathrm{We}$ are assured that some of those places are still called by the name cerro de los yerbateros. 
so that they occupy the least possible space. This phenomenon, that has been cited by some entomologists only many years later, appeared already in this Viaje [page 175] described with all desirable detail.

However, there appear in this account some interesting events of historic character, for example: the earthquakes and floods of Valdivia in 1730 and 1751, respectively; the uprising of Tupac-Amaro in 1781 [page 108]; the murders committed by the Indians in 1766 and 1772 and, not to add any more, the battle of Villagra, in which the maestro de campo of the same name was defeated and killed.

Such are, in short, the contents of the Viaje of Dn. Hipólito Ruiz, Dn. José Pavón, Dn. José Dombey, Dn. Isidro Gálvez, and Dn. José Brunete to Chile and Peru.

To complete it, it was necessary to have the official documents referring to it, and we have been fortunate indeed in finding them. They consist of the royal letters of appointments, correspondence, instructions, lists of shipments, and other matters of positive interest. With this we close this work which, according to our humble opinion, constitutes a glorious page in the scientific history of Spain. 
APPENDICES 



\section{APPENDICES}

The collection that we now insert of curious and interesting offcial documents concerning the travels of Dn. Hipólito Ruiz and his companions in Chile and Peru constitutes the natural and pertinent complement of the preceding work and an eloquent testimony to the great importance of those travels. (Archive of Alcalá. Docket 2,525, transferred to the Museum of Natural Sciences of Madrid.)

\section{APPENDIX I}

\section{APPOINTMENT OF DON HIPŐLITO RUIZ}

The King: Inasmuch as the exploration and methodical study of the natural products of my domains in America befits my service and the welfare of my subjects, not only in order to promote the progress of the physical sciences, but also to banish doubts and adulterations that are found in medicine, painting, and other important arts, and to increase commerce, and to form herbaria and collections of natural products with descriptions and delineations of the plants found in those fertile domains of mine to enrich my Cabinet of Natural History and the Botanical Garden of the Court; I have resolved to send two Spanish botanists to the Kingdom of Peru, accompanied by a French naturalist, physician, and botanist, and two draftsmen, also Spaniards, to each one of whom shall be sent a separate brevet, or appointment; and having been informed of the good work and the reputation of Dn. Hipólito Ruiz in this profession, I have come to name him as my first botanist of this scientific expedition to the Kingdom of Peru, where he shall serve under the instructions that will be given to him separately, signed by my Secretary of State and by the General Office of the Indies, and with the following conditions: 1st. From the time of his arrival in Peru, his residence in that kingdom on the said expedition shall be for the term of four years. 2nd. He shall receive the salary of one thousand pesos in the coin of the Indies, per year, from the day of his embarkation at Cádiz or at any other port of Spain, and it shall be paid him by any Royal Coffers of that kingdom nearest the place where he may be following his profession. 3rd. During his journeys in that kingdom for the above-mentioned purposes, he shall receive double salary to provide for the necessary expenses that he may incur for this purpose. 4th. When he returns to Spain, he shall be assisted by my Royal Treasury with half of the salary that he received in America, until he is given another appointment and he completes and presents the finished work that should be the fruit of his toil. 5th. That the passage by sea from Cádiz or any other port of Spain to his destination shall be paid from the account of my Royal Treasury, and the same shall apply to the journey overland from Madrid to that port, where he shall be given in advance four installments of his salary in America to equip himself with the necessities for the voyage. 6 th. That at the expense of my Royal Treasury he shall be provided with books and instruments of his profession for use in the work for which he is sent. Therefore, I order my Viceroy Governor and Captain General of the Provinces of the Kingdom of Peru, and the Regentes of my councils, Royal Officials of those coffers, and the other tribunals and justices of that kingdom to receive and accept the said Dn. Hipólito Ruiz as my first botanist, rendering and insuring him the honor and distinction that should belong to him for the success of his commission, and the Royal Officials of the Coffers of Lima to pay him, or with the corresponding order of my Viceroy 
by virtue of this, any other coffers of that kingdom, the sum of half his annual salary and assistance with the cost of the travels indicated in this, my order, and receipt shall be obtained at the time from the party concerned, for that is my will; and notice shall be taken of this order by the General Accountant's Office of my Council of the Indies. Given at Aranjuez the 8th of April, 1777.

Herewith, His Majesty names his first botanist Dn. Hipólito Ruiz for the scientific mission to the Kingdom of Peru with a thousand dollars a year salary, and under the conditions already stated.

NoTE.-The appointment of Pavón is conveyed in the same form as this.

II

\section{APPOINTMENT OF DOMBEY}

The King: Inasmuch as the exploration and methodical study of the natural products of my domains in America befits my service and the welfare of my subjects, not only in order to promote the progress of the physical sciences, but also to banish doubts and adulterations that are found in medicine, painting, and other important arts, and to increase commerce, and to form herbaria and collections of natural products, with descriptions and delineations of the plants found in those fertile domains of mine to enrich my Cabinet of Natural History and the Botanical Garden of the Court; I have resolved to send to the Kingdom of Peru a French naturalist, physician, and botanist so that, as companion to the two Spaniards of the same profession and with the same destination, he may make observations pertaining to his science; and having been asked by the Court of France to name Dn. Joseph Dombey, for this important purpose and having been informed of his good character and the reputation of his work, I have come to name him for this commission in the capacity of companion to the two botanists and the two draftsmen from Spain; he shall serve under the instructions that will be given him signed by my Minister of State and by the General Office of the Indies, and with the salary of 1,200 pesos in the coin of the Indies, which is the salary that the Court of France has indicated; it shall be paid by the Coffers of Lima or with the corresponding order of my Viceroy in accordance with this order in any of the coffers of the Kingdom of Peru nearest to the place where he may be making his botanical observations, and he shall give an account to the Royal Officials of the coffers where payment shall be made of the salary allowed to Dn. Joseph Dombey, so that reimbursement may be obtained in Spain from the Court of France: Therefore, I order my Viceroy Governor and Captain General of the Kingdom of Peru and the Regentes of my councils, the Royal Officials of those coffers, and the tribunals and justices of those kingdoms to receive and accept the said Dombey as botanistnaturalist in the capacity of companion to the Spaniards of the same profession, commissioned for the scientific expedition in those domains, rendering and insuring him the honor and position that should belong to him for the success of his commission, and the Royal Offices of Lima crediting them, if other coffers of that kingdom should pay his salary, by virtue of this, my order, and receipt shall be obtained from the party concerned, for that is my will; and notice shall be taken of this order by the General Accountant's Office of my Council of the Indies. Given at Aranjuez the 8th of April, 1777.

With the proper order to my Viceroy on account of the salary mentioned with authorization and semiannually.

In duplicate. 
His Majesty commissions Dn. Joseph Dombey for the botanical expedition to the Kingdom of Peru as a companion of the Spaniards of the same profession with the salary of 1,200 pesos a year and the stipulation of reimbursement from the French Court as stated.

\section{III}

\section{APPOINTMENT OF BRUNETE}

The King: Inasmuch as the exploration and methodical study of the natural products of my domains in America befits my service and the welfare of my subjects, not only in order to promote the progress of the physical sciences, but also to banish doubts and adulterations that are found in medicine, painting, and other important arts, and to increase commerce, and to form herbaria and collections of natural products with descriptions and delineations of the plants found in those fertile domains of mine to enrich my Cabinet of Natural History and the Botanical Garden of the Court: I have resolved to send two Spanish botanists to the Kingdom of Peru, accompanied by a French naturalist, physician, and botanist, and two draftsmen, also Spaniards, to each of whom shall be sent a separate brevet, or appointment; and having been informed of the good work of Dn. José Brunete, and his well known ability in drawing, I have come to name him as the first draftsman of this scientific expedition to the Kingdom of Peru, where he will serve under the instructions that will be given him separately, signed by my Secretary of State and the General Office of the Indies, and with the following conditions: 1st. From the time of his arrival in Peru, his residence in that kingdom on the said expedition shall be for the term of four years. 2nd. He shall receive the salary of one thousand pesos in the coin of the Indies, per year, from the day of his embarkation at Cádiz or at any other port of Spain, and it shall be paid him by any Royal Coffers of that kingdom nearest to the place where he may be following his profession. 3rd. During the trips in that kingdom for the purposes mentioned, he shall receive double salary to provide for the necessary expenses he may incur for this purpose. 4th. When he returns to Spain, he shall be assisted by my Royal Treasury with half of the salary he received in America, until he is given another appointment and he completes and presents the finished work that should be the fruit of his toil. 5th. That the sea voyage from Cádiz or any other port of Spain to his goal shall be paid for from the account of my Royal Treasury, and this shall apply to the land journey from Madrid to that port, where he shall be given in advance four installments of his salary in America to provide for the necessities for the voyage. 6th. That at the expense of my Royal Treasury he shall be provided with the books and instruments of his profession for use in the work for which he is sent. Therefore, I order my Viceroy Governor and Captain General of the Provinces of the Kingdom of Peru, and the Regentes of my councils, the Royal Officials of those coffers, and the other tribunals and justices of that kingdom to receive and accept the said Dn. José Brunete as my first draftsman of the scientific expedition mentioned, rendering and insuring him the honor and distinction that should belong to him for the success of his commission, and the Royal Officials of the Coffers of Lima to pay him, or, with the corresponding order from my Viceroy, by virtue of this, any other coffers of that kingdom, the sum of half his annual salary and assistance with the cost of the travels indicated in this, my order, and receipt shall be obtained at the time from the party concerned, for that is my will; and notice shall be taken of this order by the General Accountant's Office of my Council of the Indies. Given at Aranjuez the 8th of April, 1777. I, the King. Jph. de Gálvez. ... 
Registered in the Office of the General Accountant of the Indies: Madrid, April 12th, 1777. Tomás Ortiz de Landazuri.

Lima, April 10th, 1778. Keep and execute the above Royal Order. And to that effect the Royal Officials of the Coffers of this capital shall liquidate and pay in full to Dn. José Brunete the amount that he is entitled to on the terms that H. M. orders. First taking a memorandum in the Tribunal and Royal Office of Accounts. Don Manuel de Guirior. Pedro de Ureta.

Corresponds with the original Royal Order that for this purpose was written by said Dn. Joseph Gálvez, to whom I returned it, which I certify. And at his demand in witness of this, I, Sub-secretary of the King our Lord and of the College of this Court and City of Madrid, write the present which I sign and attest the 20th of June, 1816. Juan Martin Delgado (signed).

NoTE.-The appointment of Gálvez is written in the same form as this.

\section{IV}

Archive of Alcala. L. 2,525, transferred to the Museum of Natural SCIENCES. YEARS 1776 TO 1785.

1776. Instructions that shall be followed by the persons named by H. M. to go to South America in the Company of Doctor Dn. Josef Dombey for the purpose of examining plants and herbs and of making botanical observations in those countries.

1. They shall try to live in the best of harmony and good relations with the said Doctor Dn. Josef Dombey, to win his confidence and profit from his knowledge, not only in botany and natural history, but also in the art and methods of arranging and preserving plants and of forming herbaria.

2. They shall be careful to question him and to turn to him in cases where they think it is necessary or useful to take advantage of his knowledge and experience; although for this they shall not be, or consider themselves, dependent on him, nor shall he treat them as such in any case or matter.

3. They shall communicate to Dn. Josef Dombey the discoveries in botany or natural history that they may make, not keeping any secrets from him, so as to pledge him with this frankness and procedure to equal reciprocity in the things that he himself may discover.

4. If it happen that only one plant, herb, or simple of some odd species be found, there must be no misunderstanding or dispute over who shall keep it. If Doctor Dombey be the first to find and pick it, he shall preserve it for his herbarium, giving his companions an exact description of it, and permitting them to get an accurate sketch and if possible, without harm to the plant, to take a part of it; the said Mr. Dombey shall consent to our botanists putting at least this part of the plant in the books that they may form.

The same attitude and reciprocity shall be maintained on the part of our observers towards Mr. Dombey, if they be the first ones to see or gather any rare plant of which there may not be many examples; so that the profitable rivalry that should encourage them in discoveries that many times will be offered by chance, may not degenerate, contrary to our hopes, into disagreement, it will be well for them, as soon as they find genera and new species or such as have been badly defined up to now by botanists, to write them in their respective diaries with the name of the discoverer following the name that at that time has been 
given to the plant; and on the first occasion when they reciprocate in the communication of their finds, they shall add their signatures in each diary so that it may be clear who has the first right to publish it.

5. What has already been said is in no way contrary to the agreement that Mr. Dombey has made to present, on his return to Europe, two copies of the observations and herbaria that he may have made, to be compared, in his presence, with those from his companions by professors of our Royal Botanical Garden, and to leave one of them in Spain; it being understood that, if for some unusual reason unlikely to occur, there be only one single plant because they have not been able to find any other, he shall be permitted to leave it in his sample book that he takes to France; but with the condition that, in the one he leaves in Spain, there shall be inserted, in the corresponding place, the description and sketch of the same plant, with observations and notes of any kind that he may have made of it.

6. The Spanish botanists shall make, independently of Mr. Dombey (although consulting him and taking advantage of his knowledge and intelligence whenever they think it necessary), the description of each plant, following the principles or botanical rules of Linnaeus, and according to his sexual system already adopted generally, stating its names in the language of the country, in Spanish, and in Latin if it has one, and the name given to it in French by Mr. Dombey, the species and varieties of each genus, and whether it is a plant that is known by a different name in other provinces of the same America or of the East Indies, or of any other countries whatever.

7. They shall not forget to state in their written observations, if it be a plant known in Europe, what qualities are attributed to it in that country (for this purpose they shall try to inform themselves through intelligent persons and even countrymen), and whether any known author has written about it.

It will be well also to state in what kind of climate and temperature it is grown, to be able to tell afterwards if it be possible to grow the same plant in some different kinds of ground and in the temperature of Spain, or what degree of artificial heat may be necessary to give it in the hothouses that will be constructed in the Royal Botanical Garden of Madrid.

8. Care shall be taken to obtain several examples of the plants that are to be placed in the herbaria whenever they are very unusual, or notable for their virtues and qualities, so that if time, or dust or other accident destroy or disfigure one of them, there may be others left.

9. It will not be useless to advise that the principal care and study shall be given to plants and samples little or not at all known in Europe, or that have some special peculiarity, and that are thought to be of service in medicine, commerce, or the arts; and also those plants which, although they have been known for the uses made in Europe of their resins, gums, balsams, roots, and other parts or products, are not well described by botanists; because, in some respects it would be a waste of time to make observations about plants that are also common and known in Europe, and to fill herbaria with them, when there is no difference whatever between these and the others; it is necessary to note and indicate simply that this or that plant common in Europe is also found in abundance or sparsely in such and such territory of America.

10. For the formation of herbaria they shall consult their teachers before leaving, inspect those that these men have made for their use, and ask instruc- 
tions from Doctor Dombey, who is said to be particularly experienced in this matter; and care shall be taken that the plants and herbs be placed in said herbaria in the best manner possible for their preservation in shape, colors, flowers, and seeds. For this purpose it may be well, as has been said, to inquire of Dombey himself, and also to consult what is said about this subject in several books, written in Latin or in French, that refer to it; these shall be taken along, and among them shall not be forgotten the botanical lessons recently published by Mr. de la Tourrette for the use of the veterinary school of Lyons, France, nor some of the volumes of the learned and famous Linnaeus, who in the third volume of his work Amoenitates Academicae, seu dissertationes physicae, medicae, botanicae, in the article entitled, Instructio musaei, discusses in detail the precautions that should be taken for the formation of herbaria as to the manner, time, and condition in which it is well to gather plants in order that they be best preserved in all their parts. In the volume entitled Philosophia Botanica by the same author, there will be found a small summary of what botanists that travel should keep in mind, of the books and instruments that should be carried, and even what clothing is most suitable for the man occupied with botanical observations in the field, and of the distribution of the working hours of the day.

In another of the volumes of the same author there is an article entitled Peregrinatores Americani, in which information is found about many of the writers who have discussed the plants of America; this will no doubt shed much light on the subject. Most of these writers have written in a foreign language, and it is almost certain that Mr. Dombey will carry with him those printed in French; and in case the Latin or French language may not be very familiar to some of our observers, it may be necessary also to take several books written in Spanish that have some connection with your work, such as the Principios Botanicos of Dr. Barnades, the Disertacion of Mr. Duhamel on botanical methods that has lately been published in our language, and others that we shall not name because it is to be assumed they are not unknown to our botanists.

11. The sketches or drawings that shall be made of the plants shall be made when the plants are still fresh and with their colors and natural green because, if left for a long time after being gathered, the plants wither and lose their shape so they do not represent, or give a just idea of, their natural state.

12. Although the principal object of our botanists is the examination, study, and acquisition of all the products of the vegetable kingdom, it will be very desirable for them to apply themselves also with care to the knowledge of the rare trees of America, of their fruits, flowers, seeds, gums, oils, and balsams. Among the trees and shrubs worthy of special attention is the canela of the Quixos in Peru, the quina or cascarilla, in particular that of the province of Loxa, the $i c h u$ that is very abundant in Peru and which is used, among other things, for the smelting of cinnabar to obtain mercury, and several other trees and shrubs which are very abundant in those countries, the dried fruits, resins, and balsams of which are not well known in Europe and may be of great value in medicine and for dyes and manufactures.

As in one of the instructions that were drawn up last year by Dn. Pedro Davila by order of the King, that the Viceroys, Governors, and Magistrates of the Indies should send to the Cabinet of Natural History of Madrid all the more curious productions of nature, there is an article about those of the Vegetable Kingdom relating to some of the plants, trees, and shrubs of America, and with these instruc- 
tions there is a copy of those by Dn. Pedro Davila, in which there is also another article about the manner of preparing and preserving the same natural curiosities that might give some information to our botanists.

13. When the botanists have a considerable quantity of plants and have formed some fascicles to be used for the herbaria, they shall try to send them to some city, or safe place, as opportunity offers, and have them deposited in some suitable place in the townhouse, in the house of the judges or the house of the priests, with the necessary precautions so that no one can misplace them and so that they may not become moth-eaten or deteriorate. In this way the botanists will not increase the number of objects in their care, nor have to travel with the impediment of more loads than necessary. Afterwards they shall collect them all in order to deposit them in the capital or in the port from which they will embark to return to Europe.

14. The principal object of this trip being not so much the purely theoretical information about new useful plants as their acquisition for introduction and use in Spain and even in other countries for the extension of science and commerce and for the benefit of mankind, our botanists shall not be satisfied with examining and describing the plants and preserving their dried remains in the herbaria; they shall also pay diligent attention to making shipments of samples of onions or bulbs, grass, cuttings, and live plants whenever they have the opportunity, addressing them to the Secretary of State and the Cabinet of the Indies, on whose order they shall be deposited and cultivated in the Royal Botanical Garden in Madrid, so that on their return the traveling botanists may examine them again more leisurely and perfect their descriptions; and in the same garden care shall be taken to multiply them and make suitable experiments with their adaptation to the climate and soil of some part of Spain. For this purpose the botanists shall keep in continuous correspondence, addressed to the Ministry, with the professors of Madrid, of whose zeal and willingness to do all possible to contribute to the end that the King has in mind with this journey there is no doubt.

15. In England during these last years, there were published on a single sheet of paper brief instructions about the way to preserve live plants on a long voyage: by following these, the English have brought to London beautiful plants from our domains in America, from their own, and from the most remote countries of the universe. A copy of this paper is therefore being sent with these instructions so that it may serve as a guide to our botanists in the handling of the live plants that they have to send continuously, and so that a copy of these instructions regarding the care of the plants may be given with each sending of plants to the commander of the vessel in which they are sent. Regarding the preparation and remittance of fruits and other dried curiosities of the Cabinet of Natural History, this shall be done according to the instructions in Article 12.

16. And because not all of the plants are of such a nature that they will stand transportation, nor all arrive in good condition, it will be desirable that from all of them without exception there be sent separately seeds and fruits recently dried, numbered the same as the plants, with a small strip of parchment, and packed in pitched boxes so that rats and insects will not destroy them. These shall be accompanied by a descriptive list to which the numbers will refer.

17. Independently of the remittances of live plants and recent seeds, they shall form a collection of seeds, dried fruits, gums, resins, balsams, and other 
products and parts that may have some use or deserve to have, not only for the purpose of supplying what is missing in the Cabinet of Natural History, but also in the Archives of Seeds that have been installed by order of $\mathbf{H}$. M. in the Royal Botanical Garden, and serve as a school of botany and materia medica during the winter.

18. The previous articles concern the quality of professors, and the duties incumbent upon them as such; but there are some other very important warnings to be given to our botanists (which shall be given also directly to $\mathrm{Mr}$. Dombey).

These may be reduced to the warning that, in no case or under no pretext, by themselves or through any other person, shall they take part directly or indirectly in any commerce by sending to Europe or receiving merchandise of any kind whatever, because the moment it it is known, or a well founded suspicion arises, that they have dealings of this nature or have correspondence with any merchant of Europe or of America for that purpose, the necessary steps will be taken even to bring them back to Spain by force and to punish them severely; the persons with whom they correspond shall be warned to watch for this very carefully to give information of the least transgression of this kind.

All that has been said is understood to apply not only to merchandise of commerce, but also to objects of botany and natural history, of which there must neither be any sendings to Europe, except directly to the Cabinet of Natural History and the Royal Botanical Garden, nor any dealings in them in America with the idea of gain, because this journey and work being purely scientific, they shall not forsake, neither the Spanish professors nor Mr. Dombey or others that may accompany them, the study to which they should limit their attention.

19. They shall equally abstain from making plans or drawings of any grounds, towns, ports, or coasts, as none of these have any bearing on the objective of the commission with which they are charged.

20. A copy of these instructions shall be given to Mr. Dombey in French, not only that he may know of the friendship and co-operation that has been recommended to the Spanish professors, but also to inform him of the articles to which it is the idea of the King that Mr. Dombey also be subjected, so that he may not allege excuse or ignorance in case of violations.

21. Mr. Dombey shall not refuse to help the Spanish professors in all he can contribute to the better performance of their work, without exception of subject or substance, and there shall be reciprocal relations that each one may contribute his part to the end and object that the King has proposed for this journey, from which great advantages may be secured for the advance of the arts and sciences and consequently for the welfare of humanity, if those taking part in it proceed with the zeal, industry, and good harmony that is expected of them and which is particularly recommended.

NoTE.-The draftsmen that will accompany our botanists shall be given suitable advice (in addition to the separate instructions that will be given them) relative to the contents in the articles about the harmony and reciprocity that shall be observed among them and as to the absolute prohibition against mixing in any kind of commerce or any other affair whatsoever that has no connection with the principal object of this trip; these articles should be considered by the said draftsmen as orders and special instructions for them. 
Supplement that Dn. Casimiro Ortega thinks should be added to the instructions.

1. When the professors arrive in Lima, they shall establish themselves there for some time, which they shall occupy in gathering, examining, and remitting plants that they may observe in its vicinity and in obtaining information and making the necessary arrangements to plan the more important journeys to places that may be most advantageous. In everything they shall proceed with the approval of the Viceroy and the respective Governors; and before making their proposals they shall decide among themselves, the three botanists signing their names to the decision of the majority, in this as in any other matters that may call for deliberation. In the beginning they shall botanize together until our Spaniards think that they can make their observations by themselves, and then they may alternate in accompanying Mr. Dombey; though it has to be for short periods, for at the end of a few days they shall again get together and discuss their discoveries.

It will be well not to forget the quina tree and to arrange for the collection and preservation of its valuable bark.

The same reminder applies to the study and observation of the cinnamon tree and the ground in which it grows, and they shall consider all possible means of dulcifying it and ascertain if it is possible to make it as good as that of Ceylon which is brought to Europe by the Dutch.

These last two reminders are in addition to the longer one in article 12 of the general instructions.

\section{VI}

Instructions that are to be observed by the draftsmen who are going to Peru by order of H.M. to serve by the exercise of their profession in the Botanical Expedition.

1. As these artists will be restricted to copying Nature exactly in its products, especially its vegetable ones, without pretending to decorate it or add anything from their imagination; not only do they have to limit themselves to sketching precisely what the botanists determine to be worth being sketched; but they must work under the inspection of the latter, heeding the advice they may give, whether it is to be careful in drawing this or that part that the botanists consider important for understanding and differentiation of the plants, or when necessary to represent parts separately and sometimes greatly magnified.

2. They shall afterwards sketch separately, to one side of the general drawing of the plants, the flower and fruit, showing their anatomy as being more important; and all the sketches shall be drawn while the plants are still fresh, for the reasons stated in article 1 of the Instructions for the Botanists.

3. By the botanists they shall be given a pattern of the size to which they must make their sketches conform, so that they may be uniform and of sufficient size so that, on the return to Spain, the expense and labor of reduction may not be required for the plates to the size that will be given to the work to be published.

4. Regarding the use of colors, as the idea is to make as much progress on the expedition as possible in following the botanists in their work, they shall be satisfied with coloring only those plants that are worth it for their beauty or showiness or the strangeness of their tints, confining themselves, even in this case, to representing one flower, one fruit, and generally one part of the specimen, 
leaving the other in black ink, to be colored on the return to Spain after the sample shown; the same will be understood in respect to some special bird or other product that is judged worthy of being described and sketched.

5. They shall not decline, at times when they may be free from their principal occupation, which shall be that of drawing, to help the botanists in the formation of herbaria and in other important work that may contribute to the fulfilment of the King's service in the present expedition; in the same manner, the botanists shall not decline to help them in all cases in which they can be useful to them, assuring all individuals of the expedition the best brotherhood and mutual cooperation.

6. As it is the duty of the botanists, with their special knowledge, to determine where to botanize, the draftsmen shall go in the company of the botanists to the places where these ordinarily live, a matter which shall be determined by the botanists in private by a plurality of votes in the form expressed in the Article of Instructions, as will be all that is worthy of deliberation and relates to the fulfilment of the objectives of the Botanical Expedition.

7. All individuals on this expedition are responsible for the proper distribution and use of the instruments, books, paper, and other effects that the King has decided to furnish to them; it shall be the duty of the first botanist and, in his absence, the second, to entrust the custody and preservation of all or part of them to any of the companions, as it shall be required of all five to see that they are employed justly, and according to the idea of His Majesty, that is, for the use and benefit of the expedition.

8. The draftsmen shall not believe themselves less bound than the botanists to the rigorous observation of the rules in articles 18 and 19 of the general instructions about being absolutely forbidden to engage in dealings of commerce, in making plans of ports, plazas, etc. And so that they may not claim ignorance or insufficient notification of the order of His Majesty on this point, they shall be given a copy of all the General Instructions, so that they may observe them in this respect as in any other that may pertain to them; a copy of these Instructions being given also to the botanists so that the duty of each will be mutually evident to all and to each one of them.

Approved. April, 1777.

Francisco Manxon.-Iltmo. Sr. Don Joseph de Gálvez.

Iltmo. Señor:

Satisfying the three points that comprise the Order of V. S. I. of the 24th of last month, I should inform you that, considering the age, the naturally prudent disposition, and the greater experience in botany of Don Hipolito Ruiz, this person may be appointed first botanist, and Don Joseph Pavón as second; I have drawn up, as you have requested, the enclosed instructions dealing with the draftsmen that I pass into the hands of V. S. I. for correction or approval in the way you may find most suitable; and finally that, since I received that order, I am occupied with providing the botanists and draftsmen with the implements that they need and that were approved by the King to be provided at the expense of the Royal Treasury. For this last objective and also to give them scientific advice to help them in the performance of their duties, we have frequent conferences, at which Mr. Dombey also is present, so that at no time could he protest (which we do not expect), that we have not provided or counseled him in everything neces- 
sary for the success of a scientific expedition that will be cited with gratitude by future generations as one of the most authentic proofs of the enlightenment of the reign of Our Sovereign and of the Ministry of V. S. I.-Our Lord keep the important life of V.S. I. for as many years as I desire and as may be necessary. Madrid, April 8, 1777.--Iltmo. Señor.-I kiss the hand of V.S. Iltma.-Your most obedient servant.-Casimiro Ortega.-Iltmo. Señor Don Joseph de Gálvez.

In the margin of this letter is written.- Since Ruiz has already been named first botanist in the orders issued, the enclosed instructions are approved for the draftsmen.-April, 1777.

San Ildefonso, September 17, 1777.

VII

Note.-Decided by H. M. in executive action of November 25th, 1776.

The two professors that have agreed to make the journey to America and who are proposed by Don Casimiro Ortega as suitable for this, are Don Hipólito Ruiz and Don Joseph Pavón.

The terms that Ortega thinks can be made with them, in view of the high price of living in the country and the strenuous work of the commission in which they are engaged, the giving up of their homes and careers and the continuous moving and agitation in which they will have to live in making frequent excursions, will be 15,000 reales de vellon a year to each one. I judge that the trip from Madrid to Cadiz also should be paid for, or the money be given them to pay it.-That they also should be given transportation as is done with Mr. Dombey. He thinks that at their return they should continue with the same salary while they are employed in arranging and publishing the works that have been the fruit of their toil, which will give glory to the King and the Minister that promoted it.

He adds that to stimulate our botanists he thinks it would be a good idea to promise them that, if they deserve it, they will be employed in Spain on their return with the same salary, or that they will be maintained for life with at least half of it.

Ortega also proposes that, due to the fact that Don Joseph Pavón is financially somewhat embarrassed because of the very small pay he has had in the pharmacy of San Ildefonso, a few months' pay be advanced to him for his equipment.

That in the appointment papers to be sent to them it may be convenient to limit the time of their trip, so that they arrange their study and work accordingly; for this reason the time might be fixed at three or four years of residence in Peru, at the end of which they shall return to Spain, as it would be temerity to presume that they can discover everything that is to be found in those vast countries, and on the other hand in three or four useful years, if well employed, they may have gathered sufficient materials to publish a work that will be useful to the public and will bring glory to the nation.

Ortega judges that they need to be supplied with the books and instruments indicated in the two enclosed lists marked with the numbers 1 and 2, adding that he will, with pleasure, supply from his library and study the books that may not be found for sale in Madrid, hoping that later orders will be given to replace them for him by bringing them from France. The books and instruments that are found for sale here should be ordered bought without delay, and Ortega himself will undertake to do so (if desired). 
It is his opinion that it is absolutely indispensable that the draftsmen travel in the company of the botanists, it being well to advise them to confine themselves to sketching the natural products, that is, to copy nature exactly without trying to correct or beautify it as is done sometimes by draftsmen who add colors and ornaments, drawn from their imagination. For this reason he says that in the selection of the two individuals of this kind it will be important to look not only for ability that they may have, but also for gentleness and good temper such that they may subject themselves without difficulty to the orders and direction of the botanical professors; and if it were possible to obtain draftsmen with some knowledge of the Latin language, that would be very convenient, as they could then help the botanists in their observations, and they would unconsciously be instructed in botany.

It will also be necessary to provide for the supply in Cádiz of paper, small presses, and other instruments that are noted on the lists, which, according to Ortega, are to be found in that port.

In case it may be of use, we enclose a copy, marked number 3 , of the original account of the purchase of the colors and some utensils made for the draftsmen who went with the botanical expedition of the year 1754. This original account, which by chance is in the possession of Ortega, is from Mr. Loefling, the famous Swedish botanist who went by order of the King in company of the Spanish professors on that expedition, and might supply some information now.

As it is only just to take all possible measures to get the best results from such a useful enterprise, it might be convenient to advise the Viceroy of Peru to be ready to supply a certain determined sum, for example three or four thousand pesos, which, in case causes and circumstances not possible to foresee now might demand it, could be used, upon justifiable request by the botanists, to the extent that he might think necessary, with the idea of helping them in some urgency, and of greatly facilitating their work.

Enclosed will be found the instructions in Spanish for our professors and a translation in French for Mr. Dombey.

In the margin it is written:

The King names these two individuals, and assigns one thousand dollars to each one in the coin of the Indies, providing for their passage from his Royal Account and for the cost of the trip to Cádiz. H. M. fixes the time that they must spend in America at four years, counted from the time of their arrival in Peru, and he offers to continue half of their salary when they return, while they prepare and present the completed work that should be the fruit of their toil, and before they succeed in finding another appointment.

That in Cádiz they shall be given four payments in advance to equip themselves with that which is required, and that they shall be given time to estimate what is needed for the voyage.

Ortega has been commissioned, on the terms he proposes, to provide, according to the lists and on condition of their replacement, the books and instruments that he will give from his collection, since they cannot be found in Madrid.

The artists of the Royal Academy are asked to give to Don Ignacio Hermosilla the commission of selecting them and of agreeing to the qualifications that have been proposed.

For this give the order to the "Presidente de Contratantes." 
This paper will be used for the purpose of providing the professors and draftsmen with the things they should have.

Give this order to the Viceroy of Lima; the sum of money should amount, at most, to three thousand pesos in that coin.

My Superior: Enclosed you will find the orders or appointments of the botanists and draftsmen for Peru, and in these orders are included all the decisions made about their work so as to avoid having to give separate orders about everything. They go in duplicate so that this, or the original, may be sent to the Viceroy, as this does not cost anything, and by some chance those carried by each of the professors may get lost.

It will now be necessary in this matter that you, sir, tell S. I. that the French Ambassador ought to say officially that it is $249 \mathrm{P}$. that his Government has assigned to the French botanist, as should be stated in the records; and I have put in his order the 1,200 because they are the same 2,000 as I have heard mentioned to Ortega and Magallon, even though the same botanist Dombey has written to S. I. that this is not sufficient.

It also needs to be settled whether these men are going by the packet boat for Buenos Aires, for in this case they will find many difficulties at their arrival at Montevideo, if the passes are closed, if the cordilleras are not passable, and on their long trip to Lima they will be unable to work or gain anything by it for their profession. Aside from this, their professional instruments and other things with which we have to provide them, especially paper of all kinds and in great quantities, are perhaps not commonly to be found in Coruna, if they ship in the packet boat, and to carry everything from here will be more costly; and for this trip we shall need to take up with the Office of the Secretary of State the matter about embarkation in the mailboat.

In Cádiz everything can be found more easily and conveniently, and the four payments that have to be advanced from their salaries have been ordered in the instructions to be paid by that President.

If, although they were delayed a little longer, these botanists were sent directly by Cape Horn, they could land in Valparaiso and, even if they went straight to Callao, they could start their work immediately without the expense and perhaps the difficulties that they would have to overcome in Buenos Aires; if their trip is to be by this route, I also think that there are sailings listed in Cádiz for all of May and the beginning of June.

Please, Your Honor, present this matter to S. I. so that your intimate friend and companion may be a botanist.-Thomas Andad.-Sealed.-April 6th, 1777.

Will you please send to the sealer the papers mentioned, or they will attract attention.

Illmo. Sor.

To take the measures required by the order to send the botanists to Peru, it would be desirable to clear up the following doubts:

Whether the French botanist Mr. Dombey has to be given a certificate of appointment similar to that of the Spaniards.

Whether he has to be sent as a companion; also that Ortega report, which of the Spaniards ought to go as the principal one, chief of our own men. 
What salary shall be assigned to the draftsmen that are to accompany the botanists in their work.

The same as these.

Whether in the orders or nominations it shall be specified that in Peru all five shall be granted from the Royal Accounts, the expenses of the journeys that they may make together or separately for their observations, as with their salaries they will not cover all the expenses, or whether from here they shall be assigned the amounts that may be thought reasonable.

That during the trips the four Spaniards be given double salary to enable them to cover the expenses, since in Dombey's case his Government should bear the cost, and whatever be indicated should be supplied from there and reimbursed here.

Whether the salary shall be paid to these professors from their appointments, from their departure from Madrid, from their boarding the vessel, or from their arrival in Peru.

From the day of their boarding the vessel in Cádiz, in accordance with the custom already established for all kinds of commissioners.

To whom the commission should be given from now on to draw up the instructions to be observed by the draftsmen or delineators, which according to those handed the botanists are to be separate.

To Don Casimiro Ortega; and they shall be given copy of those carried by the botanists so that they may observe the part that refers to them.-March $20 \mathrm{th}$, 1777.

\section{VIII}

Today March 9th.

My Master and Friend: Our botanists and draftsmen are impatient to go, and they dream of nothing but the plants of America. I know that Your Honor has already given instructions and that there are only a few small matters to be decided in order that they may start. As I have given them my word to remind Your Honor about this business, these four lines go to you to ask Your Honor in a spare moment to settle as you think best the following small questions or doubts, that are those which they would like to present to Your Honor's attention.

1st. If we have to issue to Mr. Dombey, as to the Spaniards, a formal appointment separately. This Frenchman would like to go with as much authority as possible; but although because of his knowledge and botanical experience he deserves to be chief of the expedition, I do not know if it would be suitable to give him such a title; you know what the French temper is, and you will recall what has been provided in some of the articles of instruction. On the other hand it would be good to have one as the chief and head to direct the work of the expedition and the young men who have not the experience or the knowledge of Dombey.

2nd. The draftsmen desire that they be given the same salary as the Spanish botanists. As to this point I think that the expenses of the former will be as great as those of the latter, and the work may be heavier so, if the salaries of all could be equal, it would make them all happy with an addition that in itself is a trifle, and one would gain much by encouraging them in their work.

3rd. If we have to advise the Viceroy and Governors in Peru to pay to all five, including Dombey, for the extra journeys that they may make, together or separately, for their observations, since with their salaries they will not be able to 
cover those extra expenses, or if we have to assign them a certain daily allowance on the days when they may be traveling.

4th. If the pay should be given to the Spaniards from the time of their leaving Madrid, or of their appointment, or only of their embarkation.

5th. To whom we shall entrust the task of drawing up instructions that the draftsmen ought to follow, which, as is indicated in the general instructions for the botanists, will be drawn up separately. On this point, I think it well to remember that there are a few points in the general instructions of which it will be desirable that the draftsmen should be informed: for example, not to get mixed up in commercial enterprises, not to get maps or plans from the countries, and I even think that it would not be improper to give the draftsmen a copy of the instructions carried by the botanists.

I see that, inadvertently, this letter is getting to be too long, as if I did not know that Your Honor needs the time for other business of more importance; the more so if it is true that the mail from Buenos Aires has arrived with interesting information of the upstarts; although, as it appears, the dominion of Carvallo is about to come to an end completely, and things may take on a different aspect.

Good-bye, friend and sir. I am and always will be Your Honor's most devoted and sincere servant.-Magallon.-Signed.

IX

Monseigneur:

Madrid, February 20th, 1777.

Dn. Casimiro Gómez Ortega has brought me the order that Your Excellence has kindly addressed to me and to MM. Hipólito Ruiz and Joseph Pavón, as well as the samples of cinnamon and clove and the two memoirs which came with them.

I shall neglect nothing, Monseigneur, to make a success of a project of such great importance. Don Casimiro Gómez Ortega will kindly help me with his advice, and the instructions will contribute greatly to the success of our undertaking.

The good will with which Your Excellence has deigned to listen to me and to protect an undertaking from which Spain and the sciences can derive very great profit, has determined the Court of France to add three thousand pounds to my salary. That is an obligation which I should add to those which I have already received from Your Excellence, and for which I venture to beg you, Monseigneur, to accept my thanks. I shall do everything in my power to merit the continuation of your kindness and protection.

I have the honor to be, with profound respect,

Monseigneur.

Your very humble and very obedient servant.-J. Dombey.-Signed.

$\mathrm{X}$

April 29, 1777.

Illustrious Sir:

Sir: The Spanish botanists named to go to Peru believe that it is their duty to render to V. S. I. before their departure their most respectful thanks for the benefits and favors that you have been pleased to grant them and for which they will be ever grateful. The same graciousness and kindness with which V.S. I. has treated 
and distinguished them gives them courage to beg of you, not new favors, but only a change in the place where one of them has been granted. V.S. I. has graciously granted them an advance of four months' pay, as stated in the Royal Order for their appointments, in the port where they are to embark. The situation and lack of funds in which they find themselves, and the need of providing themselves with some clothes and other indispensable things, which could be done with more ease and comfort in Madrid than in Cádiz, compels them respectfully to request of V. S. I. that he be so kind as to command that their advance, which has been ordered by V.S. I. to be paid in the port of departure, be given to them in this capital. It would be for them and for their situation the same as to give a new value to the favor already granted, nor would it, they think, be harmful to the Exchequer of His Majesty.

\section{To the Presidente de la Contratacion:}

So that arrangements may be made that the four[?] botanists, Don Hipólito Ruiz and Don Joseph Pavón, the French physician Don Joseph Dombey, and the draftsmen Don Joseph Brunete and Don Isidro Gálvez embark at the expense of the Royal Exchequer in the vessel "Peruano" that is about to make a voyage to Peru, and that they receive eleven monthly payments in advance together with that which is mentioned.

In the vessel "Peruano," that is getting ready in that port for the trip to Peru, the botanists Don Hipólito Ruiz and Joseph Pavón, the French physician Don Joseph Dombey and the draftsmen Joseph Brunete and Don Isidro Gálvez should embark at the expense of the Royal Exchequer with their baggage and boxes in which they carry the books, utensils, and instruments needed for the discharge of their commission.

In the same way V. S. should arrange, in accordance with the Orders that the four Spanish individuals should present, to satisfy immediately four advance payments of their respective salaries, and for the account of the Royal Exchequer to buy books, paper, and everything else needed and stated in the enclosed note, at the earliest possible moment so that they should not for any reason fail to embark in the said vessel. I give this notice to V. S. by order of the King for its exact and due fulfilment. God keep you. C. Joseph, September 19, 1777.-Presidente de la Contratacion.

LisT of the things that have to be bought in Cádiz for the expedition to be made to Peru by order of His Majesty:

Ordinary writing paper 12 reams.--Holland paper 4 reams.-12 paper books of a folio size in which to write clean copy of their observations. - 2 thousand black pins, for arranging insects.-Boxes with cork for the same use.- 6 saws.6 hammers. -6 chisels. -6 pickaxes. -6 iron shovels. -6 small hatchets. -6 cutlasses.-2 sea-compasses. -4 dillenianos.-All these utensils packed in boxes.Casimiro Ortego.--Signed.

\section{Illustrious Sir:}

September 24, 1777.

The King has resolved to send to Peru, Don Josef Dombey, French naturalistphysician, two Spanish botanists, and two Spanish draftsmen so that they may make professional observations in that kingdom, and transmit the various productions of those fertile domains.-Don Casimiro Ortega, Botanist to S. M., 
has been commissioned to furnish everything necessary to these men for the execution of their mission, with the understanding that its cost shall be borne by the Royal Exchequer; and having presented and examined the account of all, that sums up to 8,868 rs. vellón, V. E. are notified by order of S. M. that the Ministry in your charge pay the sum mentioned so that Ortega may be satisfied with the amount in question. God keep V. E. many years. San Ildefonso, September 24, 1777 .

\section{N. N. S. D. Miguel de Muzquiz.}

With your letter of yesterday, the 23rd, I have received the two accounts of the instruments, books, and other utensils which have been provided by the botanists, French and Spanish, and their value of $8,868 \mathrm{rs}$. vellón will be allowed to Your Honor by the General Treasury, and for this purpose the appropriate order has been sent on this date to the Minister of the Exchequer; I communicate this to Your Honor for your information. San Ildefonso, September 24, 1777.-P. Don Casimiro Ortega.

\section{Illustrious Sir:}

\section{$\mathrm{XI}$}

My dear Sir and respected Superior: The 20th day of this month I sent by Baltasar Box to the Presidente de la Contratacion in Cádiz the boxes of paper, instruments, books, and other utensils that the botanists and draftsmen destined for Peru need for the work of their commission; so that they will arrive in time to be placed on board the vessel "Peruano."

The lists, minus what has been provided to them on condition of replacement from the account of the Royal Exchequer, according to what V. E. Ilustrisima kindly communicated to me in the order of the 21st of last March, are included in the two enclosed accounts, one of which I have provided directly, and the other has been provided under my direction and supplied by Don Felipe de Trapaga from the commerce of this town. I transmit them to V. S. I. so that, if they meet with your approval, they can be ordered to be paid, or as may be the pleasure of V. S. I., whose life God keep as many years as I desire and as may be necessary. Madrid, September, 1777.

Illustrious Sir:-Iltmo. Señor Don Joseph de Gálvez. I kiss the hand of Your Illustrious Honor. Your most obedient servant.-Casimiro Ortega.

In the margin it is written.- - The accounts should be examined and, if found satisfactory, an order should be sent to the Sr. Muzquiz for their payment. Today, and to Ortega the 24th of September, 1777.

Memorandum of the articles that I, Don Felipe de Trapaga, have furnished to the draftsmen and botanists that are going to the Kingdom of Peru, by Order of S. M. (may God keep him): at the request of Don Casimiro Ortega, First Botanist of the King our Lord, and in detail, is the following:

First. 25 reams of ordinary paper Marca mayor at 60 rs. $\quad 1,500$ 25 reams of the same paper middling fine at 72 rs. $\quad 1,800$ Four ounces of the very best fine lacquer at 200 rs. $\quad 800$ Half an ounce of fine ultramarine color of the first class 200 Half an ounce of ultramarine ash $\quad 075$ $\begin{array}{ll}\text { Half a pound of green destilado } & 018\end{array}$ Half a pound of green vejiga 016 
$\begin{array}{ll}\text { Half a pound of gamboge } & 030\end{array}$

Two pounds of gum arabic, fine $\quad 064$

Half a pound of vermilion of Royal monopoly 006

$\begin{array}{ll}\text { Half a pound of Jewish asphaltum } & 022\end{array}$

Half a pound of burnt saffron $\quad 020$

One pound and six ounces of fine ochre from Siena $\quad 027-17$

Half a pound of Prussian blue of first quality 064

$\begin{array}{ll}\text { A pound of fine rock alum } & 003\end{array}$

$\begin{array}{ll}\text { Two pounds of cream of tartar } & 008\end{array}$

$\begin{array}{ll}\text { Three reams of fine paper cut, at } 32 & 096\end{array}$

$\begin{array}{ll}\text { One ream of fine paper cut for letters } & 034\end{array}$

Four dozen boxes of fine English lead pencils at $22 \mathrm{rs} . \quad 088$

$\begin{array}{ll}\text { Four dozen of the same at } 14 \mathrm{rs} . & 056\end{array}$

Twelve dozen of the same, common, at $10 \mathrm{rs}$. 120

Three dozen and a half of fine assorted Lyon brushes at 26 rs. $\quad 091$

A fine brush of Holland, large, gray 010

$\begin{array}{ll}\text { Twenty-two dozen of fine paint brushes at } 8 \mathrm{rs} . & 176\end{array}$

$\begin{array}{ll}\text { Two bunches of swan feathers } & 030\end{array}$

Eight bars of fine China ink at 10 rs. $\quad 080$

Two arrobas of black pencils with points at $30 \mathrm{rs} . \quad 060$

$\begin{array}{ll}\text { And to prepare and grind the colors, I paid } & 030\end{array}$

And I paid for the making of 10 boxes with their respective locks as per receipt

And for three boxes and the nails and delivery as per receipt

To cover with asphalt, paint with oil color, and number the said boxes, I paid

And a real and a half that was the cost of a box for the brushes

To waterproof and caulk 2 containers in which several books are packed

Sealing and strapping of the 18 packages of which this shipment is composed, and four trunks of used clothes and other effects by the Señor Administrator of general taxes, so that they might not be opened in the traffic or customhouse of Cádiz

Total 6,205

And $24 \mathrm{rs}$. and $20 \mathrm{~ms}$. de vellon, which was the cost of the sealing wax and red ribbon used to tie all the boxes and seal them on top of the ribbon

I paid to the porters that brought and took the boxes and helped to load them on the carts and take them to be strapped and sealed

This account amounts at its just value to: six thousand, two hundred and sixty-three reales and twenty ms. de vellón, unless there be an error in writing or addition, which, if it appears, should be corrected.

Madrid, September 20, 1777.--Phelipe de Trapaga.-Signed.

I received from Señor Don Phelipe de Trapaga three hundred and thirty rs. von. for ten boxes with ten locks, which I have made under the direction of the First Professor of the Royal Botanical Garden and which are to be used to pack several shipments of paper that are going to be taken by the Botanical Expedition sent to Peru by order of the King, for the formation of their herbaria, and to show that 
this is correct, I sign my name in Madrid the first of June, 1777.-Gerónimo Balthasar Ucles.-Signed.-The amount is $330 \mathrm{rs}$. vn.

According to my instructions.-Casimiro Ortega.--Signed.

Account of the boxes made under the direction of the First Professor of the Royal Botanical Garden, that are to be used to carry several things to Peru.

Rs. de Von.

First, a box made to pack the rest of the big reams of paper, with thelock 033

Two other boxes to carry writing paper, pencils, and colors 036

Six hanks of tow to close the joints on the covers of the thirteen boxes.

Glue. Nails and a thousand tacks

036

024

For work done to cover with canvas and glue around the said boxes

This account amounts to one hundred twenty nine rs. de von., which I received from Sr. Trapaga. Madrid, September 12, 1777.-Gerónimo Velez.-According to my instructions.-Casimiro Ortega.-Signed.

LIST of the books, instruments, and utensils that have been delivered according to the Order of His Majesty of the 24th of March of this year, to the botanists who are going to Peru:

First. A very exact barometer, constructed in Paris with its spiral thermometer encased in the same box

Rs. de Von.

Two Réaumur thermometers, which have been compared and tried out, in their boxes

Three lenses or magnifying glasses for the observation of the more minute parts of plants

Linnaeus, Philosophia Botanica

Ejusdem, Genera plantarum

Ejusdem, Systema Naturae, in four volumes for the use of Don Hipólito Ruiz, bought from the house of Alberia

Another set of the same work for the use of Don Josef Pavón, bought from the house of Corradi

Of various drugs and chemical preparations that were also considered necessary in the Botanical Expedition that was made to the Orinoco in 1753 , and will serve in this one, as much for the examination of water as to help in accidents that may happen to them in uninhabited places where they will have to botanize

For the glass vials in which said preparations are placed, hermetically sealed for their preservation

For the amount paid the carpenter for the making of the box with several partitions for holding the said vials

For lock, hinges, and latches for said box

A copy of the Instituciones Botanicas of Tournefort in three quarto volumes, one of explanation and two of plates

The work of Loefling on the plants of Spain and America, extremely rare

Noticias Americanas by Don Antonio Ulloa, one quarto volume, in boards Caroli Pisonis, Historia naturalis Brasiliae, one volume in folio with plates El viaje al Perú by Father Feuillé, in three quarto volumes 
El viaje y observaciones of Don Jorge Juan, in five quarto volumes

P. Plumier, Nova genera plantarum, one quarto volume, rare and with plates

For several portfolios of cardboard to receive plants on botanizing trips

This account amounts to two thousand six hundred and four [?] reales de von., which have been supplied by Don Casimiro Ortega in accordance with said order of the 24th of March of this year.

Madrid, September 18, 1777.

Note.- Not having been able to find a copy of the Historia Natural de NuevaEspaña, by the First Physician Francisco Hernández, that had been considered very useful to have on this expedition, Ortega has been commissioned to continue his search so as to send it at the first opportunity to Lima.

Amount 2,6041/2 Rs. de Von.

Casimiro Ortega.--Signed.

To President Manjon.

Cádiz, October 3, 1777.

Notice is given by the Director of the Transport Fleet of having seen the botanists on the vessel "Peruano."

Illustrious Sir:

My dear Sir: By the contents of the letter of V. S. I. of the 1st of May, I am informed of the decision made by the King, to send to this Kingdom Don Hipólito Ruiz, Don Joseph Pavón, and Don Joseph Dombey, professors of botany, and the draftsmen Don Joseph Brunete and Don Isidro Gálvez, with the object of making observations of natural products according to their profession, and I am likewise informed of the conditions specified in their appointments, duplicates of which V.S. I. encloses, and of the salaries and rewards that have been assigned to them; these royal decrees will have, for my part, and in all that has been ordered regarding this matter, the fulfilment that has been requested of me, as soon as the individuals mentioned reach this capital of their destination.

Our Lord keep V. S. I. as many years as I desire. Lima, February 28, 1778.

Iltmo. Señor. B. L. M. de V. S. I. Iltma, your most devoted and humble servant. Don Manuel de Guirior.-Iltmo. Señor Don José de Gálvez.-At the margin is written:

No. 284.-The Viceroy of Peru.-Acknowledges the receipt of the Royal Order and the appointments which are enclosed, about the arrival of the botany professors and draftsmen for the purpose that is specified in the said documents.

XII

The botanists Don Josef Pavón, Don Hipólito Ruiz, Don Isidro Gálvez, and Don Josef Brunete, assigned to the Kingdom of Peru, report their arrival.

Illustrious Sir:

Sir.-The botanists and draftsmen (named by His Majesty to this Kingdom of Peru) placed at the service of V.S. I. Iltma. with due respect, have the honor and glory to report to V. S. Iltma. 
That on the 7th day of this month of April between five and six in the afternoon we anchored in the port of Callao, and our arrival has been accomplished with great good fortune without our having experienced the smallest discomfort on such a long journey, or having encountered storms as severe as are to be expected on such a voyage. The 10 th we went to Lima to present ourselves to the Señor Viceroy, whom we found in very good health; may our Lord grant the same to Your Excellency for many years.

On the 13th we landed all of our pieces of equipment which were taken to the customhouse; we think they have arrived without any damage because they have come well closed and kept in a good place. We are ready to start after Easter on our excursions so that with the aid of our Lord and the favor of V. S. Iltma., we may fulfil little by little the obligations under which you have placed us with the honors, favors, and gifts that you have bestowed upon us. May our Lord improve your life with good health and everything else that V. S. Iltma deserves.

Your humble servants kiss the hand of V. S. Iltma.-Joseph Pavón.-Hipólito Ruiz.-Isidro Gálvez.-Dombey.-Josef Brunete.

Lima, July 15, 1788.-The botanists that have been sent to Peru are occupied with making the determinations of plants that they have found, and will send them at the first opportunity.

\section{Illustrious Sir:}

Sir.-Under the date of the 16th of April, we informed V. S. Iltma. of our arrival at the port of Callao; because the short time we had been in the country did not permit us to give any other information. But at the present opportunity we must inform V. S. Iltma. that in this city of Lima and its vicinity, as far as three leagues, we have examined and seen many plants that to date are not known in our Spain or to botanical authors; and establishing a new genus after the careful examination that we have made of them; we have described them as new discoveries, among which we mention the Galvezia limensis, a name that truly belongs to you; and because it is V. S. Iltma. who has proposed this work and who contributes with so much care to have it complete in all respects, to V. S. Iltma. and not to anyone else should go the first fruits not as a gift but as a debt, and our reverent affection would like always to have something to offer you so as to manifest perpetually the indebtedness by which we are bound.

We have decided, because the time is suitable, to go on to the mountain ridges in pursuit of our commission, and no doubt we shall do it the 15th of the present month with the approval of the Excmo. Señor Viceroy, to whom we have explained the progress of our work, and whom we have convinced with our activities, of our eagerness to accomplish our trust.

At the first opportunity that offers, we shall send the plants that we have dried and the corresponding sketches and, with the trip planned, we judge that the shipment will be-large, because we have been informed of the multitude and variety of plants that at the present season are produced on the hills of the mountain ridges where we are going.

We wish V. S. Iltma. perfect health, and we repeat our protestations of obedience, always awaiting orders of your pleasure.

God our Lord keep V. S. Iltma. for many years.-Lima, July 5, 1788.

Your most attentive servants kiss the hand of V.S. Iltma.-Hipólito Ruiz.Jph. Pavón.-Josef Brunete.-J. Dombey.-Isidro Gálvez. 


\section{XIII}

Iltmo. Señor Don Josef de Gálvez.

San Lorenzo, November 24, 1779. To the Viceroy of Peru. That he may arrange that the officers of the Navy that may be in the port of Callao make certain observations about the low and high tide of another port, with the assistance of the botanist Mr. Dombey.

NotE.-This order is the result of the report of the First Botanist about this subject and various plants and herbs that were sent by the botanists of Peru by the vessel "Buen Consejo" according to the order of the November 16, 1779.

Illustrious Sir:

In the Royal Order of November 24th last, V. S. finds it convenient to inform me that His Majesty has resolved that the officers of the Navy that are in the port of Callao shall observe and take exact account of the differences between the low and high tide of another port at the various seasons of the year, the observations to be made in the presence of Mr. Dombey, botanist assigned by His Majesty to this Kingdom, and that Mr. Dombey shall oversee their due execution, sending to V.S. that which he may report in writing about this particular; and although at present the naval officers are employed on His Majesty's Fleet sent to the port of Concepción for the safety of the coasts of that Kingdom, and the said Mr. Dombey, absent in the province of Huanuco, is busy in the discharge of his commission, I shall take care that on their return they shall make the observations requested and shall send to V. S. what they may report about the matter.

Our Lord keep V. S. many years. Lima, September 20,1780. Iltmo. Señor. Your most humble servant Agustín de Jauregui kisses the hand of V. S.-Excmo. Señor Don José de Gálvez.

At the margin it is written.-The Viceroy of Peru states that he will take care that as soon as the officers of the Navy and the botanist that you mention return from the places where they are now, the observations of the low and high tide of the Port of Callao shall be made in accordance with the Royal Order in which V. S. has seen fit to give instructions under the date of the 24th of last November.

The King, having resolved that the officers of the Navy in the port of Callao shall observe and take exact account of the difference between low and high tide of another port at the several seasons of the year, requiring the assistance in these observations of Mr. Dombey, botanist assigned by V. S. to this Kingdom, I inform V. S. of this Royal Order that you may arrange for its proper execution, transmitting the written report on this matter. The Lord keep you many years.San Lorenzo, November 24, 1799.-Señor Viceroy of Peru.-In triplicate.

XIV

San Ildefonso, September 10, 1783.-To the draftsmen and botanists sent to Peru.

Acknowledging receipt of the letter of the 23rd of August of the present year, where they gave notice of the discoveries made in their profession in the Kingdom of Chile, and advising them to lose no time in making other discoveries and to send on the work that they may have entirely and perfectly finished.

The King has been informed by your letter of the 23rd of August of the present year of the discoveries you have made in your profession in the Kingdom of Chile, 
of the number of trees and plants that you have sketched with the rest that you mentioned; and S. M. having resolved that you continue (as the Visitador General of this Kingdom is advised on this same date) and perfect your investigations in South America in which is included the Viceroyalty of Buenos Aires; and that you make use of the time for your discoveries, and send on all work that may be perfectly finished, as, thanks to the peace, it can arrive safely; I communicate this to you by Order of His Majesty for your information and fulfilment. God keep you many years.-San Ildefonso, September 10, 1783.-Messrs. botanists and draftsmen ordered to Peru.-In duplicate.

\section{Excmo. Señor:}

Sir.-We inform V. E. that about the 26th of this month we are making a trip to the city of Santiago of Chile, where we shall stay describing and sketching the plants and trees of that territory until the end of this year, when we have planned to return to Lima and get together the boxes with our collections from Chile with those that we left deposited in the Royal Armory.

By previous mails we communicated to V. E. that the number of trees and plants sketched in their natural colors reached almost a thousand, and the plants described, more than 1,500; together with the letters we included different seeds for the Royal Botanical Garden, a sketch of the new species of pino with its description in Castilian, and a piece of its wood.

Of the countries through which we have passed we have not found any as fertile as the montañas of Marañon, which we entered at the end of the year 1780 and were obliged to abandon in the year 1781, without having collected any great amount of its many riches.

On our return to Lima it was our desire to enter again and examine these montañas (in spite of the great difficulties and trouble) and to live there a year in the pursuit of our work.

But this trip that could be so useful and advantageous to our Flora, as well as of much interest for the best results for the purpose that has moved the will of the Sovereign and of V.S. as the prime initiator and protector of this work; it appears to us that it might be obstructed by a letter that we have just received from the Señor Visitador, a copy of which we take the liberty of enclosing for V. E. so that you may consider it at your pleasure.

Our Lord make V.E.'s life prosperous many years.-Concepción de Chile, March 23, 1783.- - Your most obedient servants kiss the hand of V. E.-Jph. Brunete.Hipólito Ruiz.- Jph.Pavón.-Isidro de Gálvez.-Excmo. Señor Don José de Gálvez.

In the margin is written.- Tell them what has been told to Escobedo, that they continue and complete their investigations in all that South America in which is included the Viceroyalty of Buenos Aires, and send the finished work and make good use of the time.-September 4.

\section{XV}

Copy of the letter of the Señor Visitador and General Superintendent of the Royal Exchequer.

In the Royal Order that has to do with your commission for the discovery of the natural productions of this Kingdom, the first stipulation is that your stay in this country is to be four years. And this term having expired last April, doubt now arises as to whether the amounts should be paid or not, that you have been 
assigned for the time that has passed and is passing beyond that date, and in consequence it was necessary to get a ruling in respect to that particular clause, and after His Majesty's Fiscal had heard of it, he answered that you ought to have finished your work in the specified four years, explaining in ample time, in case of not having been able to use it fully, the impediments or accidents that may have hindered you, but that, on the other hand, it does not seem rational by reason of the slight loss that the Royal Exchequer might suffer, to render useless what has already been spent in your transportation and maintenance, and to leave the fulfilment of your commission incomplete, when, according to the Royal Orders, you have to be taken care of at the cost of the Exchequer until you have been placed in another position, and since the circumstances of the war do not permit your return to Spain now, it would appear to another Minister that it might be possible to pay you the equivalent of this year's salary and to notify you of the difficulties in paying you from now on, and account should be given to the King so that he may decide what may be his Sovereign pleasure.

In virtue of all this, I have resolved by a decree of this date (as you will see in a copy of the enclosed order that I am sending by you to the Royal Officers of that post of Concepción or to those of Santiago de Chile) to pay you in one or the other of these Coffers double salaries corresponding to one year starting from the first of December of last year to the last of November of this year, hoping that in regard to the time thereafter, you will tell me, in view of the doubt that makes it difficult, what you think might conduce to payment, and of this I will give account to the Court in order that H. M. may determine what may be his Royal pleasure.

All of this I ought to say to you in response to the request you forwarded to me by the First Cosmographer of the Kingdom, Don Cosme Bueno, that I send the enclosed Order from this General Superintendent, so that in one of the said Coffers they may pay you your respective salaries, which of course you will collect in the place you find most suitable.-The Lord keep you many years.-Lima, January 18, 1783.-Jorge Escobedo.

To the gentlemen of the Botanical Expedition, Don Hipólito Ruiz, Don José Pavón, Don José Brunete, and Don Isidro Gálvez.

Lima, November 15, 1783.

The Botanists of Peru.-State that the day after their landing in Lima, where they came to arrange the boxes to be ready to execute the orders that might be given to them, they went to see the Viceroy and the Visitador, who told them of not having received orders from the King or V. E. in favor of or against their stay or return to Spain, nor had they made any decision about one or the other.

That at present they are busy arranging their work to other ends. That the finished sketches amount to one thousand; and to one thousand seven hundred the descriptions of trees and plants that deserve every attention for their properties as well as for their uses. About this a work could be published that would result in much advantage and progress due to the patronage of V. E.

NoTE.-It appears that there are no further instructions required after the Order of the 7th of March of this year, in which it was provided that the botanists might continue in their commission for another year from the day of the receipt of another Order granting their salaries, and were told what they had to observe in their surveys, taking young men to be instructed, etc.

May 17, 1784.-There is nothing to be done now, and I think that from last year on they were given orders to continue. 
Excmo. Señor:

Sir.-At every opportunity our gratitude impels us to inquire about the health of V. E. and to inform you of the state of our work and progress, either by direct communication with V. E. or through the First Botanist, Don Casimiro Ortega.

Under the date March 23rd of this year 1783, we notified V. E. from Concepción de Chile of our trip to Santiago, and jointly we enclosed a copy of a letter of the Sr. Visitador of this Kingdom, in which he told us that the term of four years that the Sovereign had fixed as the period of stay here had already expired.

When we reached Santiago, we sent you in duplicate the copy of the referred letter.-Finally from Santiago under date of September 12th we took the liberty of placing in the hands of V. E. a copy of another, second letter from another Sr. Visitador in answer to the one we wrote to S. Sa. from Concepción; and at the same time the decision to pass to Lima to arrange the boxes and be ready to receive the orders of V. E.; or those that these Ministers may impose upon us.

The day following our landing, we went to see the Excmo. Señor Viceroy, and the Sor. Visitador, who told us they have not received Orders from the King in favor of or against our return to Spain, and to date they have not made any decision one way or the other.

At present we are arranging our work for the return to Spain; or to be ready for any other order.

The finished drawings number 1,000; and 1,700, the descriptions of trees and plants that deserve attention as much for their properties as for their uses.

We do not doubt that with the protection of V. E. we can produce in a short time a work of which the wise discernment of $\mathrm{V}$. E. will perceive the advantages and progress that may accrue to the public, and which among the rest of us will not cease to acclaim forever the immortal name of V. E. as its principal guide and as the patron in Spain of this science which shines so brightly in the other countries of Europe.

Our Lord keep V. E's. health and life as long as your very humble and obedient servants desire.

We kiss the hand of V. E.-Lima, November 15, 1783.-Jph. Pavón.-Jph. Brunete.-Hipólito Ruiz.-Jph. Dombey.-Isidro Gálvez.

Excmo. Señor Don José de Gálvez.

\section{Excmo. Señor:}

Sir.-We have just arrived at the city of Santiago of Chile with the idea of continuing the work of new discoveries, but the little variety noticed in this country of trees and of plants different from those already gathered in Concepción will make us, without doubt, embark for Lima after the winter, and in that capital we shall await the orders that V. E. will see fit to give us to be obeyed by us as has been done up to now.

In case that V. E. decides on our return to Spain, we beg of you to issue orders that we be assisted and directed under the same conditions that $H$. $M$. ordered when we came to this Kingdom.

From former letters and the enclosed copy V. E. will notice the variety of trees (from which choice woods are obtained for all kinds of construction) and the number of those we have already gathered, described, and drawn. 
Our Lord keep the life of V. E. many years: Santiago de Chile, May 6, 1783.

Your grateful and obedient servants kiss the hand of V. E.-Hipólito Ruiz.Jph. Dombey.-Jph. Pavón.-Jph. Brunete.-Isidro de Gálvez.-Excmo. Señor Don José de Gálvez.

Duplicate number 2.

\section{XVII}

March 7, 1784.-To the Visitador of Peru.

Among other things you are here advised of the general terms in which the botanists are to continue in their commission for the discovery of trees and plants that may be used for the Botanical Garden, and of information for the work of natural history.

The botanists of the expedition to Peru in a letter of the 12th of September of last year written from Santiago de Chile, reported the finding of beautiful trees and plants in what they have surveyed of the Kingdom of Chile; likewise they manifest the desire to penetrate the fertile interior of Huánuco and Tarma to profit by more knowledge of the valuable things that they observed there in passing. And the King realizing that this new survey will bring greater advantages to the undertaking assigned to these professors, His Majesty has agreed to extend the time to one year more, starting from the receipt of this order, and to grant the salary that they have been assigned, likewise the allowance that in the judgment of V. E. may seem to be in proportion to the time that they may have to be detained in order to continue the sending of sketches, living plants, and other things pertaining to natural history. His Majesty desires that V. E. inform them that, as soon as this term is finished, they shall embark with all their collections to return directly to Spain without undertaking any new trips by land because this is no longer necessary since a similar expedition has been entrusted to Don Joseph Celestino Mutis; and on the excursions that they may have to repeat to the montañas of Huánuco and Tarma from that capital, they shall take with them at the expense of the King, one or two young men of the necessary qualifications who may become acquainted with, and record in writing, the places where the most valuable plants are found; and who may be so instructed in botany that, when the time comes for the return of the professors to Europe, they may be able to continue the study of the science of the plants and the sending of seeds and even to satisfy any doubt or commission that may be confided to them from Madrid during the publication of the works and after it. All this is communicated to V. E. by Order of His Majesty for due accomplishment, and that the Sovereign's intentions may be carried out for obtaining the most advantageous results that can be expected from this expedition for the explanation of natural history-God keep V. S. many years.-Pardo, March 7, 1784.

Señor Visitador of Peru.-P. 3, duplicate.

In the margin it is written.-In order that this order may not conflict in any respect with another given last year, the former one should be revoked.

Having notified the King what the botanists of the expedition to Peru propose in their letter of the 12th of September, 1783 and what you suggest with regard to them on the 1st of this month, His Majesty has ordered me to issue the appropriate order (as I do under this date) addressed to the Visitador General of Peru so that he may notify the said botanists that they have been given an extension of another year for concluding their commission, allowing them the 
corresponding salary and extras, and to tell them that in repeating the expeditions to Huánuco and Tarma they shall take one or two young men so that they will be informed of the places where the most valuable plants are found and can prepare themselves to satisfy any questions that may arise during the publication of the work. This I communicate to V. E. for your knowledge. The Lord keep V. E. many years.-Pardo, March 7, 1784.-Dr. Don Casimiro Gómez Ortega.

\section{Excmo. Señor:}

\section{XVIII}

My dear and most respected Sir: The botanists of the expedition to Peru, by their last letters written in Santiago de Chile the 19th of August and 12th of September of the year 1783 last, give thanks for the distinction received by them as Members of the Royal Medical Academy of Madrid; they testify to the continuation of good harmony in which they live among themselves and also with Mr. Dombey and the draftsmen; they expected to find, as they indeed found on their return to Lima in October, the orders of V. E. for the continuation of the payment of their salaries; they speak with honest frankness of the little experience they had in all matters at their arrival at Callao, and promise to perfect their discoveries and to achieve further new ones, if His Majesty, on the proposal by V. E., pleases to permit them to stay another year in Peru in order to inspect again, with the greater practice they have already attained, the very fertile montañas of Huánuco and Tarma. To me the loyalty and zeal with which these professors offer themselves for new and more continuous work than that imposed by their official instructions appear very praiseworthy, and I am persuaded that their efforts will produce more results in the additional year for which they ask than in all the former ones, especially if they be told that on completing this term, they should plan, upon the arrival of the orders of V. E. to embark with all their collections to return straight to Europe, without engaging in new trips by land as had been thought before the expedition of Don Joseph Celestino Mutis, had been projected, and that for the excursions that they are going to repeat from Lima to the montañas of Huánuco and Tarma, they have to take with them at the expense of the King one or two young men with the necessary qualifications to become acquainted with the places where the most valuable plants are to be found, and to become instructed in botany so that, when the time comes for the return of the professors of Europe, those young men will be capable of continuing the study of the science of plants and of sending seeds and even of satisfying any question or commission that may be confided to them from here. during the publication of the work and afterwards.

The sum that was determined by His Majesty for extraordinary expenses, like that of packing the herbaria and drawings, and of protecting live plants in boxes to be shipped and other similar ones, has not been enough for the time they have traveled of late after having completed the four years of their mission; if it appears suitable and just, V. E. could order payment of the amounts that you may think necessary, according to the time that the men have been or may be detained, or whatever may be the pleasure of V. E., who will decide everything, as always, that is most proper and conducive to the service of the King, the good of the nation, and the progress of the natural sciences.

Our Lord keep the important life of V. E. the many years that I desire and that are necessary. Madrid, March 1, 1784. 
Excmo. Señor:

\section{$\mathrm{XIX}$}

Sir.-Since our arrival in these Kingdoms we have informed V. E. of the progress of our commission, announcing in our last letter the shipment that we had agreed to make of dried plants, seeds, and sketches; we are making it now under the direction of the Master and Captain of the vessel named the "Buen Consejo."

By the enclosed account V. E. will see that the shipment contains 17 boxes and with the one that contains one of these, makes 18. Of these, 11 belong to the Spanish commission; and the remaining seven are a sending by Doctor Dombey to his Sovereign. Of those of the Spanish commission, four have live plants; six are of dried plants, seeds, bulbs, roots, and other natural curiosities; and in one of these that is labeled with the number 6 , there is enclosed a small box with the sketches which complete the 11 we have mentioned.

In the same account we give information about the new genera, species, and classes in which they have been placed. Our whole desire has been to succeed and to discharge the trust that was given to us: we desire that our work shall be acceptable in the eyes of V. E., and we beg of you to excuse any error you may find, as resulting from the fallibility that is natural to the judgment of men, without ever attributing it to careless work.

We wish to inform V. E. that we have resolved to continue our commission and start for the provinces of Tarma and Jauja where we are assured there is abundant material for us to work on. May Divine Providence permit our Sovereign to see the accuracy with which we intend to carry out his Royal Instructions; and grant that his subjects by this means may find all the happiness that the Monarch has promised and that has been the spirit which has moved this important work.

Our Lord keep V. E. many years.

Lima, April.-Your most attentive servants kiss the hand of V. Exa.Hipólito Ruiz.-Jph. Pavón.-Jph. Brunete.-Isidro Gálvez.-Exmo. Señor Don Joseph de Gálvez.--Signed.

\section{List OF THE DRIED PLANTS SENT By RUIZ TO SPAIN WITH THEIR DESCRIPTIONS, NOTING SOME THAT GO WITHOUT ANY}

Canna indica Lin. sp. P.

\section{Classis I. Monandria}

\section{Classis II. Diandria}

Calceolaria integrifolia L., F. P., pinnata L., F. P. cum lam. Collinsonia verticillata F. P. c.l. Dianthera repens F. P. c.l., verticillata F. P. c.l. Salvia coccinea Jussieu, F. P. c.l., pilosa F. P. c.l. Verbena nodiflora L. Veronica limensis F. P. c.l. Utricularia bifida L., F. P. c.l.

\section{Classis III. Triandria}

Arundo Bambos L. Commelina tuberosa L., F. P. c.l. Cyperus niger F. P. c.l. Alter, vulgo vara de San Jph. F. P. c.l. Alter sine descriptione. Herba purgationis Few P. F. P. c.l. Palaua dichotoma F. P. c.l., glutinosa F. P. Schoenus? Alter s.d. Scirpus? Alter s.d. Wachendorfia? Genus novum? F. P. c.l. Valeriana chaerophylla F. P. c.l., pinnatifida F. P. sine lam. Gramina 29 s.d. 


\section{Classis IV. Tetrandria}

Buddleia occidentalis L., F. P. c.l. Cissus cordifolia L., F. P. c.l. Isnardia hastata F. P. c.l. Plantago albicans? L., F. P. c.l. Potamogeton compressus F. P. c.l., marinum F. P. c.l. Scoparia dulcis L. Sp. P. Spermacoce tenuior L. Varietas tenuioris? F. P. c.l. Tillaea perfoliata F. P. c.l., muscosa? L.

\section{Classis V. Pentandria}

Anagallis angulata F. P. c.l. Anethum parvum F. P. Asclepias curassavica L. ? F. P. c.l., hastata F. P. c.l. Atropa arborescens L., F. P. c.l., physaloides L., F. P. Anchusa L.? tiguil-tiguil. F. P. c.l. Basella rubra L., F. P. Buettneria aculeata L., F. P. c.l. Brunia videtur F. P. c.l. Capraria biflora L., F. P. c.l. Campanula peruviana F. P. c.l. Cedrela odorata L., F. P. c.l. Cestrum diurnum L., F. P. c.l., nocturnum L., F. P. c.l. Chenopodium rubrum L., quinoa amarga. Cordia Sebestena L., F. P. c.l. Convolvulus hastatus L.?, albus L., F. P. c.l., sepium L., F. P. c.l., purpureus L.? F. P. c.l. Cosmea montana F. P. c.l. Cuscuta americana L., F. P. c.l. Cynoglossum pilosum F. P. c.l. Cynanchum racemosum L.? F. P. c.l. Datura arborea L., F. P. c.l. Duhamelia Manglillo F. P. Daucus Gingidium L. Evolvulus stipulatus F. P. c.l. Gentiana americana F. P. c.l., tetrangularis F. P. c.l. Heliotropium curassavicum L., fructicosum L., indicum L., peruvianum L., F. P. c.l. Hydrocotyle umbellata L., F. P. c.l., vulgaris L., F. P. c.l. Ipomoea coccinea L., lacunosa L. Illecebrum Achyrantha L., F. P. c.l. Linum prostratum F. P. c.l. Lycium americanum Jacq. Am. Myosotis hispida F. P. Morinda? chinchimali? s.d. Nolana prostrata L. Nicotiana glutinosa L., paniculata L. Phellandrium ciliatum F. P. c.l. Physalis angulata L., prostrata F. P. c.l., pubescens L. Plumeria rubra L., F. P. c.l., inodora Jacq. Am. F. P. c.l., Turumbaco F. P. c.l. Solanum corymbosum F. P. c.l., decurrens F. P. c.l., macrocarpon L., F. P. c.l., montanum L., peruvianum L., F. P. c.l., pinnatifidum F. P. c.l., tuberosum L., F. P. c.l. Thouinia multifida F. P. c.l.

\section{Classis VI. Hexandria}

Achras mammosa L., F. P. c.l. Aloes? s.d. Alstroemeria Pelegrina L., F. P. c.l. Amaryllis aurea F. P. c.l., flammea F. P. c.l. Juncus. Alter s.d. Pancratium caribaeum? L., F. P. c.l., rubrum, sub-tribiale, flavum F. P. c.l., maritimum L., F. P. c.l. Polyanthes tuberosa L. Varietas vulgo Margaritas esmaltadas F. P. c.l. Scilla paniculata F. P. c.l. Tillandsia purpurea F. P. c.l. Triglochin fibrosum F. P. s.l.

\section{Classis VIII. Octandria}

Cardiospermum tripartitum F. P. Epilobium denticulatum F. P. c.l. Oenothera prostrata F. P. c.l., multifida F. P. c.l. Polygonum Persic. folio Lin. Sp. P. Tropaeolum majus L., peregrinum F. P. c.l.

\section{Classis IX. Enneandria}

Laurus Persea L., F. P. c.l.

\section{Classis X. Decandria}

Bauhinia aculeata L., F. P. c.l. Cassia mimosoides L., F. P. c.l. Cassia tenuissima L., F. P. c.l., Tora L., F. P. c.l. Jussiaea fruticosa L., F. P. c.l., peruviana L., F. P., repens L., F. P. c.l. Malpighia nitida L., F. P. Oxalis nitida F. P. c.l. Parkinsonia glandulosa F. P. c.l. Poinciana bijugata L., F. P. c.l., Paipai F. P. c.l.

\section{Classis XI. Dodecandria}

Euphorbia Chamaesyce L., hirta L., hypericifolia L., F. P. c.l., striata F. P. c.l. Lythrum Hyssopifolium L., F. P. c.l. Portulaca Crassa F. P. c.l., linearis F. P. c.l. Triumfetta Lappula L. 


\section{Classis XII. Icosandria}

Eugenia uniflora? L., F. P. Loasa aspera F. P. c.l., hispida F. P. c.l., urens F. P. c.l. Psidium pyriferum L., F. P. c.l. Rubus jamaicensis Sist. Naturae. Sesuvium Portulacastrum F. P. c.l. Tetragonia crystallina F. P. c.l.

\section{Classis XIII. Polyandria}

Anona muricata L., F. P. c.l., squamosa L., F. P. c.l. Bixa Orellana L. Corchorus siliquosus L., F. P. c.l. Mammea americana L. Mentzelia aspera L., F. P. c.l.

\section{Classis XIV. Didynamia}

Antirrhinum peruvianum F. P. c.l. Browallia multiflora F. P. c.l., elata L.? Crescentia Cujete F. P. c.l. Galvezia limensis F. P. c.l. Guiriora rivularis F. P. c.l. Lantana camara L., salvifolia L., F. P. c.l. Mimulus luteus L., F. P. c.l. Nepeta aut Melissa? s.d. Ruellia repens F. P. c.l. Stachys pratensis F. P. c.l. Tourretia lappacea F. P. c.l.

\section{Classis XV. Tetradynamia}

Cleome triphylla $\mathrm{L}$. Thlaspi arvense $\mathrm{L}$.

\section{Classis XVI. Monadelphia}

Geranium tuberosum F. P. c.l., moschatum L. Gossypium arboreum L., hirsutum L. Ketmia? s.d. Magallana repens F. P. c.l. Malva coromandelina L., F. P. c. 1., peruviana L., F. P. c.l. Melochia corchorifolia L., F. P. c. 1. Sida lutea F. P. c.l., multifida F. P. c.l., americana L., cordifolia? L., frutescens Few. P., F. P. c.l., hastata F. P. c.l., cristata L.?, jamaicensis L., moschata F. P. c.l., palmata F. P. c.l., paniculata L., F. P. c.l., prostrata F. P. c.l.

\section{Classis XVII. Diadelphia}

Astragalus rhombeus F. P. c.l. Crotalaria incana L., F. P. c.l., laburnifolia L., F. P. c.l. Dolichos Lablab L., F. P. c.l., uncinatus L., F. P. c.l., linearis F. P. c.l. Erythrina Corallodendron F. P. c.l., picta L. Hedysarum asperum F. P. c.l., procumbens F. P. c.l., prostratum F. P. c.l. Indigofera tinctoria L.? F. P. c.l. Lupinus stipulatus F. P. c.l. Phaseolus alatus L. ? F. P. c.l., vexillatus L., F. P. c.l. Polygala subdentata F. P. c.l., chinensis L. ? F. P. c.l. Psoralea glandulosa L., F. P. c.l.

\section{Classis XVIII. Polyadelphia}

Hypericum canadense L., F. P. c.l.

\section{Classis XIX. Syngenesia}

Ageratum conyzoides L. Aster divaricatus L.?, verticillatus F. P. c.l. Baccharis ivaefolia L., F. P. c.l., scandens F. P. c.l. Altera? Bellis pubescens F. P. c.l. Bidens cuneiformis F. P. c.l., cuneiformis varietas F. P., tripartita L., bullata L., bipinnata L., F. P. c.l. Centaurea napifolia L., F. P. c.l. Conyza cinerea L. ? F. P. c.l. Elichrysum odoratissimum L.? F. P. c.l., margaritiferum L., crispum L. Erigeron ramosum F. P. c.l., bonariense L.?, philadelphicum L. Eupatorium scandens L., F. P. c.l., valerianum F. P. c.l. Helianthus decapetalus L.? F. P. c.l., giganteus L.? Impatiens cornuta L. Lobelia decurrens F. P. c.l. Senecio scandens F. P. c.l., stipulatus F. P. c.l. Serratula quinquenervia F. P. c.l. Siegesbeckia orientalis L. Spilanthes multiflora F. P., urens Jacq. Am., F. P. c.l. Tagetes minuta L. Tragopogon glabrum F. P. c.l. 


\section{Classis XX. Gynandria}

Passiflora foetida L., F. P. c.l., minuta L., F. P. c.l., punctata L., F. P. c.l., tiliaefolia L., F. P. c.l. Pistia Stratiotes L., F. P. c.l. Serapias latifolia L., F. P. c.l. Sisyrinchium palmifolium L., F. P. c.l.

\section{Classis XXI. Monoecia}

Amaranthus gangeticus L. Ambrosia Manviona L. Casimiroa tuberosa F. P. c.l., grandiflora F. P. c.l. Cucumis Colocynthis L., maderaspatanus L., F. P. c.l. Croton ricinoides, altheaefolium F. Y. R. H. ? F. P. c.l., balsamiferum Jacq.? F. P. c.l., dubium F. P.s.l. Juglans nigra L., F. P. c.l., parthenium? s.d. Pinus. Sagittaria sagittifolia L., F. P. c.l. Sicyos angulata L., F. P. Typha angustifolia L. Urtica pumila L.? Zizania octandra F. P. c.l.

\section{Classis XXII. Dioecia}

Betula alba L. Salix Babylonicus L. Schinus Molle L., F. P. c.l.

\section{Classis XXIII. Polygamia}

Cenchrus muticus F. P. c.l., echinatus L., F. P. c.l., lappaceus L. Mimosa Inga L., F. P. c.l., cornigera L., F. P. c.l., punctata L., F. P. c.l., horrida L., latisiliqua L., F. P. c.l., pernambucana L., F. P. c.l., sensitiva L., F. P. c.l., tortuosa L.

\section{Classis XXIV. Cryptogamia}

Acrostichum trifoliatum L., F. P. c.l. Equisetum giganteum L., repens F. P. c.l. Lichen, Alter. Alter s.d. Muscus squamosus F. P. Polypodium lanceolatum L., F. P. c.l., unitum L.? F. P. c.l., vulgare L.?

\section{$\mathrm{XX}$}

List of the Seeds, Fruit, Bulbs, Roots, And Several Other Things Sent By RUiz, Giving the SPANish and INDian NameS

Ageratum conyzoides. Amaranthus gangeticus? Alstroemeria Pelegrina. Anona verticillata (anona), squamosa (chirimoya). Anagallis angulata. Antirrhinum peruvianum. Achras mammosa (lucumas). Argemone mexicana (cardo santo). Aster. Asclepias curassavica? (yerba de la seda). Avellanas de Valdivia. Arachis hypogaea (mani). Baccharis ivaefolia (chilco), scandens (chilca). Bidens cuneiformis. Buettneria aculeata (yerba de la araña). Basella rubra. Bixa Orellana (achote). Altera (achotillo). Browallia multiflora (jazmincillo de lomas). Brunia videtur. Buddleia occidentalis. Bulbi diversi. Amaryllis flammea (amancae cimarrón), aurea (amancae antiguo). Pancratium rubrum; in descriptione sub nomine flavi, caribaei. Scillae paniculatae. Bulbi tres: pancratis, junquillos, et alius liliaceae. Cedrela odorata (cedro). Corchorus siliquosus. Canna indica (achyra). Calceolaria pinnata (yerba de la bolsilla), integrifolia. Crescentia Cujete (tutumas). Campanula peruviana. Cestrum diurnum (yerba hedionda y santa), nocturnum (quiebra ollas). Convolvulus ignotus, albus (campanillas). Capraria biflora. Cordia Sebestena (membrillejo). Cynanchum racemosum (piochas). Cassia Tora (cañafistola cimarrona), mimosoides (guarangillo). Crotalaria incana (cascabelillos), laburnifolia (cascabeles). Croton ricinoides, altheaefolium T.I.R. (piñoncillos), balsamiferum, dubium. Casimirodłuberosa (flor de San Juan), grandiflora. Carica Papaya (mitos). Dolichos Lablab (frijol de Antibo). Dianthera verticillata. Duhamelia Manglillo (manglillo). Dolichos uncinatus (taconcillos). Dolichos alter. Dolichos? Eugenia uniflora (palillos). Erythrina Corallodendron (guairo). Eupatorium valerianum, scandens. Frijoles, called cocachos, morados o negros. 
Pallares (I took them from a dried plant). Geranium tuberosum. Gossypium arboreum, hirsutum. Guiriora rivularis. Galvezia limensis. Goma de molle, with sticks of arbol de lino. Hedysarum procumbens (pega-pega). Helianthus decapetalus. Hypericum canadense. Isnardia hastata. Impatiens cornuta (caiguas). Indigofera tinctoria. Jussiaea peruviana, fruticosa (flor del clavo). Ipomoea coccinea. Lantana camara, salvifolia (maestrante). Loasa urens, hispida (urtiga de la sierra), aspera. Lythrum Hyssopifolium. Lobelia decurrens (contoya). Melochia corchorifolia. Melissa seu Nepeta. Myosotis. Mimosa cornigera (guarango), latisiliqua, punctata (tapate putilla), pernambucana, sensitiva (tapate o ciérrate puta), tortuosa (aromo fino). Nolana prostrata. Nicotiana glutinosa, paniculata (tabaco cimarrón). Malva coromandelina, peruviana (malva cimarrona). Ornithogalum foliosum (margaritas de lomas). Ocimum. Oenothera prostrata. Parietaria videtur. Pistia Stratiotes (lechuga cimarrona). Passiflora foetida (puche-puche), tiliaefolia in bacca et sine bacca. Phaseolus vexillatus (wild frijoles), alatus. Psoralea glandulosa (yerba de San Agustín). Psidium pyriferum (guayaba). Poinciana bijugata (tara), Paipai (pai-pai). Portulaca Crassa. Physalis prostrata. Phellandrium ciliatum. Plantago. Palaua glutinosa. Quinoa amarga, dulce. Dugagelia peltata, radix. Polypodia indeterminata. Casimiroa grandiflora, tuberosa (flor de San Juan). Oxalis nitida (vinagrillo). Solani tuberosi sica duplici modo. Serratula quinquenervia (mata gusanos and contrayerba). Semen alicujus Helicteris? Cujusdam diadelphiae indeterminatae. Cujusdam syngenesiae indeterm. Aloes? Senecio stipulatus. Siegesbeckia orientalis. Spilanthes multiflora. Sicyos angulata. Sisyrinchium palmifolium. Spondias Mombin (ciruelas agrias). Solanum peruvianum (naranjitas de Quito), decurrens. Sesuvium Portulacastrum (llitho). Sapindus Saponaria (jabonera, bolillos, and choruros). Salvia coccinea, pilosa. Scoparia dulcis (escobilla). Sida lutea, frutescens (escoba cimarrona), jamaicensis, hastata F. P., cristata L.?, palmata, paniculata (mata hyernos). Tourretia lappacea. Tillaea muscosa L.?, perfoliata F. P. Tagetes minuta, chinchimali. Thouinia multifida. Tetragonia crystallina. Triumfetta Lappula. Verbesina alba. Veronica limensis.

A bag of amethyst stones. A rock in which the others are found. A package of small cocoanuts from Guayaquil. Several small shells. One small basket with 4 humming birds. An earthen pot found in a mine near Naturaleza. Four armadillos. Two small guaqueros. Small box with fragments of ores. Two bags of round stones used as bullets. Two marine plants.

15 packages of dried plants that are mentioned above, placed by classes, and in each one its description: there go from 6 to 12 specimens of each, except from those of which I have not found more than one, two, or three examples.

Don Joseph Pavón remits 11 packages of other dried plants; the seeds, bulbs, roots, and other things that he has found.

Don Joseph Dombey is sending a package of dried plants for the King our Lord. I do not know whether they are described and placed in order, because I placed them tied as he gave them to me, in the box I had ready to seal. He also sends a small tin can with saltpeter, which is abundant in this province and in that of Chancay.

For the French Court there are seven boxes, two with guaqueros, two with fragments of ores, and the other three with dried plants, seeds, bulbs, and other products.

The 10 boxes that we are sending to the King our Lord are numbered and are marked: To the Exmo. Señor Don Joseph de Gálvez of the Counsel of State and Secretary of the Universal Despatch of the Indies, and with the mark E. 
In numbers 1,2 and 3 , dried plants. Number 4 , several things cited above. Number 5, bulbs, roots, and some fruits. Number 6 , the seeds; and a small box with 241 drawings. Numbers 7 and 8 , two heated cases with live plants. Numbers 9 and 10 , two open boxes with living plants.

The boxes sent by Don Joseph Dombey to his Sovereign have the distinctive mark $\mathrm{F}$ and no numbers.

\section{XXI}

\section{List of the Live Plants Sent In the Heated Cases and Crates}

Cestrum diurnum, 3 plants. Duhamelia Manglillo 2. Sapindus Saponaria 5. Baccharis ivaefolia 2. Altera indeterminata 3. Dugagelia verticillata 5. Congona 2. This plant is no other than the Dugagelia verticillata cultivated in gardens; different from the Dugagelia that is found between the hills, where there are many rocks.

Conyza cinerea 2. Achras mammosa 4 (lucumas). Malpighia nitida 5 (ciruela de Fraile). Cedrela odorata 5 (cedro). Asclepias curassavica 5 (arbolito de la seda). Mimosa latisiliqua. Poinciana bijugata 6 (tara). Arachis hypogaea 7 (mani). Poinciana Paipai 4 (pai-pai). Passiflora minuta 3. Wild narbo. Cassia Tora 4 (cañafistola cimarrona). Solanum pepino 4 (pepinos). Buddleia occidentalis 2. Psidium pyriferum 5 (guayabas). Tillandsia purpurea 6 . Three different bulbs. Several seeds that have been spread on the soil.

\section{List of the SKetches Made By Don JoSeph BRunete AND transmitted}

Astragalus rhombeus. Atropa arborescens. An Genus novum? non Wachendorfia. Amaryllis aurea. Alsine stipulata. Asclepias hastata. Baccharis scandens. Bauhinia aculeata. Bellis pubescens. Bidens bipinnata. Buettneria aculeata. Buddleia occidentalis. Calceolaria pinnata. Cassia mimosoides, minutissima, Tora. Campanula peruviana. Cedrela odorata. Centaurea napifolia. Cissus cordifolia. Cosmea montana. Convolvulus sepium, purpureus. Cordia Sebestena. Commelina virginica. Croton balsamiferum. Crotalaria laburnifolia. Crescentia Cujete. Cuscuta Americana. Cucumis maderaspatanus. Cynoglossum pilosum. Cyperus. Dianthera verticillata. Dolichos Lablab, linearis, uncinatus. Epilobium denticulatum. Erigeron bonariense. Fumaria officinalis. Galvezia limensis. Gentiana americana. Geoffraea spinosa. Geranium tuberosum. Gramen. Alterum. Alterum. Alter. Alter. Alter. Hedysarum procumbens, prostratum. Heliotropium peruvianum. Herba purgationis. Hydrocotyle vulgaris. Isnardia hastata. Illecebrum Achyrantha. Juncus? Jussiaea fruticosa. Lantana galvifolia. Linum prostratum. Lobelia decurrens. Lupinus stipulatus. Loasa urens. Lycium americanum. Malva peruviana, coromandelina. Melochia corchorifolia. Mimosa latisiliqua, cornigera, punctata, pernambucana. Mimulus luteus. Oenothera multifida. Ornithogalum foliosum, corymbosum. Oxalis nitida. Palaua dichotoma. Pancratium caribaeum, flavum, rubrum. Paspalum. Passiflora minima, punctata. Phaseolus vexillatus. Phellandrium ciliatum. Plumeria inodora, rubra. Physalis prostrata. Polygala chinensis, subdentata. Potamogeton marinum, compressum. Portulaca Crassa. Polypodium unitum. Psoralea glandulosa. Ruellia repens. Sapindus Saponaria. Serapias? vel orchis? Sesuvium Portulacastrum. Serapias latifolia. Serratula quinquenervia. Schinus Molle. Sida hastata F. P., cristata Lin.?, moschata, multifida, paniculata, palmata F. P., radiata Lin.? Solanum pepinos, tuberosum. Sisyrinchium palmifolium. Stachys pratensis. Spilanthes urens. Tillaea perfoliata F. P., muscosa Lin.? Tillandsia purpurea. Thouinia multifida. Tropaeolum peregrinum. Tourretia lappacea. Verbesina alba, biflora. Vicia. Utricularia bifida. 
The sketches that are made with parts of the frutification separate.

Buddleia occidentalis. (a) Corolla. (b) Calix cum pistillo. (c) Capsula cum calyce et sine calyce. (d) Capsula aperta. (e) Semina.

Buettneria aculeata. (a) Flos.

Cedrela odorata. (a) Capsula aperta. (b) Semen.

Calceolaria pinnata. (a) Capsula clausa supra calycem. (b) Capsula in calyce aperta semina demostrans.

Cordia Sebestena. (a) Calyx. (b) Corolla aperta cum staminibus. (c) Germen. (d) Osiculum. (e) Osiculum per medium sectum.

Cosmea montana. (a) Calyx. (b) Capsula.

Crescentia Cujete. (a) Semina.

Croton balsamiferum. (a) Capsula aperta. (b) Semina.

Cucumis maderaspatanus. (a) Pomum apertum seu per medium sectum semina et loculamenta demonstrans.

Dolichos Lablab. (a) Legumen clausum. (b) Legumen apertum. (c) Semina.

Galvezia limensis. (a) Corolla cum calyce. (b) Corolla in calyce longitudinaliter incisa staminibus pistilloque demonstrans. (c) Corolla. (d) Calix cum pistillo. (e) Capsula per medium secta. (f) Semina.

Geoffraea spinosa. (a) Drupa aperta per medium. (b) Nux.

Herba purgationis. (a) Corolla cum 3 staminibus et pistillo. (b) Receptaculum in quo corolla 5 fida insidet et abit in capsula. (c) Capsulae clausae. (d) Capsula aperta. (e) Semen. (f) Corolla sexfida cum 4 staminibus et pistillo. (g) Receptaculum in quo corolla sexfida insidet.

Lobelia decurrens. (a) Corolla naturalis. (b) Folium naturale.

Mimosa latisiliqua. (a) Semina.

Mimosa cornigera. (a) Siliquae clausae. (b) Siliqua aperta. (c) Semen.

Palaua dichotoma. (a) Corolla cum staminibus. (b) Calyx cum pistillo. (c) Pistillum. (d) Capsulae clausae. (e) Capsula aperta. (f) Semen.

Physalis prostrata. (a) Bacca intra calycem.

Plumeria inodora. (a) Foliculi clausi. (b) Foliculus apertus. (c) Semen.

Plumeria rubra. (a) Foliculus clausus. (b) Foliculus apertus. (c) Semen.

Polygala subdentata. (a) Corolla cum calyce. (b) Corolla cum staminibus. (c) Stamina cum germine. (d) Germen. (e) Capsulae clausae. (f) Capsula aperta. (g) Semina.

Sapindus Saponaria. (a) Fructus saturatus. (b) Fructus abortiens.

Sesuvium Portulacastrum. (a) Capsula cum 4 pistillis. (a) Capsula cum 3 pistillis. (b) Capsula 4 locularis aperta. (b) Capsula 3 locularis aperta. (c) Semina.

Sida palmata. (a) Calyx. (b) Calyx et corolla. (c) Corolla cum germine et staminibus.

Spilanthes urens. (a) Corolla aucta. (b) Corolla propria aucta. (c) Corolla cum staminibus. (d) Pistillum cum stigmate. (e) Calyx cum receptaculo. (f) Stamina.

Tillaea perfoliata. (a) Calyx auctus. (b) Calyx, corolla, staminaque aucta. (c) Germina. 
Stachys pratensis. (a) Calyx. (b) Stamina. (c), (d) Corolla. (e) Semina. (f) Calyx semina fovens.

\section{Tillandsia purpurea. (a) Corolla. (b) Calyx. (c) Semina.}

Thouinia multifida. (a) Calyx. (b) Corolla. (c) Corolla cum staminibus et pistillo. (d) Capsula clausa. (e) Capsula apice in tres partes dehiscens. (f) Capsula per medium secta, tria loculamenta demonstrans. (g) Semina.

Tourretia lappacea. (a) Calyx. (b) Corolla clausa. (c) Corolla aperta. (d) Corolla cum staminibus et pistillo. (e) Capsula aperta. (f) Semina.

Wachendorfia non? an Genus novum? (a) Spatha cum 4 floribus clausa. (b) Spatha cum floribus aperta. (c) Capsulae in spatha. (d) Capsula clausa. (e) Capsula per medium secta. (f) Capsula longitudinaliter aperta. (g) Corolla. (h) Corolla patens. (i) Semina aucta. (j) Pistillum.

He keeps the following that have not been finished because some part is missing: Senecio scandens. Duhamelia Manglillo. Jussiaea peruviana. A Diadelphia that is not finished or examined. A Sida. A Baccharis.

\section{Sketches made by Don Isidro Gálvez and transmitted}

Achras mammosa. Acrostichum trifoliatum. Alstroemeria Pelegrina. Amaryllis flammea. Anagallis angulata. Anona muricata, folia et flores, fructus et semina. Anona reticulata, folia, fructus, et semina. Anona squamosa, folia et flores. Antirrhinum peruvianum. Asclepias curassavica? Alsine media. Aster verticillatus. Aubentonia repens (mayaca). Baccharis ivaefolia. Bidens cuneiformis. Browallia elata. Capraria biflora. Casimiroa tuberosa, grandiflora. Cenchrus echinatus. Cestrum diurnum, nocturnum. Commelina tuberosa. Conyza cinerea. Croton ricinoides Americ. fruct., altheaefolium F. I. R. H. 656. Cyperus niger. Cyperus (totora). Alter. An Cyperus? Convolvulus albus. Collinsonia verticillata. Corchorus siliquosus. Crotalaria incana. Cynanchum racemosum. Columbea minuta, palida, varietas Columbeae minutae. Datura arborea. Dianthera repens. Dugagelia verticillata, peltata. Erythrina Corallodendron, folia. Erythrina Corallodendron, flores et siliquae. Euphorbia hypericifolia, striata. Eupatorium Valerianum, scandens. Evolvulus stipulatus. Guiriora rivularis. Gentiana angularis. Gnaphalium odoratissimum. Gramen. Alterum. Alter. Alter. Alter. Alter. Alter. Helianthus decapetalus. Hydrocotyle umbellata. Hypericum canadense. Indigofera tinctoria. Jussiaea repens. Juglans nigra. Juncus? Laurus Persea. Loasa aspera, hispida. Lythrum Hyssopifolia. Mimosa Inga, sensitiva. Magallana repens. Oenothera prostrata. Ophioglossum vaginans. Oxalis spicata. Parkinsonia glandulosa. Pancratium maritimum, illyricum. Passiflora tiliaefolia, foetida. Phaseolus alatus? Physalis angulata. Pistia Stratiotes. Plantago incana, albicans L. Plumeria alba, rubra, Turumbaco. Polypodium lanceolatum. Polianthes rubra. Poinciana bijugata, Paipai. Portulaca linearis. Psidium pyriferum. Pexe Gallo. Salvia coccinea. Scilla paniculata, maritima Lin.? Scirpus A. Scirpus B. Alter. Alter. Alter. Silene pilosa. Solanum decurrens, pinnatifidum, peruvianum, corymbosum, macrocarpon. Sagittaria sagittifolia. Spermacoce tenuior, varietas. Sida lutea. Spondias Mombin. Sisyrinchium palmifolium varietas? tiguil-tiguil, prostratum, reflexum Pav. Tragopogon glabrum. Tetragonia crystallina. Valeriana chaerophylla. Verbesina Acmella. Veronica limensis. Zizania octandra. 
The sketches that are sent with some parts of the frutification in separate, are the following.

Achras mammosa. (a) Flos apertus cum staminibus. (b) Pistillum. (c) Pomum per medium sectum. (d) Semen.

Asclepias curassavica? (a) Folliculus cum seminibus. (b) Semen. (c) Pappus.

Anona muricata. (a) Fructus. (b) Semina.

Anona reticulata. (a) Fructus. (b) Semina.

Aubentonia repens. (a) Calyx clausus. (b) Calyx apertus. (c) Calyx expansus ut tria perianthia ex quibus constat videantur. (d) Corolla. (e) Pistillum. (f) Capsula clausa. (g) Capsula per medium secta. (h) Semina.

Browallia elata. (a) Calyx. (b) Corolla. (c) Stamina. (d) Pistillum. (e) Capsula clausa. (f) Capsula aperta. (g) Semina.

Casimiroa grandiflora. (a) Flos masculus. (b) Radix per medium secta.

Commelina tuberosa. (a) Radix.

Conyza. (a) Calyx cum corolla. (b) Corolla hermaphrodita. (c) Semen hermaphroditum. (d) Sem. femineum.

Convolvulus albus. (a) Capsulae. (b) Semina.

Croton ricinoides Americana frutesc. Altheaefolium T. R. H. 656? (a) Calyx masculus. (b) Corolla mascula. (c) Calyx femineus. (d) Corolla feminea. (e) Squamae. (f) Stamina mascula. (g) Germen cum stamine. (h) Capsula aperta. (i) Semen.

Columbea minuta. (a) Musca quae in omnes infra caudam invenitur. (b) Musca aucta.

Evolvulus stipulatus. (a) Stamina. (b) Pistillum. (c) Calyx cum capsula.

Eupatorium valerianum. (a) Semina.

Casimiroa tuberosa. (a) Capsula. (b) Semina. (c) Radix per medium secta.

Guiriora rimularis. (a) Corolla in calyce clausa cum bractea. (b) Stamina. (c) Corolla aperta. (d) Corolla cum pistillo. (e) Germen. (f) Capsula clausa. (g) Capsula aperta. (h) Semen auctum. (i) Semina naturalia.

Helianthus decapetalus. (a) Semen. (b) Corolla feminea. (c) Corolla hermaphrodita. (d) Folium inferum.

Hypericum canadense. (a) Calyx. (b) Petala. (c) Stamina. (d) Capsula clausa. (e) Capsula per medium secta. (f) Semina. divisus.

Laurus Persea. (a) Drupa per medium incisa. (b) Nucleus per medium

Magallana repens. (a) Calyx. (b) Calyx cum germine. (c) Semina.

Oenothera prostrata. (a) Flos cum omnibus partibus suis. (b) Capsula clausa. (c) Capsula aperta. (d) Semina.

Parkinsonia glandulosa. (a) Calyx. (b) Lacinia inferior calycis. (c) Petalum. (d) Nectarium. (e) Stamina. (f) Stamen. (g) Pistillum.

Passiflora tiliaefolia. (a) Bacca.

Pistia Stratiotes. (a) Corolla. (b) Discum membranaceum. (c) Stamen cum antheris. (d) Squama quae est in medio limbi. (e) Germen. (f) Capsula. (g) Semina.

Plumeria rubra. (a) Folliculus apertus. (b) Folliculus clausus. (c) Semina. 
Plumeria Turumbaco. (a) Folliculus.

Poinciana bijugata. (a) Corolla. (b) Petalum inferum. (c) Siliqua. (d) Folium. (e) Semen.

Poinciana Paipai. (a) Semen.

Psidium pyriferum. (a) Bacca. (b) Bacca per medium secta. (c) Semina.

Tiguil-tiguil. (a) Calyx cum corolla et staminibus.

$\mathrm{He}$ is keeping the following because some parts are not finished yet:

Malpighia nitida. Palaua glutinosa. Ketmia. Sida jamaicensis.

The Indians always duplicate the name of the plant when this or any other thing has any particular virtue or is good for dyes, or if it is a laxative or poison; as quebec-quebec for the Contoya Lobelia of Linnaeus, because it is a very strong laxative; guarmi-guarmi for the Ageratum conyzoides of Linnaeus, because it is diuretic; pai-pai for a Poinciana on account of the use they make of its pods for dyes, etc.

The word cimarrona means wild or growing without cultivation.

\section{Excmo. Señor:}

\section{XXII}

My dear and most respected Sir: Since I received the order of V. Exa. of the 31st of August last, I have busied myself as much as possible with examining the 13 boxes sent by the botanists of Peru. From their letters of the 5th of April, 1779 it appears that there must be 17 boxes, so that the four with live plants are still missing, and it is probable that they may be lost on account of the delay in Fayal and in Lisboa.

I enclose for V. Exa. a list of the contents of the seven boxes sent by Mr. Dombey to France, and it is as follows: two boxes for Mr. de Buffon, Intendant of the Cabinet of Natural History; for the Conde d'Angivillers, Director General of the French Academies, and for the State Secretaries Mr. Bertin and Mr. Furgot.

From the enclosed list V. Exa. will see that Mr. Dombey's activity has not been limited to the examination of plants, because among other things, he sends several pieces of Peruvian antiquities, of which I presume the Royal Cabinet of Madrid is not lacking, and 37 pounds of platinum ore, precious metal, on account of the scarcity of which in the Kingdom they cannot continue the experiments that I am told should be made in this Mint by order of the King. I reserve for a verbal report to V. Exa. what I have privately done beforehand in such an important matter, and to show you a tobacco box made at my request to demonstrate that it has been discovered how to make this metal ductile and malleable which for lack of this particular quality was found to be almost without use. I have a few pounds left that I ought to place at your disposal until V. Exa. gets new samples from America.

In the matter of the discovery of the saltpeter the importance of which I myself confirmed to V. Exa. from Puertollano, under date of the month of August, 1779 , it is my duty to inform V. Exa. that then, when we had not yet received the samples in Spain, I expressed myself as I did on the supposition that the discovery would be verified. Now that I have examined the samples, those remitted to Spain, as well as those sent to France, I ought to add in honor of truth, that I have purified and analyzed the salt sent, and it is not saltpeter, but another species of salt that is abundant in several provinces of our peninsula, as 
in Aranjuez, Cuenca, Laguna de Fuente de la Higuera, and other territories, where it is known by the name of sal de Compas; it is a bitter salt and a purgative that is sold at a very low price and is used in the manufacture of aqua fortis. From a pound of the material in its natural state, I have taken 8 ounces of crystallized salt that I have the honor of sending to V. Exa. so as to demonstrate that this salt does not crystallize in long needles of the regular shape that was observed constantly in the purified niter, and that it does not have the cool and prickly taste and does not light with a noise over coals; on the contrary, it puts out fire as it swells and discharges its copious moisture, and is thus worse than useless for the manufacture of gunpowder. One need not wonder at the mistake Mr. Dombey and his companions made in the naming of this mineral, first, because the object of their journey was not chemistry, for in this science they are not as learned as in botany, and secondly, because they judged what they found in the rough by its exterior appearance. In the meantime it will be proper to revoke the order given to the Viceroy of Lima about sending portions of this supposed saltpeter from the coasts of the South Sea, and if V. Exa. approve, I will on my own account, confidentially and conveniently inform Mr. Dombey of his mistake, and even his correspondents of the Royal Academy of Sciences of Paris, so that those learned men might not think, perhaps, that we here adopt blindly and without examination all that is written to the Ministry about these matters from those far lands.

I have noticed also that Mr. Dombey has not sent to Spain a herbarium as complete as the one he is sending to France, and that most of the dried plants come without name, and although some omissions may be due to the haste with which the first fruits of his work were placed on board, it will be proper to ask Mr. Dombey to be more exact from now on in citing the names assigned by our botanists. In this particular I await the orders of V. Exa,. also instructions as to whether we should make the complete delivery that Mr. Dombey begs of V. Exa. to be made of the seven boxes to the Exmo. Señor Embajador [Ambassador] of France, or to the Consul, as he is soliciting it in both names.

Our botanists and draftsmen have discharged their obligations very well by making this large shipment, and all the contents of the six boxes have been received in good condition. It remains for V. Exa. to vouchsafe to give orders about their use and preservation. I understand that the most precious are the 260 sketches and the herbaria. The first could be bound neatly, without cutting off anything, in three volumes, for greater ease in handling, and for protection so that they may not get lost; this will also enable V. Exa. to present them to His Majesty when the Court arrives in Madrid. About the herbaria, which should be gone over often and preserved from moths, they could be given proper care under my direction, if V. Exa. approve of it, until the return of our botanists, by Don Bruno de Salvador y Carmona, who served as a draftsman for the King in the Botanical Expedition to the Orinoco, and obtained appointment through the Secretaryship in charge of V. Exa. and, for this reason, enjoys a pension of six thousand reales. Of the seeds a few of each species could be planted in the Royal Botanical Garden, and the rest be distributed to the people that V. Exa. commands and that have gardens in various provinces of Spain, with the idea of facilitating and assuring the propagation of the plants. The same should be done with some roots to see if we succeed in growing them. From the fruits and seeds we could also separate samples and place them in the Royal Cabinet of Natural History, where the armadillos will also be sent as well as this or that curiosity that has come pertaining to that establishment and appearing on our botanists' list. 
V. Exa. will resolve, as always, what will be best to do.-Madrid, November 24, 1780.—Exmo. Señor.

Exmo. Señor Don Joseph de Gálvez.-Your most humble servant kisses the hands of V. Exa.-Casimiro Gómez de Ortega.

In the margin it is written.

These might have been left in the "Buen Consejo" and might have fallen into the hands of the enemy with the vessel.

Make the delivery of those boxes with their contents, except the Inca dress that we do not have in our Cabinet and that the King has ordered to be set apart.

In relation to the platinum, I have presented to His Majesty the box sent by the Count of Milly to this professor, with the copy of the memoirs of the first, presented to the Academy of Paris, and the decisions have been made in the separate despatch about the platinum.

Informed, and give the warnings you propose about this salt.

This instruction to Dombey should be official through the Viceroy, besides the one Ortega will make individually. Dated the 3rd of February, 1781.

To make the delivery as I have told you verbally.

As proposed.

All that you mention is approved, and pass the order to Salvador.

\section{XXIII}

\section{LIST OF THE CONTENTS OF THE SEVEN BOXeS SENT FROM PERU BY Mr. DoMbey For France}

1. In a big box, many sepulchral vases of different strange shapes with a piece of cloth that the Indians weave for their dresses, and some implements with which they weave it.

2. In another big box, various sepulchral vases, and two snail shells of extraordinary size, and an Inca dress that was taken from an ancient sepulcher.

3. In another big box, two small boxes of seeds and a tin can that occupies almost the whole box, and it is also filled with many bundles of seeds.

4. In another big box, four bundles of dried plants or herbaria, and two small boxes with seeds of quinoa and two tin cans with the supposed niter or saltpeter that is produced by nature on the coasts of the South Sea.

5. In a medium-sized box, many curious seeds and a herbarium of dried plants or skeletons that has 284 plants; 237 with labels, and the other 47 without them.

6. In a small box, three bundles of platinum of 11 pounds each, for different persons, and other 3 pounds of the same metal for Mr. Sage, and a magnetic stone, and other minerals for the Cabinet of Natural History.

7. In a small box, a piece of a rich silver ore and two pieces of mercury of Huancavelica.

Excmo. Señor:

\section{XXIV}

Sir.-As soon as we arrived at the port of Concepción to begin the work ordered by the Sovereign, we gave immediate notice to V. E. of our arrival and of the discoveries that we were making: before that we notified V. E. of our trip 
to this city and sent you a copy of a letter from the Señor Visitador and General Superintendent of Lima, in which he informed us of the difficulty found in allowing our salaries and the continuation of our discoveries, as His Majesty, in his Order for our stay in these Kingdoms, had provided for four years only.

Although not yet rested from our travel, from this city of Santiago we informed V. E. of the valuable finds of trees and plants that we had obtained in that district; and in duplicate we remitted the copy of the letter of said Señor Visitador; and of the desire to return to the montañas of Huánuco and Tarma, from which we were unable to get their natural products because of accidents that obliged us to leave.

Our intention is and has been, to make a second expedition in them; and as we are now more experienced, we promise, without any doubt, greater results, more likely to satisfy the desire of the Sovereign and, in consequence, the spirit of V. E., who with so much love inclines toward the public welfare, the support of the government, and the establishment of the sciences; especially of these last that can be said not to have flowered until now in our Spain.

This desire and constancy will never fail us, although it appears to us to be frustrated by the enclosed second copy of the letter we just have received from the Señor Visitador, and we take the liberty to place it in the hands of V. E., for whose life and health your most obedient servants pray to the Almighty.

We kiss the hand of V. E.-Jph. Pavón.-Hipólito Ruiz.-Jph. Brunete.Isidro de Gálvez.-Santiago de Chile, September 12, 1783.

Excmo. Señor D. José de Gálvez.

\section{LIST OF THE SEEDS CONTAINED IN THE SMALL BOX AND THE BOTTLE, THAT ARE to be planted in the Royal Botanical Garden}

First. Seeds of the new species of pine discovered in the cordilleras of Nacimiento and Santa Barbara are those that go outside of the bottle in the little box; and several that go enclosed in another without paper. From this tree there are obtained choice timbers and excellent masts for the rigging of vessels. It distils a precious resin that is applied with marvellous effect on sprains, wounds, and in small patches on the temples to mitigate headaches, and especially for migrain. The Pehuenche and Huiliche Indians subsist on the fruits or pine-nut kernels a great part of the year; they eat them raw, but they are much better boiled or roasted.

Seeds of Volkameria verticillata. Shrub, spiny, that the natives call huamum. Used to fence the fields.

Alstroemeria Ligtu, liutu. From the roots of this plant they get a very white flour that they keep to nourish the sick, in the form of a pap, or mazamorra as they call it in this country; it is easy to digest, and insipid by itself.

Alstroemeria Copihue, copihue. The pulp enclosed in the capsule is eaten; it has a sweet and agreeable taste.

Cassia Maju, mayco. The natives purge themselves with the infusion of the leaves of this shrubby plant.

Rhamnus canescens. It is used for fences in cultivated fields, and is a resistant wood on the fire.

Rhamnus dependens, frebul. The bark of this perennial shrub is sold in the pharmacies and is used for bruises instead of the calaguala: they know by experi- 
ence that it does not permit the blood to coagulate and it prevents the formation of abscesses on the breasts. The women wash their hair with the water of this bark, which makes a foam like soap.

Cestrum nocturnum, palqui. This is a shrubby plant very much used in the Kingdom to cool the blood; they administer it for jabandillo or chavalongo, making an infusion of the leaves and the barks in common water. The ashes of its roots made into lye whiten cloth better than anything else known in the Kingdom. The cows that eat of this plant invariably swell and die; this does not happen to other animals.

Sophora alata, pilo. It is a strong wood for small structures.

Hippomane Collihuasi, Collihuasi. The milk or juice of this shrub is a very poisonous purgative, and dangerous to the eyes; if any one by accident touches the eyes with it, he becomes blind. Its burnt roots exhale an aromatic odor with which the people of the country fumigate their rooms; but when a great quantity is burned, it produces headache.

\section{Coreopsis?}

Banisteria?

Seeds of Aristolochia vaginans.

Seeds of a species of Didynamia.

Helicteres. This tree is found in the other parts of the cordillera: we have not examined it. Its fruits are used as an infusion in water for a purgative.

Lleuqui or arbol de las uvas. It is grown in the cordillera of Chillán and Yumbel; we have not been able to find it in bloom. It is quite a tall tree with a strong, useful wood.

Coguill-voqui. It is a new genus of the Dioeciae. The pulp of its fruits has a delicate taste when ripe, and is not at all questionable.

Patahua. It is a new genus of the Dodecandrias. It is a beautiful tree, and its wood is very much used for construction; it is not very durable.

Huihan, maybe a Schinus; or new genus of the Dioeciae. It gives, although in small quantity, a very soothing and astringent resin. From the fruit a loathsome chicha is made that is commonly used by the Indians. For dropsy the use of this chicha is an admirable antidote.

Lithi or lithre, new genus of the Dioeciae. Its wood is among the strongest woods known. It gives an astringent resin. Its shade is very harmful to those who take shelter under this tree, causing all exposed parts of the body to swell, and later these become blebs or vescicles. Life is endangered if the remedy is not made available; it is chewed corn, its juice or the mayter mashed and applied to the boils. The same effect is produced by the smoke or vapor exhaled from the trunk when woodsmen cut it. The places suitable to plant this tree are noted in the small papers.

Although the observations in my diary are more complete, I omit them until my return.

\section{$\mathrm{XXV}$}

Excmo. Señor Don Joseph de Gálvez.

Sir:

By the letter of V. E. of the 9th of September last, I have just learned that the King has been informed of the discoveries that we have made of natural 
products in the Kingdom of Chile, and also how His Majesty, after seeing the sample of pine wood and the sketch that I sent from Concepción, has asked that the pine-nut kernels be sent, and also some plants of the same tree and others peculiar to that Kingdom; I have given a list of them to the Señor Presidente of Chile and Mre. de Campo, with an explanation of how the plants should be transplanted and carried by land and sea.

Expecting to return to Europe on account of the leave of which we were informed, I gathered, to transport personally, 31 pots of living plants and a box with bulbs of different flowers; these I now remit by the vessel "San Pedro Alcantara" in the care of José Jacobeli, to whom as an intelligent and careful man, they have been entrusted. Among these 17 plants will be found of the new species of pine of Chile and the other small trees that are mentioned in the enclosed list; and all or most of them I hope will arrive safely, if they do not lack water and the captain's attention.

So that they will be sent to V. E., I have given two folio volumes to the Señor Visitador General; in them are contained the descriptions and notes that for my part I have finished, corrected, and transcribed; I have doubled the work since I received the last order of $\mathrm{V}$. E.

The eagerness I have recognized in Mr. Dombey to advance his work even at the cost of my labor and to take the lead in printing it under his name, has obliged me to increase my concern for the advance and perfection of mine, including a well arranged index, since I am persuaded that if it were ready for printing, our Monarch would, under no circumstances, like to give France the glory of publishing it first, especially as our nation has few works of the kind and has been and is impeded so much for this reason. In comparison with that of Mr. Dombey, mine is very convenient, not alone because it is accompanied by the sketches, but also because it is smaller and, although he inserts many of my descriptions, I for my part have expended more care in preparation.

This reason and the effort that he has made to complete and correct it by mine, makes me fear also that on some pretext he may get hold of my work there; and for this reason I do not think it superfluous to caution V. E. to be careful, and not to entrust it to any printer unless he be very faithful.

There are 800 or more sketches with which to embellish the book because, although 1,013 have been made, the rest are duplicates on account of the information received that the first ones, which later were restored, had been lost with the vessel "El Buen Consejo." They are no less exact: they have a description of the fructifying parts that go separately, and all carry the generic and specific names, with the exception of those from Chile that are only numbered but correspond to the numbers in the list that I enclose with them in the same box. I know well that the printing of this second book demands more time than can be taken for the printing of the usual literary composition; but with V. E.'s zeal and the keenness of your interest, this difficulty will offer not even the shadow of an obstacle.

I also remit on this occasion a small box of seeds for the Royal Botanical Garden and a small box of fresh extract of cascarilla that, according to the latest test, in respect to the superiority of its properties, and to the preservation of the race, to the best advantage of nature and to the relief of the sick who many times abandon themselves to suffering because they cannot overcome their aversion for the woodiness, bitterness, and bulk of the rough quina; it has been made in the 
same montaña where it was cut, and care was taken to keep it in boxes of its own wood in which it should not deteriorate even though subjected to the most severe climates and weather.

If it were possible to encourage the manufacturers to employ the very small pieces of bark that break because it is very delicate (which, though the best, cannot be packed in the bags), there could be another branch of commerce no less valuable, to which could be added that of the salts of this same tree which are wasted and that I have already asked to have extracted in order to examine their usefulness.

On the new excursion that we are contemplating to the Andes, I expect to make other useful discoveries, not only because of the experience and help offered, but because of the many chances presented by that wonderful country which has never been crossed by men of learning; on all of this I shall report to V. E. as I do now to Señor Don Casimiro Ortega concerning all that pertains to the commission and present shipments.

Our Lord keep the important life of V. E. many years.-Lima, April 10, 1784.I kiss the hand of V. E., your most obedient servant. Hipólito Ruiz.

\section{XXVI}

List OF THE SMALL LIVE TREES THAT I AM SENDING IN SEVEN HEATED CASES FOR the Royal Botanical Garden of Madrid. Marks on the pots.

Case No. 1
A ..... Four huayabos.
B ..... Two paltos.
C ..... One faro, and some seeds.
D..... One tutumo and a palto.
E..... Several cedars.

Case No. 2

T . . . Five small cedars of Lima.

S.... Two trees of quina-quina.

J . . . One huayacan and one planta hedionda or santa.

I . . . . . Three bolillos or jaboneras.

F . . . . Tree small trees, ciruelas de Fraile.

H. ... Three suches.

Case No. 3

K.... Three palillos and one yerba hedionda.

LL ... Three aromos.

O .... Two walnut trees and one pacae.

N.... Two lucumos.

Q.... Two achotes, one white and the other violet.

P.... Five tumbos.

Case No. 4

M . . . Two plants of rosa de la China, and five slips of the same.

R.... Four trees of mantas of Otageti.

C .... Two gingers.

L. . . . One mamei.

V .... Two cacao.

a ..... Four cassia de Puzuzo, and one coffee. 
Case No. 5

Y ..... Four espinos or aromos of Chile; and three yerbas de la lancha.

m.... A huighan and five slips of it; and a peumo.

X..... Three pilos.

Z .....A cuentas (rosary bead) tree, and a cassia.

V..... Several yaraviscos.

G.... One aromo, and a root of calaguala.

Case No. 6

d.d.... Seventeen small pines of Chile.

b..... Four species of plantains: those of No. 1 orange, those of No. II melonshaped, those of No. III red, and those of No. IV blunt.

\section{REMARKS ABOUT THESE SAME TREES}

The huighan and peumo contained in the pot $m$ belong in cold countries and climate like that of Spain; and the same is true of the pines that go in d.d. The yaravisco $V$. requires a temperate climate, and grows profusely at the margin of brooks where there is much humidity; its leaves are healing to wounds and its bark antisyphilitic.

The cedar $E$. requires the same but, on account of the tenderness and brittleness of its shoots, these trees should be planted where they will not be exposed to strong winds, because if they are much agitated the roots move and the trees do not grow.

The quina-quina $S$., the gengibre $C$., and the cacao $V$. call for a climate that is quite torrid, and the last two need shade and humidity.

The rosa de la China $M$. and the mantica or arbol de las mantas $R$. that come from Otageti prevail in sandy and humid grounds and grow in torrid regions, and the last one is propagated like the orozuz at the margins of rivers and could be very useful if the natives would prepare its bark like flax.

The tumbo $P$. should be planted near another tree so that it may climb and twine in it, because that is the way it bears fruit; the same is true of the granadillo.

Of the achote $Q$. there are two kinds, one with a violet flower that gives the same color that goes with the dark one; and the other with a white flower which gives that of yellow color.

The plantain $b$. does not require deep soil, but it has to be very loose and fertilized with good dung. It needs heat the year round so that when the stem is reared in the winter, it may bloom in the spring and ripen its fruits before the beginning of the winter: the fruit very seldom ripens on the plant, and in Lima they cut them when they are seasoned, which is when the follicle or fruit sheds the dried flower, and they place them in the oven with a little kindled dung, where they are heated for three days. Those from No. I produce a fruit orange-colored on the outside and straw-colored on the inside; they are good fried. The No. II's are melon-shaped, and yellow on the outside; they are very good. Those from No. III are somewhat red on the inside, as the back of the leaf also is; they are excellent and the best of all. The No. IV's are blunt and very fleshy; they also are good, and all have better taste when the covering becomes brown and soft. They bear fruit after a year, and later they bear fruit at any time, providing that they do not lack a warm climate and dung for fertilizer. Be careful that they always have from 6 to 7 leaves, cutting off the rest. 
LIST OF THE SEEDS CONTAINED IN THE BOTTLE

Elaterium pedatum

Anona muricata

A. reticulata

Oenothera lineatiflora

Passiflora punctata

P. suberosa

P. quadrangularis

P. tiliaefolia

Chenopodium amarum, dulce

Hibiscus esculentus

Ayrampo, Cacti sps.

Meloncillos de olor

Poinciana bijugata, tara

Malpighia punicifolia

M. nitida

Dolichos uncinatus

Palillos

Huayaba

Dodonaea viscosa

Bixa Orellana

Yerba de la purgación

Sida paniculata

Solanum pepino

Aromo

Tropaeolum peregrinum

Frijol morado

Pallares

Cassia pubescens

Solanum macrocarpon

Ipomoea, auroras

Zapayo tripon

Alstroemeria Pelegrina

Spondias Mombin

Bulbs of the flor de la Trinidad

Arachis hypogaea, maní

Outside of the bottle in the little box are the following seeds: Cedar. Pacae. Ciruelas agrias. Narbo de la tierra. Maní. Chirimoya.

In box No. 18 with the mark $E$. and painted in oils, and in box No. 16 with the mark $E$. and bound in leather, are enclosed the small boxes of drawings.

In the other boxes are the dried plants, seeds, woods, birds, animals, mineral fragments, soils, shells, and several other natural and Indian curiosities. 


\section{XXVII}

Excmo. Señor Don José Gálvez.

Sir:

I have given V. E. accounts of the performance of my commission and of the results of my work; the zeal with which I have tried to discharge it, V. E. will have observed from the shipment made in the vessel "San Pedro de Alcantara," and in the folio volumes of my botanical descriptions, that I suppose have been sent V. E. by the direction of the Señor Visitador, under whose protection there will not be be the slightest obstacle to their publication in the shortest time possible.

At the beginning of this year, I entered these montañas of Puzuzo, conquering the innumerable difficulties that are caused by the dangers and roughness of the trails and forests, and in them I have discovered the special raiz de China that comes from Japan and China to our Europe and Americas, as a very important sudorific, antivenereal, and antirheumatic.

This plant, known to the Indians by the name of purampui, and santo palo, and by Linnaeus given the name Smilax China, caule aculeato teretiusculo, foliis inermibus, ovato-cordatis quinquenervis, is so plentiful in these montañas that in the district of 40 leagues I have observed it in trails and forests in such abundance that unlimited arrobas of its roots could be extracted each year.

By undertaking the extraction of the raiz de China, our nation will obtain another branch of commerce and will not need to beg the Chinese for it as is being done at present.

Because of the riches and fertility of these forests much tedious work is demanded for their exploitation, but the scanty means of existence and the short time that we can stay there, because of the showers, and lack of food except that brought from the city of Huánuco at excessive prices, will continue to keep us in want.

My companions, although tired by the constant labor, are endeavoring, as always, to accomplish their work; and together we pray to the Divine Majesty, for the life and health of V. Exa.-Puzuzo, July 23, 1784. I kiss the hand of Vmd., your most obedient servant.-Hipólito Ruiz.

Docket-2,526.

No. 390 .

Excmo. Señor:

My dear Sir: As soon as I received the Royal Order that V. E. sent me under date of March 4th of last year, to prolong the stay of the professors of botany sent to this Kingdom, to one year so that they might continue their discoveries and sketches, and to add two young men of such qualifications that, instructed by these professors, they might be able in their absence and retirement to continue the same work, I proceeded to fulfil the Royal Will as far as possible in which the only difficulty would be the finding of young men suitable to accompany the botanists that came from Europe, but a lucky circumstance gave me the satisfaction of fulfilling, even in this respect, the Sovereign Will of the King, because I was informed that in the Regiment of Soria there were two young men who had nearly completed their time in the regiment: one Juan José Tafalla, pharmacist by profession, and the other Francisco Pulgar, who has been employed as a draftsman (the first one has been apothecary in Navarra, and the other a 
painter in Toledo), and as the Viceroy, upon the request I made the 15 th of September gave both of them leave, I named them to accompany the botanists, each according to his classification, reducing their military terms so that they might go at once to join them in their explorations at Tarma and Huanuco, and assigning to each one of them an annual salary of 600 pesos, starting from the termination of their terms of service in Soria, and of this I notified them by a separate order, and I sent with them the proper notice to the botanists and the orders for the payment of the salaries to the Coffers of the territory, which are those of Pasco.

At this opportunity I added to the botanists only the request for their best efforts in their work of discovery, and the replacement of the heated cases and live plants that they had shipped on the vessel "San Pedro Alcantara" and that were part of the lot thrown overboard to lighten the vessel; with this the said Royal Order has been complied with, and whatever else has been necessary under the circumstances, which I communicate to V. E. as a matter of record and so that His Majesty may be informed of the exact compliance with his Royal commands.

The Lord keep V. E. many years. Lima, January, 1785.

Excmo. Señor, I kiss the hand of V. E., your most obedient servant.-Jorge Escobedo.-Excmo. Señor Don José de Gálvez.

At the margin it is written.-The Visitador Superintendente General of Peru reports the fulfilment of the Royal Order of the 4th of March of last year by which the stay of the botanists was prolonged for another year for exploration in this Kingdom, and reports the addition of two young men in accordance with the same Royal Order, and the salary that they have been assigned, as well as the notice given to the botanists for the replacing of the plants that were sent on the vessel "San Pedro Alcantara," and on its arrival were thrown overboard.

In a letter of the 5 th of January of the present year, No. 390, V. E. informed me of having appointed, according to the Royal Order that I communicated of the date of March 4th of the past year, to Juan José Tafalla, pharmacist by profession, and to Francisco Pulgar, who has been working as an artist, to accompany the botanists on their expedition through that Kingdom and to be instructed at their side and to prepare to continue in the future to discover natural objects and to furnish such information as may be required, each one of them to receive 600 pesos. For the present the King approved the appointment of these men and the salary that has been indicated by V. E., and orders me to ask you to make the corresponding provisions and to advise them of the care with which they should try to profit from the instructions, method, and knowledge of the professors of botany, so that they may make the progress expected of them. The Lord keep V. E. many years. Aranjuez, June 16, 1785.--Señor Superintendente Subalterno of the Royal Treasury of Peru.

\section{Excmo. Señor:}

No. 943.

In my letter No. 390, I reported to V. E. that in fulfilment of the Royal Order of the 7th of March, 1784, I had named the two young men, as requested in it, to accompany the professors of botany at work in this Kingdom and to be instructed at their side and to prepare to continue the explorations when His Majesty determines to withdraw the principals from here, and in the same letter I also reported that I had assigned only the moderate salary of 600 pesos to each one of the young men mentioned; they are Don Juan Tafalla, pharmacist, and Don Francisco Pulgar, painter and draftsman. 
The principal professors were satisfied with this appointment except that they indicated in their first answer that the salary assigned to the two young men was very small, but to this I answered that there would be time to increase it as their ability increased; all this V. E. will note in the document I remit with No. 1.

They repeated, among other things to this effect, the arguments that are cited in No. 2 that the salary of the assistants should be raised, or they should be given their expenses for one of the journeys they were about to make to the montaña, but I continued to oppose the increase until I could determine the value of the men, and I agreed to help with the expenses only up to 200 pesos.

The same argument was repeated by Don Hipólito Ruiz, who praised the industry, care, and accuracy of said assistants, and I could answer only that these praises seemed strange to me, coming from the same pen that had previously reported directly to V. E. against the same individuals, but I determined not to give them the desired increase in salary, as V. E. will notice in No. 3.

In another letter, No. 4, Ruiz cleared up my doubts and repeated the praises of the assistants and their need of higher salary; however, I decided not to assign it.

At last, another letter came on the 10th of March, almost two months after the appointment of said young men, and after I was convinced of their aptitude and application; under these circumstances, in justice not only to the interested parties but, what is more, for the good of the service, I was obliged to agree to increase their salary up to one thousand pesos to each one, which they are getting by virtue of my order which goes inserted as document No. 5 .

I have proceeded of my own accord in making this allowance because, although I thought of taking it to the Junta Superior, I considered that in that tribunal there is no information about this matter and that, aside from this, it is included in the cited Royal Order in which His Majesty entrusted the commission to me, and the necessity of the increase was as urgent and justifiable as my moderation in granting it, so that His Royal Piety will not disapprove this resolution, so fully in accordance with his beneficent intentions and the discharge of this commission, and I ought only to mention that the burden of the increase of the assistants today is less because of the saving of the salary of the draftsman Don José Brunete, who died last month, and his loss is also a new reason for the need of these assistants and their adequate endowment.

The Lord keep V. E. many years. Lima, June 20, 1787.

Excmo. Señor Jorge Escobedo.-Excmo. Señor Marques de Sonora.

Copy No. [?]-Decree.

Señor Superintendente General of the Royal Treasury.--Sir: Because the two assistants, Don Juan Tafalla and Don Francisco Pulgar, have to follow us in our excursions through the montañas, and their salary is too limited to enable them to defray the unavoidable expenses that are necessary on such trips, and at the same time in consideration of the advancement that is shown by them through their great industry, care, and accuracy:

I beg of V. E. to give them an allowance for expenses as V. E. did for the trip that was made last year to the montañas; it is a favor for which they will be thankful and will be in keeping with the pre-eminence of V. E., and it is likewise justice bestowed on these new and studious pupils.-God our Lord keep the life and health of V. E. many years. 
Huánuco, May 11, 1786.-I kiss the hand of V. E., your most obedient servant. - Hipólito Ruiz.

Lima, June 1, 1786.-Don Hipólito has been answered that I am surprised at his request, which is based upon the supposed progress of the two assistants, when he has informed His Majesty of the ineptitude of these men and of their lack of progress, according to a notice given to me in a Royal Order of the 29th of October of last year which I have just received, and which is filed with the previous ones. Escobedo.-This is a copy of the original: I so certify.-By order of the Señor Secretario.-Manuel Jorge Gallego.

\section{Copy No. 4}

Señor Superintendente General of the Royal Treasury.-Sir: Under date of the 21st of June last, V. E. tells me that you are surprised at the request that I made, on May 11th, about helping the new assistants with the expense allowance they obtained last year for the trip that they made to the montaña, because the basis for their advancement and industry that V. E. says I attribute to those individuals contradicts the information I have given to the contrary to His Majesty. So that V. E. may know that my attitude, now as ever, is a reasonable one, and that this which I have asked for is in order and that the Royal intentions may be fulfilled, I take the liberty of enclosing the two copies of what I wrote before and after to the Excmo. Señor Ministro about the matter. From them V. E. will judge of my good intentions.-It is known to S. S. that on the first of January, 1785 , I made the statement that the salary allotted to the assistants was insufficient to enable them to follow us on the trips and expeditions into the montañas and asked that you might do what you considered appropriate in the circumstances.-Under the date of the 11th of January of the same year, I stated to V. E. how suitable the nomination of the draftsman was although the Royal Order did not compel it; and in view of the contingencies that could develop with only one botanist on hand, I asked S. S. for the nomination of another one, proposing in the case Don Fernando Collo: I had been informed that he was a man of sufficient talent and intelligence to be able to make rapid progress in the science of botany and in guiding the two assistants.-On April 11, 1785, in the name of all my companions, I called the attention of V. E. to the small salary that had been assigned to the assistants, insufficient to pay the expenses that are necessary if they are to follow us in our excursions, and so we thought to put the matter before V. E. in order that they might be given the allowance for expenses. Since this request had no effect at that time and my companions did not decide to present a second petition, I alone, impelled by pity, took the liberty of proposing it to V. E., and immediately each one was given two hundred pesos.-I have reported to the Excmo. Señor Ministro on several occasions, exactly as to V. E., after having written the first letter enclosed, about the industry, disposition, good conduct, and progress of said assistants. When, at the beginning, I wrote the enclosed to V. E., no other motive actuated me than the desire for the appointment of one who possesses some knowledge of botany, in view of the short time His Majesty had assigned; at the same time, I consider it almost impossible for the assistant botanist, who is weak in Latin, to progress so much in such a limited time.-In His Royal Writ His Majesty ordered us to appoint one or two young men that V. E. might nominate, instructed in botanical operations, and so advanced that they might be able to answer questions asked from Madrid; and because I thought that in such a short time as a year, this knowledge could not be secured, even though the 
assistant had been a middling philosopher, I considered it indispensable to represent him as such so that they might not blame us for neglect, and also charge us with not having given them their respective instructions.- I do not doubt that the draftsman, when we return, may be able to sketch fairly well what the botanist requests as to plants; but as the botanist must be the one who has to carry the burden of the commission, if he is not well instructed, the fact that the other man can sketch a plant will be of no advantage if he has no one to tell him exactly what is needed to make a good sketch; but as the making of a good sketch does not consist simply in the representation of the visible parts of the plant, but in knowing how to give them their place, direction, size, and shape without adorning the sketch with additional matter, and without neglecting to sketch the smallest thing found on the plant although it may seem superfluous, because on these factors depend the perfection and genuine knowledge of the plant, and they are the most difficult to note and sketch.- I wrote to the First Botanist of the Royal Botanical Garden on the same date as to the Excmo. Señor Ministro, the 12th of last June, so that he might be interested and ask S. Exa. to grant what I ask.-From the contents of the enclosed letters, and from what I have already said, I have no doubt that V. E. will be satisfied as to my sincerity and of the reason that moved me to write the first time to S. Exa.; if I did wrong, I beg of V. E. to overlook my carelessness, because my intention was only to succeed and to strive for the due realization of the Sovereign's intentions. God our Lord grant V. E. life and health many years. Huanuco, July 9, 1786.-I kiss the hand of V. E., your most obliged and faithful servant. -Hipólito Ruiz.-Sor. Don Jorge Escobedo.-Lima, July 26, 1786.

Look up the preceding and answer that I have been thoroughly informed, and that he knows that, nevertheless, I have helped the assistants with the expense allowance, as in the former instance. I have nothing to add except that the appointment which Don Fernando Collo covets has not been made on account of the real obstacle of his being in his regiment and of there being evidence that he was asking for this appointment because he wanted to leave the service; all of this should be evident as it was to the Reverend Father González, through whose hands this request was passed as well as the appointment of the two assistants.-Escobedo.-

This is a copy of the original: I so certify.-By order of the Séñor Secretario. -Manuel Jorge Gallego. (Signed)

\section{Copy No. 5}

Señor Superintendente General of the Royal Treasury.-Sir: Don Hipólito Ruiz, First Botanist of His Majesty in this Kingdom of Peru, with due respect refers to V.S. and says: That in view of the fact that with the salary of 600 pesos allowed to the assistants, Don Juan Tafalla and Don Francisco Pulgar, they could not meet the cost of food, clothes, and expenses incurred in trips and excursions in which they are to accompany the expedition for their instruction and profit, and that they have always been in debt since they were appointed to this expedition: it is necessary for the petitioner to lay it before V. E. for his superior consideration so that, informed of it, as well as of the care, accuracy, and application with which said assistants are advancing by means of the instruction that we have given them, V. E. might issue the necessary instructions so that the salary would be augumented, and the assistants by this means become free from debt and be able to meet the expenses they will incur in the future; and so inspire them to go forward with more zeal in the advancement of their trust and so that the Royal intentions 
thus might be duly fulfilled. He begs and implores V. E. to be so kind as to grant this favor to said assistants, Don Juan Tafalla and Don Francisco Pulgar, increasing their salaries as you see fit so that they may become free from debt and can meet the necessary expenses that they will incur in the future; that in everything they will receive justice through the favor granted by V. E.

The Lord protect the life and health of V. E. many years. Huánuco, March 10, 1787.-I kiss the hand of V. E., your most humble and obedient servant.Hipólito Ruiz.--Señor Don Jorge Escobedo.

Lima, March 26, 1787.- With respect to that which has been stated and many times pointed out by the principal professors of the Botanical Commission about the smallness of the salary of the young assistants by virtue of the Royal Order, whom, according to the same, we have, while their progress and aptitude was being observed, been aiding with a moderate gratuity, to avoid which and to reward their industry and to stimulate it, and to prevent their being burdened with debts for lack of salary as represented, and because the fixing of the assistants' pay has been left to the judgment of this Superintendency, I increase the salary of said young men, Don Juan Tafalla and Don Francisco Pulgar, to the amount of one thousand pesos, which they shall enjoy from the month of January of this year, and in order that this salary be paid and prompt advance notice be taken of this decree in the Tribunal of Accounts, a copy shall be forwarded to the Señor Intendente of Tarma so that he may transmit it to the Royal Coffers of Pasco, so that payments may be made there to said interested parties of the amount due from January, and that which in the future shall become due to them while their commission lasts in that district, and another copy shall be made to be sent to Professor Don Hipólito Ruiz in answer to his previous letter and for his information and that of the assistants, and to inform His Majesty with the copies of the letters that are cited at the beginning of this decree and what has been done about them.-Escobedo.

This is a copy of the original.-I so certify.

By order of the Señor Secretario.-Manuel Jorge Gallego. (Signed)

\section{Excmo. Señor:}

I inform V. Exc. that today, the 13th of the present month, I arrived at this city of Cádiz with my two companions, the second botanist Don José Pavón and the second draftsman Don Isidro Gálvez, after five months and a few days of travel on the frigate "El Dragón" from the port of Callao.

On board of said "Dragón" there have arrived 15 boxes of dried plants and several other products of the vegetable, animal, and mineral kingdoms which, added to 14 that the frigate "El Jasón" is bringing, makes the number 29, which are what we could collect since the last sending of 76 boxes, shipped last year on the frigates "Pilar," "Brillante," and "La Fée."

At the same time, the sketches have arrived; they are those that, since the last sending composed of 589 sketches, have been done by the second draftsman and the one staying in Lima, following the assistant botanist, named by Order of His Majesty to continue and advance the commission and to satisfy doubts and answer the questions that may be made from the Court during the publication of the Flora Peruana.

I have also brought 24 crates of live plants of which, although some have died from the cold at Cape Horn, changes in temperature, insects, and other causes 
incident to such a long trip by sea, many have arrived, as V. Exc. will see by the enclosed list.

For my part I am bringing two volumes in folio and one in marquilla paper of botanical observations in which are contained two thousand descriptions, most of which are of new genera and species, and the rest, although very few, of species already mentioned by other botanical authors, their descriptions corrected and amplified as far as possible.

To the Excmo. Señor Viceroy of Peru I delivered a package with the 3rd part of the duplicate of my botanical observations, which I delivered sealed so that from that office it could be sent by the "Jason" to V. E. The assistant botanist has been left to copy the rest of them and with the assurance that, as soon as they are finished, he will transmit them to V. E. through another office, with the instruction that the duplicate and the triplicate be sent by different mail boats on account of possible risks.

God our Lord protect the life and health of V. Exca. for many years. Cádiz, September 13, 1788 .

I kiss the hand of V. Exca., your mast obedient servant.-Hipólito Ruiz. Excmo. Señor Don Antonio Porlier.

In the margin it is written.-Acknowledge receipt, and return to me so that I may inform His Majesty with the next despatch.

\section{Excmo. Señor:}

The natural desire to embellish my Flora Peruana $y$ Chilense, which in spite of fires, shipwrecks, and other inevitable accidents I have been able to compose, by dint of vigilance and application, with 2000 plants systematically described in their native places, with notes on their virtues and the uses of many of them, and the particular qualities of others, impels me to select meritorious persons to whom I should dedicate the new genera that are contained in it, so that at last, as the fruit of my pains and in honor of the Royal Botanical Expedition to Peru, it is indispensable that I should attend affectionately to my desire, trying to ennoble it with the names of men of learning and truly meritorious and illustrious protectors such as the name of V. Exca., who strives with so much zeal for the advancement and protection of this and other important sciences, without any other motive than public benefit and the good of the Crown. For this reason I have taken the liberty of dedicating to V. Exca. a new genus of the four that have arrived in the 23 crates of live plants, giving it the name of Porlieria precox; its description I am sending to V. Exca. so that by it you can be informed of its qualities, character, and substance.

On my arrival at Madrid, I shall try to get the duplicate sketch of the Porlieria and I shall have the honor of presenting it to V. Exca. but, until I succeed in this, I await your esteemed orders.

God our Lord protect the life and health of V. Exca. for many years. Cádiz, September 13,1788 .

I kiss the hand of V. Exca., your most humble and obedient servant.

Hipólito Ruiz.

Excmo. Señor Don Antonio Porlier. 
List AND NAMES OF THE PLANTS TRANSPORTED FROM LIMA IN 24 POTS PLACED IN 6 HEATED CASES OR BOXES, SHIPPED ON THE VESSEL "SAN CRISTOBAL" OTHERWISE KNOWN AS "El DRAGON"

Achras mammosa ............ 1

Achras mammosa, varia semina. . 0

Alliodora, Genus novum....... 3

Anona muricata........... 5

Anona squamosa, semina duo... 0

Amaryllis miniata ......... . 4C

Berberis lutea ............ 1

Bignonia scandens........... 1

Carica Papaya............ 3

Cassia bipinnata ............ 1

Cassia viminea.............. 1

Cassine peragua?...........4 4

Cedrela odorata............. 1

Celtis spinosa.............. 1

Crescentia Cujcte........... 1E

Cyrilla dependens........... 1

Clusia rotundicapsula........7

Bignonia coerulea............ 3

Ferraria Lague............. 6C

Genus novum ex Polygamos Ara-

liz addine ............ 1

Genus novum ex Dioecis.... . . . 3

Hibiscus rosa sinensis ......... 2

Duhamelia latifolia, Gen. novum. 1

Palmacea ............... 1

Pinus Chilensis............. 1

Fagara Pterota.............. 1

Laurus crassifolia........... 2

Laurus Persea ............. 1

Laurus ex Cuchero. . . . . . . . . . 4

Paullinia magnicapsula....... 5

Pancratium maritimum........ 1C

Pancratium variegatum........ 2C

Platanus Otahetianus........... 1

Plumieriae, quator Species..... 2E

Porlieria precox, Genus novum... 1

Psidium purpureum.......... 3

Pteris arborea............. 1

Poinciana bijugata........... 4 lucumo............... 0

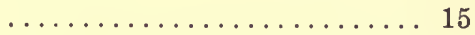

arbol del Ajo............ 1

huanabano.

chirimoyo .............. 1

lacre de montaña ........... 14

ccarhuas caja o palo amarillo

espinoso.............. 1D

...................... 0

papayo................ 2

cañafistola de Puzuzo........ 1D

..................... 0

pigna $\ldots \ldots \ldots \ldots \ldots \ldots \ldots .2$

cedro .................. 1

atpuallin $\ldots \ldots \ldots \ldots \ldots \ldots, 0$

tutumo ............... 0

pumachilca............. 0

arbol del incienso del Perú..... 0

yaravisco................ 1

lagues $\ldots \ldots \ldots \ldots \ldots \ldots \ldots 6$

palo santo.............. 2

rosa de China............. 0

lucuma de monte.......... 1

sia-sia.

pino de Chile............. 1

arbol del culantro.......... 1

...................... 1

palto o aguacate.......... 1

laurel de las montañas de $\mathrm{Cu}$ chero................ 2

lucumas de monte........ 5

coronas de R E I........... 1

claxinillos ............... 2

arbol de las mantas de Otageti... 1

suche amarillo, blanco, encar-

nado, and rosado........ 0

furucasa and guayacan....... 1

coca-coca............... 2

cucusa............... 0

$\operatorname{tara} \ldots \ldots \ldots \ldots \ldots \ldots \ldots$ 
Planta ex Valdivia......... 2

Macrocnemum carinatum...... 1

Mimosa punicea............ 1

Mimosa Inga ........... 1

Malpighia nitida.........5

Spondias Mombin........... 1

Toluifera resinifera ......... 9

$102^{*}$ orejona............... 0

ccaratu ................ 1d

huaitarebozo............. 1

pacae o huabas........... 1

ciruelas de Fraile.......... 3

ciruelas agrias............ 0

quino-quino.............. 2

$71^{*}$

NOTE.-The first number signifies the number of plants from Lima, and the second the number on hand. The letter $C$ means bulb, and the letter $E$ means a cutting from a tree.

NoTE.-The letter $D$ indicates if the sprouts that the plant has (where the $D$ has been placed) can survive.

NOTE.-Besides the plants here listed there are two other small trees, but I do not know what they are; and, similarly there are three species of liliaceous plants, and some small trees that, although half dried, show that they might sprout after reaching a warm environment as in a hothouse.

So that from the 102 trees and live plants that left Lima, 31 have died, and only 71 survive, with two more small trees the names of which I do not know, together with the bulbs of the liliaceous plants and some small plants that are bearing at present.

* These totals, copied from the Spanish edition, p. 447, appear to be incorrect. 


\section{INDEX OF CHAPTERS RUIZ, TRAVELS IN PERU AND CHILE}

\section{CHAPTER I}

Organization of the expedition. Gómez Ortega consulted. Botanists and draftsmen. Addition of Dombey. From Madrid to Cádiz. Preparations for the voyage. Departure. Good voyage. Arrival at Callao . . . . .

\section{CHAPTER II}

Presentation to the viceroy. Visits by the literati. Survey of the environs of Lima. Surprise of the Indians. Botanical work. Extent and limits of the province of Cercado. Climate. Parishes. The stay in Carabaillo. The robber Uracán. Hacienda of Torreblanca. Work accomplished . . .

CHAPTER III

The town of Arnedo. Jurisdiction of the province. Limits and extension. Ports, coves, and small bays. Rivers. Animal and vegetable products. Climate. Fertility of the valleys. The huano. Silver mines. Grave mounds. Ancient monuments. Salt mines. Parishes of this province . . . . . .

CHAPTER IV

Miraflores and Surco. Picturesque landscapes. The ruins of Pachacamac. The Lurin river. Location of Lurin. Form of the houses. Administration. Entertainments and patrons. Production. Militia. Manner of fishing. Common fishes. Fevers and their remedies. Birds. Plants . . . . . .

CHAPTER V

Stay in Surco. Plants collected and their uses. First shipment of plants and drawings sent to Spain (1779). Shipment by Dombey . . . . . . .

\section{CHAPTER VI}

Journey to Tarma. Incidents of the journey. Yauliaco. Pucará. Dangerous bridges. The encañada of San Mateo. The province of Huarocherí Fauna of the punas and lagoons. Flora. The parishes.

\section{CHAPTER VII}

Stay in Tarma. Plants found in this province and their medicinal value. Landscapes. The convent of Ocopa . . . . . . . . . . . . . . .

\section{CHAPTER VIII}

Climate. Seasonal differences in the vegetation. Abundance of cattle. The Xauxa river. Revolt of the Indians (1742). Plants. Towns and annexes. Excursions of the naturalists. Hardships and misfortunes. Journey to Huánuco. Details of the landscape. Dyeing process. The town of Reyes. Its products. Origin of the Ucayali, Huallaga, and Marañon. The town of Pasco. Its mines. Caxamarquilla . . . . . . . . . . .

From Huánuco to Acomayo. Fatiguing march. Appearance of the soil. Accident to a mule. Description of plants. Departure from Acomayo. The landscape. Rosapata. Difficulties on the march . . . . . . . . . . . . 


\section{CHAPTER X}

Extent of Cuchero. Pueblo Nuevo. The river Huánuco and its tributaries. Pampahermosa. Commerce of the Indians of Langostan. The Inca. Blowguns. Manner of hunting with them. Products of the mountains of Cuchero. Climate. Its effects and the apparel of the peons. Fauna of the district of Cuchero. Flora. Sufferings and want. Before the Chuncho Indians. Departure from Cuchero. Plants described . . . . . . . .

CHAPTER XI

Location of Chinchao. Inhabitants. The clergy. Climate and temperature. Lack of pastures and cattle. Agricultural products. Fauna. Plants gathered . . . . . . . . . . . . . . .

\section{CHAPTER XII}

Departure of Gálvez, Brunete, and Ruiz. Finding of cinchona trees. Tiresome march. Plants gathered. Stramonium and its uses. Case of intoxication. The maguey and its many uses . . . . . . . . . . . . .

\section{CHAPTER XIII}

Departure from Huánuco. The picturesque ravine of Huánuco. Loss of Gálvez' mule. Arrival at Chavinillo. The corregidor Dn. Ignacio de Ulloa. Cahuac, Ovas, and Chupán. Vegetation. Woolen works

\section{CHAPTER XIV}

Boundaries and extent of this province. The river that crosses it is the Marañón, according to $\mathrm{La}$ Condamine and other geographers. The Patay Rondos, Tazo, and Huánuco rivers. Fertility of the soil. Abundance of cattle. The trade in wool. Discovery of silver in the desert of Huayanca. Discovery of mercury and silver in the hill of Chonta and district of Ayras. Placer gold in Chavín. Thermal springs and ancient monuments. Aetites. Parishes. Quivilla and the bridge. Inhabitants of this province and their dress. Drunkenness and its consequences. Love of dancing . . . . . .

\section{CHAPTER XV}

Misfortune of a muleteer. Incidents of the trip. Work of the botanists during the year 1780-81. Plants gathered and their uses . . . . . . . .

\section{CHAPTER XVI}

Dangers of the road. The advice of a traveler. Arrival at Huariaca. Plants of this region. Sickness of Ruiz and Pavón . . . . . . . . . . . .

CHAPTER XVII

Limits of the province of Canta. Products. Rivers. Lakes. Sicknesses. Plants of this region. Population . . . . . . . . . . .

\section{CHAPTER XVIII}

The hacienda of Torreblanca and Dn. Toribio Bravo. Botanizing and plants gathered. Trip to Huaura and plants studied. Tutumos, huanábanos. Uses and common names . . . . . . . . . . . . . . 100

\section{CHAPTER XIX}

The hacienda El Ingenio. Its sugar production. Quipico. Plants described. The farm of Andahuasi. Its good management . . . . . . . . . 103 


\section{CHAPTER XX}

Location of Sayan. Its houses and ranches. Inhabitants. Barrenness of the soil . . . . . . . . . . . . . . . . . . 105

\section{CHAPTER XXI}

Plants gathered. Uprising of Tupac-Amaro 107

\section{CHAPTER XXII}

Departure from Callao. Navigation. Phosphorescence of the sea. Strong wind and heavy sea. Misfortune on board 109

\section{CHAPTER XXIII}

Arrival at Talcahuano. Hospitality of the maestre de campo. Arrival at Concepción

\section{CHAPTER XXIV}

Crossing of the Biobio. The rafts. The territory. Abundance of horse farms. The guazos. Plants and their applications. The cinnamon tree. Superstitions of the Indians. Reception of Mre. de Campo Villagra. Murders committed by the Indians. Defeat of the mre. de campo. The Araguete river. The plain. Arboreal vegetation. The Carampangue. Piedras de cruz. Salutations. Speeches. Instructions. Enthusiasm of an old man. Plants of the field near Arauco. Farewell to the Indians. Preparations for the parliaments. Revolt of 1766 . Quarrelsome character of the Indians. Cremation of dead from the plague. Pehuenches and Huiliches . . . . 113

\section{CHAPTER XXV}

Orders regarding the plaza of Corcura. Fishing on horseback in the sea. Botanizing in the vicinity of Concepción. Plants sketched and described . . . 126

\section{CHAPTER XXVI}

Woods and fields of Culenco. Cattle and fruit trees. Vineyards. A special kind of olives. Origin of the name Culenco . . . . . . . . . . . . . . 129

\section{CHAPTER XXVII}

Plants gathered. Medicinal and industrial uses

\section{CHAPTER XXVIII}

Boundaries of the province of Puchacay. Botanizing at Huilguelemu. The Chilean pine. Plants of Rere. Medicinal and industrial uses. The pizguin. More plants. . . . . . . . . . . . . . . . . . 136

\section{CHAPTER XXIX}

Boundaries of the province of Rere. Its climate. Salting industry. Gold washers. Round stones. Birds of the province . . . . . . . . 138

\section{CHAPTER XXX}

Excursions in the neighborhood of Concepción. Plants gathered. The shade of the lithre. The maythen. Uses of the merulanguen and other vegetables. Collection of woods. The Chilean pine and its great utility . . . 139 


\section{CHAPTER XXXI}

Shape, limits, and parishes of the province of Concepción. The bay of Quiriquina. Talcahuano and its castle. Valdivia and its origin. Earthquakes and inundations in 1730 and 1751. Description of Concepción. Its inhabitants. Convents. Birds. Mammals. "The amphibious horse." Fish. Crustacea. Mollusks. Echinoderms. Amphibia. Reptiles. Arachnids. Insects. Plants

\section{CHAPTER XXXII}

Gold. Metals. Lime. Gypsum. Coal. Clays. Minerals. Thermal waters. Lakes. Rivers. Ports. Products. Textile and other industries. Ulpu

\section{CHAPTER XXXIII}

From Concepción into Chile. Reception in Talca. Arrival in Santiago. Plants observed during the trip. Kindness of the authorities and nobles. Ruiz becomes ill. Survey of the mercury mine of Coquimbo by Dombey. Earthquakes and floods.

\section{CHAPTER XXXIV}

Location. Buildings. Monasteries. Inhabitants. Garrison. Provinces. Mines. Strange event

\section{CHAPTER XXXV}

Itinerary. Plants gathered. Arrival at Callao. Stay in Lima. Material shipped in the vessel "San Pedro de Alcántara" . . . . . . . . . . . . 165

\section{CHAPTER XXXVI}

Departure from Lima. Plants gathered in Yaso. Tiresome march. Illness of Ruiz

\section{CHAPTER XXXVII}

Departure from Huánuco. Itinerary, and plants found. Hardships. Arrival in Puzuzo. Work done by the botanists

\section{CHAPTER XXXVIII}

Location of Puzuzo. Lack of pastures. The river. Particles of gold. Harshness of the water and its effects. Inhabitants. Vegetable products. Commerce. Climate. Fauna. Bridges. Harmful insects. Plants . . . . 17

\section{CHAPTER XXXIX}

Itinerary. Report and seeds sent to the Ministry of the Indies. Addition of Tafalla and Pulgar to the expedition. Illness of Ruiz . . . . . . . . . . 184

\section{CHAPTER XL}

Tafalla's misfortune. Arrival at Macora. Excursions. Very abundant collections. Hardships. Comforts of the draftsmen. Excursion of the peons. Cholón. Revolt of the draftsmen. The catastrophy at Macora. Flight of the mayordomo. Great losses. Praiseworthy conduct of some hacenderos. Departure from Macora with great hardships. Return to Huánuco. Intendente Gálvez. Meeting with him, and proposal of the 
botanists. The draftsmen reprimanded by Gálvez. Illness of Ruiz. Ruiz asks permission to return to Spain. Order of the Ministry of the Indies for the discharge of the new assistants, and objections of Ruiz. Shipment of living plants

\section{CHAPTER XLI}

Shipwreck of the vessel "San Pedro de Alcántara." Plants gathered after the fire at Macora. Their uses. Curious observations . . . . . . . . . . 19

\section{CHAPTER XLII}

Stops on the way. Arrival at Muña. Excursions. Description of Muña. Occupation of the natives. Products of the country. Population. Peaceful character of the Indians. Clothing. Flora . . . . . . . . . . . . . . 208

\section{CHAPTER XLIII}

Pavón's misfortune. Itinerary. Plants, barks, and seeds. A large shipment prepared for Spain. Ruiz studies the Malvaceae of Huánuco and refutes Cavanilles. Illness of Ruiz

\section{CHAPTER XLIV}

Illness and death of Brunete. Details. Intervention of Ruiz . . . . 217

CHAPTER XLV

Chulguillo. Vegetation of hills and ravines. Preparations for the work .

\section{CHAPTER XLVI}

Location, climate, pastures, fields. Population. Building construction. Fishing. Minerals. Birds. Waters. Healthfulness of the place . . . . . .

\section{CHAPTER XLVII}

Tiresome march. Misfortunes. Narrowness of Chacahuasí. Torrential rains. Earthquakes. Landslides. Location of Chacahuasí. Dangerous environs. The Pilco river and fishing in it. Birds. Butterflies. The heat. Fogs. Unhealthfulness. Parrots and monkeys. The bridge over the Rio Grande. Hardships of the cascarilleros. Procedure in crossing the rivers. Skin affections caused by the humidity and heat . . . . . . . . . .

\section{CHAPTER XLVIII}

Miserable condition of the cascarilleros. Abuses and outrages. Improper felling of trees. Imperfect methods of packing. Order for our return to Spain. Plants gathered in Pillao and Chacahuasí. Their uses . . . . . . .

\section{CHAPTER XLIX}

Fatigue of the mules. Fury of a mule. Illness of Tafalla. Painful march. Deadly gases. Arrival and work at Huánuco. The year 1788 . . . . . .

\section{CHAPTER L}

Itinerary. Plants gathered and described. The Limonia trifoliata and Verbena citriodora. The Cerbera salicifolia. Uses of its seeds. Packing the collections. Good offices of Father González Laguna. Settlement of accounts. Preparations for embarking. Living plants for Madrid. Reversal of the edict. Sailing in the "Dragon." Arrival in Spain . . . . . . . . 237 


\section{INDEX OF CHAPTERS}

\section{EPILOGUE}

I.

Words of Lagasca. Indifference of the government to the encouragement of the natural sciences. The travels of Ruiz and Pavón in Chile and Peru. The Quinología of Dn. Hipólito Ruiz and the problem of the quinas. Description of this work and its success. Appointment of Dn. Juan Tafalla and Dn. Juan Augustín Manzanilla for the continuation of the campaign of Ruiz and his companions in Chile and Peru. Tafalla discovers new species of quina trees. Attack of Zea on the doctrines of Ruiz and the latter's answer. The

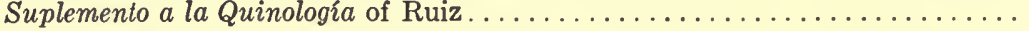

II.

The Prodomo de la Flora Peruviana y Chilense. Draftsmen and engravers. Contents. Genera dedicated to botanists and patrons of botany. Discussions between Cavanilles and the authors of the Prodromo. Criticism of Antonio Lorenzo Jussieu of this work and reply of Ruiz. The Systema Vegetabilium Florae Peruvianae et Chilensis of Ruiz and Pavón.............

III.

Publication of the first volume of the Flora Peruviana et Chilensis (1798). Inexplicable delay. Diligence of Dn. Antonio Porcel. Support of ministers Llaguno and Jovellanos. The preface to the work. Classification adopted. Character of the descriptions. New Genera. Species described. Draftsmen. Engravers. Appearance of the second volume of this work (1799). Contents.

IV.

The third volume of this work comes off the press (1802). Its contents and illustrations. New genera published by the authors. Personages to whom some genera included in the third volume were dedicated. Material sent from Peru by Dn. Juan Tafalla. Plans of Ruiz and Pavón for the Suplemento de la Flora. The preface to this volume and the letter from Ruiz to Jussieu.....

v.

Preparation of volume IV. Approximate date of its completion. New genera described in it. New species. Illustrations. Genera and species published by the authors. Genera corrected in this volume. Suppressed genus. Sending of collections by Tafalla. Ruiz and Pavón criticize the reforms introduced by several botanists in the classification of Linnaeus.................

VI

The authors of the Flora Peruviana et Chilensis continue their work. Content of the manuscript and unpublished volumes of this work: v, VI, VII, VIII, IX, X, and XI. Idem of volumes I, II, III, IV, and V of the Suplemento. The plates. The botanical work of Ruiz and Pavón..................

VII.

Time consumed in the preparation of this Flora. Those who worked on it until 1816. From 1816 until 1832. Workshops of Floras in Madrid at the time. Royal orders commanding that they be directed by the botanist. Those of the Floras of Nueva Espana and Nueva Granada also assigned to him. The Flora of Peru stays independent. Dn. Demetrio Rodriguez is assigned to this. Sums expended on the Floras of Nueva Granada and of Peru. Scientific value of the latter. Comparison with former botanical works of Spanish authors. Influence of Linnaeus in Spain. Glorious generation of botanists here during the eighteenth century. Works and drawings. Excellence of the Flora Peruana above the others mentioned. Deplorable neglect with respect to this. The voice of a deputy. What has been published of the Flora Peruana. What remains of the genera and species published by Ruiz and Pavón. . 
VIII.

Other works of Dn. Hipólito Ruiz. Other works of Dn. José Pavón

IX

José Dombey. His scientific competence. Arrival in Spain. Information about means to combat the plague of ants. His appointment as a member of the expedition. Leaves for Peru. Commissions confided to him. His botanical campaigns. His return to Spain (1784). His collections. Inaccuracy of Larousse.

$\mathrm{x}$

The journals and the Viaje of Ruiz. Date at which it was terminated. Information given in the Prodromo and in the Quinologia. The doctoral thesis of Dn. Tomás Pascual. The extract of the Viaje by Jiménez de la Espada. Our investigations. Persons who advised us. Praiseworthy conduct of Dona Isabel Pascual. Our additions. Acknowledgments to those who have helped us .

XI.

Contents of the Viaje. Geographical part. Botanical part. Mineralogical part. Zoological part. Curious entomological detail. Historical episodes.

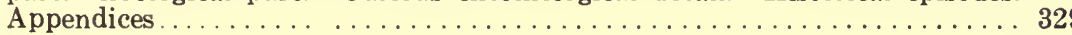




\section{INDEX OF APPENDICES}

I. Appointment of Dn. Hipólito Ruiz . . . . . . . . . . . . . 242

II. Appointment of Dombey . . . . . . . . . . . . . . . . . . 243

III. Appointment of Brunete. . . . . . . . . . . . . . . . . . 244

IV. Archive of Alcalá. L. 2,525, transferred to the Museum of Natural Sciences. Years 1776 to $1785 \ldots . . . . . . . .245$

V. Supplement that Dn. Casimiro Ortega thinks should be added to the instructions ..................... 250

VI. Instructions that are to be observed by the draftsmen who are going to Peru by Order of $\mathrm{H}$. M. to serve in the exercise of their profession in the Botanical Expedition . . . . . . . . . . . . 250

VII . . . . . . . . . . . . . . . . . . 252

VIII . . . . . . . . . . . . . . . . 255

IX. . . . . . . . . . . . . . . 256

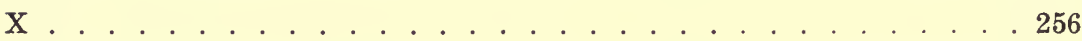

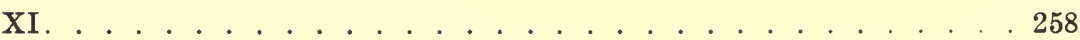

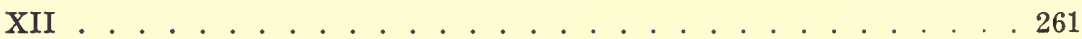

XIII . . . . . . . . . . . . . . . . . 263

$\mathrm{XIV} \ldots \ldots \ldots \ldots \ldots \ldots \ldots \ldots \ldots$

$\mathrm{XV} \ldots \ldots \ldots \ldots \ldots \ldots \ldots$

$\mathrm{XVI} \ldots \ldots \ldots \ldots \ldots \ldots \ldots \ldots \ldots \ldots \ldots \ldots$

XVII . . . . . . . . . . . . . . . . . 267

XVIII . . . . . . . . . . . . . . . . . . 268

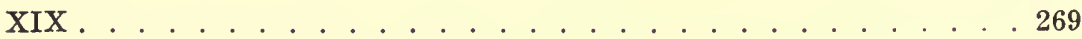

XX. List of seeds, fruit, bulbs, roots, and several other things sent by Ruiz, giving the Spanish and Indian names . . . . . . . . . 272

XXI. List of the live plants sent in the heated cases and crates . . . . . 274

XXII. . . . . . . . . . . . . . . . . 278

XXIII. List of the contents of the seven boxes sent from Peru by Mr.

Dombey for France . . . . . . . . . . . . . . . . . 280

XXIV . . . . . . . . . . . . . . . 280

XXV. . . . . . . . . . . . . . . . . . . . . 282

XXVI. List of the small live trees that I am sending in the seven heated cases for the Royal Botanical Garden of Madrid. Marks on the pots . . 284

XXVII. . . . . . . . . . . . . . . . 287 


\section{INDEX OF BOTANICAL NAMES}

Abatia

Galvetana 230

rugosa 230

Yoriturp 230

Acaena

amaerinifolia 128

amentifolia 91

globosa 230

lappacea 44

ovalifolia 44

pinnatifida 128

trifida 128

Acalypha

betuloides 181

glandulosa 212

granulata 212

indica 31

polygama 181

pubescens 78

purpurea 78

Achillea

lutea 200

urens 200

Achras

Caimito 203

mammosa 30

tetrandra 177

Achyranthes

geniculata 80

mucronata 45

obovata 91

papposa 179

purpureo-violacea 238

rigida 91

secunda 204

Acladodea pinnata 232, 233

Acosta

aculeata 80, 203

Acrostichum

acutum 92

calomelanos 44

Cuacsaro 44, 230, 231

lineare 44

Marantae 44

nitidum 44

obovatum 44

palmatum 44

revolutum 44

squamatum 44

squamato-tomentosum 44

sulphureum 44

Actinophyllum

acuminatum 212

angulatum 212

conicum 232

pedicellatum 212

pentandrum 81
Acunna

oblonga 46, 207

lanceolata 231

Adiantum

brachiatum 92

capillus-veneris 44

reniforme 213

Aechmea trapeziforme 92 paniculata 177

Aextoxicon

Agave punctatum 130

Agenium pimpinelaefolia 82

Ageratum conyzoides 31 secundum 78,80 trinerve 80

Alchemilla pinnata 45 rotundifolia 230

Aldea tripartita 230

Allionia

pinnata 133 incarnata 82

Allium angulosum 100 triquetrum 100

Alstroemeria 134 capitata 46 coccinea 46 crocea 46

discolor 136

fimbriata 177

Ligtu 133, 134, 137

peregrina 27, 28, 102

punicea 212

revoluta 136

Salsilla 132

sanguinea 136

secunda 212

spiralis 46

tomentosa 212, 230

tricolor 136

trifida 46

Althaea

cornuta 81

Alzatea verticillata 204

Amaranthus retroflexus $\mathbf{1 0 0}$ spinosus $\mathbf{1 0 0}$

Amaryllis aurea 28, formossisima 132 miniata 80 
Ambrosia 98

Marco 169

maritima 31

Amomum

racemosum 198

alba 45

Andromeda aff. alata bracteata 231

cordifolia 212

glauca 231

mellifera 231

punctata 212

purpurea 46

Anemone

digitata 45,131

Anethum pubescens 45 parvum 30

Anguloa uniflora 212

Anguria

trifoliata 178

trilobata 178

Anona

lutea 203

microcarpa 204

muricata 101

reticulata 202

squamosa 102

Anthemis

pallescens 231

striata 231

Anthericum aff. falcatum 230

Anthodon decussatum 198

Antirrhinum

Apium avenium 230

Aralia graveolens 140

digitata 48, 211

ferruginea 204

globosa 179

lanceolata 211

aff. trinervis 175

Araucaria 141

Arbutus

multiflora 46

parvifolia 230

racemosa 140

Aristolochia

caudata 181

glandulosa 127

vaginans 165

Aristotelea glandulosa 127

Artemisia

hirsuta 47

officinalis 31

Arum

aliaceum 205

auritum 176 lanceolatum 81,176

lineatum 176

parviflorum 176

rosaceum 81

tripartitum 176

tuberosum 212

volubile 176

Asclepias 27

cordata 45

curassavica 202

hastata 27

reticulata 211

Asplenium

acutifolium 44

caudatum 44

cultrifolium 44

falcato-lineare 44

fissum 44

lineatum 44

multifidum 44

obovatum 44

praemorsum 44

Aster salicifolium 92

auricularis 47

crosum (erosus?) 80

foliaceus $\mathbf{4 7}$

lanuginosus 91, 126

lyratus 91

multifidus 137

pinnatus 47

repens 132

tomentosus 47

Astragalus

capitatus 44

dependens 134

Astronemia

linearis 46

Atragene

villosa 47

Atriplex

crystallina 101

Atropa

$$
\text { monoica } 48
$$

aspera 107

biflora 45

umbellata 27, 102

Axinaea

lanceolata 212

Azara purpurea 212

eliptica 131

lanceolata 131

obovata 131

Bacasia

corymbosa 212

Baitaria spinosa 47

acaulis 238

Banisteria auriculata 175

flabelliformis $\mathbf{1 7 5}$ 
Bantisa

\section{fulgens 91}

papilionia 175

rugosa 204
Bartsia
hirsuta 46
prostrata 46
Basella purpurea 46
diffusa 230 rubra 102

ivularis 100

Bauhinia aculeata 28, 91, rosea 91

Begonia 212, 220 ciliata 198,205 coccinea 212 cucullata 178 hirsuta 212 incarnata 212 lobata 78 monadelpha 212 obliqua 78 parviflora 212 purpurea 178 repens 178 rosea 212 utriculata 212

Berberis

lutea 211, 212, 236

mucronata 46 tortuosa 46

Besleria auriculata 81

\section{biflora 78}

diversicolor 81

Betula radicans 78,181

acuminata 176

alba 48, 51 nigra 230

Bidens 62 cuneifolia 28 cuneiformis 100 nasturcifolia 47,62 pinnato-multifida 47 Bignonia tripartita 31
alba 180
brachiata 180
clavata 180 coerulea 67,68
lanuginosa 180
muricata 180
pentagona 82
planisiliqua 180 stans 42
muricata 175
Orellana 78, 175
catenulata 176

Bixa

\section{Bletia}

ensiformis 176

Bocconia

$$
\text { frutescens } 198
$$

Boerhaavia scandens 102, 200

viscosa $100,101,200$

Bombax 72, 196, 227 aculeatum 178 microcarpon 178 polyandrum or Carolinea? 204, 205

Bowlesia trilobum 81

Briza lobata 231 palmata 101 media 43

Bromelia Ananas 179, 180

bicolor 128

incarnata 177 sphacelata 128

Browallia demissa L. 78, 230

Brunellia aculeata 212

Bryonia inermis 212

Bryum cordifolia 92 nitidum 44

Buddleia 40 diffusa 202 globosa 133 incana 42, 43, 230 occidentalis 100 sarmentosa 67 spicata 211

Caballeria dentata 213 dependens 213 ferruginea 91, 213 latifolia 213 pelucida 213 venossissima 231

Cacalia pubescens 81 punctata 201

Cacaulis serrata 44 grandiflora 45

Cactus 40, 220 cancelatus 167 echinatus 167 erinaceus 167 lanatus 167 parasiticus 178

Calamus squamatus 167 hamatus 179

Calceolaria 40, 98, 220 alba 137 angustiflora 238 
bicolor 91

crenata 238

cuneiformis 238

dentata 91, 126

heterophylla 210

inflexa 238

linearis 50,51

maculata 238

nutans 238

perfoliata 78

pinnata 91, 100

pulverulenta 238

rugosa 126

scabra 45

scrophylariaefolia 126

sessilis 126

tomentosa 45

trifida 238

umbellata 230

uniflora 45

verticillata 91

virgata 238

viscosa 91

Calla 80

acuminata 80

bracteata 176

canaliculata 205

nuda 176

pinnata 176

polystachia 80, 81

radicans 176

undulata 176

Callicarpa

cordifolia 211

Callisia globiflora 204

repens 91

Calyplectus acuminatus 178

Calyptranthes paniculata 178

Calyxhymenia

expansa 102

ovata 102

viscosa 67,200

Campanula

biflora 101

denticulata 140

filiformis $\mathbf{1 3 0}$

Campomanesia

Canna palillos 202

indica 203

iridiffora 230

paniculata 203

Capsicum

frutescens L. 176

pubescens 176

Cardiospermum biternatum 91

Carica 80

canescens 237, 238

glandulosa 213 monoica 206

septemlobata 178

Carludovica

acuminata 179

angustifolia 206

latifolia 206

palmata 179

trigona 213

Carthamus

ciliatus 137

Cassia 201

hirsuta 42

mimosoides 28

procera 177

procumbens 42

reflexa 128

setacea 42

tenuissima 31

Tora 28, 101

undecimpiga 42

viminea 203

Castiglionia

lobata 31

Caucalis grandiflora 45

Cavanillesia umbellata 181

Ceanothus granulosus 198

Cecropia 73

alba 213

aquifera 78

aspera 205

canescens 176

coriacea 198

digitata 205

tubulosa 213

Cedrela

inodora 204

odorata $30,182,183$

Celastrus

corymbosus 211

dependens 135

lutescens 211

triflorus 45

Celosia

conferta 91

Celsia 40

lanceolata 42

linearis 67,230

ovata 230

Celtis 173

aspera 213

biflora 178, 179

scabra 179

spinosa 178, 179, 232

Centaurea

napifolia 102

Cerbera

salicifolia 239

Cerdana

alliodora $\mathbf{1 7 5}$ 
Cervantesia tomentosa 45

Cestrum auriculatum 237

lanuginosum 179 longiflorum 204 pulverulatum 78 racemosum 204 rigidum 169,211 undulatum 68, 199 virgatum 126

Chaetanthera ciliata 137 serrata 137

Chaetocrater pubescens 198 serrata 198

Chenopodium album 100 amarum 127 dulce 127 multifidum 127 tuberosum 46

Chiococca ovata 204

Chondodendron tomentosum 233

Cinchona angustifolia 211 grandiflora 175 hirsuta 230 magnifolia 78 nitida 77 officinalis 82,215 ovata 214 purpurea 70, 82, 224 rosea 175

Cineraria

fasciculata 132 lanceolata 231 perfoliata 82

Cissampelos 182 cordata 78 peitata 78

Cissus villosa 231

compressicaulis $\mathbf{1 0 2}, 232$

lobata 207

obliqua 48

striata 133

Citrosma

echinata 199

muricata 212

ovalis 212

pyriformis 78,212

Clarisia tomentosa 212

Clavija

biflora 176 racemosa 176

lanceolata 204 macrocarpa 211 spathulata 211
Clematis

Vitalba? 167

Cleome

aculeata 181

coccinea 204

concava 207

glandulosa 44

longisiliqua 181

triphylla 31

Clinopodium bisserratum 81 procumbens 81

Clitoria? pubescens 175

Clusia aff. decussata 232 macrocarpa 213 radicans $\mathbf{1 7 8}$ rosea 78,231 rotundicapsula 213 thurifera $\mathbf{4 8}$ triflora 198

Coccoloba trioecia 232

carinata 82 hastata 131 nidida 46 volubilis 46

Coffea occidentalis 78, 203 subsessilis 207 tetrandra 204

Columella corymbosa 230

Columellia ovalis 46

Commelina nervosa 78

Condalia lanceolata 80 obovata 80 sessilis 78

Convolvulus 206 cymosus 179 quinquefolius 78,204 secundus 27 sepium 27 stipulatus 27

Corchorus

Cordia siliquosus 31 rotundifolia 27,102

Coreopsis Bidens 127

Coriaria trifida 68,207 nervosa 127

Cornidia pinnata 48

Cosmos laciniata 47 
Costus

argenteus 198

laevis 232

ruber 81

scaber 198

Cotyledon lyratum 126

Coussapoa latifolia 78 obovata 78, 206 radicans 176,179 triloba 206

Crescentia

Crinum Cujete 28, 101

luteum 177 sagittatum 45

Crotalaria incana 28, 100 laburnifolia 102 retusa 80 trigona 205

Croton acutifolium 232

ciliatum 201 gummiferum 181, 182 hirsutum 181 nudus 82 pulverulentum 48 striatum 48 trinerve 131 umbellatum 181

Cucumis purpureus 205 quinquelobatus 205

Cucurbita fragrans 205

Cuellaria Lagenaria 133

cineraria 230

ferruginea 91, 230

linearis 230

obovata 78

revoluta 230

Cuphea

ciliata 67

Cuscuta cordata 46,230

dorata 231

Cymbanthes punctata 119, 132

Cynanchum acuminatum 232 glandulosum 45 lanceolatum 204 lanuginosum 203 macrocarpum 179 minimum 45 pentagonum 179 racemosum 30

Cynoglossum decurrens 131 pauciflorum 131 pilosum 30

revolutum 46

Cynomorium fungiforme 198 ramosum 181

Cyperus striatus 46

Cypripedium Cytisus grandiflorum 47, 78, 212

canescens 231 purpureus 47,78

Dalea? L. 43

Dalechampia rosea 169

Datura sanguinea 45 Stramonium 82

Decostea scandens 130

Desfontainia spinosa 45

Dianthera appendiculata 179

ciliata 179

hirsuta 202

mucronata 102 repens 27

Dichondra crenata 45 fragosa 45 multifida 45 reniformis 45 repens 45

Dillenia aff. rubra 230

Dioscorea 80 acuminata 91 filiformis 131 hastata 133 triloba 81

Dodartia fragilis 107

Dodonaea viscosa 46

Dolichos Lablab 28

Soja? 101 suberectus 31 umbellatus 178 uncinatus 28

Dombeya 141

Dorstenia Contrayerva 203 ovalis 203

Dracocephalum ? odoratum 80

Drimys acris 114,115

Duranta 40 plumosa 46 tomentosa 46 
Eccremocarpus viridis 211

Eclipta

$$
\text { alba } 100
$$

Echites acuminata 78, 204

glandulosa 211

laxa 233

spiralis 81

subsagittata 78

Elaterium

bifidum 101

glandulosum 207

pedatum 101

Elephantopus

capitatae 198, 232

spicatus 181

tuberosus 205

Embothrium

dentatum 130

emarginatum 46, 210

lanceolatum 130

monospermum 210, 211

obliquum 130

Encelia pinnatum 210

$$
\text { obliqua } 101
$$

Ephedra

distachya L. 48, 206

Epidendrum

acuminatum 47

biflorum 47

cordatum 205

coronatum 178

corymbosum 212

cristatum 178

croceum 47

emarginatum 47

equitans 178

ferrugineum 205

lineare 47

maculatum 47

nutans 212

paniculatum 212

parviflorum 212

scabrum 231

triflorum 47

viride 178

Erigeron volubile 47

canadense 140

philadephicum 31

Erinus scabrum 140

Eriocaulon prostratus 178

parvum 230 vaginans 230

Eryngium

ciliatum 137

coeruleum 91

trifidum 137

tripodum 137
Erysimum tuberosum 131

Erythrina articulata 178, 205

Corallodendron 28

glandulosa 178, 181

incarnata 78

Villcatauri 178

volubilis 178

Erythroxylon

Coca 80

patens 232

stipulatum 180

Escobedia

scabra 81

tinctorea 198

Eugenia procera 212

Eupatorium 62

angulatum 47

aromaticum 42

balsamicum 81

canescens 205

carinatum 80

coriaceum 80

hirtum 78

Huaramachia $\mathbf{4 7}$

obovatum 80

sagittatum 92

salvifolium 165

sambucinum 205

scabrum 91

scandens 28

stridens 231

subsessile 47

trinerve 47

urens 128

Euphorbia 40

Chamaesyce 31

erosa 180

hirta 31

hypericifolia 31

Peplis? 207

portulacoides 128

striata 100

tricuspidata 128

tuberosa 98, 238

Fabiana

Fagara

imbricata 137

Fagus

coriandriodora 179, 232

oblongifolia 140

Pellin 131

Fernandezia

contorta 212

denticulata 231

ensiformis 212

graminifolia 231

haematodes 231

laxa 212

punctata 212 
Ferraria 40, 98

Ficus

Lagues 133

subulata 45

umbellata 45

acuminata 206

cordata 206

gemina 175

hirsuta 175

lineata 206

retusa 81,175

striata 78

Foveolaria

cordata 175

ferruginea 231

oblonga 231

ovata 231

Fragaria

chiloensis 148

Fragosa

corymbosa 211

spinosa 137

Fraxinus 98

Fuchsia 40

apetala 46

grandiflora 212

involucrata 212

mutifolia 80

pubescens 212

punicea 212

rosea 165

verticillata 46

violacea 128

Galega

hirsuta 178

Galinsoga

quadriradiata 100, 200

Galium

quinqueradiata 100, 200

ciliatum 45

corymbosum 45

croceum 45

hirsutum 232, 238

lappaceum 202

Galvezia mucronatum 45

Gardenia punctata 132

longiflora 175

spinosa 45

viscosa 211

Gardoquia

canescens 43

conferta 46

multiflora 137

striata 67

Gentiana 170

biflora 45

Conchalaguala 29

luteopurpurea 91

maculata 45

minutissima 91

quinquipartita 45

serrata 91

violacea 211,230

Geoffraea

spinosa 31

Geranium

filiforme 47

Gesneria moschatum 148

acinaciformis 81

frutescens 204

hirta 175

verticillata 175

violacea 175

viscosa 175

Geum

urbanum 46, 132

Gilibertia umbellata 212

Gimbernatia oblonga 182 obovata 204

Glycyrrhiza undulata 231

Gnaphalium odoratissimum trinerve 47

uniflorum 131

Godoya Vira-vira 47

oblonga 78

Gomara spathulata 78

racemosa 181

Gomortega nitida 127, 128

Gomphrena

Gongora purpurea 45

angulata 47

quinquenervis 47

uniflora 47

Gonzalagunia

dependens 80

Gossypium arboreum 308

Gualtheria hirsutum 308

acuminata 132

alba 46, 230

albo-hirsuta

cordifolia 46

hirsuta 46

Guarea rubra 230

abrupta 177

acuminata 204

ferruginea 177

nitida 232

purpurea 177

tomentosa 179

Guatteria

dependens 204 
glauca 78

hirsuta

lutea 178

Gumillea

auriculata 211

Gunnera

thyrsiflora 131, 132

Hamelia

secunda 175

Hedyotis 170

conferta 43

filiformis 233

juniperifolia 43

setosa 43

thymifolia 43

Hedysarum

asperum 28

mimosioideum 167

pilosum 205

plumosum 133

prostratum 101

pubescens 47

virgatum 205

Heisteria coccinea L. 177

Helianthus 151

glutinosus 47

lanceolatus 47

pubescens 107

resinosus 165

Heliconia

angustifolia 81

angustiflora 232

discolor 198

latifolia 81

tricolor 231

Heliocarpus

dioica 227

glandulosa 78

serratus 178

Heliotropium

incanum 67

lanceolatum 67

oppositifolium 211

parvicalycum 67

pilosum 30

synzystachyum 100

Hemionitis

falcata 92

rigida 44

Herreria stellata 133

Heteranthera reniformis 27

Hibiscus esculentus L. 107 rosa sinensis 107

Hieracium triflorum 47

Hippocratea viridis 198
Hippotis triflora 78

Hirtella

Hopea

racemosa 203

tinctoria 78

Horminum ? salviflorum 131

triangulare 91

Huertea glandulosa 211

Humboldtia

acutiflora 205

aspera 47

contorta 212

cordata 212

lanceolata 233

oblonga 212

parviflora 212

polystachia 205

revoluta 212

spiralis 47

Hydrocotyle

alchimilaefolia, alchemillaefolia 140

asiatica 46

globosa 211

tenuis 211

umbellata 27

vulgaris 27

Hydrolea

urens 167

Hypericum 62

angulare 28

corymbosum 230

subulatum 47, 230

Hypochaeris

laciniata 133

Hyssopus?

punctata 140

Illecebrum

Achyrantha 30

lanatum 45

Indigofera

Anil 205

argentea 82

Ipomoea 205,206

acuminata 30

angulata 179

glandulifera 205, 206

hirsuta 107

subrotundifolia 30

subtriloba $\mathbf{4 5}$

villosa 179

Iriartea

deltoidea 179

Isquierdia

aggregata 206

Jarava

Ichu 45

Jatropha

aphrodisiaca 212 
Manihot 72 urens 178

Jaunulloa parasitica 182

Juglans 62 nigra 31,62

Juniperus aff. 231

Jussiaea

Justicia peruviana 100

incana 44

longistaminea 232

mucronata 203

punctata 78

racemosa 210

spicata 180

tenuifolia 78

Kagenackia

lanceolata 238

oblonga 134

Krameria

triandra 43, 200

\section{Lantana}

aculeata 78

involucrata 47

purpurea 67

salvifolia 28

Lardizabala biternata 130, 139

Larrea triternata 139

Lathyrus glauca 30

albus 133

incanus 82

lutescens 133

Laugeria

hirsuta 78

stipulata 211

Laurus 196

alba 204

aurantiana 78

coerulea 203

crassifolia 203

foetida 204

fragrans 177

obovata 204

Persea 29

Peumo 114

pubescens 177

purpurea 177

revoluta 139

rubra 134

subpubescens 204

Lepidum foetidum 67

Lettsomia

lanata 199

tomentosa 198

Lichen cinereo-viridis 44 multifidus 44 oculatus 44

pallido-viridis 44

pyxidatus 44

ruber 44

subulatus 44

Limodorum coriaceum 205 lineare 205

Limonia trifoliata 238, 239

Limosella

Linum subulata 42

Lisianthus 199 acutangulus 204

corymbosus 81

oblongus 204 ovalis 81,204 quadrangularis $7 \delta$ revolutus 211 viscosus 211

Lithospermum aggregatum 45 dichotomum 27 incanum 45 muricatum 132

Llagunoa nitida 212 triphylla 107

Loasa 40,98 laciniata 133 multifida 139 rosea 98 spiralis 46 tricolor 132

Lobelia

bicolor 47

biserrata 91 coccinea 178 decurrens 28 hirsuta 81,91 laciniata 178 purpurea $47,91,165$ purpureo-viridis 47 scabra 78 subpetiolata 91 tomentosa 47 volubilis 199

Lonchitis amomum 78 cultrifolium 78 racemosum 78 tyrsoideum $\mathbf{7 8}$

Loranthus 127 grandiflorus 212 luteus 46,231 pentandrus 46 puniceus 67 retroflexus 204 semicalyculatus $\mathbf{1 2 7}$ triflorus 199 verticillatus $\mathbf{1 2 7}$ 
Lotus

utricularius 133

Lupinus argenteus $\mathbf{4 3}$ rhombeus 133

Lycium aggregatum 102 falsum 27 obovatum 44 spathulatum 82 umbellatum 237

Lycopodium ciliatum 207 corymbosum 44 dichotomum 48 lanceolatum 44 nutans 92 peregrinum 92 prostratum 92 subulatum 44

Lygodysodea foetida 211

Macrocnemum 220 corymbosum $\mathbf{8 0}$ pubescens 78,204 venosum 80,204

Malpighia glandulosa 81 nitida 102, 202

Malva

aspera 67 coromandelina 31, 102 hispida 133

incana 91 peruviana 100 rotundifolia 28 sylvestris 28

Malvaceae 215, 236

Maranta capitata 78

Marcgravia calyptrata 199 monopetala 232 pentandra 211 pentapetala 232

Marchantia polymorpha 92

Margyricarpus subfructicosus 44

Martinezia ensiformis 179 ciliata 179 interrupta 179 lanceolata 206 linearis 179

Masdevallia uniflora 47

Matricaria tripartita 101

Maxillaria alata 47 bicolor 47,49 ciliata 212

cuneiformis 47

grandiflora 47, 212

hastata 231

ligulata 231

longipetala 212,231

paniculata 230

ramosa 205

tricolor 47

undulata 212

Mecardonia ovata 81

Melaleuca coriacea 231

Melastoma 62, 74 acuminata 203 carinata 80, 204 coerulea 203 cordata 80 crenata 80 flexuosa 78 grandiflora 78 grossularioides 78 hispida 78 latifolia 78 nitida 204 repens 212 sericea 204 serrulata 204 subsessilis 80 tomentosa 47

Melochia cordifolia 232 corchorifolia 31 plicata 82

Mendozia aspera 204 racemosa 204

Mespilus 40 ferruginea 46, 230 prostrata 46 subspinosa 47 uniflora 46, 98

Miconia emarginata 233 lanuginosa 78 pulverulentia 78,198 triplinervis 78

Milium crinense 232

Mimosa 148, 155, 201 carbonaria 129 expansa 68 farnesiana 199, 200 Inga 29, 213 latisiliqua 102 nodosa 179 pernambucana 29 planisiliqua 206 punctata 29 punicea 213 quadrijuga 179 
sensitiva 102

spicata 167

Mimulus

luteus L. 132

subumbellatus 91

Mirabilis

$$
\text { Jalapa } 200
$$

Molina 40, 98

caespitosa 47

concava 127

corymbosa 231

emarginata 47

ferruginea 47, 91

incana 231

latifolia 212

linearis 127

nitida 231

oblonga 140

obovata 47

prostrata 231

quinquenervis 78

racemosa 140

reticulata 140

scabra 47

scandens 101, 237

salicifolia 231

uniflora 47

venosa 80

viscosa 140

Mollinedia

lanceolata 203

repanda 203

serrata 203

Mollugo

radiata 127

Momordica

Morenia operculata 104

Morus

fragrans 179, 213

nigra 212

spinosa 212

Munnozia

corymbosa 230

lanceolata 212

trinervis 44

Murraya

venosissima 230

racemosa

acuminata 48

spinosa 119

subulata 127

Myoschilos oblongum 132

Myosotis corymbosa 133

gracilis 133

humilis 230

Myrica sternutatoria 48

Myriophyllum verticillatum 132
Myristica

longifolia 176, 206

oblongifolia 206

Myroxylon

Myrtus peruiferum 176, 177

acuminata 127

communis 127

limbosa 180

nuda 127

pseudopimentas 203

revoluta 127

Narcissus

odorus 92

Navarretia involucrata 137

Neea

oppositifolia 233

verticillata 180

Negretia

elliptica 212

inflexa 212

mitis 205

plana 78

planata 212

spinosa 181

Nepeta 198

calyciclausa 207

ciliata 207

Nerteria

repens? 45

Nicotiana

angustifolia 126

parvifiora 237

Tabacum 45, 202, 203

Nolana tomentosa 211 acutangula 27

Nunnezharia fragrans 179

Nycterisition ferrugineum 232

Oenanthe pedunculata 45

Oenothera grandiflora 140 incurvata 134

lineatiflora 127

lyrata 202

mitis 133

oblonga 133

prostrata 101

O'Higginsia

aggregata 78, 204

obovata 211

verticillata 211

Oldenlandia unifiora 137

Olmedia aspera 177, 198

laevis, 177 
Olyra

latifolia 231, 232

Orchidaceae $56,58,220$

Orchis

punctata 205

Ornithogalum

coeruleum 132

compressifolium 169

plumosum 132, 133

pyrenaicum 46

rubrum 203

sympagantherum 133

Oxalis 167

frutescens 180

prostrata 140

Palaua

biserrata 81

glabra 212

hirsuta 78

lanceolata 198

Pancratium

caribaeum 30

coccineum 45

flavum 28

maritimum 30

uncinatum 238

viride $\mathbf{4 5}, 46$

Panicum purpureum 43

Parkinsonia aculeata 104, 107 glandulosa 30

Passiflora

biflora 43

ciliata 43

foetida 29,102

maliformis $\mathbf{8 0}$

mammosa 43

minima 29

quadrangularis 68

rosea 231

rubra $\mathbf{1 7 6}$

serrata 176

suberosa 101

subtripartita 91

vespertilio 176

vesicularis 176

Paulina

striata 78

Paullinia 175

gracilis 175

hirsuta 175

laticinosa 175

obliqua 175

pinnata 175

rubicaulis 175

rubra 175

Pavonia

sempervirens 133

Pectis

trifida 82,200

Peonia 81
Peperomia

acuminata 210

alata 176

concava 78, 203

dependens 176

emarginata 176

filiformis 80,203

Peperomia

foliiflora 80,203

obliqua 78

pilosa 176

pubescens 45

purpurea 80,203

quadrangularis 80

rhombea 232

scandens 78

secunda 232

septemnervis 176

striata 78

tetragona 203

trinervis 80,203

uniflora 80

variegata 232

Perdicium

lanatum 47, 169, 231

Periphragmos 98

flexuosus 91, 211

foetidus 131

uniflorus 43, 91, 238

Phaseolus

Phlox vexillatus 28

aterifolia 132

Phylitidis

obovatum 44

repandum 44

revolutum 44

rhombeum 44

scolopendroides 44

virginianum 44

Phyllanthus

foetida 178

gemina 205

Niruri L. 92

Physalis

angulata 102

pubescens 203

subtrifiora 237

Phytolacca icosandra L. 230

Pineda

incana 91, 207

Pinguicula stellata 45, 230

Pinus 136, 140, 141

Chilensis 140, 141

Piper 220 acuminatum 78 acutifolium 78 angustifolium 91 asperum 232

Piper 220 betulioum 232 
Carpunya? 203, 204

Churumayu 46 crocatum 232

dichotomum 204

filiforme 78

granulosum 230

hexandrum 180

lineatum 91

longifolium 232

mite 78

nitidum 232

obliquum 78

ovale 230

ovatum 78

polystachyon 78

punctatum 232

scabrum 46,78

secundum 232

Pistia

Pitrex

Stratiotes 29

unguiculatum 175

Planata 175

Plantago

hirsuta 44

hispidula 133

tomentosa 44

Platanus

otahetianus $\mathbf{1 0 7}$

Plazia

conferta 48

Plumeria

alba

carinata 27

rubra 27

tricolor 27

Poinciana 102, 201, 220

bijuga 30, 31, 62

Polyanthes tuberosa 28

Polygala

albo-purpurea 78

coerulea 43

aff. discolor 231

incarnata 81

rhombiflora 178

tricolor 165

vulgaris 132

Polygonum

subulatum 46

Polylepis 62,65

Polymnia emarginata 43,44 resinifera 47, 50

Polypodium acanthifolium 92 acutifolium 92

Calaguala 44, 55 coronarium 44 crassifolium 44 dichotomum 92 erecto-lineare 44 exaltatum 44 fibrosum 44

furcatum 92

glabrum 44

incopcam 44

lineare 44

nutans 44

racemosum 92

serratum 44

Polypodium

simile 78

trilobum 92

volubile 92

Polytrichum

subulatum 44

Populus

glandulosa 206

Porcelia

dependens 204

Porlieria 196

hygrometrica 200, 201

Portlandia corymbosa 211

Portulaca cristallina 207

pentandra 207

pilosa 46

Potamogeton

compressus 101

compressifolium 27

Potentilla

prostrata 46

Pothos

acaulis 212

apetala 176

geniculata 176

hastata 81

laciniata 176

perforata 205

sagittato-cordata 81, 176

umbellata 176

volubilis 78,92

Pourretia

coarctata 132

lanuginosa 177, 204

paniculata 204

sympaganthera 232

- Prunus

amara 178

nigra 203

nitida 78

ovalis 231

virginiana 67, 199

Psidium

nitidum 46

pyriferum 201, 202

rugosum 180

Psoralea

americana 166

capitata 31

datesa? 169

glandulosa 129, 169

punctata $\mathbf{4 3}$ 
Psychotria acuminata 204 alba 211 angustifolia 204 coerulea 46, 230 coronata 204 glandulosa 204 hirsuta 91 lutea 78 repanda 78 rubra 78 tinctoria 204 truncata 80 umbellata 204 violacea 232 viridis 204

Pteris auriculata 92 bipartita 92 crenata 92 curvata 92 lineata 44 ternata 44 tomentosa 44 triangulata 44 trifoliata 44

Pteronia gemina 47 spinosa 43

Pullipuntu macrocarpon 206 microcarpon 206

Quadria pinnata 128

Ranunculus 170 cordatus 47

Rauwolfia flexuosa 82

Rhamnus acuminatus 45 pretiatus 132 prostatus 132 verticilatus 133

Rhexia 169

alba 212

flexuosa 204 grandiflora 204

hispida 46 purpurea 78 quinquenervis 212 repens 46 trinervis 212

Rhinanthus glutinosa 43 lutea 238 rugosa 46 Rhus sagitatta 43 atrium 203

Rhynchotheca spinosa 230
Ribes

dependens 46

luteum 46

Ricinus punctatum 131

communis 91 ruber 91

Riqueuria

Rivina avenia 78 secunda 179

Rodriguezia ensiformis 205 Roetia lanceolata 205

Rubus 220 biserratus 46 fruticosus 46, 202 salvifolius 46 roseus 46

Rudbeckia multifida 107

Ruellia alata 78

bicolor 175 ciliata 82 coccinea 175 curvata 232 maculata 175 paniculata 78 prostrata 47 punicea 175

Ruizia violacea 175

fragrans $\mathbf{1 3 0}$

Sagittaria dulcis $\mathbf{3 0}$

Salix sagittifolia 29

Salpiglossis pyramidalis 48 sinuata 133

Salsola fragilis 106

Salvia 40 acuminata 230 alba 91 excisa 102 fragtostissima 43 galeata 210 grandiflora 43 incurvata 210 linearis 237 nodosa 68 ovata 237 plumosa 43 racemosa 68 rhombifolia 43, 101 sagittata 43

Samarillaria acutangula 204 
obovata 204

subrotunda 204

Sambucus

glandulosa 45, 211

nigra $45,84,211$

Samolus

Valerandi 31

Sanchezia oblonga 78 ovata 175

Sanicula canadensis 91

Santolina scabra 128 tinctoria 126, 127

Sapindus Saponaria 28

Sapium 40 fragrans 132

Saracha 98 nitidum 48

biflora 45

contorta 238

dentata 238

punctata 213

procumbens 238

Sarmienta repens 114

Satyrium 47, 48

album 47

bicolor 47,178

luteum 47

plantagineum 178

pubescens 81

virescens 205

viride 100

Sauvagesia ciliata 78 subtriflora 232

Saxifraga 40 tridactylites 42

Scabiosa sympaganthera 133

Schinus 96, 121, 127, 135

aculeatus 206

aurantiodora 213

frondosus 139

Mayco 80

Molle 199

oblongifolia 212, 213

procera 165

Schizanthus pinnatus 114

Scirpus fragrans 232

Scorzonera

ciliata 92

peruviana 92,98

Scutellaria coccinea 238

Securidaca punctata 178 scandens 178
Sedum

Cealu 43

Semarillaria

acutangula 204

obovata 204

subrotunda 204

Senecio

abrotanifolius 44

capus 133

foetidus 230

frutescens 44

nitidus 44

odoratus 81

pyramidatus 78

quercifolius 44

revolutus 44

scandens 28

Serapias

alba 134

ciliata 81

flava 100

lutea 132

Sessea

plicata 132

dependens 44 stipulata 67

Sesuvium

Sicyos

Portulacastrum 28

Sida

cirrhosa 91

americana 102

ca pillaris 100

cristata 101

frutescens 100

incana 91

jamaicensis 101

lutea 101

repens 102

Siegesbeckia occidentalis 48

Silene

anglica L. 132

Silphium

dichotomum 92

Sisymbrium

Sophia 43

Sisyrinchium

alatum 133

anceps 230

Bermudiana? 80

caducum 132

campanulatum 137

cavum 132

echinatum 132

luteum 48

multiflorum 133

ocsapurga 230

palmifolium 31

purgans 48

quadriflorum 132

setaceum 132 
Sium

\section{biternatum 47}

Smegmadermos

Smilax emarginata 137

China 169, 178

lanceolata 205, 206

Sarsaparilla 133

Sobralia

amplexicaulis 81,198

biflora 178

dichotoma 47, 78, 81, 178, 212

Sobreyra repens 101

Solanum

acuminatum 80

acutifolium 211

anceps 78

angustifolium 91

aserplanatum, (?)aspero-lanatum 42

calygnaphalum 42

cristatum 132

dichotomum 91

diformifolium 80

diffusum 91

foetidum 42

grandiflorum 176

granulosum 212, 231

havanense 42

incanum 67, 202

incurvum 211

laciniatum 78

lineatum 211

lycioides 42

mite 176

nitidum 231

nutans 231

obliquum 80

oblongum 231

pendulum 211

peruvianum 100

pubescens 80,207

quercifolium 42

repens 100

scabrum 211

sericeum 42

sessile 211

sicioides 201

spicatum 67

stellatum 67, 212, 231

ternatum 78

tomentosum 42

tuberosum 42

Solidago

variegatum 27,80

secunda 127

Soliva

pedicellata 212

sessilis 132

Sonchus

purpureus 132

Sophora

alata 131 cassia L. 128, 129

Spermacoce

capitata 231

corymbosa 211

gracilis 202

pilosa 91

tenuior 91, 101

Spigelia

Anthelmia 175

Spilanthes urens $\mathbf{1 0 0}$

Spondias 173

Mombin 31, 201

Stachys

hastata 165

lanuginosa 137

Staehelina

sarmentosa 238

Stapelia

hirta 230

volubilis 203

Staphylaea

Statice serrata 204, 211

Armeria L. 132

Stemodia

maritima 139

Stereoxylon corymbosum 170

paniculatum 233

pendulum 211

patens 230

pulverulentum 136

resinosum $\mathbf{4 5}$

revolutum 136

rubrum 119

virgatum 136

Stramonium L.

Strychnos

auriculata 179

brachiata 179

Suriana

apetala 165

Swertia

corniculata 46, 170

Swietenia macrocarpa 177

Syngenesia 98

Synzyganthera

purpurea 205, 211, 233

Tabernaemontana corymbosa 175,176

Tafalla

angustifolia 233

glauca 78

laciniata 200

laevis 231

racemosa 233

scabra 213

triflora 206

Tagetes 201

anisidora 205 
Chinchu 205 integrifolia 91 odoratissima 47

Talinum

\section{ciliatum 47}

dichotomum 200

monandrum 131

nitidum 131

umbellatum 131

Ternstroemia

globosa 231

quinquepartita 231

Tessaria

dentata 107

integrifolia 68

Thalictrum 40 polygamum 46

Theobroma Cacao 78, 166

Tillaea

connata 102

Tillandsia 220

coarctata 44

Huehle 44

juncea 212

paniculata 212

parviflora 212

recurvata 44, 212

revoluta 44

usneoides 44

Torresia

utriculata 132

Tournefortia

longifolia 179

polystachya 45

Tournefortia

virgata 45

volubilis 179

Tovaria pendula 199, 232

Tradescantia deflexa 212

Tragia peltata 181

Tribulus maximus 82

Trichilia acuminata 203 trifoliata 203

Trichomanes crispum 44

fimbriatum 92

interruptum 92

lineare 44 obovatum 44

Tricuspidaria nutans 127

Trifolium hirsutum 205

Triglochin

ciliatum 46

palustre 31
Trillis auriculata 178

Triplaris 196 octandra 182

Triptilium spinosum 128

Triumfetta fructicosa 203

Lappula L. 82, 203 subtriloba 82

Tropaeolum 40 discolor 212 hexaphyllum 137 majus $\mathbf{3 0}$ tuberosum 46

Turraea guinata 232

Urena 81

biserrata 67

hamata 202

trilobata 67

Urtica villosa 202

aculeata 178

baccifera 178

citriodora 212

cymosa 212

dauciodora 212

diaphana 205

fumans 48

fumigera 80

geniculata 80

globifolia 206

hirsuta 212

longifolia 212

nuda 80

orbicularifolia 48

punctata 212

rugosa 91,212

sparsa 80

spiralis 48

striata 80

Utricularia aphylla 30

Vaccinium

alatum 46

bicolor 203

biflorum 46

dependens 230

Vaccinium

grandiflorum 46

lanuginosum 46

nitidum 46

punctatum 46

trinerve 46

Valdesia

ovalis 203,207

repens 203,207

Valeriana 96

chaerophylla $\mathbf{8 0}$

Cornucopiae 131 
coronata 45

crispa 131

decussata 210

globiflora 45

hyalinorrhiza 131

lanceolata 45

oblongifolia 45

officinalis 210

paniculata 210

pilosa 45

pinnatifida 100

thyrsiflora 45

Valeriana

virgata 238

Vallea

cordata 46

Vandellia

diffusa 78

Vanilla

officinalis 78

volubilis 178

Varronia

dichotoma 231

erecta 82

globosa 212

oblique 45

rugosa 45

Verbena

adpressa 78

citriodora 239

corymbosa 133

cuneata 237

hispida 68

multifida 133

virgata 178

Vermifuga

corymbosa 91, 199

Veronica

rotundifolia L. 230

serpylifolia L. 230

Verticillaria balsamifera 178

Viburnum verticillatum 45

Villarezia

emarginata 232
Viola

bicolor 91

chilensis 131

lutea 131

martia 131

obliqua 47

parviflora 47

purpurea 68

subulata 47

Virgularia

lanceolata 230

revoluta 47

Viscum

luteum 48

sessile 48

Vismia

tomentosa 78

Volkameria verticillata 128

Weinmannia 196

alata 230

corymbosa 133

oppositifolia 46

ovalis 230

ovata 230

pinnata 107

pubescens 230

Xuarezia

biflora 101

$\mathrm{Xyris}$

lutea 231

Yucca

escabra 83

laevis 83

Zinnia

pauciflora L. 82

Zannichellia

palustris 200

Zea Mays 232

Zizania

octandra 31 


\section{INDEX OF VERNACULAR NAMES OF PLANTS}

Abas 38, 39, 66, 97, 145

Abilla 179

Aceyte de María 178

Aceitunillo 130, 148

Achiote, Achote 78, 175

Achotillo 309

Achupalla 137

Achyra 80, 203, 209, 230, 309 de monte 198

Afcapichana 82

Aitacupi 78, 206, 213, 232, 233

Ají-aji 46

Albergilla $\mathbf{8 0}$

Algarrobo 148

Alhuelaguen 131

Almaciga 78, 206

Almendrón 73

Almizclilla 102

Ama de casa 42

Amancae antiguo 28, 309 cimarrón 309

Amarra judíos 27

Ancas champatra 83

Anemona 131

Anil 205

Anís-anís 205

Anisillo 137

de lomas 107

Anono 30, 80, 101, 102, 173, 203, 309

Apio 39

Arbol de cuentas de rosario 212 del incienso 48, 165, 196, 213 de las mantas 107 de lino 310 del sebo 73, 176, 196

de la seda 27, 202 del tambor 181

Arbolito de la seda 311

Arguenilla 126 blanca 137

Arnaucho 176

Aromo 152, 199 fino 310

Arquenilla 132

Arquenitas 126

Arracacha, 39, 53, 80, 97, 209 cimarrona 45

Arrayán 117, 127, 148, 152, 202 colorado 127

Artemisa 31

Ascacpichana 200

Aseca 46

Asmonich 175

Atpuallin 173, 178, 179

Auroras 205, 206

Avellano 148, 128 de Chile 128 de Valdivia 309

Avocado 80, 97
Azofaifo 31

Azucena 175

Barbas de viejo 165

Belloto 148

Berbasco 173

Bolbus 117

Boldu 130

Bolillos 28, 310

Bombilla 231, 232

Borbo cimarrón 29

Botoncillo 200

Broquin 128

Bullel 127

Caballerias 220

Cabellos de angeles 231

Cabeza de monge $\mathbf{1 7 8}$

Cabulla 83

Cacao 72,73

Cacca 48

Cacharpurin 179

Cachicasa 27

Cachigusi 169

Café 203

Caihua 101 de lomas 101

Caiguas 310

Caimito 173,177 de monte 203

Calabash 101, 104, 133, 182, 205

Calabaza cimarrona 91

Calaguala $40,44,50,98,231$ gruesa 44

Calcha 137

Callahuala 44

Camona 174, 179

Campanillas 309

de lomas 27

Campucassa 212, 231

Caña braba 222

Cañafistola 101, 177 cimarrona 28, 309, 311

Canchalagua cimarrona 200

Canelilla 132

Canelo 114, 115, 148

Capuli 203

Cardo santo 309

Cardón 132

Carpunya 204

Carrizo 222

Cascabeles 309

Cascabelillos 28, 309

Cascarilla 70, 77, 87, 209, 224, 228, 229 de pata de gallareta 214

Cascarillo 221, 230 bobo amarillo 211

Cassava 173, 226

Catas 46, 210 
Ccamcha 227

Ccarhuascassa 211, 236

Ccarato $\mathbf{8 0}$

Ceallu 43

Ceantu 238

Cedro 30, 182, 183, 309 macho 211

Cedrón 239

Cerezo 199

Chacay 133

Chachacoma 45

Chaguis 128

Chamassa, Chamisa 46

Chancano 98

Chaves 27

Cheguen 127

Chenchelcoma 43

Chicchimicuna 232

Chichillica 176, 179, 213

Chichis 48

Chihucanhuaita 238

Chilca 40, 42, 62, 101, 237, 309

Chilifruta 46

Chimchamali 98

Chimchiculma 48

Chinapaya 91, 199

Chinchanho 47, 62, 230

Chinchi 43, 47, 91

Chinchimali 310

Chincumpa 48

Chirimoya $30,39,86,97,101,102,202$, 203, 309 cabeza de negrito 202 reales 202

Chisp-huinac 43

Chocllocopa 46

Choloco 28

Chonta 173, 174, 179

Choruro 310

Chucchoclle 231

Chucholle 78

Chuchumeca 27, 202

Chuculate 212, 231

Chuncho 204

Chupillo 182

Chupón 128

Churumayu 46

Chutasllium 179

Chuuima 227

Ciarhirachero 42

Ciérrateputa 29, 102, 310

Ciruelo agrio 31, 201, 310 de Fraile 30, 102, 202

Coarhuasahuintu 201

Coca 44, 53, 79, 80, 173, 174, 192, 196,

Coguillogi 130 $198,221,225,226,227$

Coguillvogui 139

Coilhue 148

Col de montaña 206

Colle 42

Collihuay 132

Comida de venado 179
Conchaguala 29

Conco tronco 82, 83

Congama 231

Contoya 28, 310

Contrayerba 91, 182, 185 199, 310

Corcolen 131

Coronas de Rey 30

Cotalaura 44

Cuacsaro 44, 231

Cuca-cuca 44

Culandro, Culantro 179, 232

Culantrillo 44

Culén 129

Cunhur 46

Cuyol 174, 179

Cuzle 128

Deu 127

Ducasahuintu 201

Enlaora 231

Escoba amarga 200 cimarrona 31, 310

Escobilla 30, 310

Espino 44, 129, 148, 152, 155

Frijol de Antibo 309

Espino amarillo 236

Excorzonera 40

Feligranas 100

Flor de azahar 78

del clavo 100,310

del Espíritu Santo 212

de Panamá 200

de la reina 27

de San Juan 309

de todo el año 212

Floripondio encarnado 45

Franuco 82, 83

Frijol cimarrón 28, 310 de Antibo 28, 309

Frijoles cocachos 309 morados y negros 309

Frijolillos 101

Frutillas, 39, 148 de monte 45

Gaqui 80

Garbancillo 44

Gavilu 132

Godocoypo 132

Goma de molle 310

Gordura-gordura 47

Granadilla 97 de mono 80

Guairo 309

Guadalaguen 140

Gualle 131

Guarango 310

Guarangillo 309

Guarapo 86

Guava see huayabo $39,86,97,173,310$, 311 
Guayo colorado 134, 148

Guillipatahua 131, 148

Guilmo 132

\section{Hatum 198}

Hatumpacte 42

Haumun 128

Hauyros 24

Haynura 78

Heneldo cimarrón 30

Hierba hedionda 199, 237

Higarrobo 155

Higos del duende 201 de monte 199

Higuerilla de la tierra 91 mexicana 91

Hormis 42

Huachancano, Huachamccano 98, 238

Huaita rebozo 213

Huallicaya 31

Huampo 81, 227

Huanábano $30,101,102,203$

Huanarpo macho 201

Huantura 78

Huanucara 67

Huaramachia $\mathbf{4 7}$

Huarandillo 28

Huarituru 45

Huarmi-huarmi 31

Huarnapo Hembra 201

Huarnica 43

Huayabo 201, 202 de monte 180

Huayacan, 148, 200, 201

Huayansacha 42

Huayro, Huayruru 28

Huehle 44

Huevill-huevill 131

Huighan, Huignan 121, 127, 151

Huilcatauri 205

Huillca 206

Huincus 48

Huiscacassa 212, 231

Hunopergi 130

Hupaimuna 207

Ichu $36,45,94,97$

Ictnigo 127

Illmo 133

Incopcam 44

Inich 72,178

Iscumnim 175

Jaboncillo 104

Jabonera 28, 310

Jazmincillo de lomas 309

Lacre de montaña 80

Lagues 133

Laupe 78, 196

Lausahacha 202

Lechuga cimarrona 29, 310

Lengua de ciervo 44
Liga 67

Limoncillo 238, 239

Ligney(?)-lingue 139

Lingue, linge 148

Listre 148

Litho, Llitho 28, 310

Lithre or Lithi 135, 139

Litre 117, 151

Liun 136

Liutu 133, 134, 137

Llague 132

Llampañaui 181, 212

Llinlli 230

Llogui 91, 207

Lucuma 39, 213, 309

Lúcumo 30, 148

Lumas 148

Macae 210

Macapagui 102

Macca 63

Macha 230

Macha-macha 46

Machi 230

Machinparrani 210

Macignata 131

Maestrante 28, 310

Magueyes 83

Mahomi 177

Maíz de Guinea 232

Mallicas 80, 81

Malva cimarrona 310

Mancapaguí 47, 91, 230

Mandoño 136

Manglillo 213, 220, 309

Maní 309, 311

Manihue 148

Manzana de monte $\mathbf{1 7 3}$

Manzanilla cimarrona 231

Mapato 43, 200

Maqui 127

Maravillas 165

Margaritas 45, 132

blancas 28

encarnadas 45

esmaltadas 307

de lomas 310

Mascea 231

Massuas 39, 46, 65, 97

Mastimpanrani 46

Mastuercillo 30

Mastuerzo silvestre 67

Matagusanos 91, 199, 310

Matapalo 78, 231

Matayerno matahyerno 100, 310

Maxpachin 175

Mayaca 313

Mayco 95, 96, 212, 213

Mayo 128

Maytén or Magthun 117, 135, 139, 152

Mayu 128

Membrillos 39

Membrillejo 27, 102, 309 
Menhas 42

Merulanguen 140

Michtria 127

Millmahina 44

Millucassa 47

Milluscassa 45

Mito 237, 309

Miu 68, 199

Moho-moho 91

Molinas 98

Molle 199 de Chile 148, 165

Mollocanto 46

Moma 212

Monte lucuma 80, 204, 211 pacae 213 papaya 213

Muca-muca 177

Muña 198

Muyaca 46

Nalcas 131, 132

Naranjitas de Quito 310

Napu 107

Natre 132

Nebu 148

Negú 128

Nogal de la tierra 31

Nothro 130

Nuñumya 42

Ocssa 45 purga 48,230

Oca, Ocka $38,39,53,86,167$

Olla-olla 46, 212

Orejas de abad 27

Oreja-oreja 238

Ortiga 132, 133

Ortiga de la Sierra 310

Pacae 29, 39, 97, 213 de monte 179

Pachapacte 42

Paco-paco 210 de la sierra 211

Pacoyuyu 100, 200

Pagnhin 133

Pahua 62

Pahuata-huinac 43

Paico 127

Pai-pai 102, 310, 311

Paja purgante 48, 230

Pallares 310

Palillo 39, 202, 309

Palma-palma 230

Palma pullipuntu 206

Palmito 91, 174, 179

Palo amarillo 198, 211, 212 santo 182

Palto, Paltas 29, 30, 39, 86

Panke or Pangue 131

Panul 140

Papa de montaña 81
Papaya 53, 80, 178, 226

Papiru 45

Paracso 230

Parampui 178

Pargui and Palqui 126

Patacon 27

Patagua 117, 127, 148

Páxaro (pájaro) bobo $68,107,151$

Pegajosa 101, 200

Pega-pega 28, 310

Peladilla 148

Pellin 131, 140

Pepino 27, 311

Peregrina 27, 102

Peumo 117, 134, 148

Picahuai 210

Pichana 100

Pichi 137

Pichicara 67

Pichoa 128

Pichuisa 67

Picma 45, 211

Pila-pila 102

Pililla 30

Pilo, Pelu 131, 148

Pimiento-pimiento 46

Pimpinela cimarrona 128

Piña 179, 180

Piñi-piñi 46, 206

Pinoli 73

Piñoncillo 31, 309

Piñone 148

Piochas 30, 309

Pita 83

Pitau 132, 148

Plátano 30 de monte 204

Poguil 126

Polizone 45

Poroto 37,39

Puche-puche 102, 310

Pucheri 73

Puchuppus 42

Puca-campanilla 45

Pucsato 231

Pucssato 46

Puhe 47

Pullapuil 178

Pullipuntu 206

Puma 40

Pumachillea 211

Pumacuchu 43, 200

Puntu-puntu 44

Purampui 178

Purumhigo 199, 232

Purum piña 198

Puru-puru 231

Puya 132

Puyutchrin 181, 198

Quelgon 132

Quelpuan 178

Queule 127, 128, 148 
Quiebra ollas 102, 237, 309

Quila 133

Quillay 137, 148

Quilmo blanco 133

Quilo 131

Quina, Quino 70, 71, 73, 77, 96, 209, $215,221,224,226,227,228,229$

Quina-Quina, Quino-Quino 176, 196

Quina officinal 87

Quinuar, Quinhuar, Quinoar 65, 43, 62

Quinchamali 40,98

Quinclin 132

Quinoa 66, 121 amarga 127, 307 dulce 127

Quintral 127

Quisoar, Quishuara 42, 202, 230

Quitatauri 43

Raiz de China 185

Ramaysantra 98

Ram ram 230

Raral 130

Rataña 200

Ratonera 132

Retamilla 132

Rhinnin cussau 46

Rima-rima 47, 212

Rincri-rincri 238

Roble 131

Rocobo 176

Roccotico de monte 78

Romerillo 127

Rosa-rosa 46

Rurama 45, 211

Sacconche 43, 68

Sachsauro 230

Sadcopra 44

Sahuintu 201

Salivatoria 100

Salsaparrilla 133

Salvagina 44

Salvia menor $\mathbf{4 3}$ real 43

Sanacassa 46

Sandía laguen 133

Sangre de drago 181, 182

Santo palo 178, 196

Santra 40

Sarachas 98

Sencapuspu 28

Sia-sia 174, 179, 213

Siempreviva 42, 128

Siete camisas 136

Simayuca 212

Siraca 202

Socconcha 43, 67

Ssagui 80, 173, 226

Ssaire 48

Suche 27

blanco-rosado 27 turumbaco 27
Suelda consuelda 206

Suiba 170

Sumacmisqui 231

Suyunmpai 43

Tabaco cimarrón 310 verdadero 202,203

Tacma 44

Taconcillo, Taconcito 28, 309

Tacuna, 73, 78, 176, 205, 213

Tahue-tahue 212

Tambo 68

Tantarprieto 46

Tapate 102 puta 310

Tapateputilla 29, 310

Tara 30, 31, 62, 310, 311

Taraca 47, 50

Tarucasa 200, 201

Tassta 230

Tauhac-tauhac 230

Taya 47 hembra 47 macho 47

Tecal 133

Thee del Perú 101

Thilco 128

Tiaca 133

Tina 27, 102

Tiquil-tiquil, tiguil-tiguil 27,315

Tiri blanco 47 encarnado 45

Tsackeiro 182

Torongil 140

Totora 313

Traunuvoqui 130

Trifolito 28

Trompetilla 200

Tulpay 176

Tupa 165

Tuppassaire 48

Turucaffa 82

Tutumo 28, 101, 309

Uchu-uchu 46

Ucuspatállan 43

Ulluco 39,46

Ullus, Usluss 46

Uñas de gato 28

Upe 205

Urra-purupuru 43

Urtiga, see ortiga

Uspica 91, 230

Vainilla 78, 178

Vejuco blanco 211 de la estrella 182, 185

Verde sahuintu 201

Villcatauri 178

Vinagrillo 310

Vira-vira 47 del monte 47

Virgenhacha 231 
Vogui 117, 133

Voldo 148,152

Yacón, (Llacón) 37, 39, 53

Yaravisco 67

Yasmich 176, 196

Yechenor 177

Yedra 28, 102

Yelmo 130

Yerba de la araña 399

de la bolsilla 309

del carnero 31

de la culebra 67

del Gallinazo 100

de la golondrina 31, 207

de la lancha 102

de la mistela 131

de la perdiz 140 de las perlillas 44

de la purgación 102, 200

de San Agustín 31, 310

de San Martín 78, 232

de la sangre 91

de la seda 309

de la Trinidad 31

hedionda y santa 309

santa 199

Yorasahuintu 201

Yuca 80, 221

Yurahuacta 202

Yurahuanium 211

Yuyu 100

Zapayo 209

Zarzaparilla 206

Zorrino 165 


\section{INDEX OF GEOGRAPHICAL NAMES}

Achapatumam 235

Acobamba (annex) 55

Acomayo (river) 71, 235

Acomayo (pueblo) 69, 82, 186

Aconcagua (province) 160, 162, 165

Aconcagua (river) 151

Aconcagua (volcano) 151

Acotama (annex) 22

Aculeu (lake) 151

Aguamiro (pueblo) 87

Aguamiro (annex) 88

Aina Huandaro (annex) 99

Algué 151

Alhue (gold mine) 160

Allocá (annex) 40

Alto de las Salinas (gold mine) 160

Amancaes, Los (hills) 105

Ambo (asiente) 168

Ambo (pueblo) 93

Ambo (district) 66

Amolanas (gold mine) 163

Anaica (annex) 99

Ancalloma, Aucallama 22

Ancon (port) 16

Ancón (heights) 107

Andacollo (hill) 163

Andahuasi (hacienda) 104

Andalien (river) 129, 151

Andamarca (annex) 55

Andarien (river) 151

Angaraes (province) 53

Angol (pueblo) 123

Apache (annex) 22

Apata (parish) 55

Apata (pueblo) 49

Apurimac (river) 64

Araguete (river) 116, 126, 151

Arahuay (parish) 99

Arancai (valley) 88

Arauco (fort) 113, 119, 123

Arcaya (gold mine) 161

Arenisco (the island) 26

Arica 19

Arnedo (town, port) 16, 20

Arnedo (parish) 20

Arnedo (valley) 18

Ascensión 11

Atabalillos (parish) 99

Ataxpamarca (annex) 99

Aucallama (parish) 22

Auquimarca (annex) 22

Avendaño (lake) 146, 151

Ayaranga (annex) 22

Ayras (district) 87

Baños (parish) 88

Baños (annex) 99

Barranca (parish) 21, 22

Bellavista (hacienda) 41
Bellavista (parish) 13

Bení (river) 64

Bidahuel (lake) 151

Biobio (river) 113, 126, 151

Biobio, Tetas de 110, 142

Bocalemu (lake) 151

Bojeruca (lake) 151

Bombón (pampas) 63, 64

Bombón (heights) 90

Bucas (annex) 99

Bueno (river) 151

Caballero (hacienda) 95, 238

Cachapual (river) 151

Cacray (hill) 61

Cádiz 241

Cahuac (pueblo) 84

Cahuac (annex) 88

Cahuil (lake) 151

Calahuaya (annex) 40

Callao (port) 11, 109, 165, 241

Callapampa, San Gerónimo de 41

Cañadilla (district) 158

Cañete 19

Cangrejillos (hacienda) 129

Canin (annex) 22

Canta (province) 97, 167

Canta (parish) 98

Canta (quebrada) 61, 95

Carabaillo (parish) 13

Carabaillo (river) 13, 97

Cárac (annex) 99

Carampangue (river) 116, 117, 126, 151

Carahuacra (annex) 41

Carampoma (pueblo) 41

Carcamon (quebrada) 142

Caren (gold mine) 160

Carhua (annex) 98

Carhuacallanca (annex) 55

Carhuamayo (pueblo) 63

Carhuapampa (annex) 40

Carmen Bajo (convent) 156

Carpis (hill) 82, 192

Carrera del Campo 193

Carrizal (town) 157, 167

Casapalca (hacienda) 41

Casapalca 59

Casape (hills) 75

Casapillo (hills) 75

Casapillo (pueblo) 77

Casas, Las (hacienda) 63

Cascay (river) 71

Cascay (pueblo) 186

Castillo de Pachacamac 23

Caugue 151

Cauquenes (province) 144, 154

Cauquenes (mountains) 139

Cautín (river) 151

Cayumba (hills) 75 
Cayumba (river) 71

Caxamarquilla (pueblo) 65, 90, 168

Caxas (annex) 55

Caxatambo (province) 22

Ccarhuacayan (annex) 98

Ccormo (annex) 99

Cercado (province) 12

Cerro de la Sal (pueblo) 54

Cerro de la Viuda (montaña) 95, 168

Cerro del Nuevo Potosí 40

Chaclacayo 37

Chacahuasí (montañas) 225, 229

Chacahuasí 223, 224, 234

Chacahuasí (river) 71

Chacahuasí (pueblo) 225

Chacayco (pueblo) 123

Chaclla (annex) 41

Chaclla (pueblo) 169, 184, 208, 214

Chaclla 47

Chaivin (river) 151

Chanca (annex) 41

Chancay (town) 16, (parish) 20

Chancay (province) 14, 19, 100

Chancay (hills) 100

Chancayllo (port) 16, 20

Chanco 152

Chacapalca, San Lucas de (annex) 41

Chanchamayo (pueblo) 49, 57

Chanchas (parish) 22

Chapcá (annex) 99

Chaplanga or Chaplamha (plain) 35

Chaqui (annex) 98

Chatacancha (annex) 40

Chaucha (pueblo) 236, 237

Chaulan (pueblo) 236

Chaupis (annex) 99

Chavín (pueblo) 87

Chavin 29

Chavín de Pariarca (parish) 88

Chavinillo (pueblo) 84

Chavinillo (annex) 88

Checta 238

Cheguen (hacienda) 129

Cheuchin (pueblo) 55

Chicauma (gold mine) 160

Chicoplaya, San Antonio de 71

Chicoplaya (pueblo nuevo) 71,187

Chicla, San Juan de (pueblo) 33, 41

Chiloé (district) 144

Chillamahuida 163

Chillán (province) 144, 152, 154

Chillán 151

Chilos 151

Chimba (district) 158

Chimla (district) 156

Chinchao (pueblo) 70, 79, 192

Chinchao (river) 71

Chinchao (quebrada) 186

Chinchaycocha (lake) 54, 63, 64

Chinizo (rivulet) 172

Chipaco (annex) 88

Chiuchin (annex) 22, 32

Chivato (hill) 160
Choapa (river) 151 (lake) 151

Chongos (parish) 55

Chonta (quicksilver mine) 87

Chontay (annex) 40

Choras (annex) 88

Chorrillo (pueblo) 40 (annex) 14

Chulgué (hacienda) 186, 192

Chulguillo (hacienda) 220

Chumayo (river) 71

Chupaca (parish) 55

Chupán (pueblo) 84

Chupán (annex) 88

Chuqui (annex) 88

Churupallana (montaña) 57, 58

Chuspas (annex) 99

Ciricamcha (hacienda) 41

Claro (river) 151

Cocachacra 37, 61

Cochahuayco (annex) 40

Cochanhara (parish) 55

Cocinilla (gold mine) 160

Colahuaya (annex) 40

Colca (annex) 55

Colchagua (province) 151, 154, 160

Colina 151, 159

Collata (annex) 41

Collico (hacienda) 129

Collomu (port) 152

Colorado (river) 151

Colocolo (hill) 119

Comayo (pueblo) 228

Comas (parish) 55

Concepción (pueblo) 51

Concepción (city) 139, 142

Concepción (parish) 55, 142

Concepción (fields) 126, 139

Concepción (bishopric) 149, 154

Concepción de Chile (province) 142, 144,149

Concepción de Pacha (annex) 41

Conchucos, Los (province) 88

Concura (hill) 116, 126

Conuto (parish) 136

Copacabana (plain) 107, (tambo) 14

Copiapó (province) 160

Copiapó (town) 151, 163

Coquimbo (port) 152

Coquimbo (province) 160, 163

Coquimbo 149

Coquimbo (quicksilver mine) 155

Corbalan (copper mine) 164

Corcura (hill) 126

Cortes (copper mine) 164

Cosma (annex) 88

Cótoc (annex) 99

Cuchero (montañas) 74,166

Cuchero (pueblo) 71, 232

Cuchero (river) 188

Cuchero 75, 77

Cuchero (district) 73

Cuerno Retorcido 169, 214

Culenco (hacienda) 129, 150

Culiguay (mine) 161 
Culli (annex) 99

Culluay (pueblo) 95, 97, 167, 237

Culluay (annex) 99

Cullue (lake) 98

Cushi 184

Cuyo (province) 160

Descubrimiento de las Catas (gold mine) 160

Diezmo 94, 168

Durazno (gold mine) 160

Eneno (pueblo) 54

Esperanza, Buena (pueblo) 138

Esquadrón (country house) 114

Estancia del Rey (pueblo) 138

Florida (parish) 136

Gonzaga, San Luis (pueblo) 138

Guindo (gold mine) 160

Hacas (annex) 88

Hacaybamba (lake) 97

Hacaybamba (pampa) 237

Hacaybamba (montaña) 98

Higueras, Las (quebrada) 84

Huacachi (annex) 88

Huacar (annex) 22

Huacaybamba (parish) 86,88

Huaccrin (annex) 88

Huachinga (annex) 22

Huachipa (annex) 13

Huacho (port) 16

Huacho (parish) 21

Huachupampa (annex) 41

Huacos (annex) 99

Huacrachuco (parish) 88

Huacracocha (lake) 34, 39, 61

Hualgui, San Juan Baptista de 88, 136 , 192

Hualgui (parish) 142

Hualhuas (annex) 55

Huallaga (river) 64

Hualpen (quebrada) 142

Huamali (annex) 55

Huamalíes (province) 64, 86, 236

Huamanmayo 208

Huamansica (annex) 40

Huamantanha (parish) 99

Huanacache (lake) 151

Huanangui (annex) 22

Huancabamba (pueblo) 54

Huan cabamba (river) 171

Huancayo (river) 54

Huancayo (annex) 55

Huan cayre (annex) 40

Huánuco $61,77,85,90,168,184,187$, $192,196,198,203,214,218,236$

Huánuco (quebrada) 91

Huánuco (river) 86, 221, 235

Huánuco (montañas) 91, 166
Huánuco (province) 67, 83

Huánuco de los Caballeros, Léon de (city) 67,82

Huánuco el Viejo (pampa of) 87

Huanza (annex) 41

Huaral, San Juan de (pueblo) 20

Huari, San Antonio de (annex) 41

Huariaca (pueblo) 66, 93, 94, 168, 196, 217,237

Huariaca 90

Huariaca (river) 195

Huaribamba (pueblo) 55

Huarihancha (annex) 88

Huarocherí (parish) 40

Huarocherí (ravine) 36

Huarocheri (province) 33, 39

Huaroquin (annex) 99

Huasahuasi (fort) 55

Huasahuasi (montaña) 42

Huasahuasi (pueblo) 56, 57

Huasahuasi (quebrada) 47

Huascacocha (lake) 61

Huasco (valley) 164

Huasco (river) 151

Huascoy (annex) 99

Huaura (river) 16

Huaura (village) $15,21,107$

Huaura (valley) 19, 20

Huayabal 56

Huayanca (desert) 87

Huayanca (mines) 87

Huaychao (annex) 98

Huaychao (lake) 98

Huaycho (annex) 22

Huayllasrum (lake) 98

Huayllay (annex) 98

Huayucachi (annex) 55

Hucumarca, San Cristóbal de 41

Huilguelemu (pueblo) 136, 138, 140, 149

Humaya (hacienda) 103

Huombra (river) 97

Illapel (gold mine) 162

Imperial alta (pueblo) 123

Imperial baja (pueblo) 123

Ingenio, El (hacienda) 41, 103

Iscutunam (hill) 223, 234

Itata (province) 144, 152, 154

Itata (river) 151

Jeguan 19, 20, 100

Jesús (pueblo) 88

Juan Fernández (island) 144

Lachay (hills) 18, 101

La Corrida (copper mine) 161

Lacosi (annex) 13

Ladera de la Colmilla 170

La Dormida (gold mine) 161

Laguna, La (pueblo) 64

Laguna de Reyes 54

Lagunillas, Las 24 
Lahuaytambo (annex) 40

Lamas 71,72

La Ligua (gold mine) 161

Lampian (parish) 99

Langa (annex) 40

Lanco 58

Lapa (river) 151

La Punta (annex) 55

Laral 100

Laraos (annex) 41

Lampa (gold mine) 160

Late (parish) 13

Lauquen (lake) 151

Lauricocha (lake) 64, 86

Laurigancho 13

Ligua (river) 151

Lima 58, 60, 99, 105, 107, 165, 196, 238

Lima (city) 12,23

Las Bacas (gold mine) 162

Lima (river) 40

Limón (river) 151

Loicacas (hacienda) 129

Limari (valley, copper mine) 163

Loma Blanca (hill) 160

Longotoma (river) 151

Lontue (river) 151

Lurigancho (parish) 13

Lurin (river) 13, 23

Lurin (parish) 14

Lurin, San Pedro de (pueblo) 24

Llacos (annex) 88

Llacsanga (annex) 22

Llacta (parish) 88

Llamapañahui 169, 214

Llamós (annex) 88

Llancao (annex) 22

Llanas (annex) 88

Lanta (annex) 98

Machainio (hacienda) 77

Macora (hacienda) 186, 189, 194, 240

Mactara (annex) 40

Magdalena (parish) 14

Maguehue (pueblo) 123

Mala (river) 40

Mama, San Pedro de (pueblo) 41

Manzano (gold mine) 160

Mapocho (river) $151,156,165$

Marañón (river) 54,64, 71, 86

Marayo Checras (parish) 22

Marco (annex) 99

Margos (annex) 88

Marías (annex) 88

Marimarchahua (hacienda) 186

Matahuasi y Cincos (pueblo) 55

Matucana, San Juan de (pueblo) 33, 41

Maule (river) 151

Maule (province) 150, 151, 154

Maule (district) 160

Mayo (annex) 99

Maypo (river) 151

Mayro 193
Mayobamba (pampa) 186

Mazo (annex) 21

Mazon (gold mine) 161

Mejorada (annex) 55

Melipilla (province) 160

Membrillejo (gold mine) 160

Menayco (pueblo) 123

Mendoza (river) 151

Mesapaba (cocal) 187

Mesapata 204

Metraro (pueblo) 54

Millague (gold mine) 160

Millan-Antun (quebrada) 149

Miraflores (pueblo) 23

Miraflores (annex) 14, 55, 88

Mito (pueblo) 55

Mocha (valley) 143

Mochita 142

Mojon (annex) 55

Mojon de San Lorenzo (pueblo) 49

Monzón (annex) 88

Monzón (river) 64, 71, 86

Mopecura (pueblo) 123

Moyobamba (annex) 22

Mulamuerta (gold mine) 160

Muña (pueblo) 169, 184, 209

Muña (montaña) 208

Muquiyauyo (annex) 55

Musga (annex) 22

Nacimiento (pueblo) 149

Nacimiento, El (plaza) 122

Nacimiento, El (fort) 136

Nahuelguapio (lake) 151

Nancagua (town) 160

Nangos de Cochacra or Cocachacra (annex) 41

Ninacaca (pueblo) 63

Nipas 152

Nongen (river) 129

Nuñoa (parish) 159

Obeguet (annex) 22

Obrajillo (annex) 98

Obrajillo (pueblo) 237

Ocopa, Santa Rosa de (convent) 49, 50

Ollerias (pueblo) 196, 218

Olleros, Los (pueblo) 40

Ordones (pueblo) 63

Orcotuna (parish) 55

Oroya, La (pueblo) 36, 59

Oroya, (river) 54

Oroya, (bridge) 36

Otáo (annex) 41

Ovas (annex) 88

Ovas (pueblo) 84

Pacaraos (annex) 88

Paccho (pueblo) 22

Pacha (annex of La Concepción de)

Pachacamac (annex) 14

Pachacamac (island) 26

Pachacamac, Castillo de 23 
Pachachaca (hacienda) 35

Pachachaca 41, 59

Pachas (parish) 88

Pacron (hill) 217, 238

Palca (fort) 55

Palca (montaña) 42

Palca (quebrada) 47

Palcamayo (estancia) 94, 168

Palcamayo (pampa) 237

Pállac (annex) 99

Pamacocha (lake) 98

Pamacocha (parish) 98, 99

Pampahermosa (pueblo) 71

Pampamarca (pueblo) 232

Pampas (annex) 99

Panao (pueblo) 169, 208, 214,"228

Panao (river) 71

Panatahuas (province) 67

Panatahuas (montaña) 47

Pano (river) (see Bení) 64

Parquín (annex) 22

Papal (lake) 144, 151

Parí (parish) 98

Parí (river) 36, 40, 54, 59, 97

Pariahuanca (annex) 55

Pariamarca (annex) 98

Parral, El (hacienda) 129

Pasachisque (annex) 99

Pasamayo (river) 16

Pasamayo 100

Pascana 234

Pasco (town) 64, 90, 168, 195, 217, 237

Patay (river) 86

Pati (tambo) 82, 186, 192

Pativilca (hacienda) 103

Pelchoguin (hacienda) 129

Penco el Viejo (port) $150,152,154$

Penco (port) 142

Petorca (province) 151

Petorca 152, 161

Picoy (pueblo) 56

Picoy (annex) 22

Piedra Parada (hacienda) 41

Pillao (pueblo) 221, 228, 235

Pillao (bridge) 220

Pillao (montañas) 219, 229

Pillco (river) 66, 225

Piñapata 208

Pirca (annex) 99

Pisco 19

Playa (height) 184

Playa blanca 116

Playa negra 116

Polcura (hill) 151

Portachuelo 56, 170, 172, 184

Potreros (hills) 160

Potreros del Rey 154

Pucará, Prov. Huarocherí 35, 41

Pucará, Prov. Xauxa 55, 59, 61

Puchacay (province) 136, 144, 152

Pueblo Nuevo 232

Puente (hacienda) 103
Pumacancha (annex) 41

Pumacocha (annex) 41

Pumacocha (hacienda) 61

Punchac (annex) 88

Punrum (lake) 97

Punta (annex) 55

Punta de Diamante (pass) 38

Punta de San Felipe 10

Puntilla (hill) 143

Puños (annex) 88

Puñun (annex) 22

Pupio (gold mine) 162

Puruchucu (annex) 99

Puzuzo (montañas) 169

Puzuzo (pueblo) 171, 172

Puzuzo (river) 171,174

Puzuzo 183, 203

Quebrada Onda (gold mine) 163

Querchereguas (pueblo) 123

Quichuay (annex) 55

Quilacoya (gold mines) 149

Quillota (province) 151, 152, 160, 161, 165

Quinel (lake) 151

Quintay (annex) 22

Quintí (annex) 40

Quintí, San Lorenzo de (pueblo) 40

Quinua (quebrada) 65

Quion (annex ) 99

Quipan (annex) 99

Quipas (annex) 88

Quipico (hacienda) 103

Quirin (annex) 88

Quiriquina (island) $142,146,150$

Quivilla (quebrada) 84

Quivilla (House of correction) 88

Rancagua (province) 151, 154, 160

Rancagua (volcano) 151

Rauma (annex) 99

Ravira (annex) 99

Renca (parish) 159

Rere (province) 136, 138, 144

Retes 100

Reyes (pueblo) 59, 63

Ricrán (annex) 55

Rimac (river) 13

Rinconda (annex) 13

Río de Lima 40

Río de Mala 40

Ríoseco (pueblo) 95

Rodonbamba (annex) 88

Rondos (pueblo) 66, 90, 93, 168, 237

Rondos (annex) 88

Rondos (river) 86

Rosapata (hacienda) 77

Rosapata (chacra) 70

Rosario, El (hacienda) 129

Saco, Santa Rosa de (annex) 41

Sacramento (pampa) 64 
San Salvador (hacienda) 129

San Agustín (annex) 99

San Antonio of Huancani (annex) 55

San Antonio de Yauliaco (annex) 41

San Bartolomé (annex) 41

San Borja (parish) 159

San Buenaventura (capital) 167

San Cosme y San Damián (pueblo) 40

San Cristóbal de Cuchero 75

San Cristóbal de Chile (hill) 150

San Fernando (province) 151

San Fernando 152, 154, 160

San Fernando (fort) 13

San Francisco (island) 26

San Gerónimo (parish) 55

San Gerónimo de Punan (annex) 41

San Isidro (parish) 159

San José (annex) 99

San Juan (hacienda) 23

San Juan (river) 151

San Juan (annex) 99

San Juan de Chicla 33, 37

San Juan de Iris (annex) 41

San Juan de Matucana 33, 38

San Lorenzo (island) 109

San Lorenzo de Quintí (pueblo) 40

San Lorenzo (annex) 991

San Lucas de Chacapalpa (annex) 41

San Mateo (pueblo) 33, 60

San Mateo (gorge) 38

San Mateo de Huanchor (parish) 41

San Mateo de Matucana 40

San Miguel (annex) 99

San Pedro de Mama 33, 37, 60

San Pedro (fort) $114,126,134,153$

San Pedro 152

San Pedro de Casta (parish) 41

San Pedro Nolasco (silver mine) 160

San Pedro Nolasco 151

San Pedro de Quilcai (lake) 26

San Rafael (pueblo) 66, 90

San Simon (silver mine) 160

San Vicente (port) 142, 152

Santa Ana (hacienda) 129

Santa Ana (parish) 159

Santa Bárbara (pueblo) 123

Santa Catalina (pueblo) 98

Santa Cruz (annex) 22, 99

Santa Cruz de Triana (district) 160

Santa Inés (annex) 41

Santa Lucia (hill) 156, 158

Santa María (island) 110

Santa Olalla [Eulalia] 29, 40

Santa Rosa (hacienda) 129

Santiago (province) 160

Santiago de Chile (city) 142, 154, 156

Santiago de Chile (bishopric) 139,160

Santiago de Huayhuay (annex) 41

Santiago de Tuna (annex) 40

Santo Domingo de Chile 149

Santo Domingo 184, 208

Santo Domingo (quebrada) 169

Santo Domingo (river) 71, 169
Saria (hill) 234

Saulí 40

Sayan (parish) 22

Sayan (pueblo) 103, 104, 107

Sicaya (pueblo) 55

Sillcay (hill) 223

Sillcay 235

Sillapata (annex) 88

Sinfondo, Rio 151

Sisicaya (annex) 40

Siusa (river) 58

Solano, San Francisco de Trapiche (annex) 41

Sorococha (lake) 97

Suayhuay, Santiago de (annex) 444

Sumbirca (annex) 99

Sunicancha (annex) 40

Supe (annex) 21, 22

Surco (parish) 14, (annex) 41

Surco (pueblo) 20, 30, 33

Tachal (river) 151

Tahua-tahua (lake) 151

Talca (city) 154

Talca (gold mine) 163

Talcahuano, Bay 146

Talcahuano (road) 141

Talcahuano (parish) 142

Talcahuano (port) 110, 112, 142, 152

Tambillo 169

Tambillo (ravine) 208

Tambo Nuevo (clearing) 170

Tambo (plain) 70

Tanahuillin (hill) 149

Tango (parish) 159

Tantamayo (annex) 88

Tantaranchi (annex) 40

Tapaya (annex) 22

Tarma (pueblo) $36,42,48,55$

Tarma 33, 47, 58, 62

Tarma (province) 42, 88

Tarma (montañas) 166

Tarmatambo (castle ruins) 49

Taullan (farm) 208

Tazo (river) 86

Teno (river) 151

Tiltil (gold mine) 160

Tingo (hacienda) 41

Tingo (river) 235

Tinguirinica (river) 151

Tolten (river) 151

Tolten alto (pueblo) 123

Toltero Bajo (pueblo) 123

Tongos (annex) 22

Torreblanca (hacienda) 20, 100, 105, 107

Torrehuasí 235

Torre sin Agua (hill) 214

Torre sin Agua 169

Tramo 170, 184

Tucapal (pueblo) 123

Tuctu 40, Ingenio de 41

Tulumayo (pueblo) 54

Tunuyan (river) 151 
Tupicocha (annex) 40

Turpay (annex) 22

Ucayali (river) 54,64

Uchubamba (annex) 55

Uchayucarpa (annex) 98

Uca (parish) 88

Uña del Diablo (walk) 24

Urubamba (pueblo) 54

Valparaiso (government) 144

Valdivia 151

Valdivia (river) 151

Valdivia (government) 144

Valle (parish) 221

Valle (town) 169,208

Valparaiso (province) 160

Valparaiso (port) 152, 165

Vegueta (annex) 21

Vichaycocha (annex) 98

Vico (pueblo) 63

Villagra 116, 130

Villarica (lake) 151

Villa Roca (volcano) 151

Viscas (annex) 99

Viso, San Miguel de (annex) 41

Viso (tambo) 38

Viuda, La (island) 26

Xauxa [Jauja] 47

Xauxa (parish) 55
Xauxa (pueblo) 49, 51, 54

Xauxa (river) 54

Xauxa (province) 49, 53

Xican (annex) 88

Xicamarca (annex) 41

Xivia (annex) 88

Yacan (pueblo) 237

Yaco (see Saco)

Yacul (annex) 22

Yanacolpa (hacienda) 41

Yanamayo 184, 214

Yangas 167

Yarumayo (river) 71

Yaso (pueblo) 167

Yaso (annex) 99

Yaulía, San Antonio de (parish) 41

Yauliaco (hacienda) 41

Yauliaco (mill) 34

Yauricocha (hill) 237

Yauricocha (lake) 64

Yauricocha (cerro) 94

Yeguaragui (hacienda) 129

Yerro (gold mine) 162

Yguari (pueblo) 22

Yunhuy (annex) 22

Zapallanga (annex) 55

Zinha (parish) 88

THE LIBRARY OF THE 


\section{TRAVELS OF RUIZ, PAVÓN, AND DOMBEY IN PERU AND CHILE \\ (1777-1788) \\ BY \\ HiPólito RUIZ}

With an EpIlogue and OfFicial Documents

ADDED BY

AGUSTÍN JESÚS BARREIRO

THE LIBRARY OF THE

APR 131940

UNIVERSITY OF ILLINOIS

TRANSLATION

BY

B. E. DAHLGREN

CHIEF CURATOR, DEPARTMENT OF BOTANY

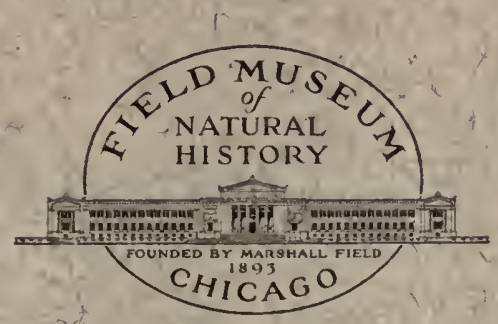

BOTANICAL SERIES

FIELD MUSEUM OF NATURAL HISTORY

VOLUME 21

MARCH 28, 1940

PUBLICATION 467 


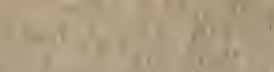

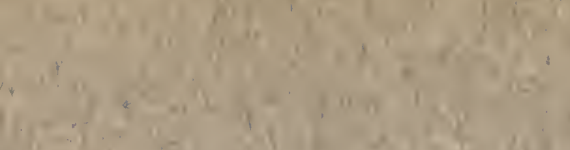

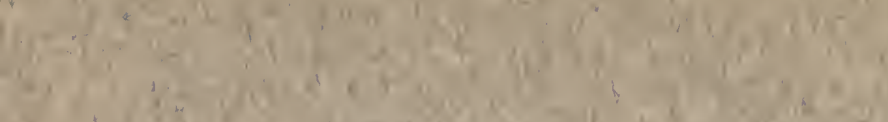

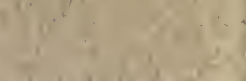
$i^{-1}, x^{2}$

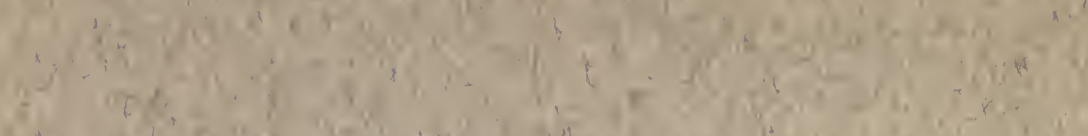

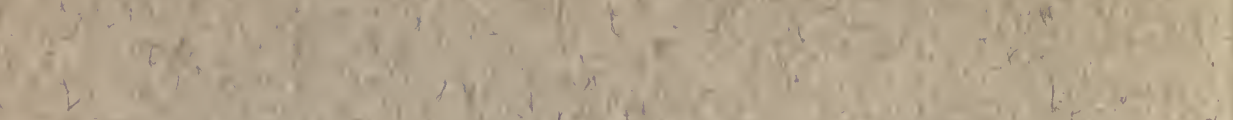

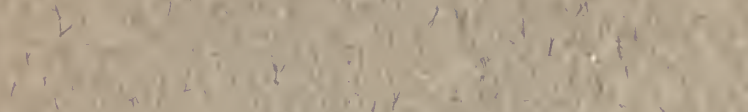

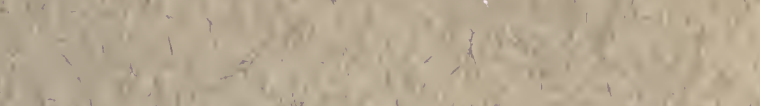

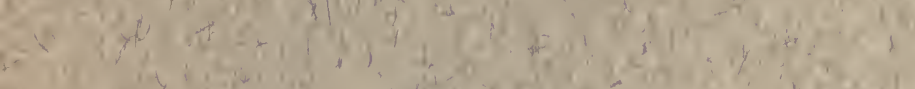

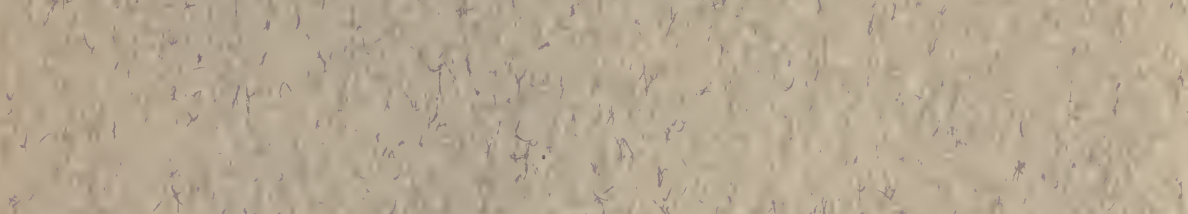

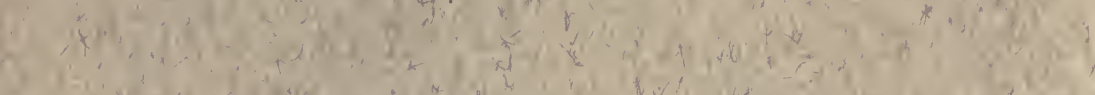

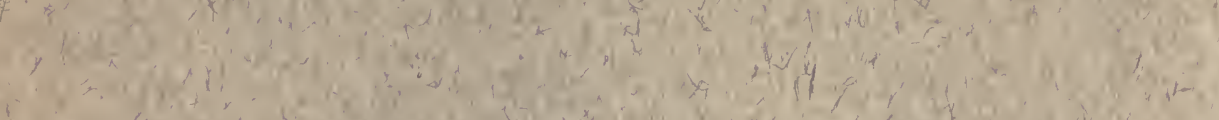

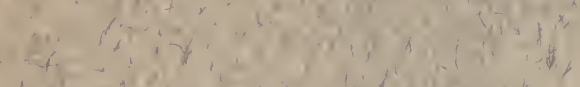

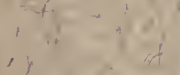

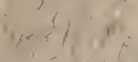

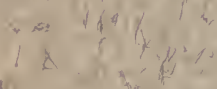

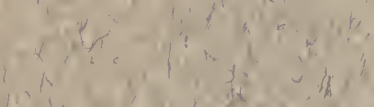
किसे

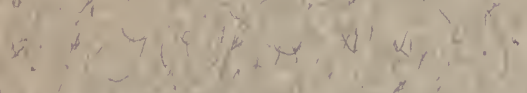
$(x)$

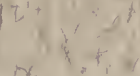

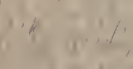

$\operatorname{lin}^{2}-2,40$

$x^{4} ;>d i$

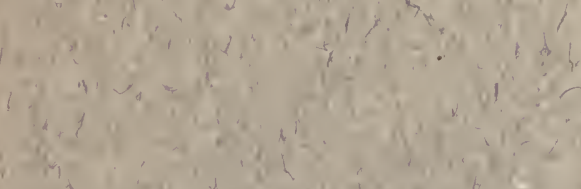

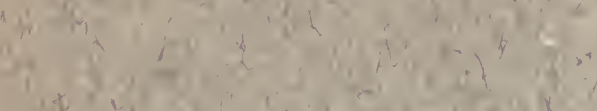

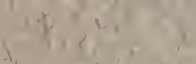

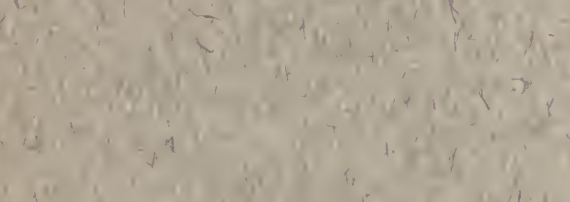

$1 y_{1}^{2}$

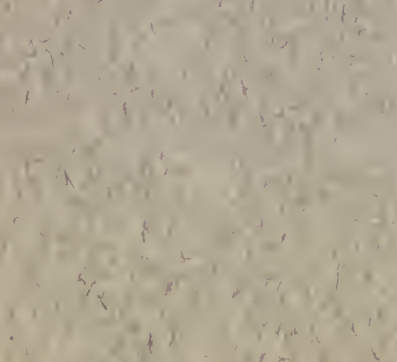

$4 x^{\prime}+1$ 8

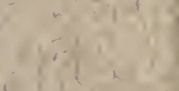
$1+1$ 





UNIVERSITY OF ILLINOIS-URBANA

| || || I I I I | ||

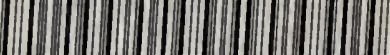

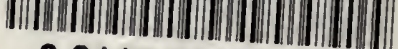

30112018259173 